


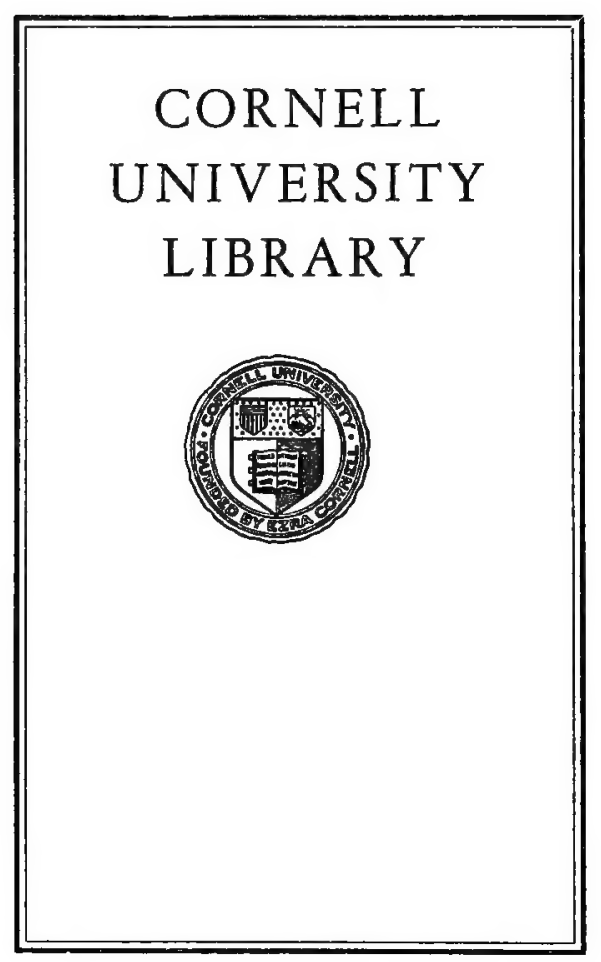


Cornell University Library

QL 3.W94S97

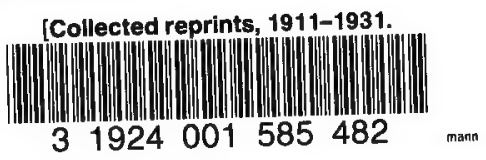




\section{Cornell University Library}

The original of this book is in the Cornell University Library.

There are no known copyright restrictions in the United States on the use of the text.

http://www.archive.org/details/cu31924001585482 




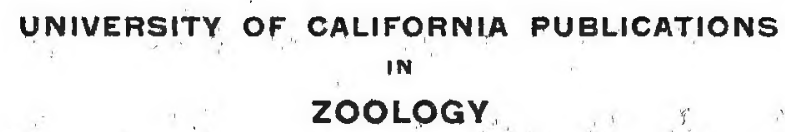

Vol. 7, No. 2, pp. 9-172, plates 1-6, 3 text-figures January 12, 1911

\section{BIRDS AND MAMMALS OF THE 1909 ALEXANDER ALASKA EXPEDITION}

BY.

HARRY S. SWARTH

BERKELEY

THE UNIVERSITY PRESS 


\section{UNIVERSITY OF CALIFORNIA PUBLICATIONS}

Note.-The University of Callformia Publications are offerea in exchange for the publcations of learned societies and institutions, universities and libraries. Complete lists of all the publications of the University will be sent upon request. For sample copies, lists of publications or other information, address the Manager of the University Press, Berkeley, California, U. S. A. All matter sent in exchange should be addressed to The Fxchange Department, University Library, Berkeley, California, U. S. A.

\section{OTTO HARRASSOWITZ IEIPZIG}

Agent for the series in American Archaeology and Ethnology, Classical Philology, Education, Modern Philology, Philosophy, Psychology.

\section{R. FRIEDLAENDER \& SOHN} BERLIN

Agent for the series in American Archaeology and Ethnology, Botany, Geology, Mathematics, Pathology, Physiology, Zoology, and Memoirs.

ZOoLoGY.-W. E. Ritter and O. A. Kofoid, Editors. Price per volume \$3.50. Commencing with Volume II, this series contains Contributions from the Laboratory of the Marine Biological Association of San Diego.

Cited as Univ, Calif, Publ. Zool.

Vol. 1. 1. The Hydroida of the Pacific Coast of North America, by Harry Beal Torrey. Pp. 1-104; plates 1-11. November, 1902.

2. A Case of Physiological Polarization in the Ascidian Heart, by Frank W. Bancroft and C. O. Esterly. Pp. 105-114. April 1903.

3. Embryology and Embryonic Fission in the Genus Crisia, by Allce Robertson. Pp. 115-156, plates 12-15. June, 1903.

4. Correlated Protective Devices in some California Salamanders, by Marion F. Hubbard. Pp. 157-170, plate 16. November, 1903.

5. Studies on the Ecology, Morphology and Speciology of the Young of some Enteropneusta of Western North America, by William E. Ritter and B. M. Davis. Pp. 171-210, plates 17-19. February, 1904

6. Regeneration and Ncn-Sexual Reproduction in Sagartia davisi, by Harry Beal Torrey and Janet Ruth Mery. Pp. 211-226, 7 textfigures. May, 1904

7. The Structure and Regeneration of the Poison Glands of Plethodon, by C. O. Esterly. Pp. 227-268, plates 20-23. June, 1904.

8. The Distribution of the Sense-organs in Microscolex elegans, by John F. Bovard. Pp. 268-286, plates 24-25. December, 1904.

9. Some New Tintinnidae from the Plankton of the San Diego Beglon, by Charles A. Kofoid. Pp. 287-306, plates 26-28. July, 1905............ Index, pp. 307-317.

Vol. 2. (Contributions from the Laboratory of the Marine Biological Association of San Diego.)

Introduction. A General statement of the Ideas and the Present Aims and Status of the Marine Biological Association of San Diego, by William E. Ritter, Director of the Station. Pp. i-rvil. 2 Maps

1. The Hydroids of the San Diego Region, by Harry Beal Torrey. Pp. 1-43. 22 text figures. December, 1904.

2. The Ctenophores of the San Diego Region, by Harry Beal Torrey. Pp. 45-61, plate 1. December, 1904.

Nos. 1 and 2 in one cover.

3. The Pelagic Tunicata of the San Diego Region, excepting the Tarvacea, by William E. Ritter. Pp. 51-112, plates 2-3. 31 text-figures. January, 1905

4. The Pelagic Copepoda of the San Diego Region, by C. O. Esterly. Pp. 113-233, 62 text figures. September, 1905.

5. The Non-encrusting Chilostomatous Bryozoa of the West Coast of North America, by Alice Eobertson. Pp. 235-322, plates 4-16. December, 1905

6. Differentiation in Hydroid Colonies and the Problem of Senescence, by Harry Beal Torrey. Pp. 232-332, 4 text-figures. December, 1905.

7. The Behavior of Corymorpha, by Flarry Beal Torrey. Pp. 333-340, 5 text-figures.

Nos, 6 and 7 in one cover

8. Dinoflagellata of the San Diego Region. I. On Feterodinium, a New Genus of the Peridinidae, by Charles Atwood Kofoid. Pp. 341-368, plates 17-19. January, 1906 Index, pp. 369-382.

* Supply limited; sold only with complete volumes. 
UNIVERSITY OF CALIFORNIA PUBLICATIONS

IN

ZOOLOGY

Vol. 7, No. 2, pp. 9-172, plates 1-6, 3 text-figures

January 12,1911

\section{BIRDS AND MAMMALS OF THE 1909 ALEXANDER ALASKA EXPEDITION}

BY

HARRY S. SWARTH.

(Contribution from the Museum of Vertebrate Zoology of the University of California.)

\section{CONTENTS.}

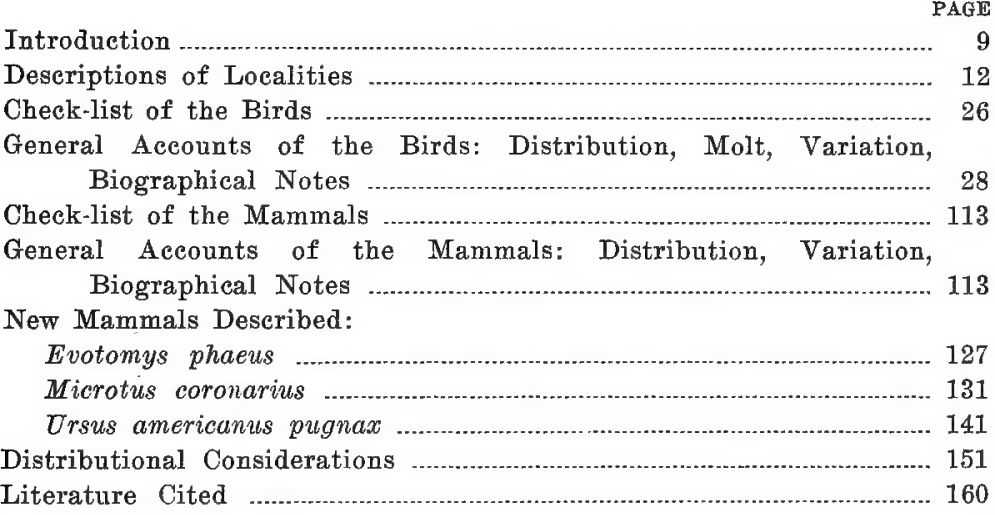

\section{INTRODUCTION.}

In 1909 Miss Annie M. Alexander organized and financed an expedition for the exploration of such parts of the Sitkan district, Alaska, as had not been touched by the expedition of $1907^{1}$ - at least to such an extent as could be done in a single

1 Field work in Alaska has been prosecuted as follows: In 1906 on the Kenai Peninsula; in 1907 in the Sitkan district; in 1908 in the Prince William Sound region; and in 1909 in the Sitkan district. 
season. The party consisted of Allen E. Hasselborg of Juneau, Alaska, and the writer. Our means of transportation was a gasolene launch, twenty-eight feet long and seven foot beam. Camp was established ashore at most of the points visited. Hasselborg spent most of his time in hunting the larger mammals, though he occasionally ran lines of small traps, or shot a few birds, leaving the writer free to devote himself entirely to the small mammals and birds.

The region explored by this expedition, together with that of 1907, includes practically the whole of the Sitkan district as restricted by later writers: the mainland coast of Alaska and the islands (the Alexander Archipelago) lying between Juneau and Cross Sound on the north, and Dixon Entrance on the south. This area is about two hundred and fifty miles long, from Cross Sound to Dixon Entrance, with an average width of about one hundred miles. The previous expedition had collected at various points on the more northern islands of the group, Admiralty, Chichagof, and Baranof, as well as at Glacier Bay on the mainland; so it was planned to begin operations south of Frederick Sound, work south along the western edge of the archipelago as far as Dixon Entrance, and, on the return trip north, to visit the inner islands, and such mainland points as time permitted and it seemed desirable to explore.

I left San Francisco on March 31, arriving in Juneau on April 8. We left Juneau on the morning of April 9, and on October 1, I sailed for home from the same point. During October and November Hasselborg visited the Taku River and points on Admiralty and Chichagof islands, collecting material which has been included in the present report. The following is the itinerary of the expedition:

ITINERARY.

Juneau, April 8.

Kake, Kupreanof Island, April 9.

Keku Straits, Kupreanof Island (two camps), April 10-18; 18.25.

Three-mile Arm, Kuiu Island, April 25 to May 6.
Port Protection, Prince of Wales Island, May 6 to 10 .

Shakan and Calder Bay, Prince of Wales Island, May 10 to 14.

Egg Harbor, Coronation Island, May 14 to 18.

Port McArthur, Kuin Island, May $18,19$. 
Warren Island, May 19 to 23.

Heceta Island, May 23, 24.

San Alberto Bay, Prince of Wales Island, May 24 to 26.

Klawak Salt Lake, Prince of Wales Island, May 26 to 29.

Suemez Island, May 29, 30.

Rocky Bay, Dall Island, May 30 to June 4.

West Coast of Dall Island, June 4 to 6 .

McLeans Arm, Prince of Wales Island, June $6,7$.

Duke Island, June 7 to 9 .

Marten Arm, Boca de Quadra (mainland), June 9 to 14.

Annette Island, June 14, 15.

Gravina Island, June 15, 16.

Chickamin River (mainland), June 17 to 28 .
Portage Cove, Revillagiged Island, June 28 to July 4.

Hassler's Pass, Revillagigedo Island, July 4, 5.

Etolin Island, July 5 to 12.

Fool's Inlet, Wrangell Island, July 12 to 18.

Bradfield Canal (mainland), July 18 to 26.

Port St. John, Zarembo Island, July 27 to August 1.

Mitkof Island, August 1 to 13.

Thomas Bay (mainland), August 13 to 23.

Port Snettisham (mainland), August 24 to September 2.

Juneau, September 2, 3.

Taku River (mainland), September 4 to 28 .

Juneau, September 28.

Thus we visited sixteen islands and six mainland localities; on some of the islands we established several camps.

The accompanying map (plate 1 ) of the region, copied from a chart issued by the United States Coast and Geodetic Survey, shows the route of the expedition and points where collecting was carried on. Names of localities used in the report are all to be found on this map.

The ornithological material collected consists of 604 bird skins; the mammals of 472 skins with skulls, 24 skulls without skins, $t \bar{t}$ small mammals in alcohol, and 13 shed deer antlers.

These specimens have all been donated by Miss Alexander to the University of California Museum of Vertebrate Zoology, and they, together with the field notes made during the season both by Hasselborg and myself, form the basis of the present report. Twenty-seven species of mammals are listed, twenty-six represented by specimens collected. One hundred and thirtyseven species of birds are included in the report, specimens being taken of one hundred and six.

In color descriptions Ridgway's "Nomenclature of Colors," 1886 edition, has been followed as closely as was practicable. Measurements are in millimeters unless otherwise specified. The species of plants mentioned in the report were identified by 
Professor H. M. Hall, of the University of California, from specimens collected and now in the University Herbarium.

I should like here to express my appreciation of courtesies received from several institutions and individuals in connection with this report: To the authorities of the United States National Museum for the loan of bird skins, as indicated under the various species in the general report following; to Dr. C. Hart Merriam, Chief of the Biological Survey, for the loan of specimens of birds and mammals; to Mr. E. A. Preble and Mr. N. Hollister for specific information on certain puzzling forms; to Professor J. O. Snyder, of Leland Stanford Junior University, for the loan of a series of skins of Sciurus $h$. vancouverensis from the collection of that institution; and to Professor Chas. A. Kofoid, of the University of California, for critical reading of the final manuscript.

\section{DESCRIPTIONS OF LOCALITIES.}

\section{KUPREANOF ISLAND.}

We made two camps on this island, the first being some five or six miles above the south end of Keku Straits. These straits, separating Kupreanof and Kuiu islands, are exceedingly narrow at this point, being, in places, less than a hundred feet across; they are navigable, even to as small a boat as ours, only at high tide, as there are series of rapids in them at low water. Thus they are practically no barrier at all to the distribution of animal life, and the same species of birds and mammals range over both islands. As the channels between Kupreanof and Mitkof, and Mitkof and the mainland, are likewise narrow and shallow, some of the mainland fauna is thus carried almost to the western extremity of the archipelago.

We remained but a few days in our first camp and then moved to a point some three miles farther south, where the presence of two fairly large streams with bordering meadow land gave promise of better results than we had been obtaining. This part of Kupreanof Island is quite flat with no conspicuous mountain ranges anywhere. There were two peaks some six or seven miles north of our camp, which are about 1500 
feet high-round-topped hills, covered with timber; while the same distance south of us was a ridge that reached an altitude of approximately 2,000 feet. Some steep cliffs were visible along the sides, and the top was bare of timber and snowcovered.

The larger of the two streams was explored inland for fifteen miles. The drainage appears to be mostly toward the west side of the island.

Near the beach, and along the streams, is a dense growth of timber, mostly spruce and hemlock, with some cedar; farther back the country opens up into a series of parks, covered with a scattering growth of scrubby pines from ten to thirty feet high, boggy and hummocky underfoot, and with a thick carpet of moss. Along the beach the forest is bordered with a scattering fringe of alder.

During our stay on Kupreanof, April 10 to 25, the weather was quite cold. The thermometer dropped as low as $6^{\circ} \mathrm{C}$., and we had several snowstorms. Land birds were extremely scarce and of few species, nor was there any species of small mammal that was at all abundant.

\section{THREE-MILE ARM, KUIU ISLAND.}

Our camp at this point was in a little cove on the east side of the inlet, and some three miles from its head. On this part of Kuiu Island the coast line is very much cut up with bays and inlets, and the country is more hilly and uneven than on Kupreanof. In vegetation the two places are essentially the same. The conspicuous feature of this place is the extensive tide flats. The whole head of the inlet is bare at low tide, exposing hundreds of acres of mud banks, and these fairly swarmed with wading birds of various species. As land birds were still very few in numbers most of my time was devoted to the securing and preparation of series of these waders, and a good representation was obtained. We remained here from April 25 to May 6.

Kupreanof and Kuiu together are generally known as the Kake Islands, from the tribe of Kake Indians, which inhabits them. 
PORT PROTECTION, PRINCE OF WALES ISLAND.

$A$ long and rather narrow inlet at the northwestern extremity of the island. The bay is some three miles long and winds so that the head of the inlet is sheltered from storms from any direction. The country surrounding is extremely rough and rugged, and the timber a mass of windfalls, so that traveling was difficult. The beach is narrow and precipitous, so much so that we were unable to establish a camp ashore, and were obliged to live on the launch during our stay at this point. Several small streams empty into the bay, none of them large enough to permit of the salmon ascending much above tide-water. Along these creeks there is a little meadow land. The forest presents the usual combination of fir and hemlock, with a little cedar, and alder along the beach. The broken hills surrounding the bay culminate at the south in the high peak of Mt. Calder. We remained at this point from May 6 to 10, and though the alders were beginning to bud, and a little green grass to appear in favored spots, the snow still lay deep in the woods. Land birds were extremely scarce.

\section{SHAKAN AND CALDER BAY.}

Shakan is a small settlement on Kosciusko Island, at the northwestern extremity of Prince of Wales Island. Calder Bay is a long inlet extending some six or eight miles north of Shakan. In a straight line these places are not more than twenty-five miles from Port Protection, and the character of the country is essentially the same. We ran traps and collected birds at three different points in this vicinity, at the Calder Marble quarry, but a short distance from Shakan, at the head of Calder Bay, and at the entrance of Klawak Passage, the exceedingly narrow channel between Kosciusko and Prince of Wales islands. The weather was stormy during the whole of our stay at this point, May 10 to 14; in fact we were waiting here, in comparative shelter, for the weather to settle and permit us to reach Coronation Island, our next objective point.

\section{CORONATION ISLAND.}

A small island lying south and west of the southern extremity of "Kuiu, and about forty miles southwest of Shakan. We 
anchored near the head of Egg Harbor, on the north side of the island, a narrow and perfectly straight inlet, about a mile long and a quarter of a mile wide. With the southerly winds prevailing during our stay this bay is quite calm and unruffled, but it is exposed toward the north, where it looks straight up Chatham Straits, and the ocean swell enters unhindered. At the head of the bay, and in places on the west side, are sandy and gravelly beaches, and quite at the head of the bay a goodsized stream empties. On the west side of the harbor is Pin Peak, about 1300 feet high, and south, towards the center of the island, Needle Peak, 1700 feet. The upper half of Pin Peak is devoid of timber, and barren but for a covering of grass. The timber on the island was a mixture of spruce, hemlock, and cedar, with alders and crabapples along the beach. At the head of the bay the forest is quite open and easy to traverse, being almost devoid of underbrush, while the ground is carpeted deeply with moss. At the foot of Pin Peak is an abandoned mine, with numerous sheds and other buildings still standing, serving as shelters for the deer, as we had opportunities of observing. There are also some caves here that had evidently been used as dwellings by the mine operators. The island is about ten miles long, and between five and six miles across at the widest point. The name "Egg Harbor" is a misnomer, as we found no colonies of sea birds anywhere in the vicinity. On the Hazy Islands, some jutting rocks ten or twelve miles to the westward, we were told that there were many such.

The mammals noted on Coronation Island were Odocoileus, Lutreola, Microtus (a species peculiar to this and Warren Island), Peromyscus, and Sorex. There was no sign of bear or wolves. The weather was pleasant during our stay here, May 14 to 18 , and birds were abundant.

\section{PORT MCARTHUR, KUIU ISLAND.}

A bay near the southern extremity of Kuiu, and about fifteen miles north of Coronation Island. We ran in here for shelter on May 18, leaving again next morning. A line of traps brought small results. 
WARREN ISLAND.

A small island lying directly between Kosciusko and Coronation islands, but much nearer the former. The affinities of the mammalian fauna proved to be distinctly with Coronation Island, but this was not true of the avifauna. The sooty grouse, so conspicuous on the latter island, is not found here, while we have strong reasons to believe that the Franklin grouse, of Prince of Wales and adjoining islands, does occur. Our camp was on the east side of the island, where a slight bend in the shore line afforded a fair degree of shelter. The forest was of the usual type throughout the region. A rather conspicuous feature of the place was the abundance of large-sized abalone shells scattered along the shore, and even far back in the woods, carried possibly by the ravens. We saw these shells nowhere else during the summer. We remained at Warren Island from May 19 to 23.

\section{HECETA ISLAND.}

Lying at the western edge of Prince of Wales Island, where it forms the southern boundary of Sea Otter Sound. On May 23 we coasted along the northern shore of the island, exploring Port Alice and two other unnamed bays, but finding no promising collecting ground. Traps set at the eastern end of the island brought few results.

\section{SAN ALBERTO BAY, PRINCE OF WALES ISLAND.}

An indentation on the west coast, and about at the center of the island. We anchored on the north shore of the bay, near where two good-sized streams emptied into it. Aside from a few small tracts of grassy land near the beach there was no open country, nothing but thick forest, and birds were very scarce. Hasselborg found sign of two bear, both of which he secured. We were here from May 24 to 26.

\section{KLAWAK SALT LAKE.}

A long, inland extension of San Alberto Bay, but so blocked by islands at its entrance as to be more like a lake than an arm of the sea. The tide, which rises to such unusual heights elsewhere 
in the region, was in this sheltered spot almost imperceptible. Along the shores of the lake are stretches of grassy meadow land, while the forest was in places open enough to be traversed readily. The weather was pleasant during our stay here, May 26 to 29 , but neither birds nor mammals were at all abundant.

\section{SUEMEZ ISLAND.}

From Klawak we headed due south, planning to go direct to Forrester Island if the weather permitted, but it turned so stormy that we were obliged to anchor in a sheltered spot at the eastern extremity of Suemez Island. A short exploration showed it to be discouragingly barren, hardly a bird to be seen anywhere, and no indication of mammals, large or small. A line of traps set out the night of May 29 brought in scanty results.

"ROCKY BAY," DALL ISLAND.

A deep and perfectly sheltered indentation at the northwestern extremity of Dall Island. This bay is unnamed and uncharted, but is shown on ou map (plate 1). The stormy weather forced us in here, where we anchored in perfect safety, but at low tide found ourselves surrounded by jagged rocks. Several good-sized streams empty into the head of the bay, and the woods are in places fairly easy to traverse, either by following these streams or by crossing the scattered series of more open parks. Many sea lions were observed in this bay, the only place where they were met with in any numbers during the summer. Exceedingly stormy weather prevailed during the whole of our stay here, so birds were naturally hard to find. Small mammals were also extremely scarce.

On these islands a fair test of the comparative abundance of the smaller mammals is the amount of meadow-mouse sign. Many well-traveled Microtus runways usually mean plenty of certain other species as well, while in the absence of these highways it is but seldom that the traps are productive.

We remained at Rocky Bay from May 30 to June 4, awaiting a favorable opportunity to cross over to Forrester Island, a small isolated island some fifteen miles to the westward. The Indians use it as a station for hunting the sea otter, and it is 
also said to harbor numerous breeding sea birds. On June 4, 5 and 6 , we made abortive efforts to reach the island, but were as often prevented by the continual stormy weather, and driven for shelter into various uncharted bays on the west coast of Dall Island. On June 6 we made our last attempt, but an impending southeaster drove us once more around the north end of Dall Island.

\section{PORT MCLEAN, PRINCE OF WALES ISLAND.}

We dropped anchor at the head of this long, narrow fiord, near the southern extremity of Prince of Wales Island, at about 11 p. m. on June 6. A hasty inspection of the place early the next morning revealed dense, impenetrable forest, with rocky, forbidding shores, with no indication of bird or animal life.

\section{DUKE ISLAND.}

At the southern extremity of the Alexander Archipelago. We anchored on the north side of the island, which is quite flat. There is a thin fringe of timber near the beach; inland there appeared to be but a scattering growth of scrubby pines. Several very small streams emptied in the vicinity of our anchorage. Most of the drainage seemed to be toward the other side of the island. There was no meadow land anywhere in the vicinity. We remained here from June 7 to 9 .

MARTEN ARM, BOCA DE QUADRA.

Boca de Quadra is a long and very narrow inlet or fiord piercing the mainland coast at what is almost the southermost extremity of Alaska. Its walls are steep and precipitous in the extreme, so much so that for miles there is not a foot of beach where a landing could be effected, the dense forest growing down to within a few feet of the high-tide mark, where the rocky walls drop perpendicularly into the water. We ascended to the head of Marten Arm, a southern branch of the inlet, where we established a camp, some twenty-five miles from the coast. Here, at its head, are hundreds of acres of grassy flats, cut up by innumerable gullies and ditches, full of water at high tide. A large river flows down the center of the valley, 
while on either side smaller streams issue from every cañon and ravine. The surrounding mountain sides are steep and heavily timbered for the most part, though with many barren cliffs and snow covered peaks in the higher parts. On the floor of the valley there are groves of timber of varying extent, together with many clumps of underbrush and patches of willow. Besides the usual spruce, hemlock and cedar, we here encountered the balsam fir for the first time. Altogether it was a beautiful and attractive spot, the broad open meadows, a mass of blooming wild flowers at this time, being particularly pleasing after the gloomy forests in which we had been working so long. Animal life was abundant and a quantity of interesting material was gathered; but unfortunately a band of Indians was in here hunting bear, and it was useless to look for big game under the circumstances. We paid a visit to the Indian camp to inspect their catch, and found that besides bear they had some beaver, otter, and wolverine, all caught within a radius of about thirty miles. Our stay at Marten Arm was from June 9 to 14. All the references in the text to Boca de Quadra refer to this camp at the head of Marten Arm.

\section{ANNETTE ISLAND.}

On our way from Boca de Quadra to Ketchikan we stopped one night, June 14, at Hassler Harbor, on the northeast coast of Annette Island. It presents the usual appearance of these southern islands, with dense timber down to the water's edge, and with little or no open meadow land. A string of eighty traps produced just one Peromyscus, and no birds of interest were observed.

\section{GRAVINA ISLAND.}

June 15 and 16 were spent in the town of Ketchikan, on Revillagigedo Island. On the evening of the 15 th we crossed the narrow channel to the neighboring island of Gravina, where I went ashore long enough to put out some traps. I did not go back far from the beach, but the timber appeared to be thin and sparse compared with most of the places we had visited, and while there were several trickling rivulets nearby there was no stream of any size. Neither was there any meadow land 
whatever in the immediate vicinity. The beach was thickly strewn with drift, affording refuge to numerous mice of the genus Peromyscus.

\section{CHICKAMIN RIVER.}

A broad, shallow river on the mainland coast of southern Alaska, emptying into Behm Canal a little north of the center of Revillagigedo Island. Our camp was located about two miles from the mouth of the river, on the north bank, and unless otherwise specified, all the specimens mentioned as collected on the Chickamin River were taken within five miles of this camp. On all sides were broad stretches of meadow land, waist high with grass and flowers, and dotted with clumps of spruce or willow, while on the edges were scattering fringes of alder, between the meadows and the forest. The valley at this point is some three or four miles across, and on either side the mountains rise steep and precipitous.

PORTAGE COVE, REVILLAGIGEDO ISLAND.

Directly opposite the mouth of the Chìckamin River. Although the chart showed only a little bay or inlet at this point, we discovered that a good-sized stream pierced the rocky wall on the south side of the cove, like a narrow gateway, opening into a broad, level valley beyond. We ascended the river about three miles and established camp on the north side of the stream. On both sides of the river are broad grass-covered meadows, intersected in all directions by winding tide sloughs. Although the river banks are ten feet high or more, these meadows are all swampy, with pools scattered everywhere. In places long tongues of woodland extend out into these open tracts, scattered growths of spruce, hemlock and cedar, with much low underbrush; but even in this timber the ground is saturated, and the trees do not thrive as there are as many dead stubs as live trees. (See plate 2.) In places there are clumps of scrubby willow, and here and there large areas entirely covered with them. The valley is about half a mile across at the site of our camp, with the mountains rising abruptly at either side. At their base the underbrush is so thick as to be impassable. Apparently the winter climate of this place is 
severe. At the time of our stay, June 28 to July 4, the snow lay deep in sheltered spots in the cañon, and also on the north slope of the hills, while the absence of any deer sign was in itself an indication of a climate much harsher than that of the more western islands.

\section{HASSLER'S PASS, REVILLAGIGEDO ISLAND.}

A narrow channel at the northeastern extremity of Revillagigedo Island. We passed the night of July 4 in a little cove at this point, where some traps were set out. The entire northern coast line of the island as observed by us is rocky and precipitous in the extreme, with no large streams nor any level land in sight.

\section{ETOLIN ISLAND.}

We camped in a bay at the southern end of the island, where an abandoned fishing camp afforded shelter. The country in the immediate vicinity is flat, with the hills some distance back; along the beach is a strip of heavy timber some tivo or three hundred yards wide, consisting of spruce, hemlock, and a good deal of cedar, and with much thick underbrush. Back of this are long stretches of parks. There is no meadow land anywhere in the vicinity. We were on Etolin Island from Juty 5 to 12.

\section{FOOL'S INLET, WRANGELI ISLAND.}

A long, narrow and extremely rocky and precipitous bay at the southern end of the island, where we remained from July 12 to 18. Hasselborg saw several bear at this place, but inclement weather made our stay here unprofitable. We traversed the entire eastern side of the island without seeing a single bay or inlet that gave promise of being good collecting ground. The shores are everywhere abrupt and rocky.

\section{BRADFTELD CANAL.}

A long, narrow fiord extending into the mainland directly east of Wrangell Island. We ascended nearly to its head, where we pitched camp on a little wooded peninsula, on the north side of the bay, at the mouth of a good-sized river. The shores of the canal are rocky and precipitous, and there is no beach anywhere, except some mud flats at the mouth of the river, 
exposed at low tide. The timber comes down to the water's edge, where it is fringed by a strip of beach grass, and is everywhere dense and impenetrable except on the extremity of the point on which our camp was located. Here the woods are fairly open. We stayed here from July 18 to 26 .

\section{PORT ST. JOHN, ZAREMBO ISLAND.}

After staying one night at the town of Wrangell (July 26) we went on to Port St. John, at the north end of Zarembo Island. This bay is about a mile long and something less than half that in width; but at low tide more than two-thirds of it is mud flats. Two small streams empty into the head of the inlet, and on the west side there is a spring of mineral water. The surrounding slopes are densely wooded, mostly with spruce and hemlock, for there is but little cedar just at this point, and there is the usual tangle of more or less dense underbrush. There is no meadow land anywhere in the vicinity. Deer are abundant on the island, but as it is a favorite hunting ground of the people at Wrangell, we found the bucks pretty well thinned out. There was some wolf sign, but no indication of bears. We were on Zarembo Island from July 27 to August 1.

\section{MITKOF ISLAND.}

On August 1 we left Port St. John, and sailed north through Wrangell Narrows, around the north end of Mitkof Island, and south along the east side, to a point about midway of the island. Here we established a camp on the beach, at a place lying between two small rivers. There is no meadow land in the vicinity, and the trapping, as well as most of the bird collecting, was done along the beach. There were quantities of drift strewn along the shore, and a broad strip of beach grass, both together affording food and shelter to quantities of whitefooted and meadow mice. The southward migration of the birds had begun at this time, and they were fairly abundant along the edge of the woods. Farther back in the timber, even along the streams, both birds and mammals were scarce. The salmon were running at the time of our visit, and as no Indians had been hunting or trapping in the vicinity, bear were fairly abundant. 
Hasselborg saw seven. Although this island is very closely connected with the mainland we failed to find any indication of the presence of such mainland forms as Erethizon, Evotomys, or Zapus, which might be expected to occur here. We remained here from August 1 to 13.

\section{THOMAS BAY.}

An indentation on the mainland about opposite the north end of Kupreanof Island. Our camp was in a little cove on the west side of the south arm of the bay. This corner of the bay is densely wooded down to the water's edge, but in the main river valley, around a point a few hundred yards distant, were broad expanses of mud flats and meadows; also stretches of gravelly bottom land, sparsely covered with grass, and at times evidently flooded by the stream. All these flat lands are intersected by numerous little rivulets and sloughs, ideal feeding grounds for numbers of ducks and geese. Below the meadow land are vast expanses of mud flats, covered at the time of our stay by flocks of thousands of small waders. The upper margins of the meadows are bordered by clumps of alder. Toward the base of the hills on either side the coniferous forest begins, and a mile or so up the river there are a few cottonwoods.

During the time of our stay at this point, August 13 to 23, the southward migration of the water birds had fairly set in, and every day throngs of ducks and waders were seen arriving and departing. The land birds also were moving, but not in so conspicuous a manner.

\section{PORT SNETTISHAM.}

A deep indentation on the mainland coast about thirty miles south of Juneau. We ascended the north arm of the bay some fifteen miles, pitching camp on the north side of the inlet. At this point a little peninsula projects out into the bay about half a mile. The best collecting grounds are on the mountain slopes to the eastward, but as there is no suitable camping ground there, we placed our camp on the beach west of this peninsula. The peninsula is densely wooded with conifers down to the shore line, with abrupt rocky slopes, but in the bay to the east 
of it, where I did most of my collecting, the mountain slopes are bare of such woods. At the water's edge are many acres of tall grass, waist high or higher, flooded at high tide, and at this time the haunt of numerous mallards. The center of the valley is occupied by a dense willow swamp, quite impenetrable, and traversed by many rushing streams. On either side, and broadening in extent as the mountain is ascended, are wide stretches of open country, apparently smooth and level, as viewed from the distance, but in reality a mass of jumbled boulders, covered with moss and hidden by tangles of vines and ferns. Some of the slopes and ridges are densely grown up with brush (Cladothamnus pyrolaeflorus) and here and there is an occasional scrubby spruce tree. Higher up, the mountains rise steep and precipitous, and at the foot of the cliffs were deep snow banks. In the bay where our camp was located the forest comes down to the water's edge, but this timbered area is comparatively narrow. We were at Port Snettisham from August 24 to September 2.

\section{TAKU RIVER.}

A deep and broad stream emptying into Taku Inlet, which in turn opens into Stephens Passage at a point some ten miles south of Juneau. We ascended the river about twenty miles, pitching camp on the south side of the stream. This river forms a direct pass from the interior of the country, and is used as such by both prospectors and Indians. Birds and mammals of the interior also reach the coast by this means, and for this reason we found it an interesting point to work. We found such inland species as Zapus saltator and Microtus drummondi among the mammals, and Geothlypis trichas occidentalis, Dendroica striata and Sialia currucoides among the birds. Hasselborg saw fresh tracks of a moose (Alces a. gigas) which had come down to the bank of the river opposite the launch during the night, this being probably as near the coast as the species is known to occur. He also heard a ruffed grouse (Bonasa u. umbelloides?) drumming several times. There was abundant sign of willow ptarmigan (Lagopus lagopus?) in the thickets, feathers and droppings, but it was impossible to penetrate the 
willow and alder swamps which they frequented. I saw grasshoppers here upon our first arrival, seen nowhere else during the summer, and also two species of butterflies not observed at any other point.

In the vicinity of our camp the river was from half a mile to a mile wide, with steep, abrupt banks all along its course and no shore at all suitable for waders, which were consequently almost absent. At this place there is a tract several miles long and half a mile wide, approximately, a short distance back from the river, grown up with dry woods such as I saw nowhere else in southeastern Alaska. There is a scattering growth of cottonwoods, with a few birch and a sprinkling of spruce, and very little underbrush, the ground below being dry and gravelly and almost bare of grass. Between these woods and the river there is a strip of alder, which, except in a few places, is very difficult to penetrate, while south of these woods is another and broader belt of alder and willow swamp. Beyond this, between the brush and the mountains, is a stretch of meadow land, thousands of acres in extent, which at the time of our stay was mostly flooded with water. Below my camp, bordering the river, were stretches of meadows that were comparatively dry. Across the river are thousands of acres of willow and alder swamp, impossible to penetrate. The mountains rise abruptly on either side of the valley, and are almost barren of timber of any sort.

We remained here from September 4 to 28 . The first four days in September were bright and sunshiny, but beginning on the 5th it rained steadily during the remainder of our stay. Toward the end of September it turned much colder, and there were several snow flurries. At the base of the mountains there were deep snow banks that had evidently remained throughout the summer. I left Juneau for home on October 1, but on October 13 Hasselborg returned to the Taku for another hunt. Continued inclement weather made the trip a failure, although he saw several mountain goats. He also saw twelve-inch tracks of what was probably a grizzly, as well as sign of several black. bear. 


\section{GAME COVE, ADMIRALTY ISLAND.}

Near Marsden Point, Admiralty Island, near the north end of Chatham Strait. Hasselborg spent several days here the middle of November.

\section{FRESHWATER BAY, CHICHAGOF ISLAND.}

On the eastern shore of Chichagof Island. IIasselborg was here a month, from November 12 to December 12, and collected a series of deer, as well as some small birds and mammals. In his notes he remarks that at the time of his arrival there were two big brown bear (Ursus sitkensis?) still out, and on November 13 he shot at one but lost the track in the falling snow. I mention this as of interest as indicating the approximate date for going into hibernation. No tracks were seen at a later date. The weather was severe at this time, with north winds and heavy snow fall. Three feet of snow covered the ground at tidewater when he left.

\section{CHECK-LIST OF THE BIRDS.}

1. Colymbus holboelli (Reinh.)

2. Colymbus auritus Linn.

3. Gavia immer (Brünn.)

4. Gavia pacifica (Lawr.)

5. Gavia stellata (Pont.)

6. Lunda cirrhata (Pall.)

7. Cerorhinca monocerata (Pall.)

8. Synthliboramphus antiquus (Gmel.)

9. Brachyramphus marmoratus (Gmel.)

10. Cepphus columba Pall.

11. Uria troille californica (Bryant)

12. Larus glaucescens Naum.

13. Larus argentatus Pont.

14. Larus brachyriynchus Rich.

15. Larus philadelphia (Ord)

16. Sterna paradisaea Brünn.

17. Phalacrocorax pelagicus Pall.

18. Mergus americanus Cass.

19. Mergus serrator Linn.
20. Anas platyrhynchos Linn.

21. Nettion carolinense (Gmel.)

22. Dafila acuta (Linn.)

23. Marila marila (Linn.)

24. Clangula clangula americana Bonap.

25. Charitonetta albeola (Linn.)

26. Harelda hyemalis (Linn.)

27. Histrionicus histrionicus (Linn.)

28. Oidemia americana Swains.

29. Oidemia deglandi Bonap.

30. Oidenia perspicillata (Linn.)

31. Chen hyperboreus (Pall.)

32. Anser albifrons gambeli Hartl.

33. Branta canadensis occidentalis (Baird)

34. Ardea leerodias fannini Chapm.

35. Grus canadensis (Linn.)

36. Lobipes lobatus (Linn.)

37. Gallinago delicata (Ord) 
38. Macrorhamphus griseus scolopaceus (Say)

39. Arquatella maritima couesi Ridgw.

40. Pisobia maculata (Vieill.)

41. Pisobia bairdi (Coues)

42. Pisobia minutilla (Vieill.)

43. Pelidna alpina sakhalina (Vieill.)

44. Ereunetes pusillus (Linn.)

45. Ereunetes mauri Cab.

46. Totanus melanoleucus (Gmel.)

47. Totanus flavipes (Gmel.)

48. Helodromas solitarius cinnamomeus (Brewst.)

49. Heteractitis incanus (Gmel.)

50. Actitis macularius (Linn.)

51. Squatarola squatarola (Linn.)

52. Aegialitis semipalmata (Bonap.)

53. Aphriza virgata (Gmel.)

54. Arenaria melanocephala (Vig.)

55. Haematopus bachmani Aud.

56. Dendragapus obscurus fuliginosus (Ridgw.)

57. Canachites franklini (Dougl.)

58. Lagopus rupestris dixoni Grin.

59. Circus hudsonius (Linn.)

60. Accipiter velox (Wils.)

61. Astur atricapillus striatulus Ridgw.

62. Buteo borealis alascensis Grin.

63. Archibuteo lagopus sanctijohannis (Gmel.)

64. Haliaeëtus leucocephalus alascanus Towns.

65. Falco columbarius columbarius Linn.

66. Falco sparverius sparverius Linn.

67. Pandion haliaëtus carolinensis (Gmel.)

68. Asio wilsonianus (Less.)

69. Asio flammeus (Pont.)

70. Cryptoglaux acadica scotaea (Osgood)

71. Bubo virginianus saturatus Ridgw.
72. Ceryle alcyon caurina Grin.

73. Dryobates villosus harrisi (Aud.)

74. Dryobates pubescens glacialis Grin.

75. Picoides americanus americanus (Swains.)

76. Sphyrapicus varius ruber (Gmel.)

77. Colaptes cafer saturatior Ridgw.

78. Cypseloides niger borealis (Kennerly)

79. Chaetura vauxi (Towns.)

80. Selasphorus rufus (Gmel.)

81. Nuttallornis borealis (Swains.)

82. Myiochanes richarasoni richardsoni (Swains.)

83. Empidonax difficilis Baird

84. Empidonax trailli alnorum Brewst.

85. Pica pica hudsonia (Sab.)

86. Cyanocitta stelleri stelleri (Gmel.)

87. Corvus corax principalis Ridgw.

88. Corvus brachyrhynchos caurinus Baird.

89. Euphagus carolinus (Müll.)

90. Pinicola enucleator flammula Homeyer

91. Lo:cia americana sitkensis Grin.

92. Loxia leucoptera Gmel.

93. Acanthis linaria linaria (Linn.)

94. Spinus pinus (Wils.)

95. Plectrophenax nivalis nivalis (Linn.)

96. Calcarius lapponicus alascensis Ridgw.

97. Passerculus sandwichensis sandwichensis (Gmel.)

98. Passerculus sandwichensis savanna (Wils.)

99. Zonotrichia leucophrys gambeli (Nutt.)

100. Zonotrichia coronata (Pall.) 
28 University of California Publications in Zoology. [Von. 7

101. Spizella monticola ochracea Brewst.

102. Junco hyemalis hyemalis (Linn.)

103. Junco oreganus oreganus (Towns.)

104. Melospiza melodia rufina (Bonap.)

105. Melospiza melodia caurina Ridgw.

106. Melospiza lincolni gracilis (Kittl.)

107. Passerella iliaca insularis Ridgw.

108. Passerella iliaca townsendi (Aud.)

109. Piranga ludovnciana (Wils.)

110. Hirundo erythrogaster palmeri Grin.

111. Iridoprocne bicolor (Vieill.)

112. Tachycineta thalassina lepida Mearns.

113. Riparia riparia (Linn.)

114. Bombycilla cedrorum Vieill.

115. Lanius borealis invictus Grin.

116. Vermivora celata celata (Say)

117. Vermivora celata lutescens (Ridgw.)

118. Dendroica aestiva rubiginosa (Pall.)
119. Dendroica coronata hooveri MeGregor

120. Denaroica striata (Forst.)

121. Denaroica townsendi (Towns.)

122. Oporornis tolmiei (Towns.)

123. Geothlypis trichas occidentalis Brewst.

124. Wilsonia pusilla pileolata (Pall.)

125. Anthus rubescens (Tunst.)

126. Cinclus mexicanus unicolor Bonap.

127. Nannus hiemathe pacificus (Baird)

128. Certhia familiaris occidentalis Ridgw.

129. Sitta canadensis Linn.

130. Penthestes rufescens rufescens (Towns.)

131. Regulus satrapa olivaceus Baird

132. Regulus calendula grinnelli Palmer

133. Hylocichla ustulata ustulata (Nutt.)

134. Hylocichla guttata nana (Aud.)

135. Planesticus migratorius caurinus Grin.

136. Ixoreus naevius naevius (Gmel.)

137. Sialia currucoides (Bechst.)

GENERAL ACCOUNTS OF THE BIRDS: DISTRIBUTION, MOLT, VARIATION, BIOGRAPHICAL NOTES.

Colymbus holboelli (Reinhardt). Holboell Grebe.

Several seen at Three-mile Arm, Kuiu Island, April 25 to May 6; scattered individuals observed about Prince of Wales Island at Port Protection, Calder Bay, and Sea Otter Sound. These all appeared to be migrants, and they were at all times very wild, usually taking flight when the launch was still several hundred yards distant. None were seen after leaving Heceta Island, May 24. 
Colymbus auritus Linnaeus. Horned Grebe.

Although the expedition of 1907 did not observe this species at all in the northern part of the Alexander Archipelago, it proved to be a very common migrant on the bays and channels of the more southern islands. First seen at Three-mile Arm, Kuiu Island, on April 28, and observed daily thereafter in rapidly increasing numbers. It was common at Port Protection, Prince of Wales Island, generally in flocks of six or eight; and, at Calder Bay, at the same island, it was abundant, May 10 to 14. No horned grebes were seen in the open sea nor about the outlying islands (Coronation and Warren), during the ensuing two weeks; and when we returned to the more sheltered waters of Prince of Wales, on May 23, they had apparently all passed on to their breeding grounds. The only subsequent occasion on which the species was observed was at Thomas Bay, on August 22, when a single individual, apparently still in the breeding plumage, was flushed from a little slough on the tide flats.

The horned grebes never attempted to escape by diving, when unwounded, but invariably took to their wings, rising from the water with but little more effort than that exerted by the diving ducks.

Four specimens were secured. A female shot at Three-mile Arm, April 29 (no. 9906) is in complete nuptial plumage, except for some white feathers on the chin and upper breast, which, in this individual, might not be molted at all. Another, taken on April 30 (no. 9907) is but beginning to lose the winter plumage, a few scattered red feathers on the throat, and black ones about the head, marking the beginning of the change. A male secured at Three-mile Arm on May 6 (no. 9908), and another from Calder Bay, May 13 (no. 9909), are both in perfect summer plumage.

Gavia immer (Brünnich). Common Loon.

Fairly common, and apparently generally distributed throughout the Alexander Archipelago. At Kuiu Island, April 25 to May 6, the species was abundant, gathered in large flocks 
and feeding on the spawning herring. An adult specimen shot at this point disgorged about two dozen herring. Individuals were seen during the summer at nearly every point visited, and the loud uncanny call peculiar to the species was heard almost daily, so it probably breeds throughout the region, though no nests were found nor young ones observed. Most of the birds seen were feeding, either singly or in pairs, in deep water.

In the large flocks observed early in May the individuals in the plain, immature plumage greatly outnumbered those in adult or summer plumage, and it seems possible that many non-breeding birds retain the winter garb throughout the year. These plain colored birds had conspicuously lighter colored bills than the others; several were pursued and killed, in the belief that they might be Gavia adamsi.

\section{Gavia pacifica (Lawrence). Pacific Loon.}

A small loon with conspicuously grayish head, presumably this species, was frequently seen, sometimes in numbers, at various places during the summer. At Three-mile Arm, Kuiu Island, they formed a large part of the flocks seen feeding on the herring, and they were subsequently seen in the bays and channels around Prince of Wales and Dall islands, and at various points along Clarence Straits, Frederick Sound, and Stephens Passage.

\section{Gavia stellata (Pontoppidan). Red-throated Loon.}

The red-throated loon was positively identified at but very few points. At Kuiu Island a number were seen in the large flocks of loons observed at that place; at San Alberto Bay, Prince of Wales Island, several were seen; and at Duke Island, June 7-9, one or two were heard calling.

Loons of some species were seen from the launch the whole summer through, as we travelled from place to place, but they were invariably very wild, diving when we were still far away, and almost never permitting us to approach within gunshot. Consequently we were frequently quite unable to identify the birds seen. 


\section{Lunda cirrhata (Pallas). Tufted Puffin.}

Seen only on Warren Channel, where, on May 23, several. were observed feeding in the tide rips in the vicinity of Whalehead Island. A single specimen secured here at this time (no. 9917, female) is in a peculiar stage of plumage, considering the time of year. It is a bird of the previous year at least, but evidently was not breeding. It was extremely emaciated, suggesting the possibility of its diseased condition causing some irregularity in the molt.

In appearance this bird is as follows: Above glossy black. Sides of head and neck, throat, upper breast, and sides, slaty black, this area rather sharply defined against the lighter colored ventral surface. Lower breast and abdomen white, the feathers tipped with slate gray, a few scattering ones tipped with dull black. Flanks and crissum, slate gray. Lower tail coverts black tipped. On the side of the head there is a line of exceedingly narrow, plume-like feathers (no longer than the rest of the plumage however), dirty whitish in color, beginning just over the eye, and extending backward $35 \mathrm{~mm}$. The bill, in size and shape, is practically like the illustration of the juvenal in winter figured by Stejneger (1885, plate II, fig. 3).

As seen from the above description, the general appearance of this bird (except for the bill) is much like that of some examples of Cerorhinca monocerata.

\section{Cerorhinca monocerata (Pallas). Rhinoceros Auklet.}

This species does not seem to venture farther into the sheltered channels than the swell of the open sea extends; we saw it only along the coasts of the more exposed western islands. Two were seen off Cape Decision, Kuiu Island, on May 18, a number were observed in Warren Channel on May 19 and 23 , and they were quite common along the west coast of Dall Island, June 4 to 6 .

Three specimens were secured (nos. 9903-9905), all in full breeding plumage. 


\section{Synthliboramphus antiquus (Gmelin). Ancient Murrelet.}

Quite common in a few places on the west side of the islands. Large, scattered flocks were encountered feeding in the tide rips in Warren Channel (between Warren and Kosciusko islands) on May 19 and 23; many were seen in various bays on the northwest coast of Dall Island, May 30 to June 4, as well as in the open sea all along the west coast of Dall Island. On June 6 we passed through numerous flocks at the northern extremity of Dall Island, where they were feeding in the swiftrunning water of the extremely narrow channel at that point; also at Cordova Bay, at the southern extremity of Prince of Wales Island. On June 7, while crossing Clarence Straits between Prince of Wales and Duke islands, more were observed than at any other place, but as soon as the sheltered waters about the latter island were reached they were no longer to be seen. The preference evinced for the open sea was very marked, and not a single individual was seen at any time in the sheltered waters of the inner passages.

On June 7, while we were passing through numerous large flocks, the sea was unusually clear and smooth, and by standing in the bow of the launch, I had frequent opportunity to observe how the murrelets used their wings under the water. When diving they make a sudden flirt of the wings that can be seen at quite a distance, but it was not until several individuals had passed close under the boat that I could see, as was plainly apparent, that they used their wings continually. They were literally flying under the water, but the manus was held about parallel with the body, and not outstretched, as when going through the air.

Though we were quite unable to discover where the nesting grounds were located, this bird was evidently breeding somewhere in the vicinity of Dall and Prince of Wales islands; for most of the females secured had laid their sets, as was apparent from the condition of the oviduct, while these females and also the single male secured, had each two denuded spots on the abdomen, the size and shape of an egg, evidently for the reception of the two eggs during incubation. 
The nine specimens secured (nos. 9891-9899), eight females and one male, vary a great deal in plumage, principally in the markings about the head and neck. A breeding female (no. 9899) has hardly a trace of the slender white plumes on the sides of the head and neck, and while the outline of the black throat patch is indicated, it is composed more than half of white or gray-tipped feathers. There are but a few scattered glossy black feathers in the ashy gray sides and flanks. But two in the series (nos. 9892, 9895) are in what appears to be perfect nuptial plumage, the others being variously intermediate between the extremes.

Brachyramphus marmoratus (Gmelin). Marbled Niurrelet.

By far the most common and most universally distributed species of water bird met with in the region. It was seen, frequently in large numbers, practically everywhere we went, except out on the open sea. Here, where the ancient murrelet appeared, the present species was lost sight of, and it seems evident that, in some respects, the requirements of the two species are totally different.

Three specimens were secured. A male shot on Frederick Sound, April 10 (no. 9900), still retains the winter plumage in its entirety, and other gray-colored individuals were seen as late as May 23, though some of these may have been young birds. An adult male taken at the southern extremity of Kuiu Island on May 18 (no. 9901), is still entirely in the winter plumage; but on dissection it proved to be a non-breeding bird, and, further the left carpus had been broken, and though the bone had healed perfectly the bird was greatly emaciated; it is possible that its general health had suffered so that it did not go through the molt at the usual time. The third specimen, also an adult male, taken in Sea Otter Sound, Prince of Wales Island, on May 23 (no. 9902), is in perfect summer plumage, the dorsal feathers being so broadly tipped with chestnut as to cause the back to appear almost uniformly of that color.

Cepphus columba Pallas. Pigeon Guillemot.

This species was generally distributed throughout the region explored, but except in one or two favored localities did not 
appear to be at all common. Nore were seen in the vicinity of Shakan and Calder Bay, Prince of Wales Island, May 10 to 14 , than at any other one point. The birds were in loose, widely scattered flocks, though some pairs were observed. Many appeared to be still in the winter, or gray plumage. Pigeon guillemots were seen at most of the points we visited, but usually there were not more than a pair or two in a bay or harbor.

\section{Uria troille californica (Bryant). California Murre.}

The only place where any murres were seen was along the west coast, and about the north end, of Dall Island, NIay 30 to June 6. Here they were fairly abundant, feeding in the turbulent waters near the shore, and doubtless breeding on the rugged rocks and ledges that line this inhospitable coast. Like the ancient murrelet this species appears to shun the more sheltered straits and channels between the islands, and except for a few individuals seen at the north end of Dall Island, just inside Meare's Passage, none were noted in any of the inner channels.

Larus glaucescens Naumann. Glaucous-winged Gull.

This, the most common gull of the region, was generally distributed and seen in numbers practically everywhere. Large flocks followed in the wake of the steamer on the way north from Seattle in the spring, and again going south from Juneau in the fall. During the sumper there was hardly a day when individuals were not seen, and in some localities ther were gathered in enormous flocks, frequently in company with other species of gulls. Sometimes, out in the broad channels, a flock would be encountered feeding on schools of herring or other small fish; or at times, as at Bradfield Canal, Zarembo Island, and Thomas Bay, flocks of hundreds would be gathered on the mud flats at low tide.

Fewer were seen from about the middle of May to the end of July-presumably the breeding scason-than at any other time, and it seems probable that the principal nesting grounds of the species lie somewhere outside the region we traversed. No breeding colony was discovered, and apparently many of the 
birds seen during the summer were non-breeders; for individuals, distinguished by some peculiarity of color or form, were known to stay in the vicinity of a camp day after day without wandering off to any great distance.

Individuals seen at Zarembo Island, Mitkof Island, and Thomas Bay, from the middle of July to about the end of August, were in the midst of the molt, and were very ragged in appearance.

\section{Larus argentatus Pontoppidan. Herring Gull.}

Evidently not a common species, and seen at but a very few points. Several individuals were observed following the steamer from time to time between Seattle and Juneau, April 4 to 9 , and others were seen in the harbors at Ketchikan, June 15, at Wrangell, July 26, and at Juneau, September 2 and 29. These were all birds in various stages of the immature plumage, and they were nearly all ragged and dirty in appearance. On the Taku River, September 4 to 28, a flock of gulls, including about a dozen of this species, remained around an Indian fishing camp by the river, where they shared with the crows and ravens the refuse thrown out.

Larus brachyrhynchus Richardson. Short-billed Gull.

In going north in the spring the short-billed gull first appeared about the steamer while we were crossing Queen Charlotte Sound, on April 6, and from then on until Juneau was reached many individuals remained in the wake of the boat. At Three-mile Arm, Kuiu Island, April 25 to May 6, the species was more abundant than at any other point visited; in fact it was subsequently observed at but few places and in very limited numbers. It was next seen at Bradfield Canal, July 18 to 26, where it was fairly common, feeding on the tide flats in company with Larus glaucescens and $L$. philadelphia. On the beach at Mitkof Island small numbers were feeding on the mud in the same association. At Thomas Bay, August 13 to 23, shortbilled gulls were fairly abundant, but the birds seen were very ragged in appearance, evidently in the midst of the post-nuptial inolt. 
One specimen was preserved (no. 9918), a female shot at Three-mile Arm, Kuiu Island, on April 26. It is not in the adult summer plumage, but in the stage described by Coues as "approaching maturity" (1903, p. 991), with all but the first two primaries lacking the white sub-apical spot, the "mantle" of a paler blue, and many of the lesser wing coverts edged with gray or brownish. It is undergoing molt about the head and throat.

\section{Larus philadelphia (Ord). Bonaparte Gull.}

First seen at Three-mile Arm, Kuiu Island, on April 30, when a flock of about a dozen passed overhead, flying in a compact body. On the evening of May 3, at the same place, several appeared near the launch, circling about over the surface of the bay. Their manner of feeding is to fly slowly back and forth, some three or four feet above the water, frequently dipping down and picking up something without checking their flight. Many were seen hawking over the water in this manner, and it seems to be characteristic of the species, for I have observed them feeding thus in southern California, and on the lakes in northern Illinois.

It was not met with elsewhere during the spring migration, and was next seen on the evening of June 16, when a large flock was encountered in Behm Narrows, at the north end of Revillagigedo Island. On June 28 a flock of a hundred or more was seen in Behm Canal, between Portage Cove and the mouth of the Chickamin River, and three specimens were secured. All of these birds were in various stages of the immature plumage, and the flock included none with black heads. Scattered individuals were seen on July 4, all along Behm Canal; and, at Bradfield Canal, July 18 to 26 , the species was very abundant on the mud flats. From then on it was met with nearly everywhere. On Mitkof Island, August 1 to 13, it was abundant along the beach, in large flocks; at Thomas Bay, August 13 to 23, it was exceedingly abundant on the broad expanse of mud flats exposed by the receding tide; at Port Snettisham, August 24 to September 2 , it was seen daily though not in large numbers; and 
on the Taku River, September 2 to 28 , it was occasionally observed flying along the stream.

The large flocks met with in June, at least, must have been composed of birds that were not breeding that year. They were, as already noted, in the immature plumage, with black barred tail and white head, but they were all evidently birds at least a year old. One specimen (no. 9887, Behm Canal, June 28) has a good many black feathers on the head, and has some of the rectrices pure white and others black tipped. In other words it is about intermediate between the ordinary first winter (immature) plumage, and that of the summer adult, so it may be taken as evidence that, in some cases at least, more than one year is required to attain the perfect adult plumage. This bird is undergoing molt about the head, but the newly appearing feathers are all pure white. The large flocks seen at Bradfield Canal (July 18 to 26 ) contained many individuals with black heads, and one of these secured (no. 9888, July 22) proved to be in worn nuptial plumage, with, as yet, no indication of the beginning of the post-nuptial molt. Other individuals in the same flocks were in the plumage usually worn by adults in the winter, of which the pure white tail is in life the most conspicuous feature distinguishing it from the immatures. All of this is rather confusing, for in the same flocks, at the same time, were to be seen birds (1) in perfect nuptial plumage, (2) in first winter plumage, and (3) in second winter plumage.

A young female (no. 9889), shot at Mitkof Island on August 4, is in the juvenal plumage, as described by Dwight (1901, p. 56), with brown upper parts (erown, neck and dorsal region), and brownish wash on the sides of the neck and breast. There is a specimen in the Grinnell collection (no. 1345, $\sigma^{\lambda}$ Sitka, Alaska; July 21, 1896) in similar plumage but with more brown above, and the brownish wash extending quite across the breast. These dark backed juvenals were seen occasionally at Mitkof Island, August 1 to 13, and they were quite common at Thomas Bay, August 13 to 23; but I have never seen this plumage represented in the flocks that appear on the coast of southern California in the fall; it is probably molted before the birds go south. 


\section{Sterna paradisaea Brünnich. Arctic Tern.}

A single specimen, an adult female, secured in Bradfield Canal on July 26 (no. 9890). Many arctic terns were seen in Frederick Sound, near Thomas Bay, on August 13; and the species was fairly common at the head of Thomas Bay, August 13 to 23 , feeding in company with the numerous gulls seen at this point.

\section{Phalacrocorax pelagicus Pallas. Pelagic Cormorant.}

Generally distributed through the region, and in places quite abundant. Probably more were seen about Kupreanof Island, and in the bays and channels on the west side of Prince of Wales Island than anywhere else, but at least a few individuals were observed at nearly every point we visited. At the north end of Kupreanof Island numerous large flocks were encountered on the evening of April 10, flying in to roost on some rocky islets.

Individuals with and without the conspicuous white flank patches were seen throughout the summer, sometimes in the same flocks. The single specimen preserved (no. 7215, Kupreanof Island, April 10) is an adult female in breeding plumage, with large white flank patches. This bird at the time of capture had many long, slender white plumes scattered over the glossy purple plumage of the neck, and some on the interscapulars, but these feathers seemed to be very brittle and easily broken, and in the manipulation necessary to the proper preservation of a greasy skin a large proportion of those on the neck and all on the back, were lost. Of the available specimens in nuptial plumage (five in the Museum collection, and two in the Grinnell collection) but a single bird (no. 1343 coll. J. Grinnell, Sitka, Alaska, July 16, 1896) shows any trace of white plumes on the back. These might be lost in the natural process of abrasion, or else in the preparation of the specimen, but in the freshly killed bird they are very conspicuous, while they are evidently entirely lacking in most museum specimens. 


\section{Mergus americanus Cassin. American Merganser.}

Though several species were far more abundant in places, there was no other duck so generally distributed throughout the region explored, for American mergansers were seen, in greater or less numbers, at every point we visited. At Kupreanof and Kuiu islands, during April, they were fairly numerous and still in flocks, though at the end of the month they began to pair off. At Coronation and Warren islands (May 12 to 23) pairs of American mergansers were seen daily, while the species was quite common at all the various points touched at along the west coast of Prince of Wales Island between May 6 and 29. At San Alberto Bay (May 24 to 26) a female was several times seen flying into a clump of trees by the water's edge where there were several dead stubs, and in one of these she probably had a nest, though I was unable to find it. Comparatively few were seen along the unsheltered western coast of Dall Island, but when we reached the head of Boca de Quadra, we found them again in large numbers. On the Chickamin River (June 17 to 28) the first broods of young were seen. Later on, during July, flocks of young birds were observed at Revillagigedo, Etolin, Wrangell and Zarembo islands, and at Bradfield Canal on the mainland; while both at Mitkof Island and Thomas Bay (August 1 to 23) the species was fairly common. On the Taku River, during September, many American mergansers were seen flying along the stream, usually in flocks of ten or twelve, each flock probably composed of a single family.

Several interesting peculiarities of the species were noted. On Kuiu Island, April 28 (and on several subsequent occasions) numerous individuals were observed feeding in a manner that was entirely new to me as far as this group of ducks is concerned. I was concealed in the shrubbery at the water's edge examining a large flock of ducks for possible rarities, when a dozen or more mergansers (both $M$. americanus and $M$. serrator) began swimming back and forth but a very short distance from my blind. They swam slowly, with neck outstretched, and with the bill held just at the surface of the water, and at a slight angle, so 
that the head was submerged about to the level of the eyes. The water was evidently filtered through the bill, as a slight "gabbling" noise was quite audible, and obviously something was being retained as food, though just what it was I could not tell. This is rather remarkable, as it is exactly the manner of feeding usually employed by the shoveller (Spatula clypeata), a species which, as regards bill structure, is further removed from the mergansers than any other member of the Anatidae. In the hroad bill of the shoveller the lamellae have developed into a whalebone-like structure, perfectly adapted to the sifting of small objects from the water which is passed through the bill; while in the mergansers they have assumed the appearance and function of teeth, to detain the slippery fish which are the usual food of these birds.

A peculiar habit which made this species quite conspicuous throughout the summer, was that of individuals rising high in the air and circling about for hours at a time, uttering at frequent and regular intervals a most unmelodious squawk. Both sexes were observed doing this, and the habit was kept up until about the end of August.

The numerous broods of young that were seen made their escape, not by diving, but by flapping along the surface of the water, in which manner they progressed somewhat faster than one can row a boat. The mother always herded them in front of her, seldom attempting to take flight unless the danger was imminent. On several occasions an old merganser was seen floating gently down a stream, with may be half a dozen downy young surrounding her, and with three or four perched upon her back.

But one specimen was secured, a young one in the down (no. 7678), on the Chickamin River, June 20.

Mergus serrator Linnaeus. Red-breasted Merganser.

At Three-mile Arm, Kuiu Island, from April 25 to May 6, the red-breasted merganser was fairly abundant, usually in small flocks of from three to six; and on May 11 three individuals were seen at Calder Bay, Prince of Wales Island. 
Anas platyrhynchos Linnaeus. Mallard.

By far the most abundant species of fresh-water duck in southeastern Alaska. Flocks of mallards were seen from the steamer in Wrangell Narrows on April 8; and they were exceedingly abundant about Kupreanof and Kuiu islands, April 10 to May 6. At this time the flocks usually frequented the heads of the numerous little bays and inlets, where they were feeding on the fish spawn in the shallow water. A few mallards were seen at Coronation Island, and at the various points visited along the west coast of Prince of Wales and Dall islands; but they were almost invariably single drakes which acted much as though their mates were on the nest somewhere near by. Very few were seen at any of the more southern mainland points visited, and they did not again become common until Thomas Bay was reached. At this place (August 13 to 23), they were abundant, in small flocks of ten or twelve, feeding in the numerous ponds and streams which intersected the meadows and tide-flats in all directions. At Port Snettisham also (August 24 to September 2), mallards were abundant, feeding in tideflooded meadows, where the grass stood nearly waist high. On the Taku River, in September, a few flocks were seen, but they were not numerous.

Two adult males secured at Kupreanof Island, April 14 and 15 (nos. 9910, 9911) are in perfect nuptial plumage, and present no obvious points of difference from the few more southern breeding birds available for comparison. A male bird, presumably adult (no 9912), taken at Port Snettisham on August 31, is just molting from the summer eclipse plumage. The body is much the same as in other male birds, but the whole head and neck is streaked and speckled with brown with but a few scattered green feathers. Other male birds, shot about the same time but not preserved, were indistinguishable from females in their markings, and the sex could only be determined by dissection. These I took to be birds of the year, still in the immature plumage. Ducks shot at this time were all excessively fat, and as they were also molting, and covered with pin feathers, it was almost impossible to preserve specimens. 


\section{Nettion carolinense (Gmelin). Green-winged Teal.}

First observed at Kuiu Island on April 28, when they were apparently just arriving from the south. During the following week they increased in numbers daily, and when we left the place (May 6), they were quite abundant, usually seen feeding in company with the mallards at the heads of the bays. The species was not seen again until we reached Thomas Bay on August 13. At this place many small flocks of six or eight individuals were flushed from the sloughs and streams. A few flocks were seen on the Taku River in September, but at this time they were evidently leaving for the south; one was shot as late as September 26.

Two adult females (nos. 9913, 9914), secured at Thomas Bay on August 18, and in newly acquired autumnal plumage, have the under parts slightly stained with rusty, in the same manner as some of the water birds from the Prince William Sound region, as already reported upon by Grinnell (1910, p. 365).

\section{Dafila acuta (Linnaeus). Pintail.}

At Kuiu Island, the only place where the species was observed, a few migrating flocks were seen from April 25 to May 6.

\section{Marila marila (Linnaeus). Greater Scaup Duck.}

Small flocks of blue-bills were seen at many of the places visited. At Kake Village, on the morning of April 11, several flocks were noted in the bay. At Kuiu Island, April 25 to May 6, some were seen daily, usually in company with the scoters. At Calder Bay, Prince of Wales Island, several flocks were seen on May 11 and 13. A single drake was observed at the head of Marten Arm, Boca de Quadra, on June 14; and, at Thomas Bay, August 13 to 23, one or two flocks were seen feeding in the open waters of the bay.

It may be that Marila affinis also was seen, and that both species are included in the above summary, for no specimens were secured at any time. The blue-bills were conspicuously wary and unapproachable, feeding in open water, where there 
was no possibility of approaching unseen, and never allowing the launch to come within gunshot.

Clangula clangula americana Bonaparte. Golden-eye.

During the month of April golden-eyes were quite common in the Keku Straits and at Three-mile Arm, Kuiu Island. At Port Protection, Prince of Wales Island, they were seen daily from May 6 to 10, though usually not more than three or four together; and a few were also observed at Calder Bay, May 11 to 13 , where one was shot, but not preserved.

The species was not detected again until June 21, when Hasselborg reported seeing an old female with a brood of downy young, at a point ten or twelve miles up the Chickamin River. In an Indian camp at the head of Boca de Quadra I saw some young ducks which the women were keeping as pets, and which may have been of this species. They cannot breed commonly in the region, however, or some individuals would surely have been seen among the numbers of ducks which began to appear toward the end of August.

Charitonetta albeola (Linnaeus). Buffle-head.

During April and May buffle-heads were very common in all the bays and in the more sheltered channels. At Kupreanof and Kuiu islands they were abundant, on Prince of Wales they were seen in numbers at Port Protection and at Calder Bay, and many small flocks were observed about Coronation and Warren islands. After leaving the latter island (May 23) they were no longer seen, nor did any appear during the southward migration in August and September.

The preponderance of males in this species was very noticeable, and nearly all of the small flocks were composed of several drakes and but one or two females. The drakes were constantly exhibiting their plumage and competing for the favor of the females; sometimes when several were fighting together furiously the single female of the flock would quietly fly away and leave them, to be presently followed by the whole gathering as soon as her defection was discovered. 
Harelda hyemalis (Linnaeus). Old-squaw.

An exceedingly common species in the spring, during April and May. Several flocks were seen at Kake Village on the morning of April 11, and in the waters about Kupreanof and Kuiu islands old-squaws were in sight almost constantly. Many were also seen about the north end of Prince of Wales Island, at Port Protection and Calder Bay. At the latter place they were particularly numerous, flocks of hundreds streaming past the launch. At Coronation Island they were fairly abundant, and many were seen about Heceta Island on May 23. None were observed anywhere after that date. The loud, peculiar call-note of the old-squaw could be heard from morning to night while the birds were around.

Histrionicus histrionicus (Linnaeus). Harlequin Duck.

Quite generally distributed through the region we traversed, though nowhere as numerous as were some of the other species. About Kupreanof and Kuiu islands it was fairly common, in flocks of eight or ten, and at Port Protection, Prince of Wales Island, it was seen daily from May 6 to 10 , though not in great numbers. At Coronation Island many were seen feeding among the rocks at the water's edge, and were very tame and easily approached. The species was probably more abundant at Marten Arm, Boca de Quadra, than at any other point, and here also the birds were noticeably tame. At this time, June 9 to 14 , they were all in pairs, but usually two or three pairs seemed to stay together. Here they were generally observed feeding in the swift-flowing streams. A great many were seen at the mouth of Portage Cove, Revillagigedo Island, June 28 to July 4.

Oidemia americana Swainson. American Scoter.

Apparently the least abundant species of scoter in the waters of southeastern Alaska. None were positively identified in the large flocks of sea ducks seen about Kuiu Island, and the species was first met with certainly at Calder Bay, Prince of Wales Island, May 30. They were fairly common about the north end of Dall Island during the first week in June, but after leaving 
this place none were observed until we reached Etolin Island, where a few were seen. Many flocks were encountered in Frederick Sound, near Thomas Bay, on August 13.

Oidemia deglandi Bonaparte. White-winged Scoter.

Seen at almost every point visited, sometimes in large numbers. In the channels between Kupreanof and Kuiu islands, during April, they were quite abundant, as also along the west coast of Prince of Wales Island in May; but by the end of May their numbers had greatly diminished. Probably the breeding birds had all gone farther north by that time; the many small flocks seen at various points during June and July were in all probability non-breeding birds. By the end of July they had vastly increased, so that flocks of hundreds were encountered in the channels, and throughout August and September they remained equally abundant.

Oidemia perspicillata (Linnaeus). Surf Scoter.

An abundant species throughout the region. They were exceedingly numerous about Kuiu Island in April, and about Prince of Wales in May. Though some were seen during the summer, they were not abundant and were probably all nonbreeding birds, as they remained gathered in flocks. By the end of July their numbers were again on the increase, and in August and September enormous flocks were seen everywhere on the salt water.

At Kuiu Island, about the first of May, they were beginning to pair off, and the courting antics of the males were curious to observe. Vast numbers were feeding close to shore, in the shallow water, and the drakes were continually on the move, flying a few yards and then sliding for eight or ten feet upon the surface of the water, with the wings held stiffly extended above the body.

\section{Chen hyperboreus (Pallas). Snow Goose.}

Flocks of white geese, presumably of this species, were seen on several occasions flying high overhead, along the Taku River, September 17 to 28. They were evidently migrating south, and none were seen to alight anywhere in the vicinity. 
Anser albifrons gambeli Hartlaub. American White-fronted Goose.

At Kupreanof Island on April 21, and on Kuiu from April 25 to May 6 , flocks of white-fronted geese were seen flying northward, their different call-note serving to distinguish them from the hordes of geese of the canadensis group which were passing over at the same time. They were all flying high, and none were seen to alight anywhere.

Branta canadensis occidentalis (Baird). White-cheeked Goose.

An abundant species throughout the summer at practically every place we visited that was at all suited to their wants. At Kupreanof and Kuiu islands, April 11 to May 6, flocks of migrating geese passed overhead daily, and the majority of them appeared to be of this group, while numbers were seen feeding at various places about the islands. None were observed at either Coronation or Warren Island, but all along the west coast of Prince of Wales and Dall islands, in May, they were quite abundant, and nearly all in pairs. One pair was seen on Duke Island, June 7 to 9 , and the birds were abundant at the head of Boca de Quadra, June 9 to 14, where they were still gathered in large flocks. A brood of young ones seen by Hasselborg on the Chickamin River, June 21, were about the size of mallards. A few were observed on Revillagigedo Island at the end of June, but the species was not again met with in numbers until Thomas Bay was reached, August 13, probably because the places visited in the meanwhile were but poorly adapted to the wants of the species. Last seen on the Taku, where but few were observed in September.

A single specimen was preserved (no. 9916) an adult female shot at Thomas Bay on August 14. This bird is in the midst of the molt, with many of the tail feathers missing and with many pin-feathers, but it is essentially like the birds secured on Admiralty Island by the expedition of 1907 . The tone of coloraation of the underparts is somewhat lighter, due to the fact that it is more thinly feathered and the slaty bases of the feathers more exposed, while in full plumaged birds it is the dark tips 
of the feathers that produces the general color effect. There is no white half-collar at the base of the neck, and but a few black spots interrupting the continuity of the white cheek patches across the throat.

As Grinnell (1910, p. 373) has already pointed out, the geese of the Sitkan district do not at all accord with the descriptions of occidentalis as currently given. It seems evident either that a few abnormal birds have been taken as typical of the form, or else that the geese of southeastern Alaska constitute a race, separate and distinct from the four varieties already recognized by name. Occidentalis is said to range "south to California in winter." I have examined hundreds of geese in the California markets, but have yet to see a large goose with a white half-collar at the base of the neck, and with a black line dividing the white cheek patches, supposedly the distinguishing characters of this subspecies.

Ardea herodias fannini Chapman. Northwestern Blue Heron.

More great blue herons were seen in the Keku Straits, and on the beaches of Kupreanof Island, April 11 to 24, than at any other place, and probably not more than six or eight birds in . all were observed at these points. The species was decidedly rare everywhere else, sometimes weeks passing without a single one being seen. One or two were seen at Port Protection, and several at Klawak Salt Isake, Prince of Wales Island. One was flushed from the banks of a stream at Boca de Quadra on June 11, and a single bird was several times observed at Fool's Inlet, Wrangell Island, July 12 to 18 . Two seen flying overhead at Mitkof Island on the evening of August 10, and a single one at Thomas Bay on August 22. They were at all times exceedingly wary and unapproachable, and no specimens were secured.

\section{Grus canadensis (Linnaeus). Little Brown Crane.}

The peculiar call-notes of this crane were heard several times at Mitkof Island, between August 1 and 13, usually late in the afternoon, but the birds were not seen. I saw three in some grassy meadows at Thomas Bay, on the morning of August 19. 
Lobipes lobatus (Linnaeus). Northern Phalarope.

A single bird shot from the launch at the mouth of Affleck Arm, Kuiu Island, on May 19, was the only one seen during the spring migration. The species was not observed again until August 23, when several small flocks, all in the gray winter plumage, were encountered in the open water of Stephens Passage. On the way south to Seattle, October 1 to 4 , many flocks were seen from the steamer at various points in the sheltered waters of the inner passage, all rapidly moving in a southerly direction.

The bird secured (no. 9882) is in freshly acquired summer plumage throughout. The molt has obviously been barely accomplished, for the slaty black feathers of the sides of the neck and the dorsum are finely edged with white, while the tertials and lesser coverts have very broad white edges. These edgings appear to wear off very rapidly, for in other specimens taken about the same time of the year, or but a week or two later, they have entirely disappeared.

Gallinago delicata (Ord). Wilson Snipe.

A Wilson snipe was flushed by Hasselborg at Three-mile Arm, Kuiu Island, on April 26, but was not secured. This was the only bird of the species seen until August 21, when I shot a single specimen at Thomas Bay (no. 9797). On the Taku River, September 4 to 28, snipe were fairly abundant on the flooded, grassy meadows. There were certain favorite spots where they could always be found, but there were vast stretches of country, apparently very similar in appearance, where the birds were never seen. They were, as they usually are, very erratic in their actions; one day all the birds in a meadow taking fright and leaving at the report of the gun, while on the next, perhaps, they would be flushed with the utmost difficulty. Certain aerial gymnastics were gone through daily. These have been described as a part of the mating process in the spring, but this was in September, during the fall migration.

Six specimens were secured at this point (nos. 9798-9803), all in fresh autumnal plumage. The series exhibits no apparent peculiarities of color or proportions. 


\section{Macrorhamphus griseus scolopaceus (Say).}

Long-billed Dowitcher.

Three-mile arm, Kuiu Island, was the only place where this species was observed, several small flocks being seen from May 3 to 6 . Six specimens were secured on May 3, all shot from the same flock. Five of these birds are in almost perfect nuptial plumage, there being but an occasional gray feather here and there over the body; but the sixth (no. 9806) is still almost entirely in the gray winter garb. They were feeding on the mud flats together with large flocks composed of several species of waders, but the dowitehers kept by themselves, and did not mingle with the others. They were quite tame and easily approached.

I cannot see why griseus and scolopaceus should still be regarded as distinct species, considering the evidence to the contrary (see Ridgway, 1880, pp. 157-160; Howe, 1901, pp. 157 162). As for the six specimens I secured, taken in the heart of the range of $M$. scolopaceus, there is no one character ascribed to the species that holds good through the series; and one or two of the birds (as no. 9808) if shot on the Atlantic coast would probably pass unquestioned as ordinary examples of $M$. griseus. The specific characters of scolopaceus, besides the generally larger size and especially longer bill, are supposed to lie in the summer plumage: the deeper toned and more uniform cinnamon color of the lower parts covering the entire belly as well as the breast, while the sides are barred instead of spotted. The most that can be said of these six birds is that none is as small as the minimum measurements given for $M$. griseus. In all there is more or less whitish on the abdomen, some are heavily spotted underneath, the spots extending well down on the belly, and several have the sides distinctly spotted instead of barred.

Altogether it seems to me the height of inconsistency to consider two such closely related forms as scolopaceus and griseus as distinct species, while, to take a parallel case, Arquatella maritima conesi is regarded merely as a race of $A$. maritima. There is apparently far greater possibility of the breeding range of 
the two dowitchers meeting somewhere in northern Canada than of the range of the two "varieties" of A. maritima touching at any point whatever.

The six specimens of Macrorhamphus g. scolopaceus secured measure as follows:

$\begin{array}{rcccc}\text { No. } & \text { Sex } & \text { Wing } & \text { Culmen } & \text { Tarsus } \\ 9804 & \wp & 154 & 67 & 37 \\ 9805 & \$ & 155 & 61 & 36 \\ 9807 & \wp & 152 & 60 & 36 \\ 9809 & \wp & 152 & 63 & 35 \\ 9806 & \text { o } & 142 & 56 & 35 \\ 9808 & \text { o } & 144 & 54 & 35\end{array}$

Arquatella maritima couesi Ridgway. Aleutian Sandpiper.

Very abundant at Three-mile Arm, Kuiu Island, during our stay there, but not seen anywhere else. This is, apparently, the southernmost locality at which the Coues sandpiper has been recorded. In company with the black turnstone and some other waders, they frequented the broad mud flats, which, at low tide, extend over hundreds of acres at this point. As the tide advanced their feeding grounds became more and more restricted, until, as the last available spot was covered, the whole flock departed, with roar of wings, to some jutting rocks at the mouth of the bay, there to remain, preening their plumage and resting, until the receding waters again exposed the mud banks.

The flocks seen at this place comprised many hundred individuals, and it is curious that the species was observed absolutely nowhere else.

The sixteen specimens secured (nos. 9839-9854) are nearly all molting into the summer plumage. Only one or two have quite completed the change, and one or two others have hardly begun to discard the winter garb; in most the winter plumage predominates, with a few chestnut bordered feathers on the back, and black ones on the breast.

Pisobia maculata (Vieillot). Pectoral Sandpiper.

Three were seen and two secured at Thomas Bay, on August 19 ; and on the 20th a single bird was obtained, possibly the survivor of the previous day. They are all three adults, two of 
them (nos. 9811, 9812) in worn summer plumage, with but a few new feathers appearing on the dorsum, the other (no. 9810) in fresh, winter plumage throughout. The only other occasion on which the species was noted was on September 26, when Hasselborg shot one, of several seen, on some grassy meadows on the Taku river. This bird (no. 9813) has also completed the molt into the winter plumage.

Pisobia bairdi (Coues). Baird Sandpiper.

Observed only at Thomas Bay. The first, a single bird, was seen on August 15, and they increased in numbers daily until we left, on August 23. Usually one or two Baird sandpipers would be seen in a large flock of $P$. minutilla, where their larger size made them conspicuous. Their call-note also was somewhat different, enough so to render them easily distinguishable. They were at all times wary and unapproachable, usually taking flight when still far beyond gunshot, though the least sandpipers with which they were associated were indifferent to approach. The six specimens secured (nos. 9814-9819) are all in freshly acquired winter plumage. Some are obviously immature, as was evident from the skull, but none were with certainty adult. There are no color differences apparent between the individuals composing the series.

Pisobia minutilla (Vieillot). Least Sandpiper.

During the first three weeks in May, small flocks were seen at every point visited. The first arrival was noted at Three-mile Arm, Kuiu Island, on May 1, and several small flocks were subsequently seen at the same place. Flocks were observed on Prince of Wales Island at Port Protection (May 6-10), and at Calder Bay (May 12), as also on Coronation Island (May 14-18), and Warren Island (May 19, 20). The species was then lost sight of until July 21, when a single bird was secured at Bradfield Canal. At Zarembo Island, July 27 to August 1, least sandpipers were exceedingly abundant on the tide flats, where they were gathered in flocks of hundreds, and the same was true at Thomas Bay, August 13-23, the last place where they were observed. 
Six specimens were secured. Three from Kuiu Island (nos. 9820-9822) and one from Calder Bay, Prince of Wales Island (no. 9823), are in fresh, nuptial plumage; while two from Bradfield Canal (no. 9824) and Zarembo Island (no. 9825) are adults in very much worn nuptial plumage, but not yet beginning to molt.

Pelidna alpina sakhalina (Vieillot). Red-backed Sandpiper.

First seen at Three-mile Arm, Kuiu Island, on April 28, when two birds were secured from a small flock. Several other flocks were subsequently observed at the same place, and three more specimens were taken on May 3. The only other place where the species was encountered was on the beach at Warren Island, where, on May 20, two individuals remained with a flock of western sandpipers, and spent the whole day on the sandy shore just below my tent.

The five birds secured (nos. 9834-9838), four males and a female, are in perfect nuptial plumage, and are very richly colored. The feathers of the black abdominal patch are slightly tipped with white, a mark which would doubtless disappear from abrasion in a very short time.

\section{Ereunetes pusillus (Linnaeus). Semipalmated Sandpiper.}

A single example secured at Thomas Bay on August 19. Numerous individuals of what I supposed at the time to be $E$. mauri were seen seattered through the flocks of least sandpipers that swarmed over the mud flats at this point, but this, the only one I shot, is undoubtedly $E$. pusillus. Possibly most, or all, of the other birds observed belonged to the same species.

This bird (no. 9833) is an immature female in first winter plumage, and is indistinguishable from comparable specimens of $E$. pusillus in the Grinnell collection, from the Atlantic coast and northern Alaska. E. mauri in corresponding plumage presents obvious color differences, besides the great discrepancy in the length of the bill. This constitutes the first known record of $E$. pusillus on the coast of southeastern Alaska. 
Freunetes mauri Cabanis. Western Sandpiper.

A common migrant in this region, at least in the spring; observed in numbers on Kuiu Island, at the north end of Prince of Wales Island, and on Coronation and Warren islands. The first specimen was taken at Three-mile Arm, Kuiu Island, on April 28, but several small waders, possibly of this species, had been seen at various times shortly before. The last time the species was noted in the spring was at the head of Port Alice, Heceta Island, on May 23. It was not observed in the fall at any time, unless (as mentioned above) it was included in the flocks of small waders seen at Thomas Bay. All seen were in small flocks of twelve or fifteen individuals.

Totanus melanoleucus (Gmelin). Greater Yellow-legs.

First observed on Kupreanof Island on April 18, when two males were secured and others seen. They subsequently became quite common at this point, as they were on Kuiu Island, though never more than two or three were seen together. At this time the males were going through various courting antics, posing with upraised quivering wings, or running in circles on the sand bars, around the object of their attentions, and incessantly uttering the shrill whistle peculiar to the species.

Subsequently seen only at Duke Island, where every evening a pair came flying down to the beach to feed, acting much as though they had a nest in the vicinity; and at Etolin Island, where a single bird was seen on July 10.

Two specimens were preserved (nos. 9858, 9859).

\section{Totanus flavipes (Gmelin). Yellow-legs.}

Seen only on one occasion, at Thomas Bay, on the evening of August 13, when a flock of six was observed on the beach, at such short range as to preclude the possibility of error in identification.

Helodromas solitarius cinnamomeus (Brewster).

Western Solitary Sandpiper.

A single bird shot at Port Snettisham, September 1, and another seen but not secured on the Taku River, September 
15, were all that were observed during the season. The species is apparently of rare occurrence on the coast of southeastern Alaska.

The specimen secured (no. 9860) has the marbling on the inner web of the outer primary characteristic of cinnamomeus.

Heteractitis incanus (Gmelin). Wandering Tattler.

Observed at but very few points. Three were seen and secured at Calder Bay, Prince of Wales Island, May 11 (nos. 9861-9863); and two at Egg Harbor, Coronation Island (nos. 9864,9865 ), where several others were noted. The species was next encountered at Mitkof Island, August 10, when a single bird was taken, still in the breeding plumage (no. 9866). A bird in the winter garb was seen at Port Snettisham on August 24.

Actitis macularius (Linnaeus). Spotted Sandpiper.

First observed at Calder Bay, Prince of Wales Island, on May 12, and subsequently met with at most of the points visited. Specific record stations are as follows: Calder Bay, Warren Island, Chickamin River, Revillagigedo Island, Etolin Island, Bradfield Canal, Zarembo Island, Mitkof Island, Thomas Bay, Port Snettisham, and the Taku River. It was everywhere a bird of the beaches and streams, invariably feeding at the water's edge, and was seldom seen, on the mud flats frequented by most of the other waders.

At Bradfield Canal (July 18 to 26) a brood of full grown young was seen daily about camp. An adult taken at Mitkof Island on August 10 had not yet begun to molt the summer plumage. On the Taku River, in September, spotted sandpipers were fairly abundant during the first half of the month, but a little later they nearly all disappeared, though one was seen as late as September 27.

Three specimens were secured, one from Portage Cove, Revillagigedo Island (no. 9855), one from Etolin Island (no. 9856), and one from Mitkof Island (no. 9857), all adults in breeding plumage. 
Squatarola squatarola (Linnaeus). Black-bellied Plover.

A small flock was seen by Hasselborg on the mud flats at Three-mile Arm, Kuiu Island, on May 3, but none were secured. The species was not met with again until September, when small flocks and scattered individuals were noted on the flooded meadow land along the Taku River. Two secured on September 26 (nos. 9880, 9881) are in freshly acquired winter plumage.

Aegialitis semipalmata (Bonaparte). Semipalmated Plover.

One of a pair was secured on Coronation Island, May 15, and on the following day a small flock was observed at the same place. Several were seen on the beach at Warren Island on May 20. The species was not met with again until the beginning of the fall migration. At Zarembo Island, July 27 to August 1 , it was abundant on the mud flats, in small companies of from two to six individuals together with much larger gatherings of least sandpipers, and at Thomas Bay it was very numerous, and in the same association. Three specimens were preserved, two from Coronation Island (nos. 9877, 9878) and one from Zarembo Island (no. 9879), all adults in summer plumage.

\section{Aphriza virgata (Gmelin). Surf-bird.}

Seen only at Three-mile Arm, Kuiu Island. At this point, from April 25 to May 6, it was abundant and in large flocks, feeding in company with the numerous other waders frequenting the mud flats.

Of the seven specimens secured here (nos. 9870-9876), six are in nearly perfect nuptial plumage. In one (no. 9874) there are many pin-feathers on the dorsal region and the chestnut marked scapulars of the summer plumage are but beginning to appear. Most of the birds secured have some of the plain colored winter feathers interspersed through the plumage of the breast, but as specimens in the Grinnell collection, taken at Sitka in late summer are in the same condition, it seems as though such old feathers are sometimes carried through to the postnuptial molt. 
Arenaria melanocephala (Vigors). Black Turnstone.

In common with several other species of waders, the black turnstone was observed only at Three-mile Arm, Kuiu Island. At this place it was abundant, nearly half of the immense flocks of waders on the mud flats being composed of this species. It is a very noisy bird, at least when gathered in such large companies, the individuals keeping up a continuous, querulous chatter while feeding, which swells to an excited outburst as the flock takes flight.

At this time (April 25 to May 6) they were just finishing the prenuptial molt, and the three specimens preserved (nos. 9867-9869), as well as others that were shot and not saved, all show some pin-feathers on the head, neck, and breast, as well as many old, brown feathers scattered over the same areas.

\section{Haematopus bachmani Audubon. Black Oystercatcher.}

We found the black oystercatcher only on the exposed, western border of the archipelago, and it is apparently entirely absent from the more sheltered inner passages and channels. The record stations for the present expedition are as follows: Kuiu Island, one pair; Coronation Island, several pairs; Warren Island, several pairs; south end of Prince of Wales Island (near Mexico Point), one heard calling; Duke Island, one heard calling. A pair secured at Egg Harbor, Coronation Island (nos. 9883, 9884).

Dendragapus obscurus fuliginosus (Ridgway). Sooty Grouse.

One of the interesting results of the season's work was the more definite determination of the distribution of this grouse in southeastern Alaska. (See text figure 2, page 155.) In general terms it may be said to be absent from those islands lying south of Sumner Straits and west of Clarence Straits, while it is generally distributed over all the other islands and along the mainland coast. We obtained specimens or saw birds at Kuiu, Kupreanof, Mitkof, Coronation, and Etolin islands, and at Boca de Quadra and Thomas Bay on the mainland. It probably occurs also on Revillagigedo and Wrangell islands, though we 
did not meet with it at the points visited. It is entirely absent from Prince of Wales and the adjacent islands to the westward (with the single exception of Coronation), and also from Zarembo Island.

This peculiar distribution is hard to account for, as the channels separating these islands from their grouse-inhabited neighbors are no wider than many of those separating the latter from the mainland or from one another, and can hardly be considered as effective barriers to such a strong flying species. For example, the channel between Zarembo and Etolin islands is barely two miles wide at one point; and a grouse could pass from Kupreanof to Prince of Wales without crossing more than three miles of water at one flight. As the broad Chatham Strait is no barrier to the dispersal of the species in the more northern islands of the group, these narrow channels, studded with little islets, can hardly act as such. The species occurs on the rather isolated Coronation Island, which was probably reached by way of Kuiu. The fact that most, or all, of the larger islands from which the sooty grouse is absent, are inhabited by a species of Canachites, is, of course, suggestive; but even if one species is able to occupy an area to the exclusion of the other, these narrow channels still would be no obstacle to the distribution of the dominant race. It seems to hold true, however, in the islands of. southeastern Alaska, that wherever one species of grouse is found the other is absent.

On Kupreanof and Kuiu islands, in April, the sooty grouse was abundant, while the peculiar habits of the male birds rendered it quite conspicuous. At this time the males remain in the hemlock trees, feeding on the foliage, and sometimes not leaving a tree for days at a time. They hoot continually, at short intervals, a sound that can be heard for a considerable distance, and an unfailing indication of the presence of the species. The tameness, not to say stupidity, of these birds is such that they may be approached without any precaution whatever, for they continue hooting in absolute indifference to observation, and sometimes even remain perched after being shot at and missed. Some individuals sitting at too great a height to be reached by a shotgun could not be dislodged in any way. The 
hooting habit continued until about the middle of August, but after the middle of July the sound was heard but rarely. The females seem to stay more on the ground, though, of course, if they were in the trees they would be easily overlooked, keeping silent as they do. The males are said also to descend to the ground in the fall.

A young bird molting into the juvenal plumage was taken on Etolin Island on July 8. On Mitkof Island, in August, several broods of half grown young were seen, sometimes in the woods, and sometimes feeding in the beach grass. They were tame and could hardly be forced to fly. Nine specimens of the sooty grouse were preserved, including three adult males and two adult females (nos.9787-9791), one young one molting from the natal to the juvenal plumage (no. 9792), and three in juvenal plumage (nos. 9793-9795).

\section{Canachites franklini (Douglas). Franklin Grouse.}

We did not ourselves meet with this species at any point, and most of the information secured regarding it was derived from various store-keepers, prospectors, and Indians. On Prince of Wales Island we received information from many people in regard to the occurrence of the "spruce grouse," and as Canachites franklini has been recorded from this island by Osgood (1905, p. 70), this is undoubtedly the bird referred to. Hasselborg occasionally reported finding shed feathers or droppings that probably pertained to this species, but neither of us was fortunate enough to see one of the birds. On Warren Island also similar evidence was found. On Zarembo Island we were told by two prospectors that the spruce grouse occurred, but not the sooty grouse, and Hasselborg saw a hunter carrying one of the former.

Judging from the information at hand the Franklin grouse occupies an isolated area in southeastern Alaska, as we were not able to learn of its occurrence on any of the islands immediately adjacent to the mainland. Of course the evidence is only negative, but this is a point in regard to which I made careful inquiry wherever opportunity offered. I also failed to find any island on which the sooty and the Franklin grouse were both known to occur. The hooting habit of the former 
makes it so conspicuous that it is hardly possible to overlook the bird if even moderately abundant. Wherever we were told of the occurrence of the Franklin grouse no hooting was heard, while on those islands where $C$. franllini is not known to occur it is one of the commonest sounds in the woods.

Lagopus rupestris dixoni Grinnell. Dixon Rock Ptarmigan.

The only place where any ptarmigan were observed was at Port Snettisham, where Hasselborg flushed two flocks while hunting mountain goats in the higher mountains. He secured one on August 29 (no. 9796). This is a young bird, largely in the stage designated by Dwight as the "first winter plumage (preliminary)" (1900, p. 160). Patches of the juvenal plumage persist on the sides of the abdomen and on the flanks. On the center of the abdomen and on the sides the pure white winter feathers are growing out. There are some white feathers on the legs and toes, and the flight feathers are white, all but the third remex, as are the greater and lesser coverts. Head, breast, back, and median coverts are barred and mottled with dusky, brown and black.

While no specimens of Lagopus mpestris from the interior of Alaska, in comparable plumage, are at hand, this bird is so exceedingly dark colored as to suggest the probability of its belonging to the island race designated by Grinnell (1909, p. 207) as Lagopus dixoni. This form may prove to occupy the whole of the mainland coast region, as well as certain of the adjacent islands, the conditions being practically the same as on the island where the type specimen was taken.

We were told by an Indian that there were a few ptarmigan on Kupreanof and Kuiu islands, seen usually during the winter months, in all probability a form of the rock ptarmigan. On Prince of Wales Island also we were told that they were occasionally seen on the higher mountains in summer and occasionally in the valleys in winter.

Circus hudsonius (Linnaeus). Marsh Hawk.

An adult male, seen at Three-mile Arm, Kuiu Island, on April 29, was the only individual observed during the spring. 
The species was not met with again until we reached the Taku River. At this point during September, marsh hawks were seen daily hunting over the meadows bordering the river. These meadows were thickly populated with meadow-mice (Microtus drummondi), which seemed easy prey, for I frequently saw the hawks drop down in the grass, to arise at once grasping a mouse. The stomach of one of the birds secured contained several meadow-mice (Microtus) and one jumping mouse (Zapus). They resented the appearance of any other birds of prey upon their hunting grounds, and I repeatedly saw them attack bald eagles, as well as a short-eared owl and a rough-legged hawk. Two marsh hawks were preserved, both males in first winter plumage (nos. 9772, 9773).

\section{Accipiter velox (Wilson). Sharp-shinned Hawk.}

Seen at various points during the spring and summer, though rare everywhere. On Kupreanof Island, on April 23, Hasselborg found a nest, finished but empty, with one of the old birds near by. On Kuiu Island a sharp-shinned hawk was seen pursuing some sandpipers. Single birds were observed at the following points: Prince of Wales Island (Calder Bay), Coronation Island, Heceta Island, Dall Island, Duke Island, Chickamin River, Revillagigedo Island (Portage Cove), Mitkof Island. At Thomas Bay during the latter part of August they became fairly common, as the immature birds began to appear, moving southward. Several were seen at Port Snettisham, and on the Taku River the species was quite abundant.

They were frequently observed in pursuit of small birds, and several of those secured had the remains of sparrows or juncos in their stomachs, but one (no. 9776) had eaten two shrews.

Six specimens were secured, as follows: adult male, Mitkof Island (no. 9774), adult female, Taku River (no. 9778), immature female, Port Snettisham (no. 9776), immature male, Thomas Bay (no. 9775), and an immature male and female, Taku River (nos. 9777, 9779). The two adults are extremely dark colored, as compared with summer specimens from California, Nevada and Illinois. The male bird (no. 9774, Mitkof Island, August 
12) is just finishing the molt into the fully adult, presumably the second winter, plumage, and is more heavily marked than any other example of the species at hand. The lower surface is chestnut, with the transverse barring reduced to disconnected spots, except on the abdominal region; the tibiae uniform chestnut, entirely without barring. The adult female is not quite so heavily marked.

An examination of the available series of sharp-shinned hawks in adult plumage reveals the fact that these two Alaska birds, together with some winter specimens from California, are much darker than other winter specimens from California, as well as those from Arizona, Nevada and ${ }^{s}$ Illinois. It seems possible that there is a recognizable, dark, northwest coast race of the sharp-shinned hawk, which in winter ranges at least as far south as southern California, where it occurs together with the paler colored, more southern form; but the material at hand is too scanty to enable me to arrive at any definite conclusions.

Astur atricapillus striatulus Ridgway. Western Goshawk.

On Kuiu Island, April 25, a goshawk was seen pursuing a flock of mallards. The species was not met with again until we reached Thomas Bay, where, on August 14, Hasselborg saw two, apparently fighting, and shot both, but lost one in the thick underbrush. A single bird secured on the Taku River, September 13, completes the list of records. This bird had just finished eating a Steller jay.

The two birds secured (nos. 9770, 9771), both males in the first winter plumage, are extremely dark colored dorsally, and heavily marked with black on the lower surface, being exactly similar to the single specimen secured on Baranof Island by the 1907 Expedition (see Grinnell, 1909, p. 211). It is interesting to note, however, that a bird in the Grinnell collection, also in immature plumage, collected at Sitka, August 5, 1895 (see Grinnell, 1898, p. 127) is apparently to be referred to $A$. atricapillus atricapillus, as it is indistinguishable from specimens of the latter from the Yukon Valley, Alaska.

Buteo borealis alascensis Grinnell. Alaska Red-tailed Hawk. Apparently not common in this region, as we noted the species 
at but two localities: At Duke Island, June 7, an adult, with the red tail, was seen circling overhead, and on the Chickamin River, June 18, Hasselborg shot one of several seen in the vicinity of a colony of marmots.

The bird secured (no.9769) is a male in the light phase of the immature plumage, and was apparently not breeding, though it is a bird of the previous year at least. In its small size it bears out one of the characters upon which the subspecies alascensis was based; but in coloration and markings I cannot distinguish it from comparable California specimens of calurus.

\section{Archibuteo lagopus sancti-johannis (Gmelin).}

American Rough-legged Hawk.

A large, dark-colored hawk, seen hunting over the meadows along the Taku River, on September 12, is, I believe, to be referred to this species. It was seen several times during the day, but was wild and unapproachable, and was driven from place to place by two marsh hawks who strongly resented its appearance in the neighborhood.

\section{Haliaeëtus leucocephalus alascanus Townsend.}

Alaska Bald Eagle.

This, the only bird of prey that is really abundant in the region, is so universally distributed that a list of the stations where it was observed would include every point visited during the season. The numbers seen varied greatly from place to place, the varying food supply being probably the cause of the differences. About San Alberto Bay, Prince of Wales Island, especially large numbers were seen, sometimes forty or fifty being in sight at once, and here they were feeding on the spawning herring. At this point Hasselborg killed a bear, and passing by the place the following day, found about thirty eagles feasting on the carcass. It seems hardly probable that all the birds seen were breeding, for few nests were observed anywhere, compared with the large numbers of the birds encountered. At Kupreanof and Kuiu islands, in April, several occupied nests were seen, but we did not disturb them. By the middle of July young 
birds were met with wherever we went, tame and unsuspicious as a rule, and easily approached. Early in August the old birds began to molt, becoming very ragged, and showing gaps in wings and tail as they circled overhead.

\section{Falco columbarius columbarius Linnaeus. Pigeon Hawk.}

At Three-mile Arm, Kuiu Island, April 25 to May 6, a pigeon hawk was seen almost daily, and on May 3 Hasselborg found a nest that appeared to belong to this bird, for it remained near by. The nest, empty at the time, was built in a spruce tree, in the angle formed by the junction of a limb with the trunk, and was about thirty-five feet from the ground. This hawk was seen at various times in pursuit of small waders and of robins.

The species was not met with again until we reached Thomas Bay, where, on August 18, a single bird was secured. At Port Snettisham two were shot on August 24 and 27, respectively. On the Taku River pigeon hawks were more numerous, for at least eight or nine were seen during the time we spent there, and one was secured on September 26. One was seen here in the blue-backed, adult plumage, but he was too wary to be approached.

of the four secured three had the remains of spotted sandpipers in their stomachs, while the fourth contained a finch, probably a Zonotrichia.

The four specimens obtained (nos. 9780-9783) are all females, and probably all immatures in their first winter plumage. They are distinctly referable to columbarius rather than to suckleyi, which might be supposed to be the form occurring in this region. Compared with winter specimens of columbarius from southern California they are somewhat darker dorsally, being rather sooty where the latter are earthy brown, but there is little or no difference in the intensity or amount of the dark markings below.

\section{Falco sparverius sparverius Linnaeus.}

American Sparrow Hawk.

A female secured on the Taku River on September 16 was the only one of the species seen. This bird was observed at the 
edge of the woods, sitting on the top of a little spruce tree, from which it had just driven a pigeon hawk. Its stomach contained a meadow mouse (Microtus drummondi).

This is, I believe, the first individual of the species to be taken in the southeastern coast district of Alaska, if not in the entire territory. Bishop has recorded it from the Yukon Valley (1900, p. 75), but within the Canadian boundary, with the exception of Circle, where the species was doubtfully identified.

The specimen secured (no. 9784) is in fresh, fall plumage, and compared with examples from more southern localities is decidedly dark toned, especially on the dorsal surface. The black cross-bars are broad, and the chestnut bars consequently restricted in area, and also very rich colored.

Pandion haliaëtus carolinensis '(Gmelin). American Osprey.

Observed at but few points. In Wrangell Harbor, on the evening of July 26, one was seen. At Zarembo Island, July 27 to August 1, a pair of the birds were observed daily. On Mitkof Island, August 9, one was seen passing overhead, and on the Taku River, September 27, one lit on the mast of the launch.

\section{Asio wilsonianus (Lesson). American Long-eared Owl.}

A male secured on the Taku River, September 26 (no. 9786), probably constitutes the northernmost record of the species on the Pacific Coast. This bird, the only one seen, was flushed from the tangled roots of a fallen tree, lying half hidden in the long meadow grass on the banks of a stream: a singular shelter to be taken in preference to the many thickets and bushes on all sides.

It is rather dark colored, though not more so than some California birds at hand, but it differs from any specimens available in its extremely small size, being below the minimum measurements as given in literature. It measures : wing $248 \mathrm{~mm}$., tail 145 .

Asio flammeus (Pontoppidan). Short-eared Owl.

Seen only on the Taku River. At this point a short-eared owl, probably the same individual, was seen several times on 
September 19 and 20, hunting over the meadows along the river. I had several good views of the bird at close enough range to make identification certain, but was unable to secure it.

\section{Cryptoglaux acadica scotaea (Osgood).}

Northwest Saw-whet Owl.

One specimen, a juvenal female, Mitkof Island, August 4 (no. 9785), shot just at the edge of the forest bordering the beach. The stomach contained the fur and bones of Microtus macrurus, a mouse that was fairly abundant at this point. This bird is molting from the juvenal to the first winter plumage, with new feathers appearing in the pectoral tracts, and many pin-feathers in the facial dises. There can be no doubt, I think, that it is an example of the northwest coast form of $C$. acadica, which Osgood (1901, p. 43) has called scotaea, for compared with a juvenal of acadica from Illinois, it presents differences corresponding to those distinguishing adults of the two races. The dorsal region, upper surface of wings, and upper breast, are very dark brown, almost bistre, as compared with the vandyke brown of corresponding areas in young acadica, the facial discs darkening to clove brown. The cinnamon of the abdominal region is, however, but little darker than in acadica. The rectrices are very dark, almost black, but the white spots are not perceptibly diminished in size. The new feathers of the first winter plumage appearing on the sides of the breast are of a distinctly darker shade of brown than corresponding feathers on eastern examples of the species, or even than that of two specimens from Oregon.

Bubo virginianus saturatus Ridgway. Dusky Horned Owl.

Horned owls are apparently of rare occurrence in this region, and we saw but little evidence of their presence. At Three-mile Arm, Kuiu Island, there was more owl sign than at any other point, consisting of a few shed feathers and a number of cast pellets picked up from time to time. These pellets consisted largely of deer hair, from which it would seem that the owls sometimes feed on carrion; dead deer were numerous in the 
woods. A horned owl was heard hooting at this point on the evening of May 5. One was also heard at Mitkof Island on the night of August 10, and at Thomas Bay, August 22, Hasselborg saw a large owl in the woods that was probably of this species.

Hasselborg afterward sent in a specimen from Douglas Island on December 20. According to the accompanying notes a friend heard his cat squall in the night, and, going out, found the owl attempting to fly away with it. He killed the bird with a stick. This specimen (female, no. 1065) is apparently to be referred to saturatus, as it is quite dark colored, and heavily barred with black underneath. The feet and legs, however, are but very slightly mottled.

\section{Ceryle alcyon caurina Grinnell. Northwestern Belted} Kingfisher.

Kingfishers were decidedly rare over the whole of the region traversed, and none at all were seen along the western edge of the archipelago, where we spent April and May. At Marten Arm, Boca de Quadra, June 9 to 14, a pair was observed digging in the gravelly bank of a stream, and on the Chickamin River one or two of the birds were seen, but no nest found. At Bradfield Canal a pair of kingfishers probably had a brood of young near by, for they were continually carrying fish up the stream. At Mitkof Island, in August, several were seen along the coast, evidently migrating, as were others observed at Thomas Bay.

Two specimens were secured, both adult males in freshly acquired winter plumage, no. 9767, Mitkof Island, August 9, and no. 9768, Thomas Bay, August 14. These two birds appear to bear out the characters ascribed by Grinnell (1910, p. 388) to the Alaskan race.

Dryobates villosus harrisi (Audubon). Harris Woodpecker.

The hairy woodpeckers of the Sitkan district exhibit a diversity of characters that is decidedly puzzling. In general there is a tendency to vary from typical harrisi, shown in a less marked smoky suffusion of the underparts, together with the frequent presence of conspicuously white-spotted lesser wing 
coverts, while some individuals evince a decided leaning toward the characters of Dryobates $v$. picoideus. Such proclivities cannot, however, be correlated with any particular region, the picoideus-like examples not being necessarily found closest to the range of that race. For the present at least, it seems best to include all under the form harrisi.

The specimens available in the present study are as follows: ten from the 1909 Expedition, i.e., Calder Bay, Prince of Wales Island, one (no. 9735); Egg Harbor, Coronation Island, one (no. 9734), “Rocky Bay," Dall Island, one (no. 9736) ; Etolin Island, two (nos. 9739, 9740); Boca de Quadra, two (nos. 9737, 9738); Wrangell Island, one (no. 9741); Admiralty Island, one (no. 9319) ; Chichagof Island, one (no. 10648); three from the 1907 expedition, all taken on Admiralty Island (nos. 462-464); one from the Grinnell collection, collected at Sitka (no. 1246), and two specimens of $D . v$. picoideus borrowed from the Biological Survey collection, one from Skidegate, Queen Charlotte Islands (no. 166821), the other (hardly typical of the form however) from Kasaan Bay, Prince of Wales Island (no. 186243).

Excluding the Queen Charlotte Island specimen, the individuals showing the most marked smoky suffusion on the underparts are from Admiralty and Chichagof islands, at the northern extremity of the region, and from Dall Island, and Kasaan Bay, Prince of Wales Island (the supposed D. $v$. picoideus), at the south. Specimens with this tendency at a minimum, some being nearly as white below as examples of hyloscopus, are from Admiralty, Coronation, Prince of Wales, Etolin, Wrangell, and Baranof islands, and from Boca de Quadra.

The presence of conspicuous white spots on the lesser wing coverts is also an unstable character, though such markings are usually evident to some degree. Of two specimens collected at Boca de Quadra, one (no. 9738) has conspicuously white-spotted coverts, while on the other (no. 9737) there are no white spots at all. The one specimen from Dall Island (no. 9736) shows an inclination toward the characters of picoideus, evidenced by the restricted area of the white dorsal stripe, together with slight barrings on the back and flaniss; but the same peculiarities are evident to an even greater degree in one from Admiralty Island 
(no. 462), which is geographically far removed from this race. Altogether it does not seem to me expedient to consider such variants as examples of picoideus; for these exceptional individuals are, in some respects, more like typical harrisi than are the majority of the birds of this region. Neither do I feel like giving a new name to the Sitkan bird, for, as shown above, the characters that might be ascribed to it (of which the white underparts and white-spotted lesser wing coverts are the most apparent) are extremely unstable.

Harris Woodpecker is quite generally distributed over south-• eastern Alaska, but apparently is nowhere very common. The first was noted on Kuiu Island, April 30, though the species is probably to be found in the region through the winter. Hasselborg secured one at Freshwater Bay, Chichagof Island, as late as November 2. Single individuals were seen at many scattered points, but the only place where the species was even fairly abundant was at the head of Marten Arm, Boca de Quadra, where it was seen or heard daily. A fully fledged juvenal was secured on Etolin Island, July 6, the first young one seen flying about. It is rather curious that absolutely no Harris woodpeckers were observed on the Taku River, the only point where a form of the downy woodpecker was met with.

\section{Dryobates pubescens glacialis Grinnell.}

Valdez Downy Woodpecker.

Observed only along the Taku River. On September 4, the only bright, sunny day we had at this point, they were active and rather noisy, and five or six were seen flying about, calling and rapping on the trees. In the rainy weather that followed they were quiet and inconspicuous, and but very few were noticed.

Two specimens were secured, an adult male, September 13 (no. 9733), and an immature male, September 4 (no. 9732). They agree minutely with Grinnell's characterization of Dryobates pubescens glacialis (1910, p. 390) ; nor am I able to distinguish any differences on comparison with his specimens, except that one of my birds (no. 9733) has somewhat heavier black barring on the rectrices than has either of those from Prince William Sound. 
This appears to be a fairly well marked race, easily distinguishable from gairdneri or nelsoni, whose ranges it adjoins, but curiously similar to $D . p$. medianus of the eastern United States. It is thus comparable with the isolated western "colonies" of Penthestes atricapillus atricapillus and Passerculus sandwichensis savanna. We are fortunately able to recognize certain slight differences in the woodpecker, and thus in this case avoid the absurdity of calling the variety by the name of a race with which its affinities are doubtless remote.

\section{Picoides americanus americanus (Swainson).}

American Three-toed Woodpecker.

A single specimen, a female, collected by Hasselborg at Freshwater Bay, Chichagof Island, November 27 (no. 10649). This bird has not a trace of smoky suffusion beneath, the distinguishing character of the single specimen on which Grinnell (1909, p. 217) based his Picoides a. fumipectus, also from Chichagof Island. However, although this specimen is as pure white ventrally as any of a series from the Yukon Valley, it does show a smoky suffusion in the white speckling on the top of the head, while the area of the white dorsal markings is somewhat contracted.

The three-toed woodpecker of the Sitkan district may still prove to be a recognizable form, but the diversity of coloration shown by the two specimens at hand necessitates the examination of additional material to demonstrate the distinctness of the race proposed by Grinnell (l. c). For the present it seems best to consider $P$. a. fumipectus as a synonym of Picoides americanus (Swainson). This bird was taken at a time when it may well have been a migrant from some other region. The species was not met with at any time during the summer.

Sphyrapicus varius ruber (Gmelin). Red-breasted Sapsucker.

Generally distributed throughout the region, but nowhere at all common. It was noted at the following points: Kupreanof Island, Kuiu Island, Prince of Wales Island (Klawak Salt Lake), Chickamin River, Etolin Island, and Wrangell Island. 
On the Chickamin River (June 17 to 28) Hasselborg found three nests at various points some eighteen or twenty miles up the river. All were in high, rotten stubs, and all evidently contained young birds. On Etolin Island a nest was located, also high up in a dead tree, and also containing young.

Three specimens were secured, from Kupreanof Island (nos. 9742, 9743) and the Chickamin River (no. 9744). They are very deeply colored, the red and yellow areas being particularly intense, and in one (no. 9742) the light dorsal markings are reduced to the slightest of yellowish flecks, and the back consequently almost uniform black.

Colaptes cafer saturatior Ridgway. Northwestern Flicker.

Flickers were decidedly scarce in the whole region traversed, and the few individuals met with were so wild as to be approached with the utmost difficulty. More were observed on Kupreanof Island than at any other one place, and here, from April 12 to 24, six or eight were seen or heard. At Rocky Bay, Dall Island, May 31, one was heard calling. On Gravina Island the call note of a flicker was heard on the evening of June 15, and one was secured early the next morning. At Portage Cove, Revillagigedo Island, on July 2, a nest was found, and the pair of birds shot. On Etolin Island, July 5 to 12, a flicker was heard on several occasions, but I was never able to catch sight of it. Single birds were seen on the Taku River, on September 10 and 13 , but they were so wild as to be unapproachable.

Four specimens were secured: an adult male at Kupreanof Island, April 16 (no. 9728); an adult male at Gravina Island, June 16 (no. 9729); an adult male (no. 9731), and female (no. 9730) at Portage Cove. No. 9728 may be taken as typical of the race saturatior, the upperparts being rich mars brown, as compared with the drab backs of southern California birds, while the black markings are broad and lustrous. The underparts are strongly tinged with vinaceous-pink. No. 9729 is somewhat paler dorsally, though decidedly more pink underneath, and has a slight admixture of auratus characters as evidenced by a few black specks in the red malar stripes, and a slight indication of a red nuchal crescent. Nos. 9730 and 9731 were a pair, and 
though the female may be considered as typical of saturatior, the male shows an almost equal intermingling of the characters of cafer and auratus. It has the black malar stripes and nuchal crescent of the latter species, with the red quills of the former. The lower parts have an olivaceous tinge, similar to but not so pronounced as in auratus, while the colors of the head (gray on the occiput and brown on the throat in auratus, and the reverse in cafer), have been modified so that the whole head is an almost uniform brownish gray.

The nest found at Portage Cove was in a dead stub, some fifty feet from the ground. The stump was so rotten that an attempt to climb it brought down the whole upper portion, including the nest, in a mass of disintegrated punk. In the debris we found five newly hatched young birds and one rotten egg. The young were far too small to give any indication as to the extent to which the varying characters of the parents would be developed. The nest tree was in a valley bordering a stream, in fairly open country, with clumps of scattered timber interspersed between the open meadows.

The four flickers secured measure as follows:

$\begin{array}{rcrcc}\text { No. } & \text { Sex } & \text { Wing } & \text { Tail } & \text { Culmen } \\ 9728 & \delta & 166 & 111 & 42 \\ 9729 & \delta & 167 & 117 & 42 \\ 9731 & \delta & 162 & 113 & 38 \\ 9730 & \delta & 166 & 106 & 38\end{array}$

Cypseloides niger borealis (Kennerly). Black Swift.

First seen at the head of Marten Arm, Boca de Quadra. Here during the middle of June the black swift was numerous, large flocks hovering over the meadows in company with Vaux swifts and barn and tree swallows. The swallows fed close to the ground, almost brushing the grass, but the swifts stayed high in the air; and it was only occasionally that an individual would swoop down, affording an opportunity for a hasty, and usually ineffective, shot. Two rainy mornings were devoted almost entirely to an endeavor to secure a series of these birds, and six specimens were obtained. On the following day the weather changed, the sun came out, and the swifts disappeared.

In life its great size alone readily distinguishes the black 
swift from the little Vaux swift, with which it was here associated; but the two species differ in many minor respects also. The black swift soars a great deal and flutters its wings comparatively little, is almost absolutely silent, and individuals were seldom seen pursuing one another.

It was undoubtedly breeding somewhere in the vicinity for one of the females secured contained an egg that would have heen laid in a few days.

It was met with again at Portage Cove, Revillagigedo Island, where a few individuals appeared nearly every evening at dusk, flying about until dark. It is rather curious that the species was not observed on the Chickamin River, on the mainland directly opposite Portage Cove, the character of the country being very similar to that at Boca de Quadra. At Bradfield Canal Hasselborg saw a large black swift that he supposed was of this species.

Eight specimens were secured, two males and four females at Boca de Quadra (nos. 9360-9365), and two males at Portage Cove (nos. 9366, 9367). The four males are uniform sooty black (save for the paler markings about the head), only one (no. 9366) showing slight whitish tips on the feathers of the abdomen and the lower tail coverts. Of the four females, one is like the males in that it is uniformly black (except for a single pure white feather on the upper breast). The other three have the feathers of the abdomen and the lower tail coverts tipped with white in varying degrees. These white tips probably disappear as the individual becomes older, and when fully adult the sexes are apparently alike in coloration, but from the specimens in hand there seems to be one point in which they constantly differ. The four males have the tail deeply forked; in the four females it is uniformly square, there being no difference in this respect between the black individual and the white marked ones. In the males the tail is so deeply forked that the lower coverts extend beyond the middle rectrices.

I believe that this is the first time that the species has been taken in Alaska.

The eight specimens secured measure as follows: 


\begin{tabular}{|c|c|c|c|c|}
\hline No. & Sex & Wing & Tail & $\begin{array}{c}\text { Extent of forking } \\
\text { in tail }\end{array}$ \\
\hline 9360 & $\delta^{\prime \prime}$ & 162 & 59.5 & 8 \\
\hline 9362 & $d$ & 163.5 & 62 & 9.5 \\
\hline 9366 & $\sigma^{\pi}$ & 163 & 58 & 8.5 \\
\hline 9367 & $\sigma^{x}$ & 166.5 & 61 & 10.5 \\
\hline 9361 & $q$ & 161 & 51 & square \\
\hline 9363 & $q$ & 165.5 & 57 & square \\
\hline 9364 & $q$ & 160 & 53 & square \\
\hline 9365 & q & 160 & 55 & square \\
\hline
\end{tabular}

\section{Chaetura vauxi (Townsend). Vaux Swift.}

Although I believe this species has not been previously reported from Alaska we found it at all the mainland points visited, as far north as Thomas Bay. At Marten Arm, Boca de Quadra, it was common. Along the Chickamin River it was, at times, very abundant, and a female shot at this point (no. 9359, June 18) contained a partly formed egg, so that the species was evidently breeding. At Portage Cove, Revillagigedo Island, Vaux swifts were seen occasionally, usually in the evening; while a single bird was seen at Bradfield Canal on July 19. At Thomas Bay, August 13 to 23, the species was very abundant, hovering over the meadows in company with the barn swallows, but they flew high and I failed to get any at this point. Three specimens were secured, two males from Boca de Quadra (nos. 9357, 9358), and a female from the Chickamin River (no. 9359). The latter evinces a tendency toward albinism, shown by two patches of pure white feathers on the lower surface of the body.

The three individuals secured from this the northern extremity of its range are not different from California specimens with which they were compared.

Selasphorus rufus (Gmelin). Rufous Hummingbird.

First seen at Three-mile Arm, Kuiu Island, on April 26, when a male bird was several times observed hovering over a blossoming huckleberry bush by the tent. The species was next met with at Calder Bay, Prince of Wales Island, where a female was seen on May 11, and a male secured on May 12 (no. 9356). From then until about the end of June it was, though not com- 
mon, quite generally distributed, and we met with it at nearly all points visited. Specimens were seen at Coronation and Warren islands, and at San Alberto Bay and Klawak Salt Lake, Prince of Wales Island, at Rocky Bay, Dall Island, Boca de Quadra, the Chickamin River, and Portage Cove, Revillagigedo Island. But a single bird was seen on Zarembo Island, and at Thomas Bay, about the middle of August, the species was evidently becoming scarce. The last hummingbird was observed at Port Snettisham, on August 31, a single bird seen several times at the edge of a willow thicket.

\section{Nuttallornis borealis (Swainson). Olive-sided Flycatcher.}

Three specimens secured at Thomas Bay, where several others were seen. The first was observed on August 17; and they were subsequently noted daily, evidently migrating. Their habit of perching on the tops of the tallest available trees made them difficult birds to shoot, and it was only by using heavy loads that any specimens were obtained. At Port Snettisham two were seen on August 29, but neither was secured. While the species may breed along the coast of southern Alaska, I do not think it probable that it does, but believe rather that the individuals seen were migrants from some interior region, as were several other species of birds that appeared about the same time.

The three specimens secured are not perceptibly different from others taken in southern California and Arizona. The two adult males (nos. 9707, 9708), taken on August 17 and 20, respectively, are in worn summer plumage, and just beginning the post-nuptial molt, as evidenced by a few new, partly ensheathed feathers on the top of the head and on the dorsum. The third, an immature male in first winter plumage (no. 9709), August 21, compared with others in corresponding plumage from southern California, is actually somewhat paler colored throughout, and with the whitish areas more extensive than in most of the latter. This is a species that is wonderfully resistant to the effects of varying local conditions, specimens from southern California to Alaska, and from the Atlantic to the Pacific, presenting exactly the same appearance. 


\title{
Myiochanes richardsoni richardsoni (Swainson).
}

\author{
Western Wood Pewee.
}

Wood pewees were met with at most of the mainland points visited, but on none of the islands. At Boca de Quadra, June 11 , one was heard calling on a wooded hillside, but the vegetation was so thick that I was unable to catch sight of the bird. On the Chickamin River probably five or six individuals were seen at various times between June 17 and 28. They appeared to be migrating, and were usually perched on little scrubby willows scattered over the meadow land. I saw no indication that any were breeding at the time; the specimens secured certainly were not. At Thomas Bay the species was frequently seen, evidently migrating southward. The birds were excessively. wild, and usually fled to the tops of the tallest trees, where they were far beyond shot-gun range. At Port Snettisham several individuals, possibly six or seven all told, were seen at different times, but here also they were wild and unapproachable. A single bird was seen on the Taku River, on September 8, the last one observed. I had but a glimpse of this bird as it flew over an alder thicket, and failed to find it again.

Three specimens were secured, two adult males from the Chickamin River, June 20 and 22 (nos. 9710, 9711), and an immature female from Port Snettisham, August 28 (no. 9712). While there may well be a recognizable northwest coast form of the western wood pewee, as claimed by Bishop (1900, p. 116), I am unable to uphold it with the scanty material at hand. My three specimens are certainly appreciably darker colored than the breeding birds available from southern California; but there are specimens in the museum collection, taken in June in the northern Sierras, which are indistinguishable in color from the Alaskan birds. In a fairly large series from southern Arizona, some are pale colored, but there are others nearly, if not quite, as dark as those from Alaska. Neither can the size of the bill be depended upon to distinguish them, as there seem to be both large and small-billed individuals in series from all localities. The two Alaskan adults show as much variation in this respect as can be seen in large series from more southern localities. 
Empidonax difficilis Baird. Western Flycatcher.

Generally distributed and fairly common, as birds go in this region, but during the breeding season at least, very retiring and hard to find. The sharp, two-syllabled whistle was frequently. heard, but the author of it was seldom seen. First noted on Coronation Island, on May 15, and subsequently observed, evidently migrating, on Warren Island, Heceta Island, and at San Alberto Bay and Klawak, Prince of Wales Island. On the west coast of Dall Island, the first week in June, they appeared to be in pairs, and were seen pursuing one another through the tree tops. On Duke Island they were fairly abundant, judging from the frequency with which the call-note was heard. At Boca de Quadra the species was uncommon, but on the Chickamin River a number were seen, and an incubating female secured on June 26. Small numbers were seen at Portage Cove, Revillagigedo Island, at Etolin Island, and Bradfield Canal. At Zarembo Island the species was far more abundant than at any other place visited, this being partly due, perhaps, to the fact that at this time the young birds had left the nests and were beginning to appear in the woods. At Mitkof Island several were seen, as also at Thomas Bay. At this time they were evidently rapidly moving southward. Very few were observed at Port Snettisham, the last being seen on August 29. The species was not seen at all on the Taku River.

Fourteen specimens were collected, from the following localities: Dall Island, one (No. 9714), Duke Island, one (no. 9715), Chickamin River, two (nos. 9716, 9717), Revillagigedo Island, one (no. 9718), Etolin Island, one (no. 9719), Bradfield Canal, one (no. 9720), Zarembo Island, five adults (nos. 9721, 9722, 9725, 9727), and two juvenals (nos. 9723, 9724). These birds as far as I can see are absolutely indistinguishable from specimens taken in southern California and Arizona.

\section{Empidonax trailli alnorum Brewster. Alder Flycatcher.}

A single bird, an adult male, secured on the Chickamin River, June 21. At least one other, possibly the mate of the bird shot, was seen on various occasions up to June 28 , but it was too wary 
to be approached. The vicinity was admirably suited to the needs of this flycatcher, the stream being bordered with broad grassy meadows, interspersed with clumps of willows, and I have little doubt that the birds seen were preparing to breed. This river valley forms a direct and expeditious highway from the interior to the sea, and the alder flycatcher, together with one or two other species, probably reaches the coast by following the stream westward, and not by traveling north along the seacoast.

The specimen secured (no. 9713) is distinctly referable to the subspecies alnorum, having the yellowish flanks and sides, the distinct wing-bars, small bill, and long wing of that race. It is in color and markings practically indistinguishable from a specimen of alnorum from the Prince William Sound region, Alaska (see Grinnell, 1910, p. 392), and is very similar to other specimens at hand from Maine and the Mississippi Valley.

Pica pica hudsonia (Sabine). American Magpie.

Met with only on the Taku River. No magpies were seen during the first part of our stay at this point, but on September 14 a single bird was secured, and shortly after the species became fairly common. They were apparently migrating from the interior toward the coast, sometimes flocks of eight or ten individuals being seen passing overhead. The camp was an evident attraction to them, and one or more were frequently seen foraging in the refuse.

The two specimens secured (nos. 9765, 9766) are immatures in first winter plumage, with a few juvenal feathers still lingering on the lower abdomen. They show no trace of the dusky suffusion below, apparent on the juvenals from the Prince William Sound region (see Grinnell, 1910, p. 393).

\section{Cyanocitta stelleri stelleri (Gmelin). Steller Jay.}

Throughout the spring and in the early part of the summer jays were decidedly rare at every point visited. On the Kake Islands, in April and early May, but three or four individuals were seen. Single birds or an occasional pair were observed at most of the localities visited on Prince of Wales, Dall, and others 
of the more southern islands; but not until the middle of July, when the young birds began to appear in the woods, was the species at all abundant. It was most numerous at Mitkof Island, early in August, when old and young together, in scattering troops of a dozen or more, were encountered along the streams and in the more open places in the woods. Two males were shot at Boca de Quadra June 11 which were evidently keeping together, and on dissection they proved to be non-breeding birds.

A young bird, nearly full grown but in the juvenal plumage throughout, was taken on Etolin Island on July 7 (no. 9756). Another, with patches of first winter plumage appearing in the pectoral tracts was secured on Mitkof Island, August 10 (no. 9758). An adult from the latter locality, August 4 (no. 9757) is in the midst of the post-nuptial molt, with little of the old plumage remaining, but with many of the new feathers but partly grown out. An immature male from the Taku River, September 9 (no. 9759), is in the first winter plumage throughout, but with only two rectrices. As these are grown out to their full length and the others entirely absent, this was probably due to an accident, and does not represent the normal molt.

Although the subspecies carlottae is stated (Osgood, 1905, p. 70) to occur in the southern part of Prince of Wales Island, I must confess my inability to distinguish two forms in the material collected. Some individuals taken south of Sumner Straits certainly do exhibit an extreme of dark coloration, with the color of the blue areas somewhat intensified, and might possibly be considered to represent the more southern race; but the differences are very slight. On the whole the jays collected show no tangible points of difference, either among themselves or compared with other series in the Museum collection, from the northern part of the Alexander Archipelago or from Prince William Sound, and I have no alternative but to include them all under the form stelleri. Though carlottae is alleged to be larger than stelleri, the published measurements show but trifling differences (cf. Ridgway, 1904, pp. 351-354); but even so, none of my specimens exceed the minimum dimensions ascribed to carlottae, and are thus well within the range in size of true stelleri. The differences distinguishing the two forms are slight, at the best, and any 
attempt to account for individual extremes of the latter by referring them to carlottae and thus extending its range into the southern part of Prince of Wales Island, is, it seems to me, bound to cause confusion.

Two mainland specimens from Boca de Quadra (nos. 9755, 9761) are quite as dark above as any from Prince of Wales, while others from Dall Island (no. 9752) and San Alberto Bay, Prince of Wales Island (no. 9750) are indistinguishable from specimens from Admiralty Island and other more northern points.

Seventeen specimens of the Steller jay were collected, as follows: Kupreanof Island, three (nos. 9745-9747), Coronation Island, one (no. 9748), Heceta Island, one (no. 9749), Prince of Wales Island, Calder Bay, one (no. 9760), San Alberto Bay, one (no. 9750), Klawak, one (no. 9751), Dall Island, three (nos. 97529754), Etolin Island, one (no. 9756), Mitkof Island, two (nos 9757, 9758), Boca de Quadra. two (nos. 9755, 9761), and the Taku River, one (no. 9759).

\section{Corvus corax principalis Ridgway. Northern Raven.}

Seen at every point we visited, sometimes in considerable numbers. They were usually quite tame, and made no effort to get far out of our way, while at several of our camps the ravens visited us daily for the purpose of carrying off refuse-the bodies of skinned birds and mammals, or the scraps trimmed from bear or deer skins. From the actions of some of the birds seen on Kuiu Island the first week of May, and at Klawak Salt Lake, Prince of Wales Island, towards the end of the same month, I judged them to have nests near by, containing eggs, or more probably young, but I was unable to find them. At Etolin Island, July 5 to 12, a brood of noisy young ones hovered about the camp daily, the old ones assiduously feeding them on the scraps I threw out, a process accompanied by gasping, choking, and gurgling noises.

One specimen of the northern raven was preserved, a juvenal female, Etolin Island, July 8 (no. 9762). This bird is just molting from the juvenal into the first winter plumage, with lines of glossy black feathers appearing in the pectoral tracts, on the throat, and on the top of the head. 
Corvus brachyrhynchos caurinus Baird. Northwestern Crow.

A common species nearly everywhere, though seldom seen far from tide water. It was noted at the following points: Kupreanof, Kuiu, Prince of Wales, Coronation, Warren, Dall, Duke, Revillagigedo, Etolin, Wrangell, Zarembo and Mitkof islands, and at Boca de Quadra, Chickamin River, Bradfield Canal, Thomas Bay, and the Taku River, on the mainland. Curiously enough the species was not seen at all at Port Snettisham.

At Three-mile Arm, Kuiu Island, a colony occupied a small island in the bay. They vigorously resented the appearance of any raven or eagle in the vicinity, the whole flock turning out to battle with the intruder, who was always glad to beat a hasty retreat. At Marten Arm, Boca de Quadra, a colony of about fifteen pairs of birds occupied an isolated clump of spruce trees, about an acre in extent, in the midst of meadow land. The nests were built at varying heights, from thirty feet up, and were usually placed on a large limb, and against the trunk of the tree. At this time-June 9-14-they were all occupied by young birds. At Portage Cove, Revillagigedo Island, at the end of June, many young birds were out flying around, but still attended by their parents.

At Etolin Island crows were excessively abundant along the beach. Here they were continually observed feeding on clams in the manner already reported by Dixon (see Grinnell, 1909, p. 222), flying in the air with the molluse so as to drop it on the rocks and break the shell.

At Bradfield Canal they were common, and many old nests were observed in a corner of the woods. On the Taku River in September the species was abundant, and at this time gathered in large flocks, sometimes of a hundred or more individuals.

Two specimens of the beach erow were collected, an adult male from Boca de Quadra, June 12 (no. 9763), and a juvenal female from Etolin Island, July 6 (no. 9764).

Euphagus carolinus (Müller). Rusty Blackbird.

Hasselborg reported a single specimen seen at Freshwater Bay, Chichagof Island, on November 25. He is familiar with the 
species and I have no hesitation in accepting his identification. On the morning of April 6 while the steamer on which I was traveling north lay at anchor, storm bound, in a little cove at the southern end of Queen Charlotte Sound, a large flock of blackbirds, possibly of this species, was observed feeding along the rocky beach some hundred yards distant.

Pinicola enucleator flammula Homeyer. Kadiak Pine Grosbeak.

Apparently very rare in the region traversed. Two single, bright-plumaged males were seen on the Chickamin River and at Portage Cove, on June 23 and July 3, respectively. In each case the bird was sitting in a tree top, singing, and was too shy to permit a near approach. Hasselborg secured an adult female at Bradfield Canal, on July 25 (no. 9546). The single bird obtained is similar in color and proportions to specimens in the Museum collection from other parts of the Sitkan district, and from the Prince William Sound region, and, together with these, is referable to the subspecies flammula.

\section{Loxia americana sitkensis Grinnell. Sitka Crossbill.}

Red crossbills were not observed at all during the early part of the season, when the white-winged was seen, but they first appeared about the end of May. Hasselborg saw a flock on Warren Island, on May 20, and several flocks were seen near Klawak, Prince of Wales Island, a week later. None were observed on Dall Island, but several single birds were seen on Duke Island, and flocks at Boca de Quadra, the Chickamin River, Portage Cove, and Etolin Island. At Zarembo Island the crossbills were more numerous than at any other point, some in pairs but many in small flocks. The males were in full song at this time, and all were very restless, flying about continually. A few were seen at Mitkof Island, at Thomas Bay, and Port Snettisham, but none on the Taku River.

Though observed at so many points, sometimes in comparatively large numbers, I found it practically impossible to collect specimens, as the birds seen were almost invariably flying high overhead or else perched in the tops of the tallest trees. I 
secured one, an adult female, at the Chickamin River, June 19 (no. 9545), out of a large flock.

As I have not at hand any additional material-nor even as much as Grinnell (1909, p. 223) had when he described the race sitkensis-I do not feel qualified to argue very strongly either for or against the recognition of this subspecies, though with his Alaskan specimens before me I am quite able to appreciate the points he makes, both concerning the color of the male birds, and the general size of the form. There is this much, also, to be said in support of the naming of a northwest coast race of the red crossbill, that although in size it closely approaches the eastern minor, it appears to be separated from the range of that bird by a robust, large-billed form. The crossbills wintering in the Mississippi Valley approach very nearly the variety bendirei in size, and are as conspicuously different from the southern Alaska birds as from those of the Atlantic states. It is fair to assume that this is the breeding bird of the interior of Canada, and that the race sitkensis is hence completely separated from the form which it most nearly resembles.

Loxia leucoptera Gmelin. White-winged Crossbill.

Apparently mainly a migrant or winter resident in the southern part of the Sitkan district, for none were seen after May 6. On Kupreanof Island, in April, the species was fairly common in flocks in the woods, and on Kuiu Island a little later a few were seen at various times. We left the latter island on May 6, and saw no more white-winged crossbills at any time. Males in fully adult plumage formed but a small proportion of the flocks seen.

Eleven specimens were secured: three adult males in bright red plumage of various degrees of intensity, two from Kupreanof Island (nos. 9535, 9540) and one from Kuiu Island (no. 9544); also one dull colored male from Kuiu Island (no. 9543); and seven females, six from Kupreanof (nos. 9534, 9536-9539, 9541) and one from Kuiu (no. 9542.)

Several of the birds secured appear to have recently accomplished a partial molt, and are in noticeably bright, fresh, plumage, as compared with certain others. 
Acanthis linaria linaria (Linnaeus). Redpoll.

On Kupreanof Island, in April, the redpolls were fairly common, in flocks together with the white-winged crossbills. They were shy and restless, moving continually from place to place, and were consequently hard to secure. After leaving Kupreanof, April 24, the species was lost sight of, and was not seen again until August 17, at Thomas Bay, when Hasselborg secured a bird in the streaked juvenal plumage, from a flock of the same species. Were it not for this juvenal I would suppose the species to be merely a winter resident or transient in the region; and the capture of this young bird by no means constitutes a breeding record, as the flock containing it may well have wandered from somewhere in the interior, other birds having begun to move at this time.

Five specimens were secured : two adult males and two adult females from Kupreanof (nos. 9548-9551), and the young bird mentioned above (no. 9552). These are not perceptibly different from others from the interior of Alaska and other parts of North America.

Spinus pinus (Wilson). Pine Siskin.

In view of the abundance of the species on Admiralty and Chichagof islands, as reported by the 1907 Expedition, it seems strange that we found it at so very few points. A few flocks of siskins were seen at Boca de Quadra, and a number on the Chickamin River. At the latter place they were feeding in company with the Sitka crossbill, and in both localities they kept high in the trees, out of shotgun range for the most part. One specimen was secured, an adult male (no. 9547), Chickamin River, June 24. This bird is very dark colored, though not more so than some individuals from other localities.

\section{Plectrophenax nivalis nivalis (Linnaeus). Snow Bunting.}

A single bird was seen on the wharf at Douglas Island, opposite Juneau, on the morning of April 9, feeding among the refuse and hopping about through the litter on the dock. 
Calcarius lapponicus alascensis Ridgway. Alaska Longspur.

An abundant species on the grassy meadows bordering the Taku River. During our stay at this point, September 4 to 28, longspurs were seen almost daily, usually in flocks of from twenty to thirty individuals, and evidently migrating. They were hard to see in the tall grass in which they were feeding, and still more difficult to secure, for they would sit quietly until nearly trodden upon, when the whole flock would dart away simultaneously.

They were observed at no other point, unless Hasselborg was correct in his belief that a bird seen on the summit of Pin Peak, Coronation Island (altitude 1300 feet), on May 16, belonged to this species.

The fourteen examples of the Alaska longspur collected (nos. 9553-9566), all immatures in first winter plumage, bear out the characters ascribed to the race, being conspicuously paler and more buffy on the upper parts as compared with a series of comparable fall specimens of lapponicus from Illinois.

\section{Passerculus sandwichensis sandwichensis (Gmelin).}

Aleutian Savannah Sparrow.

Four specimens referable to this race were secured, one from Three-mile Arm, Kuiu Island, May 3 (no. 9571), and three from Egg Harbor, Coronation Island, May 15 (nos. 9567, 9568, 9570), all adult males. As no examples of this subspecies were found among the Savannah sparrows collected at other points, it looks very much as though the line of migration of this form lies along the extreme western edge of the archipelago; and as Kuiu Island lies actually farther north than the breeding ground of this bird on Unalaska Island and the Alaska Peninsula, it may be that instead of following the coast line any farther they strike directly westward across the Gulf of Alaska. This assumption is somewhat borne out by the fact that the 1908 Expedition failed to find the species in the Prince William Sound region (see Grinnell, 1910, p. 399), which must be traversed if the coast line is followed. On Kuiu Island, on May 3, the first 
date at which any Savannah sparrows were seen, one specimen of sandwichensis and three of savanna were secured. On Coronation Island, Savannah sparrows were quite abundant in the grass growing on the sandy beach at the head of Egg Harbor, and of five secured, three are sandwichensis.

\section{Passerculus sandwichensis savanna (Wilson).}

Savannah Sparrow.

First observed on Kuiu Island, May 3, when three were secured and others seen. It was subsequently met with, evidently migrating, at most of the points visited during MayCalder Bay and Klawak Salt Lake, Prince of Wales Island, and on Coronation, Warren, and Heceta islands. On the Chickamin River, in June, the species was fairly common and evidently breeding, the males singing from the tops of the scrubby willows scattered over the meadows. It was next seen at Thomas Bay, in August, where the birds were abundant in the swampy meadows. At Port Snettisham and on the Taku River they were also abundant, and evidently migrating.

Twenty-three specimens were collected (nos. 9572-9594), twelve summer adults, and one adult and ten immatures in fresh winter plumage. Although I designate this series by the name savanna, it is merely as a matter of convenience, for this Alaskan race can hardly be considered the same as the one inhabiting eastern North America, although the two forms have developed a wonderful similarity. I am unable to detect a single constant difference-at any rate certain selected individuals from the eastern and Alaskan series at hand are absolutely indistinguishable. As a rule the Sitkan birds seem to have rather more yellow over the eye than the eastern; other average differences are the somewhat larger size and more slender bill of the former, in both of which respects they approach alaudiuus. It is probably a rather local race, inhabiting the Pacific Coast region from the Sitkan district southward for an undetermined distance, and separated from the range of the eastern $P$. s. savanna by the broad stretch of country occupied by alaudinus. 


\section{Zonotrichia leucophrys gambeli (Nuttall).}

\section{Intermediate Sparrow.}

First seen at Thomas Bay, on August 22, when a flock of six or eight was observed in an alder thicket. At Port Snettisham, August 24 to September 1, intermediate sparrows were fairly common on the brushy hillsides, but were shy and difficult to approach. Only immature birds were seen, that is, those with the brown head markings. On the Taku River, during September, they were fairly common, but irregularly so, the numbers seen varying greatly on different days. On September 18 the first adults-with white head stripes-were observed.

The principal migration route of this bird does not seem to include the islands of southeastern Alaska, since the 1907 expedition did not find it on Admiralty Island in the spring, while I did not note it at an island locality at any time.

Five specimens were secured, three from Port Snettisham (nos. 9626-9628) and two from the Taku River (nos. 9629-9630), all immature males in first winter plumage.

\section{Zonotrichia coronata (Pallas). Golden-crowned Sparrow.}

Two specimens secured at Calder Bay, Prince of Wales Island, on May 11, were the only ones noted in the spring at any time. These two are adult male and female, and in perfect nuptial plumage (nos. 9623, 9624). The species was met with next at Port Snettisham where a female in first winter plumage was shot on August 29 (no. 9625). It was quite probable that they were fairly common at this point, as Zonotrichias were very numerous in the brush; and although all that were seen near enough to identify were $Z . l$. gambeli, still, in the immature plumage, the two species are so much alike as to be easily confused.

On the Taku River during September golden-crowned sparrows were seen on several occasions, but were never at all common. 
Spizella monticola ochracea Brewster. Western Tree Sparrow.

Hasselborg reported tree sparrows as abundant along the Taku river on October 20, and again at Game Cove, Admiralty Island, on November 8. No specimens were secured, but as he is familiar with the species, I have no hesitation in accepting his statement.

Junco hyemalis hyemalis (Linnaeus). Slate-colored Junco.

On. September 4, on the Taku River, one specimen was secured, which was in company with another, apparently of the same species. On several subsequent occasions during September I saw what I supposed were examples of slate-colored juncos, in flocks of oreganus, but failed to get any. The single specimen obtained (no. 9620) is an immature male, in first winter plumage, and is typical of the species, but with the gray of the back somewhat overcast with brownish, as is usually the case with young birds. This bird, in common with the small series at hand from Prince William Sound, is remarkable in that the outer tail feather only, is pure white. The next has about the terminal third of the outer vane black, and the third has no white on it at all. Specimens of hyemalis at hand from the interior of Alaska and from the eastern United States all have more or less white on the three outer rectrices.

A junco taken on the Taku River on September 12 (no. 9619) is, I believe, a hybrid between hyematis and oreganus. It is an adult male, in its second year at least, as was apparent from the condition of the skull, and is in fresh, winter plumage. In general it may be said to be like oreganus above, and like hyemalis below. The brown of the dorsum is sharply defined against the head, but is of a darker shade than is ever the case in oreganus, being between mummy and prout brown, while the feathers of the back are only brown-tipped, being black basally. The outline of the black throat is convex against the white of the lower surface, but the sides and flanks are slaty, with but a slight tinge of vinaceous. 


\section{Junco oreganus oreganus (Townsend). Oregon Junco.}

Though we found the Oregon junco quite generally distributed over the region traversed, it was not common anywhere until late in the summer, when the broods of young began to appear about the woods. The first arrival was noted on Kuprean of Island, on April 19, a single bird, and on the following day a small flock was seen at the same place. A few scattered individuals were seen on Kuiu, Prince of Wales, Warren, Heceta, and Dall islands. At Portage Cove, Revillagigedo Island, juncos were fairly common and evidently breeding in the brush bordering the meadows. At Etolin Island, July 5 to 12, the first broods of young were seen flying about, and at Bradfield Canal, Zarembo Island, and Mitkof Island they became comparatively abundant. At Thomas Bay, August 13 to 23, juncos were common, feeding in the open, grassy meadows, or on the ground in the shelter of the alder thickets. Old and young were in the midst of the molt at this time, and were all very ragged in appearance. At Port Snettisham a few juncos were seen, but they were not abundant. On the Taku River in September, small flocks were seen daily. Young birds taken during the first week in September had nearly finished the post-juvenal molt, having but a few spotted feathers remaining, while an adult female shot on September 22 (no. 9622) has also practically completed the change. This adult differs from young females in first winter plumage in having the black of the head sharply defined against the brown back, while in the latter there is no line of demarcation, the brown extending over most of the head.

Twenty-six specimens were secured from the following localities: Kuiu Island, one (no. 9595), Warren Island, one (no. 9596), Heceta Island, one (9597), Rocky Bay, Dall Island, two (nos. 9598, 9599), Portage Cove, Revillagigedo Island, one (no. 9600), Etolin Island, one (no. 9601), Bradfield Canal, one adult (no. 9605) and three juvenals (nos. 9602-9604), Zarembo Island two juvenals (nos. 9606, 9607), Mitkof Island, one juvenal (no. 9608), Thomas Bay, two adults (nos. 9609, 9610), Port Snettisham, one adult (no. 9611), Taku River, one adult (no. 9622) and eight immatures (nns. 9612-9621). 
Although Junco oreganus is generally considered to be a race of $J$. hyemalis, and the trinomial used to designate it, I have seen no conclusive evidence in support of this view, while there is much to be said against it. Hyemalis ranges, without perceptible change, from the Atlantic coast to the interior of Alaska, to within a comparatively short distance of the Pacific coast, where it is abruptly replaced by oreganus. There is no blending of characters where the ranges of the two species meet - the criterion usually accepted as the test of a subspecies. Alaskan examples of hyemalis are indistinguishable from those taken in eastern North America; neither can the races or species of juncos occupying intermediate regions farther south be said to illustrate intergradation. Occasionally individuals are met with combining the characters of hyemalis and oreganus (such as the specimen no. 9619 described in this paper under $J$. hyemalis); but I am inclined to accept Ridgway's view (1901, p. 276), and to consider such birds as hybrids.

Melospiza melodia rufina (Bonaparte). Sooty Song Sparrow.

When I arrived in Alaska, early in April, there were no song sparrows to be seen anywhere, and it seems evident that rufina does not remain through the winter in the northern part, at least, of its breeding range. It was first seen at Three-mile Arm, Kuiu Island, on April 30, when two specimens were secured, and from then on it was observed, though usually in small numbers, at almost every point visited. By the third week in May they had begun to pair off; and the female of a pair secured on Duke Island, June 8, was evidently incubating, as were others secured on the Chickamin River, June 17 to 28. At Portage Cove, Revillagigedo Island, a nest containing four eggs was found on June 28, built in tall meadow grass about a foot above the ground. The first young were seen at Etolin Island, on July 6, and specimens in juvenal plumage were secured at various points up to as late a date as September 4.

One taken at Port Snettisham on August 28 (no. 9698) has almost completely acquired the first winter plumage, and others obtained on the Taku River during September are in this plumage throughout. An adult female shot at Thomas Bay on 
August 21 (no. 9697) is in the midst of the post-nuptial molt, and is but scantily covered with feathers. At all the island localities visited the sooty song sparrow was distinctly a bird of the beaches, and was observed nowhere else; but at several of the mainland points, Chickamin River, Thomas Bay, and Taku River, it was common in the grassy meadows bordering the streams.

Twenty-five specimens were secured, from the following localities: Kuiu Island, three (nos. 9677, 9678, 9684) ; Klawak, Prince of Wales Island, one (no. 9687); Warren Island, two (nos. 9685, 9686) ; Duke Island, two (nos. 9688, 9689); Boca de Quadra, one (no. 9693); Chickamin River, three (nos. 96909692); Etolin Island, one (no. 9694); Thomas Bay, three (nos. 9695-9697) ; Port Snettisham, one (no. 9698) ; and Taku River, eight (nos. 9699-9706).

Melospiza melodia caurina Ridgway. Yakutat Song Sparrow.

The first song sparrows to appear in the region in the spring were large sized, gray colored individuals, conspicuously different, even in life, from the smaller, brownish birds which arrived soon after. The earliest arrival was seen on Kupreanof Island, on April 18; the next at Three-mile Arm, Kuiu Island, April 26, when three were secured. These gray colored birds were seen from time to time up to about the middle of May, when they disappeared. Specimens were collected as follows: Three-mile Arm, Kuiu Island, five (nos.9673, 9676, 9679-9681) ; Port Protection, Prince of Wales Island, one (no. 9682) ; Calder Bay, Prince of Wales Island, one (no. 9683). Through the courtesy of the authorities of the National Museum I have been able to compare these birds with a series of specimens of caurina from Yakutat Bay, and, allowing for the slight differences due to the different seasons at which the two series were collected (the latter were taken in June), find them indistinguishable in color and proportions.

In studying the song sparrows of the present collection I took occasion to go over the specimens secured by the 1907 Expedition; and, in the light of much additional material, together with a better knowledge of local conditions, have arrived at 
conclusions regarding these birds differing from those expressed by Grinnell in his report upon the collection of that year (1909, pp. 229-231). On the supposition that song sparrows were resident wherever found in this region, all the specimens collected were included by Grinnell under the subspecies rufina, with comment upon the variability of the form. The supposedly aberrant specimens, however, are all very much alike, were all secured upon dates on which they might well be migrating, and are all, I believe, to be referred to Melospiza $m$. caurina. The individuals referred to are as follows: one specimen from Windfall Harbor, Admiralty Island, April 21 (no. 528); two from Peril Strait, Baranof Island, August 24 (no. 507), and August 25 (no. 508); three from Helm Bay, September 14 (no. 517), and September 15 (nos. 518, 519); and one from Thomas Bay, September 3 (no. 515). Of two breeding birds from Glacier Bay, one (no. 512) is a good example of rufina, while the other (no. 514), both in coloration and in slenderness of bill, is decidedly like caurina, as already stated by Grinnell ( $l$. c.). Glacier Bay being about at the dividing line between the breeding ranges of the two forms, specimens from this point might be expected to manifest a mingling of the characters of the two, in other words to show intergradation between them, but such cannot be said to be the case with these two individuals. One is an extreme example of rufina, the other an average specimen of caurina.

Included in the series loaned me by the National Museum is one taken at Howkan, Alaska (on Long Island, near the southern extremity of Prince of Wales), on January 6, 1897 (no. 154414). This would indicate that caurina spends the winter as far north as the southern part of the Alexander Archipelago, though, judging from my experience, it does not do so on the more northern islands of the group.

Melospiza lincolni gracilis (Kittlitz). Forbush Sparrow.

First met with at San Alberto Bay, Prince of Wales Island, on May 25, when a single bird was secured; while a day or two later several were observed in the meadows about Klawak Salt Lake. The species was not encountered again until we reached 
the Chickamin River, where it was quite common, and evidently breeding. No nests were found, but a female shot at this point had laid part of its set; the males were observed continually singing from the tops of small trees.

It is of special interest to note that here the Forbush and song sparrows were about equally abundant, and breeding in precisely the same places-the broad grassy meadows bordering the stream-furnishing an instance of two species of a genus occupying exactly the same area during the breeding season. This is of interest as an apparent exception to what seems to be a very general rule to the contrary among vertebrates, and one that holds in regard to these species in other parts of their range, as in most of our record stations in southeastern Alaska. While elsewhere in this general region the song sparrows are found on or near the beach, the Forbush sparrow occurs in the grassy meadows or swamps, usually some distance from tidewater, and never along the shore.

The song sparrow (Melospiza melodia) with its various subspecies, and the Lincoln sparrow with its two races, Melospiza lincolni lincolni and $M$. l. gracilis, are found over nearly all parts of North America, the former in the Sonoran Zone over most of its range, the latter in the Canadian and Hudsonian. The mild climate of the northwestern Pacific Coast region has enabled the song sparrow to extend farther north here than elsewhere, and the ranges of the two species have thus overlapped. Even, here, however, local conditions keep them slightly separated for the most part, and of the places visited by us it was only in this one river valley that environmental conditions seemed to be favorable to both species. The song sparrow is apparently the most recent arrival, as in other seemingly very similar places it was either very rare or entirely absent, while the Forbush sparrow was found in all such meadows.

At Portage Cove, Revillagigedo Island, it was quite common in the boggy meadows. A nest was found built on the ground, and well concealed under a bunch of drooping dead grass, which gave it almost the appearance of a domed structure. In the morning of July 1 it contained five young birds, which had all left before night. 
On Mitkof Island several broods of young birds were seen along one of the streams. One secured here on August 8 ( $\delta$ juv. no. 9640) is just beginning to molt the juvenal plumage, a few pin feathers appearing on the throat, breast and crown. At Thomas Bay (August 13 to 23) the species was fairly abundant in the meadows, all that were secured being immatures that had assumed the first winter plumage, few showing even a trace of juvenal feathers. They were also exceedingly abundant at Port Snettisham, feeding in the tall grass at the edge of a dense willow swamp. Along the Taku River they were fairly common, usually at the edge of the meadows, where bordering thickets afforded an abundance of shelter.

Twenty-four specimens were secured, as follows: San Alberto Bay, Prince of Wales Island, one (no. 9631), Klawak Salt Lake, one (no. 9632), Chickamin River, four (nos. 9633-9636), Portage Cove, Revillagigedo Island, one (no. 9637), Mitkof Island, three juvenals (nos. 9638-9640), Thomas Bay, four immatures (nos. 9641-9644), Port Snettisham, five immatures (nos. 9645-9649), Taku River, five immatures (nos. 9650-9654).

Passerella iliaca insularis Ridgway. Kadiak Fox Sparrow.

A single fox sparrow taken at Three-mile Arm, Kuiu Island, on April 30, is apparently to be referred to this form. It is a pale colored, large-billed bird, widely different from the breeding bird of the region ( $P$. i. townsendi). Neither is it to be referred to the breeding bird of the Prince William Sound Region (P. i. sinuosa) from which it differs in browner color and much larger bill.

This bird ( $ठ$ ad. no. 9655) was caught in a mouse trap set on a little island in the bay. It was the only fox sparrow that was seen on any of the islands south of Frederick Sound, no form of Passerelln being found breeding at any point.

Passerella iliaca townsendi (Audubon).

Townsend Fox Sparrow.

As no fox sparrows wene observed at any of the numerous places visited between Frederick Sound and Dixon Entrance, this 
bird can hardly be considered as a component part of the fauna of the region, as has been supposed. I could hardly have overlooked the species entirely if it had been present, for I was on the lookout for it constantly, but with the exception of the single example of $P$. $i$. insularis noted above, no fox sparrow was observed at any island locality visited; nor at any mainland point until we reached Port Snettisham. This is the more remarkable in that while the species is common on the more northern islands of the Alexander Archipelago (Admiralty, Chichagof, and Baranof), it is also known to occur abundantly on the Queen Charlotte Islands to the southward (Osgood, 1901, p. 48).

At Port Snettisham, August 24 to September 2, fox sparrows were abundant. The hillsides at this point were covered in places with dense masses of low underbrush, these thickets being composed almost entirely of a single species of plant (Cladothamnus pyrolaeflorus). This provided the fox sparrows with an abundance of shelter and here most of them were found, though a few were also observed in willow thickets and in the alders along the beach. These brush-covered slopes bore a strong general resemblance to the chinquapin-covered hillsides of the higher mountains of southern California-the favorite haunt of Passerella $i$. stephensi-a similarity further borne out by the presence of these sparrows.

On the Taku River, during September, fox sparrows were irregularly abundant and evidently migrating, the last being noted on September 19.

Seventeen specimens were collected. One (no. 9664, ð juv. Port Snettisham, August 29) is in the juvenal plumage purely; three others from Port Snettisham (nos. 9657, 9658, 9661) are molting from the juvenal to the first winter plumage; the remainder of the series, nine from Port Snettisham (nos. 9656, 9659, 9660, 9662, 9663, 9665-9668) and four from the Taku River (nos. 9669-9672), are all in first winter plumage. No adults were secured. They are extremely dark colored, as compared with spring and summer specimens of townsendi, but this is probably due to the fresh unworn state of the plumage. 


\section{Piranga ludoviciana (Wilson). Western Tanager.}

A single bird taken on the Chickamin River on June 21, (no. 9354 ) is, I believe, the first of the species to be reported from any part of Alaska. This specimen is a male adult, in rather dull plumage, with but little red on the head. It was heard singing in the distance and at first mistaken for a robin and nearly passed by as such. Search finally revealed the singer in the top of an alder, at the edge of the woods, where it was secured. From the bird's appearance and actions I feel quite sure that it had a mate on a nest somewhere in the vicinity. It is the only one of the species that was seen.

\section{Hirundo erythrogaster palmeri Grinnell.}

Western Barn Swallow.

First seen at Marten Arm, Boca de Quadra, June 9 to 14. Here the barn swallows were fairly common, hovering over the grassy meadows in company with the swifts and tree swallows. On the Chickamin River they were seen daily, though not in any numbers; all observed being in pairs.

A few pairs were seen at Portage Cove, Revillagigedo Island, the only island locality where barn swallows were noted. At Thomas Bay the species was far more abundant than at any other point, large gatherings of adults and young together circling about over the meadows. At this time, August 13 to 23, many of the young were still attended by their parents. At Port Snettisham, August 24 to 31, small flocks were occasionally seen passing high overhead, evidently migrating southward.

Six specimens were collected: adult male, Boca de Quadra (no. 9373), adult female, Revillagigedo Island (no. 9374), and two adults and two juvenals from Thomas Bay (nos. 9375-9378).

These specimens, as well as others in the Museum collection from the Sitkan district, bear out the ascribed characteristics of palmeri, at least as regards the dark coloration of the ventral surface, broad, chestnut forehead patch, and deeply forked tail-as compared with specimens from the eastern United States,- -but I am unable to appreciate any difference in the wing length. 
Iridoprocne bicolor (Vieillot). Tree Swallow.

First noted at San Alberto Bay, Prince of Wales Island, on May 24, when several migrating swallows, apparently of this species, were seen. During the next few days numerous small flocks were observed, usually flying so high overhead that they would not have been noticed were it not for their continual twittering. At Boca de Quadra there were a few pairs, but the species was not common. On the Chickamin River they were noted daily, and several were seen entering holes in dead trees. At Portage Cove, Revillagigedo Island, there were also a few pairs. Only one or two single birds were seen at Bradfield Canal, but at Zarembo Island flocks of juvenals were observed hovering about over the mud flats, but a few inches from the ground. On Mitkof Island a single bird was seen flying south on August 12. At Thomas Bay, August 13 to 23, the species was abundant over the grassy meadows, in company with the barn swallows. This is the last point at which it was noted.

Five specimens were collected: two adult males, Chickamin River (nos. 9368, 9369), adult male, Portage Cove, Revillagigedo Island (no. 9370), juvenal male, Zarembo Island (no. 9371), and juvenal male, Thomas Bay (no. 9372). There are no apparent differences between these and California specimens.

\section{Tachycineta thalassina lepida Mearns.}

Northern Violet-green Swallow.

On the Chickamin River, June 17 to 28, I several times saw violet-green swallows, the lateral white patches at the base of the tail serving to distinguish them from the tree swallows with which they were associated. Hasselborg saw some "white-rumped" swallows twenty-five miles up the river. At Thomas Bay several were seen in the large flocks of barn and tree swallows, and a juvenal male secured on August 22 (no. 9379).

Riparia riparia (Linnaeus). Bank Swallow.

At Thomas Bay, August 15, a single bank swallow was seen repeatedly. This was the only occasion on which the species was observed, but the peculiar flight and coloration both served to 
distinguish this bird from the other species of swallows it was associated with at the time, and I have no doubt as to the correctness of the identification.

Bombycilla cedrorum Vieillot. Cedar Waxwing.

A single bird, an adult male, taken June 22 on the Chickamin River (no. 9355). This bird was feeding by itself in a spruce tree, when my attention was drawn to it by its occasional utterance of the low hissing sound peculiar to the species. This was the only cedar bird seen during the summer; it had no appearance of being a breeding bird, and was doubtless a straggler from the interior, strayed down the river. It is, I believe, the first individual of the species to be recorded from Alaska.

Lanius borealis invictus Grinnell. Alaska Shrike.

Hasselborg saw a shrike on the Taku River on October 20, and another at Game Cove, Admiralty Island, on November 8. He was very close to the latter, but had no means of securing it, and remarks that it is the only one of the species that he has seen on any of the islands.

Vermivora celata celata (Say). Orange-crowned Warbler.'

Met with only at Port Snettisham. It was seen high up on the mountain sides only, beyond the timber and almost always in thickets of Cladothamnus pyrolaeflorus, in company with the Townsend and intermediate sparrows. Lutescens, which was also common at Port Snettisham, was never seen in this association, but kept lower down, usually in the alders along the beach, where celata was never observed. Possibly ten or twelve individuals were seen in all. They were restless and shy, and evidently migrating, flitting from bush to bush, or occasionally rising high in the air manifestly for a long flight, and disappearing in a southerly direction.

Four specimens were secured, three in complete first winter plumage (nos. 9493-9495), and one which has nearly finished the molt from the juvenal to the first winter plumage (no. 9496). An immature male (no. 9495) has the concealed orange crown fairly well indicated. In the other three (all immature females) 
there is no indication of such a mark. All four are typical, even extreme, examples of celata, with white orbital ring and gray head, and with the underparts streaked with grayish. They can be matched with fall specimens from southern California, as well as with some from other parts of North America.

Vermivora celata lutescens (Ridgway). Lutescent Warbler.

The first of the species, a single bird, was seen on Warren Island May 19, and during the rest of our stay at this place, until May 23, they were occasionally observed flitting through the alders along the beach. The only other place along the western edge of the archipelago where the species was seen was at Rocky Bay, Dall Island, where one was secured, and several others seen on May 31. On the Chickamin River they were rare; At Portage Cove, Revillagigedo Island, they were fairly common, and apparently breeding in the scrubby thickets. The males were in full song at this time. At Bradfield Canal, July 18 to 26 , they were seen daily, the first juvenals being observed at this point. But a single bird was seen on Zarembo Island.

At Mitkof Island, August 1 to 13, they were observed in numbers, evidently migrating, usually in the fringe of alder along the beach. At Thomas Bay they were quite common, as also at Port Snettisham. A few were seen on the Taku River up to September 7; no more were observed until September 19, when a single bird was met with, the last record for the season.

Eleven specimens were collected, as follows: Warren Island, one (no. 9497) ; Rocky Bay, Dall Island, one (no. 9498) ; Chickamin River, one (no. 9499) ; Portage Cove, Revillagigedo Island, one (no. 9500); Bradfield Canal, two juvenals (nos. 9501, 9502); Bradfield Canal, two juvenals (nos. 9503, 9504); Thomas Bay, one immature (no. 9505); Port Snettisham, one immature (no. 9506) : Taku River, one immature (no. 9507).

Dendroica aestiva rubiginosa (Pallas). Alaska Yellow Warbler.

Apparently of quite rare occurrence in this region, for it was seen in very few places, and in limited numbers. A single bird, an adult male, seen, but not secured, at Rocky Bay, Dall Island, on May 30, was the first observed, and also the only individual 
seen on any of the islands. At Boca de Quadra, June 9 to 14, one was heard singing on several occasions. On the Chickamin River, June 17 to 28 , probably eight or ten were seen or heard singing, in clumps of willow on the meadows, but they appeared to be migrating, and specimens secured at this time were evidently not breeding. At Thomas Bay, August 13 to 23 they were migrating southward, a few individuals being seen in mixed flocks composed of Townsend and pileolated warblers, kinglets and chickadees. On the Taku River they were seen from time to time up to the last day of our stay, September 28. All that were observed were exceedingly wild and unapproachable, and it was with the greatest difficulty that any were obtained. Eight specimens were secured, three adult males and two adult females from the Chickamin River (nos. 9508-9512), two immatures, male and female, from Thomas Bay (nos. 9513, 9514), and an immature female from the Taku River (no. 9515).

\section{Dendroica coronata hooveri MeGregor.}

Alaska Myrtle Warbler.

Met with only on the Taku River, where, however, the species was not at all uncommon. First noted on September 7, and seen daily thereafter up to the end of my stay, evidently migrating, and usually in loose flocks of from six to ten individuals.

Nine specimens were collected, all immatures in first winter plumage. At this stage hooveri is apparently but very slightly distinguished from true coronata. Compared with a small series of autumnal immatures from Illinois the Alaskan birds average slightly larger, while the coloration of the upper parts is somewhat darker. The specimens secured measure as follows:

\begin{tabular}{|c|c|c|c|c|c|c|}
\hline No. & Sex & Date & Wing & Tail & Tarsus & $\begin{array}{l}\text { Bill from } \\
\text { Nostril }\end{array}$ \\
\hline 9524 & $\delta^{\pi}$ & Sept. 7 & 74.0 & 58.0 & 17.5 & 7.0 \\
\hline 9525 & $\sigma^{\prime \prime}$ & Sept. 7 & 73.0 & 54.0 & 18.0 & 7.0 \\
\hline 9257 & $\sigma^{2}$ & Sept. 10 & 76.0 & 58.0 & 18.0 & 7.0 \\
\hline 9828 & $\delta^{*}$ & Sept. 10 & 77.5 & 60.8 & 16.5 & 7.2 \\
\hline 9529 & $\delta^{x}$ & Sept. 12 & 74.0 & 56.0 & 17.5 & 7.2 \\
\hline 9531 & $\sigma^{\pi}$ & Sept. 14 & 73.0 & 58.2 & 17.5 & .... \\
\hline 9526 & q & Sept. 9 & 69.0 & 54.0 & 17.0 & 7.2 \\
\hline 9530 & $q$ & Sept. 13 & 69.0 & 55.0 & 17.2 & 7.0 \\
\hline 9532 & $q$ & Sept. 24 & 70.5 & 52.8 & 16.0 & $\ldots$. \\
\hline
\end{tabular}


Dendroica striata (Forster), Black-poll Warbler.

A single specimen, an immature female in complete first winter plumage, secured on the Taku River, September 4 (no. 9533). It was in a mixed flock of warblers, kinglets, and nuthatches, evidently migrating. Probably but a straggler from the interior, as it was not previously known to occur in the coast region, its southward line of migration lying east of the moun. tains entirely.

\section{Dendroica townsendi (Townsend). Townsend Warbler.}

Nowhere very common in this region, though observed at many scattered localities. The first was seen at Calder Bay, Prince of Wales Island, on May 12, an adult male. Next observed at Warren Island, where one was secured on May 21 and several others seen during the next few days. The species was then lost sight of until Boca de Quadra was reached. Here I secured the male bird of a pair which was possibly preparing to breed in the vicinity, though they were the only ones seen at this point. This individual, though a breeding bird, is not in perfect, mature, plumage, the black of the throat being much obscured by the yellow tips of the feathers. No more were observed until we arrived at Mitkof Island, in August. By this time the southward migration was under way, and an occasional Townsend warbler could be seen in the flocks of small migrants flitting along the shrubbery at the edge of the woods. At Thomas Bay also they were seen almost daily, usually in the alders, while on the Taku River occasional individuals were seen up to September 14.

Eight specimens were secured: adult male, Warren Island (no. 9516); adult male, Boca de Quadra (no. 9517); adult female, Mitkof Island (no. 9518) ; two immatures, Thomas Bay (nos. 9519, 9520); three immatures, Taku River (nos. 9521-9523).

The female from Mitkof Island (no. 9518, August 11) is in the midst of the post nuptial molt. The immatures are all in complete first winter plumage. 
Oporornis tolmiei (Townsend). Tolmie Warbler.

Although this species has not been previously reported from Alaska, we found it at nearly all the mainland points visited, as far north as Port Snettisham. At Boca de Quadra, where it was first seen, my attention was drawn to the birds by the singing of the males, usually in the willow thickets bordering the meadows. Several were seen or heard, and an adult male and female secured. At this time (June 11 to 14 ) they were apparently preparing to breed. On the Chickamin River, later in June, the species was fairly common in similar situations, and was undoubtedly breeding. The males were heard singing continually, but they were exceedingly shy, and hard to catch sight of, as they clung to the dense thickets and tangled shrubbery. At Bradfield Canal, the middle of July, several were seen, while at Port Snettisham, August 25 to September 1, four were secured and several others noted. At this latter place all that were seen were in thick vegetation about the edges of a dense willow swamp, and the birds were very quiet and unobtrusive. They were probably fairly numerous at this point, though comparatively few were secured. The species was not observed at any island locality.

Nine specimens were secured: two adults from Boca de Quadra (nos. 9463, 9464), two adults from the Chickamin River (nos. 9465, 9466), an adult female from Bradfield Canal (no. 9467), four immatures from Port Snettisham (nos. 9468-9471).

I am unable to appreciate any points of difference whatever between these specimens and others from more southern localities, including a series of breeding birds from Nevada.

\section{Geothlypis trichas occidentalis Brewster.}

Western Yellowthroat.

One of the most interesting results of the season's work was the discovery of the western yellowthroat at two points on the coast of southeastern Alaska, at one of which it was most assuredly breeding. On the Chickamin River it was fairly common in the meadows of tall grass. All that were seen were in pairs, while of the two adult females secured, one shot on June 20 (no. 
9473) had laid part of its set, and contained a partly formed egg that would have been laid in a day or two, and the other, shot on June 23 (no. 9475) was evidently incubating. The males were in full song, and it was the familiar "witch-a-ree" note that first drew my attention to the presence of these birds, so unexpected in this region. They were shy and retiring, the grass they were in was waist high and higher, and altogether it was no easy matter to see them in the first place, or to find a bird after it was shot. The species was subsequently met with only on the Taku River, where a few were seen on September 4, and again on September 9, none being observed after the latter date.

Ten specimens were secured, five adult males and two adult females from the Chickamin River (nos. 9472-9478), "and two immature males and an immature female from the Taku River (nos. 9479-9481), the latter in complete first winter plumage. They are, as far as I can see, quite indistinguishable from a șeries of breeding birds from Humboldt County, Nevada, which may be considered as typical of occidentalis; but even aside from the appearance of the birds, the manner of their occurrence alone would incline one to place their affinities with the form of the interior, rather than with arizela of the more southern coast region. It will be noticed that the two places where yellowthroats were found were along the margins of large rivers which pierce the mountains paralleling the coast, and form direct and favorable passes from the interior; it is my belief that the birds reached the coast by following down these streams. If the form found in southern British Columbia (arizela) reached Alaska at all it would be by way of the coast, where it might be expected to occur at all suitable points. Besides the places where we found yellowthroats, we worked at several mainland points apparently admirably adapted to their needs, Boca de Quadra, Thomas Bay, and Port Snettisham, but in these localities we failed to find them. At none of these points, however, is there any such highway to the country beyond the mountains, the streams either arising from the glaciers, or if they go back into the mountains for any distance, passing through rough, precipitous country, utterly unsuited to the birds' requirements. Hasselborg ascended the Chickamin River some twenty-five miles, finding meadow 
land all along the stream, and he shot a yellowthroat at the farthest point he reached.

We find here an extraordinary instance of a bird race from the arid interior which has invaded a region of extreme humidity through narrow passes, and which has undergone no modification in its coloration in the direction of melanism.

\section{Wilsonia pusilla pileolata (Pallas). Pileolated Warbler.}

By no means as generally distributed as I had expected to find it, and not seen on any of the more western islands of the archipelago. First noted at Portage Cove, Revillagigedo Island, June 28 to July 4, where several were observed in thickets bordering the meadows. The males were in full song at this time, and making themselves so conspicuous thereby that I could hardly have overlooked the species had it been present at any of the points previously visited. It was next encountered at Mitkof Island, evidently migrating, and fairly common in the alders along the beach. At Thomas Bay and Port Snettisham also it was quite abundant at times, and on the Taku River it was frequently observed during the early part of September. By the middle of the month the birds were practically all gone, though a belated straggler was seen as late as September 21.

Eleven specimens were secured : two adult males from Revillagigedo Island (nos. 9482, 9483), a juvenal male from Mitkof Island (no. 9484), and eight immatures from Mitkof Island, Thomas Bay, and Port Snettisham (nos. 9485-9492). No. 9484 (male juvenal August 4) is molting from juvenal to first winter plumage, with the former predominating. It has no trace of the black cap, the pileum being concolor with the back, though the forehead is decidedly yellowish. The greater wing coverts are distinctly tipped with whitish, forming a conspicuous bar across the wing. The immature males in first winter plumage have the black cap quite as extensive and distinct as the adults though the black feathers are more or less tipped with yellowish, but in the immature females such marking is either entirely absent or indicated by but one or two black feathers. 
Anthus rubescens (Tunstall). American Pipit.

Observed at comparatively few points. At Kupreanof Island on April 21, a small flock was seen on a sand bar near the camp. At Calder Bay, Prince of Wales Island, May 11 and 12, several small companies were flushed from the grass on the beach, while at Egg Harbor, Coronation Island, scattered individuals were observed, also along the beach. The species was then lost sight of until we reached Marten Arm, Boca de Quadra, where, on June 9, large flocks were encountered on the meadows, evidently still migrating. It was next seen on the Taku River, September 4 to 28 , single birds being occasionally met with along the banks of the stream.

- Two specimens were secured, an adult male from Egg Harbor, Coronation Island (no. 9461), and an immature male (in complete first winter plumage) from the Taku River (no. 9462). There is singularly little difference in the color and markings of the two birds. High plumaged old males from California have the lower surface of the body distinctly cinnamomeous and sometimes almost entirely devoid of black streaking, while winter birds are entirely devoid of this cinnamon tinge. This Alaskan immature is quite as cinnamomeous below as is the adult, and there is practically no difference between the two in the character and extent of the black streakings.

Cinclus mexicanus unicolor Bonaparte. American Dipper.

A single bird seen by Hasselborg on May 11 on a stream emptying into Calder Bay, Prince of Wales Island. This is the only occasion on which the species was met with during the entire summer.

\section{Nannus hiemalis pacificus (Baird). Western Winter Wren.}

Quite generally distributed over the region but common nowhere until the young birds began to appear, toward the end of July. The first was seen at Three-mile Arm, Kuiu Island, April 29. On Prince of Wales Island, at Port Protection and Calder Bay, one or two were heard singing in the woods. Several were observed on Coronation Island. On Warren Island one was 
singing about the tent continually, probably with his mate on a nest somewhere near by. At Boca de Quadra, Chickamin River, Portage Cove and Etolin Island they were seen or else heard singing in the woods occasionally, but were anything but abundant. At Bradfield Canal, July 18 to 26, the first juvenals were seen flying about. A few were observed at Zarembo Island, and on Mitkof Island they were quite abundant in the masses of drift along the beach. On the Taku River many were seen during the first two weeks in September, but they nearly all disappeared by the middle of the month. The last was observed on September 24.

Nine specimens were secured: two adults from Kuiu Island (no. 9407) and Shakan, Prince of Wales Island (no. 9408), and seven in juvenal plumage: two from Bradfield Canal (nos. 94099410), one from Zarembo Island (no. 9411), and four from Mitkof Island (nos. 9412-9415).

Certhia familiaris occidentalis Ridgway. Tawny Creeper.

Seen at but very few points. On Kupreanof Island, the first arrival, a single bird was observed on April 20, and on April 23 two were seen and one of them secured. The species was not met with again until we reached Zarembo Island at the end of July, where several were seen within a few days, though curiously enough, none was noted on neighboring islands visited immediately before and after. A single bird, seen, but not secured, at Port Snettisham on August 26 completes the list of records for the summer.

Five specimens were secured : an adult male from Kupreanof Island (no. 9416) and an adult (no. 9418) and three juvenals (nos. 9417, 9419, 9420) from Zarembo Island. The single adult from Kupreanof Island, in fresh, unworn plumage, exhibits the characteristics of occidentalis to a marked degree, the upper parts generally being suffused with tawny cinnamon to such an extent that there are no pure white markings anywhere, either on back or wings. The only other adult secured (female, Zarembo Island, July 30), is in exceedingly shabby, abraded plumage, but is nevertheless evidently to be referred to this form. The three young birds, all in full juvenal plumage, are also unquestionably occidentalis, being markedly cinnamomeous 
above, as compared with the paler backed juvenals of montana from the Prince William Sound region.

Sitta canadensis Linnaeus. Red-breasted Nuthatch.

A single bird, seen, but not secured, by Hasselborg, at Egg Harbor, Coronation Island, on May 17, was the only one of the species observed on any of the islands. It was not again met with until September, on the Taku River, where it was fairly common, though irregularly so, many individuals being seen in the flocks of migrating warblers and kinglets. Six specimens were shot at this point, two male and three female immatures in complete first winter plumage (nos. 9381-9385), and one adult female, also in perfect winter plumage (no. 9380). The adult differs from the young females in having the top and sides of the head dull black, in marked contrast to the slateblue dorsum. In the immatures the head is concolor with the back. The two immature males have the pileum glossy black, apparently not differing from the adult males in any respect.

\section{Penthestes rufescens rufescens (Townsend).}

Chestnut-backed Chickadee.

Quite generally distributed, and fairly common, as land birds go in this region. On Kupreanof Island, upon our arrival early in April, the species was not common, but was becoming more so daily. On Kuiu it was decidedly scarce. On Prince of Wales Island some were seen at ewery point visited, Port Protection, Calder Bay, San Alberto Bay, and Klawak, but they were nowhere at all common. On Coronation Island (May 14 to 18) a number were seen, some in small flocks, but many in pairs; the latter strongly resented our appearance, and probably had nests somewhere near by. On Warren Island also they were quite numerous, and all in pairs. A few were observed at all the points touched on Dall Island, and on Duke Island. On the Chickamin River and Portage Cove, Revillagigedo Island, they were not common. The first young were observed flying about on Etolin Island, July 11, several broods being observed. They were scarce at Bradfield Canal and on Zarembo Island, but on Mitkof Island, Thomas Bay and Port Snettisham, many 
were seen, almost always in small flocks together with migrating kinglets and warblers.

It is rather remarkable that during our whole stay on the Taku River, September 4 to 28, not a single chickadee of any kind was observed, though I had hoped from the many inland forms which appeared from time to time, that I might find $P$. a. turneri at this point, as well as $P$. rufescens.

Twenty-one specimens of the chestnut-backed chickadee were preserved, from the following localities : Kupreanof Island, eight (nos. 9386-9393), Kuiu Island, two (nos. 9394, 9395), Prince of Wales Island, three (nos, 9396, 9397, 9400), Coronation Island, two (nos. 9398, 9399), all adults; and the following juvenals: Etolin Island two (nos. 9401, 9402), Mitkof Island, two (nos. 9403-9404), and Thomas Bay, two (nos. 9405, 9406).

Juvenals from Mitkof Island and Thomas Bay, shot on August 11 and 16, are just beginning to molt into the first winter plumage.

\section{Regulus satrapa olivaceus Baird.}

Western Golden-crowned Kinglet.

One of the few species of land birds that was fairly common, and quite generally distributed over the region. The first, a single bird, was seen April 12 on Kupreanof Island where occasional small flocks were met with thereafter. A few were observed on Kuiu Island, and also at the various points visited on the north and west coasts of Prince of Wales and Dall islands. On Coronation and Warren islands, in May, it was quite common and still in flocks. Several pairs were seen at Boca de Quadra and the Chickamin River, on the mainland. The first juvenals were observed on Etolin Island, July 6 to 12, several small flocks being encountered, probably composed each of a single family. The species was subsequently met with at Bradfield Canal, Zarembo and Mitkof islands, Thomas Bay, Port Snettisham, and the Taku River, at all these latter points being gathered in small flocks, traveling southward, frequently in company with migrating warblers.

Fifteen specimens were collected: Kupreanof Island, one (no. 9446), Kuiu Island, two (9447, 9448), Prince of Wales Island, 
two, (nos. 9449, 9450), Etolin Island, four (nos. 9451-9454), Bradfield Canal, two (nos. 9455, 9456), Zarembo Island, one, (no. 9457), Mitkof Island, one (no. 9458), and the Taku River, two (nos. 9459, 9460).

Nos. $9452-9454,9457$ are in juvenal plumage, while nos. 9459 , 9460 , male and female, Taku River, September 10 and 12, are in complete first winter plumage, and apparently indistinguishable from adults. No. 9458, adult male, Mitkof Island, August 9, is in the midst of the annual molt.

Regulus calendula grinnelli Palmer. Sitka Kinglet.

Though seen throughout the region at many scattered points, the Sitka kinglet was nowhere at all common until late in the summer, when the young birds were flying about and the southward migration had begun. Single individuals were observed at various points on Kupreanof, Kuiu, Prince of Wales, Coronation, and Warren islands, and at Boca de Quadra and the Chickamin River on the mainland. On Mitkof Island, August 1 to 13 , they were seen occasionally in the alders along the beach, evidently migrating and they were subsequently met with in steadily increasing numbers at Thomas Bay and Port Snettisham. On the Taku River, during September, they were seen daily, being far more abundant than at any other point. The character of the vegetation may have had something to do with their abundance here as they were almost always found in the alders or in other deciduous trees or shrubs, such as grow in abundance at this point, while the golden-crowned kinglet evinced a marked preference for the conifers.

A series of twenty-five specimens was secured (nos. 94219445). Of these two are adult males, nos. 9421, 9422, from Kuiu and Warren islands, respectively. Eleven are juvenals, nos. 9423-9432, 9436, and twelve, all from the Taku River, are immatures in complete first winter plumage. Some young birds taken the middle of August are already beginning to molt into this plumage, but one shot on September 9 (no. 9436) is still in the juvenal plumage throughout. Of the twelve in first winter plumage, eleven are males.

The juvenals are appreciably darker than specimens of 
$R$. calendula cineraceus in corresponding plumage from the mountains of southern California, being of a sooty olive-green cast, as compared with the decidedly grayish color of the latter. The immatures in the newly acquired winter plumage are of a noticeably deep tone of coloration. The immature males all have the red crown patch, though it appears to be the last of the plumage acquired; in the single immature female there is no trace of it.

\section{Hylocichla ustulata ustulata (Nuttall).}

Russet-backed Thrush.

Seen at very few points and in limited numbers. The first were observed on the Chickamin River, June 24, when several were seen or heard in the woods. I am under the impression that they had just arrived, for we had been at this point for a week without seeing any, while from then on they were heard almost every day. At Portage Cove, Revillagigedo Island, several were heard singing in the woods, at Bradfield Canal several were seen at various times, while on the Taku River two were observed on September 4, the last time that the species came under my observation. They were at all times exceedingly shy and difficult to approach, moving from place to place in the tree tops, and though frequently heard singing, it was but rarely that a bird was seen.

One specimen was secured, an adult male, shot on the Chickamin River on June 25 (no. 9363).

Hylocichla guttata nana (Audubon). Dwarf Hermit Thrush.

Quite generally distributed, and fairly common throughout the whole of the region, but during the spring and summer at least, very difficult to get sight of. They could be heard singing on all sides, especially about dusk, but it was only occasionally that I could catch a fleeting glimpse of a bird flitting through the shrubbery, or feeding on the ground under the thick bushes. The first arrival was noted at Kuiu Island, on May 4, and from then on they were seen or heard at practically every point, visited. Points of record are as follows: Prince of Wales Island (Port Protection, Calder Bay, and Klawak Salt Lake), Corona- 
tion, Warren, Dall, and Duke islands, Boca de Quadra, Chickamin River, Revillagigedo Island (Portage Cove), Etolin Island, Bradfield Canal, Zarembo Island, Mitlrof Island, Thomas Bay, Port Snettisham, and the Taku River. Young birds in complete juvenal plumage were taken on Mitkof Island, early in August, one secured at Port Snettisham on August 28 has nearly completed the post-juvenal molt, and immatures taken on the Taku River the middle of September are in the first winter plumage throughout. Hermit thrushes were seen on the Taku River during the whole of our stay, during September, though their numbers diminished rapidly toward the end of the month.

Fourteen specimens of the dwarf hermit thrush were secured (nos. 9339-9352). Of these, six are adults, three in juvenal plumage, one undergoing the post-juvenal molt, and four immatures in complete first winter plumage. I had hoped to find guttata migrating at the Taku River, but the specimens secured there, as well as all the others, appear to be strictly referable to the form nana.

\section{Planesticus migratorius caurinus Grinnell.}

Northwestern Robin.

Observed at many scattered points, but seldom in any numbers. The first was noted on Kupreanof Island, April 19, when one was secured from a small flock, feeding in one of the parks. During the next few days several were heard singing in the tree tops about camp. A fleck of eighteen or twenty was seen at Three-mile Arm, Kuiu Island, on April 26, and several were heard singing in the woods at Port Protection, Prince of Wales Island. On Coronation Island, May 14 to 18, at Port MeArthur, Kuiu Island, May 18, and at Warren Island, May 19 to 23, robins were quite abundant, feeding in scattered flocks along the beaches, and evidently migrating. From then on until the end of the summer they were but rarely seen. At Duke Island, on the Chickamin River, and at Portage Cove, Revillagigedo Island, scattered individuals were observed, or heard singing in the woods. Juvenals were first seen at Mitkof Island, early in August, but they were always singularly wild and unapproachable. A very few were noted at Thomas Bay, and, on the Taku 
River in September, they were occasionally met with in flocks of eight or ten individuals, usually very wild. Many were seen about the shipping at Juneau, September 30, and Hasselborg reported them as abundant at Game Cove, Admiralty Island, as late as November 8 .

Nine specimens were secured (nos. 9322-9330), five adults and four juvenals. Of four adult males, two are in practically perfect adult plumage (nos. 9322, 9323), and two (nos. 9326, 9327, Coronation Island, May 17) are indistinguishable from average females. No. 9330, juvenal female, Taku River, September 12, has just begun the post-juvenal molt. On the whole the series bears out the characters ascribed by Grinnell (1909, p. 241) to the form caurinus. One of the two high plumaged males (no. 9322) has the terminal white spots on the outer rectrices unusually extensive, but as this same bird has many white feathers scattered over the head, neck and throat, large white tail spots may be merely a further manifestation of this albinotic tendency. The juvenals are appreciably darker, especially ventrally than are specimens of propinquus in corresponding plumage from Nevada, California and Arizona. Robins were observed on Mitkof Island and on the Taku River, feeding on the seeds of the devil's club (Echinopanax horridum).

\section{Ixoreus naevius naevius (Gmelin). Varied Thrush.}

Found throughout the region though abundant at but few of the points visited. First encountered on Kupreanof Island, April 17, when two were seen and one secured. No more were noted until we reached Port Protection, Prince of Wales Island, on May 6, when several were heard singing in the woods.

On Coronation and Warren islands, and at Port McArthur, Kuiu Island, many were seen feeding along the beaches, in company with the robins, and evidently migrating. Varied thrushes were subsequently seen, or heard singing in the woods, at Heceta and Dall islands, Boca de Quadra, the Chickamin River, Portage Cove, Revillagigedo Island, Etolin, Zarembo and Mitkof islands, Port Snettisham, and the Taku River. Many were noted on the wharves and among the shipping at Juneau, September 30. 
Eight specimens were secured (nos. 9331-9338). Nos. 9331 and 9332 , are adult males in breeding plumage; no. 9333 Mitlrof Island, August 4, and no. 9336, Taku River, September 10, are in the juvenal plumage purely; no. 9334, Port Snettisham, August 31, and no. 9337, Taku River, September 4, are in the midst of the post-juvenal molt; while no. 9335, female, Taku River, September 4, is in the complete first winter plumage, and no. 9338, male, Taku River, September 13, has but a few juvenal feathers left.

Sialia currucoides (Bechstein). Mountain Bluebird.

Mountain bluebirds were occasionally met with along the Taku River during September, evidently migrating, and, toward the end of the month, in rapidly increasing numbers. The first were noted on September 8, two birds, one of which was secured. Two more were seen on September 11, and thereafter they were frequently observed, usually passing overhead, sometimes in flocks of twenty or more. Two specimens were secured, nos. 9320, 9321, male and female, respectively, both immatures in complete first winter plumage. These two individuals are of noticeably small size, as compared with specimens from more southern localities. They measure as follows:

$\begin{array}{cccccc}\text { No. } & \text { Sex } & \text { Wing } & \text { Tail } & \text { Culmen } & \text { Tarsus } \\ 9320 & \delta & 107.5 & 63 & 12 & 20 \\ 9321 & q & 111 . & 64.5 & 13 & 20\end{array}$

This is, I believe, the first time that the species has been reported from the coast district of Alaska, if not from the territory in general. 


\section{CHECK-LIST OF THE MAMMALS.}

1. Odocoileus columbianus sitkensis Merriam

2. Oreamnos montanus columbianus Allen

3. Sciurus hudsonius vancouverensis Allen

4. Marmota caligata (Esch.)

5. Sciuropterus alpinus zaphaeus Osgood

6. Castor canadensis leucodontus Gray

7. Peromyscus maniculatus macrorhinus (Rhoads)

8. Peromyscus maniculatus hylaeus Osgood

9. Peromyscus sitkensis sitkensis Merriam

10. Evotomys phaeus n. s.

11. Miorotus drummondi (Aud. and Bach.)

12. Microtus macrurus Merriam

13. Microtus coronarius ш. s.
14. Fiber zibethious spatulatus Osgood

15. Synaptomys dalli Merriam

16. Zapus hudsonius alascensis Merriam

17. Zapus saltator Allen

18. Erethizon epixanthum nigrescens Allen

19. Canis pambasileus Elliot

20. Lutra canadensis periclyzomae Elliot

21. Lutreola vison nesolestes Heller

22. Mustela nesophila Osgood

23. Putorius cicognani alascensis Merriam

24. Ursus americanus pugnax $\mathrm{n}$. ss.

25. Sorex personatus streatori Merriam

26. Sorex obscurus longicauda Merriam

27. Myotis lucifugus alascensis Miller

\section{GENERAL ACCOUNTS OF THE MAMMALS: DISTRIBU- TION, VARIATION, BIOGRAPHICAL NOTES.}

Odocoileus columbianus sitkensis Merriam. Sitka Deer.

Probably in no other part of North America are deer as abundant as on the islands off the coast of southeastern Alaska; and this too despite the heavy mortality during the winter months. At every island visited, with one exception as noted beyond, deer were seen, without any effort on our part to hunt for them, and sign of various sorts was in evidence everywhere. At Kupreanof and Kuiu islands, during April, many were encountered, very thin, and in poor condition, and quite indifferent to approach. They were abundant on Coronation and Warren islands, and some were seen at various points on Prince of Wales and Dall islands, while on Heceta Island fresh sign was observed though no deer were seen during our brief stay.. Several were seen on Duke Island, and we were afterward told that these deer were noted for their large size, as compared with those from other Alaskan points, but we failed to collect any specimens at this place. Portage Cove, on the east side of Revillagigedo Island, was the one island locality where deer appeared to be almost entirely 
absent, tracks of a single individual seen far up the cañon, being the only evidence of the presence of the species. This is probably due to the fact that this place, in close proximity to the mainland, is subject to much more severe winters than are the more western islands. Deer are almost unknown along the mainland coast, a single buck seen by Hasselborg at Bradfield Canal being our only record. They were quite abundant on Etolin, Mitkof and Zarembo islands.

The Alexander Archipelago forms the northern limit of deer in North America, the comparatively mild climate of the islands permitting their existence, though they could not survive on the neighboring mainland. There is an apparent contradiction in the manner of their occurrence here. They are probably more abundant than at any other part of their range, and so conditions would seem to be favorable. But conditions are obviously unfavorable to this extent, that except in the mildest winters large numbers succumb to cold and starvation, while every year the majority of the deer finish the winter in a very enfeebled condition. Those seen early in April were emaciated to a degree, and too feeble and listless to make any great effort to get out of the way, while the woods were fairly strewn with carcasses. On the islands south of Frederick Sound the wolves also do much to reduce their numbers. At our first camp on Kupreanof Island I counted twelve dead deer on the beach within half a mile of camp, and probably half of these had been killed by wolves. Ateother points partly dismembered skeletons entangled in masses of windfall, and with the skin of the legs turned inside out, told of the tragedies enacted, even without the added suggestion from the bits of coarse black hair caught on the surrounding twigs.

Early in April the deer were feeding largely on the tender shoots of the skunk cabbage, about the first green vegetation to appear. A little later they were seen eating the green grass along the stream margins and in the meadows, but during the summer they seemed to subsist largely on the foliage of bushes and shrubbery in the woods. They frequently came down to the beaches, usually in the mornings and evenings, where several were seen eating seaweed, possibly for the salt. The woods were 
everywhere intersected by a network of deer trails, extending in all directions. The narrow channels between the islands are evidently no barriers to this animal, for deer are found on every island of any size in the entire archipelago. To just what extent they continue to cross the wider arms of the sea it is impossible to say, but they were occasionally seen swimming long distances, and also observed on small islets in the bays which must have been just casually visited.

Four adult females were preserved (nos. 8336-8339), from Etolin, Zarembo, Mitkof, and Kupreanof islands. No bucks were preserved, those that were shot being in the process of shedding and having large areas quite naked of hair. They were without horns, of course, but shed antlers were frequently found wherever we went and I saved a number from Kupreanof, Kuiu, Coronation, Warren, Heceta, and Prince of Wales Island. Later in the year, in November, Hasselborg visited Freshwater Bay, on the east side of Chichagof Island, and near the northern extremity of the Alexander Archipelago, and he there collected a series of seven bucks which he sent to the Museum (nos. 8980-8986). Of four of these, the specimens consist of the entire skin with the skull; the other three, of the skin of the head and neck, together with the skull. He also sent in a shed antler from the same place. A comparison of the antlers of these deer with those from the more southern islands is of decided interest (see plate 3). The seven Chichagof bucks were all in the prime of life, all taken at the same place and at the same time, and their antlers are wonderfully uniform in size and shape. They are dark, reddish brown in color, rather stout, and beautifully symmetrical, more so than those of any other black-tail deer I have seen. Two of them have two prongs starting from the main antler, beside the short snag at the base, two have two prongs on one side and one on the other, while three have but one prong and the basal snag on the antler on each side. The striking point about them, however, is that not one of the series forks dichotomously, while of the shed horns picked up on the more southern islands, all do, except one or two small single-tined antlers. I examined in the field many shed antlers which we did not save, and all were of the same pattern. On the other hand I saw many mounted heads 
in Juneau, most of them probably from Admiralty Island, and they were all similar to the Chichagof heads. So it seems that these differences between the antlers from the northern and southern islands are quite constant; but I am unable to appreciate any other differences between the deer from the different regions. The skins at hand are not comparable. The Chichagof bucks agree very closely with the description of a Kupreanof buck given by Dr. Allen (1903, p. 528). The principal difference lies in the white half collar on the lower neck, which is in some cases but faintly indicated, and in others entirely absent, leaving the whole neck uniformly brown below the throat.

Below are the measurements of the seven Chichagof skulls. For the sake of comparison I give the same measurements as those given of the Kupreanof bucks by Dr. Allen, in the paper cited above. 


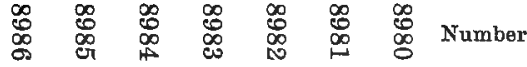

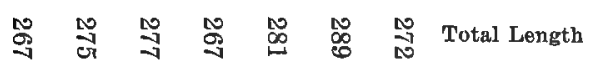

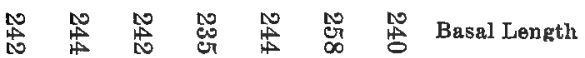

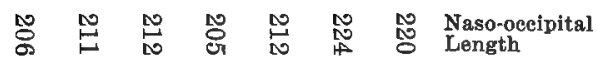

Front border of

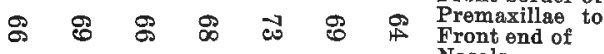
Nasals

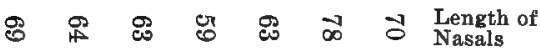

○

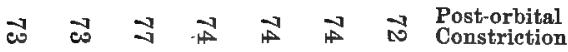

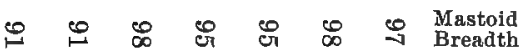

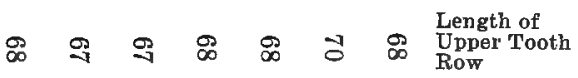

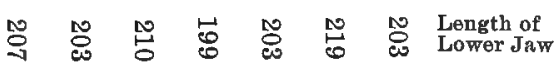

$\overrightarrow{0} \quad \vec{\sigma} \forall \vec{A}$ जै

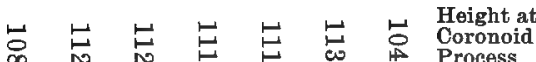

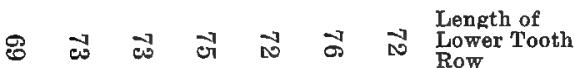

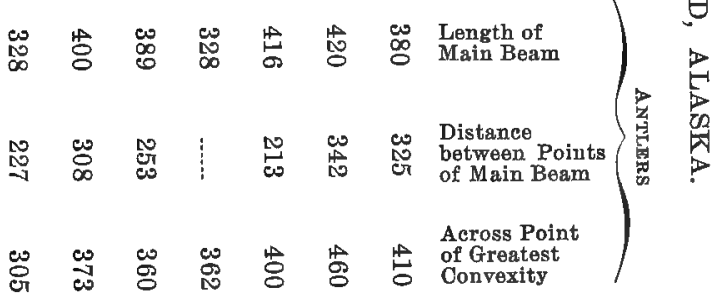




\section{Oreamnos montanus columbianus Allen.}

\section{Columbian Mountain Goat.}

Mountain goats occur at all suitable points along the mainland coast of southeastern Alaska, but apparently on none of the islands. They were first noted at Boca de Quadra, the first mainland point visited. Hasselborg made several long trips back into the mountains from our camp at the head of Marten Arm, and on June 13 he saw three goats, an old female with a kid, and a young female which he secured (no. 8335). It was in a bad place, high up in the cliffs, and the animal was shedding to such an extent as to be quite naked in patches, so he saved only the head, together with one hind leg for the meat. It was apparently a yearling, possibly the kid of the previous year of the old female with which it was associated, but nevertheless the meat was wonderfully tough, so much so as to require much boiling to make it edible.

On June 21 an old female with a kid was seen on a cliff at a point some ten or twelve miles up the Chickamin River, but in an utterly inaccessible place. At Port Snettisham old sign was abundant, and Hasselborg saw one goat but was unable to get a shot at it. None were seen on the Taku River in September, but Hasselborg returned to this place toward the end of October, and on one occasion saw seven goats at once, but was unable to cross the glaciers surrounding them.

\section{Sciurus hudsonius vancouverensis Allen.}

\section{Vancouver Island Squirrel.}

Red squirrels are found on such islands of the southern part of the Alexander Archipelago as lie close to the mainland, and on a few that extend far to the westward; being absent from those situated south of Summer Straits and west of Clarence Straits, of which Prince of Wales and Dall islands are the largest and most important. They occur on Kuiu, Kupreanof, Mitkof, Wrangell, Zarembo, Etolin, and Revillagigedo islands, specimens being secured or seen on all these islands. None were observed on Duke, Annette, or Gravina islands during the short time we 
spent on them, but I should think it very possible that they occurred on the two latter. On the mainland, red squirrels or signs of their presence, were seen at practically every point we visited. (See text figure 1, page 153.)

Specimens were collected as follows: Kupreanof Island. eight (nos. 8761-8768), Kuiu Island, five (nos. 8769-8773) Revillagigedo Island, one (no. 8780), Etolin Island, two (nos 8781, 8782), Mitkof Island, two (nos. 8784, 8785); and from mainland points: Chickamin River, six (nos. 8774-8779), Bradfield Canal, one (no. 8783), Thomas Bay, one (no. 8786), and the Taku River, two (nos. 8787, 8788), a total of twenty-eight.

Those from Kupreanof and Kuiu, taken in April, are in winter pelage throughout. After leaving these islands no squirrels were secured until we arrived at the Chickamin River, the middle of June. Of the four adults secured here, three were molting from winter to summer pelage; the fourth (no. 8778) has completed the change, but is abnormal in coloration, having a tendency to albinism, evinced by small, scattered spots of pure white on the back, head and under tail surface. Two juvenals were taken here (nos. 8775,8776 ), about two-thirds grown. The single specimen from Revillagigedo Island, shot July 4, is still in the winter coat, the new summer hair just beginning to appear upon the toes and feet. Of the two from Etolin Island, a female taken on July 6 (no. 8781) is largely in the winter pelage, while a male secured July 11 (no. 8782), is in summer pelage throughout. All collected later are in summer pelage.

On the islands inhabited by them these squirrels are quite numerous, apparently much more so than on the adjacent mainland, where the individuals are probably more widely distributed. On Kupreanof and Kuiu islands their shrill bark was frequently heard in the woods, but they were quite shy, and kept well out of sight. At this time they were feeding largely on various fungi and on buds and green stuff. Later in the summer, at the Chickamin River, Bradfield Canal, etc., they appeared to be living mainly on the spruce cones, the stripped scales of which formed large mounds under some of the trees. One shot on Mitkof Island was busily engaged in tearing strips of bark from some dead brush, possibly as material for a nest, as his 
stomach was filled with a mass of berries, mushrooms, etc. Along the Taku River they remained in the alder thickets, these impenetrable tangles forming secure retreats, whence their shrill chatter could frequently be heard, though the squirrels themselves were but seldom seen.

The number of young produced at birth seems to be two; pregnant females shot the middle of April contained each two embryos, while the two juvenals secured on the Chickamin River were apparently of the same litter, and were the only ones seen at the place where they were secured.

Compared with a series of thirteen skins from Vancouver Island, all in winter pelage, these Alaska squirrels differ so slightly that it seems best to use the name vancouverensis for the form, though there appear to be certain appreciable differences. The Vancouver Island squirrels have larger ears, the upper surfaces of which are mostly brownish in color; while in the Alaskan squirrels they are black, in striking contrast to the color of the crown. The former are also not quite so heavily vermiculated with gray underneath. Two from Mitkof Island, in summer pelage, have some tawny fulvous underneath, but those from more southern points-Etolin Island and Chickamin River -are almost pure white below. These specimens are also the smallest of the series, and thus least like typical vancouverensis in all respects, though nearest it geographically.

In his description of Sciurus h. petulans Osgood (1900, p. 27) lays some stress on cranial characters, ascribing to that form a sharp indentation or notch on the orbital arch, which (by implication at least) he denies to vancouverensis. This feature is present in all the specimens I collected, in quite as great a measure as in examples of petulans from Glacier Bay. If it should prove to be constantly absent from the Vancouver Island squirrels it would be an effective means of distinguishing them from those living in southern Alaska. The Vancouver skins seen by me had the skulls inside, so they could not be examined.

\section{Marmota caligata (Eschscholtz). Hoary Marmot.}

Found at several points on the mainland, but at no island locality. The species has sometimes been considered as peculiar 
to the Hudsonian, or to the Alpine-Arctic zone in this region, but from our observations its presence would seem to depend largely upon local conditions, open ground being the main requirement. At Marten Arm, Boca de Quadra, there was a small colony in a meadow at the edge of tide water. They were apparently quite rare at this point. On the Chickamin River Hasselborg found two colonies some distance up the stream, and secured an adult female and an unsexed juvenal. At Port Snettisham they were abundant, the only place where we found them so. Conditions were peculiarly favorable to their occurrence here, the mountain slopes being bare of trees to a great extent, and strewn thick with boulders, between which the marmots had their burrows (see plate 4, figure 2). Their shrill whistles were heard from morning to night and the animals themselves could be seen running to and fro, or keeping a lookout from the top of some jutting rock. They were distributed down to tide water. Many half to three-quarter grown juvenals were seen, comparatively tame and unsuspicious, but the adults were more wary and hard to approach. Two females were collected here, one adult, the other about half grown. On the Taku River Hasselborg reported hearing one whistle, the only one noted at this point. He ascribes their scarcity to the Indians, who are very fond of the meat. I ate two myself and found them quite palatable; they were both exceedingly fat.

The four specimens preserved (nos. 8358-8361) are not appreciably different from a series of $M$. caligata from the Prince William Sound region. They, as well as many others seen at close range, are quite uniformly colored, with black occiput and gray shoulders, shading into tawny on the hind quarters and tail, and none were observed that semed to approach at all the very dark colored $M$. vigitis of Glacier Bay (see Heller, 1909, p. 248).

\section{Sciuropterus alpinus zaphaeus Osgood.}

Osgood Flying Squirrel.

Two flying squirrels were secured during the summer. One was taken on Etolin Island on July 12 (no. 8789), and one at Bradfield Canal on July 22 (no. 8790). This is, I believe, the 
first time that a flying squirrel has been reported from any island locality in Alaska, but it is such an absolute accident to run across them during the summer months in this region that they might well occur in comparative abundance and still be overlooked. I should consider it very possible that they might yet be found on such islands as Revillagigedo, Wrangell, Mitkof, or the Kake islands. They occur all along the mainland coast, where the Indians told us that they frequently catch them in winter in their marten traps, though they seldom see them in summer.

The one secured on Etolin Island entered the cabin I was occupying, and foraged in my boxes of provisions for several nights before it was caught in a rat trap. The Bradfield Canal specimen was taken in a rat trap set on the roof of an old Indian cabin at the edge of the woods. They are both old females which had apparently recently reared litters of young.

In coloration they are precisely alike, being, perhaps, a shade darker and richer brown than four specimens in the Museum collection (topotypes of $S$. a. zaphaeus) taken at Helm Bay, Cleveland Peninsula, in September.

\section{Castor canadensis leucodontus Gray. Pacific Beaver.}

Beaver sign, mostly quite cold, was found at many scattered localities, enough to indicate the former wide-spread distribution of the species over the larger islands of the group, and on the mainland. Incessant trapping has reduced their numbers to such an extent, however, that it is only in an occasional obscure locality that a few individuals still survive, usually living in the banks of a river, near the head of the stream. On Kupreanof Island fresh sign was seen some ten or twelve miles up the stream on which we were camped, but a party of Indians was trapping in the locality at the time. At Three-mile Arm, Kuiu Island, Hasselborg found some old dams at the head of the creek, but the beaver had apparently been gone several years at least, and the Indians trapping in the vicinity had caught none during the winter. On Prince of Wales Island old dams were seen at Port Protection, abandoned for many years, while at Klawak Salt Lake an Indian told us he had caught several during the winter. Hasselborg found indications of the presence of a few "bank 
beaver" at Boca de Quadra about five miles up a stream emptying into the head of Marten Arm; and at Portage Cove, Revillagigedo Island, he reported some cuttings of the previous year, found at the head of the creek. At Thomas Bay he found a chain of beaver ponds in the woods, but the beaver were gone; all but one solitary individual which had apparently been living there alone for several years. He left one front foot in a trap, but escaped with his life. On the Taku River, some fresh cuttings were seen.

As no specimens were secured the identity of this form with the Vancouver Island race leucodontus is of course merely conjectural.

Peromyscus maniculatus macrorhinus (Rhoads).

Rhoads White-footed Mouse.

Found at all the more southern mainland points visited, and on several of the more southern islands. The mice collected became less and less typical of macrorhinus as we advanced northward, and the species evidently intergrades with hylaeus at various points. In a general way Clarence Straits may be said to. be the dividing line between the two forms in extreme southern Alaska, and typical macrorhinus was not found north of Wrangell Island.

Specimens were secured at the following points: Boca de Quadra, one (no. 8559), Annette Island, one (no. 8552), Gravina Island, six (nos. 8553-8558), Chickamin River, six (nos. 85728576, 9138), Revillagigedo Island, five (nos. 8568-8571, 9137), Etolin Island, seven (nos. 8561-8567), Wrangell Island, two (nos. 8539-8540), and Bradfield Canal, ten (nos. 8541-8551). The Museum collection also contains nine additional specimens from Etolin Island, and from Helm Bay, Cleveland Peninsula (nos. $449,450,456,461-464,469,470$ ).

Those from the more southern mainland points are apparently most like typical macrorhinus. Northward the size diminishes and intergradation with hylaeus appears to take place. The single specimen from Boca de Quadra is rather small; those from the Chickamin River, though clearly referable to this form, as is evident from the large size of the skulls, are, in their external 
measurements, mostly within the maximum of hylaeus. Specimens from Bradfield Canal are of large size, but with rather light skulls. Those from Etolin and Revillagigedo islands are rather small, both externally and as to the skulls, but still much larger than typical hylaeus. Five adults (nos. 8553-8557) collected on Gravina Island, directly opposite Ketchikan, are almost exactly intermediate between macrorhinus and hylaeus, their measurements averaging : length 200.2, tail vertebrae 105.4, hind foot, 23.8. The skulls are likewise of. an intermediate size. Any one of these specimens, taken singly elsewhere, might be referred to either of the two races, but on the whole, I believe they belong with macrorhinus. They clearly do so on geographical grounds, and, though they vary in the direction of hylaeus, there is no place where the ranges of the two races actually come together in this part of Alaska.

A single, imperfect specimen from Annette Island (no. 8552) is, I believe, also referable to macrorhinus, though even smaller (except its feet) than those from Gravina Island. In other places, as at Bradfield Canal and northward along the coast, intergradation appears to take place with hylaeus in varying degrees as the range of that race is approached.

On the whole the range of macrorhinus in Alaska may be said to lie along the mainland coast and on the islands east of Clarence Straits and Zarembo Island and, approximately, south of the Stikine River. (See text figure 3, page 156.)

\section{Peromyscus maniculatus hylaeus Osgood.}

Osgood White-footed Mouse.

Ninety-two specimens of this mouse were taken, from Kupreanof, Kuiu, Mitkof, Prince of Wales, Dall, Suemez, Heceta, and Zarembo islands; and on the mainland at Thomas Bay, Port Snettisham, and the Taku River (nos. 8471-8538, 8577-8591, 9129-9136). The Museum collection also contains a large series from Admiralty Island, the form thus being represented from almost all parts of its known range.

Compared with Prince of Wales specimens, the mice from the outlying western islands-Heceta, Suemez, and Dall islands -have rather large feet, measuring from 23 to 25 millimeters, 
as compared with 22 to 23.5 in the former. One of the two specimens taken on Kuiu Island (no. 8485) also exceeds in every respect the maximum measurements ascribed to hylaeus by Osgood (1909, p. 54), its dimensions being as follows: length $213 \mathrm{~mm}$., tail vertebrae 120 , hind foot 24 .

The Kupreanof mice, in cranial characters, resemble those from Prince of Wales less closely than do those from Admiralty Island, curiously enough considering their intermediate geographical position. The skulls of Admiralty specimens are indistinguishable from those from Prince of Wales Island, whereas those from Kupreanof are appreciably longer and more slender. Specimens from Mitkof Island in their slightly larger size show an approach to macrorhinus, as previously noted by Osgood (1. c.). The single example secured on Zarembo Island (no. 8560 ) is apparently to be referred to hylaeus. Those taken on the mainland at Thomas Bay, Port Snettisham, and the Taku River, are apparently all of this form. The single adult secured on the Taku (no. 8591) is rather large for hylaeus, but no more so than the Kuiu Island specimen mentioned above.

One specimen from Dall Island is abnormally colored in exactly the same manner as an example of macrorhinus described by Osgood (l. c., p. 57, footnote). This mouse (no 8497 \& Rocky Bay, Dall Island, May 31, 1909) has the entire under parts rich brown, similar to the sides. The hind feet are grayish, and the front feet white, while there are small white spots on the lips and on the center of the throat.

Although white-footed mice were taken at most of the places where we collected, there were but a few points where they were really abundant. As observed in this region, hylaeus and macrorhinus were exactly alike in habits and mode of life, and both seemed rather to favor the littoral zone. A beach well strewn with large drift logs, trees, etc., and thus affording plenty of shelter, was quite sure to yield a harvest of mice. Another place where they could generally be found was in the vicinity of cabins or human habitations of any sort, occupied or deserted, such dwellings in this region being almost invariably placed just above tide water. Elsewhere in the woods or meadows, it was a mere chance to secure them. 


\section{Peromyscus sitkensis sitkensis Merriam.}

\section{Sitka White-footed Mouse.}

I took mice which I have referred to this species on Coronation, Warren, and Duke islands, these scattered localities still further emphasizing the peculiar distribution of the animal. (See text figure 3, page 156.) Four specimens were secured on Coronation Island (nos. 8592-8595), two in abandoned mine buildings, one in an old shed in the woods, and one in a Microtus runway. They were rather more numerous on Warren Island, where nine were trapped (nos. 8596-8603, 9128), all in Microtus runways. On Duke Island eighty traps produced three whitefooted mice in three nights (nos. 8604-8606). No other species of Peromyscus was found on the islands where sitkensis occurs.

Osgood (1909, p. 103) has referred two examples from Forrester Island, Alaska, to $P$. s. prevostensis and possibly my specimens might be considered as belonging to that race, but the differences between the two forms are extremely slight, and the specimens under consideration show so much variation that it seems best to refer them to the stock form. They are smaller than typical sitkensis from Baranof Island though no more so than those from Chichagof Island. There are no appreciable color differences in the series from the different islands. While the skulls of some of my specimens show the somewhat elongated posterior palatine foramina supposedly characteristic of prevostensis, others are not different from typical sitkensis in this respect.

The specimens secured measure as follows:

\begin{tabular}{|c|c|c|c|c|c|c|c|c|c|}
\hline $\begin{array}{l}\text { No. } \\
8592\end{array}$ & $\begin{array}{r}\text { Sex } \\
0\end{array}$ & $\begin{array}{c}\text { Length } \\
201\end{array}$ & $\begin{array}{c}\text { Tail } \\
97\end{array}$ & $\begin{array}{c}\text { Hind } \\
\text { Foot } \\
26\end{array}$ & $\begin{array}{l}\text { No. } \\
8593\end{array}$ & $\begin{array}{c}\text { Sex } \\
q\end{array}$ & $\begin{array}{c}\text { Length } \\
190\end{array}$ & $\begin{array}{r}\text { Tail } \\
93\end{array}$ & $\begin{array}{r}\text { Hind } \\
\text { Foot } \\
26\end{array}$ \\
\hline 8594 & $\delta$ & 210 & 102 & 26 & 8595 & ㅇ & 188 & 90 & 25 \\
\hline 8596 & $\delta$ & 212 & 109 & 26 & 8598 & 웅 & 185 & 84 & 25 \\
\hline 8597 & $\delta$ & 206 & 105 & 25 & 8599 & $q$ & 181 & 87 & 25 \\
\hline 8600 & 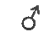 & 205 & 101 & 26 & 8601 & q & 190 & 98 & 24 \\
\hline 8604 & $\sigma^{*}$ & 207 & 100 & 26 & 8602 & 우 & 208 & 107 & 25 \\
\hline \multirow[t]{2}{*}{8606} & $\sigma^{*}$ & 212 & 108 & 26 & 8603 & q & 182 & 90 & 24 \\
\hline & & & & & 8605 & 우 & 217 & 104 & 26 \\
\hline
\end{tabular}


Evotomys phaeus, new species.

Dark-colored Red-backed Mouse.

Type--Male adult no. 8742, Univ. Calif. Mus. Vert. Zool., Marten Arm, Boca de Quadra, Alaska; June 13, 1909; colleeted by H. S. Swarth; orig. no. 7647 .

Characters.-Size rather large. Differs from $E$. wrangeli, nearest it geographically, in cranial characters and in much longer tail; from $E$. caurinus, the species to the southward in British Columbia, in larger size and longer tail.

Coloration.-Dorsal stripe dark brown, between chestnut and walnut brown, covering the whole back from the eyes to base of tail; not very sharply defined against the color of the sides. Sides and cheeks dark Isabella color. Below gray (about no. 8), sharply defined against the sides. Fairly conspicuous oval patches of gray hair over the hip glands. Tail bicolor, brownish above, yellowish below.

Skull.-Short and broad, with wide spreading zygomata. Rostrum short. Premaxillae usually extending slightly beyond posterior end of nasals. Frontals depressed.

Measurements.-Average of nine adults: total length 155.7 (149-164); tail vertebrae 51 (46-58); hind foot 19.9 (19-20). Skull: Average of eleven adults: length 24.8 (23-25.5); basal length 21.2 (19.5-23) ; zygomatic breadth 13.8 (13-14.8); mastoid breadth 11.1 (10.5-11.8); length of nasal 7.2 (6.8.7.8); length of upper tooth row 5.1 (5-5.2).

Remarks.-I had supposed that the red-backed mouse occurring on the majnland coast of this region would prove to be $E$. wrangeli, but the latter appears to be purely an insular species. I have had no specimens of that race for comparison, but the Evotomys secured differ so widely from it in all the essential peculiarities of the species as given in the published descriptions that there seems little doubt of their belonging to a different species. Wrangeli has a short tail, less than twice as long as the hind foot-in adults of phaeus the tail is invariab'y more than twice the length of the foot, frequently more than a third of the entire length of the animal. From $E$. caurinus of southern British Columbia it is distinguished by its generally larger size 
and longer tail. The single specimen from Bradfield Canal has a noticeably more slender and elongated skull, with much lighter teeth.

We found red-backed mice at but three mainland points, and on none of the islands. At Boca de Quadra four were secured (nos. 8741-8744). These were caught in a thin line of spruce trees extending into one of the damp meadows, the scanty undergrowth below the trees showing here and there traces of faintly defined runways. The mice evidently were not abundant, as several nights trapping produced but the four specimens, and lines of traps in other similar places brought in nothing at all. On the Chickamin River they were rather more common, and during our stay there I secured fifteen (nos. 8745-8759). These also were all caught in scattered clumps of trees in the meadow land; there was little or no indication of runways, or other such evidence as is always to be found where meadow-mice (Microtus) are living. The only other place where the species was met with was at Bradfield Canal, where a single specimen, an adult female, was caught on July 24 (no. 8760).

\section{Microtus drummondi (Audubon and Bachman).}

Drummond Meadow-mouse.

This is a species belonging more peculiarly to the interior valleys east of the mountains, and it finds its way to the coast at apparently but very few points. We met with it only on the Taku River, a stream which forms a direct pass into the interior, and where other mammals, and birds also, were found, which properly belong to the fauna of the interior rather than to that of the coastal region. Bordering the river are miles of meadow land, and here these mice live in great numbers; in fact in no other place did we find any species of Microtus so abundant. Narrow, well-defined runways intersected the meadows in all directions, centering in little clumps of brush, or where a log or fallen tree gave shelter to the entrances of the burrows. They evidently avoided the comparatively dry woods near by, where none were caught, nor were any runways seen there, though at times the meadow land was flooded almost everywhere, and the runways resembled little creeks through the grass. 
At this time, September, the mice were still breeding, and many of the females secured contained embryos, six or seven in number. Fifty specimens were obtained (nos. 8669-8713, 91219125) a large proportion of them being young of various ages. All are in summer pelage, short haired and rather shabby and worn in appearance.

Although I have considered these specimens as $M$. drummondi they are not typical of this species. In size they are uniformly very large, a peculiarity of northern examples of the species which has already been commented upon by various writers. The skull is large and heavy, with the exception of the audital bullae. These are actually smaller than in typical drummondi, proportionally much more so. The zygomata are wide spreading. It is decidedly suggestive that in all respects as they depart from typical drummondi they approach Microtus admiraltiae (Heller 1909 , p. 256), and they might be considered as intermediate between the two forms, but for their strongly curved incisors, in which particular they have not varied. There can be little doubt however, that it is with this species that the affinities of Microtus admiraltiae lie, as seems evident from the relative geographic position of the two forms, as well as their close general resemblance.

Sixteen specimens of Microtus drummondi, eight males and eight females, taken on the Taku River, measure as follows: length, 157.4; tail vertebrae, 46.4 ; hind foot, 20.2. Skull : basal length, 23.2 ; zygomatic width, 14.7 ; mastoid width, 11.3 ; diastema, 7.9 ; length of nasals, 7.1.

Microtus macrurus Merriam. Olympic Meadow-mouse.

Possibly quite generally distributed over the southern part of the archipelago, though there were a number of islands where we failed to secure any, or to see any indication of their presence.

Sixty-two specimens were obtained (nos. 8609-8668, 9126, 9127) at the following points: Kupreanof Island, Kuiu Island (Three-mile Arm; Port McArthur), Prince of Wales Island (Port Protection; Calder Bay; Shakan; Klawak Salt Lake); Dall Island; Mitkof Island; and on the mainland at Bradfield Canal and Thomas Bay. At most points they were decidedly 
scarce. On Kupreanof Island no runways were seen, and the few specimens secured were taken in the grass just above the high tide mark. At Kuiu Island there were a few small colonies on some little islands in the bay, but almost none elsewhere. The same was true at Port Protection, where most of those secured were taken on a little rocky knob, an island at high tide, though some meadows along a stream near by showed indubitable evidence of the presence of the meadow-mice during the winter months. At several other points similar conditions were encountered, indicating a seasonal shifting of the colonies from the meadow land, where extensive systems of runways were seen, with many burrows, and some balls of grass formed into nests and lying on the ground. The mice can move freely about under the snow that covers these meadows through the winter; but in the summer all such places were completely deserted, and nearly all the mice were on the little rocky islets, as noted above.

As we traveled south they became more and more scarce; assiduous trapping at three points on the west coast of Dall Island produced but a single specimen, and no runways were seen anywhere. On Annette Island many runways were seen in a little meadow, but they were all deserted, and no specimens were secured. On Suemez, Duke, Gravina, Revillagigedo, Etolin, Wrangell, and Zarembo islands no meadow-mice were secured, nor any sign of their presence observed, at the points visited, though they certainly may be supposed to occur at most, if not all of these places.

On Mitkof Island they were fairly abundant along the beach, though not nearly as much so as I expected, judging from the sign. They were feeding largely in the tall beach grass, inundated at high tide, and the receding waters carried out quantities of cut grass, so much so that it looked almost as though some one had been cutting hay in the vicinity. They apparently were living in burrows at the edge of the forest, which here as elsewhere, extends to the high tide mark, and travelled back and forth across the gravelly beach under the logs and other drift with which it is thickly strewn. Under these logs little piles of cut food were found, consisting mostly of two plants growing in abundance on the beach, Arenaria peploides and Galium aparine. 
At Thomas Bay many well-defined runways were seen in thick growths of lupines, but they were apparently the work of but a few individuals, for only three were secured. The only other mainland point where the species was encountered was at Brad. field Canal, where two were trapped under logs in the woods.

Very small juvenals were caught in the traps on Kuiu Island at the end of April, and thereafter in varying numbers and of all sizes at nearly every point where the species was encountered.

Alaskan examples of this mouse are uniformly quite small as compared with those from the type locality of the species, Olympic Mountains, Washington, judging from the published measurements of the latter. The specimens at hand from the Kake Islands, Prince of Wales, and Dall islands are all of about the same size, eleven adult males from Prince of Wales Island. averaging : length 188.2, tail 73, hind foot 21.2. Curiously enough those from Mitkof Island appear to be a trifle smaller, although they were taken nearer the mainland than any others from island localities, and the mainland specimens are much the largest of the series. The five adults at hand from Bradfield Canal and Thomas Bay average : length 198, tail 78, hind foot 22.2 .

Microtus coronarius, new species.

Coronation Island Meadow-mouse.

Type.-Female adult; no. 8721, Univ. Calif. Mus. Vert. Zool.; Egg Harbor, Coronation Island, Alaska; May 16, 1909; collecter by. H. S. Swarth; orig. no. 7487.

Characters.-Similar to Microtus macrurus in coloration and proportions but size very much greater throughout.

Coloration.-Essentially like Alaskan examples of $M$. macrurus, being perhaps a trifle grayer and less brown. Upper parts generally' dark Vandyke brown, this color somewhat darkened and obscured by numerous overlying black hairs. Sides and that portion of the head anterior to and below the eyes much paler, nearer broccoli brown, this in turn changing rather abruptly to the dark gray of the entire under surface. Feet pale gray, almost white. Tail distinctly bicolor, upper surface darker and less brown than the back, under surface whitish. 
Skull.-Lilke that of $M$. macrumus but much larger and more robust. I cannot perceive any difference in shape or proportions (see plate 5).

Measurements.-Type: length $215 \mathrm{~mm}$; tail vertebrae 84; hind foot 25. Average of five adult males: length 216.8 (208232); tail vertebrae 81.6 (76-92); hind foot 25.4 (24-26); average of sixteen adult females: length 214.5 (203-232); tail vertebrae 83.9 (70-92); hind foot 25.1 (24-26).

Skull (type) : basal length 27 ; zygomatic width 17.5 ; mastoid width 13.5 ; diastema 9 ; nasals 8.5. Average of twenty-one adults : basal length 27.2 ; zygomatic width 17.6 ; mastoid width 13.5; diastema 9.3 ; nasals 8.5 .

Remarks.-This is a very distinct species, not requiring close comparison with any other Alaskan meadow-mouse. It is of about the size of $M$. elymocetes, but belongs, of course, to an altogether different section of the genus. It appears to be a gigantic insular development of $M$. macrurus, but none of the specimens secured show intergradation with that species.

We found it only on Coronation and Warren islands, two outlying and rather isolated islands on the western edge of the archipelago. It was rather abundant in the woods, where deep, well-defined runways intersected the mossy carpet in every direction. These runways generally led from the tangled roots at the base of some old tree to another similar location, and in such places we uncovered several nests, round balls of moss, some eight or ten inches in diameter. This apparently was the summer home of the species, for although there were runways and burrows in some little meadows bordering a stream on Coronation Island, the work was all old and the mice had apparently deserted the place. In these same meadows several old nests were found lying on top of the ground, composed of dry grass, and of about the same size and shape as the ones of moss in the woods.

At the time of our visit to the islands, May 14 to 18 on Coronation, and May 19 to 23 on Warren, no young ones were out yet and I believe that none had been born, though juvenals of $M$. macrurus had got into the traps several weeks earlier. Most of the females secured contained large sized embryos, from four to seven in number, but no females were taken which were nursing. 
Twenty-two specimens were secured (nos. 8714-8734, 9120), seventeen from Coronation, and five from Warren Island, twentyone of these being preserved as skins, and one in alcohol. These examples are quite uniform in every respect, and none exhibits any marked divergence from the general type. One or two have a greenish stain on the underparts, which is probably wholly adventitious, possibly caused by some of the wet vegetation in which they live.

Fiber zibethicus spatulatus Osgood. Northwest Muskrat.

A small series of muskrats taken at Portage Cove, Revillagigedo Island, are in many respects very similar to specimens at hand from Yukatat Bay, Alaska, and I provisionally refer them to this Alaskan race. Ten specimens of spatulatus from the Yukon Valley are more reddish in color, and apparently smaller, though there are no measurements with the skins. Compared with examples of osoyoosensis from northern Washington these island muskrats are paler colored and smaller, with short tails and proportionately large feet. The skulls are short, but very heavy and massive, with wide spreading zygomatic arches. The five specimens secured are quite uniform in size and color, as well as in the appearance of the skulls. They measure as follows :

$\begin{array}{ccccc}\text { No. } & \text { Sex } & \text { Length } & \text { Tail } & \text { Hind Foot } \\ 8355 & \text { o } & 490 & 210 & 75 \\ 8356 & \text { o } & 510 & 220 & 75 \\ 8354 & \text { o } & 510 & 220 & 78 \\ 8357 & \text { o } & 480 & 195 & 72 \\ 8353 & \text { o } & 495 & 210 & 75\end{array}$

SKULL MEASUREMENTS.

\begin{tabular}{|c|c|c|c|c|c|c|c|c|}
\hline & Sex & $\begin{array}{c}\text { Basal } \\
\text { Length }\end{array}$ & $\begin{array}{l}\text { Zygo- } \\
\text { matic } \\
\text { Width }\end{array}$ & $\underset{\text { Width }}{\text { Mastoid }}$ & $\begin{array}{l}\text { nterorbita } \\
\text { Constric- } \\
\text { tion }\end{array}$ & Nasals & Diastema & $\begin{array}{l}\text { Alveolar } \\
\text { Length of } \\
\text { Upper } \\
\text { Molars }\end{array}$ \\
\hline 8353 & $\sigma^{\prime}$ & 57 & 40 & 24 & 6.8 & 22 & 22 & 15 \\
\hline 8356 & d & 58 & 40.5 & 25.5 & 6.5 & 22 & 22.5 & 14.5 \\
\hline 8355 & d & 57.5 & 40 & 25 & 7 & 22.5 & 22.5 & 14 \\
\hline 8357 & q & 55.5 & 38.5 & 23.5 & 7 & 21 & 21 & 14 \\
\hline 8354 & 웅 & 57 & 39.5 & 25 & 6.2 & 22.5 & 22 & 14.8 \\
\hline
\end{tabular}

Revillagigedo Island was the only place during the entire summer where muskrats were encountered. The meadows border- 
ing the river at Portage Cove were intersected by numerous winding gulches, large and small, formed by the various streams flowing down from the mountain sides, filled with water at high tide, and nearly empty at low tide. These gulches diminished in size as they left the river until they became mere narrow ditches, sometimes completely hidden by the tall overhanging grass; and here the muskrats had their home. There were not many of them, and Hasselborg, who discovered them, captured probably almost the entire colony at this point. Besides the five secured, one was eaten in the trap, probably by an otter. This seems to be an unusual place for them to winter, as all the swamps freeze solid, and there are no ponds. Old trails show that they have wintered on the surface of the meadows, under the snow, feeding on twigs, roots, grass and shoots.

The holes they were occupying were in the walls of the gulches, the entrances being under water at high tide (see plate 4, figure 1). About these holes and in their trails, were piles of cut grass, and other green stuff. No sign of muskrats was seen in the meadows along the Chickamin River, on the mainland directly opposite Portage Cove, in a region of very similar character.

\section{Synaptomys dalli Merriam. Dall Lemming Mouse.}

Six specimens secured (nos. 8735-8740), one from the Chickamin River, four from Thomas Bay, and one from Port Snettisham. At Thomas Bay the meadows in the river valley were strewn with logs and other drift brought down by the stream at high water, and it was under these that the lemming mice were captured. The single specimen from the Chickamin River was caught under a log in the woods, in a trap set for Evotomys. The one secured at Port Snettisham was taken high up on the mountain side, at the edge of deep snowbanks, in an open marmot meadow.

These six specimens are quite indistinguishable from a series of $S$. dalli from the Prince William Sound region, Alaska. Neither in external nor in cranial characters am I able to perceive any differences whatever, although it might be supposed that the form inhabiting this region would be $S$. wrangeli. 
Zapus hudsonius alascensis Merriam. Alaska Jumping Mouse.

One specimen, an adult female, taken at Portage Cove, Revillagigedo Island, July 1 (no. 8607). It was caught at the entrance to a tiny hole in the moss at the base of a large tree near the edge of the forest. Numerous traps set in similar localities, as well as in the adjoining meadow land, failed to bring any additional specimens to light. The one secured contained six embryos.

This specimen was submitted to E. A. Preble, of the U. S. Biological Survey, who remarks that it "belongs to the $Z$. hudsonius group, and as it seems to have some of the characters of alascensis, I refer it to that form." Since the type locality of alascensis is Yakutat Bay, over three hundred miles northwest, south of which I believe it had not previously been taken, and since we secured a different species of $Z$ apus at an intermediate point, it is desirable that more data be secured for the further elucidation of this peculiar irregularity in distribution.

Zapus saltator Allen. Stikine Jumping Mouse.

An adult male secured on the Taku River on September 8 (no. 8608). I believe they were fairly abundant in the meadows at this point, for on September 4 and 5 Hasselborg and myself saw probably half a dozen in the grass. When the rainy weather set in once more they were no longer to be seen.

The single example obtained, as well as the specimen of $Z$. h. alascensis, was identified by E. A. Preble.

Erethizon epixanthum nigrescens Allen. Dusky Porcupine.

Porcupines, or indications of their presence, were seen at almost every mainland point visited. At Boca de Quadra several were seen, and one killed but not saved as it was shedding badly. On the Chickamin River many were noted, all shedding hair and quills, some of them almost naked. There were many trails through the long grass at this point, made by the porcupines on their travels. At Bradfield Canal I saw but one, though the trees bore abundant evidence of their presence. At Thomas Bay they were fairly abundant. None were seen either at Port Snettisham nor on the Taku River, though there was a little sign at the 
former place. The only island localities where the species was observed were on the neighboring Etolin and Wrangell islands, in close proximity to the mainland. On Etolin some sign was observed, and I found a dead porcupine in the woods, but we saw no living ones. On Wrangell, a number were observed.

But one specimen was preserved, an adult female taken at Thomas Bay on August 17 (no. 8352). This one is abnormal in coloration, possibly albinotic. The whole animal is of a yellowish color, about the clay color of Ridgway, becoming appreciably darker on the rump. The lower surface is a dark grayish brown. The short quills on the body are uniformly yellow, the larger ones on the rump and tail yellow basally, but abruptly darker at the distal end. The claws are of a dirty yellowish color. Other porcupines seen at the same place, and at other points, were all very dark, with the exception of one on Wrangell Island, which was also rather pale colored, though not as markedly so as the Thomas Bay specimen. The skull of the latter appears to be that of an old animal and exhibits the peculiarities ascribed to the form nigrescens by Allen, notably the fronto-parietal depression, together with the great development of the temporal ridges.

\section{Canis pambasileus Elliot. Alaska Timber Wolf.}

Wolves occur on all of the larger islands south of Frederick Sound, as well as along the mainland, and we found signs of their recent presence at most of the points we visited. About our camp on Kupreanof Island there were abundant tracks, apparently made by a single individual, while many of the dead deer scattered through the woods, had quite evidently been killed and devoured by wolves. At Three-mile Arm, Kuiu Island, one was heard howling in the night. More or less fresh sign was seen on Prince of Wales Island, at Port Protection and at Klawak Salt Lake, and at the latter place a skin was purchased from an Indian, who had killed the animal the same morning. This Indian informed us that wolves were particularly numerous on several of the islands lying west of San Alberto Bay, islands that we did not visit. Fresh tracks were seen on the beach at Heceta Island; and at Rocky Bay, Dall Island, wolf sign was 
- abundant. On the Chickamin River Hasselborg had a shot at one, at a point some twenty miles up the river, where he heard several howling in the night. Fresh sign was seen at Bradfield Canal and on Zarembo Island. A wolf remained in the vicinity of our camp at Mitkof Island during the whole of our stay at that point; I heard him howling in the night, and saw fresh tracks day after day, where he had followed me, making the round of my small mammal traps. Once also a deer burst from the woods near the camp, panting and panic stricken, and in evident fear of some unseen pursuer. At Thomas Bay one was heard howling, and his tracks seen almost daily along my line of traps; and though the Mitkof wolf was too suspicious to venture very near to the little mouse traps, this one was troubled with no such fears, but carried off several with the animals they held. Hasselborg reported seeing some wolf tracks at Port Snettisham. There appeared to be no wolves on Coronation, Warren, and Duke Islands; on Annette and Gravina islands we saw no sign; but our stay at these points was too short to decide any such matters. No wolf sign was observed on Revillagigedo, Etolin, or Wrangell islands, though they may occur on all three.

The one specimen secured is an old male, purchased from an Indian who had caught it in a trap at Klawak Salt Lake, Prince of Wales Island, on the morning of May 26 (no. 8321). He stopped at our camp the same day and exhibited the skin, which he had roughly removed, leaving the head, feet and tail unskinned. It was the second he had caught during the winter.

This animal is extremely dark colored, in general appearance almost black. The whole head and muzzle is glossy black, with a sprinkling of grayish, due partly to a mixture of white hairs, and partly to the fact that some of the black hairs are white basally. Back and legs are black, mixed with a few scattered white hairs; the sides of the neck brownish, and of the body dark gray, changing to dark brown on the middle of the abdomen. The tail is black, and black tipped, but about the basal half of the ventral surface is a dirty whitish color. The hair on the soles of the feet is chestnut. That on the median line of the back has not grown out to its full length, and the color of this part 
is consequently a dirty yellowish brown, the worn remnant of the old coat, but the new hairs coming out are glossy black, with a few white ones intermixed. The captor, John Darrow, gave us much information about these and other animals, and told us that the wolves will sometimes even attack a bear. Several of the Indian hunters and trappers that I talked with expressed considerable fear of them, and they all gave exaggerated accounts of their ferocity and cunning. He also told us that he had twice killed pregnant females, each containing twelve embryos.

Several hunters, white men and Indians, told us that the island wolves were sometimes black, sometimes gray or yellowish, and sometimes a mixture of these colors. I saw several skins of Alaskan wolves at various times, and some were very dark, much like the one described above, some grayish, and a few gray or yellowish with black dorsal stripe and tail and a black mark across the shoulders.

The specimen secured measures as follows: approximate length of tanned skin from tip of nose to tip of skin of tail $1945 \mathrm{~mm}$; ; tail vertebrae 487 ; hind foot 304 . Skull : total length $268 \mathrm{~mm}$; basal length, 229; zygomatic width 152; width across post-orbital processes 73 ; median length of nasals 97 ; palatal length 132; length of upper tooth row (anterior edge of canine to posterior edge of last molar) 110 ; length of canine 34 ; length of lower jaw 205; height of coronoid process 77 .

\section{Lutra canadensis periclyzomae Elliot. Island Otter.}

Otter appear to be quite generally distributed over this whole region, but they have been so incessantly trapped that their numbers are greatly reduced. We saw more or less fresh sign at Kupreanof, Kuiu, Coronation, and Warren islands, and also on the Taku River. At Three-mile Arm, Kuiu Island, an Indian trapping there had caught just two during the winter. One specimen, a female, was secured by Hasselborg on Warren Island, May 19 (no. 8331) as it was swimming across a stream, when he saw it and shot at it with his 45-70 rifle. On skinning it no hole could be found, nor were any bones broken, and as its lungs were greatly congested, and it bled profusely at the mouth and nostrils, we concluded that the bullet must have struck the water immediately beneath the animal, the concussion killing it. 
Lutreola vison nesolestes Heller. Island Mink.

Generally distributed over this entire region, and fairly abundant where they have not been trapped to excess. The mink is the Indian trapper's best standby on the islands, and wherever we went we found in the woods scores of little deadfalls of various ages arranged for their capture. One Indian at Three-mile Arm, Kuiu Island, had some thirty mink, one marten and two otter to show as the result of his winter's trapping. Hasselborg caught two mink at this point (nos. 8791, 8792), besides a third destroyed in the trap, probably by another mink, two at Egg Harbor, Coronation Island (nos. 8793, 8794), and one on the Taku River (no. 8795). I also purchased seventeen skulls from the Indian on Kuiu Island (nos. 8796-8812), and found an additional skull on Coronation Island (no. 8813).

More or less fresh sign was seen at many of the points visited, and $I$ saw a mink running along the bank of a stream at Boca de Quadra, but failed to secure it.

The island specimens all exhibit to a marked degree the characters of nesolestes, the crowded tooth row, and greatly enlarged last upper molar. The single mainland example (no. 8795 , Taku River, September 24), is much darker colored than any island specimens at hand, winter or summer, closely resembling a Prince William Sound example of $L$. $v$. melampeplus (no 858, 9 , Disc Island, September 4), but the dental characters are clearly those of nesolestes.

Mustela nesophila Osgood. Queen Charlotte Marten.

A single marten skull (no. 8814) was obtained at Three-mile Arm, Kuiu Island, purchased from an Indian who had caught the animal somewhere in the immediate vicinity. It is apparently most like $M$. nesophila of the Queen Charlotte Islands, from which it differs in slightly greater width, with especially wide spreading zygomata, judging from the published measurements and figures of the species ( see Osgood, 1901, p. 33). The small audital bullae and short, heavy rostrum, with crowded upper tooth row and large sized last upper molar, all serve to distinguish it from the mainland forms. Should additional specimens 
show the wide spreading zygomatic arches to be a constant feature, the marten of the Alexander Archipelago should be considered a distinct species.

The skull secured measures as follows: occipito-nasal length 77.5 ; basal length 75 ; palatal length 42 ; post-palatal length 33 ; zygomatic breadth 51.5 ; width across post-orbital processes 26 ; interorbital constriction 17.2 .

We failed to obtain very definite information as to the distribution of the species over these islands, where it does not appear to be abundant at any point. The above mentioned individual was the only one caught during the season by the man who secured it, and he apparently knew of just one other captured in the vicinity during the same period. Tracks of a single individual were seen in newly fallen snow on Kupreanof Island; at no other point did we personally meet with the species.

\section{Putorius cicognani alascensis Merriam. Alaska Weasel.}

But three weasels were secured, all that were seen during the summer, one from Zarembo Island (no. 8815), one from Mitkof Island (no. 8816), and one from the Taku River (no. 8817). Our Indian friend at Three-mile Arm, told us that on the Kake Islands weasels were very scarce. During the past winter (1908-9) he had caught none; the winter before he got seven. The one secured on Zarembo Island entered my tent and carried away a shrew. It returned the next day, and catching sight of it in the wood pile I shot it. The Mitkof specimen was seen darting through a tangle of drift on the beach, and by squeaking in the manner commonly used in attracting small birds I easily induced it to return and expose itself. At this point I lost a number of mice, carried away or partially eaten in the traps, in a way that made me believe weasels were responsible.

Island specimens, compared with a single individual from Helm Bay on the mainland, exhibit the same dental peculiarities as do most of the other small carnivores of the islands, a noticeable crowding of the cheek teeth, together with an enlargement of the last upper molar, but two specimens from Juneau and the Taku River, have the same characteristics. 
Ursus americanus pugnax, new subspecies. Island Black Bear.

Type.-Adult male; no. 8332, Univ. Calif. Mus. Vert. Zool. : Rocky Bay, Dall Island, Alaska; May 31, 1909 ; collected by A. Hasselborg; orig. no. 15.

Characters.-Differs cranially from Ursus americanus americanus from the adjacent mainland; skull broad and heavy, with the frontal bones conspicuously flattened. (See plate 6, figures 1 and 2.)

Remarks.-The island bear exhibit certain cranial peculiarities which seem to justify their separation as an insular race. They are certainly widely different from black bear taken at other Alaskan points, Kenai Peninsula, Yakutat Bay, and Taku Inlet. Compared with skulls from these localities, as well as with others from California and Oregon, the island specimens present a very different profile. The frontal bones are flattened and the sagittal crest raised, so that the highest part of the cranium lies very far back, about at the fronto-parietal suture rather than over the orbits, as in typical americanus. The postorbital processes are largely developed and raised, being in one case actually higher than the intervening frontal region. The temporal ridges are conspicuous, and the zygomata heavily built and wide spreading, producing a relatively very broad skull. In three examples (nos. 8332, 8333, 8326) the zygomatic breadth is actually, as well as proportionately, greater than in any other specimens of black bear at hand, or than any published measurements I have seen. In general appearance these island skulls are short and broad, heavily built and conspicuously ridged. The larger ones bear a striking general resemblance to a grizzly skull from the interior of Alaska.

Their conspicuous feature is the flat depressed forehead. Ursus a. carlottae from the Queen Charlotte Islands has the cranium less arched than in americanus, but has an elongated skull, whereas in these it is short and broad. Ursus americanus kenaiensis (not Ursus kenaiensis Merriam, 1902) from the Kenai Peninsula has a long narrow skull (see Allen, 1910, p. 6). ${ }^{1}$ Skulls

1 Since the above was written Dr. Allen has proposed the name Ursus americanus perniger to replace his $U$. a. kenaiensis preoccupied. (See " Errata," Bull. Am. Mus. Nat. Hist., vol. xxviii, A pril, 1910, p. 115.) 
in the collection of this Museum from the Kenai Peninsula, Yakutat Bay, and other mainland points in Alaska, have the frontal region high and rounded, a form of development that apparently is at its maximum in Ursus altifrontalis Elliot, from the Olympic Mountains, Washington. According to Allen (1.c., p. 5) one of the usual results of age in the black bear is "the marked building up of the frontal region." In these island bear age produces exactly the opposite effect, for through the development of the post-orbital processes and temporal ridges a decidedly more flat-headed appearance is presented in the older skulls.

In color the island bear secured are all black, and according to the Indians, the brown phase is unknown on the islands. It is not so on the mainland, however, where the cinnamon phase is fairly common, though this fact does not seem to be generally known (ef. Osgood, 1909, p. 3). At Marten Arm, Boca de Quadra, I examined over twenty bear skins in an Indian camp, all recently killed in the immediate vicinity, and over a third were in the cinnamon phase. The Indians, though they prize them higher than they do the black ones, as they fetch a better price, do not regard them as different species. A young female killed on the Taku River September 7 (no. 8328) is dark cinnamon brown in color, the legs and feet somewhat darker, and the under fur paler, with a white spot on the breast.

Eleven specimens of the black bear were collected, nine from island localities and two from the mainland, besides a skull picked up on Kupreanof Island. In detail they are as follows:

No. 8329, $q$ adult, Kupreanof Island, April 24. Hair very long and thick, as it is in winter pelage throughout. Black everywhere except on the muzzle, which is dark brown. Under fur dark gray, almost black.

No. 8330, ơ young, San Alberto Bay, Prince of Wales Island, May 24. In very worn ragged pelage, the hair on the sides and shoulders being rubbed off to a marked extent. Black, except where the hair is much worn down, these areas having faded to a rusty brown.

No. 8331, $q$ young, San Alberto Bay, May 25. Also in worn pelage, though not so much so as the last. Hair largely rubbed 
off on inner side of thighs and front of foreleg, the worn places showing rusty brown. Otherwise black, with slightly lighter colored muzzle.

No. 8332, ð’ adult, Rocky Bay, Dall Island, May 31. In worn winter pelage, with small patches of the new summer coat appearing on the inner sides of the thighs. Rusty brown on the sides, where most of the hair is worn off; otherwise black.

No. 8322, ơ adult, Fools Inlet, Wrangell Island, July 12. All that remains of the old pelage is a line along the spine, and some ragged patches on the shoulders. On these areas the hair is longer than elsewhere, and differently colored, being rusty brown, whereas the new coat is glossy black with a few white hairs interspersed. Muzzle light tan color. A small pure white spot on the middle of the breast.

No. 8324, ð young, Mitkof Island, August 2. Very ragged. in appearance, and presenting a mixture of old and new pelage. Black with slightly paler muzzle.

No. 8325, $q$ young, Mitkof Island, August 2. Also very ragged, with much of the old pelage remaining. The new hair black, the old rusty brown. Muzzle very dark, with lips slightly paler.

No. 8326, ठ̋ adult, Mitkof Island, August 4. In very worn pelage. Dull rusty black throughout.

No. 8327, o young, Mitkof Island, August 8. Much like no. 8322 , but with more of the long, rusty winter hairs on rump and shoulders. Otherwise glossy black with dark brown muzzle and a small white spot on the center of the breast. Very thinly haired.

No. 8323, of young, Bradfield Canal, July 19. Very thinly haired. Summer pelage on the back, worn winter pelage on legs and thighs. Black, with under fur brownish. Muzzle and lips very dark brown.

No. 8328, 9 young, Taku River, September 7. Dark cinnamon brown, with the legs and feet somewhat darker and the under fur paler. A small white spot on the breast.

We had heard rumors, more or less vague, in regard to the occurrence of brown bear on the more southern Alaskan islands, and one of the objects of the present expedition was to ascertain as 
definitely as possible the range of the big brown bear in this region. Hasselborg is familiar with them, and with their habits and mode of life, having hunted them in other parts of Alaska, and at each point we visited he made it his first object to hunt for bear or signs of their presence. We also questioned prospectors and storekeepers as well as the Indians at every opportunity. There can be no doubt, I believe, that the brown bear do not occur south of Frederick Sound and Christian Sound, on the islands, while on the mainland coast we had not the slightest evidence of their presence anywhere south of Juneau. The Indians on the Kake Islands and on Prince of Wales use the same names as the more northern tribes for the brown and the black bears, but those we interrogated all declared that there were none of the former on their islands.

On the mainland, where the cinnamon phase of the black bear is of fairly common occurrence, the Indians refer to the cinnamon colored individuals as brown bear, but they distinguish between these and the big northern brown bear, referring to the latter as the "fighting brown bear." Both white men and Indians declared that there were no large bear immediately along the coast on the mainland, nothing but black bear, though there were grizzlies twenty or thirty miles inland, in a few places. I saw some grizzly skins that had been obtained about that distance from the mouth of the Stikine River, and at the head of Port Snettisham, and on the Taku River Hasselborg saw tracks of what he believed were grizzly bear.

Black bear are generally distributed over all the larger islands from Kupreanof southward, and all along the mainland coast. Specimens were secured or signs of the very recent presence of bear seen on Kupreanof, Kuiu, Prince of Wales, Heceta, Dall, Revillagigedo, Etolin, Wrangell, and Mitkof islands, and at all the mainland points visited. They appeared to be absent from Coronation, Warren, Duke, and Zarembo islands. "The material at hand is not sufficient to demonstrate whether the island bear ranges along the mainland coast immediately adjacent. Several skulls from the Taku Inlet, all of rather young individuals, however, have high, rounded frontals. The young cinnamon bear secured at this point in September (no. 8328) has this part as flat as any of those from the islands. 
Upon our arrival on Kupreanof Island, early in April, snow lay deep in the woods, and even along the beaches, and Hasselborg declared that while some of the brown bear should have emerged from their hibernation, it was still too early for black bear. On April 14 he found fresh tracks of one, and on the 16th he scared what was probubly the same bear from a thicket in which it was sleeping, but failed to get a shot at it. On April 24, while hunting in the same place, he secured this bear, a female, probably two or three years old, in good condition, and very fat. All the tracks that were seen at this point were apparently made by this one bear. The weather was so cold and stormy that it is doubtful whether very many had come out yet. At Three-mile Arm, Kuiu Island, fresh tracks of a single bear were seen.

At Port Protection, Prince of Wales Island, Hasselborg found sign of several individuals, but they were ranging over the country, hunting for green grass, which was just beginning to appear in places. At San Alberto Bay, Prince of Wales Island, he secured two, on May 24 and 25 respectively, along the same stream, where they were eating the grass which was now quite tall. The next place where bear sign was observed was at Rocky Bay, Dall Island. They were fairly numerous in this region, and apparently the Indians had not been hunting or trapping there recently. On May 31 Hasselborg secured an adult male, the largest and best specimen obtained. At most of the places visited subsequently the Indians had been trapping earlier in the season, and the bear killed or frightened away. However, on Mitkof Island we found a place where they had not been disturbed, and where they were feeding on the running salmon. Hasselborg saw seven during our stay here, and secured four of them.

Early in the season, when they first came out of their holes, the bear were feeding on grass wherever they could find it, and we also found many places where they had dug up and eaten the roots of the skunk cabbage. The one killed on Kupreanof Island had been feeding largely on the dead deer strewn throughout the woods, and one was found that may have been killed by the bear itself judging from the blood and the appearance of the carcass. This bear's stomach was stuffed with deer hair, hoofs and pieces of bones, together with some skunk cabbage roots and grass. 
The one killed on Dall Island contained steel-head trout and grass. By the time we reached the Taku River, in September, the run of salmon in the smaller streams was over, and the bear had scattered over the country.

According to the Indians, the island black bear are much more savage and ferocious than those on the mainland, a state-ment that is borne out to some extent by the summer's observations. They told us that the island bear would not hesitate to attack a man when wounded, and that they generally rushed right in and seized him, not rearing up on their hind legs in the usual manner of the brown bear. The old male that Hasselborg secured on Dall Island rushed for him at the first shot, very much to his surprise, as he had frequently expressed his contempt of the fighting ability of the black bear. It would have been easier for this animal to have made his escape in almost any other direction, for he had to go around a fallen tree and cross a running stream some two feet deep in order to reach his assailant, but he doggedly kept on in spite of several bullets, finally dropping dead on the sandbar, within thirty feet of the hunter. This bear had had his lower jaw fractured, a triangular piece of bone containing the left canine which is also broken square across, hanging loose, attached only by the skin and muscles. This injury had been received apparently not more than two weeks before, and it had very possibly been done in a fight with another bear, for there were numerous partly healed wounds on his neck and body.

Another individual, also an old male, killed on Mitkof Island (no. 8326), had undergone a still more frightful injury, the lower jaw on the left side being fractured squarely across, immediately before the last molar, which had dropped out. The only external indication of this injury was a running sore on the jaw. From the appearance of the bone this wound must have been received months before.

In connection with the present study of the Alaska black bears I took occasion to carefully examine the series of Ursus emmonsi contained in the Museum collection. These are seven in number, consisting of the following specimens: three skins with skulls, one skin with the complete skeleton, two skins without skulls, and one skull without the skin. The theory has 
recently been advanced by Osgood (1909, pp. 1-3) that possibly the glacier bear is not a species, nor even a subspecies, but merely a color phase of $U$. americanus. This idea would seem to be distinctly worthy of consideration, for the distinguishing differences of emmonsi are of color only, and in this it seems to be extremely variable. That as a gray phase of the black bear it replaces in Alaska the common cinnamon phase is not borne out by the facts, however; for as mentioned above brown colored examples of $U$. americanus are of fairly common occurrence on the southern mainland coast. Emmonsi has a curiously limited distribution, specimens having been taken only in the region lying between Lynn Canal and Cape St. Elias. Indians that we questioned in the regions farther south knew nothing of a blue-colored bear, having never seen or heard of any such animal, and such evidence though negative, is worth taking into consideration. Hasselborg informed me that the Yalkutat Bay Indians, though aware of their existence did not regard them as different from the black bear. When pressed for an explanation of the peculiar color they expressed their belief that the gray bears were the very old individuals. Of course while their opinion as to the specific standing of the bear is of little or no value, it is of interest as illustrating the nature of the differences between emmonsi and americanus. They oceur in the same region, and appear to be alike in their habits, despite the supposed predilection of the former for the vicinity of glaciers.

The color of the fur appears to be the only distinguishing characteristic. I am unable to appreciate any difference between skulls of emmonsi and those of americamus from Yakutat Bay, nor do I find the alleged differences in the claws (supposedly smaller and more curved in emmonsi) to be borne out in the specimens at hand.

In view of the rarity of the species it seems worth while to place on record brief descriptions of the skins contained in the Museum collection.

No. 4331, + ; Anklin River, Yakutat Bay ; May 6, 1908 ; collected by A. Hasselborg. Skin and skull. Very pale; general body color creamy white. Rump, legs and feet darker, being dark, bluish gray. Toes black, but with scattered white hairs. A dark line from the head along the middle of the back, becoming less dis- 
tinct posteriorly. Inner surface of ears black; basal two-thirds of outer surface whitish; tip black. Head, before the ears, abruptly darker, black, mixed with many pure white hairs. Muzzle and chin brownish, from a line a little before the eyes.

No. 4369; Fairweather Range, Lituya Bay, 1906. Skin only. General color creamy white; lower part of fore legs mixed with black hairs, producing a somewhat darker effect; toes abruptly black. An indistinet dark line along the middle of the back, disappearing anteriorly and posteriorly. Ears whitish, edged with black. Head darker, but not black, mixed whitish and black hairs extending forward to the eyes. Muzzle and chin brownish.

No. 4368; Fairweather Range, Lituya Bay; 1906. Skin and skull. General color dirty whitish, palest on neck and sides of body, bluish gray on legs, rump, and along the back. Head darker, mixed black and white hairs extending forward to a line just before the eyes. Chin and muzzle brownish.

No. 4370; Lituya Bay, near Mt. Fairweather; spring of 1906. Skin only. Color of body bluish white, palest on neck and shoulders; darkening on the posterior part of the back, the rump, legs and feet. Upper part of head abruptly darker, being black interspersed with many long white hairs. Ears black. Muzzle and chin brownish.

No. 4371, ; ; base of Mt. Cook; June 1, 1907. Skin and skull. Dark bluish gray, palest on shoulders and abdomen, darkest on rump, legs and feet. Upper part of head black, mixed with white hairs. Muzzle and chin brownish.

No. 4367 ; Fairweather Range, Lituya Bay; 1907. Skin and skeleton. The darkest of the series. Very dark bluish gray, with no whitish anywhere. Palest on shoulders, darkest on legs and rump. Feet and toes black. Upper part of head black, silvered with many white hairs. Chin and muzzle brownish.

\begin{tabular}{|c|c|c|c|c|}
\hline \multicolumn{3}{|c|}{ MEASUREMENTS (IN MILLIMETERS) } & OF BLACK & BEARS \\
\hline No. & Locality & Sex & Length & Hind Foot \\
\hline 8329 & Kupreanof Island & q & 1422 & 228 \\
\hline 8330 & Prince of Wales Island & $o^{+}$ & 1524 & 254 \\
\hline 8331 & Prince of Wales Island & 우 & 1371 & 228 \\
\hline 8332 & Dall Island & o & 1752 & 266 \\
\hline 8322 & Wrangell Island & $0^{\pi}$ & 1422 & 241 \\
\hline 8323 & Bradfield Canal & $0^{\pi}$ & 1371 & 228 \\
\hline 8324 & Mitkof Island & $a^{x}$ & 1422 & 254 \\
\hline 8326 & Mitkof Island & $0^{3}$ & 1574 & 254 \\
\hline 8325 & Mitk of Island & 오 & 1371 & 228 \\
\hline 8327 & Mitkof Island & $q$ & 1270 & 203 \\
\hline 8328 & Taku River & q & 1141 & 203 \\
\hline
\end{tabular}




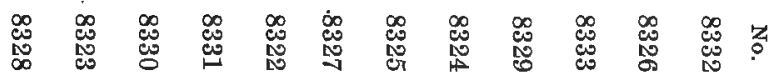

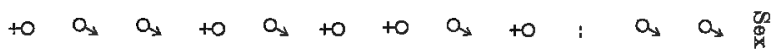

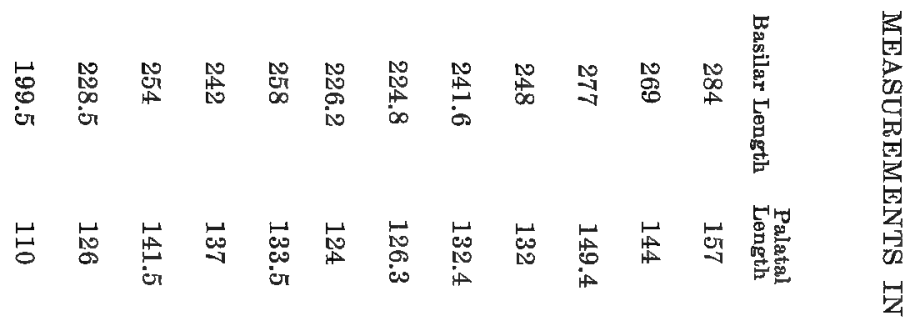

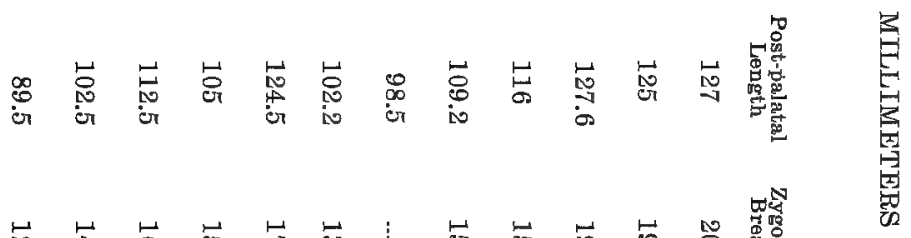

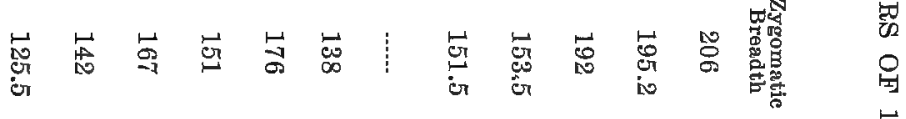

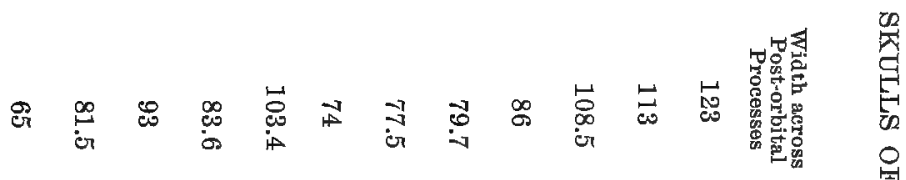

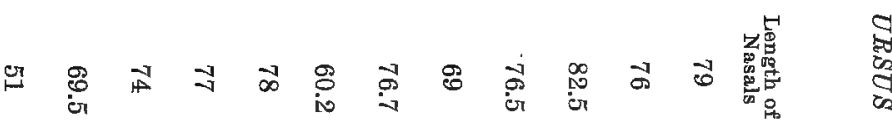

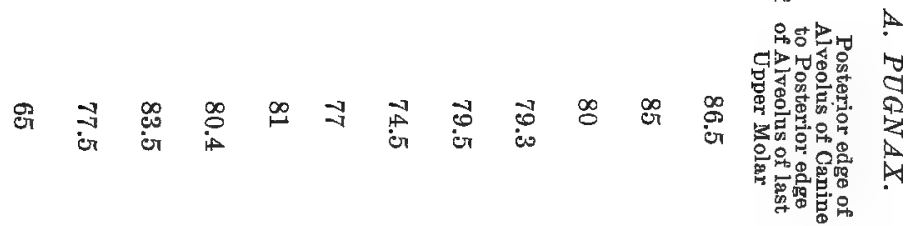

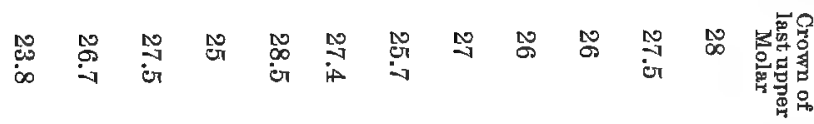

幽 
Sorex personatus streatori Merriam. Streator Shrew.

Represented by a series of twenty-eight specimens from various mainland points and from some of the islands lying close to the coast (nos. 8412, 8422, 8425, 8430, 8431, 8434-8444, 8450, $8461-8463,8465-8470,9154,9155)$. No specimens were taken on any of the more western islands. Points of capture are as follows: Chickamin River, 1; Portage Cove, Revillagigedo Island 1; Etolin Island 1; Wrangell Island 2; Bradfield Canal 11; Mitkof Island 1; Thomas Bay 5; Port Snettisham 2; Taku River 4.

Sorex obscurus longicauda Merriam. Long-tailed Shrew.

Generally distributed over the whole of this region, and in many places the most abundant species of mammal. Ninety-two specimens were secured from the following localities: Kupreanof and Kuiu islands, Prince of Wales Island (Port Protection, Calder Bay, Shakan, San Alberto Bay, Klawak Salt Lake), Coronation, Warren, Heceta, Duke, Gravina, Dall, Revillagigedo, Etolin, Wrangell, Zarembo, and Mitkof islands, and from the mainland at Boca de Quadra, the Chickamin River, Bradfield Canal, Thomas Bay, Port Snettisham, and the Taku River (nos. 8365-8411, 8413-8421, 8423, 8424, 8426-8429, 8432, 8433, 8445$8449,8451-8460,8464,9153,9156-9166)$. It was thus found at practically every point visited.

Where meadow-mice occurred shrews were frequently taken in their runways, but they were also caught in traps set in almost every conceivable situation, under logs in the woods or amongst the drift on the beaches. Almost as many were caught in the daytime as at night, and in some places they were a source of annoyance, eating portions of animals caught in the traps. At Thomas Bay I watched one for some time, feeding in refuse by the camp. I had just cleaned some ducks, and the clotted blood lying on the ground attracted the shrew to the exclusion of everything else. He tugged and pulled at it, eating all he could hold, while I stood watching, standing within a foot of him, and though the least sound or movement on my part 
sent him darting into the grass, he quickly returned, and eventually finished his meal.

I have referred all of these shrews collected to longicauda although there is considerable variation in the size and proportions of the series from different points. Those from most of the more northern and western islands average rather small and have short tails, as compared with those from more southern island and mainland points. Two examples from Boca de Quadra are particularly large. The largest of these (no. 8409, female) measures: length 140 ; tail vertebrae 62 ; hind foot 17. Various intermediate sizes may be found between this and the smaller, more northern individuals, however. There is no apparent color variation in the series from different points.

Myotis lucifugus alascensis Miller. Alaska Brown Bat.

Bats were seen at but two points, at the head of Marten Arm, Boca de Quadra, and at Portage Cove, Revillagigedo Island. At the former place perhaps six or eight were observed, usually flitting about some sheltered corner at the edge of the woods, where it became dark sooner than out in the open meadows. At Portage Cove they were quite numerous, but usually feeding over the surface of the river, and consequently hard to retrieve. I looked for them carefully at the other places visited, but saw none.

Seventeen specimens were collected (nos. 8362-8364, 9139 9152). At Boca de Quadra I shot one which I made into a skin, and Hasselborg shot two which were put in alcohol. At Portage Cove I made skins of two, and Hasselborg secured twelve which were saved in alcohol.

\section{DISTRIBUTIONAL CONSIDERATIONS.}

Groups of islands usually present interesting facts and problems in the distribution of animal life, taken in connection with the conditions on the neighboring mainland, and the Alexander Archipelago is no exception to this general rule. The present expedition together with the previous one to this same region, has brought together many specimens and recorded many facts of significance along these lines. The present distribution of animals on these islands is in many cases difficult or impossible 
to explain satisfactorily, though in some instances the causes of the present conditions are fairly obvious.

The relationships of the vertebrate fauna of the Sitkan district are for the most part distinctly with the mainland region to the southward, the temperate climate of the coast having permitted this northern extension of the ranges of many species of birds and mammals. The greater part of the area included is composed of islands, the strip along the mainland between the mountains and the sea being narrow and restricted. Though the fauna of the various islands has, as a rule, apparently been derived from the adjacent mainland, there are several exceptions, as noted beyond, some of them difficult to understand.

The northern islands of the group are separated from the more southern ones by broad, deep channels, and many of the mammals of these islands are more closely related to more northern mainland forms. Of the southern islands those lying closest to the mainland have the greatest number of mainland species.

Island forms of several species are somewhat smaller than the mainland races, but it is remarkable that on the westernmost islands, those farthest from the mainland, these same species should be represented by exceedingly large races.

Climatic and physiographic conditions are quite uniform throughout the whole of the area under consideration, which is a region of rough, precipitous mountains and impenetrable. forests, and is likewise noted for its copious rainfall and comparatively mild climate. The most noticeable local climatic variation is between the mainland and the more western islands. The winter climate of the mainland coast, though much milder than that of the region east of the mountains at the same latitude, is more rigorous than that of the islands. The islands nearest the coast, as Revillagigedo, are on their east sides also subject to severe winter weather. One of the results is that on the mainland the heavy precipitation of the region takes the shape of snow which covers the ground to such a depth as to render impossible the presence of animals like the deer. Despite the general uniformity of conditions it is interesting to note that with one or two possible exceptions there is no species of mammal that ranges unchanged throughout the whole of the region. With 
birds it is different. Excepting the singular distribution of the grouse on the islands, the avian fauna is everywhere much alike.

For the purpose of this discussion the islands of the archipelago may be roughly divided into three groups: northern (Chichagof, Baranof, and Admiralty), central (Kuiu, Kupreanof, and Mitkof), and southern (Prince of Wales and the islands to the westward). Zarembo possibly belongs in the latter category, while those islands lying east of Clarence Straits are, as regards their animal life, most like those of the central group. In the first group we find several species of mammals apparently of

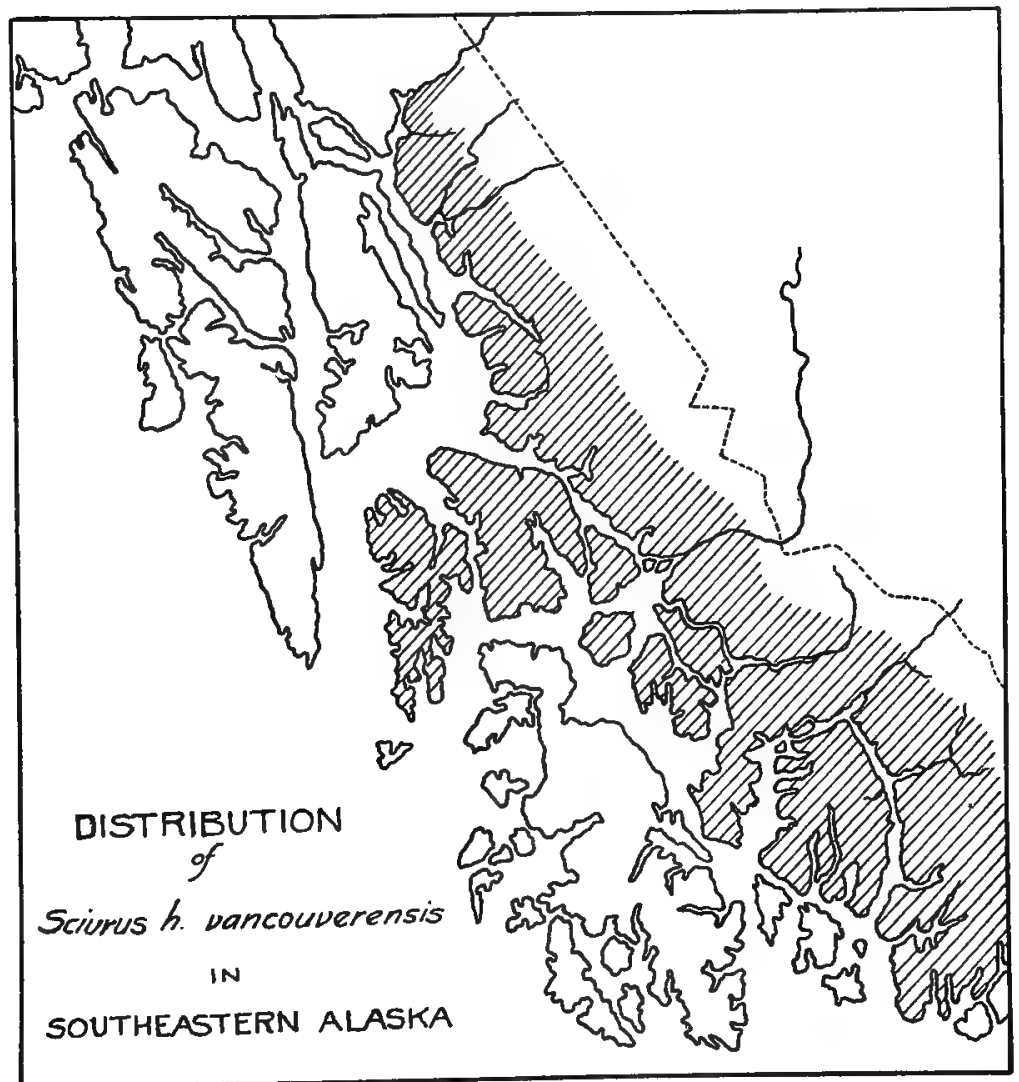

Hig. 1.-Map showing the range of the red squirrel (Sciurus hudsonius vancouverensis) in southeastern Alaska. It has invaded only the islands most easy of access from the mainland. 
northern derivation. Here the big Alaska brown bears find their southern limit at Frederick Sound and Christian Sound. Microtus sitkensis is closely related to more northern forms, while $M$. admiraltiae is curiously enough an offshoot of an inland species (M. drummondi) that reaches the Alaskan coast at very few points-one of them being that part of the mainland most closely adjacent to Admiralty Island.

The central group of islands, though extending to the western edge of the archipelago, is nevertheless but narrowly separated from the mainland, and it contains one characteristic mainland mammal (Sciurus) that does not occur on either the northern or the southern group. (See text figure 1, page 153.) These islands centrally located, are in a sense a meeting ground of the faunas of the surrounding regions. Besides the aforementioned squirrel they contain the sooty grouse found on the islands to the north but not on those directly southward, and also the black bear, of which the reverse is true.

The southern group is distinguished by the absence of the red squirrel, and the presence of the black bear and wolf, which find their northern limit on the islands at Frederick Sound; but the most conspicuous feature of this group is the fact that on these islands the spruce grouse (Canachites) occurs, to the exclusion of the sooty grouse (Dendragapus?), of general distribution elsewhere in the region. (See text figure 2, page 155.)

The islands lying east of Clarence Straits are mostly but slightly separated from the mainland, and contain many mainland forms-Evotomys on Wrangell and Revillagigedo, Synaptomys on Wrangell, Zapus and Fiber on Revillagigedo, Erethizon on Etolin and Wrangell, Sciuropterus on Etolin, and Sciurus on all of them. That the jumping mouse of Revillagigedo Island should prove to be of the Zapus hudsonius group seems remarkable, as this is hundreds of miles south of the previous known range of this species and as an entirely distinct species occurs at intervening mainland points.

Coronation and Warren, two small outlying islands west of Prince of Wales, present some curious and interesting conditions. Coronation lies close to Kuiu, and Warren close to Prince of Wales, being more widely separated from one another than they 
are from these adjacent islands. They have one species of mammal (Microtus coronarius) common to the two, and as far as known occurring nowhere else; and one other species (Peromyscus sitkensis) found on both which is not found on either of the large islands closest to them. The sooty grouse

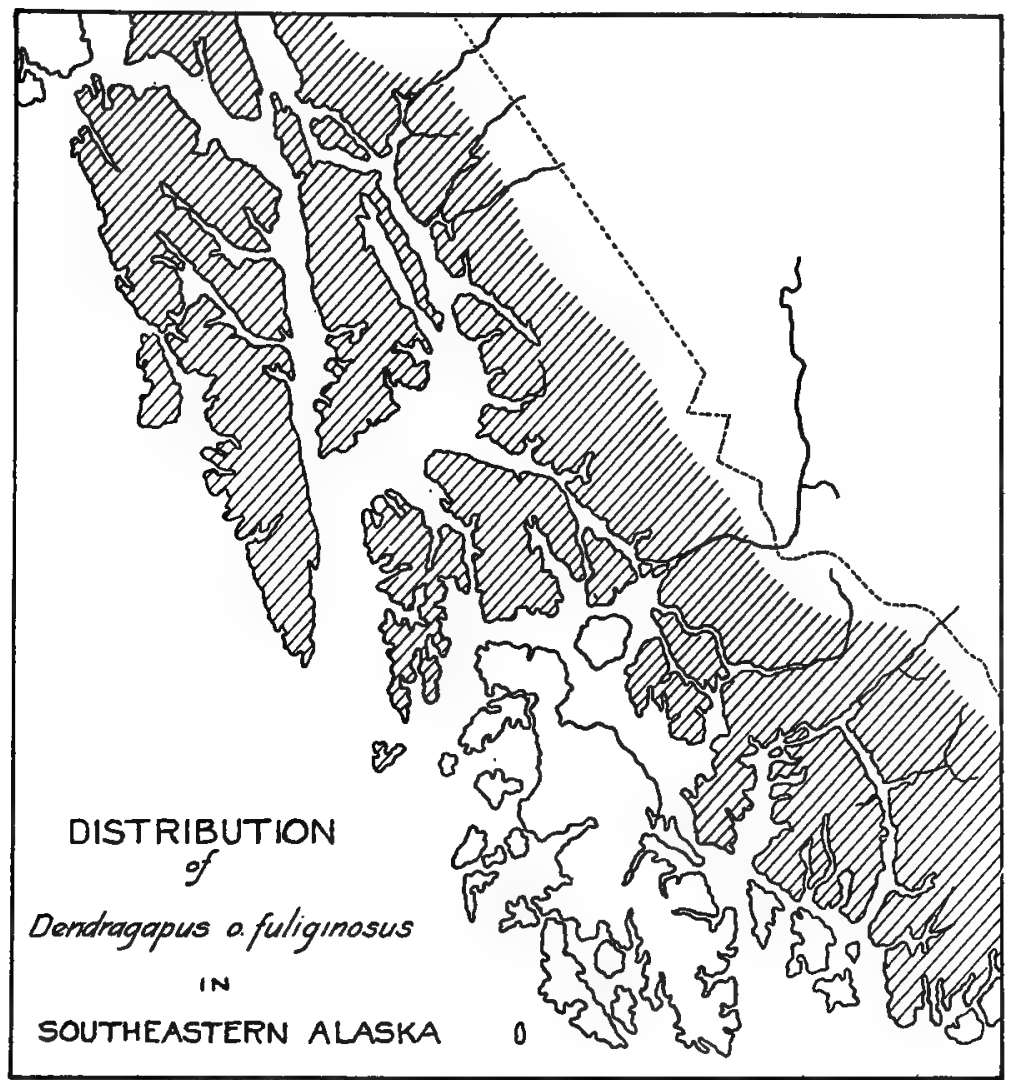

Fig. 2,-Map showing the range of the sooty grouse (Dendragapus obscurus fuliginosus) in southeastern Alaska. It occurs on some of the more remote western islands of the archipelago, but is absent from others lying nearer the mainland.

(Dendragapus) is found on Coronation Island, but is absent from Warren where apparently the spruce grouse (Canachites) occurs. What the obstacle may be that stops a strong flying bird, and yet permits the passage of small and feeble terrestrial mammals it is hard to imagine. It is of interest to note in this connection 
that at our camp on the east side of Warren Island the beach was strewn with the wreckage of a ship that had gone on the rocks on the west side of Coronation Island some months previously. Although the two islands lie on different sides of a channel through which the prodigious tides of the region rush

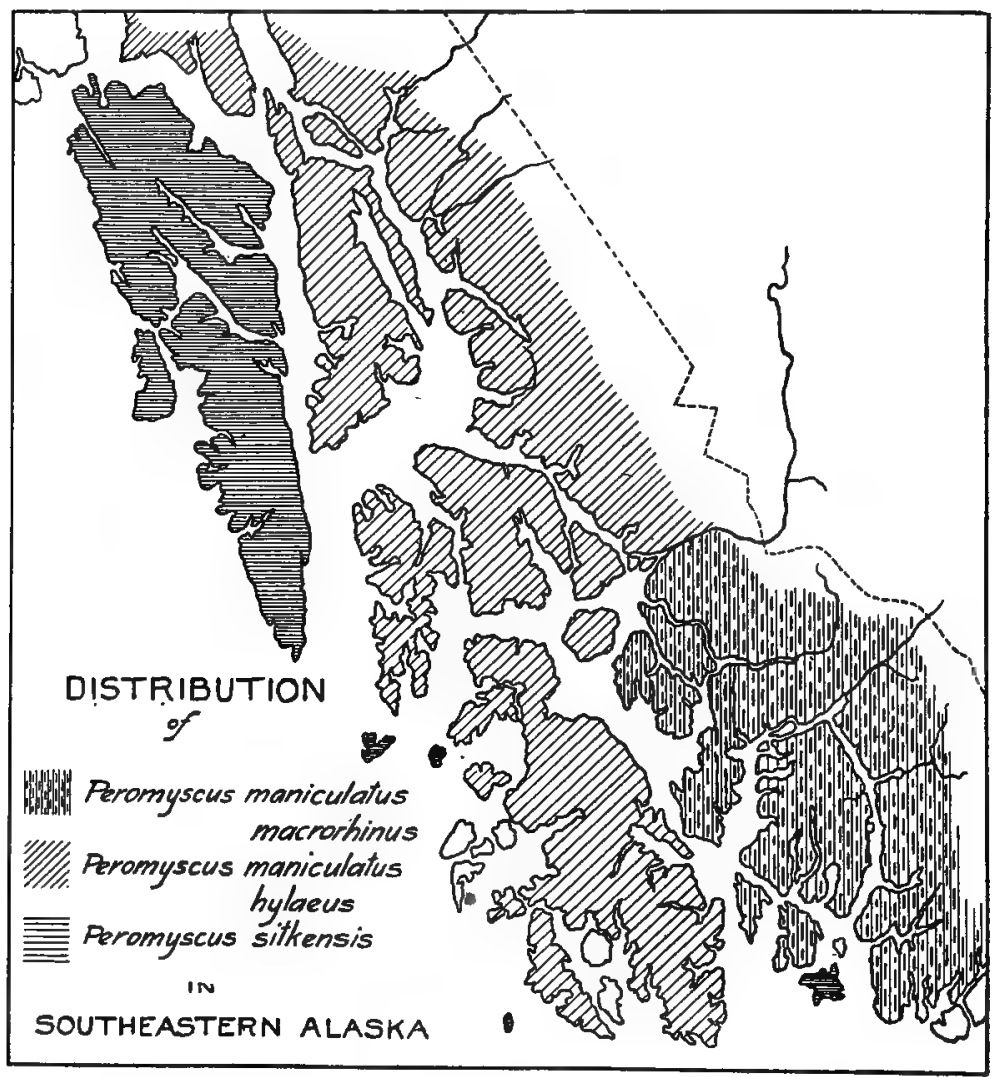

Fig. 3.-Map showing the distribution of the species of Peromyscus in southeastern Alaska, Vertical lines indicate the range of $P$. maniculatus macrorhinus, diagonal lines, $P$. m. hylaeus, horizontal lines, $P$. sitkensis. Note the peculiarly diseonnected range of Peromyscus sitkensis.

back and forth twice daily, it is evident from this fact that it is quite possible for something to drift from Coronation to Warren, at any rate.

The distribution of the mouse mentioned above (Peromyscus sitkensis) is in itself of considerable interest (see text figure 3 , 
page 156); in fact there is probably hardly another North American species of mammal with so extraordinary a range. It is known to occur on Chichagof, Baranof, Coronation, Warren, Forrester, and Duke islands. in Alaska, and on Prevost Island, at the southern extremity of the Queen Charlotte group. (The Prevost Island mouse has been separated as a slightly differentiated subspecies, P. s. prevostensis Osgood, and Forrester Island specimens considered as of this form, but for the purposes of this discussion they may be considered the same.) These islands are most of them widely separated, between Duke and Forrester and between Duke and Coronation and Warren lie whole groups of islands inhabited by a different species (P. $m$. hylaeus), while those islands nearest to Duke contain still another species ( $P$ m. macrorhinus). Between Forrester and Prevost lies the entire group of the Queen Charlotte Islands. It might be argued that the mice of these various islands are really distinct species developed similarly through similar conditions and that their present appearance does not indicate their true relationships, but it is hard to appreciate how these particular islands differ from the scores of others in the region sufficiently to have produced such results. No other Peromyscus has been found on the islands where this form occurs.

Some interesting comparisons can be drawn regarding the distribution of the species of Microtus and Peromyscus in the southern part, at least, of the Sitkan district. In each the species arrange themselves, roughly, in parallel north and south lines. In the white-footed mice we find on the mainland, and on those islands lying closest to it, a large, robust form, Peromyscus maniculatus macrorhinus. A little farther west, throughout the middle line of islands, reaching the mainland in the northern part of the region, is a much smaller variety of the same species, $P$. $m$. hylaeus. Still farther west on the outlying islands, is an exceedingly large mouse, $P$. sitkensis. This, though considered a distinct species, is apparently but a robust form of the maniculatus group.

So also with the meadow-mice: Microtus macrurus is the common form of the southern part of the region. Mainland specimens are much the largest, those from the islands inhabited 
by $P . m$. hylaeus are very small, and still farther west we come abruptly to an exceedingly large form, $M$. coronarius. This does not appear to intergrade with $M$. macrurus, just as $P$. sitkensis does not with $P$. $m$. hylaeus, but nevertheless in each case they seem to be merely gigantic insular races.

The mammals of general distribution are surprisingly few in number. The otter (Lutra) ranges, apparently unchanged, throughout the region, and it is easy to see why it should. Beaver occur on most of the larger islands, but according to Heller (1909, p. 251) those from the more southern islands are a different form from the northern ones. Deer also are found throughout the archipelago; but I am strongly of the impression that the deer found south of Frederick Sound will prove to be distinct from the more northern $O$. c. sitkensis. A species of shrew (Sorex obscurus) is found apparently on every island and all along the mainland coast, and there is surprisingly little variation in the series from different points. Those from the northern islands, however, appear to be referable to $\mathbb{S}$. o. glacialis, from the southern to $S$. o. longicauda.

The land birds of the Sitkan district are for the most part the same as, or closely related to, species ranging along the mainland coast farther south. The equable and comparatively warm climate of this region, compared with the interior at the same latitude, is apparently responsible for this, permitting along the coast the northern extension of the ranges of species whose centers of distribution lie much farther south. Such species as Cyanocitta stelleri, Colaptes cafer saturatior, Sphyrapicus varius ruber, and Empidonax difficitis, some of the commonest and most characteristic birds of the Sitkan district, are examples of birds whose ranges extend much farther north along the coast than in the interior. Many species find their northern limit in this region, while a few extend somewhat farther north and west along the Alaskan coast. Almost none of the birds of this region, however, are also found in the cold, dry interior. The exceptions are mostly species of northern derivation, occurring here in the Alpine-Arctic Zone of the mountain tops, the ptarmigan (which has undergone some change, however) and the titlark being good examples of this class. 
Still another group is composed of a few species, which, finding their northern limit at about this latitude in the interior, have apparently followed one or two of the broad river valleys to the coast. Examples of these, already treated in detail, are Geothlypis trichas occidentalis, Empidonax trailli alnorum, and possibly Piranga ludoviciana.

Judging from our experience the islands of the Sitkan district do not lie in the main migration route of the birds of the Pacific coast. This is true of the western part of the archipelago to a striking degree. During April and May, and in the first week in June, when the migration should have been in full force, we were visiting the western islands, and, though in some places we found vast numbers of waders and many ducks and geese, the smaller land birds were almost entirely absent. In one or two places, noticeably on Coronation and Warren islands, small flocks of migrating warblers or sparrows were met with from time to time; but we visited numerous other points where it was quite possible to spend several hours in the woods without seeing a single small bird; and when the stillness was broken it was more apt to be by a chickadee or junco than by any transient. I found the west coast of Dall Island to be unusually barren of bird life.

Possibly the migrants travel more along the inner, sheltered islands. On the east coast of Mitkof Island, in August, there was a steady stream of migrating warblers, kinglets, and other small birds following the shore line southward. At Thomas Bay on the mainland, also in August, migrants were much in evidence.

The numerous water fowl of the Sitkan district are for the most part species of wide distribution. The sea birds are, with one or two exceptions, of quite general distribution in the North Pacific; the fresh water species are numerous during the migrations, but comparatively few seem to find congenial breeding grounds in this region. They also are mostly of general distribution in North America. There are two exceptions, however, a goose (Branta canadensis occidentalis) and a heron (Ardea herodias fannini), which are restricted to the northwestern coast region.

Museum of Vertebrate Zoology, University of California, Berkeley, June 8, 1910. 


\section{LITERATURE CITED.}

Allen, J. A.

1903. Mammals collected in Alaska and Northwestern British Columbia by the Andrew J. Stone Expedition of 1902. Bull. Am. Mus. Nat. Hist., v. 19, pp. 521-567.

1910. The black bear of Labrador, Bull. Am. Mus. Nat. Hist., v. 28, pp. 1-6.

Bishop, L. B.

1900. Results of a biological reconnaissance of the Yukon River Region. Annotated list of birds. North American Fauna, no. 19, pp. 47-96.

1900. Descriptions of three new birds from Alaska. Auk, v. 17, pp. 113-120.

Coues, E.

1903. Key to North American Birds. Fifth edition, v. 1, pp. i-xli, 1-535; v. 2, pp. i-vi, 537-1152.

Dwight, J., Jr.

1900. The moult of the North Ameriean Tetraonidae (quails, partridges and grouse). Auk, v. 17, pp. 34-51, 143-166, pls. IV, V.

1901. The sequence of moults and plumages of the Laridae (gulls and terns). Auk. v. 18, pp. 49-63.

\section{Grinnell, J.}

1898. Summer birds of Sitka, Alaska. Aulk, v. 15, pp. 122-131.

1909. Birds and mammals of the 1907 Alexander Expedition to Southeastern Alaska. The birds. Univ. Calif. Publ. Zool., v. 5, pp. 181-224.

1910. Birds of the 1908 Alexander Alaska Expedition, with a note on the avifaunal relationships of the Prince William Sound District. Univ. Calif. Publ. Zool., v. 5, pp. 361-428, pls. 32-34.

\section{Heller, E.}

1909. Birds and mammals of the 1907 Alexander Expedition to Southeastern Alaska. The mammals. Univ. Calif. Publ. Zool., จ. 5, pp. 245-264, pl. 26.

Howe, R. H., Jr.

1901. A study of the genus Macrorhamphus. Auk, v. 18, pp. 157-162. 


\section{Osgood, W. H.}

1900. Results of a biological reconnaissance, of the Yukon River Region. General account of the region and annotated list of mammals. North American Fauna, no. 19, pp. 1-45, pls. I-VII.

1901. Natural history of the Queen Charlotte Islands, British Columbia. 'North American Fauna, no. 21, pp. 1-50, pls. I-V.

1905.' In Alaska's rain belt. Condor, v. 7, pp. 68-71.

1909. Revision of the mice of the American Genus Peromyscus. North American Fauna, no. 28, pp. 1-285, pls. I-VIII.

1909. A peculiar bear from Alaska. Field Mus. Nat. Hist., Publ. 138, Zool. Ser., v. 10, pp. 1-3, pl. 1.

\section{Ridgway, R.}

1880 On Macrorhamphus griseus (Gmel.) and M. scolopaceus (Say). Bull. Nutt. Orn. Club, v. 5, pp. 157-160.

1901. The birds of North and Middle America. U. S. Nat. Mus. Bull., no. 50, part 1, pp. I-XXX, 1-715, pls. I-XX.

1904. Ibid. Part III, pp. I-XX, 1-801, pls. I-XIX.

\section{Stejneger, L.}

1885. Results of ornithological explorations in the Commander Islands and in Kamtschatka. U. S. Nat. Mus. Bull., no. 29, pp. 1-382, pls. I-VIII. 


\section{EXPLANATIONS OF PLATES.}

PLATE 1.

Map of the region traversed by the 1909 Alexander Alaska Expedition. Dotted line shows route of the Expedition; crosses indicate collecting stations. 

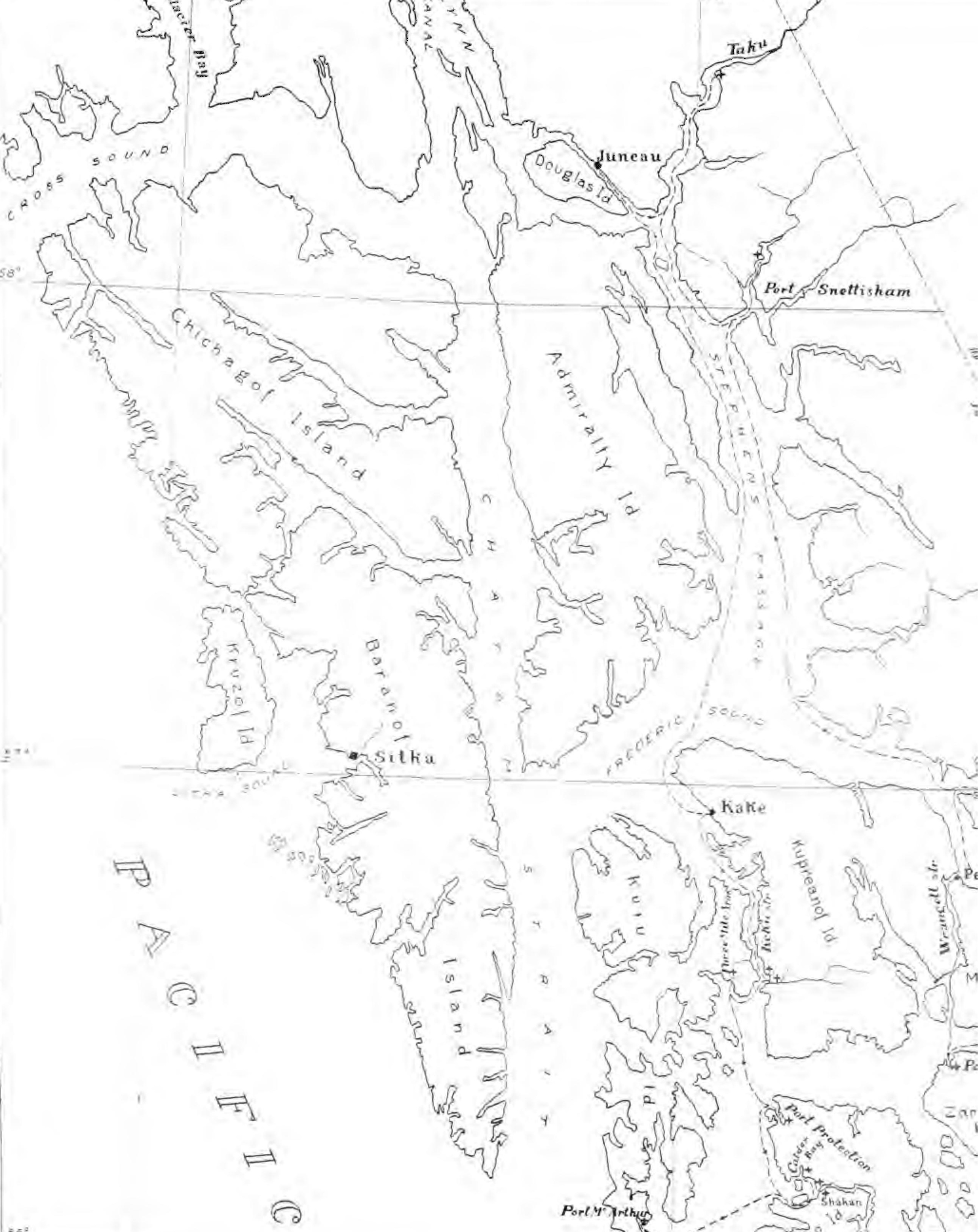

2 ह ?

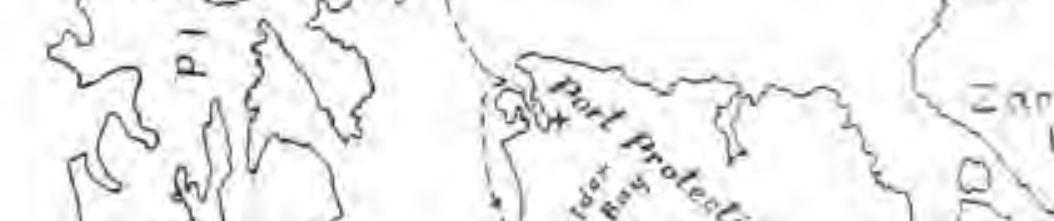

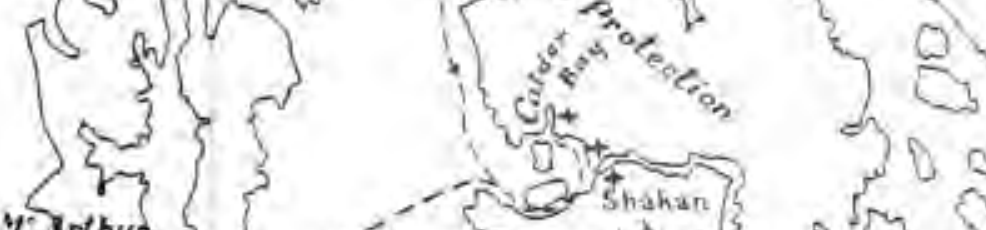

Prorty $x$ in

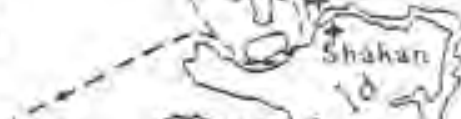

30

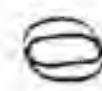

ल

Hazy Ids

Coronation ld ang

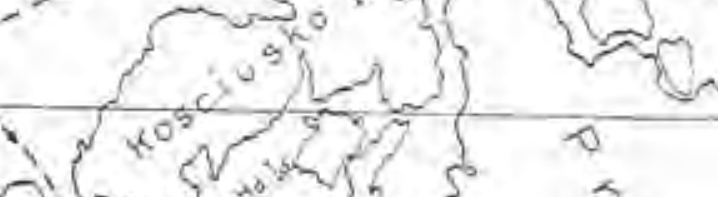

[3.

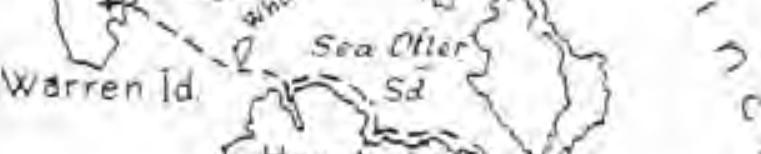
Hecetalding 


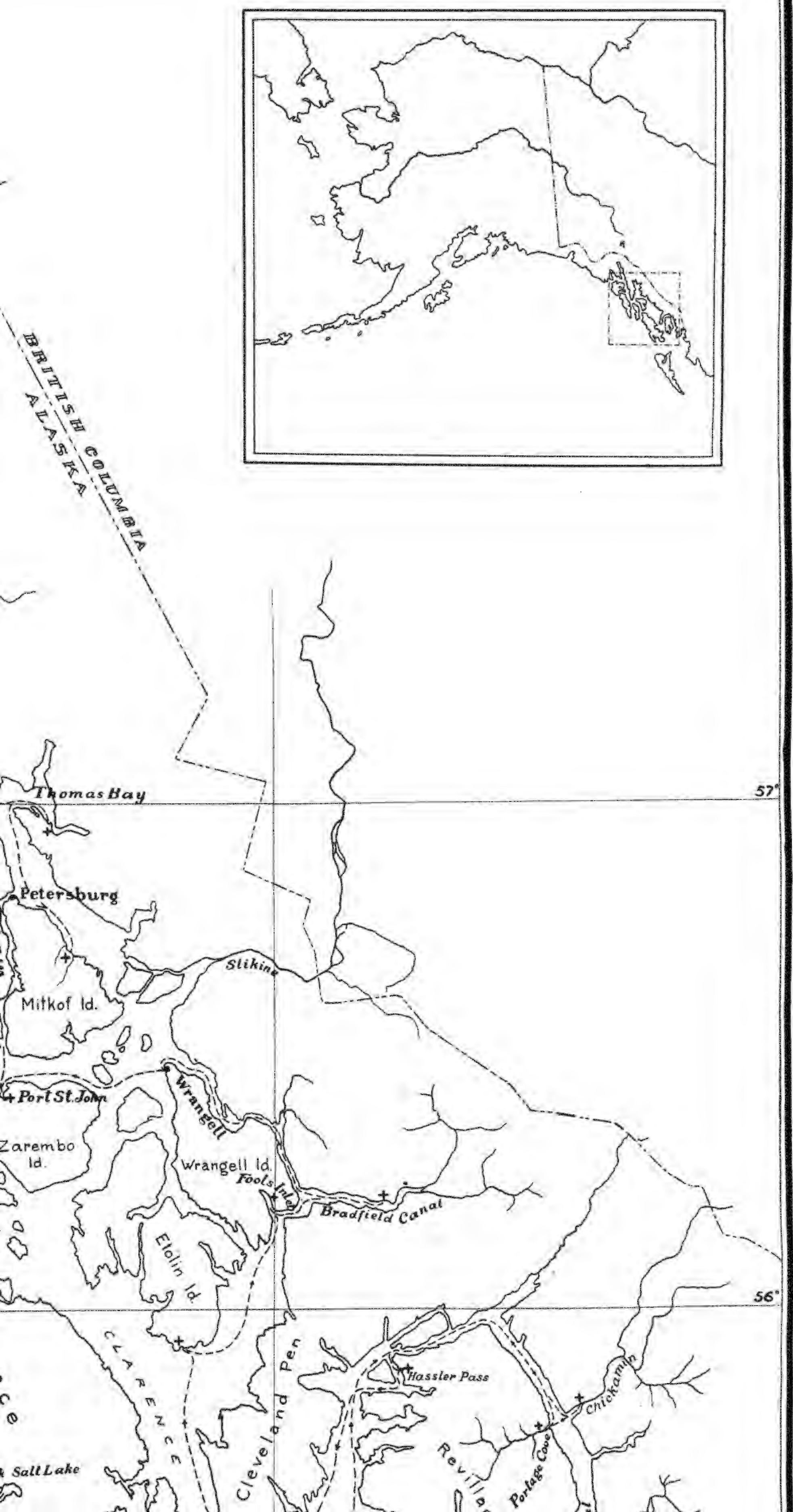




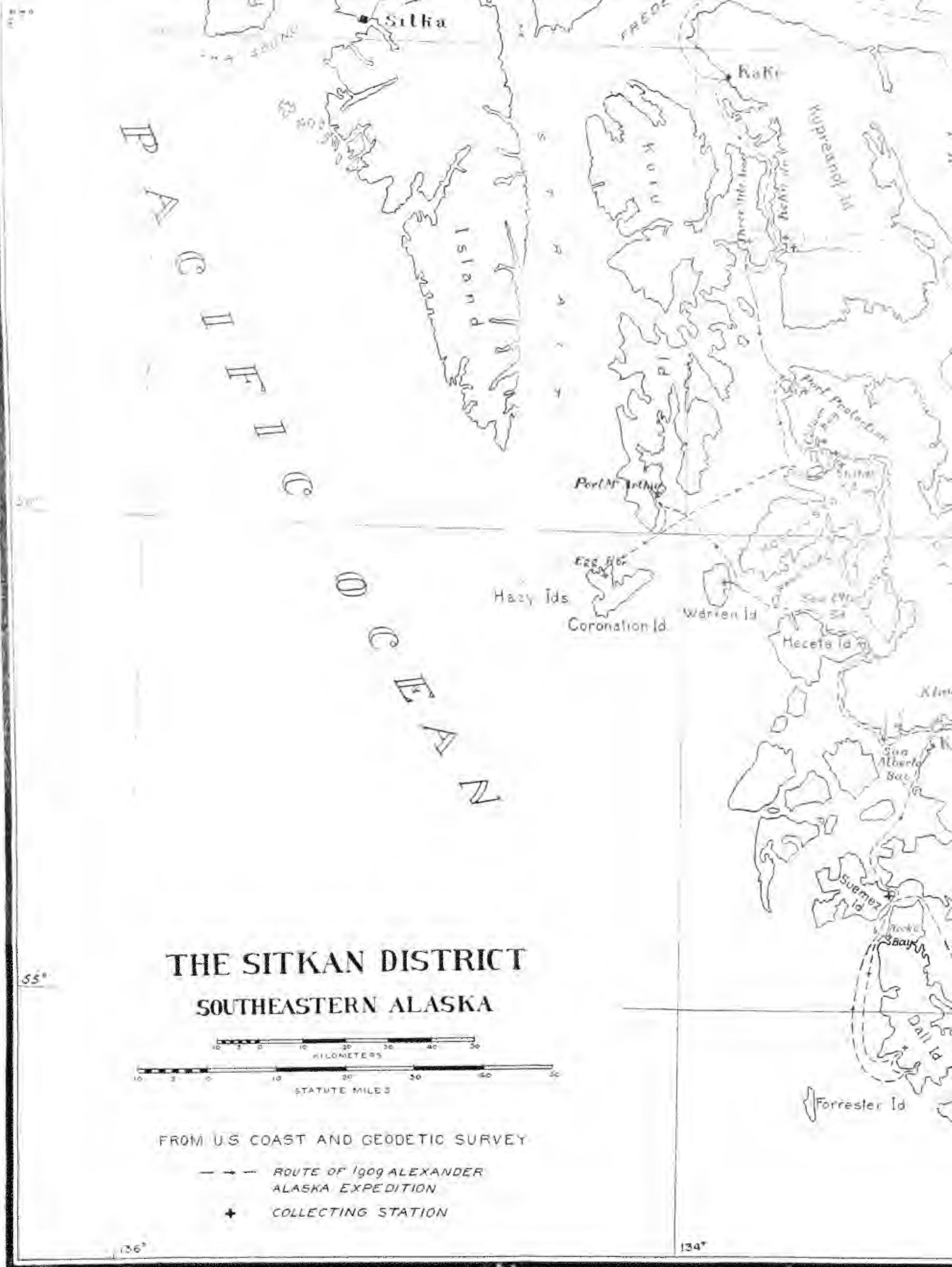



PLATE 2.

Woods and meadows at Portage Cove, Revillagigedo Island; July 3, 1909. This is typical of the region visited in southeastern Alaska. (See page 20.) 


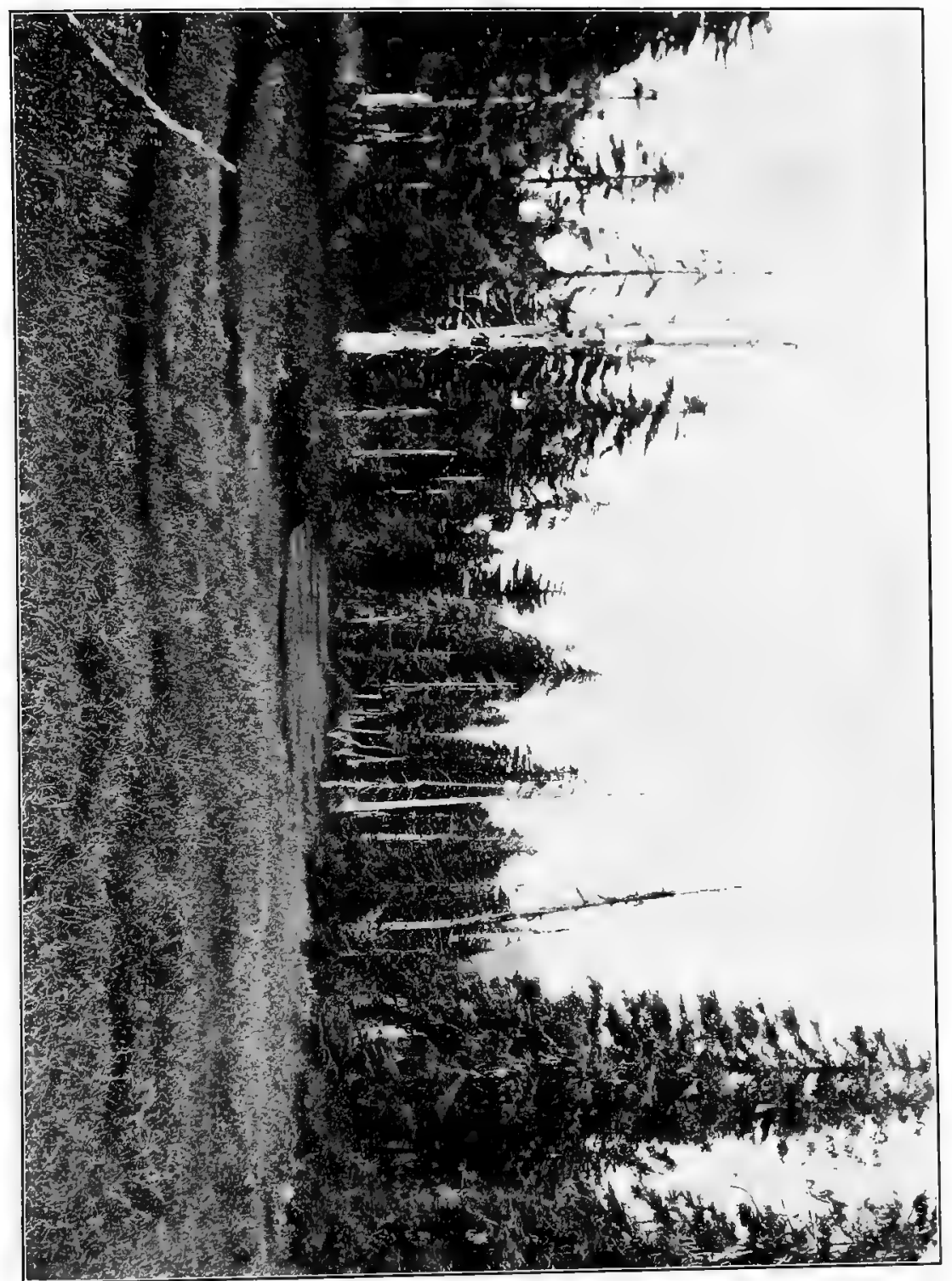

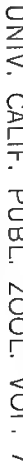

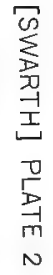






\section{PLATE 3.}

Antlers of black-tail deer (Odocoileus columbianus sitkensis) from southeastern Alaska. Those on the right from Chichagof Island, on the left from islands south of Frederick Sound. Note the difference in the forking; in the series on the left the branching tines are conspicuously forked, while in those on the right they are straight. 


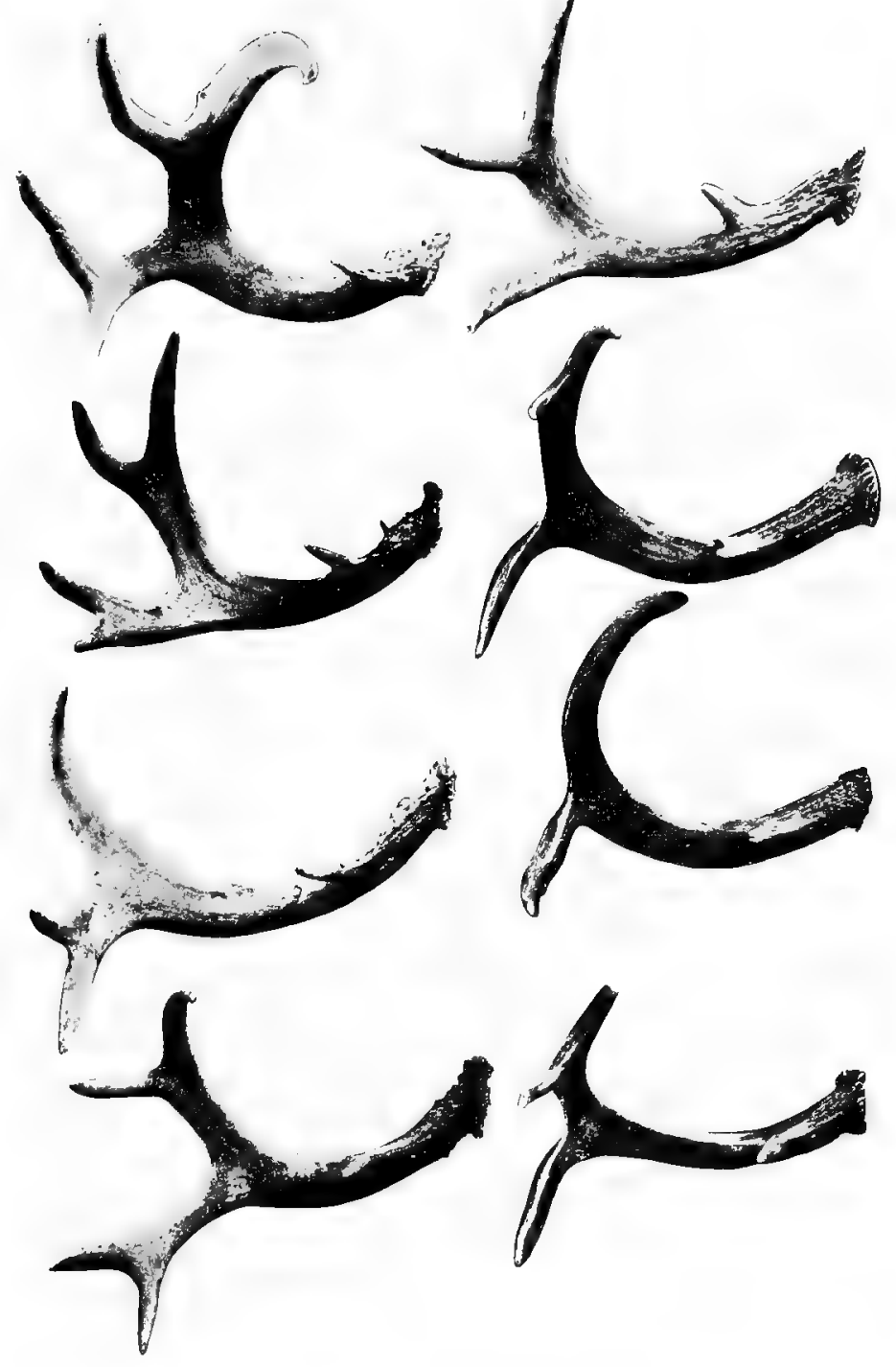






\section{PLATE 4.}

Fig. 1.-Banks inhabited by muskrats (Fiber z. spatulatus) at Portage Cove, Revillagigedo Island; July 3, 1909. The burrows were excavated in the walls of the gulches, the entrances being covered at high tide. A pile of eut food is at the mouth of one of the burrows shown.

Fig. 2.-Hoary Marmot (Marmota caligata) at entrance to burrow; Port Snettisham, August 25, 1909. 


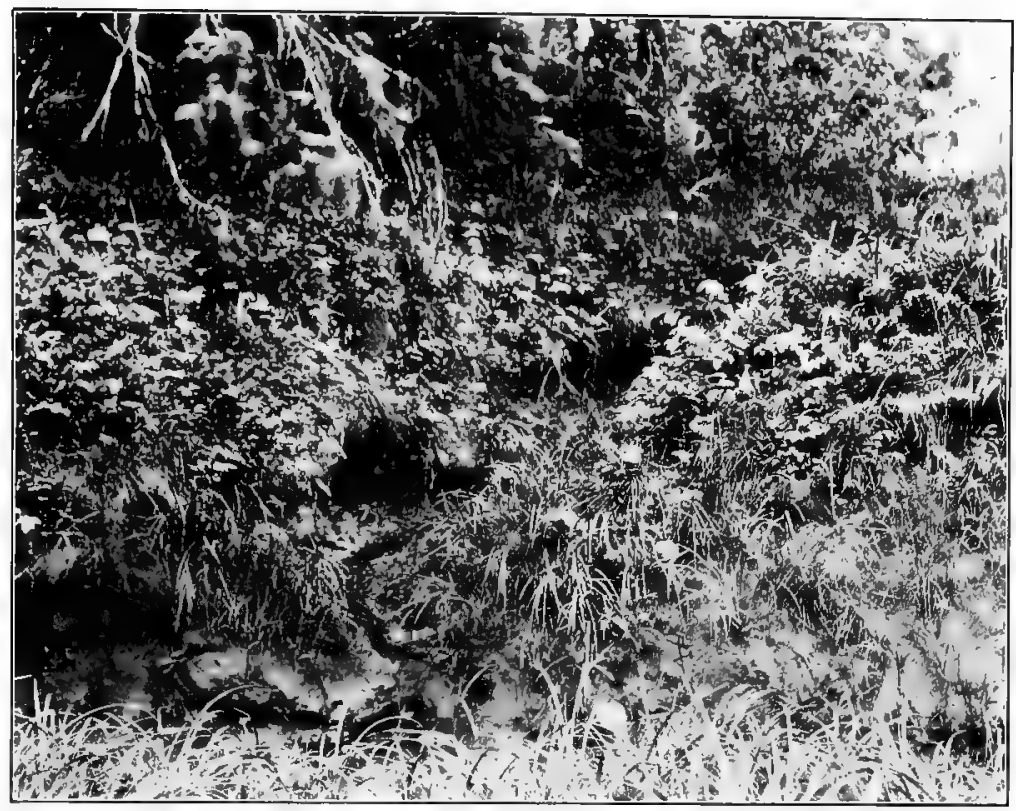

Fig. 1

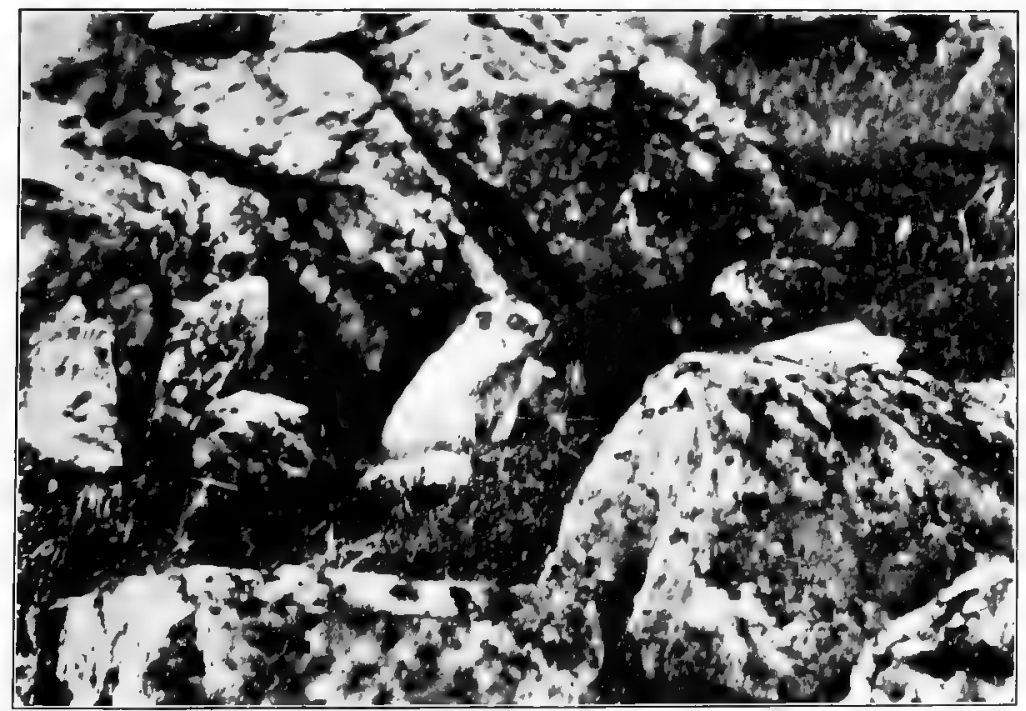

Fig. : 




\section{PLATE 5.}

Dorsal view of skulls of Microtus coronarius (series on the left) and Microtus macrurus (series on the right). Enlarged to 11/3 natural size. The former are uniformly larger, there being no differenes in shape or proportions. 


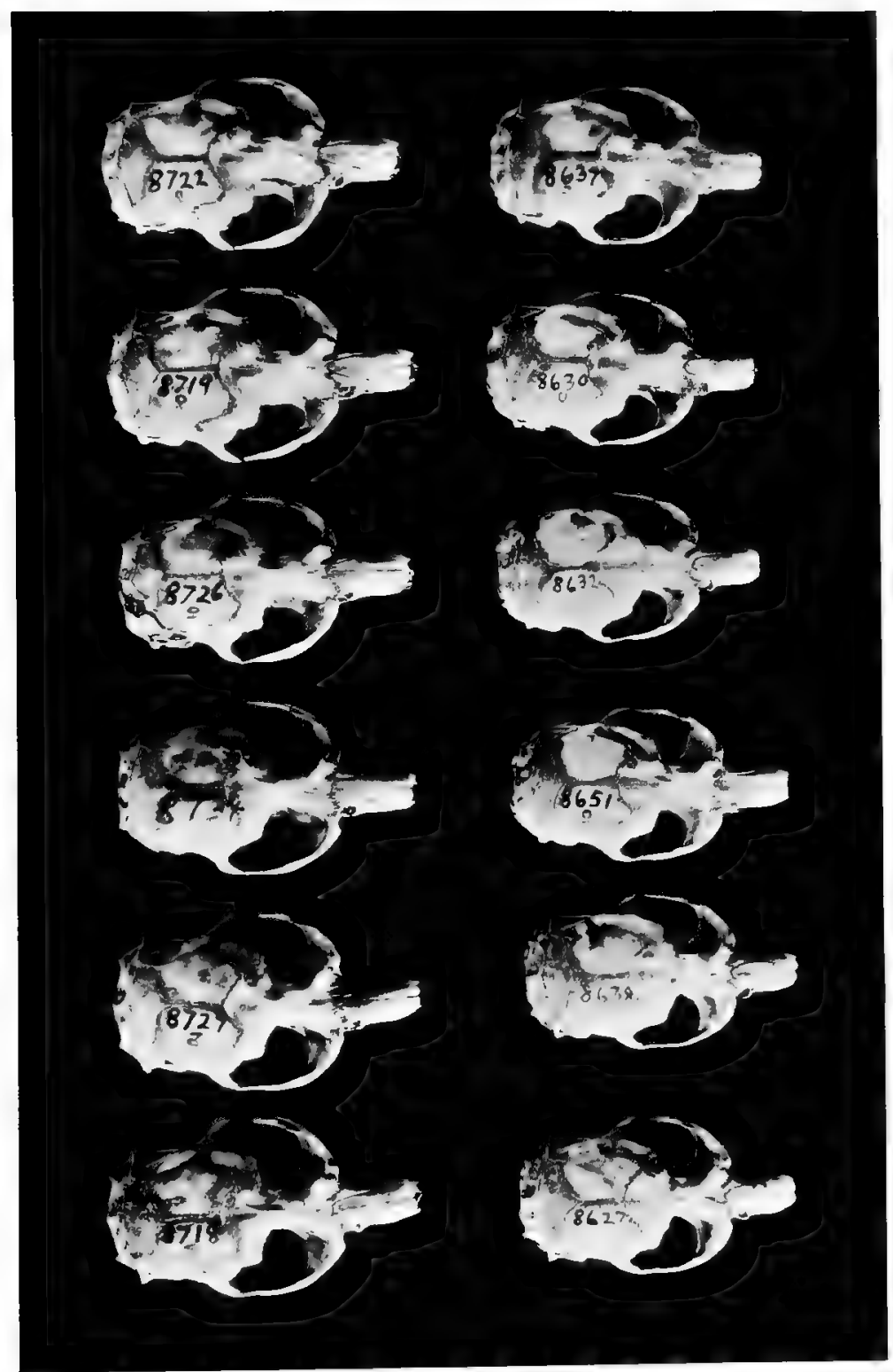




PLATE. 6.

Fig. 1.-Lateral view of skull of type of Ursus americanus pugnax. Reclueed to $1 / 3$ natural size. Note the depressed frontals, prominent postorbital processes, largely developed sagittal crest and general appearance of massiveness.

Fig. 2.-Dorsal view of skull of type of Orsus americanus pugnax. Reduced to $1 / 3$ natural size. Note the conspicuous sagittal crest and temporal ridges, and the heavily built and wide-spreading zygomata. 


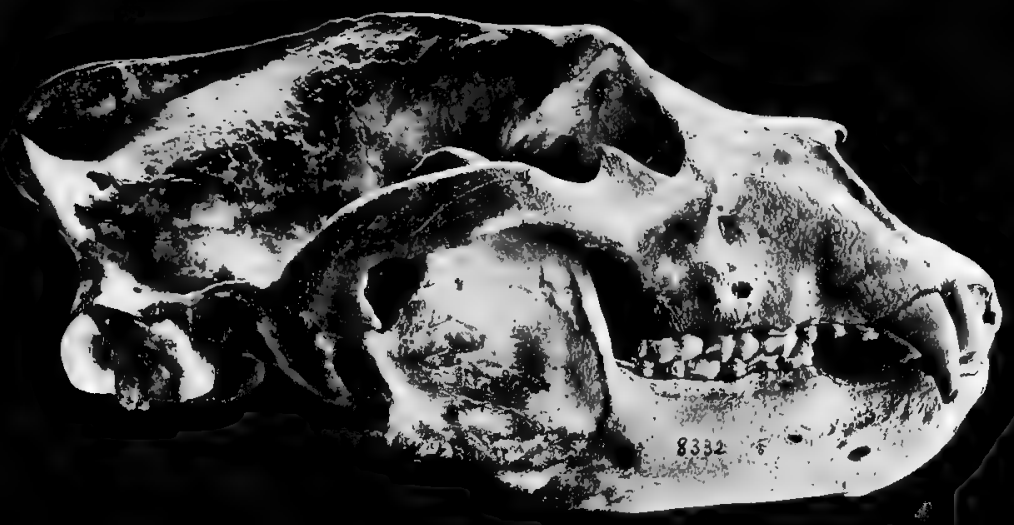

Fig. 1.

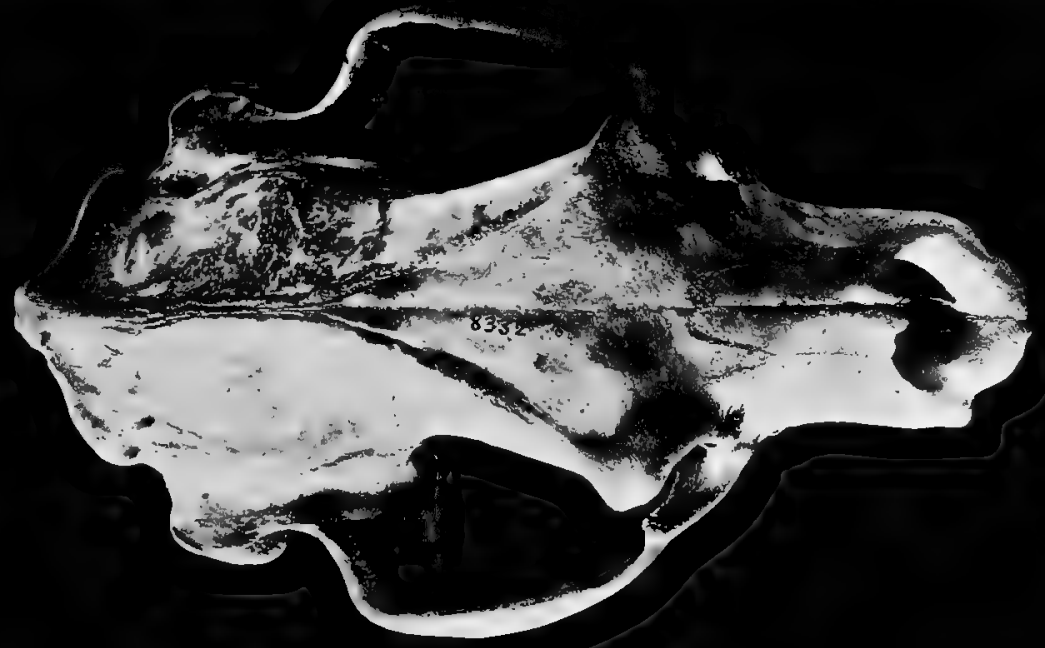

Fig. 2. 

Vol. 3. 1. Some Observations on the Nervous System of Copepoda, by c. 0 . Esterly. Pp, 1-12, plates 1-2. January, 1906.

2. (IX)*, Ostracoda of the San Diego Region. 1. Halocypridae, by Chancey Juday. 'Pp. 13-38, plates 3-7. April, 1906

3. (X) The California Shore Anemone, Bunodactis xunthogrammica, by Harry Beal Torrey, Pp. 41-46, plate 8, April, 1906.

4. (XI) Sexual Dimorphism in Aglaophenia, by Harry Beal Torrey and Ann Martin. Pp. 47-52, 9 text-figures. April, 1906. Nos. 3 and 4 in one cover.

5. (XII) New Copepod Fauna from the San Diego Begion, by Calvin Olin Esterly. Pp. 53-92, plates 9-14. December, 1906

6. (XII) Dinoflagellata of the San Diego Region, II. On Triposolenia, a New Genus of the Dinophysidae, by Charles Atwood Kofoid. Pp. 93-116, plates 15-17.

7. A Discussion of the Species Characters in Triposolenia. I. The Nature of Species Characters. II. The Adaptivé Significance of Species Characters. III. The Colncident Distribution of Related Species. By Charles Atwood Kofoid. Pp. 117-126.

8. On the Significance of the Asymmetry in Triposolenia, by Charles Atwood Kofoid. Pp. 127-133.

Nos. 6, 7, and 8 in one cover. December, 1906

9. (XIV) Ostracoda of the San Diego Region. II. Littoral Forms, by Chancey Juday. Pp. 135-156, plates 18-20.

10. (XV) Cladocera of the San Diego Region, by Chancey Juday: Pp. $157-158,1$ text figure.

Nos. 9 and 10 in one cover. January, 1907 .

11. (XVI) The Marine Fishes of Southern California, by Edwin Chapin Starks and Earl Leonard Morris.' Pp. 159-251, plate 21. March, 1907.

12. Blological Studies on Corymorpina. II. The Development of C. Palma from the Egg. By Harry Beal Torrey. Pp. 253-298, 33 text flgures. June, 1907

13. (XVII) Dinoflagellata of the San Diego Region. III. Descriptlons of New Species. By Charles Atwood Kofoid. Pp. 299-340, plates 22-23. April, 1907

14. The Structure and Movements of Condylostoma patens, by John $\mathbf{F}$. Bovard. Pp. 343-368, 21 text figures. September, 1907 Index, pp. 369-383.

Vol. 4. 1. The Ascidians Collected by the United States Fisheries Bureau steamer Albatross on the Coast of California during the Summer of 1901, by William Emerson Ritter. Pp. 1-5́2, plates 1-3. October, 1907

2. (XVIII) Behavior of the Starfish Asterias forreri de Lortiol, by $\mathbf{H} . \mathbf{s}$. Jennings. Pp. 53-185, 19 text figures. November, 1907

3. (XIX) The Early Life-Fistory of Dolichoglossus pusillus Ritter, by $\mathbf{B}$. M. Davis. Pp. 187-226, plates 4-8. March, 1908

4. Notes on two Amphipods of the Genus Corophium from the Pacific Coast, by J. Chester Bradley. Pp. 227-252, plates 8-13. April, 1908.

5. (XX) The Incrusting Chilostomatous Bryozoa of the Western Coast of North America, by Alice Robertson. Pp. 253-344, plates 14-24, May, 1908

6. (XXI) On Bxuviation, Autotomy, and Regeneration in Ceratium, by Charles Atwood Kofoid. Pp. 345-386, with text figures.

7. (XXII) Notes on some Obscure Species of Ceratium, by Charles Atwood Kofoid. Pp. 387-393.

Nos. 6 and 7 in one cover. April, 1908.

Index, pp. 395-400.

Vol. 5. 1. The Blota of the San Bernardino Mountains, bJ Joseph Grinnell. Pp. 1-170, plates 1-24. December, 1908

2. Birds and Mammals of the 1907 Alexander Expedition to Doutheastern Alaska. Pp. 171-264, pls. 25-26, figs. 1-4. February, 1909 ................

3. Three New Song Sparrows from California, by Joseph Grimell. Pp. 265-269. April 9, 1909

4. A New Harvest Mouse from Petaluma, California, by Joseph Dixon. Pp. 271-273. August 14, 1909

5. A New Cowbixd of the Genus Molothrus, with a note on the Probable Genetic Relationships of the North American Forms, by Joseph Grinnell. Pp. 275-281, 1 text figure. December, 1909.

6. Two New Rodents from Nevada, by Walter P. Taylor. Pp. 283-302, plates $27-29$.

7. A Northern Coast Form of the California Gray, Fox, by Joseph Dixon. Pp. 303-305.

Nos. 6 and 7 in one cover. February, 1910

* Roman numbers indicate sequence of the Contributions from the Laboratory of the Marine Biological Association of San Diego. 
8. Two Heretofore Unnamed Wrens of the Genus Thryomanes, by Joseph Grinnell. Pp. 307-309.

9. The Savannah Sparrow of the Great Basin, by Joseph Grinnell. Pp. 311-316,

10. A Second Record of the Spotted Bat (Euderma maculatum) for California, by Joseph Grinnell. Pp. 317-320, plate 30.

Nos. 8, 9, and 10 in one cover. February, 1910

11. Mammais of the 1908 Alexander Alasisa Expedition, with Descriptions of the Localittes Visited and Notes on the Flora of the Prince William Sound Region, by Edmund Heller. Pp. 321-360, plates 31-32.

12. Birds of the 1908 Alexander Alaska Expedition, with a Note on the Avifaunal Relationships of the Prince William Sound District, by Joseph Grinnell. Pp. 361-428, plates 33-84, 9 text-figures.

Nos. 11 and 12 in one cover. March, 1910 Index, pp. 429-440.

Vol. 6. 1. (XXIII) On the Weight of Developing Eggs. Part I, The Posstble Significance of Such Investigations, by William E. Ritter; Part II, Practicability of the Determinations, by Samuel E. Bailey. Pp. 1-10. October, 1908

2. (XXIV) The Leptomedusae of the San Diego Region, by Harry Beal Torrey. Pp. 11-31, with text figures. February, 1909

3. (XXV) The Ophiurans of the San Diego Region, by J. F. Mcclendon. Pp. 33-64, plates 1-6. July, 1909

4. (XXVI) Halocynthia johnsoni n. sp.: A comprehensive inquiry as to the extent of law and order that prevails in a single animal species, by Wm. F. Ritter. Pp. 65.114, plates 7-14. November, 1909..

5. (XXVII, Three Species of Cerianthus from Sonthern Callfornia, by H. B. Torrey and F. I. Kleeberger. Pp. 115-125, 4 text-figures. December, 1909

6. The Life Fistory of Trypanosoma Dimorphon, Dutton \& Todd, by Edward Hindle. Pp. 127-144, plates 15-17, 1 tezt-figure. December, 1909

7. (XXVIII) A Quantitative Stady of the Development of the Salpa Chain in Salpa fusiformis-runcinata, by Myrtle Elizabeth Johnson. Pp. 145-176. March, 1910

8. A Ievision of the Genus Ceratocorys, Based on Skeletal Morphology, by Charles Atwood Kofoid. Pp. 177-187. May, 1910

9. (XXIX) Preliminary Report on the Hydrographic Work Carried on by the Marine Biological Station of San Diego, by George F. McEwen. Pp. 189-204; text-figure and map. May, 1910

10. (XXX) Bioligical Studies on Corymorpha. III. Regeneration of Hy. dranth and Holdfast, by Harry Beal Torrey. Pp. 205-221; 16 textfigures.

11. (XXXI) Nate on Geotropism in Corymorpha, by Harry Beal Torrey. Pp. 223-224; I text-figure.

Nos. 10 and 11 in one cover. Angust, 1910

12. The Oyclostomatous Bryozoa of the West Coast of North America, by Alice Robertson. Pp. 225-284; plates 18-25. December, 1910.

13. Significance of White Markings in Birds of the Order Passeriformes, by Henry Chester Tracy. Pp. 285-312. December, 1910.

Vol. 7. 1. Two New Owls from Arizona, with Description of the Juvenal Plumage of Strix accidentalis occidentalis (Xantus), by Harry S. Swarth. Pp. 1-8. May, 1910

2. Birds and Mammals of the 1909 Alexander Alaska Expedition, by Harry S. Swarth. Pp. 9-172; plates 1-6; 3 text-figures. January, 1911.

MEMOIRS OF THE UNIVERSITY OF CALIFORNIA (Quarto).

Vol. 1. No. 1. Triassic Ichthyosauria, with special reference to the American Forms. By John C. Merriam. Pages 1-196, plates 1-18, 154 text figures. September, 1908

Vol. 2. The Silva of California, by Willis Linn Jepson. 480 pages, 85 plates,

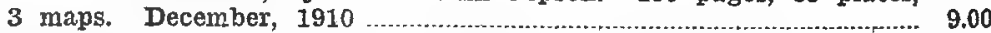

Other series in Classical Philology, Economics, Education, Egyptian Archaeology, Englneering, Entomology, Graeco-Roman Archaeology, Mathematics, Psychology, Semitic Philology, Modern Philology.

UNIVERSITY OF CALIFORNIA CHRONICLE.-An official record of University He, issued quarterly, edited by a committee of the faculty. Price, $\$ 1.00$ per year. Current volume No. XIII.

Address all orders, or requests for information concerning the above publications to The University Press, Berkeley, Oallfornia.

European agent for the series in American Archaeology and Ethnology, Classical Phllology, Education, Modern Philology, Philosophy, and Semitic Philology, Otto Harrassowtty, Ieipzig. For the Memoirs, and the series in Botany, Geology, Pathology, Physiology, Zoology and also American Archaeology and Ethnology, R. Friedlander \& Sohn, Berlin. 


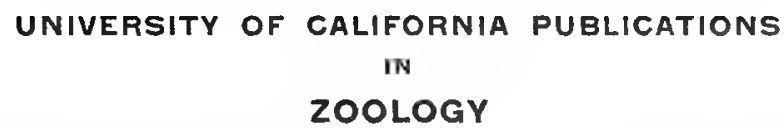

Vol. 7, No. 6, pp. 201-204

February 18, 1911

\section{TWO NEW SPECIES OF MARMOTS FROM NORTHWESTERN AMERICA}

$B Y$

H. S. SWARTH

BERKELEY

THE UNIVERSITY PRESS 


\section{UNIVERSITY OF CALIFORNIA PUBLICATIONS}

Note.-The University of California Publications are offered in exchange for the publications of learned societies and institutions, universities and libraries. Complete lists of all the publications of the University will be sent upon request. For sample copies, Hsts of publications or other information, address the Manager of the University Press, Berkeley, California, U. S. A. All matter sent in exchange should be addressed to The Exchange Department, University Library, Berkeley, California, U. S. A.

\section{OTTO HARRASSOWITZ} LEIPZIG

Agent for the serics in American Archaeology and Ethnology, Classical Philology, Fducation, Modern Philology, Philosophy, Psychology.

\section{R. FRIEDLAENDER \& SOHN} BERIIN

Agent for the series in American Archaeology and Ethnology, Botany, Geology, Matiematics, Pathology, Physiology, Zoology, and Memoirs.

ZOOLOGY.-W. E. Ritter and C. A. Kofoid, Editors. Price per volume \$3.50. Commeneing with Volume II, this series contains Contributions from the Laboratory of the Marine Biological Association of San Diego.

Cited as Univ, Calif. Publ. Zool.

Vol. 1. 1. The Hydroida of the Paciflc Coast of North America, by Harry Beal Torrey. Fp. 1-104; plates 1-11. November, 1902.

2. A Case of Physiological Polarization in the Ascidian Heart, by Franl W. Bancroft and C. O. Esterly. Pp. 105-114. April, 1903...............

3. Embryology and Embryonic Fission in the Genus Crisia, by Alice Robertson. Pp. 115-156, plates 12-15. June, 1903

4. Correlated Protective Devices in some California Salamanders, by Marion E. Fiubbard. Pp. 157-170, plate 16. November, 1903...

5. Studies on the Ecology, Morphoiogy and Speciology of the Young of some Enteropneusta of Western North America, hy William E. Ritter and B. M. Davis. Pp. 171-210, plates 17-19. February, 1904.

6. Regeneration and Ncn-Sexual Reproduction in Sagartia davisi, by Harry Beal Torrey and Janet Ruth Mery. Pp. 211-226, 7 textfigures. May, 1904

7. The Structure and Regeneration of the Poison Glands of Plethodon, by C. O. Esterly. Pp. 227-268, plates 20-23. June, 1904

8. The Distribution of the Sense-organs in Microscolex elegans, by John F. Bovard. Pp. 268-286, plates 24-25. December, 1904......................

9. Some New Tintinnidae from the Plankton of the San Diego Eegion, by Charles A. Kofoid. Pp. 287-306, plates 26-28. July, 1905 Index, pp. 307-317.

Vol. 2. (Contributions from the Laboratory of the Marine Biological Association of San Diego.)

Irtroduction. A General Statement of the Ideas and the Present Aims and Status of the Marine Biological Association of San Diego, by William E. Ritter, Director of the Station. Pp. i-xvij. 2 Maps

1. The Hydroids of the San Diego Region, by Harry Beal Torrey. Pp. 1-43. 22 text figures. December, 1904.

2. The Ctenophores of the San Diego Region, by Harry Beal Torrey. Pp. 45-51, plate 1. Decernber, 1904.

Nos. 1 and 2 in one cover

3. The Pelagic Tunicata of the San Diego Region, excepting the Iarvacea, by William E. Ritter. Pp. 51-112, plates 2-3. 31 text-flgures. January, 1905

4. The Pelagic Copepoda of the San Diego Region, by 0. O. Esterly. Pp. $113-233,62$ text figures. September, 1905

5. The Iron-encrusting Chilostomatous Bryozoa of the West Coast of North America, by Alice Eobertson. Pp. 235-322, plates 4-16. December, 1905

6. Differentiation in Hydrold Colonies and the Problem of Serescence, by Harry Beal Torrey. Pp. 232-332, 4 text-figures. December, 1905.

7. The Behavior of Corymorpha, by Harry Beal Torrey. Pp. 333-340, 5 text-figures.

Nos, 6 and 7 in one cover.

8. Dinoflagellata of the San Diego Region. I. On Heterodinium, a New Genus of the Peridinidae, by Charles Atwood Kofoid. Pp. 341-368, plates 17-19. January, 1906 Index, pp. 369-382.

* Supply limited; sold only with complete volumes. 
UNIVERSITY OF CALIFORNIA PUBLICATIONS

IN

ZOOLOGY

Vol. 7, No. 6, pp. 201-204

February 18, 1911

\section{TWO NEW SPECIES OF MARMOTS FROM NORTHWESTERN AMERICA}

BY

H. S. SWARTH

(Contribution trom the Museum of Vertebrate Zoology of the University of California)

Of the two species of marmots described in the following pages, one, Marmota vancouverensis, is based upon specimens secured on the Alexander Expedition to Vancouver Island in 1910. The other, Marmota ochracea, upon two skins included in a. collection of birds and mammals made by C. L. Hall in the Yukon Region, Alaska, subsequently acquired by the University of California as a gift from Mrs. Phoebe A. Hearst, and now a part of the collection of the California Museum of Vertebrate Zoology.

Marmota vancouverensis, new species.

VANCoUver Island Marmot.

Trpe.-Female adult; no. 12094, Univ. Calif. Mus. Vert. Zool.; Mt. Douglas (altitude 4,200 feet), twenty miles south of Alberni, Vancouver Island, British Columbia; July 8, 1910 ; collected by E. Despard; orig. no. 30 ; skin and complete skeleton.

Diagnostic Characters.-Belongs to the caligata group; about the size of $\boldsymbol{M}$. caligata or $M$. olympus, but differing widely from either in coloration; differs cranially from $M$. caligata. (No skulls of $M$. olympus are at hand.)

CoLoraTION.-Dark brown above and below, varying through shades from burnt umber to seal brown, in some lights appearing almost black; tip of nose and chin, and an irregular streak along 
center of breast and abdomen, white; a few white hairs scattered over dorsal surface of body.

SkulL.-Compared with that of $M$. caligata: audital bullae smaller; nasals more narrow, and pointed posteriorly; palate broader and more shallow. The foramen in the parietal (immediately above the auditory meatus, and posterior to the posterior root of the zygoma) is very small, not more than half the size of that in $M$. caligata.

Measurements.-Type : total length, $720 \mathrm{~mm}$; length of tail vertebrae, 240; hind foot, 105; ear, 30 . Average of five males: total length, 684 (660-710) ; length of tail vertebrae, 222 (200$300)$; hind foot, 98.4 (90-102) ; ear, 30. Average of six females : total length, 646.6 (580-720) ; length of tail vertebrae, 198.3 (170240 ) ; hind foot, 92 (80-105) ; ear, 28.7 (24-30).

REMARKS.-The eleven specimens of Marmota vancouverensis secured are quite uniform in coloration, allowing for the great difference between the old, worn pelage, and the new coat which most of them are just acquiring. One is in the new pelage throughout, the type is in fresh pelage except for a patch of old rusty hair on the tail, while the others are variously advanced in the molt, some of them being very ragged, and in spots quite bare of hair. As the long hairs wear off, the under fur becomes exposed, and this fades to a cinnamon or wood brown, many shades paler than the newly grown hair.

From the appearance of the specimens secured it would seem that the molt occurs but once year in this species. There is no indication that a gray winter pelage is assumed, as in $M$. olympus of the mainland to the southward across the Straits of Juan de Fuca. The area covered by the white marking on the ventral surface varies among the specimens at hand, being most extensive on the type, and almost entirely absent on two of the others.

The series on which this description is based was secured in the vicinity of MLt. Saunders and Mt. Douglas, at the head of China Creek, some twenty miles south of Alberni, and within a radius of ten miles. The species is in all probability confined to Vancouver Island, and as far as known to the very small portion of it indicated above. 
Marmota ochracea, new species.

YUKON MARMOT.

TyPE.-Female adult; no. 5872, Univ. Calif. Mus. Vert. Zool.; Forty-mile Creek, Alaska, August 19, 1901 ; collected by C. L. Hall ; orig. no. 477.

Diagnostic Characters.-Like $\boldsymbol{M}$. flaviventer, from which it differs in coloration and pattern of markings.

Coloration.-Hairs of upper parts pale cinnamon-rufous basally, with a black central band. On the forepart of the body, from the neck to a point behind the shoulders, the hairs are the same color at the tip as at the base. From the middle of the body to the rump the exposed portions of the hairs are hoary whitish, producing a distinctly paler effect posteriorly. Tail uniform cinnamon-rufous above and below, slightly darker at the tip. Whole top of head from tip of nose to and including the ears, prout brown. Sides of head and neck, including the eyelids, the same color as the shoulders and sharply defined against the darker brown of the top of the head. Lower surface of the body and legs all around, hazel. Feet and claws black.

SkULL.-Represented only by a fragment of the rostrum with incisors attached, and the lower jaw: Compared with skulls of $M$. faviventer these parts are small and weak, the teeth conspicuously so.

REMARKS.-Only two examples of the new species are at hand, an adult female and a young male, both from the head of Fortymile Creek, a tributary of the Yukon crossing the Canadian boundary. The latter was mounted but has been removed from its stand. Both were prepared with the anterior portions of the skull left within the skin. Those of the adult have since been removed.

These two specimens differ from available skins of $M$. flaviventer from California and Colorado in various details of coloration and markings. They are more yellowish above and darker below, and lack the distinctive head markings of that species. In examples of flaviventer in comparable pelage the head and muzzle are much darker, sometimes black, with a conspicuous white 
patch on lips and chin, sometimes including the top of the nose as well, markings entirely absent in the present species. In flaviventer the ventral surface of the tail is distinctly darker than the upper part, sometimes black; in ochracea the tail is uniformly colored above and below.

There are no measurements with the single adult example of ochracea, but the skin indicates an animal smaller than flaviventer. The young individual (about half grown) is practically like the adult, except that the hoary area above is more extensive, including the whole back, as well as the sides of the neck.

Transmitted December 27, 1910. 
Vol. 3. 1. Some Observations on the Nervous System of Copepoda, by 0. Esterly. Pp. 1-12, plates 1-2. January, 1906.....................................

2. (IX)* Ostracoda of the San Diego Region. 1. Halocypridae, by

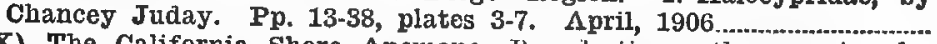

3. (X) The California Shore Anemone, Bunodactis xanthogrammica, by Harry Beal Torrey. Pp. 41-46, plate 8, April, 1906.

4. (XI) Sexual Dimorphism in Aglaophenia, by Harry Beal Torrey and Ann Mariin. Pp. 47-52, 9 text-figures. April, 1906.

Nos. 3 and 4 in one cover

5. (XII) New Copepod Fauna from the San Diego Region, by Calvin Olin Esterly. Pp. 53-92, plates 9-14. December, 1906.

6. (XII) Dinotlagellata of the San Diego Region, II. On Triposolenia, New Genus of the Dinophysidae, by Charles Atwood Kofoid. Pp. 93-116, plates 15-17.

7. A Discussion of the Species Characters in Triposolenia. I. The Nature of Species Characters. If. The Adaptive Significance of Species Characters. III. The Coincident Distribution of Related specles. By Charles Atwood Kofoid. Pp. 117-126.

8. On the Significance of the Asymmetry in Triposolenia, by Charies Atwood Kofold, Pp. 127-135.

Nos. 6, 7, and 8 in one cover. Decernber, 1906

9. (XIV) Ostracoda of the San Diego Region. II. Iittoral Forms, by Chancey Juday. Pp. 135-156, plates 18-20.

10. (XV) Cladocera of the San Diego Region, by Chancey Juday. Pp. $1.57-158,1$ text figure.

Nos. 9 and 10 in one cover. January, 1907.

11. (XVI) The Marine Fishes of Southern California, by Edwin Chapin Starks and Earl Leonard Morris. Pp. 159-251, plate 21. March, 1907.

12. Biological Studies on Corymorpna. II. The Development of C. Palma from the Egg. By Harry Beal Torrey. Pp. 253-298, 33 text figures. June, 1907

13. (XVII) Dinoflagellata of the San Diego Region. III. Descriptions of New Species. By Challes Atwood Kofoid. Pp. 299-340, plates 22-23. April, 1907

14. The Structure and Movements of Condylostoma patens, by John $\mathbf{F}$. Bovard. Pp. 343-368, 21 text figures. September, 1907. Index, pp. 369-383.

Vol. 4. 1. The Ascidians Collected by the United States Fisheries Bureau steamer Albatross on the Coast of California during the Summer of 1904, by William Emerson Ritter. Pp. 1-52, plates 1-3. October, 1907.

2. (XVIII) Behavior of the Starfish Asterias forreri de Lorriol, by $\mathbf{H}$. $\mathbf{s}$.

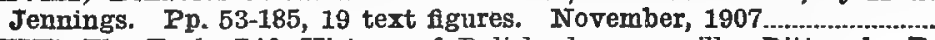

3. (XIX) The Farly Life-History of Dolichoglossus pusillus Ritter, by B. M. Davis. Pp. 187-226, plates 4-8. March, 1908.

4. Notes on two Amphipods of the Genus Corophium from the Pacific Coast, by J. Chester Bradley. Pp. 227-252, plates 9-13. April, 1908.

5. (XX) The Incrusting Chilostomatous Bryozoa of the Western Coast of North America, by Alice Robertson. Pp. 253-344, plates 14-24, May, 1908

6. (XXI) On Exuviation, Autotomy, and Regeneration in Ceratium, by Charles Atwood Kofoid. Pp. 345-386, with text figures.

7. (XXII) Notes on some Obscure Species of Ceratium, by Charles Atwood Kofoid. Pp. 387-393.

Nos. 6 and 7 in one cover. April, 1908............................................... Index, pp. 395-400.

Vol. 5. 1. The Biota of the San Bernardino Mountains, by Joseph Grinnell. Pp. 1-170, plates 1-24. December, 1908

2. Birds and Mammals of the 1907 Alexander Expedition to Southeastern Alaska. Pp. 171-264, pls. 25-26, figs. 1-4. February, 1909 .................

3. Three New Song Sparrows from California, by Joseph Grinnell. Pp. 265-269. April 9, 1909

4. A New Harvest Mouse from Petaluma, California, by Joseph Dixon. Pp. 271-273. August 14, 1909

5. A New Cowbixd of the Genus Molothrus, with a note on the Probable Genetic Relationships of the North American Forms, by Joseph

Grinnell. Pp. 275-281, 1 text figure. December, 1909...................
6. Two New Rodents from Nevada, by Walter P. Taylor. Pp. 283-302, plates 27-29.

7. A Northern Coast Form of the California Gray Eox, by Joseph Dixon. Pp. 303-305.

Nos. 6 and 7 in one cover. February, 1910.

* Boman numbers indicate sequence of the Contributions from the Laboratory of the Marine Biological Association of San Diego. 
8. Two Heretofore Unnamed Wrens of the Genus Thryomanes, by Joseph Grinnell. Pp. 307-309.

9. The Savannah Sparrow of the Great Basin, by Joseph Grinnell. Pp. 311-316.

10. A Second Record of the Spotted Bat (Euderma maculatum) for Califormia, by Joseph Grinnell. Pp. 317-320, plate 30.

Nos. 8,9 , and 10 in one cover. February, 1910.

11. Mammals of the 1908 Alexander Alaska Fxpedition, with Descriptions of the Localities Visited and Notes on the Flora of the Prince William Sound Region, by Edmund Heller. Pp. 321-360, plates 31-32.

12. Birds of the 1908 Alexander Alaska Expedition, with a Note on the Avifaunal Relationships of the Prince William Sound District, by Joseph Grinnell. Pp. 361-428, plates 33-34, 9 text-figures.

Nos. 11 and 12 in one cover. March, 1910

Index, pp. 429-440.

Vol. 6. 1. (XXIII) On the Weight of Developing Eggs, Part I, The Pogsible Significance of Such Investigations, by William E. Ritter; Part II, Practicability of the Determinations, by Samuel E. Bailey. Pp. 1-10. October, 1908

2. (XXIV) The Leptomedusae of the San Diego Region, by Harry Beal Torrey. Pp. 11-31, with text figures. February, 1909

3. (XXV) The Ophiurans of the San Diego Region, by J. F. McClendon. Pp. 33-64, plates 1-6. July, 1909.

4. (XXVI) Halocynthia jchnsoni n. sp.: A comprehensive inquiry as to the extent of law and order that prevails in a single animal species, by Wm. E. Ritter. Pp. 65-114, plates 7-14. November, 1908............

5. (XXVII) Three Species of Cerianthus from Southern California, by H. B. Torrey and F. L. Kleeberger. Pp. 115-125, 4 text-flgures. December, 1909

6. The Life History of Trypanosoma Dimorphon, Dutton \& Todd, by Edward Hindle. Pp. 127-144, plates 15-17, 1 text-figure. December, 1909

7. (XXVIII) A Quantitative Study of the Development of the Salpa Chain in Salpa fusiformis-runcinata, by Myrtle Elizabeth Johnson. Pp. 145-176. March, 1910

8. A Kevision of the Genus Ceratocorys, Based on Skeletal Morphology, by Charles Atwood Kofoid. Pp. 177-187. May, 1910

9. (XXIX) Preliminary Report on the Hydrographic Work Carried on by the Marine Biological Station of San Diego, by George F. McEwen. Pp. 189-204; text-figure and map. May, 1910

10. (XXX) Bioligical Studies on Corymorpha. III. Regeneration of Hydranth and Holdfast, by Harry Beal Torrey. Pp. 205-221; 16 textfigures.

11. (XXXI) Note on Geotropism. in Corymorpha, by Harry Beal Torrey. Pp. 223-224; 1 text-figure.

Nos. 10 and 11 in one cover. August, 1910

12. The Cyclostomatous Bryozoa of the West Coast of North America, by Alice Robertson. Pp. 225-284; plates 18-25. December, 1910............

13. Significance of White Markings in Birds of the Order Passeriformes, by Henry Chester Tracy, Pp. 285-312. December, 1910.

Vol. 7. 1. Two New Owls from Arizona, with Description of the Juvenal Plumage of Strix occidentalis occidentalis (Xantus), by Harry S. Swarth. Pp. 1-8. May, 1910

2. Birds and Mammals of the 1909 Alexander Alaska Expedition, by Harry S. Swarth. Pp. 9-172; plates 1-6; 3 text-figures. January, 1911.

3. An Apparent Hybrid in the Genus Dendroica, by Walter P. Taylor. Pp. 173-177. February, 1911

4. The Linnet of the Hawaiian Islands: a Problem in Speciation, by Joseph Grinnell. Pp. 179-195. February, 1911 .................................

5. The Modesto. Song Sparrow, by Joseph Grinnell. Pp. 197-199. Feb-

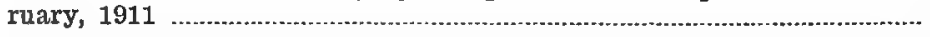

6. Two New Species of Marmots from Northwestern America, by $\mathbf{H} . \mathbf{S}$. Swarth. Pp. 201-204. February, 1911 


\section{PROCEEDINGS}

OF THE

\section{CALIFORNIA ACADEMY OF SCIENCES}

Fourth Series

Vor. VI, No. 4, pp. 53-85, pl. 2. MAY 8, 1916

IV

The Pacific Coast Races of the Bewick Wren

BY

Harry S. SWARTh 
COMMITTEE ON PUBLICATION

George C. Edwards, Chairman

C. E. GRUNSKY

BARTON WARREN EvermaNN, Editur 


\section{PROCEEDINGS}

OF THE

\section{CALIFORNIA ACADEMY OF SCIENCES}

\section{Fourth Series}

Vor. VI, No. 4, pp. 53-85, pl. 2.

MaY 8, 1916

\section{IV \\ THE PACIFIC COAST RACES OF THE BEWICK WREN $^{1}$}

BY

HARRY S. SWARTH

\section{INTRODUCTION}

The material upon which these observations are based is mainly from the collection of the California Museum of Vertebrate Zoology. Besides the Museum collection proper there are on deposit in that institution the Grinnell, Morcom and Swarth collections. The total aggregation of skins of Thryomanes berricki in that Museum numbers 425 specimens. There was also available material in the Los Angeles Museum of History, Science and Art, including the collections of Messrs. Daggett, Law, Lamb, Richardson, and Willett, in all 109 specimens. To Messrs. Joseph Mailliard and John W. Mailliard the writer is under obligations for the loan of 52 skins, including splendid series of marinensis, and series of drymoecus and charienturus from regions not otherwise represented. From Mr. A. B. Howell 11 skins were borrowed, illustrating special points. Altogether, a total of 597 examples of the Pacific coast forms of Thryomanes bewicki were examined in the preparation of this paper. To the institutions

${ }^{I}$ Contribution from the University of California Museum of Vertebrate Zoology. 
and individuals above mentioned the writer is under deep obligations for the use of this material.

Next to the data obtained directly from this splendid series of specimens, the writer is inclined to give high place to the informational value of the field work incidental to its collection, in much of which he took an active part. The ideal material upon which to base conclusions as regards relationships and distribution consists of specimens in freshly acquired autumnal plumage, taken at the exact localities where the birds were born. As we have not usually any means of knowing the exact birthplace of a bird, the results of our studies must often depend upon assumptions based largely upon one's knowledge of the species in general and its usual mode of life. Just here is where it would seem that experience and information acquired through extensive field work would be invaluable in aiding in an analysis of the facts presented by series of skins-facts often in apparent conflict. The man who works from the dried skin alone is handicapped more than he usually realizes. In working out the relationships and distribution of closely connected forms, a labor entailing the handling of large series, anomalous specimens are frequently encountered, calculated to lead one astray. Some knowledge of the country and climate, the physical surroundings of the species in general, will frequently give a clue to the explanation, while intimate acquaintance with the bird in life will enable one, to a certain extent, to imagine himself in the bird's place and figure out what, under given conditions, is most apt to occur. The life history and habits of the species in general, the faunal complexion of its usual habitat, the nature and extent of variation in the individual and in the race, are all factors of prime importance, and are all to be learned in the course of field work, some of them in no other way. It is not enough, because a specimen bears a superficial resemblance to a race geographically placed more or less remotely from where it was taken, to place the said specimen with such race. In the writer's opinion, this has been done but too frequently in late years, resulting in extraordinary extensions of ranges of certain subspecies without due justification. Familiarity with the birds in life should serve as a most excellent check to such hasty conclusions. 
For many reasons the genus Thryomanes as occurring in California is an attractive one to the student of geographical distribution. The birds exist in numbers where conditions are favorable. As the species is not sharply delimited associationally, conditions are more generally favorable than in many other groups of birds, and Thryomanes is consequently abundant and widely distributed throughout the state. The variability of the group is notable, birds from different regions exhibiting to a marked degree the types of characteristics which we have learned to look for in animals of the various areas. Thus there are these several factors:-abundance, with consequent accumulation of extensive series of specimens; disregard of associational barriers effective in many other species, with resulting general distribution, this condition permitting careful scrutiny of conditions existing between many stations but slightly separated geographically, though of different faunal aspect; and variability, birds from different regions exhibiting peculiarities of color, etc.-all combining to make this genus a profitable subject for careful examination.

\section{MANNER OF OCCURRENCE}

Wrens of the genus Thryomanes occur in fair abundance practically throughout the state of California. The genus in this state belongs pre-eminently to the Upper Sonoran zone, but it also occurs commonly in places in Transition, as in the northern coast region, and sometimes in Lower Sonoran, as in parts of the San Diegan region and the San Joaquin Valley. It is not found, however, in the high Transition and Boreal of the Sierra Nevada and the southern Sierras, and it is notably absent from the arid Lower Sonoran of the Colorado and Mohave deserts. This last was unexpected, as the species occurs commonly in regions of similar zonal character elsewhere. The above statements all apply to the breeding range of the bird. In seasons other than the nesting time there are exceptions, as noted beyond.

In certain other variable groups, such as the Song Sparrows (Melospiza. melodia), Horned Larks (Otocoris alpestris) and Bush-tits (Psaltriparus), associational requirements 
are of such a nature as to bar the species from large areas, but Thryomanes demands no such rigid conditions for its existence. The essential environmental requisite is underbrush, affording shelter, and this is a condition so universally met with in California that there are few regions that do not answer.

Just one of the California forms of this species has truly migratory habits, Thryomanes $b$. eremophilus. The others are practically resident wherever found. It is true that this fact is not generally recognized, and that there are records of several subspecies from points more or less remote from the breeding ground, but I am convinced that for the most part these records are not well founded. In the extensive series of skins here assembled, and in the field work incidental to the accumulation of the large proportion of them in which the writer took part, there has been no evidence evolved indicating regular migrations of these birds. As evidence to the contrary, the following facts may be adduced: Thryomanes $b$. calophonus is stated to remain in winter at the northern limit of its range (Oberholser, 1898, p. 441), which is also the northern extreme reached by the genus in North America. We do not find marincnsis or spilurus wandering south in winter along the coast of southern California, any more than we do certain other forms of comparable distribution and faunal restriction, such as Pipilo maculatus falcifer, Zonotrichia leucophrys nuttalli, Junco oreganus pinosus, etc. In the extensive series of wrens assembled from southern California and from parts of the Mohave and Colorado deserts, numbering some hundreds of skins secured at all seasons of the year, there is none that can be considered as typical of Thryomanes $b$. drymoecus, to be taken as proof of a southward winter movement of this form.

Thryomanes $b$. cremophilus appears to be truly migratory. Data are lacking to show whether or not the breeding ground is entirely deserted in winter, but the subspecies is known to occupy parts of the Colorado desert during the winter months, while it does not nest in that region. The birds found on the Colorado Desert during winter are apparently migrants from the desert mountains to the northward, and not from eastern Arizona, where this wren is a common resident. Though the Desert Wren has been found in winter to the eastern base 
of the mountains separating the desert and coastal regions, there is no known instance of an individual of this subspecies having crossed the divide and invaded the Pacific slope.

While I am convinced of the truth of the statements made above regarding the generally non-migratory habits of the California wrens of the genus Thryomanes, excepting eremophilus, there do take place certain limited and irregular movements which are not to be considered as migrations. The late summer dispersal of birds in general, the "scatter movement," as it has been called, is common to many parts of the country, and may take individuals, mostly immatures, in any direction. The northward wandering of herons at the close of the breeding season is a well-known instance in point. In parts of California this movement takes the form of an invasion of high mountain regions by many low zone species from the adjacent valleys and foothills (see Grinnell, 1908, p. 22), and Thryomanes participates in this to a notable extent. In southern California during July and August, T. b. charienturus is one of the most abundant birds in the higher mountains, at altitudes where it never breeds, occurring in numbers to the summits of the highest peaks. As early as the middle of September this invading army has again withdrawn. Several specimens at hand from parts of the Sierra Nevada seem also, from dates and altitudes, to have been wanderers from lower elevations.

This general movement is apt to carry occasional individuals of any of the forms slightly beyond the usual faunal confines of their respective races, and there are several instances in the assemblage of skins examined where circumstances seem to indicate a happening of this nature.

The occurrence of $T . b$. charienturus in winter at stations in the western parts of the Mohave and Colorado deserts (as at Barstow, Victorville and Palm Springs), is easily explained as due to continuous favorable avenues of approach from the normal breeding grounds in the foothills of the nearby mountains. Other species properly belonging to the San Diegan faunal region have been similarly found at the same places. 


\section{VARIATION}

There are but two distinguishable stages of plumage in this species (besides the natal down) - the juvenal and those of the first and subsequent winters. The juvenal differs from the later stages mainly in being mottled or spotted over much of the area that is subsequently uniformly colored. After loss of the juvenal plumage, in the first August and Septenber, there are no further changes in appearance, immatures of the first winter being indistinguishable from adults; after the first year there is but the one molt annually, at the end of the summer. There are thus no seasonal changes in appearance other than those produced by the mechanical wear and tear upon the plumage, amounting to fading of colors proportionate to the nature and extent of exposure, and obliteration of finer markings as the feather tips are worn away. There are no appreciable sexual distinctions of color or markings, merely slight average differences in measurements, males averaging a trifie larger than females.

It is seen that the wrens of this genus have a wide zonal range, and that where a change in life-zones acts as a check, it is, in this group as in most others, usually an absolute barrier to the species rather than an accompaniment of subspecific variation. It is also evident that environmental requirements are not rigid, the species being readily adaptive within rather wide limits. While the species as a whole is wide ranging, however, there is a strong tendency toward separation into different forms or races distinguished by peculiarities of color and proportions. Study of this variation demonstrates close accordance of appearance with locality. In this group of birds each faunal area represented tends to a remarkable degree to produce its own peculiar type. So that it is seen that Thryomanes, wide ranging and with the faculty of thriving under varied climate and surroundings, exhibits to an extraordinary extent - perhaps as part of this same adaptability-variation of appearance in accordance with every change in environment.

It must be understood, of course, that the differences alluded to are not always conspicuous. There are frequently variations in proportions requiring careful measuring for detection, or slight differences in color which in scattered speci- 
mens might be thought of no especial significance. With a series as extensive and representative as the one here assembled, however, these variations can be recognized as parts of a coördinated whole, and in the occasional instance where an insufficient specimen or two from some obscure locality exhibits an unexpected line of development, there is usually to be found at least a possible explanation of the occurrence.

The extent and manner of variation illustrated in this series of birds can not be too strongly emphasized. For one thing there are enough specimens at hand to show a surprising range in characteristics from any one locality. Many stations are represented each by numerous specimens of freshly molted fall birds, undoubtedly individuals of the resident form of each respective place, as they appear prior to any wear and tear of the plumage. In every case there are individuals exhibiting wide variation in appearance, though extremes may be shown by but one or two specimens. These differences can not be explained save as illustrating the amount of variation to be encountered among individuals at any one point.

These variants are not of the same nature as the "intermediates" encountered near the line of meeting of two different races. In the latter case, as is well illustrated from many such localities in the series here assembled, we find whole populations showing characters variously intermediate between two extremes. The occasional variants found elsewhere may crop up at any place, and in appearance do not necessarily incline towards any other subspecific type. It would almost seem as though the species as a whole was in a formative stage, showing occasional response to stimuli which we cannot at present understand.

In this connection it is well to consider conditions in the juvenal plumage. In the several distinguishable Pacific coast forms of Thryomanes bewicki the color differences shown in the adults are accurately reflected in the juvenal plumage, young birds of the different recognizable subspecies exhibiting variations of precisely the same nature as are seen in adults, usually in about the same degree. This, according to the general understanding of the significance of characters of the juvenal plumage, would argue great age and consequent deep-seatedness of the color characters observed, which is hard to recon- 
cile with the generally variable nature of the several subspecies as observed at this time.

The above statements must not be understood as weighing against the validity of the several "subspecies" so far described from California, for in nearly every case where a name has been applied to a local race it covers an aggregation of characters fairly easily defined and recognized. In fact, the races of Thryomanes bewricki, as occurring on the mainland of the Pacific coast, may be taken as an ideal illustration of subspecific division as it is applied in systematic ornithology. There are six recognized forms in this region-marinensis, spilurus, drymoecus, charienturus and eremophilus in California, and calophonus in the coast region to the northward. In every case it is an easy matter to distinguish typical examples of the races. Typical specimens are not necessarily topotypes. The best manifestation of a race may be found at some distance from the type locality; usually at about the center of the geographical area occupied. As departure is made from the habitat of one race toward that of another, in just such proportion is variation encountered among individuals of the races. Geographical continuity of range with corresponding intergradation of characters is usually taken as the test of subspecific, rather than specific, difference, but there are few instances among North American birds where these conditions are as ideally met with as among the Pacific coast forms of Thryomanes bervicki.

A brief resume of the course of variation in some of the most salient features of these races may be profitable. At the extreme northern limit of the species, on the mainland of southern British Columbia and Washington, is calophonus, of relatively large size and extremely dark coloration. On the adjacent Vancouver Island is a slightly paler colored, rather more reddish, form (included under the name calophonus), of practically the same size. Farther south, on the coast of northern California, southward to the Golden Gate, is marinensis, about like Vancouver Island calophonus in color but ap-preciably smaller. South of the Golden Gate is spilurus, occupying the narrow coastal strip west of the Coast Ranges, south to about the southern end of Monterey Bay. This form is of a somewhat paler and brighter red than is marinensis, 
and of slightly greater size. South of spilurus is charienturus of the coast of southern California, a large sized, pale colored, and long tailed race. There are two inland races of Thryomanes in California, drymoecus and eremophilus. Typical drymoecus of the Sacramento Valley is of distinctly reddish coloration, most nearly like, though paler than, marinensis and spilurus, whose ranges it adjoins in places. Eremophilus is a desert race, exhibiting an extreme of pale coloration, and with relatively long tail. Of the insular forms, nesophilus of Santa Cruz and Santa Rosa islands, and catalince of Santa Catalina Island, are but slightly different from the geographically adjacent charienturus. They are a trifle darker in coloration, and show certain differences in proportions. Leucophrys, of San Clemente Island, is a short tailed race of distinctly pale coloration.

As regards the coastal races, from calophonus through morinensis and spilurus to charienturus, the line of variation is continuous, to be traced from one to another without a break. In coloration, from the sooty calophonus to the pale charienturus, intergradation is perfect. The intermediate stages are represented in marinensis and spilurus, the dividing lines between these several races being impossible of exact definition. This gradual color change is nicely correlated with the climatic variation of the region, from the extremely humid Puget Sound district, with its somber hued calophonus, southward through lessening degrees of humidity accompanied by corresponding brightening of color in the birds. As regards size and proportions, variation is also continuous. Calophonus is of large size and with proportionately short tail. Southward, as far as the Golden Gate, as shown by.marinensis of Humboldt and Marin counties, there is diminution in size. South of this point spilurus shows slightly greater dimensions, and, as illustrated by specimens from many intermediate stations, there is steady increase in this regard southward through the range of charienturus. Together with increased size southward from the Golden Gate there is correlated a proportionately greater length of tail. In calophonus, marinensis and spilurus, the tail is shorter than the wing. Specimens collected in the region of meeting of spilurus with charienturus have tail and wing of about equal length, while in typical charien- 
turus the tail is usually decidedly the longer. Eremophilus, of the southern deserts, shows still greater extremes of pallid coloration and length of tail. Between eremophiius and charienturus, where there is a wide gap in distribution except in one limited region, as noted beyond, there can not be traced the nicely graded series of changes found between the other California mainland forms; judging from the imperfectly representative material here assembled from the southern Sierra Nevada (where apparently the ranges of eremophilus and charienturus closely adjoin), such a condition may be existent in this region. Further collecting here at the proper seasons is necessary to demonstrate this.

Thus on the whole it is seen that the Pacific coast races of Thryomanes bewicki may be divided into two general groups, of pale colored, long tailed forms in the arid southwestern region, and dark colored, short tailed forms in the humid northwestern coast region, with maximums of size at the extreme north and south. In every type of variation, connecting chains of intermediates may be traced, corresponding as exactly in geographical position as in extent of variation. Drymoecus, as detailed beyond, occupies a central position, almost surrounded by the other mainland forms, and the characteristics of birds of this subspecies vary exactly as the confines of the several contiguous races are approached.

The insular forms of Thryomanes bewicki do not exemplify continuous variation such as seen on the mainland. Vancouver Island calophonus, in its comparatively paler browns, shows a departure from the mode that does not accord with the general manner of variation of the species in this region. San Clemente Island leucophrys, in its gray coloration, might be regarded as exhibiting results of the same nature as are shown in the comparatively gray Pipilo maculatus clemente of the same island. This theory is upset by the fact that on the closely adjacent Santa Catalina Island (lying directly between San Clemente and the mainland), where Pipilo $m$. clemente also occurs, the representative form of Thryomanes, $T$. b. catalince, is distinguished from the mainland charienturus by slightly darker brown coloration. T. b. nesophilus of Santa Cruz and Santa Rosa islands is again differentiated from charienturus by slightly darker, more rufescent, coloration. 
In fact, in the insular forms of Thryomanes berwicki (as well as in other races of birds occurring upon the 'several islands of the Santa Barbara group) it is at present impossible to detect generally uniform results of any factor or factors, either as to the occurrence or non-occurrence of species upon the different islands, or in the amount and nature of differentiation that has taken place.

Possible criticism may be invited by the fact that in the present paper certain local races (subspecies) are pointed out and their characteristics described, but no names affixed. This applies particularly to the Vancouver Island form of calophonus, and to the wren of the southern boundary of the Great Basin region as distinguished from typical eremophilus of the Gila Basin. It is the writer's opinion that the aggregations of individuals occupying these several areas are geographically separated from the typical forms. whose names they bear. They are also probably to be distinguished, though with some difficulty, by the average differences indicated; possibly they are local races in early stages of differentiation. The objections to formally affixing names in their cases are two in number: first, in the slightly distinguished races in question it is impossible to indicate more than obscure average distinctions; and second, the extreme variability shown in individuals of even the most strongly marked of the several described forms militates against the recognition of these apparent geographic variants even though they appear to be isolated. The peculiar characters of the Vancouver Island wren are perhaps to be explained as solely a result of isolation. The Desert Wren of southeastern California, in its departure from typical eremophilus, shows a distinct approach to charienturus, and it may be that in its affinities, as it is geographically, it is intermediate between the two. 
DIAGRAM SHOWING INTER-RELATIONSHIPS OF PACIFIC COAST RACES OF THRYOMANES BEWICKI.

Island forms; discontinuous variation.
Mainland forms; continuous variation. Dark to light coloration, short tail to long tail.

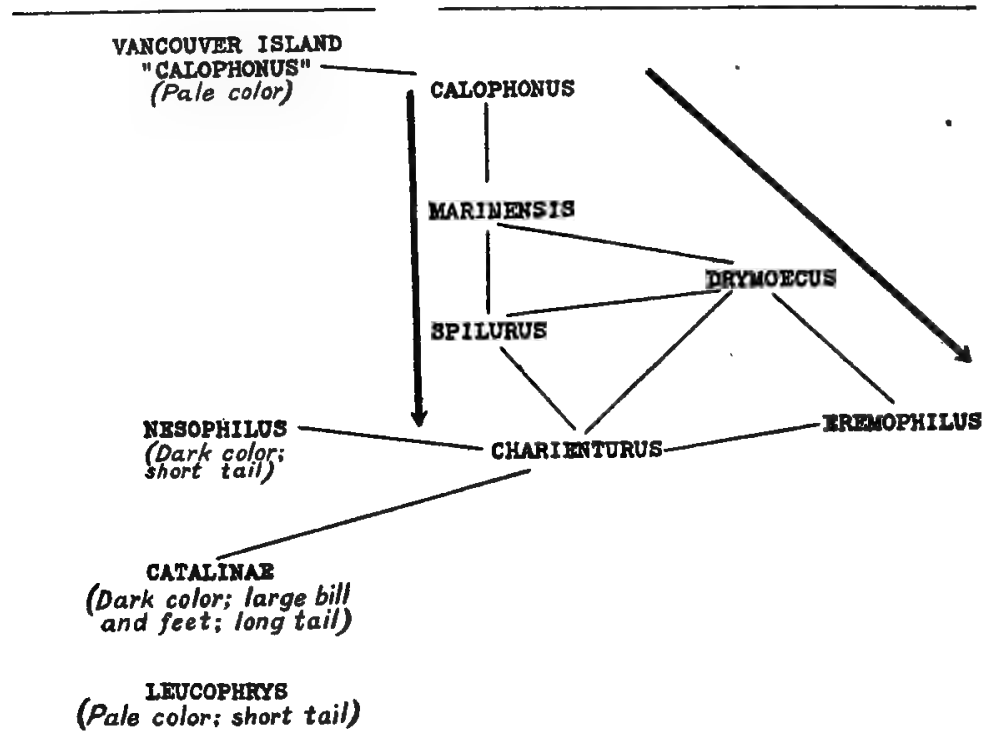

\section{DETAILED DISCUSSION OF CALIFORNIA RACES \\ Thryomanes bewicki inarinensis Grinnell.}

Type locality-Nicasio, Marin County, California.

Range - The humid coast belt north of the Golden Gate, at least to Humboldt Bay; probably to the Oregon line.

Specimens examined from the following localities: Humboldt County: Capetown, 1; Ferndale, 1. Mendocino County: Covelo, 7; Sherwood, 3; Willits, 1; Gualala, 3. Sonoma County: Guerneville, 5; Freestone, 2; Fulton, 1. Marin County: San Geronimo, 14; Nicasio, 3; Inverness, 8. Total, 49.

Distinguishing characters-Similar to T. $b$. spilurus, of the coast region immediately south of San Francisco Bay, but dorsal coloration appreciably darker. Compared with calophonus as represented on Vancouver Island, marinensis is 



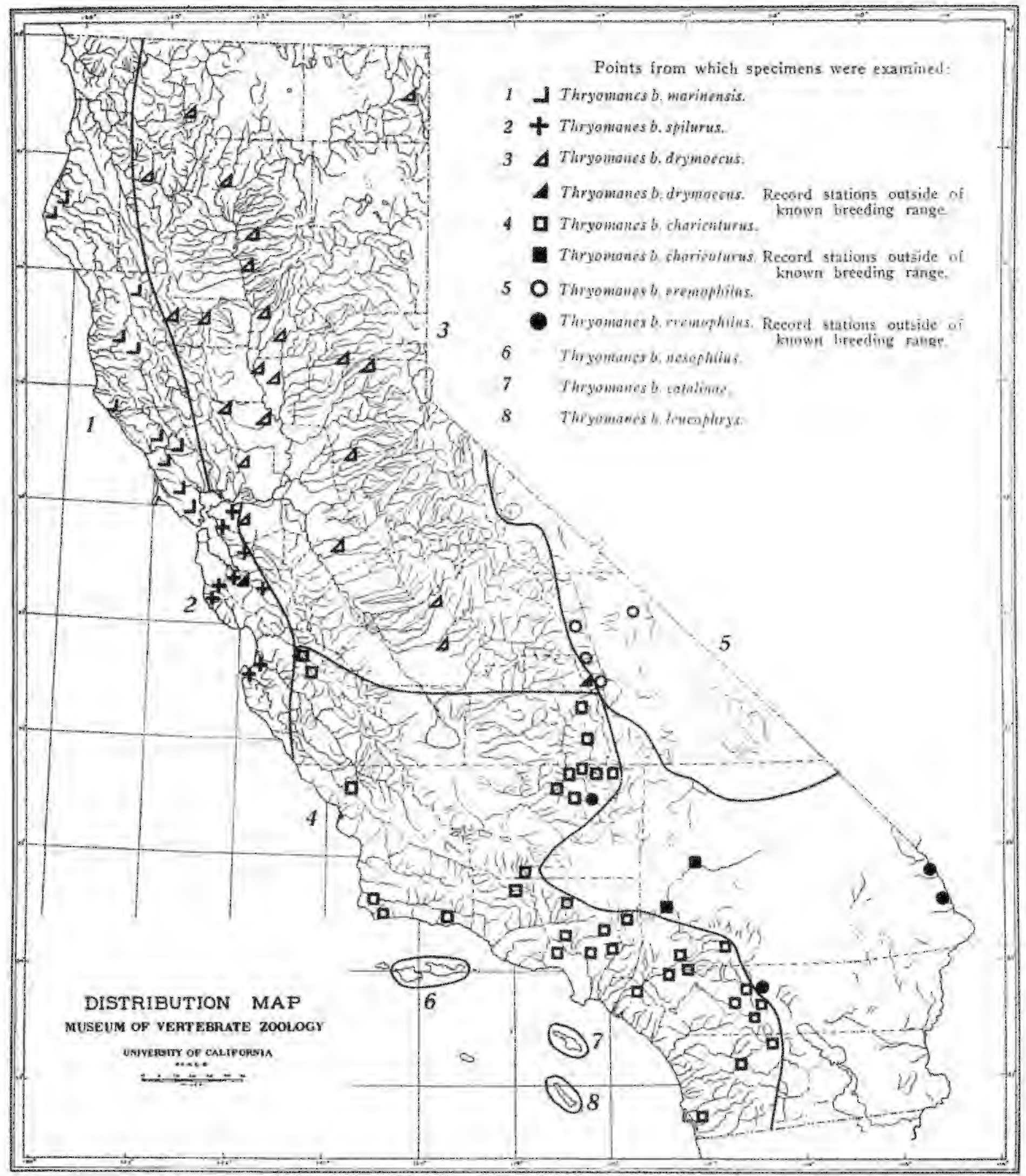

Distribution in Califorma of the Subspecies of Thoyomater beavick. 
closely similar in coloration; compared with calophonus as represented on the coast of Washington and Oregon, it is brighter and less sooty. In size and proportions, intermediate between calophonus and spilurus, though nearer the latter.

Remarks-The wrens of the northern coast region of California present certain peculiarities of appearance which were commented upon, first by Oberholser (1898, p. 440), and later by Ridgway (1904, p. 565 , footnote). The race marinensis was formally described by Grinnell (1910, p. 307) upon the basis of these same peculiarities.

There have been available for comparison in the present connection, besides the series of the several California subspecies, 18 skins of calophonus from Vancouver Island, and 10 from the mainland of the Puget Sound region of Washington and Oregon. Inspection of these series develops several interesting points in regard to the wrens of the northwestern coast region in general. Judging from the material at hand it seems evident that calophonus does not occur in California, unless it is to be found on the coast of the extreme northwestern corner of the state, from which point there are at this time no specimens available. Furthermore, in the range of country at present ascribed to calophonus, there appear to be two distinct types existent, lumped under the one name, races which eventually may have to be separated in nomenclature. Specimens from the mainland of Washington and Oregon, which may be considered as typical of calophonus, present the extreme of dark coloration in this species. Vancouver Island birds are distinctly paler and more reddish, though of practically the same size. Thus there is the dark colored mainland calophonus situated between the Vancouver Island (unnamed) form to the northward, and marinensis to the southward, these latter two being paler colored and more reddish, and practically alike in coloration.

To put it a little differently: Beginning at the northern limit of the range of Thryomanes bervicki on the Pacific Coast, there is first, on Vancouver Island, a dark, reddish-colored bird of relatively large size. Immediately to the southward, on the mainland of the Puget Sound region, there is an appreciably darker, more sooty form (typical calophonus), of 
approximately the same size. South of this, along the northern coast of California southward to the Golden Gate, is marinensis, paler colored again, practically the same color as the Vancouver Island bird, but smaller. Spilurus, from south of San Francisco Bay, is still paler but a trifle larger, gradually. merging, both in color and size, into the larger and more pallid charienturus of southern California.

The two birds at hand from the vicinity of Humboldt Bay are typical of marinensis. They are like the average of Marin County birds, and are correspondingly unlike calophonus of the mainland farther north. In the series from Marin and southern Mendocino counties there are several notably pale colored specimens. A female from San Geronimo (no. 2158, Mailliard coll.) is quite grayish above, and there are several juvenals from southern Mendocino County also aberrantly colored. Such a bird is mentioned by Ridgway $(1904$, p. 565, footnote), from Nicasio; so altogether, it evidently is not uncommon to encounter such pale colored individuals at this point. This is at once suggestive of exactly similar conditions found prevailing among the bush-tits (Psaltriparus) of the region (see Swarth, 1914, pp. 513-515), and it would seem that in both instances the phenomena are to be explained in the same way.

The conditions described as probably explanatory in the case of the bush-tit are as follows: "Marked restriction of territory appropriate to the humid coast races, ineffective barriers interposed against complementary forms of much greater numbers occupying adjacent territory, and continual encroachment of individuals (the radiating overflow) of the latter subspecies" (Swarth, loc. cit.). The genus Thryomanes appears to offer a parallel instance, though to not so marked an extent as in Psaltriparus. Aberrant individuals occur as mentioned above, in a manner similar to that observed in the latter genus, but not so numerously.

A series of juvenals from Marin County is appreciably less bright reddish above than is the case in young birds of spilurus from Palo Alto. A series of juvenals from Mendocino County contains several pale colored individuals, more nearly approaching the coloration of drymoccus. 
Thryomanes bervicki spilurus (Vigors)

Type locality-Near San Francisco or Monterey, California.

Range-Coast region of central California (Santa Cruz faunal district); southern and eastern sides of San Francisco Bay, south to southern end of Monterey Bay. Restricted to the region west of the Coast Range.

Specimens examined from the following localities: Contra Costa County: Martinez, 1. Alameda County: Berkeley, 3; Oakland, 7; Piedmont, 2; Alameda, 1; San Lorenzo, 1; Haywards, 2. San Mateo County: La Honda, 1; Woodside, 2; Pescadero, 2. Santa Clara County: Palo Alto, 24; Milpitas, 1. Monterey County: Pacific Grove, 3; Monterey, 1. Total, 51.

Distinguishing characters-Most nearly like $T . b$. marinensis, whose range adjoins that of spilurus at the north, but of lighter brown coloration dorsally, and of slightly greater size. Compared with drymoecus it is brighter reddish above. From charienturus it differs in deeper red coloration, and in different proportions. In spilurus the tail is slightly shorter than the wing; in charienturus the tail is longer than the wing.

Remarks-Thryomanes bewicki spilurus, as here restricted, ranges over a limited area in the central coast region of California between San Francisco and Monterey bays. Geographically it occupies a position between marinensis and charienturus, and analysis of the characters of spilurus demonstrates that in this latter respect also it is a transitional step between the races to the northward and to the southward. Palo Alto specimens present the best manifestation of the characters of spilurus of any of the series at hand. These birds are quite uniformly bright reddish above, the only exceptions being two or three individuals, rather duller colored, and apparently verging toward drymoecus.

Birds from the east shore of San Francisco Bay (Berkeley, Oakland, etc.) present a certain peculiarity of coloration, for with hardly an exception they are extremely dark and sooty in appearance, as remarked by Oberholser (1898, p. 439). This is undoubtedly partly, but not altogether, due to smoke stain, the darkening effect of which has been noted in certain 
other species at these points. I an inclined to class the birds of this region as representing an intergradient stage between typical spilurus of the coast region and drymoecus of the interior. The plumage, normally of a less bright 'rufescence than in the former, is still further modified by the action of the smoke, producing the extremely dark effects seen in the specimens at hand. Of the available skins from the east side of San Francisco Bay, practically all were secured at suburban points in the various towns, where they would be subject to the effects of the smoke of the communities. There is one specimen in the series that forms a striking exception to the above remarks. This is no. 4284, coll. Mus. Vert. Zool., collected by Dr. J. G. Cooper, at Martinez, Contra Costa County, December 15,1863 . This bird is bright, clear reddish above, closely similar to certain of the Palo Alto specimens, and even brighter colored than many from that point. It shows no sign of smoke stain. This latter fact may possibly be due to the fact of there being less smoke in the atmosphere in this general region at that early date.

There are in the series four specimens from the vicinity of Monterey Bay, three from Pacific Grove and one from Monterey. This is too small a series to draw conclusions from, but one of these birds (coll. J. \& J. W. Mailliard, no. 4691) displays what appears to be a distinct trend toward the coloration of charienturus.

\section{Thryomanes bewicki drymoecus Oberholser}

Type locality-Baird, Shasta County, California.

Range-The central portion of California; the Sacramento Valley, and northward at least to the Oregon boundary; northeast to the Warner Mountains, on the Nevada boundary; the west slope of the central Sierra Nevada, everywhere below Transition; southward over about the northern half of the San Joaquin Valley. Specimens from the east slope of the Sierra Nevada at Carroll Creek, taken in September, may have been wanderers from the west side of the mountains, and not necessarily within the normal breeding range.

Specimens examined from the following localities: Modoc County: Cedarville, 2; Sugar Hill, 1. Trinity County: Hel- 
ena, 1. Siskiyou County: Callahan, 2. Shasta County: Baird, 1. Tehama County: Tehama, 5; Tuscan Springs, 1. Glenn County: Winslow, 1. Colusa County: Stony Ford, 2. Butte County: Chico, 3; Oroville, 2. Sutter County: West Butte, 2; Sutter, 5. Yolo County: Grand Island, 1; Rumsey, 3. Solano County: Vacaville, 11. Amador County: Carbondale, 2. Nevada County: Cherokee, 4; Montezuma Hill, 2. Placer County: Blue Canyon, 1. Inyo County: Carroll Creek (east slope of the Sierras), 4. Fresno County: Lane Bridge, 1. Madera County: Raymond, 2. Stanislaus County: Modesto, 7. Mendocino County: Mount Sanhedrin, 1. Contra Costa County: Walnut Creek, 8; Mount Diablo, 6. Santa Clara County: Palo Alto, 1. Total number of specimens, 82.

Distinguishing characters-Compared with charienturus, drymoecus has the upper surface darker and more rufescent. The tail is somewhat shorter, and in different proportion to the wing. In charienturus the tail is slightly longer than the wing, in drymoecus slightly shorter. Compared with spilurus, the upper surface of drymoecus is a duller and less rich brown. In the juvenal plumage the character of intensity of rufescence of the upper surface is also apparent, young of drymoecus being less deeply colored than young of spilurus and marinensis on the one hand, and somewhat darker (though slightly so) than the young of charienturus on the other. It is noteworthy in this regard that whereas in typical drymoecus (Sacramento Valley birds) the adults approach spilurus more nearly than they do charienturus, the juvenal plumage is but slightly different from the same stage in charienturus.

Remarks-Of the available material of this form, the greater part consists of summer adults in rather worn plumage, with a good proportion of juvenals. There is a lack of birds in fresh fall plumage.

Thryomanes berwicki drymoecus is a composite race, and one probably not subject to exact definition. It differs from all the other California forms of Thryomanes in the nature of its geographical position, being centrally placed and apparently intergrading with each of the surrounding races at the various points of contact. Consequently birds from different re- 
gions exhibit a diversity of appearance that renders it difficult in the extreme to frame a satisfactory characterization of the race, and in places the dividing lines must be somewhat arbitrarily drawn.

Birds from the Sacramento Valley exhibit the best manifestation of the characters of the subspecies. These characters consist of decidedly reddish dorsal surface (though not so rich a red as in marinensis and spilurus) and short tail, bearing a different relation to length of wing than is seen in charienturus and eremophilus. Thus in the last analysis the form drymoecus is seen to be an intergradient between the long-tailed, pale colored, southern and desert races, charienturus and eremophilus, and the short-tailed, richly colored, coastal subspecies, marinensis and spilurus. This is so markedly the case that while in the Sacramento Valley drymoecus may be considered a fairly well marked form, just as this center is departed from so is there encountered a variation of characters tending toward whichever of the other subspecies is approached.

There is at hand one adult from Baird, Shasta County, California, the type locality of $T . b$. drymoecus. There are also available one from Trinity County and two from Siskiyou County, all in the same general region in north central California. As indicated by this small series the birds from this part of the state seem to belong to the subspecies $d r y$ moecus.

Warner Mountain District. There are one adult and two in juvenal plumage from the Warner Mountains, in the extreme northeastern corner of California. The old bird is decidedly gray, as compared with Sacramento Valley specimens, but the two young ones are even more rufescent than are comparable examples from the latter locality. The dull color of the adult is so noticeable as to suggest the possibility of the existence of a definable local race in this little known portion of the country, but in view of the manner of variation shown by drymoecus in others of the outlying parts of its range, I prefer at present to regard this specimen as another example of the variability of the form. In this connection it may be well to call attention to the possibility that the wren recorded from Camp Harney, southeastern Oregon, by Bendire (1877, 
p. 113), and tentatively referred to eremophilus by Oberholser (1898, p. 429), may well be of the same race as the Warner Mountain bird.

Sacramento Valley. Thirty-eight specimens from the following counties: Tehama, Glenn, Butte, Colusa, Sutter, Yolo, Solano, and Amador. Of this series 25 are adults, the remainder in juvenal plumage. They were collected during spring and summer, from early March until the middle of July, hence the adults are all in rather worn plumage. Despite this wear, however, these specimens uniformly exhibit to a marked extent the characteristic feddish dorsal surface of the subspecies. As indicated above Sacramento Valley birds may be regarded as typically representative of the interior form, drymoecus.

San Joaquin Valley. Birds from this valley are not so easily or satisfactorily disposed of. Both Oberholser (1898, p. 437) and Ridgway (1904, p. 563) have included this region in the habitat of drymoecus, but the former author at least had no examples from this valley, as shown by his list of the localities from which specimens were examined. The region is not satisfactorily represented in the series now available, but there is at hand a series of seven skins from Modesto, Stanislaus County (Mailliard coll., nos. 6987, 6993, 7125, $7333,7385,7386,7400$ ), two specimens from Raymond, Madera County (Mus. Vert. Zool., nos. 19,688, 19,689), and one from Lane Bridge, near Fresno (Mus. Vert. Zool., no. 19,687). All of these points are in the east central portion of the San Joaquin Valley. Of these the Modesto birds were collected in January, February, March, and May, the Lane Bridge and Raymond examples in April. Some of them are breeding birds, and the probabilities are that the January and February specimens are also examples of a resident form. At any rate peculiarities of appearance can hardly be explained on the ground that the birds are wandering examples of charienturus, for this more southern form would hardly be found represented by individuals wintering so far north of their summer home. On the other hand, these San Joaquin Valley birds are too unlike Sacramento Valley drymoecus to be regarded as southward traveling visitants from that region. 
So, on the whole, the series may safely be considered as representing the form breeding in this same general region. In coloration the whole series is quite uniform and but slightly distinguished from charienturus, being more nearly like this race than like Sacramento Valley drymoecus. In measurements the birds stand about midway between the two forms, though rather nearer the latter (see table). All things considered, I have regarded these birds as illustrating intergradation between typical drymoccus and charienturus, and as representing about the extreme southern valley locality which the name drymaecus may be used to cover.

Sierra Nevada. There are six spring birds from Nevada County. Two are from Montezuma Hill, taken March 30, and four from Cherokee, April 5 and 7. From these dates they may fairly be assumed to be representative of the breeding bird of the region. In coloration they closely approach Sacramento Valley drymoecus, though they are not quite so reddish; in measurements and proportions there is no difference.

There are at hand four immatures in fresh winter plumage: a male, Blue Canyon, Placer County, October 21; two males and a female, Carroll Creek, east slope of Sierra Nevada in Inyo County, September 11 and 12; all collected at altitudes from 5000 to 7500 feet. A difficulty arises in the proper weighing of the characters of these birds, in that they were evidently late summer wanderers from lower altitudes, from just where, it is impossible to say.

The Blue Canyon specimen (Mus. Vert. Zool., no. 23,295) is dark reddish above, widely different from autumnal charienturus, but not so readily distinguished from fall specimens of marinensis. It is presumably typical of the fall plumage of drymoecus as occurring in the centrai Sierra Nevada. The three birds from Carroll Creek (Mus. Vert. Zool., nos. 20,858, $20,859,20,866)$ are quite different in appearance. They are but slightly reddish above, and with a grayish cast not seen either in charienturus or in typical drymoecus. As to the precise region occupied by these latter birds during the breeding season, that, of course, is problematical, for they might have wandered even from over the crest of the Sierras; but their appearance leads to the assumption that they represent an ex- 
treme southern outpost of Sierran drymoecus, where that race abuts on eremophilus. The grayish cast of the dorsal surface may well be explained as evidence of intergradation between the two.

From Walnut Creek and Mount Diablo, Contra Costa County, there is a series of two adults and 12 juvenals. The adults, June birds in excessively worn plumage, bear no resemblance to the ruddy colored spilurus of the nearby coast region. The young birds, too, lack the clear reddish tone of Palo Alto juvenals, and are very similar to young birds from the Sacramento Valley. The series is unsatisfactory in the lack of fresh plumaged adults, but is apparently to be referred to drymoecus, though tending toward the coast form spilurus. Birds from the east shore of San Francisco Bay (Berkeley, Oakland, etc.), the nearest point in the range of spilurus, are themselves for the most part not typical of that race, so that specimens from this whole general region may be regarded as illustrating intergradation between the coastal spilurus and drymoecus of the interior. The reference of the Walnut Creek and Mount Diablo birds to drymoecus is necessarily based almost wholly upon the appearance of the juvenals. Fortunately there are certain characteristics at this stage, as shown by the large series from the Sacramento Valley, apparently justifying such procedure.

There is one specimen at hand from a point outside of the general breeding range of drymoecus, which I feel obliged to refer to this form. This is an inmature female (no. 5268, Grinnell coll.) taken at Palo Alto, California, September 27, 1902 , and in complete first winter plumage. In color and proportions this bird appears to be unequivocally drymoecus. Without conceding any regular migratory habits to the form, it is quite possible for occasional individuals to stray during late summer and fall for as short a distance as is indicated by this capture. I believe this specimen to be such a wanderer from the breeding ground.

The subspecies Thryomanes berwicki drymoecus has been denied recognition by the American Ornithologists' Union Committee, and declared to be "not separable from Thryomanes b. spilurus" (1901, p. 314). At a later date, in the third edition of the Check-List (1910, p. 339), the ascribed range 
of drymoecus is included in that of $T . b$. charienturus. Conceding that drymoecus is not as sharply defined a race as certain other forms of the species, still the disposition accorded it under this latter ruling is certainly unsatisfactory, and not tending to assist to an understanding of existing conditions. The wren of the Sacramento Valley is as widely different from charienturus of southern California as is the northern coast bird, to which it is more nearly related. If it is not deemed desirable to recognize these slightly differentiated forms in the Check-List, a better compromise would be effected by extending the range of spilurus to include the Sacramento Valley and central Sierra Nevada, that of charienturus to extend through the San Joaquin Valley. Such treatment would be nearer the truth than is the present accepted arrangement; but even so, there would be encountered the difficulties and discrepancies bound to arise in the attempt to define by rigid lines the many fluctuations encountered in the birds of these wide and varied regions.

\section{Thryomanes bervicki charienturus Oberholser}

Type locality-Nashoguero Valley, Lower California (near Mexican and United States boundary line).

Range-Coast region of southern California, south from San Benito County and into northwestern Lower California. Breeds mainly on the coastal sfope, but in winter is found eastward to the western edges of the Colorado and Mohave deserts, as at Palm Springs, Victorville and Barstow.

Specimens examined from the following localities: San Benito County: Paicines, 13; Mulberry, 4. San Luis Obispo County: Paso Robles, 1. Santa Barbara County: Santa Barbara, 2; Lompoc, 4; Point Conception, 1; Santa Inez River, 1. Ventura County: Mount Pinos, 1; head of Piru Creek, 1. Tulare County: Cannell Meadow, 1; Monache Meadow, 1; Trout Creek, 7. Kern County: Weldon, 3; Onyx, 3; Isabella, 2; Bodfish, 2; Walker Pass, 3 ; Piute Mountains, 4. Los Angeles County: Pasadena, 91; San Fernando Valley, 19; Santa Monica Mountains, 3; Sierra Madre, 3; Monrovia, 1; San Gabriel Mountains, 6; San Francisquito 
Canyon, 2; Los Angeles, 7; El Monte, 2. San Bernardino County: San Bernardino Mountains, 5; Cajon Wash, 1; Victorville, 5; Barstow, 1; Reche Canyon, 3. Riverside County: Riverside, 5 ; San Jacinto Mountains, 28; Vallevista, 4; Palm Springs, 6; San Gorgonio Pass; 1. Orange County: Santa Ana Canyon, 1. San Diego County: San Diego, 1; Witch Creek, 1; Cuyamaca Mountains, 2. Total, 252.

Distinguishing characters-Coloration paler, less rufescent dorsally than in any other form of Thryomanes from the mainland of California, save eremophilus. In fresh fall plumage adults of charienturus average close to Saccardo's umber, a color about intermediate between the richer, more rufous', raw umber of spilurus, and the grayer hair brown of eremophilus. In measurements charienturus differs from eremophilus in smaller size; from spilurus, marinensis and drymoecus in different proportions, usually having tail longer than wing, whereas in the latter three forms the reverse is the case.

Remarks-It is in the relative geographical positions accorded to charienturus and drymoecus that the results of my observations are most at variance with those of the writers who have previously studied the group. Both Oberholser (1898, p. 437) and Ridgway (1904, p. 563) define the habitat of drymoecus as inclusive of the entire San Joaquin Valley, and as extending westward to the coast in San Luis Obispo County. As already stated under drymoecus, birds from the central San Joaquin Valley are not typical of that form, being rather of the nature of intergrades toward charienturus. Still less are birds from the coast region of San Luis Obispo and Santa Barbara counties to be regarded as representative of drymoecus. Such divergence from the mode of charienturus as they exhibit appears to be an approach toward spilurus, whose territory they border. This, to my mind, is a satisfactory explanation of the slightly more reddish coloration of certain individuals, as well as of the variation in measurements.

Seventeen skins from San Benito County, 13 from Paicines and four from Mulberry, most of them in fresh, unworn plumage, afford excellent comparative material from an intermediate locality, about at the meeting place of the ranges of 
charienturus, spilurus and drymoecus. These birds in coloration are practically like southern California charienturus, being no more rufescent than are most specimens from that region, and less reddish than birds from the coast of Santa Barbara County. In measurements the San Benito County birds are shorter tailed than is typical charienturus, and thus approach spilurus or else San Joaquin Valley drymoecus. There is very little difference in measurements between these latter two.

There is at hand one skin from San Luis Öbispo County and eight from the coast of Santa Barbara County. Some, but not all, of these birds are slightly darker and more rufescent above than charienturus from points farther south, but I believe that all are to be referred to that form. It is probably the type of specimen such as I have at hand from San Benito and Santa Barbara counties that formed the basis for the extension of the range of drymoecus to these points, but I prefer to regard such birds as illustrating intergradation between charienturus and spilurus, over the intermediate territory which they occupy. They are with difficulty distinguished from typical charienturus, and are certainly quite different in appearance from typical drymoecus of the Sacramento Valley.

The excellent series of skins at hand from the coastal region of Los Angeles, San Bernardino and Riverside counties, includes specimens in all stages and from all seasons, and, judging from these, it would seem that the race charienturus, as confined to southern California, is as well defined as any of the forms of the genus Thryomanes. Here, too, however, there is a certain amount of variation, usually in shade of rufescence dorsally, even in specimens in fresh fall plumage taken at practically the same points; differences that can hardly be explained on any grounds save that they represent the variability existing among individuals of the one race. Segregation according to age or sex yields no uniform or satisfactory divisions.

In the series at hand there are six winter birds from points at the western edge of the Mohave Desert, five from Victorville and one from Barstow. These specimens have been recorded as drymoecus (Mailliard and Grinnell, 1905, p. 101; Grinnell, 1901, p. 70), but I am unable to distinguish them 
from Pacific Slope charienturus, and believe that they are probably wanderers from the nearby San Bernardino Mountains. Midwinter specimens from Palm Springs, at the western edge of the Colorado Desert, belong in a similar class, of winter visitants from the adjacent San Jacinto Mountains.

There is available a series of 23 skins from the southern Sierra Nevada, in Tulare and Kern counties. Of these, 14 are juvenals, while the nine adults are in midsummer plumage, so frayed and faded as to be of little value for color comparisons. It is evident, however, that this series is not to be referred to drymoecus, and at present it seems best to include it under charienturus. The young birds are decidedly less reddish than juvenals of drymoecus, averaging closely similar to young charienturus. The variability shown among them tends toward grayish extremes, certain individuals being even paler colored than the average of eremophilus. The adults closely approach charienturus in similarly worn plumage, and in measurements and proportions also approximate this form.

There are at hand, fortunately, three adults in fresh, unworn plumage, taken in December in the Piute Mountains, at the southern extremity of the Sierra Nevada. These birds are unequivocally charienturus, and I believe it is fair to assume that they represent the resident form of this region. Altogether the available material is sufficient to justify the statement that the wren of the extreme southern Sierra Nevada is not drymoecus. At first it seemed questionable as to whether or not the birds were representative of eremophilus, which breeds on the east slope of the Sierras a short distance to the northward. The juvenals, as noted above, tend toward an extreme of grayish coloration, while the faded adults have something of the appearance of the Desert Wren. Also the presence in the series of an undoubted example of eremophilus from the Piute Mountains in September tended to obscure the facts, but this bird in all probability was a migrant from the desert regions to the eastward.

Fresh plumaged Thryomanes from the Sierra Nevada of Kern and southern Tulare counties are desirable, and it may be that such will exhibit characteristics intermediate between typical charienturus and eremophilus. 
Thryomanes bewicki nesophilus Oberholser

Type locality-Santa Cruz Island, California.

Range-Santa Cruz and Santa Rosa islands, California.

Specimens examined from the following locality: Santa Cruz Island, 19 (14 adults, 5 juvenals).

Distinguishing characters-Most nearly like $T . b$. charienturus of the adjacent mainland, from which it is but slightly differentiated. In coloration the dorsal surface and flanks are of a somewhat darker brown than is the mode in the mainland form. Tail usually shorter than wing; in just one of the adults at hand is it the reverse. In charienturus the tail is generally longer than the wing.

Remarks-The Santa Cruz Wren is apparently one of the most illy defined of any of the described forms of Thryomanes bewicki. The available series affords satisfactory material for comparison, containing four September specimens in newly acquired winter plumage, others taken in early spring, before becoming excessively worn, and some juvenals. Judging from these specimens this island form has become but slightly differentiated from the mainland race. I am able to appreciate the average slightly darker coloration of upper surface and flanks, but it is covered in the range of variation shown by mainland charienturus, occasional individuals of the latter being quite as dark.

The difference in proportions is perhaps the most tangible character, for the proportionately shorter tail of nesophilus is evident upon measurement. It is perhaps noteworthy that the slight differences serving to distinguish nesophilus from charienturus are steps in the direction of spilurus, the slightly more reddish dorsal coloration, darker flanks, and shorter tail, being just the characteristics encountered in birds occupying the intermediate coastal region between the ranges of charienturus and spilurus. The mainland nearest to Santa Cruz Island forms part of this intermediate region.

\section{Thryomanes bewicki catalince Grinnell}

Type locality-Avalon, Santa Catalina Island, California. Range-Santa Catalina Island, California. 
Specimens examined from the following locality: Santa Catalina Island, 14.

Distinguishing characters-Closely similar to the mainland form charienturus, but averaging slightly darker dorsally, and with somewhat heavier bill and feet.

Remarks-The peculiarities of the Santa Catalina Island Wren had been already commented upon (Oberholser, 1898, p. 436) before Grinnell (1910, p. 308) affixed a name to the race. The differences distinguishing this form from charienturus of the neighboring mainland, however, are but slight, barely sufficient to indicate average distinctions in series from the two regions. Of the skins at hand, 13 are adults, mostly in winter plumage, fresh and unworn. These show the color difference claimed for the race, as well as differences of proportions, and, admitting that these differential characters are not trenchant, still they exist, and their existence justifies the use of a separate name, especially in an insular form.

\section{Thryomanes bewicki leucophrys (Anthony)}

Type locality-San Clemente Island, California.

Range-San Clemente Island, California.

Specimens examined from the following locality: San Clemente Island, 23.

Distinguishing characters-In coloration leucophrys is noticeably grayish as compared with the darker colored neighboring races, catalina, nesophilus and charienturus. In its pale color leucophrys thus approaches eremophilus, but is easily distinguishable by size and proportions; leucophrys has shorter wings and tail, and longer bill. It also has tail shorter than wing, while in eremophilus the reverse is true. The broader superciliary stripe of leucophrys is diagnostic.

Remarks-The San Clemente Wren is a strongly marked form presenting various points of difference easily appreciated by the most casual observer. The generally pale coloration is apparent in the juvenal as in the adult plumage, and the broader and more conspicuous superciliary stripe is also a feature in the juvenal plumage. 
The series available contains 10 adults and 13 juvenals. The adults are all spring and summer birds, more or less worn and faded, there being no fresh autumnal specimens in the lot. Fall birds are probably more rufescent.

\section{Thryomanes bewicki cremophilus Oberholser}

Type locality-Big Hatchet Mountains, Grant County, New Mexico.

Range in California-The part of California known to be occupied by this form during the breeding season is linited to the higher mountains of the desert regions of the eastern part of the state in Inyo and Mono counties, and on the east slope of the Sierra Nevada from Lone Pine Creek an undetermined distance northward. In winter it occurs over the breadth of the Mohave and Colorado deserts, westward to the Piute Mountains and to Palm Springs.

Specimens examined from the following localities: California. Inyo County: Inyo Mountains, 2; Kearsarge Pass, 1; Lone Pine Creek, 1; Little Cottonwood Creek, 1. Kern County: Piute Mountains, 1. Riverside County: Palm Springs, 1. Colorado River between Needles and Riverside Mountain, 9. Arizona: Fort Mohave, 3; Huáchuca Mountains, 33; Chiricahua Mountains, 6; Fort Lowell, 13; Santa Cruz River near Tucson, 1. Tptal, 72.

Distinguishing characters-Largest of the California forms of Thryomanes (see table). Tail longer than wing. Coloration pallid, the palest colored of the California subspecies of the genus.

Remarks-The series here accumulated from different points in southeastern California presents certain peculiarities of appearance that suggest the possibility of these birds representing a form recognizably distinct from typical eremophilus. In general the California birds appear to be slightly darker dorsally and on the flanks, and slightly smaller, with proportionately shorter tail. Also in the California birds the ground color of the black-barred central rectrices is usually brownish, where in specimens from Arizona it is more decidedly gray; in the California birds there is a tendency toward a dusky, un- 


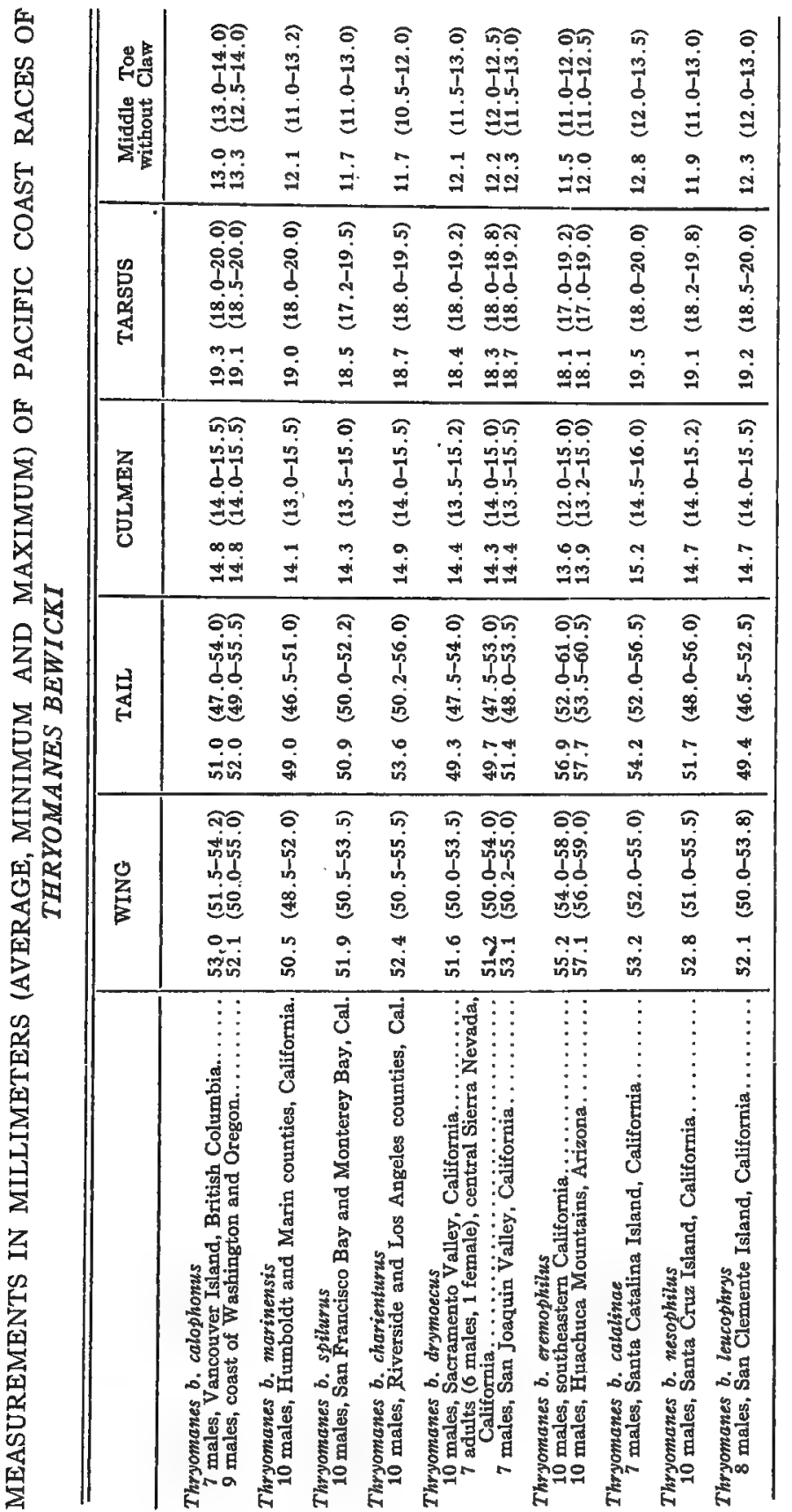


barred area at the tip, as shown in a considerable proportion of specimens.

In southeastern Arizona eremophilus is a common resident of both the Upper and Lower Sonoran zones, being abundant in the Lower Sonoran river valleys. In eastern California this wren appears to breed only in Upper Sonoran, migrating down into Lower Sonoran in the winter months. It is, I believe, the only California wren of this genus that has truly migratory habits.

That individuals of the species should be found in the valley of the Colorado River, at the western boundary of Arizona, in winter only (Grinnell, 1914, p. 209), while the species is resident the year through in valleys of similar zonal character in the eastern part of the state, argues, it seems to me, that these sets of individuals represent two entirely separate aggregations, two distinct subspecies, if we wish to call them so. Furthermore, observations so far made as regards other species show that the valley of the Colorado does not serve as a winter home for birds from the colder country to the eastward. The transient winter population of this valley seems to come almost entirely from the Great Basin region to the northward, with its surrounding mountains, and it is fair to assume that these winter visiting wrens are also from that region. The slight differential characters apparent, as enumerated above, appear to bear out this assumption.

Personally I believe that there are at least two separate forms included under the term eremophilus as now used, one occurring in the Great Basin region of southern Nevada and eastern California, migrating over the Colorado and Mohave deserts in winter, the other represented by the resident bird of southeastern Arizona. Additional material is needed from California, in the nature of fresh autumnal and early spring specimens from breeding stations, more clearly to demonstrate the presence of differentiating characters. In the absence of such material, and bearing in mind the variability shown by the wrens of this genus where different subspecies meet, it seems advisable to refrain from formally affixing a name to the possibly recognizable California race. It is significant in this connection to note that in proportion as California specimens of 
eremophilus differ from the mode of that subspecies, so do they approach charienturus or drymoecus.

There is a specimen of the Desert Wren at hand collected in the Piute Mountains, Kern County, September 6, 1903. As noted previously in this paper, under charienturus, examples of the latter race were taken in winter in the same mountain range; and circumstances make it appear that charienturus is the resident form. With little doubt eremophilus is but a migrant or winter visitant at this point. There is at hand another example of this subspecies from Palm Springs, Riverside County, taken December 30, 1903. The Desert Wren thus ranges in winter over the breadth of the Colorado Desert, and probably over the Mohave Desert as well, but it evidently is rare at the western borders of these tracts. Considerable winter collecting at points on the Mohave River, as at Victorville and Yermo, has failed to disclose its presence there, and the one specimen from Palm Springs is the only example recorded from the latter station. Apparently the bottom lands of the Colorado River form the main winter home of the species in this region.

The series of skins from southeastern Arizona contains an excellent representation of both adults and juvenals, taken at all seasons of the year. The individuals of this series, although true in the main to the characteristics of the race, exhibit a certain amount of variation, apparently to be explained only as due to individual peculiarities. This is true of both adults and juvenals. As having bearing upon the extremes of variation encountered, mention might be made of the recorded occurrence of drymoecus at Calabasas, southern Arizona (Oberholser, 1898, p. 438). In the series before me there is a single individual taken in the Chiricahua Mountains, Arizona, October 27, 1914 (no. 2538, coll. of J. E. Law), that might be considered as belonging in the same category. This last mentioned bird is short tailed and rather dark colored, being not unlike certain examples of drymoecus in appearance, while it is even darker colored than selected specimens of charienturus. While this specimen in certain respects thus bears a casual resemblance to some California birds rather than to typical eremophilus, I cannot believe that it belongs to the race drymoecus, in the sense that this is an individual 
that has actually traveled from central California to southeastern Arizona. Such action would be so remarkably at variance with all known conditions prevailing among the subspecies of Thryomanes of the central valley and coast regions of California that I do not for a moment consider that it is to be taken into account in explaining this circumstance.

As affording additional evidence to the contrary, there is in my series a molting bird taken in the Huachuca Mountains, Arizona, August 17, 1902 (no. 3082, Swarth coll.). This specimen, covered with pin feathers, and with rectrices and remiges but partly grown, is assuming a dorsal coloration far more rufescent than the average of eremophilus, freshly molted birds being used in comparison, and it is closely similar to the Chiricahua Mountain bird just described. Yet there can be but little doubt that this individual was in its summer home when captured, and that it is representative of an extreme of color variation occasionally reached in the subspecies eremophilus.

\section{LITERATURE: CITED}

American Ornithologists' Union Committee, J. A. Allen, Chairman and Editor.

1901. Tenth supplement to the American Ornithologists" Union Check-list of North American birds. Auk, 18, pp. 295-320.

1910. Check-list of North American birds. Ed. 3, revised (New York, American Ornithologists' Union), 430 pp., 2 maps.

Bendire, C.

1877. Notes on some of the birds found in southeastern Oregon, particularly in the vicinity of Camp Harney, from November, 1874, to January, 1877. Proc. Boston Soc. Nat. Hist., 19, pp. 109-149.

GRINNELL, J.

1901. Midwinter birds at Barstow. Condor, 3, pp. 70-71.

1908. The biota of the San Bernardino Mountains. Univ. Calif. Publ. Zool., 5, pp. 1-170, pls. 1-24. 
1910. Two heretofore unnamed wrens of the genus Thryomanes. Univ. Calif. Publ. Zool., 5, pp. 307-309.

1914. An account of the mammals and birds of the lower

Colorado Valley with especial reference to the distributional problems presented. Univ. Calif. Publ. Zool., 12, pp. 51-294, pls. 3-13, 9 text figs.

Mailliard, J., with Grinnell, J.

1905. Midwinter birds on the Mojave Desert. Condor, 7, pp. 71-77, 101-102.

Oberholser, H. C.

1898. A revision of the wrens of the genus Thryomanes Sclater. Proc. U. S. Nat. Mus., 21, pp. 421-450.

RIDGWAY, R.

1904. The birds of North and Middle America. U. S. Nat. Mus., Bull. 50, part 3, pp. xx+801, 19 pls.

Swarth, H. S.

1914. The California forms of the genus Psaltriparus. Auk, 31, pp. 499-526, p1. XL. 





\section{PROCEEDINGS}

\section{Fourth Series \\ VOLUME I}

Expedition of the California Academy of Sciences to the Galapagos Islands, 1905-1906.

Pages 1-6. I. Preliminary Description of Four New Races of Gigantic Land Tortoises from the Galapagos Islands. By John Van Denburgh. (Issued December 20, 1907).................

Pages 7-288. II. A Botanical Survey of the Galapagos Islands. By Alban Stewart. Plates I-XIX. (Issued January 20, 1911)...

Pages 289-322. III. The Butterflies and Hawk-Moths of the Galapagos Islands. By Francis X. Williams. Plates xx-xxI.

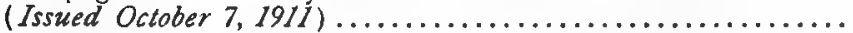

Pages 323-374. IV. The Snakes of the Galapagos Islands. By John Van Denburgh. Plates XXII-Xxx. (Issued January 17, 1912)

Pages 375-404. V. Notes on the Botany of Cocos Island. By Alban Stewart. Plates XxxI-XxxIv. (Issued January 19, 1912)

Pages 405-430. VI. The Geckos of the Galapagos Archipelago. By John Van Denburgh. (Issued April 16, 1912) ............

Pages 431-446. VII. Notes on the Lichens of the Galapagos Islands. By Alban Stewart. (Issued December 17, 1912)......

\section{VOLUME II, PART I}

Expedition of the California Academy of Sciences to the Galapagos Islands, 1905-1906.

Pages 1-132. VIII. The Birds of the Galapagos 1slands, with Observations on the Birds of Cocos and Clipperton Islands (Columbiformes to Pelecaniformes). By Edward Winslow Gifford. Plates I-VII. (Issued August 11, 1913)............

Pages 133-202. IX. The Galapagoan Lizards of the Genus Tropidurus; with Notes on the Iguanas of the Genera Conolophus and Amblyrhyncus. By John Van Denburgh and Joseph R. Slevin. Plates vIII-XI. (Issued September 19, 1913).

Pages 203-374. X. The Gigantic Land Tortoises of the Galapagos Archipelago. By John Van Denburgh. Plates XII-CXXIV.

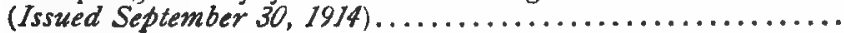

\section{VOLUME III}

Pages 1-40. A Further Stratigraphic Study in the Mount Diablo Range of California. By Frank M.Anderson. Plate I. (Issued

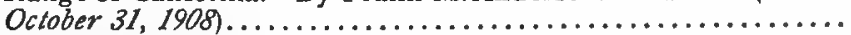

Pages 41-48. Description of a New Species of Sea Snake from the Philippine Islands, with a Note on the Palatine Teeth in the Proteroglypha. By John Van Denburgh and Joseph C. Thomp-

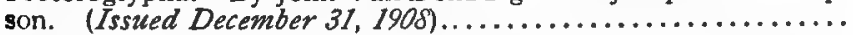

Pages 49-56. New and Previously Unrecorded Species of Reptiles and Amphibians from the Island of Formosa. By John Van Denburgh. (Issued December 20, 1909).....................

Pages 57-72. Water Birds of the Vicinity of Point Pinos, California. By Rollo Howard Beck. (Issued September 17, 1910) ..........

Pages 73-146. The Neocene Deposits of Kern River, California, and the Temblor Basin. By Frank M. Anderson. Plates II-XIII.

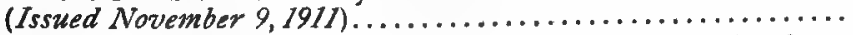

Pages 147-154. Notes on a Collection of Reptiles from Southern California and Arizona. By John Van Denburgh. (Issued

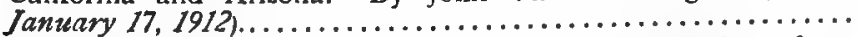

Pages $155-160$. Notes on Some Reptiles and Amphibians from Oregon, Idaho and Utah. By John Van Denburgh. (Issued

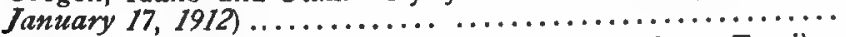

Pages 161-182. Geologic Range of Miocene Invertebrate Fossils of California. By James Perrin Smith. (Issued April 5, 1912)...

Pages 183-186. Description of a New Genus and Species of Salamander from Japan. By Surgeon J. C. Thompson, U. S. Navy.

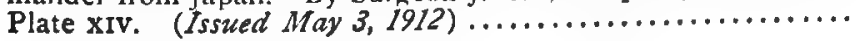




\section{PROCEEDINGS}

\section{Fourth Series}

VOLUME III-Continued

Pages 187-258. Concerning Certain Species of Reptiles and Amphibians from China, Japan, the Loo Choo Islands, and Furmosa. By John Van Denburgh. (Issued December 16, 1912.)........

Pages 259-264. Notes on Ascaphus, the Discoglossoid Toad of North America. By John Van Denburgh. (Issued December

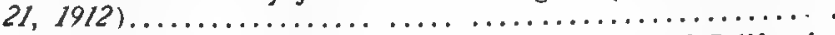

Pages 265-390. A Distributional List of the Mammals of California. By Joseph Grinnell. Plates Xv-xvi. (Issued August 28, 1913)

Pages 391-454. A List of the Amphibians and Reptiles of Arizona, with Notes on the Species in the Collection of the Academy. By John Van Denburgh and Joseph R. Slevin. Plates XVII-

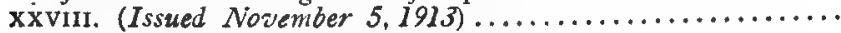

\section{VOLUME IV}

Pages 1-13. I. Report of the President of the Academy for the Year 1913.

II. George Davidson. (Issued April 8, 1914) ......

Pages 15-112. III. Neocene Record in the Temblor Basin, California, and Neocene Deposits of the San Juan District. By Frank M. Anderson and Bruce Martin. Plates I-X. (Issued

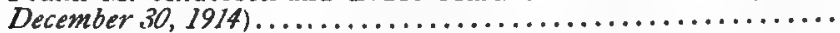

Pages 113-128. IV. The Fauna of the Siphonalia sutterensis Zone in the Roseburg Quadrangle, Oregon. By Roy E. Dickerson.

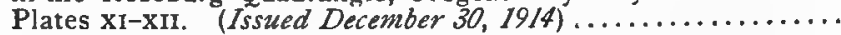

Pages 129-152. V. Reptiles and Amphibians of the Islands of the West Coast of North America. By John Van Denburgh and Joseph R. Slevin. (Issued December 30, 1914)..............

Pages 153-160. VI. The Pocket Gopher of the Boreal Zone on San Jacinto Peak. By J. Grinnell and H. S. Swarth. (Issued December 30, 1914).................................

VOLUME V

Pages 1-31. I. Report of the President of the Academy for the year 1914.

II. Report of the Director of the Museum for the year 1914. (Issued March 26, 1915)..........

Pages 33-98. III. Fauna of the Type Tejon: Its Relation to the Cowlitz Phase of the Tejon Group of Washington. By Roy E.

Dickerson. Plates I-XI. (Issue I Jne 15, 1915).............

Pages 99-110. IV. A list of the Amphibians and Reptiles of Utah, with Notes on the Species in the Collection of the Academy. By John Van Denburgh and Joseph R. Slevin. Plates XII-XIV. (Issued June 15, 1915)...............................

Pages 111-161. V. Description of a new subgenus (Arborimus) of Phenacomys, with a Contribution to Knowledge of the Habits and Distribution of Phenacomys longicaudus. By Walter P. Taylor. Plate xv. (Issued December 30, 1915) ............

Pages 163-193. VI. Tertiary Deposits of Northeastern Mexico. By E. T. Dumble. Plates XvI and xIx. (Issued December 31, 1915).

Pages 195-223. VII. Report of the President of the Academy for the Year 1915.

VIII. Report of the Director of the Museum for the Year 1915. (Issued May 4, 1916) ... VOLUME VI

Pages 1-17 I. Eocene of Lower Cowlitz River Valley, Washington. By Charles E. Weaver. Plate 1. (Issued May 6. 1916).

Pages 19-40. II. The Post-Eocene Formations of Western Washington. By Charles E. Weaver. (Issued May 6, 1916).

Pages 41-52. III. The Oligocene of Kitsap County, Washington. By Charles E. Weaver. (Issued May 6, 1916). Price fur the

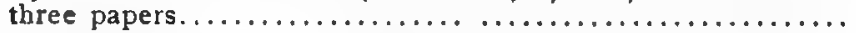

Pages 53-85. IV. The Pacific Coast Races of the Bewick Wren. By Harry S. Swarth. Plate 2. (Issued May 8, 1916) .........

The Academy cannot supply any of its publications issued befure the year 1907, its entire reserve stock having been destroyed in the conflagra tion of April, 1906. 


\title{
PROCEEDINGS
}

OF THE

\section{BIOLOGICAL SOCIETY OF WASHINGTON}

\section{THREE NEW SUBSPECIES OF PASSERELLA ILIACA.}

\author{
BY H. S. SWARTH.
}

(Contribution from the Museum of Vertebrate Zoology of the Jniversity of California.)

The writer has been recently engaged in a study of the fox sparrows (Passerella iliaca and subspecies) with special reference to the manner of occurrence of the several forms in California. In the course of this work evidence was soon forthcoming demonstrating the existence of certain distinguishable local races, as yet unnamed, the terms megarhyncha and schistacea proving each to cover composites of several forms. As the proposed general account of the group will not be ready for publication for some time to come, it is desirable that designations be affixed to these subspecies in advance of the appearance of the longer paper.

One of the first fruits of the study was comprised in a better understanding of the race which Mailliard (Condor XX, 1918, p. 138) has named Passerella iliaca brevicauda, material gathered together from various sources by the present writer proving fortunately to include specimens which supplied Mr. Mailliard with the final evidence needed to demonstrate the distinctness of this subspecies. In the present-paper three additional races are named, all from California. The total number of recognizable subspecies of Passerella iliaca is now sixteen, and all of these occur at some season within this State.

Passerella iliaca mariposae, new subspecies. YOSEMITE FOX SPARROW

Type.-Adult male; no. 25693, Mus. Vert. Zool.; ridge at 7000 feet, near Chinquapin, Yosemite Park, California; June 10, 1915; collected by $J$. Grinnell; original number 3284 . 
Subspecific characters.-In bill structure intermediate between Passerella iliaca megarhyncha and $P$. $i$. stephensi. In megarhyncha the bill is broad and stubby, in mariposae it is relatively long, with more attenuated tip, just the same shape as in stephensi, but smaller. $P . i$. mariposae also differs from megarhyncha in its more grayish coloration. It is closely similar to stephensi in general appearance, save for the smaller bill; similar to monoensis in general appearance, but with larger bill. Geographically and structurally mariposae occupies an intermediate position between monoensis and stephensi.

Remarks. - Through the courtesy of the authorities of the United States National Museum I have been permitted to examine the type of Passerella megarhynchus Baird. This bird (U. S. Nat. Mus. no. 12402) was collected at Fort Tejon, California, by Xantus, and while no date of capture is entered upon the label, it is obviously a winter collected specimen. Passerella $i$. megarhyncha is the "thick-billed sparrow" that is of most common occurrence in winter in southern California, but, contrary to previous belief, it is not the same as the "thick-billed sparrow" of the Sierra Nevada. $P . i$. megarhyncha has a stubby bill, and is of relatively brownish coloration; $P$. $i$. mariposae has a larger bill, more finely pointed, and is distinctly gray in color. The type specimen of megarhyncha is rather more grayish dorsally than the average of the race, but the shape of the bill in this specimen is outside the range of variation in $P$. i. mariposae, and exactly like that of the majority of the brown colored birds found commonly in winter in southern California.

Passerella $i$. mariposae, as shown by specimens at hand, occurs in summer from the vicinity of Mount Shasta south along the Sierra Nevada, on the west slope at least as far as the Yosemite region, on the east slope to Kearsarge Pass. There are a few winter examples of mariposae at hand from the San Diegan district, California, but so few that it is evident that these localities do not represent the main winter home of the race. On the other hand, megarhyncha occurs in this section in winter in abundance, but its breeding range is as yet not defined.

Passerella iliaca fulva, new subspecies.

WARNER MOUNTAINS FOX SPARROW.

Type--Adult male; no. 14795, Mus. Vert. Zool.; Sugar Hill $\langle 5000$ feet), Warner Mountains, Modoc County, California; May 19, 1910; collected by W. P. Taylor and H. C. Bryant; original number 2887.

Subspecific characters.-Bill intermediate in size between Passerella iliaca schistacea and $P . i$. mariposae; about the same size as in $P$. i. monoensis, but more slender and attenuated than the short but rather heavy bill of that subspecies. Coloration more brownish than in mariposae and monoensis; about as in schistacea. Wing and tail measurements somewhat less than in mariposae, about the same as in schistacea.

Remarks.-Size of bill alone suffices to distinguish Passerella i. fulva from any of the other fox sparrows save monoensis. From the latter form fulva may be told by the somewhat differently shaped bill, and by dif- 
ference in coloration. In worn summer plumage color differences are more or less obscured, but in freshly molted fall specimens they are readily apparent.

There is a large series of specimens at hand from the Warner Mountains, the summer home of this subspecies, but there are no winter birds or migrants available indicating its range at other seasons.

Passerella iliaca canescens, new subspecies. WHITE MOUNTAINS FOX SPARROW

Type.-Immature male (in nearly complete first winter plumage); no. 28439, Mus. Vert. Zool.; Wyman Creek at 8250 feet altitude, east slope of White Mountains, Inyo County, California; August 15, 1917; collected by A. C. Shelton; original number 3549 .

Subspecific characters.-Most nearly similar to Passerella iliaca schistacea, under which name the White Mountains bird has formerly been included, but differing from that race in its much more grayish coloration.

Remarks. -This subspecies is based upon a series of twelve specimens from several points in the Boreal zone on the White Mountains, in Mono and Inyo counties, California. The series includes three adults in rather worn summer plumage, two adults undergoing the annual molt but mostly in the new winter plumage, one immature (the type) in nearly complete first winter plumage, and six in juvenile plumage, some of them showing a few feathers of the first winter plumage.

Comparisons with $P$. $i$. schistacea were made with series of breeding birds from northern Nevada and south central Oregon, and with migrants and winter visitants from various points in California. There are no noticeable differences in measurements between these two races, though, as canescens is at the minimum of bill development in the species, it is possible to make a selection of specimens of schistacea from certain parts of the range of that subspecies, showing very much larger bills.

The gray coloration of canescens as compared with the browner schistacea is least noticeable in abraded summer plumage, but in newly acquired fall plumage it is evident at a glance; in juveniles also the difference in color between the two subspecies is apparent, though to a lesser degree.

There are two winter birds at hand that appear to be referable to the subspecies canescens, one from Mount Wilson, Los Angeles County, California, the other from Blythe, Riverside County (on the Colorado River), California. These afford as yet our only clue as to the winter home of the race. 




\section{THE RED SQUIRREL OF THE SITKAN DISTRICT, ALASKA "}

\section{By H. S. Swarth}

The red squirrel of southeastern Alaska was placed with Sciurus hudsonicus vancouverensis by J. A. Allen in his "Revision of the Chickarees," where vancouverensis was first described (Bull. Am. Mus. Nat. Hist., vol. 10, 1898, p. 269). The present writer, in a report upon a collection of birds and mammals from Vancouver Island, comments upon certain features that distinguish the red squirrel of southeastern Alaska from typical vancouverensis of Vancouver Island (Swarth, Univ. Calif. Publ. Zool., vol. 10, 1912, p. 88), without formally naming the Alaskan race. Further study of the red squirrels of the northwest coast region has emphasized the desirability of giving a name to this Alaskan form. It may be diagnosed as follows:

Sciurus hudsonicus picatus new subspecies

\section{KUPREANOF RED SQUIRREL}

Type.-Male adult, skin and skull; no. 8767, Mus. Vert. Zool.; Kuprean of Island, 25 miles south of Kake Village, at southern end of Keku Straits, southeastern Alaska; April 23, 1909; collected by H. S. Swarth; original no. 7281.

1 Contribution from the Museum of Vertebrate Zoology of the University of California. 
Diagnosis.-A red squirrel with the general characters of Sciurus hudsonicus. Cranially, most nearly resembling Sciurus hudsonicus petulans; externally, more nearly like $S . h$. vancouverensis.

Comparisons.-Sciurus $h$. petulans, as compared with vancouverensis, is stated by Osgood (N. Am. Fauna, No. 19, 1900, p. 27, pl. V, figs. 1, 2) to have the "nasals longer and posteriorly more compressed than in vancouverensis; orbital arch with a sharp indentation between lachrymal and postorbital process." These differences do not exist between petulans and picatus. There are individuals in the latter series that show intergradation toward vancouverensis in shape of nasals or in partial elimination of the orbital indentation described, but the series as a whole is, cranially, not to be distinguished from petulans.

As regards color, Sciurus $h$. picatus is dark as compared with petulans, but it is distinctly brighter than vancouverensis. The differences are most apparent in winter pelage; in the summer coat the two forms are closely similar in general appearance, differing only in certain minor details. In the winter coat vancouverensis is nearly uniform dark chestnut above, with the reddish dorsal stripe poorly defined; the tail is reddish above, but decidedly grayish on the ventral surface. In picatus the reddish color is generally brighter, there is a fairly welldefined hazel dorsal stripe and the center of the tail below is reddish. The black lateral stripe on the body is much more prominent. In all pelages picatus has the tip of the tail much less extensively black than is the case with vancouverensis. Sciurus $h$. picatus is slightly the larger of the two. For external measurements of Sciurus $h$. picatus and S. h. vancouverensis see Swarth, Univ. Calif. Publ. Zool., vol. 10, 1912, p. 88.

Distribution.-The area inhabited includes parts of the Sitkan district, Alaska, and extends for an undetermined distance southward. There are specimens at hand from the following islands: Kupreanof, Kuiu, Mitkof, Wrangell, Zarembo, Etolin, Revillagigedo, and Sergief. From mainland points: Taku River, Thomas Bay, Stikine River, Bradfield Canal, Chickamin River. (For details of distribution see Swarth, Univ. Calif. Publ. Zool., vol. 7, 1911, pp. 118, 153, map, fig. 1.)

Remarks.-The material upon which the above comparisons are made is as follows: Sciurus $h$. vancouverensis, 28 specimens from Vancouver Island (Mus. Vert. Zool.). Sciurus h. picatus, 36 specimens from the Alaskan localities previously indicated (32 in Mus. Vert. Zool., 4 in the E. P. Walker collection). Sciurus $h$. petulans, 17 from Glacier Bay (Mus. Vert. Zool.), 4 from Wells, Chilkat Valley (E. P. Walker collection).

The Glacier Bay specimens appear to be typical of petulans. The four skins from Chilkat Valley are, in color, intermediate between petulans and picatus; the skulls are not available. In his description of petulans, Osgood (loc. cit.) treats vancouverensis as a distinct species, a view that has since been disregarded (see Miller, List of North American Land Mammals, 1912, p. 321), and which my own material controverts. The race picatus is in itself intermediate between petulans 
and vancouverensis, and in the picatus series there is individual vari tion tending to bridge the gap in either direction. The indentation the orbital arch, given by Osgood as a feature distinguishing petula from vancouverensis, is not a character to be absolutely relied upc This little notch is sharply indicated in the petulans series, as I belie it is in the red squirrels of the interior of the northwest generally. the Vancouver Island skulls at hand there are none in which it is at. deeply cut. In some it is entirely absent, but usually there is a su gestion of a notch at that point. The southern Alaskan series contai none in which the notch is as nearly eliminated as in most of the $\mathrm{Va}$ couver Island skulls, and as a rule it is as apparent as in the petula series. It is not a character the presence or absence of which c be indicated in each of the skulls; it appears in all degrees from o extreme to the other.

Berkeley, California. 


\title{
BIRDS AND MAMMALS OF THE STIKINE RIVER REGION OF NORTHERN BRITISH COLUMBIA AND SOUTHEASTERN ALASKA
}

\author{
BY \\ H. S. SWARTH \\ Universtity of California Publications in Zoology \\ Vol. 24, No. 2, pp. 125-314.
}

BERKELEY, CALIFORNIA 


\section{UNIVERSITY OF CALIFORNIA PUBLICATIONS}

Note.-The University of California Publications are offered in exchange for the publcations of learned societies and institutions, universities, and libraries. Complete lists of all the publications of the University will be sent upon request. For sample coples, lists of publications or other information, address the MANAGER OF THE UNIVERSITY PRESS, BERKELEY, CAIIFORNIA, U. S. A. All matter sent in exchange should bo addressed to THE EXCHANGE DEPARTMENT, UNIVERSITY LIBRARY, BERKELEY, CALIFORNIA, U.S.A.

WILLAM WESLEY \& SONS, LONDON

Agent for the scries in American Archaeology and Ethnology, Botang, Geology, Physiology, and Zoology.

ZOOLOGY.-C. A. Kofoid, S. J. Hoimes, and J. Grinnell, Editors.

This series contains the contributions from the Department of Zoology, from the Marine Laboratory of the Scripps Institution for Blological Research, at La Jollh California, and from the Callforna Museum of Vertebrate Zoology in Berkeley.

Cited as Univ. Callf. Publ. Zool.

Volume 1, 1902-1905, 317 pages, with 28 plates $\$ 3.50$

Volume 2, 1904-1906, 5vil + 382 pages, with 19 plates ........................................... \$3.50

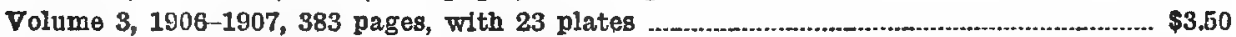

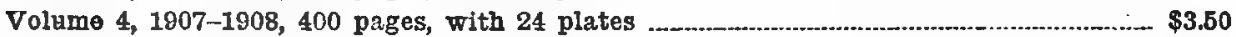

Volume 5, 1908-1910, 440 pages, with 34 plates .......................................................... $\$ 3.50$

Volume 6, 1908-1911, 478 pages, with 48 plates ............................................................ \$3.50

Volume 7, 1910-1912, 446 pages, with 12 plates ......................................................... $\$ 3.50$

Volume 8, 1911, 357 pages, with 25 plates ....................................................................... \$3.50

Volumo 9, 1911-1912, 365 pages, with 24 plates .................................................................. \$\$.50

Volume 10, 1912-1913, 417 pages, with 10 plates _................................................. \$3.

Volume 11, 1912-1914, 538 pages, with 26 plates ................................................. \$5.00

Volume 12, 1913-1916, 558 pages, with 22 plates ................................................ $\$ 5.00$

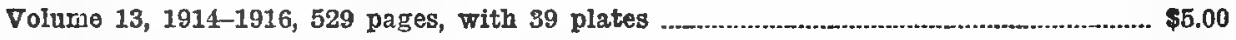

Volume 14, 1914 1918, 452 pages, with 60 plates ................................................. $\$ 5.00$

Volume 15, 1915-1916, 360 pages, with 38 plates …................................................... \$4.00

Volume 16, 1915-1917, 522 pages, with 46 plates ........................................................... \$5.00

Volume 17, 1916-1918, 545 pages, with 24 plates .......................................................... $\$ 5.00$

Volume 18, 1917-1919, 529 pages, with 20 plates .................................................... $\$ 5.00$

Vol. 18. 1. Mitosis in Giardia microti, by WHliam C. Boeck. Pp. 1-26, plate 1. October, 1917

2. An Unusual Extension of the Distribution of the Shipworm in San Francisco Bay, California, by Alber' I. Barrows. Pp. 27-43. December, 1917

3. Description of Some New Spectes of Polynotdae from the Coast of Calsfornia, by Christine Essenberg. Pp. 45-60, plates 2-3. October, 1917 ......

4. New Spocies of Amphinomidae from the Pacific Coast, by Christine Essenberg. Pp. 61-74, plates 4-5. October, 1917

5. Crithidia euryophthalmi, sp. nov., from the Hemipteran Bug, Euryophthalmus convirus Stäl, by Irene IIcCulloch. Pp. 75-88, 35 figures in text. December, 1917

6. On the Orientation of Erythropsis, by Charles Atwood Kofold and Olive Swezy. Pp. 89-102, 12 flgures in text. December, 1917

7. The Transmission of Nervous Impulses in Relation to Locomotion in the Farthworm, by John F. Bovard. Pp. 103-134, 14 figures in text. January, 1918

8. The Function of the Glant Fibers in Earthworms, by John F. Bovard. Pp. 135-14.1, 1 figure in text. January, 1918

9. A Rapid Method for the Detection of Protozoan Cysts in Mammallan Freces, by William C. Boeck. Pp. 145-149. December, 1917 .........................

10. The Musculature of Heptanchus muculatus, by Pirie Davidson. Pp. 151-170, 12 figures in text. March, 1918

11. The Factors Controlling the Distribution of the Polynoldae of the Pactfic Coast of North America, by Christine Essenberg. Pp. 171-238, plates 6-8, 2 figures in text. March, 1918

12. Differentials in Behavior of the Two Generations of Salpa democratica Relative to the Temperature of the Sca, by Ellis L. Michael. Pp. 239-298, plates 9-11, 1 figure in text. March, 1918

13. A Quantitative Analysis of the Molluscan Fauna of San Francisco Bay, by E. L. Packard. Pp. 299-336, plates 12-13, 6 figures in text. Aprll, 1918 ....

14. The Neuromotor Apparatus of Euplates patella, by Harry B. Yocom. Pp. 337-396, plates 14-16. September, 1918 



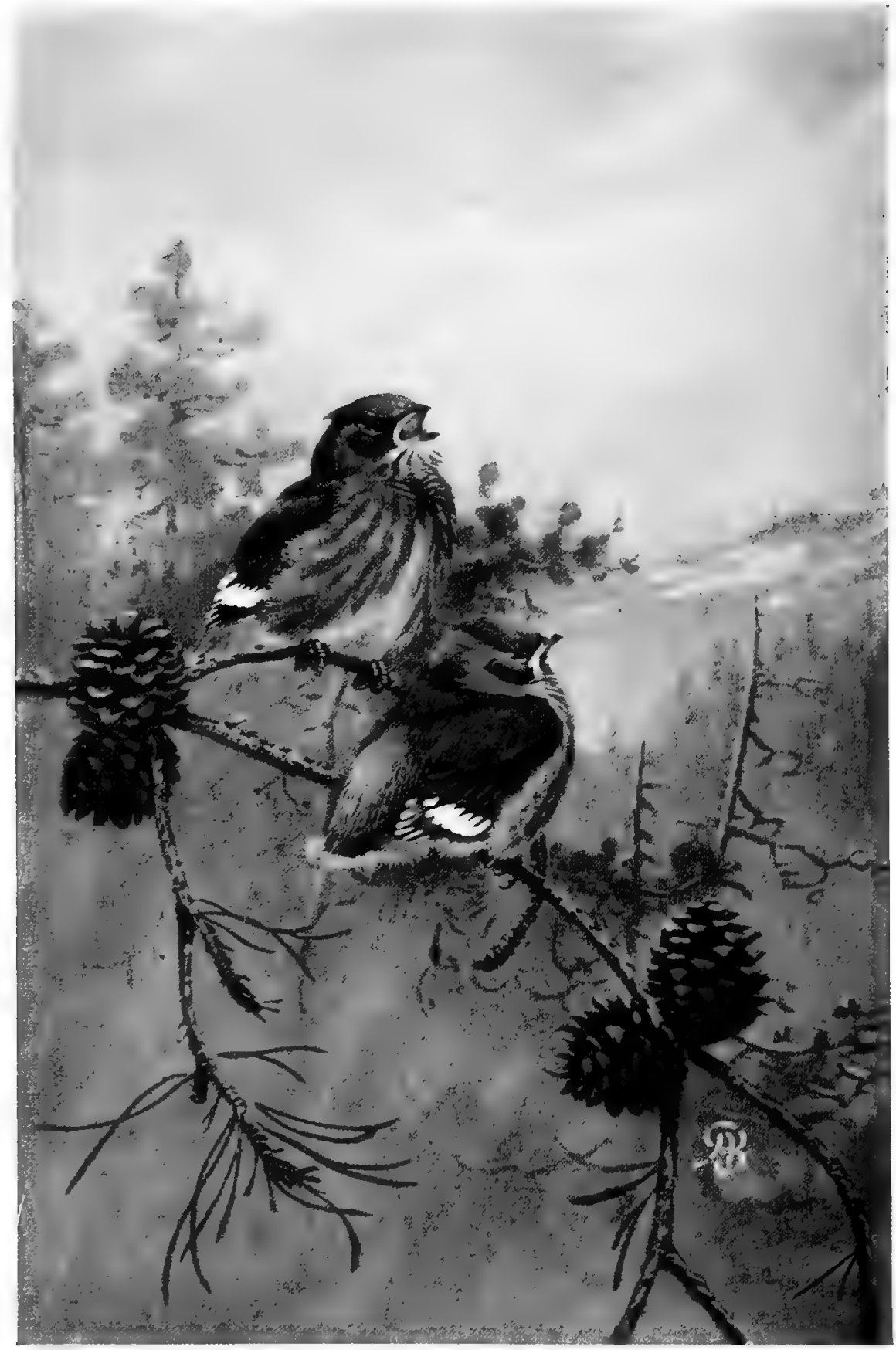

Young of the Bohemian waxwing (Bombucilla garrula pallidiacps) just out of tho nest. Figured from specimens collected near Telegraph Creek, July 5, 1919. Upper, female; lower, male. The young birll possesses the same wing and tail markings as loes the altult, with the yellow areas more vivid; the inside of the mouth is brilliantly colored. 


\section{BIRDS AND MAMMALS OF THE STIKINE RIVER REGION OF NORTHERN BRITISH COLUMBIA AND SOUTHEASTERN ALASKA}

BY

H. S. SWARTH

(Contribution from the Museum of Vertebrate Zoology of the University of California) 
University of California Publications in Zoology

Vol. 24, No. 2, pp. 125-314, plate 8, 34 figures in text Issued June 17, 1922 


\section{BIRDS AND MAMMALS OF THE STIKINE RIVER REGION OF NORTHERN BRITISH COLUMBIA AND SOUTHEASTERN ALASKA}

BY

H. S. SWARTH

\section{CONTENTS}

PAGE

Introduction 126

Itinerary and descriptions of localities ................................................................ 130

Topography of the region and its bearing upon animal life

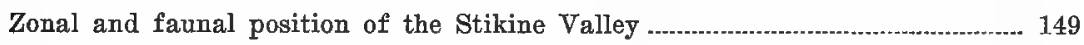

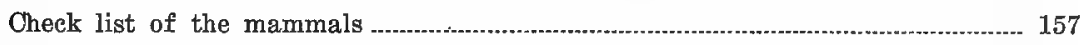

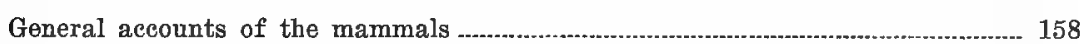

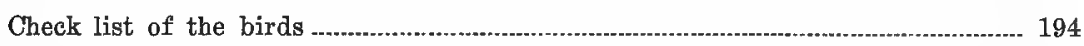

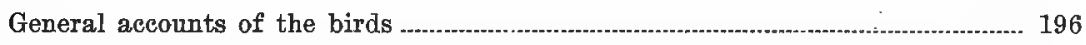

Literature cited 


\section{INTRODUCTION}

In years past the Museum of Vertebrate Zoology has conducted several expeditions to the coast of southeastern Alaska, covering in all a large part of that district, and one to Vancouver Island, British Columbia, nearby and of somewhat similar character. ${ }^{1}$ As one result of this field work the Museum has obtained a representative collection of the birds and mammals of this strongly characterized northwestern coast region of North America. Of the closely adjacent interior of British Columbia, however, the Museum contained no specimens whateyer.

In a general way it has been understood that the faunas of the coast and of the interior are markedly different, that the boundary between the two is sharply defined, and that this boundary lies very near to the coast. It is obvious that collections could be made over a relatively limited area and still include a strip of country extending from the one region to the other. Such an expedition would supply series of specimens of species new to the Museum collections or but scantily represented therein, and would also provide valuable data regarding distribution, especially with respect to the behavior of animal forms at the margins of their habitats.

The valley of the Stikine River seemed to satisfy all requirements. It crosses the boundary between the two faunal areas, and, piereing the formidable barrier of mountains that intervenes, affords a feasible route from one region to the other. Furthermore, we already had extensive series of birds and mammals from the country about the mouth of the river, to supplement whatever collections might be made farther up stream. Dr. J. A. Allen (1903) had published a report upon a collection of mammals from the upper Stikine region, made by A. J. Stone and M. P. Anderson, but this collection had been gathered to the eastward of the debatable strip that we especially desired to explore.

The expedition thus outlined was made possible through the generous provision by Miss Annie M. Alexander, founder of the Museum of Vertebrate Zoology, of a sufficient sum to defray the cost, this in

1 Previous field work on the northwest coast has been prosecuted as follows: in 1906 on the Kenai Peninsula; in 1907 in the Sitkan district; in 1908 in the Prince William Sound region; in 1909 in the Sitkan district; and in 1910 on Vancouver Island. 
addition to her regular yearly appropriation for the maintenance of the Museum. Miss Alexander had long been especially interested in the natural history of Alaska and British Columbia and had herself personally participated in previous field work carried on in those regions by this Museum.

Our party consisted of two, the writer and Mr. Joseph Dixon, Economic Mammalogist of the Museum. Mr. Dixon collected most of the mammals and took entire charge of the photographic work, making this an important feature of the trip. He also supplied most of 'the notes regarding the nesting activities of various species of birds. The writer collected most of the birds, and worked with the mammals enough to enable him to better understand local conditions. The material collected consists of 534 mammals, 638 birds, 24 sets of birds' eggs (mostly with nests), 70 amphibians, 195 photographic negatives. The present report is concerned with the mammals and birds; the amphibians are not included.

In treating the birds I have followed the nomenclature of the American Ornithologists' Union Check-List (1910) and its supplements $(1912,1920)$, with some modifications. I have made no attempt to be "up to date" in the adoption of the scores of changes proposed of recent years, not yet acted upon by the Committee and regarding which I have no new facts to offer or upon which I cannot form an independent opinion. There are certain cases, however, dealing mostly with matters of ornithology rather than nomenclature, where the presentation of new facts or a new point of view, or the conviction of the correctness of the course of some previous writer, at variance with the Check-List, impels me to the use of names not included in that standard. This, it seems to me, is proper. These changes are thus formally presented for consideration, but their general adoption by others prior to action of the Committee is not expected, any more than I, myself, expect at once to adopt other changes regarding which I can have no personal knowledge. I have endeavored in every case at variance with the Check-List to indicate my reason for adopting the name in question. With mammals there is no such standard, and the opinion of the latest monographer of a group is usually accepted.

My sincere acknowledgments are due to a number of institutions and individuals for aid of one sort or another. For the prosecution of the field work I was generously granted by the following authorities permission to collect specimens of birds and mammals: the United States Biological Survey and the Dominion Parks Branch, Department 
of the Interior, Canada, for the taking of migratory birds; the United States Department of Agriculture, for game mammals in Alaska; the United States Department of Commerce, for fur-bearing mammals in Alaska; Mr. F. Kermode, Director of the Provincial Museum, Victoria British Columbia, for game and non-game birds and mammals in British Columbia.

I am under obligations to the Bureau of Biological Survey of the United States Department of Agriculture, through its chief, Dr. E. W. Nelson, for the loan of specimens, for the identification of certain species, and for the determination of the contents of bird stomachs. In this connection particular mention should be made of the identification of the shrews of the genera Sorex and Microsorex by Dr. Hartley H. T. Jackson, who examined all my material except four specimens in alcohol; and of the examination of a considerable number of birds' stomachs by Mr. Charles C. Sperry.

From the Victoria Memorial Museum, Ottawa, through Mr. P. A. Taverner, and from the Provincial Museum, Victoria, British Columbia, through the director, Mr. F. Kermode, I received the loan of specimens of various species of birds.

The plant names used in this report were supplied by Dr. F. J. Smiley, of the University of California Herbarium, based upon specimens collected on this expedition that have been deposited in the Herbarium.

Advice and information was received from Mr. Ernest P. Walker, an employee of the United States Bureau of Fisheries who was stationed at Wrangell, Alaska, at the time we were pursuing our field work in that region. Mr. Walker supplied data on certain species from the vicinity of Wrangell, and he has presented to the Museum of Vertebrate Zoology specimens of birds and mammals from the same region that are desirable additions to the Museum collection.

I take pleasure in expressing my gratitude to Mr. W. H. Dodd, government agent at Telegraph Creek, for assistance and advice during our stay in the region over which he has jurisdiction. 


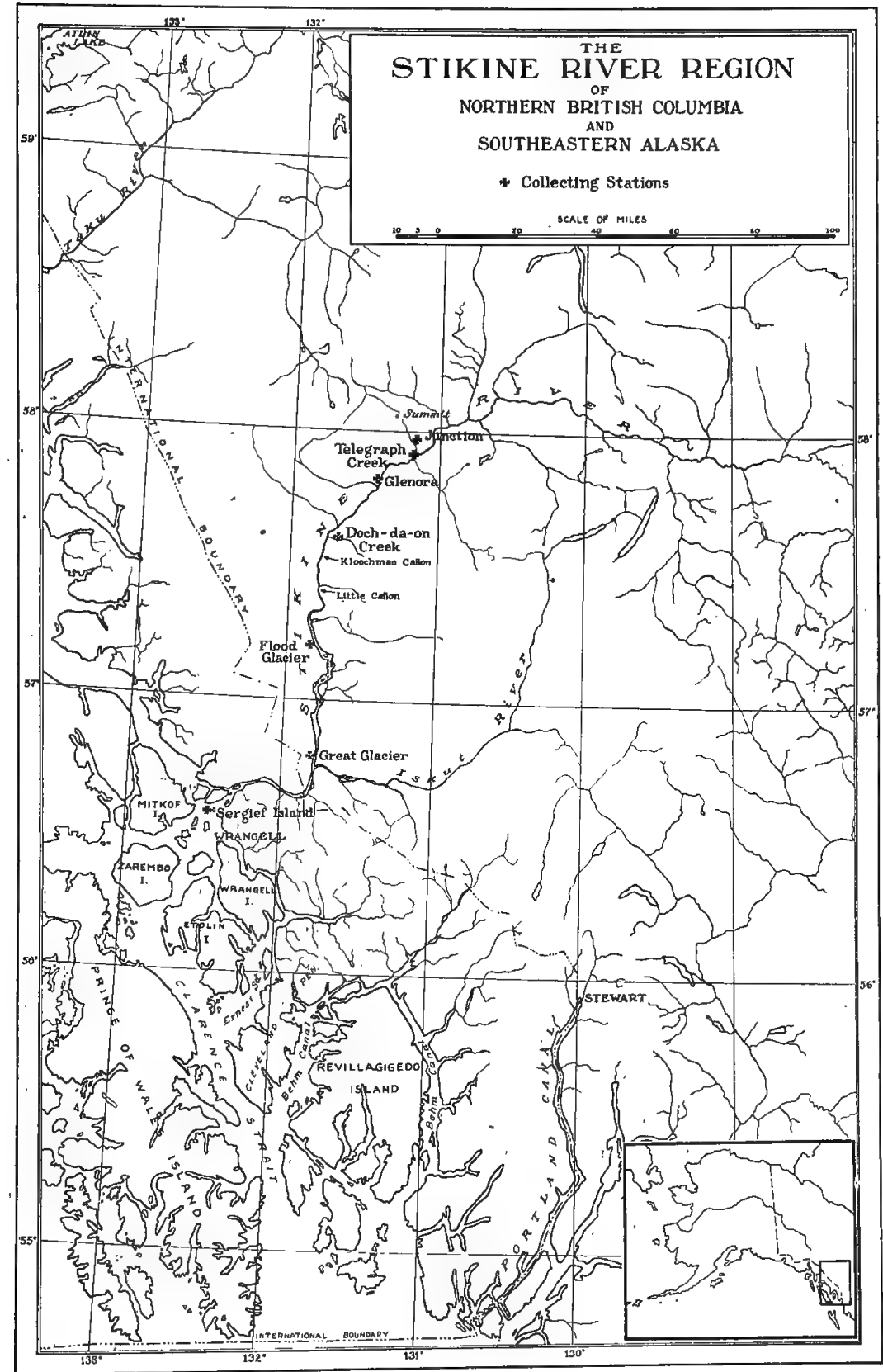

Fig. A. Map of the lower Stikine River, British Columbia and Alaska, showing stations from which collecting was carried on by the 1919 expedition from the Museum of Vertebrate Zoology: 


\section{ITINERARY AND DESCRIPTIONS OF LOCALITIES}

From Berkeley we proceeded directly to Telegraph Creek, the head of navigation on the Stikine River. There we made arrangements with the Barrington Transportation Company whereby their river boat, running on fairly. regular schedule, deposited us at various selected camp sites. Our collecting stations were carefully chosen, both with regard to their location on the river, and to the accessibility of stretches of surrounding territory. The last item is of importance in a wilderness as generally impenetrable as are the forests of the lower Stikine.

Our itinerary, in detail, was as follows: left Berkeley, May 14; left.Wrangell, Alaska, May 21; arrived Telegraph Creek, B. C., May 23 ; The Junction, May 25 to June 6; Telegraph Creek, June 6 to 26 ; Glenora, June 27 to July 8; Doch-da-on Creek, July 8 to 26 ; Flood Glacier, July 26 to August 8; Great Glacier, August 8 to 16; Sergief Island, August 17 to September 7 ; Mitkof Island, August 26 to 29; arrived Berkeley, September 15.

\section{TELEGRAPH CREEK}

The town of Telegraph Creek is on the north bank of the Stikine River, about 130 miles from, and 540 feet above, tidewater (Brooks, 1906, p. 49). It is about 160 miles from the general line of the coast at the mouth of the river, following the course of the stream; less than half that distance in an air line from the nearest point on the coast. Telegraph Creek, the stregm, flowing from the north, empties into the river at this point. Near the town the river banks rise steeply on either side to a series of terraces beyond: At many points these enclosing walls are sheer cliffs of basaltic rock, several hundred feet high, with long steep taluses extending below, sometimes to the river's edge. Telegraph Creek, for the last mile or two of its course, flows along a narrow cañon, the steep walls rising abruptly to the level terraces above. In its upper reaches it follows a cañon the walls of which are not particularly steep. The stream has its source in a string of lakes at "the Summit," some twelve miles north of the point where it empties into the Stikine, at an altitude of about 2600 feet. The mountains rise to a much greater height on either side. About two miles northwest of the town of Telegraph Creek is Sawmill Lake, about a mile long. Four or five miles farther west lies the much larger Alkali Lake. 
In the Telegraph Creek region the principal feature of the vegetation is the poplar woods. Poplars grow everywhere in the lowlands, sometimes in almost pure stands with but a sprinkling of other trees, and for miles in extent. In swampy places willow thickets form dense growths that are hard to penetrate. On some of the drier ridges these willows form open woods that are quite easy to traverse, composed of rather large trees, widely spaced and with little brush below. At some points there are stretches of dry, gravelly benches, with a sparse growth of small lodgepole pines (Pinus contorta) and here and there a few cottonwoods, birches, and poplars, with very little undergrowth and all together very park-like in appearance.

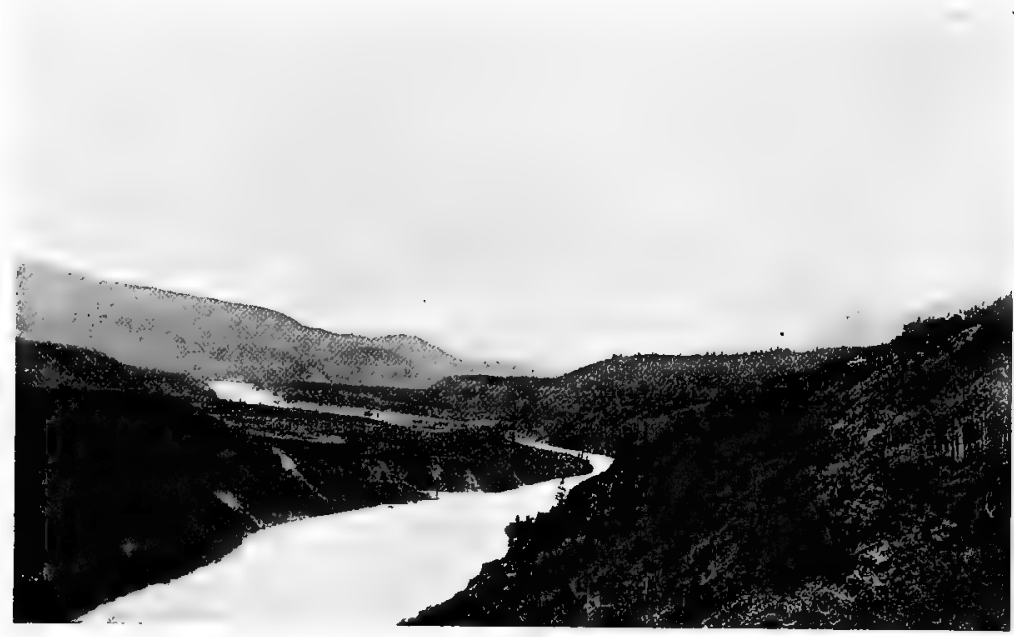

Fig. B. Looking down the Stikine River from a point about a mile below Telegraph Creek, just above the junction of the First South Fork. The Stikine today follows the same general course to the sea as it did before the present coastal ranges were elevated; the river valley was cut deeper and deeper during the slow uplift of the mountain barrier. In the Telegraph Creek region, here shown, the valley consists of a series of sharply defined terraces, rising step by step from the river to the bases of the mountains on either side. These terraces presumably indicate the level of the river at different periods of its history. Photograph taken June 24, 1919.

The valley on the north side of the river, extending west and south at least as far as Glenora, is relatively level with a few low hills and ridges here and there, stretching from the abrupt banks that border the river up to the higher mountains some miles to the northward. This rolling country is nearly all covered with forest of poplar, willow, cottonwood, and birch, and a few scattered pines. In places the woods are quite dense; sometimes fairly open; some of the hills and ridges are 
quite destitute of trees. There are occasional small lakes, and here and there marshes and small streams. s

On the drier slopes and ridges two species of juniper occur, Juniperus communis var. sibirica and Juniperus horizontalis, both to be seen in abundance from the river bank up to the Summit. Both species grow as rather low, rounded bushes. On the higher mountain slopes are groves of spruce and balsam fir, extending downward in cool, shaded cañons, as along Telegraph Creek, or occurring sometimes as

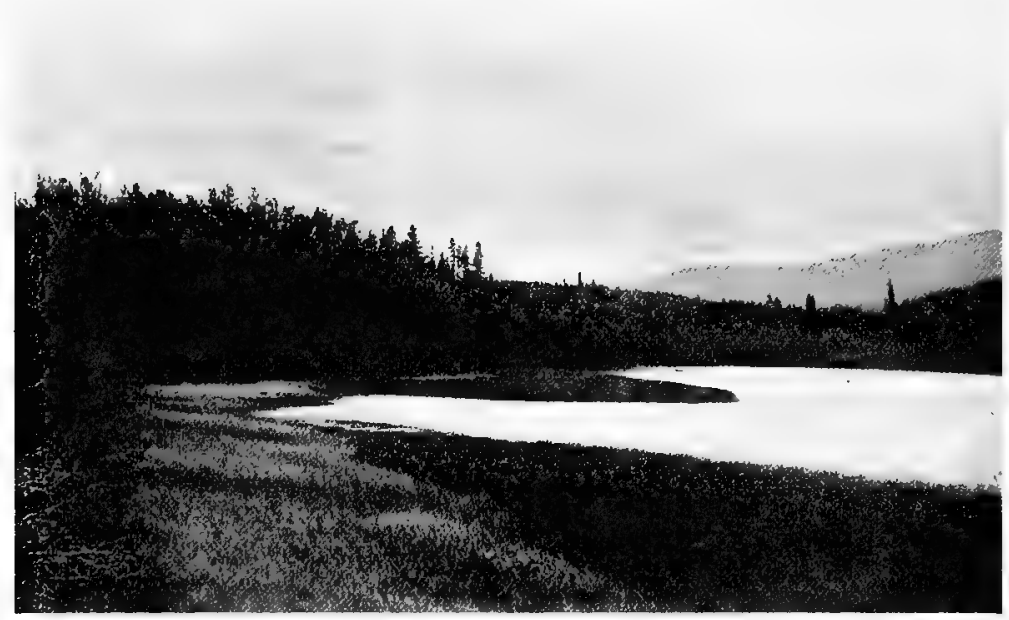

Fig. C. East end of Sawmill Lake, near Telegraph Creek. Mammals that especially frequent the grass and bushes about the shores of the lake are shrews (Sorex personatus personatus and $S$. obscurus obscurus), Drummond meadow mouse, and Stikine jumping mouse. Birds that nest amid the same surroundings are the spotted sandpiper, alder flycatcher, rusty blackbird, rusty song sparrow, and Forbush sparrow. The lesser yellowlegs was seen feeding about the shores of the lake, but apparently was not nesting there. Grebes; loons, and ducks were seen daily upon the lake during June and probably were nesting. Photograph taken June 20, 1919.

small, isolated clumps on some north-facing slope well down in the poplar forest.

Of low-growing shrubbery, a conspicuous plant of the drier slopes is Shepherdia canadensis (locally known as soapberry), which forms dense thickets of considerable extent. The berries are an important bird food. The wild cherry (Prunus demissa) was another noticeable plant, forming dense thickets along the banks of the stream near the town, the bushes from three to six feet high and, by the middle of June, a mass of white flowers. The service berry (Amelanchier florida) grows abundantly, forming bushes from four to ten feet high, 
and also blooms before the middle of June. Wherever land had been cleared and allowed to go back to a wild state, there were dense growths of lupine.

\section{THE JUNCTION}

Years ago a road led from Glenora, skirting the base of the hills and joining the trail from Telegraph Creek at the Junction, four miles from the Stikine, up Telegraph Creek. The old road has long been in disuse, and most of it is now a poorly defined trail, used by moose

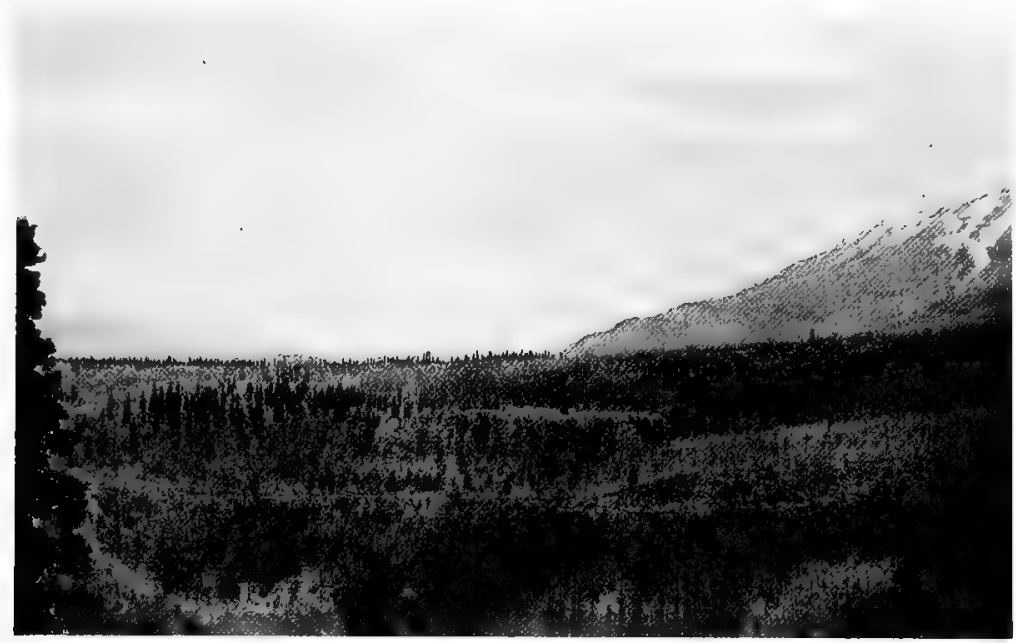

Fig. D. Type of country seen in the lowlands of the Telegraph Creek region. The terraces extending from the Stikine River northward to the mountains are covered mostly with poplar woods. Here and there clumps of spruce occur, with occasional groves of lodgepole pine. At the time this photograph was taken, May 26, 1919, and at the point shown, near the base of the hills, the poplars had not yet leaved out, though four miles to the westward, near the river, the trees were green with foliage. Telegraph Creek, the stream, flows along the bottom of the narrow cañon in the foreground.

This is the habitat of moose, bear, and red squirrel, among mammals, of Hammond flycatcher, Cassiar junco, robin, hermit thrush, and long-tailed chickadee, among birds.

and other wild animals, but seldom by man. At the Junction there is a small meadow by the side of the stream, and there we camped. Just above this point the hills begin to rise rather abruptly.

The Junction was our first collecting station. In some respects we would have done better to have stayed near the river, for though the distance was short and the altitude at the Junction but little higher, there was an appreciable difference in temperature between the two places, which was reflected in the plant life and in the birds. While 
the air was warm on the Stikine, and most of the trees and bushes well leaved out, at the Junction the temperature was below freezing each night, and the deciduous trees and shrubbery were all bare or just beginning to show bursting leaf buds. Still higher, at the Summit, the lakes were almost entirely ice covered, and there were deep snowdrifts on all sides. The snow was melting in the daytime, however, and the meadows as a result were nearly all flooded.

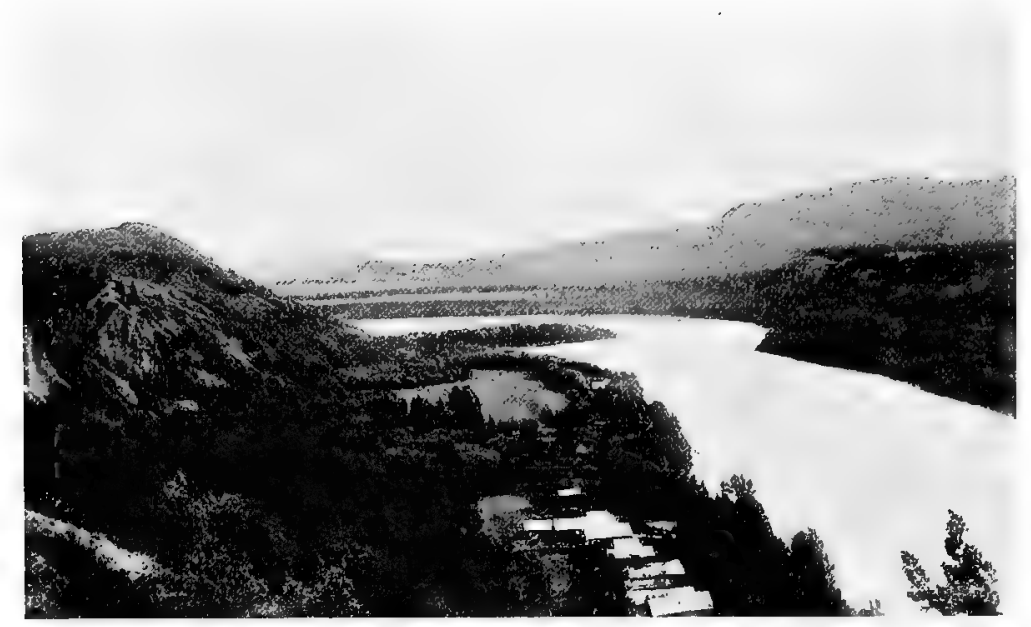

Fig. E. Looking up the river from Glenora, fifteen miles below Telegraph Creek. Here there are extensive tracts of open meadow land, much of it covered with grass and wild strawberries, parts of it densely grown up with lupine and fireweed. Bordering river and meadows are rows of tall cottonwoods rising above thickets of alder and willow. Poplar is the predominant tree of the drier ground. The mountains immediately to the eastward are low and rounded, in striking contrast to the high, jagged peaks of the coast range, which rise but a short distance west of this point. Photograph taken July 6, 1919.

\section{GLENORA}

Fifteen miles down stream from Telegraph Creek, on the west side of the river, lies Glenora, a deserted village. Years ago this was the metropolis of the region, but circumstances caused the entire population to move to Telegraph Creek. The houses were mostly of logs, material that could not be moved, and they stand there today, slowly succumbing to decay, a refuge for white-footed mice and bushytailed wood rats.

Glenora occupies a strip of flat ground several hundred yards in width, extending for perhaps a mile along the river, the stream in front, steep banks behind, two or three hundred feet high, rising to a 
series of terraces above. This low-lying strip is but slightly above the normal high water mark of the river.

There are extensive tracts of open meadow land, some of it grass covered, other parts densely grown with lupine and fireweed (E bium angustifolium). The fireweed in particular grows densely and to a great height everywhere about the houses. There are places acres in extent covered solidly with wild strawberry plants. Bordering the meadows and along the river banks are rows of tall cottonwoods

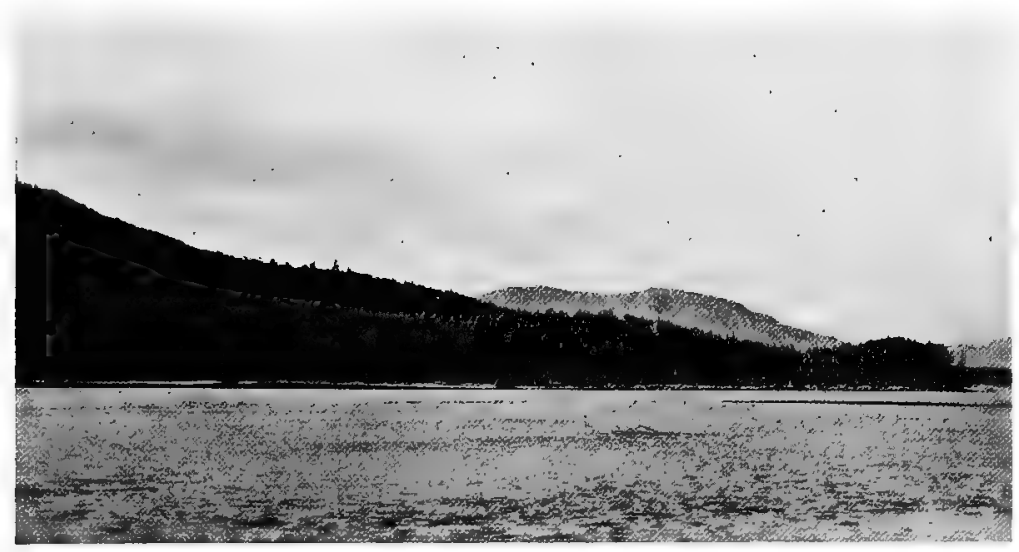

Fig. F. The Stikine River just above Grand Rapids, about fifty miles below Telegraph Creek and about 110 miles from the mouth of the river. Here the Stikine begins its passage through the Coast Range, the mountains rising steeply and to great heights on either side. Coastal conditons begin to be apparent, more in the character and density of the vegetation than in the animal life. On the west bank of the river, shown in the photograph, coniferous woods extend down to the water's edge. On the east side poplar and birch prevail, trees that do not extend much farther down stream. Photograph taken July 20, 1919.

(Populus trichocarpa), in the wet places are thickets of alder, and elsewhere mixed woods, just as about Telegraph Creek.

Glenora Mountain lies north of the town, rising abruptly from the terraces bordering the river. It is a long ridge, rather than a peak, much of the summit ascending well above timber line.

\section{DOCH-DA-ON CREEK}

Some thirty miles south of Glenora is Doch-da-on Creek, flowing into the Stikine from the southeast, just above Grand Rapids. Here is the ranch of Mr. and Mrs. Frank Jackson, where we made our camp.

Doch-da-on Creek emerges abruptly from steep rocky walls at the base of a mountain, then, before reaching the river, flows for about a 
mile along a broad, gravelly, rock-strewn wash. Half a mile to the northward, a branch of the Stikine nearly as wide as the main stream enters from the east. This branch is the outlet of a slough that begins some miles farther north and passes behind a series of islands. The Jackson ranch thus occupies a peninsula between the creek and the slough, a low-lying flood plain resulting from the deposits of the creek.

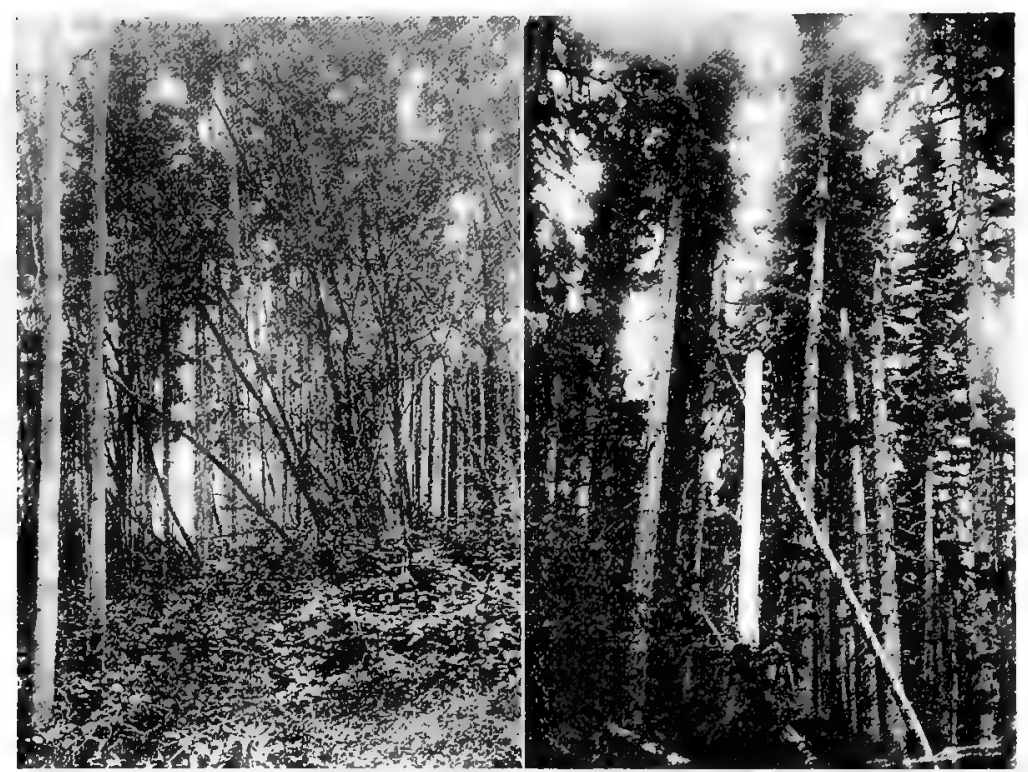

Fig. G

Fig. $\mathrm{H}$

Fig. G. Poplar woods along shore of Sawmill Lake, near Telegraph Creek. Poplars grow quite densely and sometimes in nearly pure stands, though there is often an admixture of willow. Bird species that particularly frequent this type of woods are the ruffed grouse, northern flicker, western warbling vireo, yellow warbler, Tolmie warbler, American redstart, and olive-backed thrush. Photograph taken June 19, 1919.

Fig. H. The spruce woods of the middle altitudes on the mountain sides are made up of large sized trees and occupy a well defined area above an altitude of about 1500 feet. In the woods here shown we saw the goshawk, western winter wren, short-tailed chickadee, ruby-crowned kinglet, Alaska hermit thrush, and northern varied thrush. At the upper edge of the timber the Fleming grouse was seen. Photograph taken on mountain above Doch-da-on Creek, July $23,1919$.

On the east side of the river the mountains lie back a mile or more from the stream, rising by alternate stretches of rather gentle slopes and much steeper pitches, to ridges far above timber line, probably 4000 feet altitude and higher. On the west side of the Stikine, just 
opposite, rocky walls rise abruptly from the water's edge; exposed granite cliffs and steep, forested slopes reach to a height of perhaps 1500 feet, then a stretch of gentler slopes ascends to the base of the higher mountains beyond.

Vegetation here is of the interior, but the underbrush is much denser than we found it farther up the river. Alder thickets cover large areas of the bottom lands and poplar groves the lower slopes of the hills. Fir (Abies amabilis) grows in abundance down to the level of the river, forming groves of considerable extent, mixed with

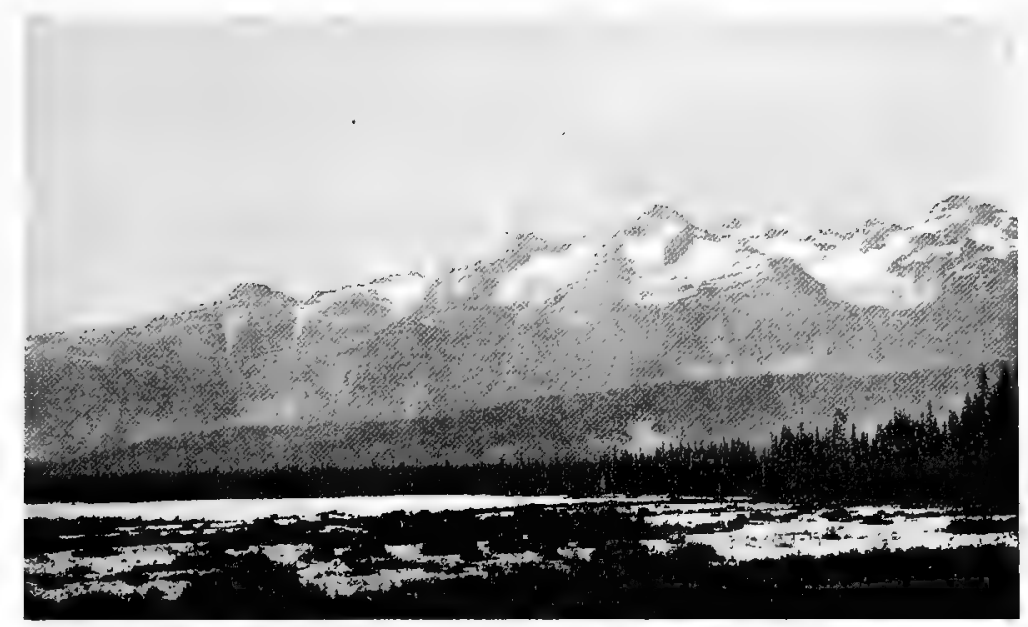

Fig. I. Stikine Valley from Flood Glacier; view toward the river from the front of the glacier. The opening in the foreground, the present terminal moraine, owes its snowy appearance to the white, glacier-polished rocks with which the ground is strewn; there was no snow at that level. The ridge in the middle distance is on the far (east) side of the Stikine. On the upper slopes of the distant mountains there is a series of hanging glaciers, with running streams descending from each one. Photograph taken August 1, 1919.

some spruce. There are also cottonwood, willow, and birch, all growing to large size, and, of smaller trees, mountain ash (Sorbus sitchensis) and maple (Acer douglasii).

On the mountainside above we found a well defined belt of spruce timber of large size, above that a belt of scrubby and prostrate balsam (Abies lasiocarpa), and still higher an area that is destitute of any trees or bushes, given over to heather, moss, and grasses. 


\section{FLOOD GLACIER}

Flood Glacier is on the west side of the Stikine, approximately fifteen miles below the Little Cañon, and about seventy miles from the coast. Its terminal moraine is about two miles back from the river. Our camp here was below the southern end of the glacier, on a knoll by the river frequently used as a camp site and locally known as "the barley cache." We found ourselves here amid conditions very similar to those on the seacoast, in a dense forest of spruce and hemlock, with thickets of alder and devil's-club in the wet places and of

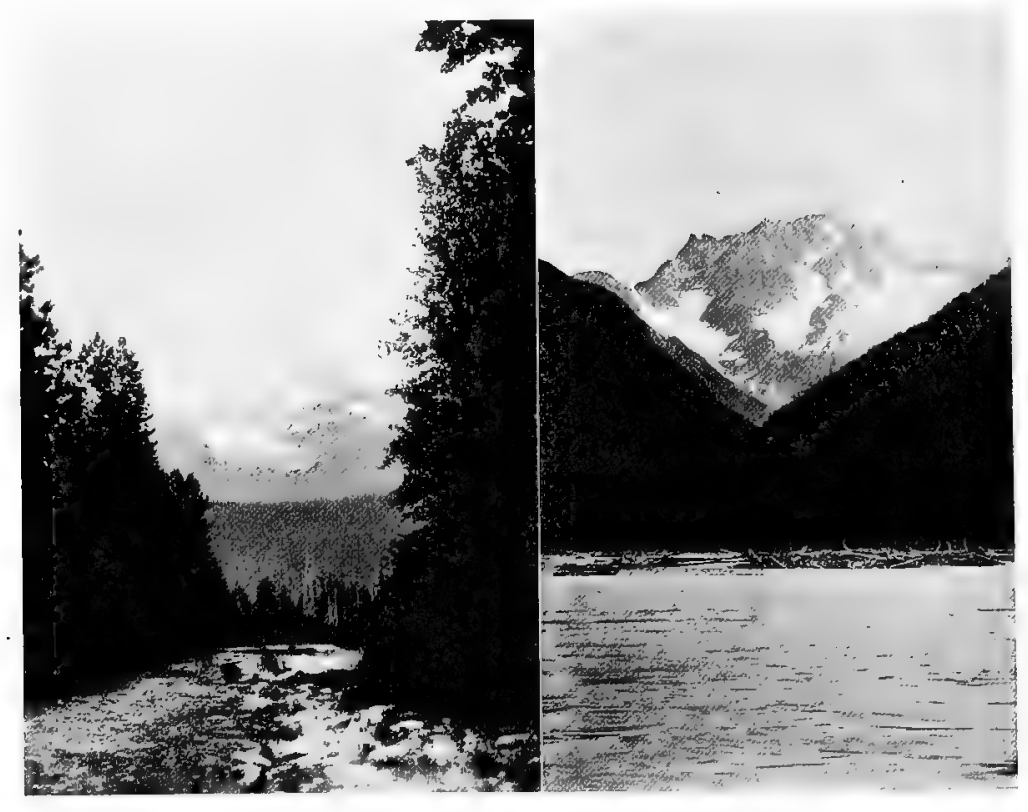

Fig. J

Fig. K

Fig. J. Clearing through the forest below Flood Glaeier. The woods here are so dense as to be all but impassable. Immediately below the glacier, however, there are several straight, open lanes, extending down nearly to the river's edge, apparently ploughed through the woods by descending masses of ice or rocks. These lanes are used as avenues of travel by moose and bear, as indicated by the tracks. We also found far more small birds in such openings than in the surrounding woods. Photograph taken August 1, 1919.

Fig. K. Mountain opposite Great Glacier at its southern extremity. This point, some thirty miles from the sea, is in the heart of the Coast Mountains; the peaks and ridges here seen form the very backbone of the range. The higher crests, jagged and unworn, apparently never were glacier-covered. The sheet of ice may be seen today, below the summit of the range, extending for many miles as a series of disconnected hanging glaciers, all at about the same level. (See also fig. I.) According to Indian legend, an ice bridge extended across the Stikine at the point here shown at a not very remote time. Photograph taken August 9, 1919. 
huckleberry in the drier woods. The only open ground was found in some long, narrow lanes extending down from below the glacier, where apparently strips of forest had been swept away by avalanches of ice or rocks.

The moraine consists of huge, angular rocks massed in ridges and is largely hidden by forest growth, which extends close to the glacier. Large spruce and hemlock trees grow between the rocks, and devil'sclub, salmonberry, and other shrubbery cover the surface of the boulders. Most of the depressions were flooded by beaver ponds, with surrounding borders of alder.

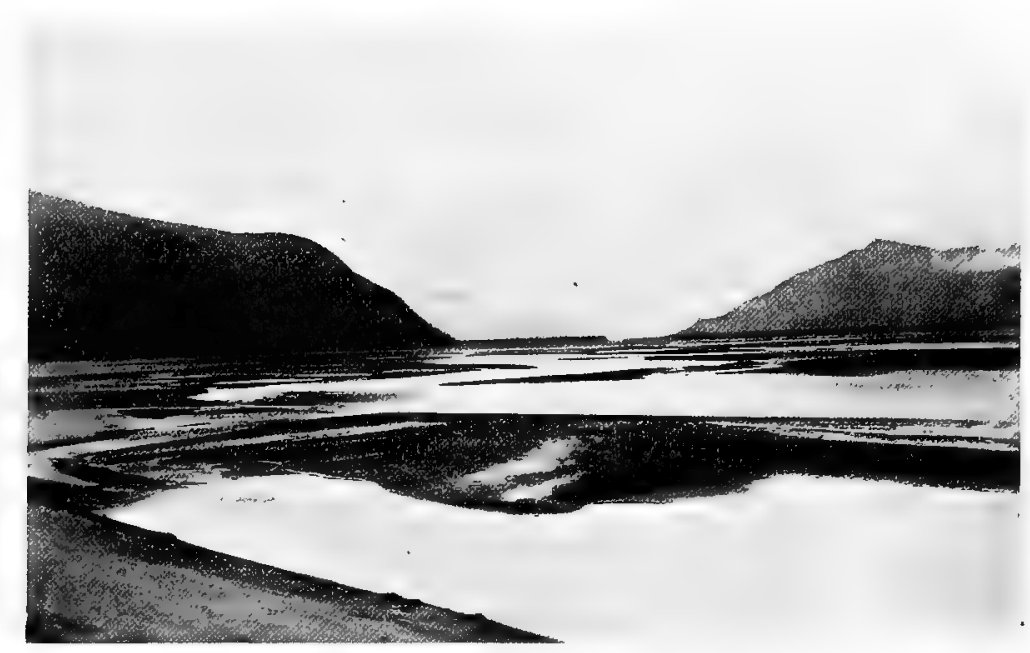

Fig. L, Mouth of Stikine River at low tide. The ocean tides ascend many miles up stream. At low water extensive sand bars are exposed at the river's mouth; the channel is then broken up into numerous small, shallow passages, impassable to even a very small boat. Photograph taken at Sergief Island, Alaska, September 5, 1919.

\section{GREAT GLACIER}

The fanlike front of the Great Glacier, four or five miles across, issues from the mountains on the west side of the. Stikine about fifteen miles above the British Columbia-Alaska boundary line. Our camp site was below the southern end of the Glacier. The river bank at that point is rather high and abrupt, cut through a deep layer of gravel that extends back to the terminal moraine of the glacier. This dry, well drained strip is not of a nature to support such forest growths as we found below Flood Glacier, and the woods were fairly open. There are extensive areas grown with scattered thickets of alder and a few scattered spruce and cottonwoods, the open ground between being 
covered everywhere with thick, soft lichens, carpet-like in their effect. On strips of damper ground nearby the spruce forest had secured a foothold, with the accompanying tangle of devil's-club and alder underneath.

Immediately below the glacier, fed by the melting ice, a string of little ponds extends, barren of vegetation and surrounded by low, rounded hills of gravel and rocks. Streams issuing from these ponds flow over gravelly beds to the river, a mile or more distant.

\section{SERGIEF ISLAND}

This islet lies at the mouth of the Stikine, about eight miles north of the town of Wrangell. The main rocky mass of the island is about a mile in its greatest diameter. On the north and east sides, toward the river, there is a flat belt of sandy soil, half a mile or more across, that lies at a level above even the highest stage of river or tide at the present time. This strip has some timber upon it, cotțonwood, spruce, alder, and willow, but is mostly grown with tall grass and pea vines. The river flows close to the island. There are no mud flats on the east side, but extensive sand bars are exposed at low tide. The rocky backbone of the island rises abruptly from the surrounding marsh, and is covered with the dense forest growth characteristic of the Sitkan district. Spruce is predominant in the woods, with tangled undergrowth beneath, in which devil's-club is most prominent. At the edge of the woods is a fringe of alder, these bushes diminishing in size and density as salt water is approached. At the upper edge of the tidal flats the alders give way to scrubby willows, which extend far out on the marshes, over much of the ground that is not regularly inundated by the tides. Alders and willows together form a relatively narrow strip surrounding the island, and beyond the last straggling bush the grass-covered marsh land extends. Part of this marsh land is covered by salt water every day, part of it only by the highest tides. Large areas are covered by the marsh grass to the exclusion of all other vegetation; in places it grows taller than a man's head. Toward the higher ground, where there is much fresh water, this tall, coarse grass is absent, and there is a covering of shorter growths, composed of a number of different plants. This higher area is dotted with small ponds, some surrounded by reeds. Beyond the margin of the marsh grass are the bare mud flats, exposed only at low tide. The marshes throughout are intersected by numerous channels, of varying depth and width, extending upward from the low water mark in many cases clear to the rocky center of the island. 
Sergief Island is the home of Mr. W. E. Parrott, who has cleared a small tract of land and for some years has successfully raised garden. vegetables and ginseng. We established our camp in a cabin in the woods about a mile from his place. From Sergief Island, Dixon, in company with Mr. Parrott, made a four days' trip to Blind Slough, Mitkof Island, ten or twelve miles to the westward.

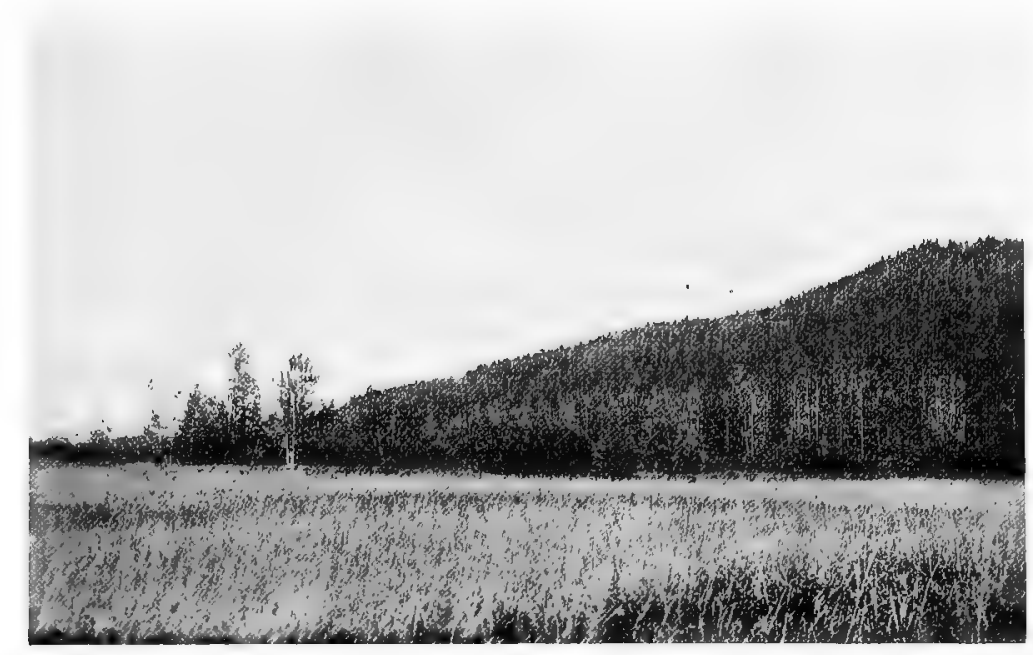

Fig. M. Sand flat at eastern end of Sergief Island, Alaska. On that side of the island, deposition of sediment from the Stikine has resulted in the building up of a strip of sandy soil that now lies above the level of the highest stage of river or tide. This strip is grown up with tall grass and pea vines. At the landward margin there are bordering thickets of alder and willow, and groves of cottonwood. Beyond, steep slopes arise, covered with spruce. The tall grass was the haunt of the rusty song sparrows. The bordering thickets at the time of our visit harbored numbers of migrants, such as the golden-crowned sparrow, Oregon junco, lutescent and Townsend warblers, dwarf hermit thrush, northwestern robin, and varied thrush. Photograph taken August 20, 1919.

\section{TOPOGRAPHY OF THE REGION AND ITS BEARING UPON} ANIMAL LIFE

The Stikine River rises in northern British Columbia east of the Coast Range and flows southerly and westerly to the Pacific. Its headwaters interlock with those of the Liard and with streams that flow into the Yukon. Thus, the height of land that traverses northern British Columbia serves as a divide between several great river systems. The Liard flows northeastward through the Rocky Mountains to the Mackenzie, which flows into the Arctic Ocean; the Yukon flows north- 
westward to Bering Sea; on the west, the Taku, Stikine, and Skeena rivers follow parallel courses westward through the Coast Range to the Pacific. Headwaters of all these streams rise from nearby points in northern British Columbia.

For some distance from its source the Stikine flows from east to west, following fairly closely the 58th parallel of latitude, and receiving from time to time tributaries of considerable size. In the Telegraph Creek region the river gradually turns, first toward the southwest, then almost due south. Some twenty miles from the coast, about at the British Columbia-Alaska boundary, it bends sharply to the westward once more, and reaches salt water near the town of Wrangell, amid the network of islands forming the Alexander Archipelago.

A tributary of importance to the upper Stikine is Clearwater Creek, entering from the northwest some thirty miles below Telegraph Creek. Near the Boundary there is a small stream that is locally called "Clearwater Creek," and there is apt to be confusion between the two if the facts are not known.

Our work did not take us above the middle Stikine Valley, with its uppermost limit at Telegraph Creek. In this section, from Telegraph Creek down stream nearly to Doch-da-on Creek, the valley is rather broad, the mountains rising at a distance on either side. Just south of Doch-da-on Creek the Stikine begins its passage through the Coast Range. The valley, already much narrowed, becomes still more constricted; some five miles below Doch-da-on Creek the river is hemmed in between the rocky walls of Kloochmap Cañon, the uppermost of the two narrow gorges through which the Stikine passes in the lower part of its course. The mountains from this point on become much higher and more precipitous. From Doch-da-on Creek looking northward and eastward the valley is broad in extent and the mountains are relatively low and rounded. Many of the summits are bare of snow during the summer months. To the southward and westward a jumbled mass of jagged peaks and ridges arises, forbidding in the extreme, and pressing closely in upon either side of the river.

Where the Stikine passes through the mountains, the river valley is exceedingly rough and covered with a forest that is virtually impenetrable. In this connection it is of interest to quote some statements of Emmons (1911, pp. 9-10) in his description of the country of the Tahltan Indians, who occupy the region of the upper Stikine.

The lower valley of the Stikine from just, below Glenora to the coast, a direct distance of about eighty miles, is included within the coastal range and constitutes a region of great humidity, with leaden skies and an annual precipitation 
equalling if not exceeding that of the coast which reaches a mean of eighty-six inches. The snowfall thereabouts is excessive, and accounts for the extensive glaciers that fill the valleys; and long after spring has opened in the colder interior the lower river flats are covered, with their burden of snow and ice . . . . . Forests of spruce, fir, cedar and hemlock cover the mountain slopes to the limit of tree growth, while in the river valleys cottonwoods grow to considerable size, and groves of alder and willow, with the devil's club and berry bushes, form an almost impenetrablo barrier. . . . . It may be pertinent to remark here, that this region which may be characterized as the wet belt has never been inhabited by either Tabltan or Tlingit in the sense that they have permanently occupied it and it is scarcely more popular as a hunting ground owing to its porrerty and inaccessibility.

At the mouth of the river and in the channel beyond there are numerous small rocky islands. Surrounding these centers there are miles of meadow, marsh land, and mud flats, resulting from the deposition of silt by the river. During the period of high water. in midsummer the stream is gray and opaque with silt carried in suspension, and this silt has been dropped in the channels immediately beyond the river's mouth until they are well-nigh filled.

A conspicuous forest tree of the lower Stikine is the cottonwood. This tree covers all the low ground near the water, grows densely and to a large size. It finds a foothold on sand bars and aids in the building up of such areas into more stable bottom land. Consequently, there are hundreds of acres of cottonwood in almost pure stands but slightly above the level of the river or even submerged at the highest water. East of the Coast Range, cottonwood is much less conspicuous than along the lower river, though still persisting in considerable numbers.

In the country in general at the mouth of the Stikine, the Sitka spruce is the dominant tree. This tree, with other associated conifers, extends some distance up stream, forming an evergreen forest that covers all but the unstable bottom land where the quick-growing cottonwoods occur. Where rocky slopes rise abruptly from the river's bank, the conifers range down to the water's edge. The higher ground back from the first bottom is covered densely with woods of spruce and hemlock, and with undergrowth of devil's-club, alder, and huckleberry. Such woods extend with but slight breaks to a point a little above the Little Cañon. Farther inland the spruce woods ascend higher and higher on the mountain sides, until at Doch-da-on Creek the lower limit of this belt lies at an altitude of about 2000 feet. Somewhere below Doch-da-on Creek the Sitka spruce of the coast gives way to other conifers of the interior, but just where this happens we did not ascertain. On the upper Stikine, poplar becomes the dominant growth of the valley, mixed, here and there, with groves of conifers or of cottonwood. 
The Sitkan district of southeastern Alaska is characterized by excessive humidity and by relatively equable temperature. The annual rainfall at many points is 100 inches or more, the number of rainy days per year around 200. There is a great deal of foggy and cloudy weather. The winters are not extremely cold nor are the summers very warm. The vegetation of this region is comprised mostly of an extremely dense growth of coniferous forest trees, and, beneath the trees, underbrush almost tropical in its luxuriance. The Sitkan district is here considered as including the islands between Cross Sound and Dixon Entrance, together with a narrow strip of the adjacent mainland coast. Its eastward limits are sharply defined by the towering and precipitous range of mountains that, rising abruptly from the shore, parallels the coast. To the eastward of this Coast Range, in the interior of British Columbia and Alaska, is a region of widely different character. I have not exact meteorologic data for this section, but certain general facts are obvious. Dawson (1889, pp. 58b-59b) remarks on this subject as follows:

It may be stated here, as showing the broad general contrast, that while the annual precipitation at Wrangell, at the mouth of the Stikine, is over sixty inches, that in the vieinity of Telegraph, Creek on the inland side of the mountains, is so small that it is necessary to irrigate cultivated land. Nor does this comparison of rain-fall suffeiently mark the great diversity which actually obtains between the two climates, the prevalence of clouded skies in the coast region being accompanied by a saturated state of the atmosphere, while precisely opposite conditions are found on the eastern side of the mountain belt, at not more than eighty miles inland from the general line of the coast.

The country east of the mountains is subject to far greater extremes of temperature than the coast region, with hot summers and with extremely cold winters. The forest covering includes a considerable proportion of conifers, but there is also a still larger proportion of deciduous timber. The animal life in these two regions, the Sitkan district of the coast and the adjacent interior, is widely different.

The valley of the Stikine forms a highway between the two faunal areas, otherwise separated by physical barriers and sharply contrasted in nearly all particulars, though lying in close juxtaposition. The presence of this channel of communication affords excellent opportunity for observation of the geographic behavior of the many animal species that by this means are permitted an outlet in either direction. Certain contrasted species and subspecies oceupying comparable positions in each of the two faunal areas are brought together, and thus into competition; others with no such direct rival in the adjacent area are brought into contact with climatic conditions, adverse in that they are unaccustomed. 
The Stikine is one of several large rivers of the northwest that break through the Coast Range at right angles to the lines of those mountains, their valleys thus lying transverse to the main lines of the range. In a published report upon the geology of Alaska, A. H. Brooks (1906) makes the following statement regarding the Copper, Alsek, Taku, and Stikine rivers: "These, together with the other large rivers of British Columbia, seem to traverse the coastal mountain barrier along valleys determined by antecedent conditions. Their lower valleys at least have the same direction as before the present coastal mountains were elevated, and the streams maintained their courses across the barrier during the slow uplift"' (p. 286). A.gain: "The valleys of the Stikine and Taku rivers, .... . which lie transverse to the Coast Range, have probably inherited their courses from a former mature drainage system which was developed on the old peneplain" (loc. cit., p. 287).

In this connection it is worth while to note the appearance of the river valley of the upper Stikine in the Telegraph Creek region. There, and for many miles down stream from that point, the stream is bordered by series of terraces, rising step by step to the base of the mountains beyond. Viewed from some overlooking height the course of any one of these terraces may be traced for a long distance. It seems obvious that they represent the level of the river valley at different periods of its history. (See fig. B.)

The evidence of the geologist goes to show that, diverse as the coast region and the interior are, as regards fauna and flora, the two have not been absolutely separated by the Coast Range at all times in the past any more than they are at present. A channel of communication through the mountains has been there continuously from very remote geologic times, save for a period when it must have been blocked by ice.

Presumably all animal life was swept from both regions when the whole country was glacier-covered. Presumably, too, conditions in the areas on either side of the Coast Range permitted the return of animals and plants from the southward when the mountains between were still mostly ice. Even now the range is glacier-covered over a large portion of its area. The higher peaks and ridges protrude, steep and serrated, far above the ice. From the jagged, unworn appearance of these higher crests they apparently never were covered. The sheet of ice as seen today lies below the summit of the range, and can be traced as a series of hanging glaciers appearing and re-appearing for many miles at about the same level, visible from the river below. In certain cañons and valleys, tongues of this glacial covering extend downward 
far below the general level, some of them to within a mile or two of the river. It cannot be such a very long period of time since ice blocked the entire valley. In fact, there are today legends among the Tahltan Indians of a time when an ice bridge still extended across the Stikine at the Great Glacier, connecting ice masses that are now perhaps four or five miles apart. Of course, as remarked by Dawson (1889, p. $53 b$ ) about this same tale, it is impossible to determine whether "this is a remembered fact or a fancied inference." (In this connection see also Emmons, 1911, p. 15.)

The hypothesis of a glacial blockade of communication between the interior and the coast would imply the separate derivation of the animal life of each. That is, that there was invasion from the southward on either side of the coast range, of the same or of different species, as the case might be. Doubtless, at a still later period, there was invasion of certain species from the northward as well. Among birds in particular detailed comparisons may be made (see fig $\mathrm{P}$ ), and upon comparing the avifauna of the interior and of the coast in the Stikine region, it will be seen that not only are comparable ecologic niches on either side of the mountains usually filled by different species rather than subspecies, but that frequently the species are not especially closely related. Furthermore, among the few cases where two subspecies of a species do occur abundantly on either side of the mountains, there is hardly an instance where we were able to trace intergradation along the connecting valley of the Stikine. In some few cases where the birds were abundant enough for us to ascertain the fact, it was evident that certain subspecies, at this particular point, met as distinct species. All this argues for invasion from the southward, on either side of the Coast Range, of bird species and subspecies that met at a much later period along such channels as the Stikine Valley.

The intrusion of a range of high mountains was productive of diverse climatic conditions in the two regions. This, in turn, resulted in differences in the reëstablished plant and animal life to a far greater extent than would follow from the mere presence of a physical barrier such as a mountain mass. Differences of temperature and of humidity arose, so that at the present time the two areas, east and west of the Coast Range, respectively, form strongly contrasted faunal areas (dependent upon relative humidity), and they are somewhat different zonaliy (dependent upon temperatures).

At a considerably later period than that at which the regions on either side of the mountains became habitable, conditions in certain 
of the river valleys traversing the barrier (as the Stikine) became such as to permit the existence of animal and plant life, and various species extended their ranges up or down such channels of communication, as circumstances permitted. One factor that may be of present importance in limiting the use of the Stikine Valley as such a channel, so far as birds are concerned, is the late advent of summer conditions on the lower Stikine compared with the regions on either side, a seasonal tardiness that unquestionably prevents the nesting of many species in this intermediate strip at the time of their arrival from the south. (In this connection see Dawson, 1889, p. 59b; Emmons, 1911, pp. 9-10.)

The general hypothesis outlined seems to accord with conditions as we now see them. Among birds it may be pointed out that it is consistent with the manner of occurrence of forms like Hylocichla ustulata ustulata and $H$. $u$. swainsoni, closely related subspecies of one species but behaving at this point like two distinct species. It is consistent with the extension inland a certain distance of forms like Sphyrapicus varius ruber and Passerella iliaca fuliginosa, and toward the coast of Piranga ludoviciana (see Swarth, 1911, p. 95) and Empidonax trailli alnorum, and it is consistent with the restriction on one side or the other of such distinct and sharply delimited forms as Bombycilla garrula pallidiceps and Cyanocitta stelleri stelleri.

In this connection, certain facts regarding the present-day migration of birds in the region should be considered. If there were any general travel between the interior and the coast such river valleys as the Stikine would be the highways most generally followed. Our work in the region shows pretty clearly that such is not the case. It seems evident that the birds of the interior travel north and south almost entirely east of the coast ranges. Some of them, it is well known, even pass east of the Rocky Mountains as they get farther south. Birds of the coastal region remain west of the mountains.

We found many characteristic inland'species of birds, some breeding, others, perhaps, merely migrants, as far down stream as Great Glacier, some thirty miles from the coast.' The species seen there include Penthestes atricapillus septentrionalis, Setophaga ruticilla, Hylocichla ustulata swainsoni, and Vireosylva gilva swainsoni, none of which has been taken on the coast. Dendroica aestiva was an abundant migrant, though almost entirely absent at the mouth of the river. The Stikine in its passage through the Coast Range travels almost due south, and it is natural that birds from the headwaters should migrate in numbers along this valley. It is not so clear why 
they should not arrive at the mouth. However, a short distance below the Great Glacier, about at the boundary, the stream turns sharply to the westward. Just above this bend is the mouth of the Iskut, a tributary of the Stikine that is nearly as large as the main stream. At the point of junction the broad valley of the Iskut enters from the southeast and its course is east and west for some distance. A perfectly feasible outlet is thus afforded for migrating birds from the northward at just the point where the Stikine Valley would lead them astray. I do not know that this is the course that is actually followed, but it may very well be, and if so it serves to explain the absence at the mouth of the river of species that were migrating southward in numbers at a point some thirty miles up stream.

There are, however, certain inland species that appear to migrate regularly coastward, though doubtless in lesser numbers than go directly south. Dendroica coronata hooveri has been taken in the fall near the mouth of the Taku River (Swarth, 1911, p. 99), and we obtained it at the mouth of the Stikine, each time in sufficient numbers to appear to be of regular occurrence. Sialia currucoides has been found near the mouth of the Taku under similar circumstances (Swarth, loc cit., p. 112), and while we, ourselves, did not meet with this species at the mouth of the Stikine, specimens have been taken there.

The question arises as to the migration of such species as Melospiza melodia rufina and Passerella iliaca fuliginosa, coastal forms primarily but breeding far inland up the Stikine. Whether or not they ascend and descend the river in their travels is not clear, and the facts will be difficult to ascertain.

The casual occurrence at the mouth of the Stikine in the spring of such species as Myadestes townsendi and Sialia currucoides (see pp. 301,309 ) is noteworthy. Such wanderers in the fall might be explained as individuals that had mistakenly followed the river to its mouth. In the spring, they can not be regarded as having gone astray. The fact that they had reached this point is evidence that they were confidently traveling to a definite goal, though along a path not usually followed by their kind.

At high water, quantities of drift are carried down the river. It is probable that small mammals living in the bottom lands often take refuge in fallen trees or in masses of brush that are suddenly floated away, and are thus transported far down the river. This may be one factor tending toward the more general extension coastward of inland species as compared with the sharper restriction of coastal forms (see fig. Q). 
Thus there are certain species of birds and mammals for which the valley of the Stikine River acts as a channel of communication between interior and coast. There are none to which it acts in the opposite rôle, as a barrier to farther distribution, north or south. It would not to birds, of course, in any event. As regards mammals, conditions here are very different from what, for example, they are in the valley of a stream like the Colorado River, of the southwestern United States. In that region, not only the river itself but also the wide strips of adjacent bottom lands absolutely prevent the passage of certain desert mammals, so that there are a number of species and subspecies restricted to one side or the other (cf. Grinnell, 1914).

In the Stikine Valley no local conditions ("associations") exist that tend to keep certain groups of animals either close to or far distant from the river banks, and the same forms range unhindered from the water's edge well up the mountain sides. For a period of months the river is frozen over quite to its mouth, and there is no doubt that at that season individuals of many species of mammals cross from one side to the other.

\section{ZONAL AND FAUNAL POSITION OF THE STIKINE VALLEY}

The Sitkan district of southeastern Alaska has been generally considered to be mostly of the Canadian life zone. The areas that extend above timber on the higher mountains afford a strip of Alpine Arctic of considerable extent, and a drawback to the recognition of the lower altitudes as Canadian is the absence of any well defined intervening strip of Hudsonian. Some birds and mammals that occur elsewhere in the Canadian zone do occur in the lowlands of the Sitkan district, but on the other hand species generally regarded as indicative of the Hudsonian zone are found throughout the whole region. Altogether it seems as though all the Sitkan district below Alpine-Arctic should be considered as of the Hudsonian zone, with a strong infusion of Canadian in the southern part at least. Certainly this coastal strip is of a higher life zone than the adjacent interior.

In the country immediately east of the Coast Range there has not been sufficient work to permit detailed mapping of the life zones. The most recent zonal map covering that section is the one published in the A. O. U. Check-List (1910, pl. 1) and is on too small a scale to permit of much detail. On that map the Hudsonian zone covers practically all of northern British Columbia, extending considerably farther southward there than in southern Alaska, to the westward, or 
in northern Alberta, to the eastward. The adjacent coastal strip of southeastern Alaska is indicated as Canadian, and there are narrow strips of Canadian extending inland along certain river valleys, of which the Stikine is one. The interior is thus regarded as of a higher zone than the coast. This is not in accordance with our own findings. One of the rules upon which life zones are based is as follows: "The northward distribution of terrestrial animals and plants is governed by the sum of the positive temperatures for the entire season of growth and reproduction"' (Merriam, 1898, p. 54). Exact figures are lacking for the region we visited, but there can be no doubt that the summer temperature of the country immediately east of the mountains is appreciably higher than on the coast. In further illustration of the relative zonal positions of the two regions, the following lists of some characteristic summer birds of the lowlands should be considered.

\section{COAST}

Dendragapus obseurus sitkensis Oyanocitta stelleri stelleri

Nannus hiemalis pacificus Regulus satrapa olivaceus Regulus calendula grinnelli

Ixoreus naevius naevius

\section{INTERIOR}

Bonasa umbellus umbelloides Buteo swainsoni Nuttallornis borealis Spizella passerina passerina Vireosylva gilva swainsoni Setophaga rutieilla

Furthermore, in the course of our work the interesting fact was developed that certain species of birds that occur commonly at sea level on the coast occur inland at constantly increasing elevations. Ascending the Stikine it is noticeable, at a point about a hundred miles inland, that the characteristic spruce forest found at sea level on the coast and on the banks along the lower reaches of the river, here begins to ascend the mountain sides, its place in the valley being taken by the poplar woods. In the Telegraph Creek region we found the spruce belt at an altitude of perhaps 1500 to 2000 feet, and found therein the bird species to which reference is made. It is an additional complication that whereas certain subspecies extend unchanged from the coast to the interior as inhabitants of this spruce belt, some species are represented by differeat subspecies, at the two extremes. Nannus hiemalis pacificus and Regulus satrapa olivaceus belong in the first mentioned category. In the second, Dendragapus abscurus sitkensis, Regulus calendula grinnelli, and Ixoreus naevius naevius, of the coast, appear to be replaced in the interior by Dendragapus obscurus flemingi, Regulus calendula calendula, and Ixoreus naevius meruloides. Among manmals, Marmota caligata is one conspicuous species that occurs at sea level on the coast ( $M$. c. caligata) and at high elevations inland (M. c. oxytona). It is a matter for regret that we were unable to give 
more study than we did to the fauna of the spruce belt of the interior mountains, for our data are admittedly scanty; but at any rate it is evident that the bird population, at least, of that region contains a large proportion of forms that are characteristic of lower levels at the coast. The presence of the several animal arid plant species noted serves for the recognition of a strip of Hudsonian zone on the mountain

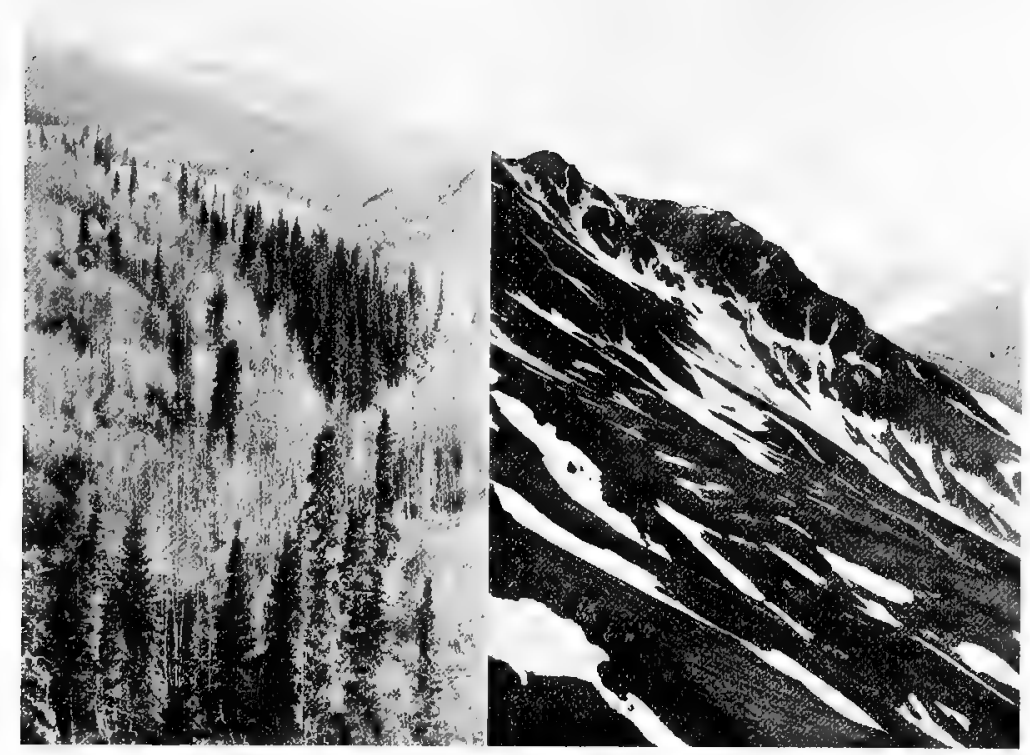

Fig. N

Fig. $\mathrm{O}$

Fig. N. Ascending the mountains, the poplar woods are gradually left behind while spruce and fir, appearing first as scattered thickets on north-facing slopes or in cool cañon beds, gradually become the dominant forest growths. This, the Hudsonian zone, is the home of the Canada jay, pine grosbeak, goldencrowned sparrow, and golden-crowned kinglet. Photograph taken in the upper reaches of Telegraph Creek, looking toward the Summit, June 28, 1919.

Fig. O. Above the spruce woods is a strip of dwarfed and prostrate balsam fir; still higher, Alpine-Arctic slopes and ridges extend that are bare of trees but well covered with grass, heather and moss. This timberless area is the home of the mountain goat and marmot, among mammals; of white-tailed ptarmigan, pallid horned lark, Hepburn rosy finch and pipit, among birds. Photograph taken on the mountain above Doch-da-on Creek, July 23, 1919.

sides, as distinguished from the Canadian zone of the valley below. There are certain birds, apparently all of high altitudes inland, of which we learned regrettably little regarding their relationship to the coast fauna. They are as follows: Canachites canadensis osgoodi is believed to be mainly a bird of the spruce belt on the mountains. 
Perisoreus canadensis canadensis was quite through nesting when we reached the region, but presumably does not breed in the valley near the river. Pinicola e. flammula appeared to belong to the spruce belt, but this is doubtful. Zonotrichia coronata is in this latitude unquestionably a high mountain species, reaching its greatest abundance in the scrubby balsam at timber line. The unsettled question concerns its extension coastward. In the coast region it does not occur in the lowlands, but may occur on the mountains. Spizella monticola ochracea is a high mountain bird in the Telegraph Creek region, probably near the southern limit of the bird's distribution.

We ourselves did not get far back from the Stikine Valley at any point, and it might be argued that our finding there of certain species not extending into the Hudsonian is no more than corroborative of the narrow line of Canadian extending along the Stikine Valley, shown in the zone map cited. However, recent work has been done in the interior at Hazelton and at Atlin, which shows the general distribution of the bird species to which reference is made; on this basis it seems altogether likely that northern British Columbia should be regarded as predominantly of the Canadian life zone rather than of the Hudsonian.

It seems worth while to make such comparisons as are possible of the results attained by the other ornithological work recently done in northern British Columbia. Taverner (1919) has reported upon a collection of birds from Hazelton, and E. M. Anderson (1915a) upon a collection from Atlin. The three points, Atlin, Telegraph Creek, and Hazelton, are about the same distance inland. Atlin is about 150 miles north of Telegraph Creek, near the head of the Taku drainage, Hazelton about 225 to the southward, on the upper Skeena. The three localities are thus very similarly placed as regards their relation to the coast.

Species common to Atlin, Telegraph Creek, and Hazelton:

1. Bonasa umbellus umbelloides

2. Falco sparverius sparverius

3. Colaptes auratus borealis

4. Chordeiles virginianus virginianus

5. Selasphorus rufus

6. Nuttallornis borealis

7. Myiochanes richardsoni richardsoni

8. Empidonax hammondi

9. Empidonax wrighti

10. Perisoreus canadensis canadensis

11. Euphagus carolinus

12. Spinus pinus pinus 
13. Zonotrichia leueophrys gambeli

14. Spizella passerina passerina

15. Tachycineta thalassina lepida

16. Dendroica aestiva aestiva

17. Penthestes atricapillus septentrionalis

18. Hylocichla ustulata swainsoni

19. Hylocichla guttata guttata

20. Planesticus migratorius migratorius

21. Sialia currucoides

Species common to Atlin and Telegraph Creek, probably finding their southern limit near Telegraph Creek:

1. Spizella monticola ochracea

2. Junco hyemalis connectens

3. Dendroica coronata hooveri

Species common to Hazelton and Telegraph Creek, probably finding their northern limit near Telegraph Creek:

1. Dryobates villosus monticola

2. Cypseloides niger borealis

3. Chaetura vauxi

4. Melospiza melodia rufina

5. Piranga ludoviciana

6. Vireosylva gilva swainsoni

7. Oporornis tolmiei

8. Setophaga ruticilla

Species found at Atlin and not at Telegraph Creek, probably finding their southern limit between these points :

1. Surnia ulula caparoch

2. Dendroica striata

3. Penthestes hudsonicus hudsonicus

Species found at Hazelton and not at Telegraph Creek, probably finding their northern limit between these points :

1. Cyanocitta stelleri annectens

2. Junco oreganus shufeldti

3. Stelgidopteryx serripennis

4. Vireosylva olivacea

5. Dendroica auduboni auduboni

6. Dendroica magnolia

7. Geothlypis trichas occidentalis

In this discussion of the life zones of the regions involved, so much more information was forthcoming from the birds than from the mammals that more stress is necessarily given to evidence derived from them. A large percentage of the mammals of the interior are of species of which it is difficult to obtain specimens, especially in summer. A number of species we failed to meet with at all, though possibly they 
occur in fair abundance, and of others but an unsatisfactory representation was obtained.

As faunal areas, the Sitkan district and the country east of the mountains are strongly contrasted. Differences of humidity are as striking as those of temperature, and these differences are reflected in the mammal, bird, and plant life of the two regions. The peculiarities of the Sitkan district are well known, and the accepted boundaries well defined. Of the country east of the mountains, as typified in the Telegraph Creek region, the peculiarities are equally well marked. This district, of undetermined extent, save where it impinges upon the Sitkan district, appears worthy of a name as a recognizable faunal area, for the sake of convenient reference, at least, and I would suggest the adoption of Cassiar district, a name applied to it as a political division.

The birds of the two regions are more widely different than are the mammals, that is, there are more distinct types in each region. The two mammal faunas are distinct enough, and there are certain conspicuous species in each district that are not found in the other, but in many cases closely related species or subspecies replace one another on either side of the dividing line. Certain species of which a large representation was obtained (Peromyscus and Microtus) exhibit intergradation between related forms along the river to an extent far beyond anything found among the birds.

The two accompanying tables (figs. $\mathrm{P}, \mathrm{Q}$ ) serve to show the relationships of the bird and mammal faunas of the two regions, and the nature of the occurrence of the various species in the Stikine Valley, as observed by us. Certain geperalizations may be drawn from these tables. (1) There are, as previously remarked, more distinct types of birds in the two contrasted regions than there are of mammals. (2) There are more bird forms in the interior than on the coast. (In addition, it may be said that bird life, as regards number of individuals, is far more abundant in the interior than on the coast.) In the Stikine Valley, at least, there are a number of species of the interior that extend far toward the coast, while very few coastal races extend any distance inland the fauna of the Sitkan district is closely confined to the region west of the Coast Range. In certain respects these tables are imperfect. It would take many seasons of field work to fill in gaps in our knowledge that are here apparent. Also, in the case of some species there are differences of altitude concerned (implying zonal differences) as well as those of linear distance, and such distinctions could not be made in this table. 


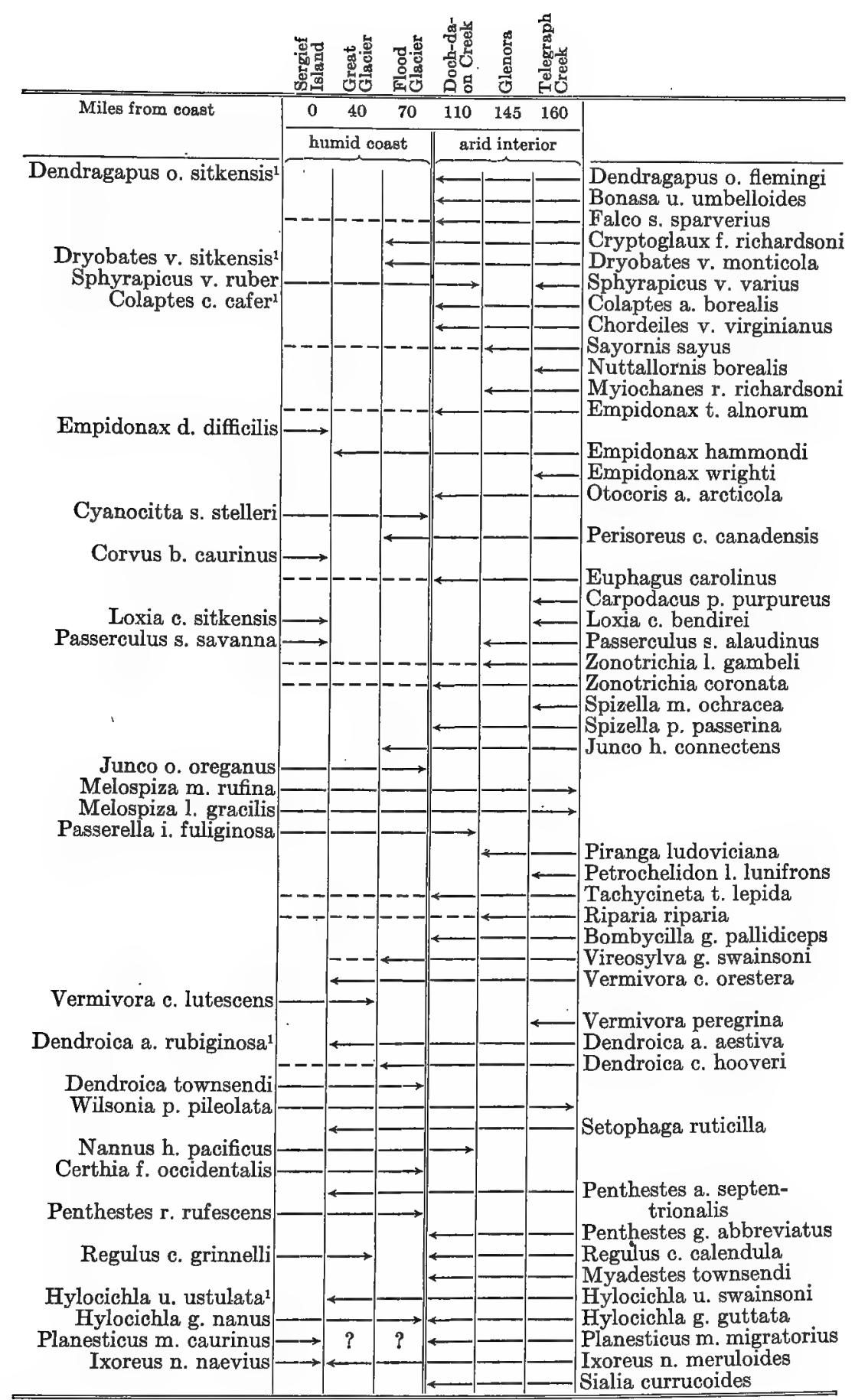

IKnown to occur on the coast of southeastern Alaska, but not encountered on the lower Stikine by this expedition.

Fig. P. Showing manner of occurrence in summer of certain land birds of the Stikine region. Species and subspecies primarily of the coast are listed in the left-hand column; those of the interior in the right-hand column. The intervening columns indicate collecting stations of the 1919 expedition, from the coast toward the interior reading from left to right, with the approximate distance of each place from the coast. Arrow indicates direction and extent of dispersal of each species from the center of abundance. Broken line indicates occurrence as migrant beyond the breeding limits. 


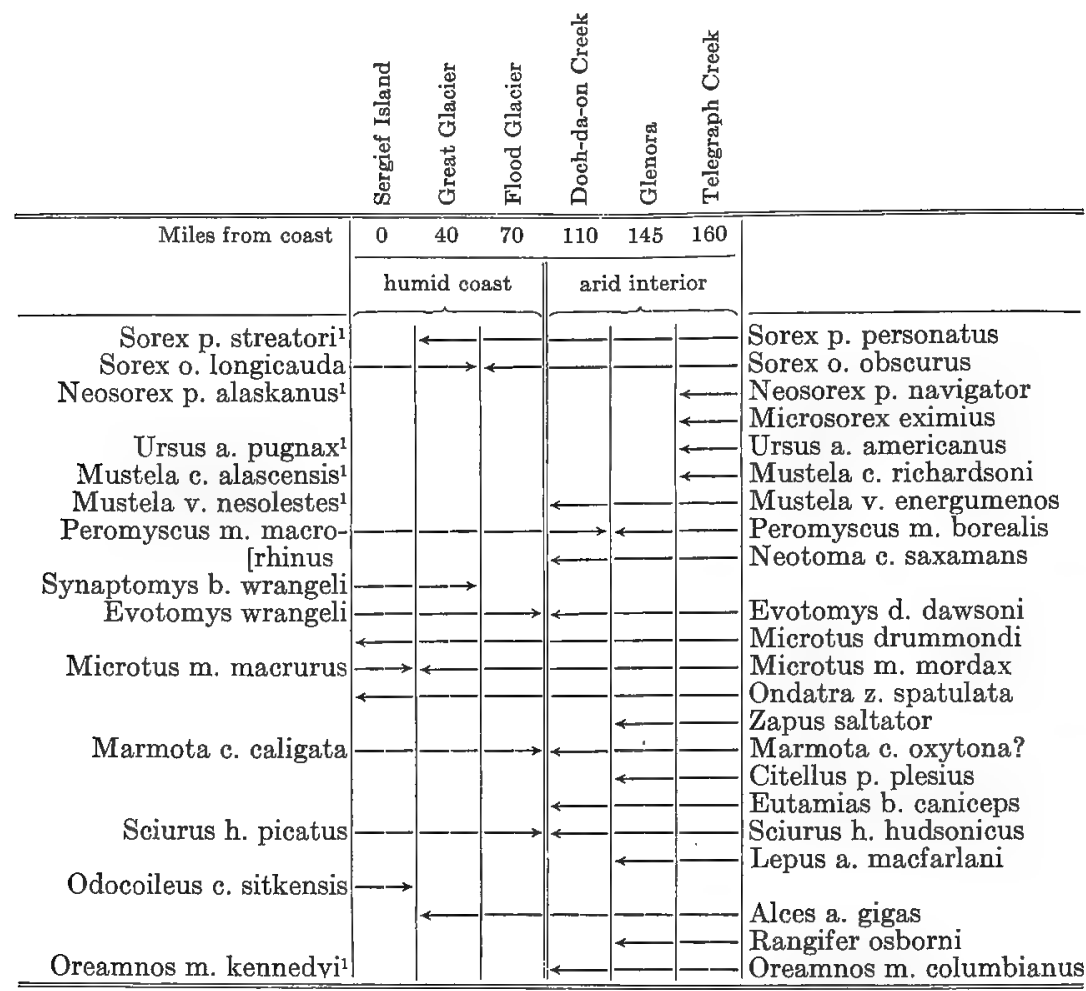

IKnown to occur on the coast of southeastern Alaska, but not encountered by this expedition.

Fig. Q. Showing manner of occurrence of certain mammals of the Stikine region. Species and subspecies primarily of the coast are listed in the left-hand column; those of the interior in the right-hand column. The intervening columns indicate collecting stations of the 1919 expedition, from the coast toward the interior, reading from left to right, with the approximate distance of each place from the coast. Arrows indicate direction and extent of dispersal of each species from the center of abundance.

The 127 species and subspecies of birds treated in this report probably form a fairly complete representation of the summer avifauna of the region. It seems curious, though, that we should have seen no three-toed woodpeckers (Picoides), no magpies ( $P$ ica), and no yellowthroats (Geothlypis).

Numerous species of the mammals known to occur in the region we did not meet. We caught glimpses of bats on two occasions, but got no specimens. A coyote (Canis) is said to range this far north, but we neither saw nor heard one. Vulpes, Martes, Gulo, and Lynx are fur bearers that are regularly trapped throughout the region. Whether or not there are seasonal differences affecting local distribution we did 
not learn, but we did not come in contact with any of these species. Sheep (Ovis stonei) occur in the neighboring mountains, of course; we were not within their territory. Flying squirrels (Glaucomys) occur, we were told by trappers, but we saw none. Phenacomys constablei was described from Telegraph Creek, but our trapping did not produce a single specimen.

\section{CHECK LIST OF THE MAMMALS}

1. Sorex personatus personatus I. Geoffroy

2. Sorex obscurus obscurus Merriam

3. Sorex obscurus longicauda Merriam

4. Neosorex palustris navigator Baird

5. 'Microsorex eximius (Osgood)

6. Ursus, species?

7. Ursus amexicanus americanus Pallas

8. Canis oceidentalis Richardson

9. Mustela cicognani richardsoni Bonaparte

10. Mustela vison energumenos (Bangs)

11. Phoca richardi richardi (Gray)

12. Peromyscus maniculatus borealis Mearns

13. Peromyscus maniculatus macrorhinus (Rhoads)

14. Neotoma cinerea saxamans Osgood

15. Synaptomys borealis wrangeli Merriam

16. Evotomys dawsoni dawsoni Merriam

17. Evotomys wrangeli Bailey

18. Mierotus drummondi (Audubon and Bachman)

19. Microtus mordax mordax (Merriam)

20. Ondatra zibethica spatulata (Osgood)

21. Mus musculus museulus Linnaeus

22. Zapus saltator Allen

23. Erethizon epixanthum nigrescens Allen

24. Marmota caligata caligata (Eschscholtz)

25. Citellus plesius plesius (Osgood)

26. Eutamias borealis eaniceps Osgood

27. Sciurus hudsonicus hudsonicus (Erxleben)

28. Sciurus hudsonicus picatus Swarth

29. Castor canadensis canadensis Kuhl

30. Lepus americanus macfarlani Merriam

31. Odocoileus columbianus sitkensis Merriam

32. Alces americanus gigas Miller

33. Rangifer osborni Allen

34. Oreamnos montanus columbianus Allen 


\section{GENERAL ACCOUNTS OF THE MAMMALS}

Sorex personatus personatus I. Geoffroy. Masked Shrew

Obtained only in the vicinity of Telegraph Creek and at Great Glacier. Seven taken at Telegraph Creek and five at the nearby station of the Junction (nos. 30527, 30535, 30554-30559, 30561, 31052-31054). Seven specimens from Great Glacier (nos. 30544, 30562-30567), though referred to Sorex personatus personatus, show intergradation toward S. p. streatori. These determinations, as well as those of the other forms of Sorex and Microsorex here treated, were made by Dr. Hartley H. T. Jackson, of the United States Biological Survey.

\section{Sorex obscurus obscurus Merriam. Dusky Shrew}

Seven specimens taken at the Junction, five at Telegraph Creek, three at Glenora, two at Doch-da-on Creek, and one at Flood Glacier (nos. 30522-30526, 30528-30534, 30536-30541). Shrews were nowhere abundant.

\section{Sorex obscurus longicauda Merriam. Long-tailed Shrew}

Ten from Great Glacier and two from Sergief Island (nos. 30542, $30543,30545-30551,31055$ ). The series from Great Glacier is intermediate between Sorex obscurus obscurus and S. o. longicarida, but on the whole is nearer longicauda.

\section{Neosorex palustris navigator Baird. Water Shrew}

An adult male (no. 30568) was trapped near Telegraph Creek on June 22, in a bit of swampy land near the ștream. Allen (1903, p. 567) has referred the water shrew of this region to Neosorex palustris alaskanus (Merriam), but our one specimen does not exhibit the characters ascribed to that race (cf. Merriam, 1900, p. 18). As compared with Californian examples of navigator, the Telegraph Creek specimen is exactly similar in general size and in skull characters, but is of slightly more grayish coloration.

I have seen one specimen of Neosorex from the coast of southeastern Alaska (in the collection of E. P. Walker), taken at Rudyard Bay, about one hundred miles south of the Stikine River, and this animal does exhibit the cranial peculiarities ascribed to alaskanus. It seems likely that the latter is confined to the coastal region. 


\section{Microsorex eximius (Osgood). Osgood Shrew}

A single Microsorex (no. 30560) was trapped at the east end of Sawmill Lake, near Telegraph Creek, on June 16. The skull was crushed, debarring definite specific identification, but the specimen has been provisionally referred to the species Microsorex eximius by Dr. Jackson.

\section{Ursus, sp.? Grizzly Bear}

Grizzlies are still numerous in the Stikine region. We ourselves saw fresh sign at many points, though no animal was encountered. The most obvious indication of their presence was, of course, footprints, but other evidence was frequently found, such as rotten logs ripped to pieces by the bears for the insect food they contained. At Dochda-on Creek an unoccupied cabin in the woods was entered by a bear several times during the two weeks we spent at that place, and more or less damage done. At this point we saw grizzly tracks in the snow at timber line, about 4000 feet altitude.

At Hyland's store, Telegraph Creek, we examined ten grizzly skins, killed the previous fall, all from about the same place, on the Klappan River (a tributary of the Stikine) about 100 miles east of Telegraph Creek. Of these we purchased a skin with the skull of an old male (no. 31015) and a skin alone of a smaller animal, apparently a female (no. 31016). These specimens, both skins and skull, answer fairly well to the description of Ursus stikeenensis given by Merriam (1914, p. $178 ; 1918$, p. 88 ).

There are no less than seven species of big bears accredited to this general region by Merriam (1918). Whether or not I have ascribed our specimens to the correct form, I think there is no doubt that all the skins in the above mentioned series belonged to one species, for there was really remarkable uniformity in color and markings in the lot. Subsequently the skin of another bear was examined, a huge male killed on Clearwater Creek, and it again was of exactly the same type. The noticeable color features are the general dark coloration, the yellowish or grayish grizzling on the shoulders and along the back, and the black feet, legs, and lower parts. The tanned skin of the male specimen, an animal that, from the appearance of the skull was evidently past maturity, measures from tip of nose to base of tail approximately 1680 millimeters; the one from Clearwater Creek, above mentioned, was very much larger. The claws are short for a grizzly, the longest claw on the male obtained measuring, with dividers, 55 millimeters. They appear to be much worn. 


\section{Ursus americanus americanus Pallas. Black Bear}

Black bears occur in some abundance throughout the whole of the region we traversed. They are frequently seen from the river boat in its travels up and down the Stikine. On June 5 one was seen not far from our camp at the Junction, rooting about under some rotten logs near the trail. Fresh tracks or other sign of the recent presence of black bears were seen practically everywhere we went except on Sergief Island.

Five black bear skulls were purchased from Mr. A. M. Vickery, of Telegraph Creek, the animals having been killed by him while he was patrolling the telegraph line to the southward of that place. One of these (no. 31017) is an old male, killed 122 miles south of Telegraph Creek, on May 25, 1919. The others are an old female and three small cubs (nos. 31018-31021) killed on June 17, 1919, 31 miles south of Telegraph Creek.

The two adult skulls from the Telegraph Creek region present certain evident points of difference from those of the black bear ( $U$. $a$. pugnax) from the islands of southeastern Alaska. In the former the frontal region is relatively high and rounded, in the latter it is noticeably low and flat. In pugnax the whole skull is more angular in appearance. In pugnax, too, the teeth are large, as compared with those of bears from the interior, especially the last upper molar. This last character is one that persists in black bears from all the islands off the coast of southern Alaska and British Columbia. It is conspicuous in pugnax of the southern islands of the Alexander Archipelago, which has a large, squarely built, low browed skull. It is one of the characters of carlottae, from the Queen Charlotte Islands (cf. Osgood, 1901, p. 30), which has an elongate skull. It appears again in the black bear of Vancouver Island, which, judging from the several specimens at hand, is a smaller animal than carlottae or pugnax, with a rather high, rounded skull, and with the teeth of large size, especially the last upper molar.

There is very little material at hand from the mainland coast of southeastern Alaska. One rather young male from Bradfield Canal (a short distance south of the Stikine River) has the enlarged last upper molar of pugnax, and is apparently to be referred to that form. Thus it may be that pugnax occupies a narrow strip of coast on the mainland of southeastern Alaska as well as the islands, and that the type of black bear found in the Telegraph Creek region is confined to the territory east of the coastal range of mountains. 
Of the available material, the Telegraph Creek skulls are most nearly of the type of those from the Kenai Peninsula and Yakutat Bay, Alaska. It may be that the name given to the black bear of the Kenai region by Allen (1910, p. 115), Ursus americanus perniger, should also be applied to the bears of the Stikine section, but at present it seems best to use the name americanus for the Stikine specimens. A revision of the group is necessary to determine, among other things, the applicability of the name Ursus americanus Pallas, and the characters pertaining to the form to which that name should be subspecifcally restricted. In the present connection the main interest lies in the apparent occurrence of two different forms of the black bear in the Stikine region, americanus at the headwaters of the river, and pugnax in the coastal region near its mouth.

\section{Canis occidentalis Richardson. Timber Wolf}

Wolves, from all accounts, occur in some numbers throughout the interior of northern British Columbia, along the length of the Stikine Valley, and along the adjoining Alaskan coast and on the nearby islands. We saw none, nor any fresh sign, until we reached Sergief Island. There fresh wolf tracks were seen in the sand of the river bank, and on several occasions, when shooting out on the marsh, the reports of our guns started wolves howling in the forest nearby. On August 20 two of the animals were seen, and investigation showed that the place was the home of a wolf family, as it probably had been since the young were born, two or three months earlier. The two we saw were pups, not yet full grown, and they were probably awaiting the parent's return from a foraging expedition. Certain areas in the grass had been trampled flat, for beds, and a large flat rock nearby furnished an ideal lounging place. This rock rose above the marsh grass, and thus afforded an excellent observation station. Some cracks in the granite gave foothold to two scrubby spruce trees, arching over the rocky platform, and the rock below was covered with a deep layer of spruce needles, affording a dry, soft bed. This shelter had been occupied so much that the wolf smell clinging to it was apparent even to the duller olfactories of a human being. Broad trails led away through the grass over the marshes in various directions and into the impenetrable fastnesses of the spruce woods on the adjoining hillside. The trampled grass showed here and there bunches of feathers or a few crushed bones of ducks and geese; water fowl were evidently a staple food. 
There were apparently three pups and one adult in this family. Two of the young were taken, and the old wolf then removed the survivor, evidently to some distance; no trace of the two was found anywhere about the island. The parent had been seen several times before the two young were caught.

Mr. W. E. Parrott, living upon Sergief Island, gave us the skin of an adult male wolf that he had shot on July 20. He was sitting at breakfast when his cat rushed into the house for protection from the wolf, which had chased the cat through the garden. Looking through the window, he saw the wolf, leisurely retreating toward the beach, and shot the animal. It was no new experience for the cat. Whenever his owner went to town a ladder was left leaning against the house, as a refuge in case of such pursuit, and apparently there was not infrequent occasion to use it.

The wolf thus obtained may have been the male parent of the family we encountered. In color this adult and the two pups are very much alike. The adult is rather dark, though not so black as some from this region. There is a good deal of black on the upperparts from the eyes to the tip of the tail, produced by black tippings to long hairs that are yellowish or reddish basally, the muzzle is reddish, the legs decidedly reddish, and the underparts a somewhat paler brown. It is not a gray appearing animal at all. The two pups are somewhat duller colored, with the black not so intense, and the reddish areas paler. In life, however, the young wolves looked quite dark.

There is at hand an adult male wolf from Prince of Wales Island, Alaska (southwestward from Sergief Island), that is almost entirely black. Another specimen from the interior, the Yukon region, is also black, so that evidently dark color alone can not be considered as distinguishing the wolves of either of these two regions. Two skulls of fully adult wolves from Iskut Summit, sixty miles southeast of Telegraph Creek, do not present any obvious points of difference from the above mentioned adult from Prince of Wales Island. The Iatter has been recorded by the present writer (Swarth, 1911, p. 136) as Canis pambasileus Elliot, in the belief that that name was applicable to a coastal subspecies. The Prince of Wales specimen presents characters of size and color such as are ascribed to pambasilens (Elliot, 1905, p. 79). Whether or not the name pambasileus may properly be used for a local race from the type locality, the Mt. McKinley region, it does not seem that any distinction can be made as between the wolf 
of the coast of southeastern Alaska and the wolf of the adjoining interior. In the light of our limited material, and with the lack of a systematic revision of this group of mammals, it is safer to consider them as all one form, to which the name Canis occidentalis Richardson seems applicable.

The material obtained by us in the Stikine region consists of the following specimens: skulls and limb bones of two adults (nos. 31042, 31043) taken at Iskut Summit, sixty miles southeast of Telegraph Creek, the gift of an acquaintance at Telegraph Creek; an adult male (apparently not quite full grown), skin only (no. 31009), shot at Sergief Island, July 20, 1919; and two young females (about halfgrown), skins and skulls (nos. 31010, 31011), taken at Sergief Island on August 24 and August 25, 1919.

Mustela cicognani richardsoni Bonaparte. Richardson Weasel

Weasels undoubtedly occur throughout the region traversed, though we ourselves did not see one during the summer. At a trapper's cabin a few miles from Telegraph Creek a pile of desiccated weasel carcasses, his catch of the previous winter, yielded a series of nineteen skulls (nos. 31023-31041), with complete skeletons in most cases. These skulls, in comparison with a series from the coast of southeastern Alaska, exhibit the differences stated by Merriam (1896, pp. 11-13) to distinguish the two subspecies, Musteta c. richardsoni of the interior and $M$. c. alascensis of the coast. The Telegraph Creek skulls, as is claimed for richardsoni, are perceptibly narrower between the orbits and across the muzzle, and there is a slight difference in the shape of the zygomatic arches in the two lots.

Allen (1903, p. 563) has described Putorius microtis from Shesley, British Columbia, near the headwaters of the Stikine, but our series of skulls from Telegraph Creek are evidently all of one species, Mustela c. richardsoni.

\section{Mustela vison energumenos (Bangs). British Columbia Mink}

One trapped at Doch-da-on Creek on July 19 (no. 31002), and a skeleton preserved that was picked up near Telegraph Creek (no. 31022). The species occurs, probably in fair abundance, throughout the whole Stikine region. The one skin obtained is notably dark colored as compared with specimens of Mustela $v$. nesolestes from certain islands of the Alexander Archipelago, and we were told that the mink 
from the Stikine were all dark. The skull pertaining to this specimen has the small sized last upper molar that is supposed to distinguish energumenos from nesolestes, but in the skull from Telegraph Creek this tooth is as large as in most examples of the latter subspecies. There is at hand a mink from near the mouth of the Taku River and one from Wrangell, both of which are of the same dark color as our Stikine River specimen. Thus the specimens available suggest the existence of a dark colored mainland form extending toward the coast at least along the larger rivers, and reaching some of the islands lying nearest the mainland, and a lighter colored subspecies existing upon most of the islands of the Alexander Archipelago. There is not suffcient material available, however, to verify this surmise.

At any rate, the mink of the upper Stikine Valley is a relatively small form, and not the large ingens of the nearby Yukon drainage. At present it seems proper to use for this race the name Mustela vison energumenos (Bangs), originally applied to the mink of southern British Columbia. Our one specimen is very similar in appearance to an example of energumenos from the vicinity of Seattle.

\section{Phoca richardi richardi (Gray). Harbor Seal}

Seals were observed as far up the Stikine River as Doch-da-on Creek, at times in considerable numbers. On May 21, as we began our trip up the river, they were seen in veritable herds over the first thirty miles. At one place there were at least a hundred in sight at once. Farther up stream they became less and less abundant. No specimens were obtained, and the identification here accorded the animals seen is purely inferential.

Peromyscus maniculatus borealis Mearns. Northern White-footed Mouse

\section{Peromyscus maniculatus macrorhinus (Rhoads). Rhoads White-} footed Mouse

One hundred and thirty-eight specimens of white-footed mice were preserved, as follows: The Junction, 24 (all adults) ; Telegraph Creek, 29 (24 adults and 5 young); Glenora, 27 (23 adults and 4 young); Doch-da-on Creek, 27 (15 adults and 12 young); Flood Glacier, 28 (10 adults and 18 young); Great Glacier, 2 adults; Sergief Islaud, 1 young. (Museum numbers 30569-30705, 31050.) 
A series of white-footed mice collected at and near Telegraph Creek in 1902 has been reported upon by Allen (1903, p. 540) under the name Peromyscus arcticus (Mearns) (= Peromyscus maniculatus boreatis Mearns [1911, p. 102]). What is undoubtedly the same series of specimens is listed by Osgood (1909a, p. 49) under Peromyscus maniculatus arcticus (Mearns). Therefore, though this museum possesses no examples of Peromyscus maniculatus borealis other than our series from the Telegraph Creek region, I feel justified, on the grounds above mentioned, in assuming this series to be representative of the subspecies borealis. The chief interest attaching to the Telegraph Creek form in the present connection lies in its relationship to the subspecies Peromyscus $m$. macrorhinus, from the region adjacent to the mouth of the Stikine River. Of macrorhinus this museum possesses an abundant representation from various points in southeastern Alaska.

Before proceeding with a discussion of the specimens we collected, certain features of the problem should be stated, in the interest of a clear understanding of conditions. Osgood (1909a) in his comments upon arcticus (= borealis) and macrorhinus makes no direct comparison between the two; at that time there were no specimens extant to show that these forms came together at any point. From his "key" and descriptions, however, certain contrasting characters of these subspecies may be summarized as follows:

Peromyscus $m$. macrorhinus. General size larger; hind foot, 24 to $25 \mathrm{~mm}$. Tail longer than head and body; usually more than 90, often more than $100 \mathrm{~mm}$. Coloration darker.

Peromyscus $m$. borealis. General size smaller; hind foot, 19 to 21 mm. Tail about equal to or shorter than head and body; usually less than $90 \mathrm{~mm}$. Coloration paler.

On the Alaskan coast just north of the habitat of macrorhinus is the subspecies hylaeus. Between hylaeus and borealis, in the region north of Telegraph Creek, is the subspecies algidus, "the interior representative of the dark coast form hylaeus" (Osgood, 1909a, p. 56). According to Osgood (loc. cit.), algidus and borealis occur together in places within the general range of the former, and maintain their distinctness. Algidus, compared with borealis, is a long-tailed form; it differs from the latter in this respect just as macrorhinus does. Allen (1903, p. 544) records as Peromyscus oreas a single mouse taken in the Cheonnee Mountains (near Telegraph Creek), where borealis also was secured. This same specimen, presumably, is recorded by Osgood (loc. cit.) as algidus. The Cheonnee Mountains are a short distance 
southeast of Telegraph Creek; if algidus occurs in that range it should be at Telegraph Creek also.

We obtained several long-tailed specimens of Peromyscus at and near Telegraph Creek, and supposed that they were examples of algidus. Study of the series as a whole, however, inclines me to another explanation of the variation, that seems more satisfactory, namely, that there is continuous distribution of Peromyscus along the Stikine Valley, from the habitat of borealis in the interior to that of macrorhinus on the coast, that there is intergradation between these two subspecies in the Stikine Valley, that Telegraph Creek is about the easternmost point to which intergrades with macrorhinus extend, and that the variants obtained by us at that point are all the results of intergradation.

The long-tailed individuals from the Telegraph Creek region, aside from this peculiarity, are not notably different in color or otherwise from the general run of specimens obtained there. At any rate, they could not be grouped together as presenting an aggregation of characters justifying their separation as a distinct subspecies. Neither were they obtained under circumstances that would tend to establish the belief that two different races were concerned.

The Peromyscus taken at the Junction are lighter colored than macrorhinus of the coast, and they are smaller and shorter tailed. This station is some five miles north of the Stikine River; presumably these mice are more nearly typical of borealis than any others we obtained. In this series there is one aberrant individual with an exceedingly long tail; otherwise there is great uniformity in the lot. At the town of Telegraph Creek we obtained more long-tailed mice, and noted a slight increase in general size, as compared with the series from the Junction. Descending the Stikine River from Telegraph Creek, the Peromyscus collected at our various stations were progressively larger and darker colored as the coast was approached.

The accompanying diagrams (figs. $R, S, T$ ) show variation in hind foot, length of tail vertebrae, and ratio of tail vertebrae to total length, in the white-footed mice taken at our various collecting stations in the Stikine region, as compared with macrorhinus of the Alaskan coast. Color and general size vary in about the same way as the characters illustrated. Barring the series from the Junction, which are probably close to true borealis, the Stikine River Peromyscus are typical of neither borealis nor macrorhinus. They form a series of intergrades between the two. It is not possible to draw a hard and fast line as a 
boundary, both on account of the gradual change in the entire Peromyscus population of the intermediate territory and because of individual variation, which brings typical examples of each far within the margin on either side of the debatable strip. Allowing for such variation, however, it seems proper, though an arbitrary division, to consider as borealis the mice from the upper Stikine, as far down as Glenora, macrorhinus extending up stream as far as Doch-da-on Creek.

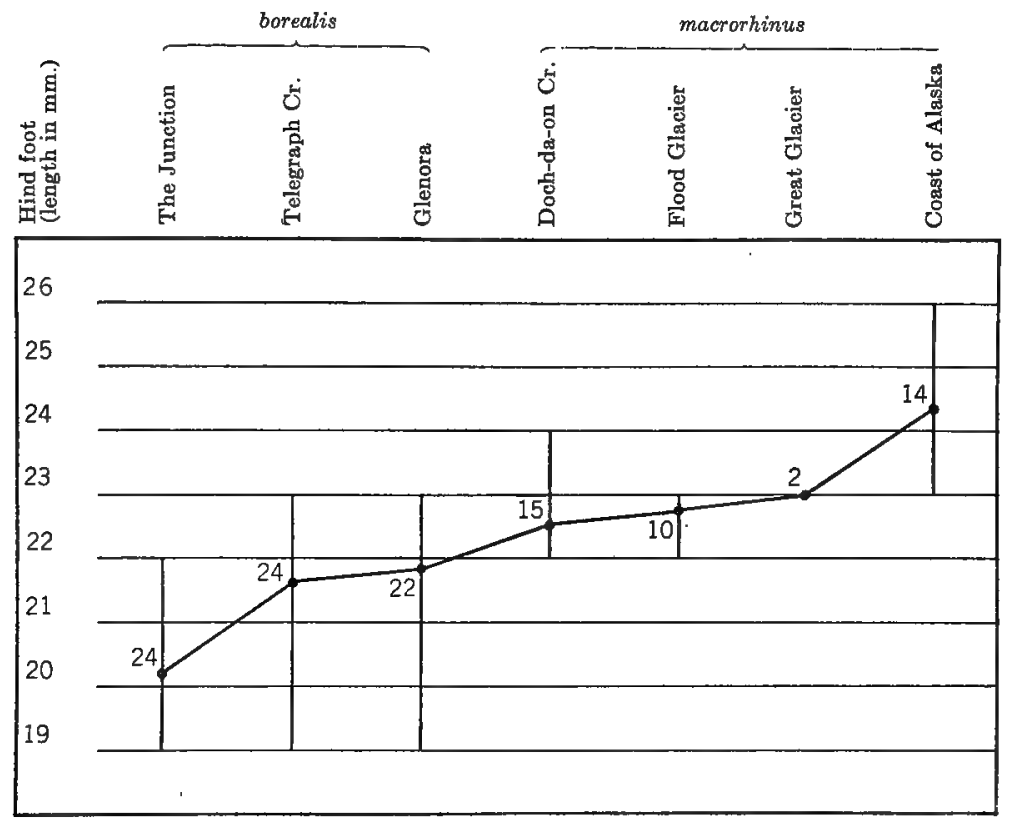

Fig. R. Diagram showing individual and geographic variation in length of hind foot of adult white-footed mice (both sexes). Figures at left of the vertical lines indicate numbers of specimens measured; length of lines shows range of individual variation; points connected by lines mark positions of averages.

White-footed mice were found in abundance about human habitations. Usually they were uncommon elsewhere. At the Junction the trapping was done along a stream and in poplar woods, miles from houses, and white-footed mice, while perhaps more abundant than any other small mammal, were not at all numerous. At Telegraph Creek most of our specimens were caught in the house in which we were staying; a few were taken in our several trap lines a mile or more from town. The rows of empty houses at Glenora formed a haven for white-footed mice, and they swarmed there in almost incredible numbers. At Doch-da-on Creek white-footed mice were abundant in the 
weed-grown bottom lands, much more so than we found them to be on any other wild land. At Flood Glacier we had difficulty in getting specimens, and at Great Glacier, though some small mammals were more abundant than we found them elsewhere, only two white-footed mice were obtained. At Sergief Island they were extremely scarce; only one specimen was taken.

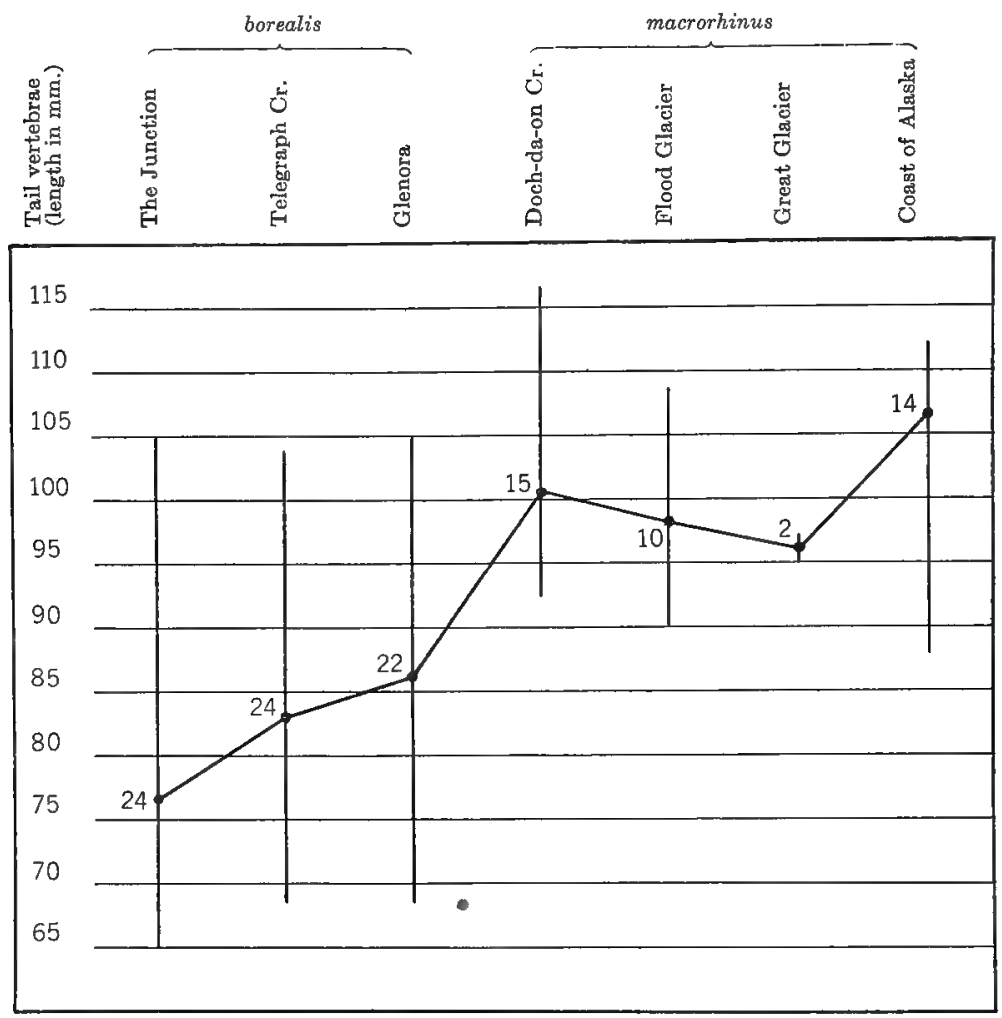

Fig. S. Diagram showing individual and geographic variation in length of tail of adult white-footed mice (both sexes). Figures at left of the vertical lines indicate numbers of specimens measured; length of lines shows range of individual variation; points connected by lines mark positions of averages.

At the Junction, May 25 to June 6, all Peromyscus taken were adult. Most of the females contained embryos, four or five in number; one or two were nursing young. At Telegraph Creek the first week in June young mice began to get into the traps. From the third week in June, on during the rest of the summer, the dark coated juvenals formed the greater part of the catch. At Glenora two Peromyscus were caught which had their cheeks filled with a mass of small seeds. The cheeks were distended to the utmost, just as is so often seen in 
chipmunks and ground squirrels. This, I believe, is an unusual action for a Peromyscus. At the same place an adult female was trapped that had lost one hind leg at the knee and all of the tail. These mutilations were evidently of long standing and the animal was in good condition otherwise. It may be doubted, however, whether it could . . have survived them in other surroundings; the old cabins here oceupied by the mice probably afforded exceptional shelter from many dangers.

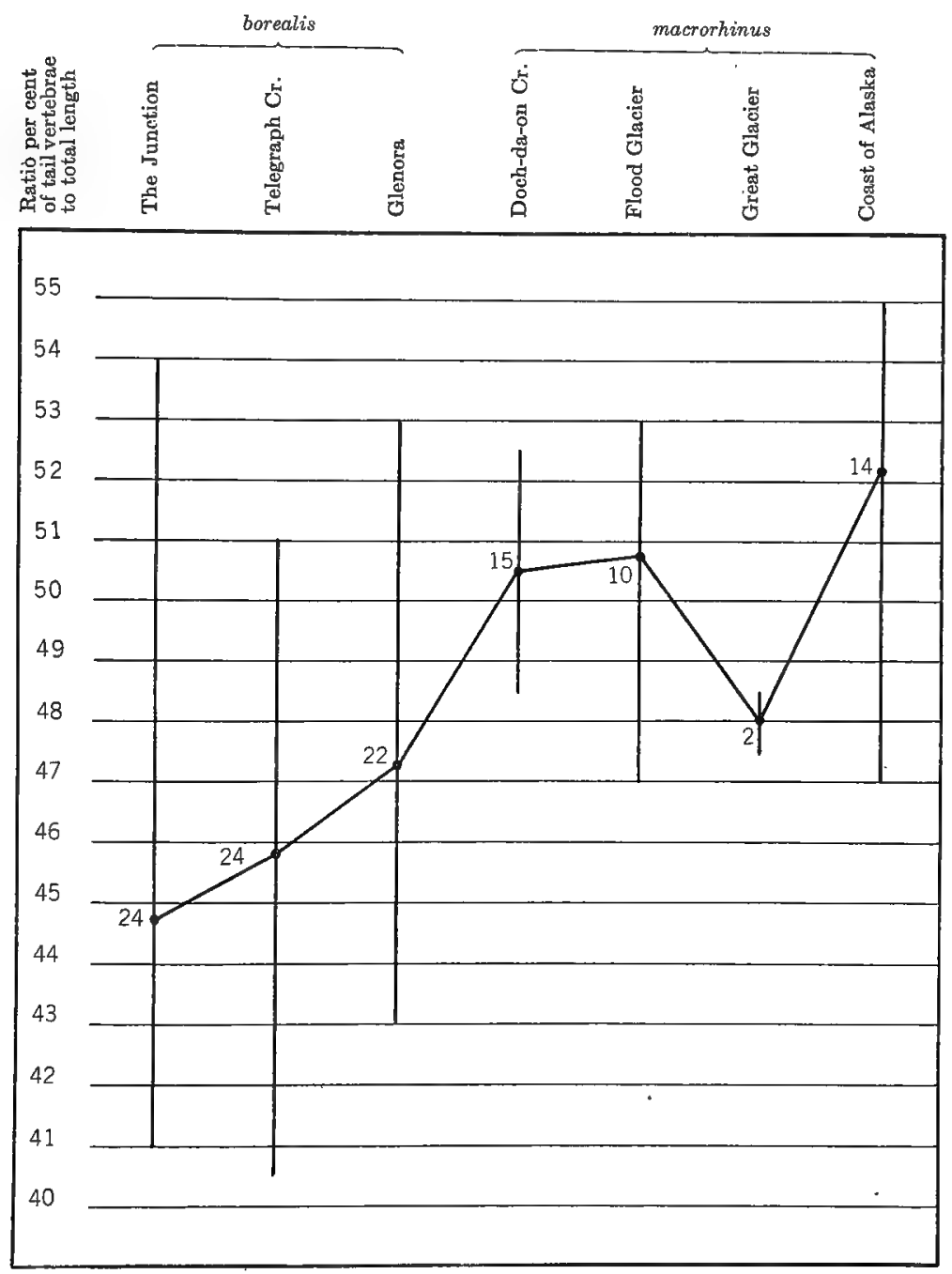

Fig. T. Diagram showing individual and geographie variation in ratio of length of tail vertebrae to total length in adult white-footed mice (both sexes). Figures at left of the vertical lines indicate numbers of specimens measured, length of lines shows range of individual variation; points connected by lines mark positions of averages. 
Neotoma cinerea saxamans Osgood. Northern Bushy-tailed Wood Rat.

Fourteen specimens collected at the following points in the upper Stikine Valley: Telegraph Creek, six adults, two young; Glenora, one adult, four young; mountain above Doch-da-on Creek, one adult. (Museum nos. 30706-30719.) At Telegraph Creek specimens were taken in the talus at the base of certain rocky cliffs that rise back of. the town. The rats were not numerous, and after one or two had been caught at a place the traps usually remained undisturbed. The old houses of the abandoned town of Glenora afforded shelter to the wood rats, but apparently not more than one or two families occupied any one cabin. From several of the cabins the rats had well worn trails leading into the surrounding thickets. There they cut quantities of green vegetation, some to be carried into the houses and eaten at once, some apparently to be dried for later use. Most of the old cabins had the doors and windows boarded up, and in the gloom of the interior the rats and mice were active all day.

The cabins and warehouses with their miscellaneous contents, long abandoned, formed a veritable wood rats' paradise, and they gave their imagination full swing in the lines of nest building and the accumulation of useless objects, for which their tribe is famous. In one place a storeroom full of snowshoes had been entered, and of the contents there was little but the wooden frames left. The leather thongs were hanging in shreds. In an old barn, round masses of baling wire had been filled out with horse manure and grass to form extraordinary globular nests.

The one specimen of Neotoma from the vicinity of Doch-da-on Creek was taken on the mountain side at an elevation of about 2000 feet. This was the farthest down stream that we found the species, but I was told by a trapper that he had occasionally seen wood rats near the mouth of the Iskut River, which empties into the Stikine a little above the British Columbia-Alaska boundary line.

A young one taken, at Telegraph Creek on June 9 was about onethird grown. Others were trapped at Glenora three weeks later, of about the same size. Three adult females caught at Telegraph Creek on June 9 contained embryos; two had three each, one had four. 


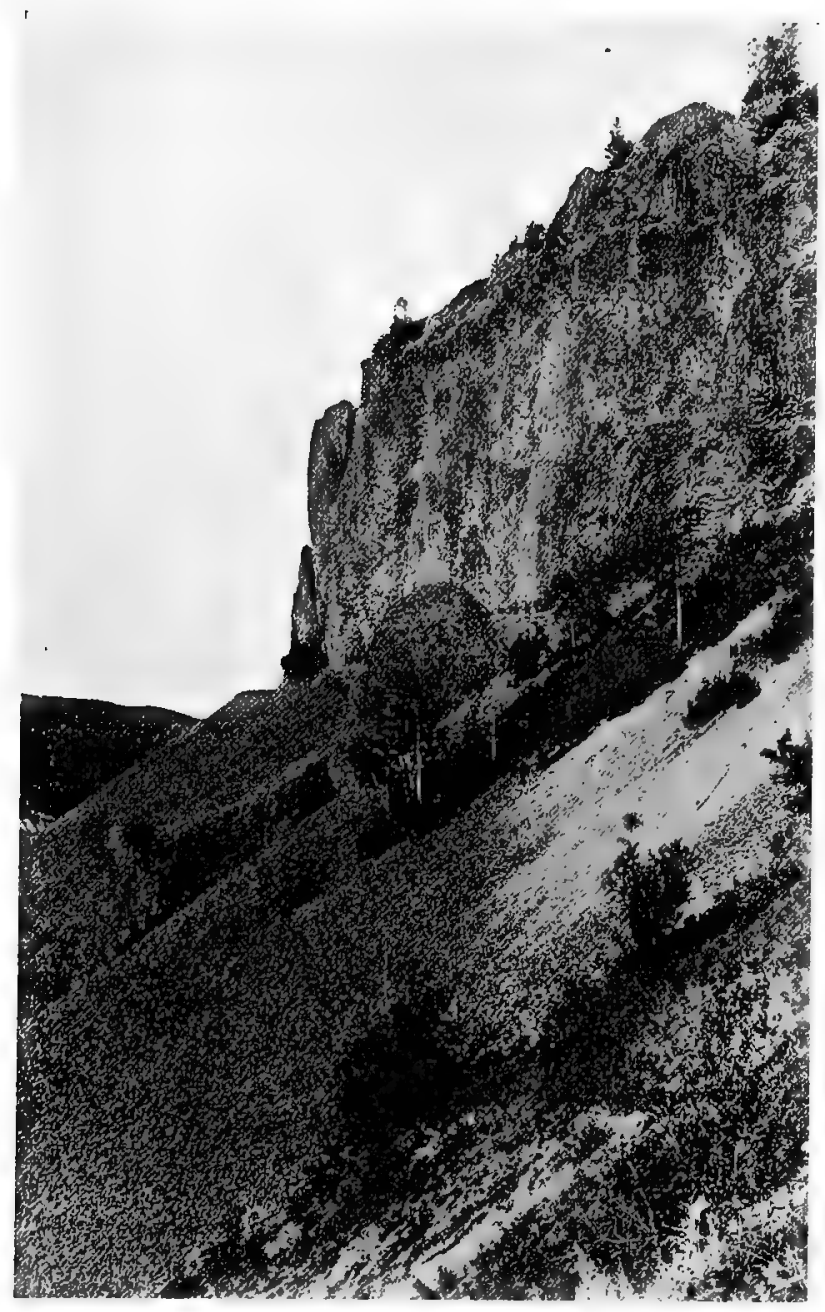

Fig. U. Basaltic cliff at Telegraph Creek. The talus beneath is a favorite habitat of the bushy-tailed woodrat. At the upper edge of the loose rocks in particular, many sticks and other rubbish accumulated by these rats were to be seen between the larger boulders. Photograph takeń June 12, 1919. 
Synaptomys borealis wrangeli Merriam. Wrangell Lemming Mouse

Found at but one place on the river, at Great Glacier. Three specimens obtained (nos. 30752-30754), all males, taken on August 10, 13, and 14, respectively. Just one, the largest and the only one that is fully mature, shows the gray patches over the hip glands. All three were trapped in alder thickets, in places frequented by Evotomys.

There have been available for comparison three specimens of lemming mice (in the E. P. Walker collection), from Wrangell, Alaska, the type locality of Bynaptomys wrangeli, ten from mainland points in southeastern Alaska, ranging from Boca de Quadra to Port Snettisham, and nine from the Prince William Sound region, Alaska. I also received, as a loan from the United States Biological Survey, six typical specimens of Synaptomys borealis dalli, three from points near the base of the Alaska Peninsula, two from the Kuskokwim drainage, and one from the Yukon.

As far as I can see, the specimens from the coast of southeastern Alaska, island and mainland, are all alike. They are all wrangcli. Furthermore, the differences between wrangeli and dalli are slight, and as these differences in the series here assembled are bridged by individual variation and to some extent by geographic variation, I consider the two forms as subspecies of one species, Synaptomys borealis. (For the use of this name, see Preble, 1908, pp. 183-186. See also Hollister, 1912, p. 19.)

The skull of dalli, compared with wrangeli, is somewhat larger, and rather more angular, and more heavily built. Otherwise, I can see no differences in the two lots. Some of those from the Prince William Sound region incline toward dalli in their larger size, as compared with more southern specimens, indicating, perhaps, intergradation between vrangeli and dalli at what is probably the northern limit of the form wrangeli. Externally, four specimens of dalli are appreciably more reddish than any in the wrangeli series. The two remaining dalli are of the same coloration as the mode of wrangeli.

Thus, instead of wrangeli being an insular species, confined to Wrangell Island, my conception of it is as being a rather wide ranging form, and a coastal subspecies, contrasted with dalli of the interior. Its range is the coast of southeastern Alaska, from Prince William Sound south at least to Boca de Quadra. It has been taken upon two islands, Hinchinbrook Island, Prince William Sound, and Wrangell Island, both but slightly separated from the mainland. 
Another species, Synaptomys andersoni, has been described by Allen (1903, p. 554), based upon a single specimen from Level Mountain, near the headwaters of the Stikine River. In all likelihood, therefore, mice of this genus occur throughout the entire length of the Stikine Valley. At present, however, with the few specimens extant in collections, it is not possible to form an opinion as to whether or not there are two species or subspecies in existence, at the head of the river, and toward its mouth, respectively.

\section{Evotomys dawsoni dawsoni Merriam. Dawson Red-backed Mouse}

An adult female (no. 30720) was taken at the Junction, June 4, trapped during the day on a dry, poplar-covered hillside. It is. apparently a typical example of Evotomys dawsoni dawsoni. The next obtained (no. 30721) was caught at Doch-da-on Creek, July 17, in a tangle of alders, grass, and nettles bordering a slough. This specimen is a male, not fully mature but evidently referable to dawsoni. Somewhere in the section of the river between Doch-da-on Creek and Flood Glacier lies the dividing line between dawsoni and wrangeli. It would be of interest to find if the two occurred together at any point.

\section{Evotomys wrangeli Bailey. Wrangell Red-backed Mouse}

Thirty specimens taken (nos. 30722-30751), three at Flood Glacier, . twenty-three at Great Glacier, and four at Sergief Island. Of this series there is one old male (no. 30735, Great Glacier), with conspicuous gray patches over the hip glands, and showing rooted molars with deeply worn surfaces. There are eleven more that may be termed adult, as being in the adult pelage (though none of these has the gray flank patches more than faintly indicated). The remainder are young at various stages of growth.

The red-backed mice from these three stations are all $E$. wrangeli, indistinguishable from specimens at hand from Wrangell Island. The range of that species is thus carried far inland up the Stikine Valley, very close to the habitat of dawsoni, if in fact the two do not meet. The four specimens from the uppermost station, Flood Glacier, show no appreciable departure from the mode of wrangeli; there is no indication here of intergradation toward the nearly adjacent dawsoni.

The two species, however, resemble each other so closely in form, and in some pelages in color also, that wrangeli would seem to be a coastal offshoot of dawsoni, bearing somewhat the same relation to that 
species as Microtus admiraltiae, of Admiralty Island, does to M. drummondi of the adjacent mainland. The two Microtus, however, are less widely separated than the Evotomys have become. Further, it may be assumed that Evotomys phoeus, of the Alaskan mainland south of the habitat of wrangeli, is of a different line of descent, it differs so markedly from both dawsoni and wrangeli in its combination of large size, pale coloration, and long tail. Much remains to be learned regarding the distribution and relationships of the red-backed mice of the northwest.

TABLE I

Measurements in millimeters (average, minimum and maximum) of adult Evotomys wrangeli from Wrangell, Alaska; measurements taken by Ernest P. Walker

$\begin{array}{cccc}\text { Total length } & \text { Tail vertebrae } & \text { Hind foot } & \text { Ear } \\ 10 \text { adult males.........141 (130-159) } & 35.7(31-42) & 18.2(18-19) & 11.8(10-13) \\ 10 \text { adult females......131.4 (127-152) } & 32.4(28-40) & 17.9(17-18) & 11.9(10-13)\end{array}$

\section{TABLE II}

Measurements in millimeters of adult Evotomys from the Stikine River

\begin{tabular}{|c|c|c|c|c|c|c|c|}
\hline \multicolumn{3}{|c|}{ Evotomys wrangeli } & & \multicolumn{2}{|c|}{$\begin{array}{c}\text { Tail } \\
\text { Length vertebrae }\end{array}$} & $\begin{array}{l}\text { Hind } \\
\text { foot }\end{array}$ & Ear \\
\hline 30724 & $\sigma^{7}$ & Flood Glacier & Aug. 4, 1919 & 135 & 34 & 19 & 11 \\
\hline 30735 & $\sigma^{7}$ & Great Glacier & Aug. 13, 1919 & 145 & 39 & 20 & 11 \\
\hline 30751 & $\sigma^{7}$ & Sergief Island & Aug. 24, 1919 & 135 & 34 & 20 & 11 \\
\hline 30726 & \% & Great Glacier & Aug. 11, 1919 & 140 & 33 & 20 & 11 \\
\hline 30728 & \% & Great Glacier & Aug. 12, 1919 & 147 & 34 & 19 & 11 \\
\hline 30732 & \% & Great Glacier & Aug. 13, 1919 & 125 & 33 & 20 & 11 \\
\hline 30749 & q & Sergief Island & Aug. 22, 1919 & 148 & 36 & 19 & 11 \\
\hline \multicolumn{3}{|c|}{ Evotomys dawsoni dausoni } & & & & & \\
\hline 0720 & o & $4 \mathrm{mi}$. N. Telegraph Creek & June 14, 1919 & 120 & 29 & 17 & 12 \\
\hline 30721 & $\sigma^{7}$ & Doch-da-on Creek & July 17,1919 & 129 & 28 & 18 & 11 \\
\hline
\end{tabular}

Microtus drummondi (Audubon and Bachman).

Drummond Meadow Mouse

Fifty-five specimens taken (nos. 30755-30809), from the following points: Sawmill Lake, near Telegraph Creek, 16; Glenora, 20; Dochda-on Creek, 18; Sergief Island, 1.

Around Telegraph Creek we found this species at but one place, in the immediate vicinity of Sawmill Lake. Some parts of the lake shore were grown with tall grass, partly flooded, and strewn with logs and other drift. Here the Drummond meadow mice had their homes; their runways traversed the moss-grown logs, and, in the intervals between, they evidently traveled through very deep water when necessary. 
Allen (1903, p. 550) comments upon the capture of but a single specimen of $M$. drummondi at Telegraph Creek, compared with an abundance of $M$. mordax, as indicative of the two species having different centers of abundance, but from our own experience there seems to be demonstrated merely a preference for different sorts of surroundings. Microtus mordax, about Telegraph Creek, wảs mainly caught along stream sides, the kind of habitat it is known to frequent in other parts of its range, and none was taken in any of the semi-aquatic runways where $M$. drummondi was obtained.

At Glenora the two species occurred in exactly the same places, runways used commonly by both traversing the weed-grown meadows about the old houses. At Doch-da-on Creek also they were found together in the bottom lands.

We took no Drummond meadow mice at either Flood Glacier or Great Glacier, but the capture of a single specimen at Sergief Island may be taken as indicative of the occurrence of the species over the entire length of the river. There are probably times when drummondi is abundant at Sergief Island, but our visit there was during a period of scarcity.

Half-grown young were taken at Telegraph Creek the middle of June, and a little later young not more than two-thirds the bulk of adults were breeding. Embryos in gravid females ranged from four to ten in number.

Microtus mordax mordax (Merriam). Cantankerous Meadow Mouse

Found at every collecting station except Sergief Island, but not equally numerous at all places. One hundred and one specimens taken (nos. 30810-30909, 31051), from the following points: The Junction, 12 ; Telegraph Creek, 16; Glenora, 38; Doch-da-on Creek, 21; Flood Glacier, 12; Great Glacier, 2. At the Junction, May 25 to June 6, specimens came in slowly. There was a little meadow at that point that showed signs of having been populated by meadow mice during the winter months, but the animals had since moved into the nearby woods. Those we obtained were taken along the streams or in wet places among the trees. They were apparently rather solitary in their habits and there were no well defined runways in use. At Glenora meadow mice were extremely abundant. The open meadow land was not frequented to any extent, but there were extensive clearings, since grown up with fireweed, that were intersected in every direction with 
much-traveled runways. The shelter afforded by' rail fences and the sides of the crumbling houses was also taken advantage of, and traps placed in such situations yielded mice night after night. A great many more were caught at that station than the thirty-eight that were preserved.

At Doch-da-on Creek, this meadow mouse was not especially abundant. Most that were caught were taken in weed-grown bottom lands. At Flood Glacier, well defined rumways, with many little piles of freshly cut green stuff, gave an appearance of an abundance of meadow mice, but despite the plentiful sign, specimens were taken but slowly. Apparently one full-grown Microtus can establish and operate an elaborate system of runways. One weed-grown area some fifty feet square, intersected with well used paths in which were found fifteen or twenty little piles of freshly cut green weed stems, yielded just one adult meadow mouse. At Great Glacier but two specimens were trapped.

The occurrence of a meadow mouse of the longicaudus group over the entire length of the Stikine River is of interest as bearing upon the relationship of Microtus mordax of the interior and $M$. macrurus of the coast. The two forms are closely related, and though heretofore recognized as distinct species, the differences between them are comparable to what is found among subspecies of some one species in other sections of the genus. The main differences between the two are of coloration and of length of tail. There are skull differences also but not trenchant ones. Macrurus, like other coastal species, is of dark brownish coloration, quite reddish-brown dorsally; mordax is distinctly gray. Macrurus has a longer tail than mordax, longer in actual measurement and longer in relation to total length. Both macrurus and mordax in the northern parts of their respective ranges (southeastern Alaska and northern British Columbia) are somewhat smaller than they are at their southern limits.

We obtained long-tailed meadow mice at various points on the Stikine River down as far as Great Glacier, and I have at hand several additional specimens (from the collection of E. P. Walker) taken at Clearwater Creek, just below the British Columbia-Alaska boundary line. There are also available specimens from Wrangell and Mitkof islands (near the mouth of the Stikine), and from various points on the mainland short distances north and south of the mouth of the river. Macrurus is abundantly represented in the collection of this Museum from various points in the Alexander Archipelago. 
Macrurus, as represented by specimens from the more western islands of the Alexander Archipelago, is a very different looking animal from mordax of the interior. The brown coloration of the one, and the gray of the other, correlated with the differences in size and length of tail, render the two series absolutely unlike. Meadow mice from Mitkof and Wrangell islands, however, are, in color, about midway between the extremes indicated, and the few specimens at hand from the lower Stikine tend still further to bridge the gap. As regards color, it is possible to arrange specimens with regard to geographical position, so as to produce a graded series of changes from one extreme to the other, with no abrupt break at any point. The same is true of general size, and of skull characters. The accompanying diagram (fig. V)

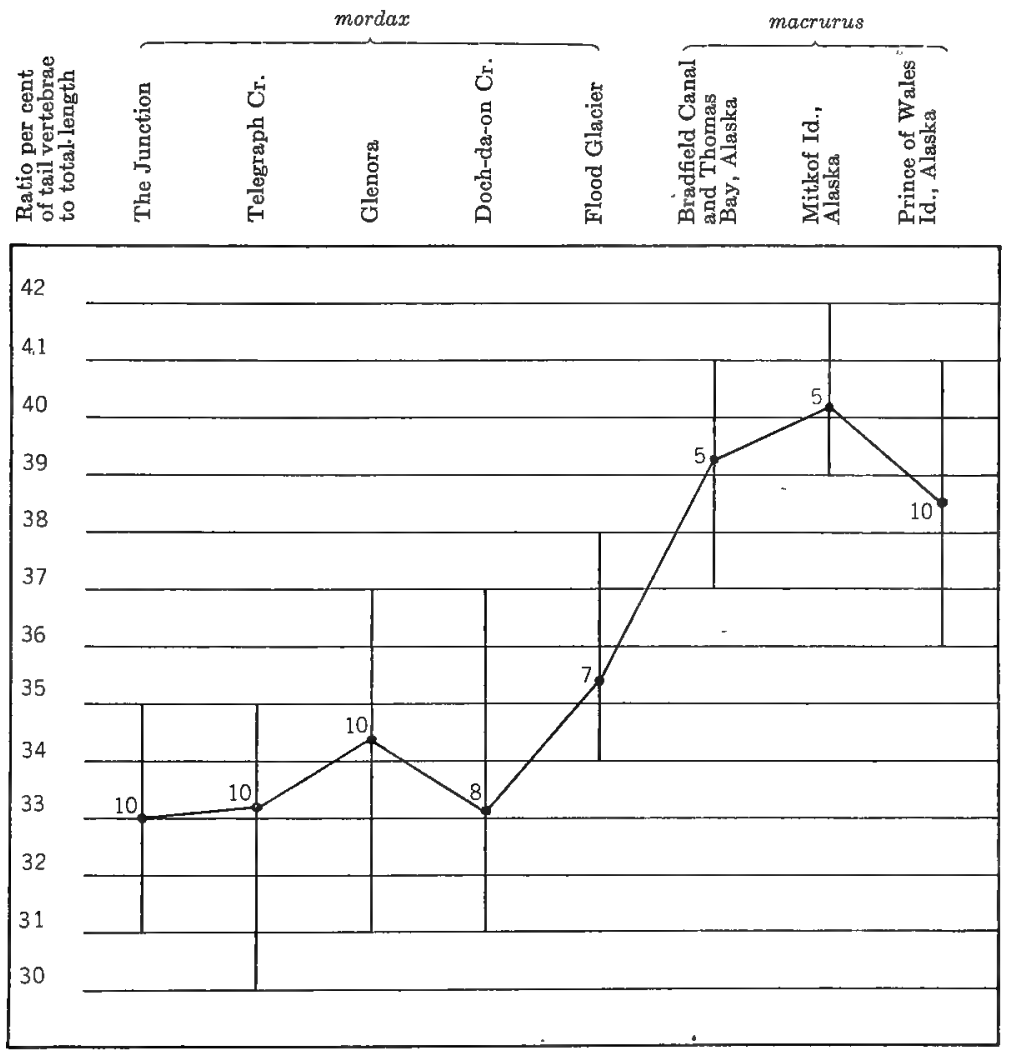

Fig. V. Diagram showing individual and geographic variation in ratio of length of tail vertebrae to total length in adult long-tailed meadow mice (both sexes). Figures at left of the vertical lines indicate numbers of specimens measured; length of lines shows range of individual variation; points connected by lines mark positions of averages. 
shows the manner in which ratio of length of tail to total length acts between one extreme and the other. There is a gradual lengthening of tail as the lower river is approached. On these grounds I believe that macrurus should be treated as a subspecies of Microtus mordax. Microtus mordax mordax may be regarded as occurring along the Stikine River at least as far down as a point (Clearwater Creek) some twenty miles from the mouth of the river.

Microtus vellerosus was described by Allen (1899, p. 7) from the Liard River, and specimens from Telegraph Creek were referred by the same writer (1903, p. 548) to that form, regarded as a subspecies, Microtus mordax vellerosus. Bailey, in his revision of the genus Microtus (1900, p. 48, footnote), denies recognition to this race, regarding it as inseparable from typical Microtus mordax mordax. Comparing our Telegraph Creek specimens with series of mordax from northern California, I am unable to distinguish between them, consequently I follow Bailey in the use of the name mordax for the northern animal.

\section{TABLE III}

Measurements in millimeters (average, minimum and maximum) of adult Microtus from the Stikine region and from southeastern Alaska

\begin{tabular}{|c|c|c|c|}
\hline Microtus mordax mordax & Total length & Tail vertebrae & Hind foot \\
\hline $\begin{array}{c}10 \text { adults, The Junction, } \\
\text { Stikine River }\end{array}$ & $170.6(155.0-180.0)$ & $55.3(50.0-62.0)$ & $20.9(20.0-22.0)$ \\
\hline $\begin{array}{c}10 \text { adults, Telegraph Creek, } \\
\text { Stikine River }\end{array}$ & $182.5(170.0-197.0)$ & $60.8(51.0-70.0)$ & $21.0(20.0-22.0)$ \\
\hline $\begin{array}{l}10 \text { adults, Glenora, Stikine } \\
\text { River }\end{array}$ & $192.2(170.0-206.0)$ & $66.7(52.0-76.0)$ & $21.4(21.0-22.0)$ \\
\hline $\begin{array}{l}8 \text { adults, Doch-da-on Creek, } \\
\text { Stikine River }\end{array}$ & $184.1(170.0-200.0)$ & $62.9(55.0-70.0)$ & $21.0(20.0-22.0)$ \\
\hline $\begin{array}{l}7 \text { adults, Flood Glacier, } \\
\text { Stikine River }\end{array}$ & $186.4(180.0-200.0)$ & $66.1(62.0-70.0)$ & $22.4(22.0-23.0)$ \\
\hline Microtus mordax macrurus & & & \\
\hline $\begin{array}{l}5 \text { adults, Mitkof Island, } \\
\text { s.e. Alaska }\end{array}$ & $174.2(164.0-183.0)$ & $70.4(68.0-72.0)$ & $21.8(21.0-22.0)$ \\
\hline $\begin{array}{l}10 \text { adults, Prince of Wales } \\
\text { Island, s. e. Aláska }\end{array}$ & $189.3(172.0-207.0)$ & $73.3(63.0-80.0)$ & $21.1(20.0-22.0)$ \\
\hline
\end{tabular}


Ondatra zibethica spatulata (Osgood). Northwestern Muskrat

Taken at but one point, on Sergief Island. Six specimens were taken (nos. 30996-31001), on September 3, 4 and 5, of which three are adult and three young. Of one the skin was subsequently lost, leaving the specimen represented by a skull only. The muskrats frequented a series of little ponds just above the reach of the tides, where the grasses of the salt marsh gave place to clusters of reeds and thickets of alder and willow. These ponds were connected by well trodden trails through the grass, like large Microtus runways, paths that could be

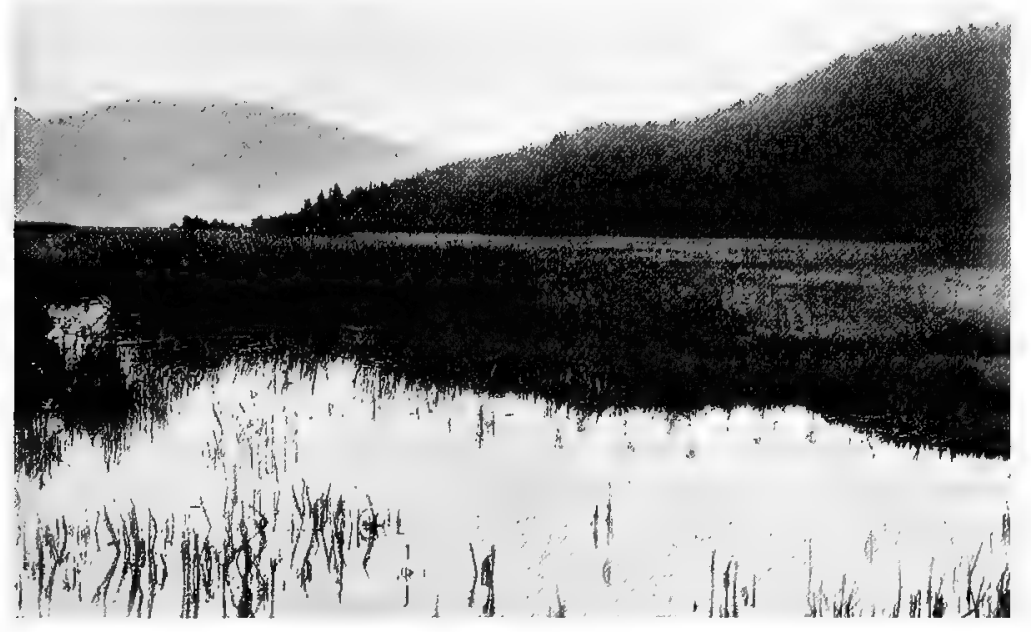

Fig. W. Marsh at western end of Sergief Island, Alaska. The rocky backbone of the island, densely covered with spruce, rises abruptly from the surrounding swamps. At the base of this slope is a bordering fringe of bushes, mostly alder, red-berry elder and willow, with, underneath, tangles of salmonberry and devil's club. The marshes farthest inland, as here shown, are mostly of fresh water, with growths of tules and other fresh-water plants. This pond and others nearby were frequented by muskrats. The surface of this pond was in part covered with floating tules that had been recently cut by these mam. mals. Birds seen in such surroundings were green-winged teal, pintail, mallard, pectoral sandpiper, and Wilson snipe. Black swifts were seen almost daily soaring over this marsh. Photograph taken September 5, 1919.

traced in the muddy bottom of shallow water and even across the deeper ponds, for the line of travel parted the floating moss and other aquatic vegetation and left just as distinctly marked a highway in the water as elsewhere. All along these trails there were signs of muskrat activities, masses of cut reeds floating in the ponds, and piles of coarse grass and other vegetation in the drier places. There were 
no "houses" to be seen anywhere. Apparently the animals were living in the shallow banks bordering some of the ponds, but this must have been farther back in the alder thickets than we penetrated, for we found no occupied burrows.

Muskrats presumably occur the length of the Stikine River, but if so they are scarce, or else, perhaps, in widely scattered colonies that are easily overlooked. Fresh sign was found about a beaver pond at Flood Glacier, but evidently of but a few individuals. We were told of the occurrence of muskrats at Doch-da-on Creek, but we, ourselves, saw no evidence of their presence.

The specimens obtained present such marked peculiarities of appearance as may very well be indicative of an undescribed race from the coast of southeastern Alaska, but at present it does not seem advisable to affix a name to this isolated series. In color they. are dark dorsally, and extremely gray elsewhere. Spatulata, as represented in this Museum by comparable specimens from various parts of its range to the northward of the Stikine, is decidedly reddish. Our Sergief Island specimens are closely similar to fall examples of osoyoosensis from the Puget Sound region. Some of the latter have an indication of cinnamon on the underparts and sides, which is seen in none of the Sergief Island specimens, but there are certain skins from the neighborhood of Seattle that are exactly like them in color. Osoyoosensis, however, is a large species, and the specimens in question are of small size, agreeing with spatulata in this respect. Thus the Sergief Island muskrats are like osoyoosensis in color, like spatulata in size. The skull is of the spatulata type, being relatively broad, with wide spreading zygomata.

There are five muskrats at hand (Mus. Vert. Zool., nos. 8353-8357) from Revillagigedo Island, Alaska, which lies south of the Stikine River, hence nearer the range of typical osoyoosensis. These specimens, according to Hollister (1911, p. 23), "while typical of spatulatus in size and color, show a slight approach toward osoyoosensis in the shape of the audital bullae and in the high, rounded jugals." It is obviously necessary that specimens be taken from various points along the coast between the known habitats of spatulata and osoyoosensis before the peculiarities of the series at hand from Revillagigedo and Sergief islands can be explained. In the meantime, while those from the latter point are not particularly like spatulata, I prefer to list them by that name, as the race they most nearly resemble, rather than apply a new one, based upon characters the meaning of which is not understood. 


\section{TABLE IV}

Measurements in millimeters of adult Ondatra

\begin{tabular}{|c|c|c|c|c|}
\hline \multicolumn{5}{|c|}{ Neasurements in millmeters of adult Undatra } \\
\hline & & Total length & Tail vertebrae & $\begin{array}{c}\text { Hind } \\
\text { foot }\end{array}$ \\
\hline 30996 & Sergief Id., Alaska & 502 & 235 & 76 \\
\hline 30998 & Sergief Id., Alaska & 520 & 225 & 74 \\
\hline 31006 & $r^{\lambda}$ ad. Sergief Id., Alaska & 590 & 246 & 77 \\
\hline \multicolumn{2}{|c|}{ Average of 4 adults of Ondatra $z$. spatulata, } & 530 & 232 & 74.5 \\
\hline \multicolumn{2}{|c|}{$\begin{array}{l}\text { Average of } 10 \text { adults of Ondatra z. osoyoosensis, } \\
\text { from Uroville, Wash. }{ }^{2}\end{array}$} & 589 & 271 & 83 \\
\hline & $\begin{array}{l}\text { Hollister, 1911, p. } 22 \\
\text { Hollister, 1911, p. } 25\end{array}$ & & & \\
\hline
\end{tabular}

\section{Mus musculus musculus Linnaeus. House Mouse}

One specimen preserved (no. 30910), an immature female caught at Sawmill Lake, June 12; several were trapped in a warehouse at Telegraph Creek. Allen (1903, p. 540) has recorded the occurrence of Mus musculus at Telegraph Creek in 1902, and it has probably been established there since a much earlier date, but from our experience it would seem not to be increasing in numbers or extending its range to any extent. It is an interesting fact that we did not obtain any at Glenora. House mice must have been there when the town was occupied by people. Apparently upon the withdrawal of the human population, the introduced Mus musculus was unable to compete successfully with the native Peromyscus, even under as favorable conditions as prevailed in the wooden houses of the abandoned city.

\section{Zapus saltator Allen. Stikine Jumping Mouse}

Found only near Telegraph Creek and at Glenora. The former is the type locality of this species (see Allen, 1899, p. 3) and a special effort was made there to get a series but the mice were not so numerous as at Glenora. Altogether, thirty-seven Stikine jumping mice were preserved (nos. 30911-30945, 31048, 31049), as follows: from The Junction, 1; Telegraph Creek, 7; Glenora, 29. All that were taken were adults. No young ones were seen and no gravid females were collected until June 30. After that date embryos, three to five in number, were found in most of the females taken.

At Telegraph .Creek specimens were caught in traps set about the edge of Sawmill Lake, mostly in thickets or under logs. At Glenora the jumping mice were found using Microtus runways extensively, 
in the tall grass and fireweed. They were evidently more or less active during the day, at least in the early morning. There is considerable color variation in the series we collected, about one-fourth of the specimens being notably grayish as compared with the rest, and with very little brown on the back or ochraceous on the sides.

Zapus saltator has been taken at the mouth of the Skeena River (Preble, 1899, p. 32), and at the mouth of the Taku River (Swarth, 1911 , p. 135). It would seem therefore that it might also range the entire length of the Stikine River, and I believe it to be very possible that it does so, despite our failure to obtain specimens along the lower part of that stream.

\section{Frethizon epixanthum nigrescens Allen. Dusky Porcupine}

Porcupines occur throughout the whole of the region we traversed, but they are apparently not abundant. We saw very few. On June 12 one was taken a few miles west of Telegraph Creek. On July 11 one was seen on the mountain side above Doch-da-on Creek, and on July 17 one entered our camp at the same locality. These were all that were encountered during the summer. The one obtained (no. 31001), a male, is not much more than half the bulk of an ordinary adult porcupine, but aside from its small size there is little about the animal to suggest immaturity. It must have been born the preceding year at least. It was badly infested with tapeworms, the abdominal cavity containing packed masses of the parasite in almost incredible amount, and this condition might, perhaps, explain the poor physical development of the host. The general coloration of this animal is pale yellow, the long overhairs being extensively tipped with this color and the quills being mostly yellowish. The basal portion of the body hairs is dull brownish, as is also the entire face. The two other porcupines that were seen, apparently normal adults, were extremely dark colored.

\section{Marmota caligata caligata (Eschscholtz). Northern Hoary Marmot}

Apparently a timber-line species in the upper Stikine region, and descending to sea level at the coast. Whether or not it also occurs at high altitudes in the coastal region $I$ do not know. We saw none in the immediate vicinity of Telegraph Creek, though the species doubtless occurs in the surrounding mountains. An acquaintance who climbed Glenora Mountain on July 2 told us of seeing a marmot on the heights above the timber. We ran across more or less sign on the bare ridges above Doch-da-on Creek in July; on July 23 one of the animals was 
seen there, far above the timber, too wary for a near approach. On Kirk's Mountain, some miles north of Doch-da-on Creek, Dixon heard a number of marmots whistling.

At Flood Glacier some marmots. were residing in rock piles at the base of the mountain, several miles back from the river but at a not much higher altitude. Dixon shot two here on August 1, an adult male (no. 31005) and a young one, perhaps a quarter grown (no. 31004). The species was not encountered farther down the river.

The marmots of the mountains about Doch-da-on Creek and Glenora may well be Marmota caligata oxytona Hollister. This would be at about the western limit of that subspecies. The adult male from Flood Glacier has a large skull, well within the limits of oxytona, and exhibiting the characters of that race as detailed by Howell (1915, p. 63), but in external measurements this animal is no larger than coastal specimens of the subspecies caligata. The young male from Flood Glacier is at the same stage of growth as a young caligata at hand from the mouth of the Chickamin River, Alaska, and the two are indistinguishable in appearance. The peculiarities of the skull in the adult may be an indication of intergradation between caligata and oxytona in the middle reaches of the Stikine, but the material at hand does not suffice to settle that point.

\section{Citellus plesius plesius (Osgood). Bennett Ground Squirrel}

On June 4 two ground squirrels were taken at the Summit (nos. 30994,30995 ), and one other was seen. This same place was visited on May 29 and again on June 5 without any animals being encountered. It was still quite wintry at that altitude, with much snow on the ground and ice on the lakes, and it seemed likely that most of the ground squirrels were still in hibernation. M. P. Anderson had found them in abundance at the Summit in July and August, 1902 (Allen, 1903, p. 534). The species occurs in the Stikine region only on the mountain slopes above timber line; it is found nowhere in the lower valleys.

The three animals seen were all observed within a radius of two hundred yards. There were a number of fresh looking burrows at the same place. These holes were scattered, though sometimes there were two or three fairly close together; some were amid thickets of low bushes, others out in the open meadows. They were small, considering the size of the animal, and there were no noticeable mounds of earth at the entrances. Of the two animals collected, the stomachs 
were well filled with masticated moss and lichens. The female contained four small embryos. Anderson (Allen, loc. cit.) in 1902 collected young squirrels "one-fourth to one-half grown" at the same place on July 31.

When we were at Glenora two acquaintances who were camped nearby made a trip to the summit of Glenora Mountain, which rises just north of the town. They reported an abundance of ground squirrels on the slopes above the timber. We kept a careful lookout for the species on the mountains above Doch-da-on Creek where the surroundings were apparently ideal, but saw none of the animals nor any burrows or other certain sign of their presence.

\section{Eutamias borealis caniceps Osgood. Gray-headed Chipmunk}

Of general distribution in the region about Telegraph Creek and Glenora; not abundant but apt to be encountered anywhere in the lowlands. At Doch-da-on Creek chipmunks were noticeably less abundant, and the species was not seen at all farther down the river. While apparently mostly at low altitudes, chipmunks were sometimes found well up the mountain sides. On July 11 one was seen at timber line (about 3000 feet) above Doch-da-on Creek.

Dandelions were a favorite food. Toward the end of June and in July these were going to seed, and chipmunks were constantly seen stripping the fluffy heads. Individuals had certain favorite spots for eating, and at such places there were heaps of dandelion fuzz and parts of the blossoms.

Twenty-eight specimens were collected (nos. 30946-30973), as follows: Telegraph Creek, fifteen adults ; Glenora, five adults; Doch-da-on Creek, two adults and six young.

The chipmunk of the Telegraph Creek region was identified as Eutamias caniceps by Allen (1903, p. 533). Preble (1908, p. 169) considers caniceps as a subspecies of Eutamias boreatis, and I am here following his opinion. No topotypes of caniceps nor any examples of boreatis have been available for comparison.

Sciurus hudsonicus hudsonicus (Erxleben). Northern Red Squirrel Sciurus hudsonicus picatus Swarth. Northwest Coast Red Squirrel

Red squirrels were not abundant at any point visited by us in the upper Stikine Valley, though seen in small numbers almost everywhere. About Telegraph Creek and Glenora from five to ten individuals might 
be encountered in the course of a day's walk. At Doch-da-on Creek they were less numerous, due perhaps to their having been incidentally killed by the systematic trapping that had been carried on during the previous winter over much of the ground we covered at that point. At Flood Glacier and Great Glacier, red squirrels were extremely scarce. We realized, of course, the fact that this species occurred as two different geographic races, at the mouth of the Stikine and at the head of the river, respectively, and that there was probably continuous distribution of the species for the entire length of the stream. We

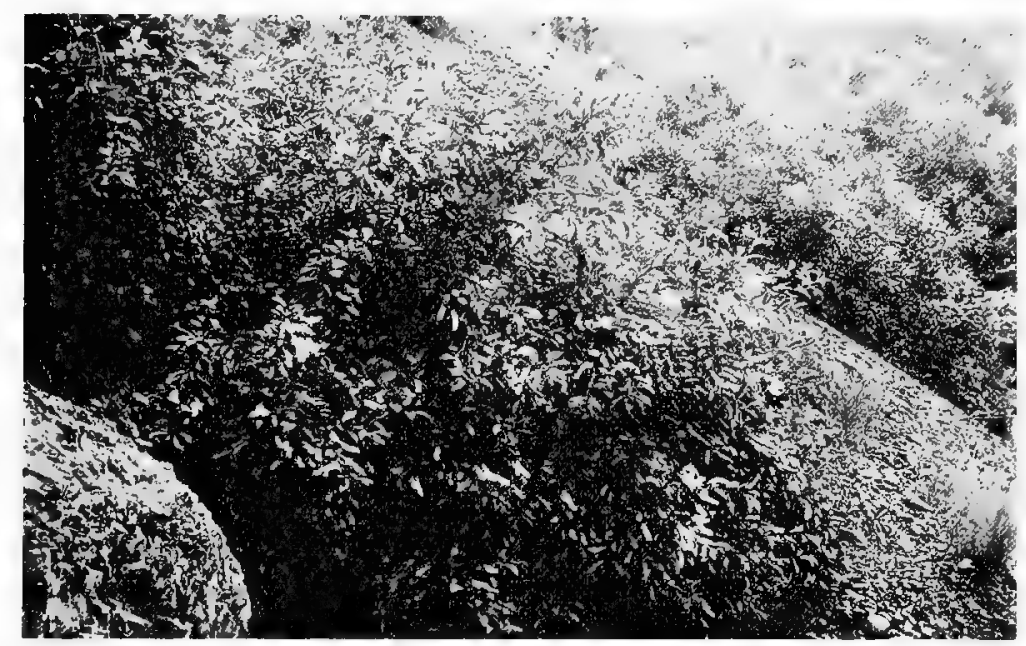

Fig. X. Thicket of wild cherry (Prunus demissa) at Telegraph Creek. This shrub grows in abundance in that region; by the middle of June the bushes are covered with white flowers. The gray-headed chipmunk was characteristically found in such surroundings as are here shown, on rather broken ground that was grown up with bushes of this sort. Photograph taken June 15, 1919.

realized also that in all probability somewhere near Flood Glacier or Great Glacier was the critical point where the two subspecies meet, and for that reason we bent every effort toward getting specimens from those stations. However, not more than two or three were seen at each place. At Sergief Island, too, red squirrels were scarce.

Altogether we collected twenty specimens. (nos. 30974-30993), fifteen adults and five young, from the following localities: Telegraph Creek and vicinity, ten; Glenora, two adults and one young; Doch-da-on Creek, three full-grown young; Flood Glacier, one ; Great Glacier, one; Sergief Island, one adult and one young. The Telegraph Creek speci- 
mens were taken at various points between that town and the Summit, twelve miles to the northward. Six specimens from Telegraph Creek were submitted to Mr. E. A. Preble, of the United States Biological Survey, for subspecific determination. His conclusion is that these squirrels are "virtually identical with Sciurus $h$. hudsonicus. In some respects, notably in the color of the back, they show some slight approach to $S$. $h$. petulans of the coast. They agree, however, with hudsonicus as regards the color of the fringe of the tail."' The Glenora and Doch-da-on Creek specimens are clearly in the same category as the Telegraph Creek specimens; they are all $S$. $h$. hudsonicus. The squirrels from Flood Glacier, Great Glacier, and Sergief Island are just as unequivocally S. h. picatus.

As between hudsonicus and picatus, there are differences of color and of the skull. Red squirrels from Doch-da-on Creek (three fullgrown young) are in both respects typical of hudsonicus and they represent the farthest point down stream at which this subspecies was taken. Our next collecting station was Flood Glacier, some forty miles down the river, and, as noted, there was taken at that point but the one red squirrel, typical of picatus, both as regards color. and skull. Whether there actually is a stretch of country in this intermediate region where red squirrels are as scarce as our experience seems to indicate, or whether we were merely unlucky in the necessarily limited areas our field work covered at Flood Glacier and Great Glacier, remains still to be determined. It may be, of course, that there is actually a notable scarcity of the animals throughout this intermediate region, that there is some attribute of the country that is unfavorable to the red squirrel, and hence serves to keep apart these two subspecies. (For the use of the name Sciurus hudsonicus picatus see Swarth, $1921 b$, p. 92.)

We gained but little information regarding the life history of the red squirrel in the region explored. Near the Junction individuals were several times seen to enter holes in the ground, holes that, from their appearance, evidently served as homes. Squirrel nests were sometimes seen in the trees, but they were not numerous. Females collected May 25 and 26 contained embryos, four and five in number, and about 30 millimeters long. A young male shot at Glenora, July 2, is about two-thirds the length of an adult, and about a quarter the weight. The three young ones from Doch-da-on Creek, taken July 14, 17, and 22, respectively, are nearly full-grown, being but slightly below adults in measurements and weight. 
The first red squirrel collected near Telegraph Creek, on May 26, had almost completely finished the molt into the summer pelage. Others shot during the next two weeks are either in the winter pelage throughout or else variously advanced in the change, showing ragged patches of the old coat. Those taken farther down the river are all in summer pelage.

An adult female taken at Glenora July 4 (no. 30986) has the incisors of both jaws malformed so that they could not meet, the two lower teeth passing together to the left of the upper ones. All four had grown to abnormal length, but not so much so as to endanger the animal's life. They were evidently worn down somewhat by the friction sideways; the teeth are beveled, but not on the same plane as in normal individuals. This squirrel was in good condition, in fact there was some fat under the skin. A western goshawk collected at Flood Glacier contained in its stomach the remains of a red squirrel; doubtless all the hawks of the region prey upon this species to some extent.

\section{TABLE V}

Measurements in millimeters of Sciurus from the Stikine Region and from southeastern Alaska

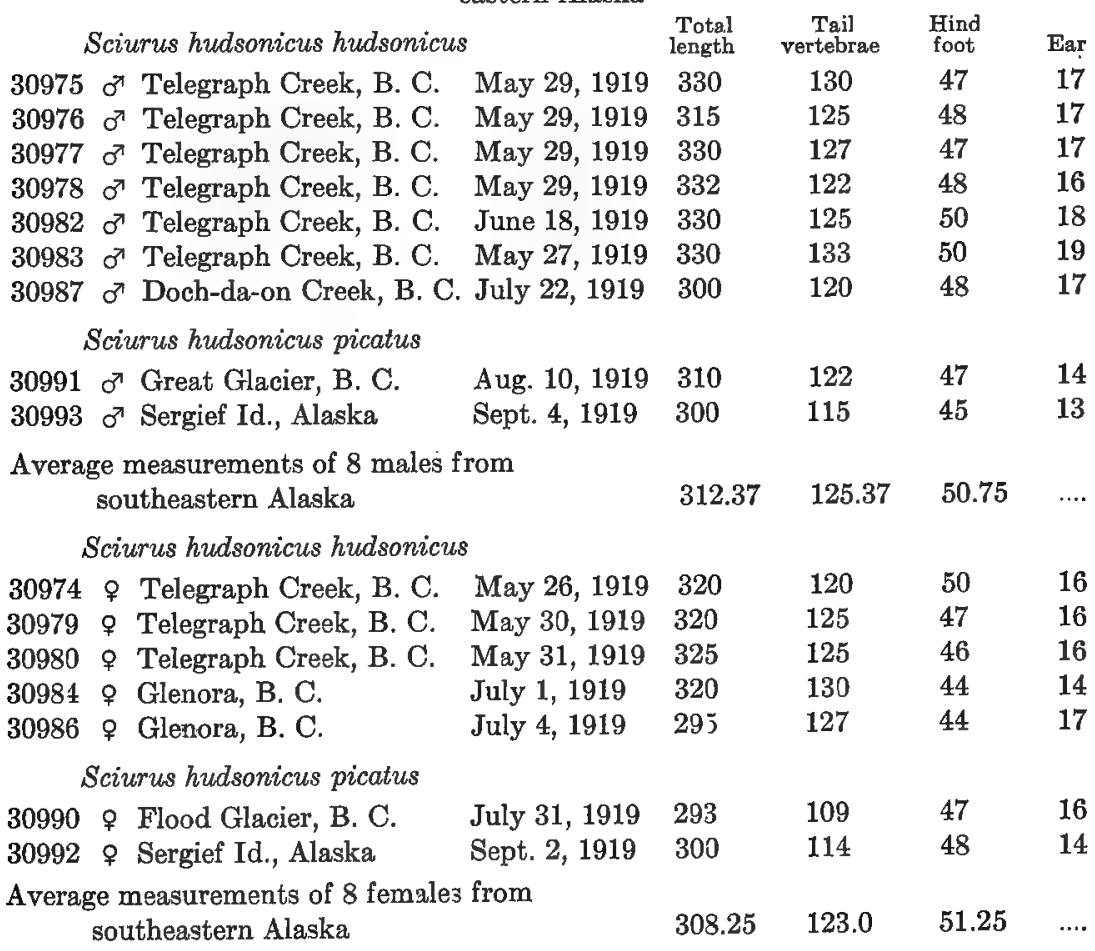




\section{Lepus americanus macfarlani Merriam. Mackenzie Varying Hare}

We were told that some years rabbits occurred in abundance in the country about Telegraph Creek, but we were there during a period of scarcity, and they were all but totally absent. As evidence of former abundance we found scattered through the woods many crumbling rabbit skeletons, bleached and weathered, which had lain there for a year at least, perhaps longer. On June 18 fresh rabbit tracks were seen in the dust of a trail some five or six miles west of Telegraph Creek, and on July 7 a young rabbit about two-thirds grown (no. 31003) was taken near the Stikine River opposite Glenora. No others were seen, nor any indication of their presence, at any other point.

\section{Castor canadensis canadensis Kuhl. Beaver}

An abundant species on the lower Stikine, where the many miles of flooded bottom lands, the mazes of winding channels and sloughs, and the abundant forest growth, all combine to make conditions that are well-nigh ideal for the beaver. Above "the Cañon" the species is scarce. There are undoubtedly many obscure little ponds hidden in the woods and blind sloughs and channels running back from the river that still shelter small and scattered colonies, but the beavers have been so nearly extirpated in this region that trapping is no longer profitable.

A few miles from Telegraph Creek there were beaver ponds, some of considerable size, but we were told that the beavers had long been wiped out. At Glenora, one evening, the resounding "plop" of a beaver's tail in the water near the river's edge gave evidence of one survivor, at least. Near Doch-da-on Creek, several miles back from the river, there was a series of ponds, all occupied by beavers, though so many had been caught there during the several years immediately preceding our visit that there were probably but few still left.

At Flood Glacier and at Great Glacier beavers were seen, and also abundant evidence of recent activities. At Farm Island, just above Sergief Island, at the mouth of the river, Dixon found a colony of some size, and on September 5 he trapped two at that point. These two specimens (nos. 31013, 31014), immatures, probably born the preceding year, were the only ones taken.

This material is too scanty to definitely determine the subspecific position of the beaver of the Stikine region, but it may be said that the two animals obtained are appreciably paler in coloration than phaeus, of Admiralty Island, or even than leucodonta, of Vancouver Island. 
We saw trappers' skins, also, from various points on the Stikine, and they all appeared to be paler colored than phaeus. It seems safe to assume that but one subspecies of beaver occurs over the entire length of this river, and apparently it is a relatively pale-colored form. There are probably beavers on the mainland coast of southeastern Alaska wherever conditions are suitable, and also on most of the islands. From this whole general region, however, specimens are available only from Admiralty Island, where the dark colored Castor c. phaeus occurs. Whether this form occupies a habitat more extensive than this one island, and the extent of the area on the coast of Alaska that is occupied by the paler colored subspecies of the Stikine region, are points that still remain to be ascertained.

\section{Odocoileus columbianus sitkensis Merriam. Sitka Deer}

No deer nor any sign of their presence was seen until we reached the mouth of the river. At Sergief Island the fresh tracks of one individual were seen on the beach during the first week in September. Deer are fairly numerous on the nearby Farm Island, but they seldom cross over to Sergief. Dixon spent several days (August 26-29)' on a trip to Mitkof Island. Deer are abundant there, as on' most of the islands of the Alexander Archipelago, and on August 28 three were shot. One of these (no. 31012), a spike buck, was preserved as a specimen.

\section{Alces americanus gigas Miller. Alaska Moose}

The most important game mammal of the region and the main source of fresh meat for the residents of the country. We were told that twenty or thirty years ago moose were scarce in the Telegraph Creek region and almost unknown farther down the river, and that they had steadily increased in numbers since that time. At present they are abundant. We saw fresh sign everywhere we went, in the immediate vicinity of each of our camps (including points within two miles of the town of Telegraph Creek), and as far down the Stikine as the Great Glacier. Moose are known to occur regularly even farther down stream, and we were told of one being killed at the river's mouth some years ago. On the mountains above Doch-da-on Creek fresh moose tracks and droppings were seen just above timber line, at about 4000 feet elevation. 
At the Junction, on May 27, Dixon was going quietly through the poplar woods in search of birds when a cow moose suddenly burst forth from a clump of alders some thirty yards away and charged viciously upon him with mouth open and neck bristles all on end. When she was within fifteen yards and still coming, he fired a load of dust shot, whereupon she swerved to one side and went off through the trees. A search of the bushes from which she had emerged disclosed a newly born calf, still unable to do more than totter about on its long and very wobbly legs.

Dixon's observations upon this animal read in part as follows :

When first found, on the very spot where it was born, the calf was not frightened but came up to me, whining like a puppy dog. Later this low whine was found to be a usual call note of the youngster. The moose characters of large ears, overhanging nose, high shoulders, low rump, and long legs, were all conspicuous. The face and particularly the ears, were much lighter colored than the body. An incipient mane of black hairs showed as a narrow line from the back of the head to a point just back of the shoulders. The metatarsal glands were conspicuously colored by a patch of whitish hairs covering an area one inch long by one-half inch wide. The body was elothed with thick warm hair, plumbeous at the basal half, then brown, and with a faint tipping of black. In walking on level ground the young moose stood 30 inches high at the shoulder and 27 inches at the rump. The distance from the nose to the tip of the tail in life was 30 inches.

The sense of hearing was most keen, sight second, and smell last. A cracking twig always startled her violently. The upper eyelid had eyelashes over an inch long, which helped to keep the myriad mosquitoes out of the eyes. A swarm of these bloodthirsty pests were sucking blood from the helpless youngster when first discovered.

In attempting to nibble grass the little moose knelt down on her front legs, and in this position was able to bite off the tender grass with her eight sharp lower incisors, well developed even in this 24 hour old calf. Attempts were also made to nibble budding willow twigs. In lying down she knelt on her front legs first, then the posterior was lowered and the long hind legs tucked up under or to one side of the body. In getting up, the animal rose to its knees on its front legs, and then the hind quarters were raised. By mid afternoon the young moose followed me about the camp so that $I$ had difficulty in keeping far enough away to use the camera.

\section{Rangifer osborni Allen. Cassiar Caribou}

We ourselves were at no time in caribou territory, and my only reason for including the species here is to place on record information received regarding the distribution of this animal. Telegraph Creek is the outfitting place of hunters who visit the region each fall, and many caribou are killed by them, but the mountains where the hunting is usually done are reached by long pack trips to the northward and eastward. 
We were told by the caretaker at Mr. Callbreath's farm, across the river from Glenora, that a band of ten or twelve caribou had spent the previous winter on the unforested summit of Glenora Mountain, where he had often watched them with a field glass. This may represent the extreme western point reached by the species in this region. Twentyfive miles farther down the river there are other mountains with extensive areas rising above timber line, which have been hunted over for many years past by Captain A. B. Conover, residing at the mouth of Clearwater Creek. He told us that he had never seen any caribou there, nor any sign of their presence.

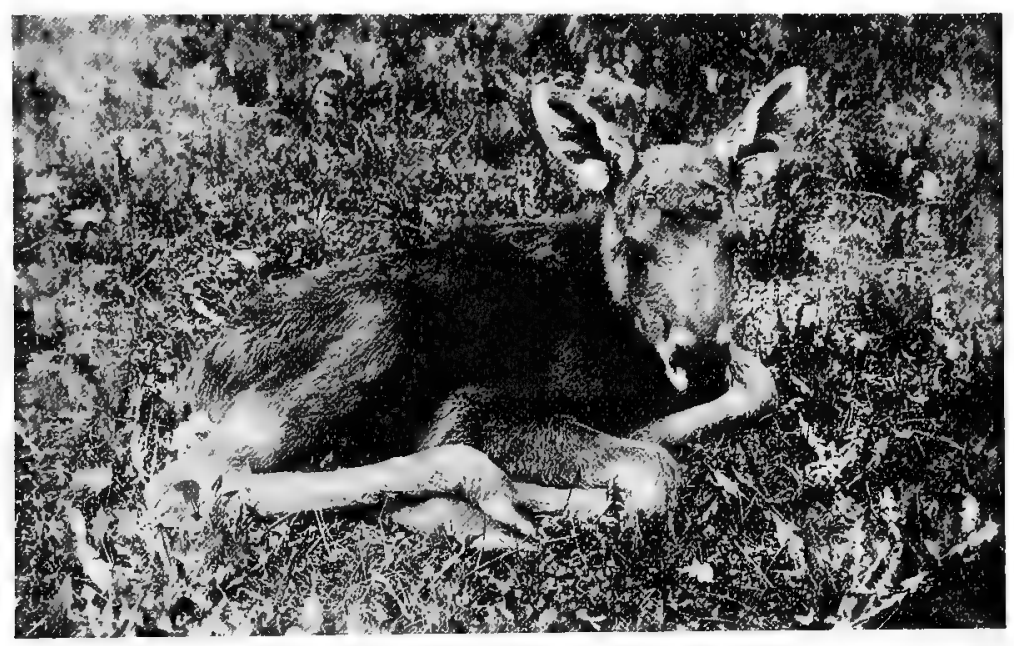

Fig. Y. Young Alaska moose (Alces americanus gigas), twenty-four hours old. The long legs of the adult moose is a feature that is much accentuated in the ealf, giving an appearance of extreme ungainliness to the short-bodied animal, whether standing upon these stiltlike members or lying down with the legs awkwardly folded underneath. Photograph taken near Telegraph Creek, May 27, 1919.

Oreamnos montanus columbianus Allen. Columbian Mountain Goat

Mountain goats are probably of general distribution on the higher mountains from Telegraph Creek west to the coast. Our own experiences were limited to three localities. At Glenora, on July 3, an aequaintance ascended the mountain that rises behind the town, and he told us that he saw two goats near the summit. On July 11 and 23 we climbed the mountain just south of Doch-da-on Creek. As soon as the belt of upright timber was passed, goat sign was seen on all sides. Broad, well-beaten trails wound through the thickets of prostrate 
balsam, to split again and again and finally become indistinguishable on the open grass-covered slopes above. The balsam branches along the trails were decorated with streamers of long white hair, caught from the shedding animals as they passed along. Recently occupied beds could be distinguished at many points, and numerous footprints and droppings all attested to the presence of mountain goats in some numbers. We saw none here, however, though on the 11th, when we started to descend the mountain toward evening, fresh tracks were seen at one point where a goat had crossed our trail since morning.

Four days, July 16 to 19 , were devoted by Dixon to a hunt on the mountain above Kirk's Creek, some eight or ten miles north of Dochda-on Creek. He saw a number of the animals and shot an adult male (no. 31008). Several were in sight at once when this one was killed, and Dixon's observations on the behavior of the remainder of the band include some interesting items. His notes read in part as follows:

While we were skinning our specimen another goat came back, and after grazing about awhile laid down against a granite boulder, where, with head propped up against a stone, he watched us as we worked. Although we were in plain sight and only 150 yards away, he lay there placidly observing us. As soon as $I$ started to sneak down out of sight, in an attempt to approach near enough to get a photo, the goat got up and went over the ridge and across a narrow ravine, where he stood waiting, watching me as I came over the crest of the ridge 100 yards away. I followed him over the next ridge and saw him disappear down a snow slide toward a hanging valley below. From this latter point I searched the cliffs above me with the binoculars, and saw a goat lying in a niche in the cliff, high above me. This animal lay motionless with outstretched neck, watching me intently. Going around the ridge out of sight at one side of the cliff, I worked my way up to a level with him, then edged around the cliff so that when I stepped out in sight I was less than thirty feet distant. The goat bounded to his feet, then slowly and deliberately jumped from niche to niche along the face of the cliff until a slide was reached. Here he bounded and slid down, scattering the rocks as he went. The spot where he had been resting, about the center of the eliff, was like the eyrie of a golden eagle, and about as difficult of access. It seemed incredible that so large an animal could ever have reached it along the face of the cliff. A man certainly could not have done so.

His tracks led across a snow slide to a eavity at the south side of a large boulder. The snow melting away from the rock left a hole about six feet long, three feet wide and four feet deep, and in here the goat had lain down, resting on the snow and peering at me over the brink. Only the dark eyes and horns could be seen, the otherwise white coloration blending perfectly with the snow. I walked down to within 100 feet of the animal and took two photos while he lay perfectly still. Then I crawled to the edge of the snow bank, too steep for me to cross, and threw rocks at him. Arising, at first he stood his ground, stamping his fore feet or making feints at charging me. I finally struck him with a stone and he jumped to the edge of the snow bank, where he stood with arched neck and tail erect as though in challenge. Then he started down the 
snowslide. With hind legs flexed and spread well apart, and front legs rigid, almost on his haunches, he slid and wriggled in safety down the dangerous slide, which at the bottom dropped over a precipice. At the top of this eliff he crossed to the solid rock beyond, and then turned to see if $\mathrm{I}$ was coming.

The goat taken was a male, fully mature but not of great age. His weight was estimated at two hundred pounds. This animal has almost none of the long shaggy covering with which we usually associate the species. It is white, just as in winter, but the hair is extremely short. Over much of the body there is no more than a scanty covering of tightly curled wool, which presumably would develop later into a dense body covering, completely hidden by the long straight hairs of the winter coat.

Oreamnos montanus columbianus was described from the Shesley Mountains, in the same general region and some sixty or seventy miles north of the place where our specimen was taken (see Allen, 1904, p. 20). Mountain goats occur on the mountains along the mainland coast of southeastern Alaska directly to the westward of this region, and with very little doubt at all suitable places between. Whether or not the subspecies columbianus extends westward to the coast we have not the material to decide, though the specimens at hand suggest otherwise. There are three specimens available from the coast of southeastern Alaska, an adult female and two young males. The old female has horns that are nearly as widespreading as in a female Oreamnos kennedyi, from Cook Inlet, of about the same age. They are more widespreading than in our adult male from the Telegraph Creek region. These are the only comparisons that it is feasible to make. This material thus suggests the possibility at least of the existence of a coastal race, kennedyi, as distinct from columbianus of the interior. In all probability kennedyi should be regarded as a subspecies of Oreamnos montanus, rather than a distinct species. There is with little doubt sufficiently continuous distribution of mountain goats along the Alaskan coast to insure intergradation between the several described forms, and the goat occurring on the mainland of the Sitkan region may well prove to be referable to kennedyi, though perhaps not exhibiting the characters of that race in their extreme. 


\section{CHECK LIST OF BIRDS}

1. Colymbus holboelli (Reinhardt).

2. Colymbus auritus Linnaeus.

3. Gavia immer (Brünnich).

4. Larus philadelphia (Ord).

5. Sterna paradisaea Brünnich.

6. Mergus americanus Cassin.

7. Anas platyrhynchos Linnaeus.

8. Nettion carolinense (Gmelin).

9. Spatula elypeata (Linnaeus).

10. Dafila acuta (Linnaeus).

11. Marila, sp.?

12. Glaucionetta islandica (Gmelin).

13. Histrionicus histrionicus (Linnaeus).

14. Oidemia deglandi Bonaparte.

15. Branta canadensis occidentalis (Baird).

16. Ardea herodias fannini Chapman.

17. Gallinago delicata (Ord).

18. Pisobia maculata (Vieillot).

19. Pisobia minutilla (Vieillot).

20. Totanus melanoleucus (Gmelin).

21. Totanus flavipes (Gmelin).

22. Tringa solitaria oinnamomea (Brewster).

23. Actitis macularia (Linnaeus).

24. Oxyechus vociferus vociferus (Linnaeus).

25. Dendragapus obscụrus flemingi Taverner.

26. Dendragapus obscurus sitkensis Swarth.

27. Canachites canadensis osgoodi Bishop.

28. Canachites canadensis atratus Grinnell.

29. Bonasa umbellus umbelloides (Douglas).

30. Lagopus leucurus leucurus (Swainson).

31. Zenaidura macroura carolinensis (Linnaeus).

32. Circus hudsonius (Linnaeus).

33. Accipiter velox (Wilson).

34. Astur atricapillus atricapillus (Wilson).

35. Astur atricapillus striatulus Ridgway.

36. Buteo borealis calurus Cassin.

37. Buteo swainsoni Bonaparte.

38. Aquila chrysaëtos (Linnaeus).

39. Haliaeëtus leucocephalus alascanus C. H. Townsend.

40. Falco peregrinus pealei Ridgway.

41. Falco columbarius columbarius Linnaeus.

42. Falco sparverius sparverius Linnaeus.

43. Asio flammeus (Pontoppidan).

44. Cryptoglaux funerea richardsoni (Bonaparte).

45. Bubo virginianus, subsp.?

46. Glaucidium gnoma, subsp.?

47. Ceryle alcyon caurina Grinnell.

48. Dryobates villosus monticola Anthony.

49. Sphyrapicus varius varius (Linnaeus). 
50. Sphyrapicus varius ruber (Gmelin).

51. Colaptes auratus borealis Ridgway.

52. Chordeiles virginianus virginianus (Gmelin).

53. Cypseloides niger borealis (Kennerly).

54. Chaetura vauxi (J. K. Townsend).

55. Selasphorus rufus (Gmelin).

56. Sayornis sayus (Bonaparte).

57. Nuttallornis borealis (Swainson).

58. Myiochanes richardsoni richardsoni (Swainson).

59. Empidonax difficilis difficilis Baird.

60. Empidonax trailli alnorum Brewster.

61. Empidonax hammondi (Xantus).

62. Empidonax wrighti Baird.

63. Otocoris alpestris areticola Oberholser.

64. Cyanocitta stelleri stelleri (Gmelin).

65. Perisoreus canadensis canadensis (Linnaeus).

66. Corvus corax principalis Ridgway.

67. Corvus brachyrhynchos caurinus Baird.

68. Euphagus earolinus (Müller).

69. Pinicola enueleator flammula Homeyer.

70. Carpodacus purpureus purpureus (Gmelin).

71. Loxia curvirostra bendirei Ridgway.

72. Loxia eurvirostra sitkensis Grinnell.

73. Loxia leucoptera Gmelin.

74. Leucosticte tephrocotis littoralis Baird.

75. Spinus pinus pinus (Wilson).

76. Calcarius lapponicus alaseensis Ridgway.

77. Passerculus sandwichensis savanna (Wilson).

78. Passerculus sandwichensis alaudinuis Bonaparte.

79. Zonotrichia leucophrys gambeli (Nuttall).

80. Zonotrichia coronata (Pallas).

81. Spizella monticola ochracea Brewster.

82. Spizella passerina passerina (Bechstein).

83. Junco hyemalis connectens Coues.

84. Junco oreganus oreganus (J. K. Townsend).

85. Melospiza melodia rufina (Bonaparte).

86. Melospiza melodia caurina Ridgway.

87. Melospiza lincolni gracilis (Kittlitz).

88. Passerella iliaca unalaschcensis (Gmelin).

89. Passerella iliaca fuliginosa Ridgway.

90. Piranga ludoviciana (Wilson).

91. Petrochelidon lunifrons lunifrons (Say).

92. Hirundo erythrogaster Boddaert.

93. Iridoprocne bicolor (Vieillot).

94. Tachycineta thalassina lepida Mearns.

95. Riparia riparia (Linnaeus).

96. Bombycilla garrula pallidiceps Reichenow.

97. Vireosylva gilva swainsoni (Baird).

98. Vermivora celata orestera Oberholser.

99. Vermivora celata lutescens (Ridgway).

100. Vermivora peregrina (Wilson).

101. Dendroica aestiva aestiva (Gmelin). 
102. Dendroica coronata hooveri McGregor.

103. Dendroica townsendi (J. K. Townsend).

104. Seiurus noveboracensis notabilis Ridgway.

105. Oporornis tolmiei (J. K. Townsend).

106. Wilsonia pusilla pileolata (Pallas).

107. Setophaga ruticilla (Linnaeus).

108. Anthus rubescens (Tunstall).

109. Nannus hiemalis pacifieus (Baird).

110. Certhia familiaris oceidentalis Ridgway.

111. Sitta canadensis Linnaeus.

112. Penthestes atricapillus septentrionalis (Harris).

113. Penthestes gambeli abbreviatus Grinnell.

114. Penthestes rufescens rufescens (J. K. Townsend).

115. Regulus satrapa olivaceus Baird.

116. Regulus ealendula calendula (Linnaeus).

117. Regulus calendula grinnelli W. Palmer.

118. Myadestes townsendi (Audubon).

119. Hylocichla ustulata ustulata (Nuttall).

120. Hylocichla ustulata swainsoni (Tschudi).

121. Hylocichla guttata guttata (Pallas).

122. Hylocichla guttata nanus (Audubon).

123. Planesticus migratorius migratorius (Linnaeus).

124. Planesticus migratorius caurinus Grinnell.

125. Ixoreus naevius naevius (Gmelin).

126. Ixoreus naevius meruloides (Swainson).

127. Sialia currucoides (Bechstein).

\section{GENERAL ACCOUNTS OF THE BIRDS}

Colymbus holboelli (Reinhardt). Holboell Grebe

A pair was nesting on Sawmill Lake in June. They kept far out on the lake, but with binoculars we were able to determine their specific identity.

\section{Colymbus auritus Linnaeus. Horned Grebe}

Small grebes were seen on Sawmill Lake several times during June, always at a great distance, and on June 12 a pair was seen on Alkali Lake.

\section{Gavia immer (Brünnich). Common Loon}

At least one pair on Sawmill Lake. The birds were quiet and unobtrusive, never being heard calling at that point. Another pair, encountered in a small lake near Doch-da-on Creek, was more noisy, and our arrival at the lake shore was invariably heralded by an outburst of sound from both birds. At that time, the middle of July, they were caring for two young, apparently about a third grown. The four birds were almost always seen together. 


\section{Larus philadelphia (Ord). Bonaparte Gull}

One or two flocks were seen just after we passed Dixon Entrance, going north, on May 19. They were apparently migrating, the only migrants in evidence at that time, and were traveling in a manner characteristic of the Bonaparte gull, but different from most of our other species. The flocks were in compact formation and flying swiftly, more like large waders than gulls in appearance; there was no soaring whatever, and no lingering.

A single Bonaparte gull was seen on Sawmill Lake, June 17. A small gull seen flying up stream past our Flood Glacier camp on August 4 was probably of this species.

\section{Sterna paradisaea Brünnich. Arctic Tern}

On our trip up stream, May 21 to 23, terns believed to be of this species, were seen at intervals up to within thirty miles of Telegraph Creek. On July 14, at Doch-da-on Creek, several were flying about over some sand bars in midstream; from then on they were noted at various times and places, always far out over the river.

\section{Mergus americanus Cassin. American Merganser}

On May 21, mergansers were seen in fair abundance at the mouth of the Stikine; they lessened in numbers as we went up stream, and finally disappeared, none being observed above "the cañon." Those that came near enough for identification wंere all $M$. americanus.

Later in the summer, at Flood Glacier, at least two different broods of mergansers were seen, but of what species could not be ascertained. On July 29 a family of ten or twelve plunged into the stream opposite our camp, hotly pursued by a bald eagle. The eagle was very much in earnest, but it was curious to see, once the water was reached, the indifference with which the mergansers regarded their formidable pursuer. None took the trouble to dive, even, except the one specifically selected as a victim. Then, at the last moment, that particular individual disappeared easily beneath the water, leaving the eagle floundering and gathering himself for another try at the flock. He soon gave up the task, and the mergansers swam down stream out of our sight. 


\section{Anas platyrhynchos Linnaeus. Mallard}

A single bird, seen June 12 in a beaver pond some five miles west of Telegraph Creek, was the only indication we had that this species might be breeding in the upper Stikine Valley. Ducks are quiet and retiring during the nesting season, however, and we spent but little time in places where we would be apt to find them, so that our negative results are no proof of the actual scarcity of this and some other species.

At Sergief Island, August 17 to September 7, mallards were present in considerable numbers. All that we shot proved to be young birds.

Nettion carolinense (Gmelin). Green-winged Teal

A pair was seen June 12 in a beaver pond some five miles west of Telegraph Creek. At Sergief Island, toward the end of the summer, teal were present in abundance, usually in flocks of ten or twelve individuals. Two specimens were preserved, an immature male taken on September 2 (no. 39705), and an adult female, September 5 (no. 39706).

\section{Spatula clypeata (Linnaeus). Shoveller}

A single bird was seen at close range in a slough on Sergief Island on August 29. A Peale falcon shot at the same locality on September 1 had the remains of a shoveller in its stomach.

\section{Dafila acuta (Linnaeus). Pintail}

Seen only at Sergief Island There, during the whole of our stay, pintails were present in fair abundance, usually in flocks of ten or twelve individuals. These small flocks were, presumably, each a single family.

The three common fresh-water ducks here were the mallard, greenwinged teal, and pintail. Of none of these species, seen almost daily from August 17 to September 7, and in considerable numbers, were any male birds seen in the normal adult winter plumage. Presumably the old males were still in the eclipse plumage, but our efforts to obtain any failed; those birds that we shot proved to be young of the year, with one or two old females.

\section{Marila, sp.? Scaup Duck}

Flocks and single birds were several times seen on Sawmill Lake during June. Most of them were males (on June 11 a flock was noted 
consisting of ten males and one female), suggestive of the possibility that the females were sitting on eggs nearby. The birds were seen at close enough range to identify them as scaups, but whether Marila marila or $M$. affinis, or both, would, of course, have required the capture of specimens for determination.

\section{Glaucionetta islandica (Gmelin). Barrow Golden-eye}

Seen at various points within ten or twelve miles of Telegraph Creek : at the Summit, June 4 and 5, a flock of five females and several single birds, both male and female; at Sawmill Lake, occasionally during June; and on a small stream south of Telegraph Creek. Two females were shot at the Summit, June 5, and one of them was preserved (no. 39707). These two birds were evidently not breeding.

The species encountered was apparently Glaucionetta islandica. The identity of the one specimen saved was determined mainly through a study of the characterization of the two forms, americana and islandica, as given by Brooks (1920, p. 356). This decision, though, is also influenced by the fact that the adult males seen were unquestionably islandica, the triangular white facial patch being plainly discernible with the binoculars. This is a curious instance, in which the identity of a specimen in hand (a normal adult female) is confirmed by sight identification of others not obtained.

\section{Histrionicus histrionicus (Linnaeus). Harlequin Duck}

Not seen along the lower Stikine River, but fairly common along the upper part of the stream. Frequently observed at close range from the river boat, always seen in swift water, flying up when approached too nearly, or perhaps swimming fearlessly through a swirl of rapids alongside, paying little heed either to the boat from whose path it just withdrew, or to the rocks and snags between which it picked its way. Seen as far up the river as Telegraph Creek.

Oidemia deglandi Bonaparte. White-winged Scoter

Undoubtedly nesting on Sawmill Lake, where varying numbers were seen during the month of June. Twenty or more of both sexes were noted on June 17, and lesser numbers on many other occasions. Not met with elsewhere. 
Branta canadensis occidentalis (Baird). White-cheeked Goose

We were told of the occasional, though rare, occurrence of geese as far up the river as Telegraph Creek, but it seems doubtful that birds seen so far inland should be occidentalis. In our ascent of the Stikine River, May 21 and 22, flocks of geese, presumably of this subspecies, were seen at intervals about as far up as Great Glacier. None was seen by us during the summer any farther inland. When we camped at Great Glacier in August, we found an abundance of old "sign" of the presence of geese, many droppings on the sand bars about some shallow ponds, and the marks of webbed feet in sticky mud that had since remained undisturbed. The geese themselves had probably not visited the place for many weeks. These ponds, in a sheltered location, apparently received a maximum of sunshine early in the summer, and were correspondingly attractive to the birds at that time.

In our descent of the river, the first white-cheeked geese were seen at the boundary, August 16. From there on down an occasional small flock was noted, but not until the mouth of the river was reached were they seen in any numbers. At Sergief Island they were abundant. Flocks of large size frequented the marshes at that point, changing their feeding ground as the tides advanced and receded. These local movements covered but a few miles at most, and, of course, were gone through with daily as regularly as the tides. Aside from this hourly shifting, which kept some flocks on the wing practically throughout the day, there was no appearance of migration. Flocks of whitecheeked geese were never seen to depart in a manner suggestive of the beginning of a long flight, not were any seen arriving as though from a distance.

During the last two weeks in August the geese were still molting extensively. In some the breast and belly were almost entirely devoid of feathers, only the down remaining, and nearly all were renewing the tail feathers. Flight feathers were fully grown, or at any rate sufficiently so for flying. Presumably the birds would not gather upon these open and exposed marshes until they could fly; nesting and the beginning of the molt, including loss of the remiges, probably takes place in more sheltered localities.

Five specimens of white-cheeked geese were preserved, an adult male and adult female saved entire (nos. 39708-39709), and two males and a female (nos. 39710-39712), of which head and neck only were preserved. Four of the five specimens preserved have more or less 
indication of a black line on the chin separating the white cheekpatches. In one case this bar is fairly well defined, though as each separate feather is narrowly edged with white and has a white base, a mottled effect is produced. In three the black is not continuous, merely a string of disconnected black spots, and in one the white patch extends uninterruptedly from cheek to cheek. Usually in the geese of this region there is either a string of disconnected spots, as in the specimens just described, or else a beginning of such a line extending forward and backward on the center of the throat but not meeting. Very rarely the black dividing line is continuous, broad, and well defined. I, myself, have seen two such specimens, but in neither case was there absolute assurance that they were birds breeding in the Sitkan district. Such birds might occur as migrants from a more northern region, where intergradation of occidentalis and minima might result in the occasional appearance of such a marking.

\section{Ardea herodias fannini Chapman. Northwest Coast Heron}

Only two seen during the entire summer. One observed on a sand bar in the Stikine River some eight miles below Telegraph Creek on July 5 may or may not have been of the coast subspecies, fannini. One was seen flying overhead on Sergief Island, September 5.

\section{Gallinago delicata (Ord). Wilson Snipe}

Seen only at Sergief Island. At that point, during the whole of our stay, August 17 to September 7, Wilson snipe were abundant on the marshes, not generally distributed, but always to be found about certain favored spots, generally near fresh-water ponds. While the usual manner of occurrence was for a single bird to be flushed, or perhaps two or three within a few square yards, therre were times when snipe were noted in small flocks, almost like sandpipers in their actions. Groups of ten or twelve individuals were seen circling about through the air, in close formation and wheeling or turning in perfect unison. At such times almost the only thing to betray the identity of the birds was the call note, uttered at frequent intervals. At no time, however, did birds flushed from the ground depart in flock formation. Eight specimens were collected (nos. 39713-39720), taken on dates ranging from August 18 to September 1. 
Pisobia maculata (Vieillot). Pectoral Sandpiper

Seen only at Sergief Island. Upon our first visit to the marshes, on August 18, pectoral sandpipers were seen in small numbers, just a few single birds, or, at most, two or three together. They increased in numbers daily, and by September 1 flocks of from twenty to thirty individuals were frequently encountered. Like the Wilson snipe, they favored the fresh-water ponds, and there they could be seen walking about through the short grass, the flocks loosely spaced so that the individual birds were from ten to twenty feet apart. They were tame and unsuspicious, usually permitting a near approach. Three specimens preserved (nos.. 39721-39723).

\section{Pisobia minutilla (Vieillot). Least Sandpiper}

Seen only at Sergief Island, where it was present in fair abundance. The small size of the least sandpiper kept it out of the grassy areas frequented by some of the other waders, and it was usually found on the bare mud banks or sand bars. There were places, however, where the flocks of geese had trampled down the tall marsh grass, sometimes acres in extent, and the least sandpipers were fond of feeding in such spots, where they could run about freely over the prostrate grass. One specimen collected (no. 39724).

\section{Totanus melanoleucus (Gmelin). Greater Yellowlegs}

Seen only at Sergief Island. Not abundant, but a few single birds and sometimes two together were encountered at various times from August 19 to September 2. One specimen collected (no. 39725).

\section{Totanus flavipes (Gmelin). Lesser Yellowlegs}

Seen during June about Sawmill Lake and some smaller ponds near Telegraph Creek. Probably nesting somewhere within a few miles, but apparently not in the immediate vicinity of these lakes. Occasionally one was seen coming down from a great height in the air, evidently to feed on the shores of one or another of the lakes. It seemed likely, from the birds' actions, that the nesting grounds might have been in meadow land high up in some of the nearby mountains. Four specimens preserved, all adults (nos. 39726-39729). 
Tringa solitaria cinnamomea (Brewster). Western Solitary Sandpiper

This species might be expected to breed throughout the region in which we were working, but we failed to find it doing so. It was met with but once during the summer, an immature male (no. 39730) being secured at Flood Glacier on August 7. This individual, a fully grown bird of the year, was, of course, a migrant, and might have traveled a long distance.

Actitis macularia (Linnaeus). Spotted Sandpiper

Fairly common in the upper Stikine Valley. A nest with four eggs was discovered at Sawmill Lake, June 14, placed in a bank of sawdust on the site of the long abandoned sawmill. At Glenora a set of four eggs (no. 1806) was collected on July 3 . The nest in this case was in a grassy meadow near an abandoned building. Another nest was found at Glenora, on a sand bar at the edge of the river. At least one brood was hatched near our camp at Doch-da-on Creek. No spotted sandpipers were seen farther down the river, but there is no reason to doubt that the species occurs the whole length of the Stikine. It is known to be a summer visitant on the coast of southeastern Alaska. One specimen collected (no. 39731), an adult female taken at Glenora with the set of eggs previously referred to.

\section{Oxyechus vociferus vociferus (Linnaeus). Killdeer}

On the evening of August 22, Dixon heard the unmistakable notes of a killdeer from a mud bank in the river near our camp at Sergief Island. Search the next day, and for several days thereafter, failed to bring the bird to our sight, but the call note is so distinctive that a person familiar with the species could not mistake it for any other.

\section{Dendragapus obscurus flemingi Taverner. Fleming Grouse}

In summer, at least, this species is restricted to high altitudes in the mountains of the upper Stikine region. We met with it at but one point, at timber line, in the mountains above Doch-da-on Creek. A female with a brood of small young was seen there, at about 4000 feet elevation, on July 11 . On July 23, two broods were found near the 
same place, the young ones the size of mountain quail (Oreortyx), strong on the wing, and apparently well able to care for themselves. On July 11 a cock bird was flushed from the heather at the edge of a snow bank, far above the timber. Another was seen by Dixon at the upper edge of the timber on Kirk's Mountain on July 17. No males were heard hooting at any time.

Of the two broods seen on July 23, one consisted of three young, the second of but one. These birds were found in open, grassy patches, close to dense and extensive thickets of prostrate balsam fir, that afforded shelter from almost any enemy. The parent of the brood of small young seen on July 11 was extremely solicitous for their safety. She was not aggressive in her solicitude, however, as is the ruffed grouse under similar circumstances, nor did she feign a broken wing or other disability. She simply sat on the top of a thicket, obviously greatly worried, clucking nervously to the chicks until they had reached what she considered a safe distance, when she followed after through the bushes. The larger young ones seen on July 23 were evidently expected to look after themselves to a great extent; they were as wary and resourceful as their parents.

Five specimens were secured (nos. 39732-39736), two adult females and a male and two females in juvenal plumage. These birds appear to belong to the subspecies Dendragapus obscurus flemingi, described by Taverner (1914, p. 385), from Teslin Lake, one hundred and forty miles north of the Stikine. This form is most nearly related to $D$. $o$. richardsoni; it is widely different from fuliginosus and sitkensis, the coastal subspecies. Richardsoni-and flemingi are not "hooters." The call note of the male bird is not, the loud, far-reaching hoot that is so characteristic of fuliginosus and sitkensis, and also of the California race, sierrae. In these latter subspecies the male bird has on each side of the neck an area of bare skin that is brilliant yellow, greatly thickened, and capable of wide distention, part of the hooting apparatus and not highly developed in the non-hooting forms. (See Brooks, 1912 , p. 252.) This is a structural difference of sufficient importance to warrant the specific separation of these groups of grouse. Whether or not D. o. obscurus of the southern Rocky Mountains is a hooter I do not know, and any changes of nomenclature would hinge upon this fact.

Flemingi is described as differing from richardsoni in darker general coloration and in having the tail rounded, not truncate. Both are described as lacking a terminal tail band. The general dark colora- 
tion, including extension of dark areas and restriction of light ones, is evident in the Stikine birds, as in topotypes of flemingi loaned me by the Victoria Memorial Museum, and is sufficiently marked to justify the recognition of flemingi. It is doubtful whether the tail characters are valid. The sharply truncate tail of the male richardsoni is a feature that is not acquired until the second year at least. The young male, the first year, has the whole tail rounded, and the individual tail feathers are narrow and rounded as compared with the broad, truncate feathers of the old bird. Also, richardsoni can hardly be said to lack entirely a terminal band on the tail. An indication, at least, of this marking is always present.

\section{Dendragapus obscurus sitkensis Swarth. Sitka Grouse}

On May 21, on the trip up the river from Wrangell, we stopped at the Canadian custom house, just above the Alaska-British Columbia boundary, and while anchored there heard a grouse hooting in the nearby woods. Presunably this was the coast subspecies. The only specimen collected during the summer was an adult female (no. 39737) taken by Dixon at the southern end of Mitkof Island, during a three days' hunt for deer which he made to that point, August 26 to 29. A number more were seen at the same place. (For the use of the name Dendragapus obscurus sitkensis see Swarth, 1921a, p. 59.)

\section{Canachites canadensis osgoodi Bishop. Alaska Spruce Grouse} Canachites canadensis atratus Grinnell. Valdez Spruce Grouse

From the reports we heard it is to be inferred that the spruce grouse is of general distribution in the region we visited, and in fair abundance though locally restricted to suitable surroundings. We were informed that about Telegraph Creek this grouse was usually found in the spruce forests on the hillsides well up above the river valley. We, ourselves, met with the species at but two points. Late in the evening of July 5, as we were returning to our camp at Glenora, a young spruce grouse flew up into a tree by the road and was taken. It was still partly in the natal down, too young to be supposed to be shifting for itself, but neither the parent nor any other of the brood was seen.

At Flood Glacier an adult female and one chick were taken on August 4, an adult male on August 7. No others were seen. These birds were collected in dense spruce woods, in the bottom lands between the river and the glacier. The old male was feeding on huckleberries. 
Of the specimens collected, the adult male (no. 39740, August 7) had virtually completed the annual molt. There are partly grown feathers over various parts, but the old plumage is all discarded. The adult female (no. 39739, August 4) is still mostly in the worn, last year's plumage, though feather renewal is in progress in some tracts. The two young (no. 39741, male, Glenora, July 5; no. 39738, female, Flood Glacier, August 4) are at precisely the same stage of development, though taken just a month apart. The natal down persists upon head, throat and belly, and the juvenal feathers clothe the back, breast, flanks, and wings.

The two adults are noticeably different from examples of Canachites c. osgoodi from points in the interior. Of the latter I have had for comparison specimens from various points in northern British Columbia, Yukon, and Alaska. Osgoodi, described from Lake Marsh, some 250 miles north of Telegraph Creek, is a grayish colored bird, compared with other races of $C$. canadensis, a character that becomes more and more accentuated to the northward. Birds from the Kowak River region reach the extreme of differentiation in this regard (see Grinnell, 1900, p. 30). Our Flood Glacier adults are extremely dark colored, matching exactly examples of the coastal race, Canachites c. atratus, from Prince William Sound, Alaska (Grinnell, 1910, p. 380). C. c. atratus was not admitted to the Check-List by the A. O. U. Committee (1912, p. 385), its characters being deemed "insufficient for recognition," but it seems to me to be a recognizable form. The inference resulting from the capture of our Stikine birds is that that race of spruce grouse will prove to be of continuous distribution in the coastal district between the Stikine River and Prince William Sound.

The two young birds, from Glenora and Flood Glacier, respectively, are somewhat different in appearance. The Glenora bird is more grayish in coloration, the Flood Glacier specimen more rufescent and with more extensive black areas upon individual feathers. These differences might pass unnoted, perhaps, were it not for the peculiarities of the Flood Glacier adults as compared with typical adult osgoodi. As it is, I believe the observed differences in the juvenals to be of signifcance, for they are just the sort of differences that would be expected to distinguish the young of atratus and osgoodi. The Glenora juvenal may be an example of Canachites c. osgoodi. This indicates the possible presence of two forms of Canachites canadensis in the Stikine Valley (as is the case with so many other species of birds), C. c. asgoodi of the interior extending westward at least to Glenora, C. c. atratus of the coast extending inland at least to Flood Glacier. 


\section{Bonasa umbellus umbelloides (Douglas). Gray Ruffed Grouse}

Fairly common in the poplar forests of the upper Stikine Valley. We ourselves saw none below Doch-da-on Creek, but the species undoubtedly ranges farther down stream, regularly. We were told of its occasional occurrence at the mouth of the river, but whether breeding or merely in winter I do not know.

During the first week in June single birds were several times seen at the, Junction. Three that were shot at this point were all males; the females were undoubtedly sitting on eggs at that time. On June 12 the first young were seen, two broods being encountered near Telegraph Creek. The young of one brood were still unable to fly. Our first knowledge of their presence was derived from the mother bird, who burst forth from the bushes and charged us furiously. She kept tail and ruff widely spread, the head crest depressed. She was mewling in a very catlike fashion, and also hissing from time to time. There was an occasional faint peep from the grass nearby, and once I caught a glimpse of a yellow chick slipping away through the shrubbery, but the young were too agile to be captured.

The young of the second brood were somewhat larger and able to fly. This second mother tried to toll us away from the chicks by feigning a broken wing; the noise she made was not unlike the whining of a small puppy. Her actions, all together, gave the impression that she was frightened rather than angry. However, if frightened, she still did not desert her trust, but remained nearby, dragging herself back and forth across the road, with wings drooping and all her feathers pressed closely against her body. Her tail was not spread nor were her ruffs displayed at any time, all in striking contrast to the behavior of the first bird met that morning.

From later observations it appeared that these two parents were fairly typical of their kind in such an emergency. The mother either charged the intruder viciously, in an apparent attempt to frighten him, or else she endeavored to distract attention from the chicks to herself by feigning injury and inviting pursuit. On one occasion the parent of a brood came charging at me through the woods from a distance of fifty yards.

At Doch-da-on Creek, July 8 to 26, ruffed grouse were seen on many occasions. On July 15 an adult male was shot that proved to be in the midst of the molt; only one or two of the old rectrices were left and the body was covered with pin feathers. On July 18 the last drumming was heard. 
The series collected comprises four adult males, one adult female, one in juvenal plumage, and one in natal down (nos. 39742-39747). These birds are relatively gray colored, but not so ashy as Bonasa umbellus yukonensis, from the Yukon region (see Grinnell, 1916, p. 166). I have had for comparison three specimens of Bonasa u. umbelloides from points on the Saskatchewan and Athabasca rivers, Alberta, practically topotypes of that form, loaned me by the United States Biological Survey. The Stikine River birds are of exactly the same type of coloration.

Of our series of five adults, three are in the gray phase, two in the red. Apparently these color phases occur throughout the entire range of the species Bonasa umbellus. The point arises as to whether the confusion that exists between the subspecies umbellordes and togata (cf. A. O. U. Committee, 1910, p. 140), a relatively gray race and a relatively reddish one, is not largely due to a misunderstanding of the color variation within any one subspecies. No attempt has been made by me to go thoroughly into this question, but it may be said that the reddest umbelloides examined is a very different looking bird indeed from the few grouse I have seen from eastern Canada, the habitat of the reddish colored togata.

The crop contents of two ruffed grouse from the Stikine region (determined at the United States Biological Survey) are as follows :

No. 39742, adult male. Percentage of vegetable matter, 100. Contents of crop: 1 pupa of plant louse, many leaves and a few stems of Populus trichocarpa (75 per cent), leaves, stems, etc., of Galium triflorum (25 per cent), 1 leaf of Artemisia, sp., and bits of leafy moss.

No. 39748, adult male. Percentage of vegetable matter, 100. Contents of crop : 105 leaves of Populus tremuloides and a few bud scales of the same (90 per cent), 9 berries and a leaf of Viburnum pauciflorum (10 per cent), bits of vegetable débris.

\section{Lagopus leucurus leucurus (Swainson). White-tailed Ptarmigan}

Met with at but one place, on a mountain above Doch-da-on Creek. Here, on the heather covered slopes above the timber, two broods were seen on July 11. Of one, the entire family was obtained, the adult female and three downy young (nos. 39749-39752). The second lot, a female with seven or eight young, escaped.

While we were camped at Glenora an acquaintance climbed Glenora Mountain, nearby, and informed us that he saw a single ptarmigan 
on the summit during the day. This same man had spent several winters trapping on the Iskut River some miles above the junction of the latter with the Stikine, and he told us that at times ptarmigan were plentiful there during the winter months. He described them as of two species, one smaller and entirely white (obviously leucurus), the other larger and with black feathers in the tail. The latter was evidently either rupestris or lagopus; both species may occur there.

The three young taken on July 11 are in the natal down throughout, save that the wing feathers had grown out to a slight extent. They could fly a little, skimming down hill a few inches above the ground.

The crop contents of these birds (determined at the United States Biological Survey) are as follows:

No. 39749, adult female. Percentage of vegetable matter, 100 . Contents of crop, fragments of mosses, a few leaves of Geranium, sp., 24 flowers of Dryas octopetala (25 per cent), many leaves, stems, etc., of Salix, sp. (75 per cent).

No. 39750, young. Percentage of animal matter, 30 ; of vegetable, 70. Contents of crop : 1.Scymnus, sp., at least 1 Sciara, sp., about 50 plant lice (including Psylla, sp.) (30 per cent) ; vegetable matter, including Myrica gale, unidentified leaf buds (probably Salix, sp.), and Ranunculus, sp. (70 per cent).

- No. 39751, young. Percentage of vegetable matter, 100. Contents of crop : fragments of several leaf buds, probably Salix, sp.

No. 39752, young. Percentage of animal matter, 60; of vegetable, 40. Contents of crop : 12 plant lice and several unidentified leaf buds, probably Salix, sp.

\section{Zenaidura macroura carolinensis (Linnaeus). Eastern Mourning} Dove

On June 17 a mourning dove was seen near Telegraph Creek. Mr. W. H. Dodd, who has been government agent at that point for some years past, informed me that the species occurs in the fall with a fair degree of regularity. That is, one or two of the birds might be expected to appear each year.

On September 3 an adult female (no. 39753) was collected on Sergief Island, at the mouth of the Stikine River. Mr. Fred H. Gray, of Wrangell, a deputy of the Bureau of Fisheries, and a man who has observed and collected birds for many years, informed me that he had 
seen mourning doves in and about Wrangell on several occasions. Mr. Allen Hasselborg, of Juneau, once informed me of seeing a dove near that city, in November, 1911. Straggling individuals have been recorded from Metlakatla, British Columbia (Kermode, 1904, p. 28), from Sitka, September 14 (Willett, 1914, p. 81), and from Hydaburg, Prince of Wales Island, September 1 (Willett, 1917, p. 22).

The bird I took was flushed from tall marsh grass, at a point that was regularly covered by the tides. In many places on the marsh this grass was beaten down by rain or wind, and it was from one of these flattened patches that the dove was flushed.

If southeastern Alaska is an unusual point of occurrence for the species, at any rate this individual reached the place without suffering any undue hardships, for it was excessively fat. The crop contents of this bird were as follows: percentage of animal matter, 1 ; of vegetable, 99 ; of gravel, etc., a trace. Contents of erop: 16 Oribatid mites and 2 young Polygyra, sp., 1 per cent; 9 Carex, sp., 4 per cent; 388 Alsine, sp., 20 per cent; 221 Impatiens, sp., 75 per cent.

The Sergief Island specimen, compared with examples of Zenaidura macroura marginella from California, is darker colored throughout, with richer brown coloration on scapulars, and with larger black spots upon the latter. It is not marginella. It bears closer resemblance to the eastern form, Z enaidura macroura carolinensis, and for the present may remain under that name. There is not enough material available to demonstrate whether the birds that occasionally reach southeastern Alaska really are examples of the eastern race, extending northwestward into northern British Columbia and sometimes to the coast, or northern strays of the coastal subspecies, $Z$. m. caurina, described by Ridgway (1916, p. 348) from Oregon.

\section{Circus hudsonius (Linnaeus). Marsh Hawk}

First noted at Sergief Island on September 3, when two brown immatures appeared, beating over the marsh. A number more were seen during the next few days.

\section{Accipiter velox (Wilson). Sharp-shinned Hawk}

Not seen until the close of the nesting season. First noted at Flood Glacier, August 3, next on August 6, and thereafter almost daily. At Great Glacier, on August 11, a Steller jay was shot and wounded, and, being retrieved, screamed loudly. Almost instantly a sharp-shinned hawk appeared, evidently drawn by the cries of distress, and lit in a tree as near by as he dared to come. 
Two specimens collected, an immature male at Great Glacier, August 11 (no. 39754), and an immature female at Sergief Island, August 22 (no. 39755).

Astur atricapillus atricapillus (Wilson). Eastern Goshawk Astur atricapillus striatulus Ridgway. Western Goshawk

Goshawks doubtless occur in summer throughout the region east of the coast ranges, but apparently in widely scattered pairs. We saw them at various localities, single individuals encountered at considerable intervals of time. At our camp at the Junction, the end of May, a recently dropped wing quill was evidence of the passage of one of the birds. One was seen flying overhead at the Summit, May 29, another at Glenora, July 7. On July 11 an adult male was shot at the upper limit of timber (about 3000 feet altitude) on the mountain above Doch-da-on Creek. On August 4 an immature female was taken at Flood Glacier. This bird contained in its stomach the remains of a red squirrel.

The adult male collected (no. 39756) is referable to the eastern subspecies, Astur atricapillus atricapillus, and is, I assume, representative of the form that inhabits the entire region east of the coast ranges. The young bird taken at Flood Glacier (no. 39757) may or may not have been hatched in that immediate neighborhood. No other goshawks were seen there, and other species of hawks (pigeon hawks and sharp-shinned hawks) were at that time beginning to appear, apparently migrating. At any rate, this individual appears to be an example of the western subspecies, $A$. a. striatulus. It is closely matched by four young of striatulus from their nesting ground in the Warner Mountains, California, and it is quite unlike a series of six immatures of atricapillus from the Yukon region. Compared with the Yukon series the Flood Glacier bird is darker colored throughout, it is more heavily marked below, and the brown edgings to the feathers dorsally are broader and of a darker brown. Specimens of striatulus taken on the coast of southern Alaska during the migrations are closely similar to the Flood Glacier bird.

\section{Buteo borealis calurus Cassin. Western Red-tailed Hawk}

Red-tailed hawks were seen at several points in the interior, but never in any numbers. Two or three were noted near Telegraph Creek at close enough range to enable their rufous tails to be distinguished; some dark colored hawks, supposed to be of this species, were seen at 
a distance. At Glenora, July 1, an extremely dark individual was seen, the body almost black; this again was identified by means of the characteristic tail color. Others were observed at Doch-da-on Creek, during July.

All the birds of this species seen thus far had been either in the dark phase or else were light breasted birds that were not notably light colored otherwise. Then, at Flood Glacier, a family of extremely light colored individuals was encountered. On July 26, and on subsequent days, an adult red-tail was several times seen from our camp, sometimes perched in a tall spruce, sometimes flying past. The breast and belly of this bird appeared to be gleaming white, and the back seemed to have much white spotting.

On July 31 Dixon found this adult feeding two full-grown young ones in an opening in the forest; though the parent was too wary to be captured, he took both the immatures. These, like the old one, are extremely light colored. Chin, throat and breast are continuously white, the breast with a buffy suffusion, and the lower abdomen and lower tail coverts are white. In the spotted tract across the middle of the body below, and on the flanks, the dark spots are relatively small and separated by wide areas of white. The area immediately surrounding the eye, and between eye and bill, is white. In the feathers on the top of head and back of neck are small central spots of black or dusky, and extensive basal and marginal areas of white. Over the entire upperparts the feathers are extensively white spotted and with broad margins of white or pale buffy.

In a large series of young calurus from various parts of the western United States we have nothing at all like these birds. An immature male borealis from Wisconsin is like the Stikine River specimens in the uniformly white chin, throat, and breast, and in the restriction of the black spots below, but it is not so white on the head and upperparts. Buteo borealis krideri has been recorded from Alaska on the basis of a light colored bird taken at Eagle during the winter of 1903 (B. H. Bailey, 1916, p. 321). The red-tails, however, form a puzzling aggregation of geographical races and color phases, and it does not simplify matters in this case to assign to the subspecies krideri a range covering part of the habitat of calurus. The present writer is disinclined to regard the light colored birds just described as examples of krideri, thereby extending the range of that form far to the westward. Most of the red-tails seen throughout the Stikine region were of the recognized calurus type. Until the meaning of the diverse phases of 
plumage seen is thoroughly understood it is safer to regard all the birds of that part of the country as of the one subspecies, calurus.

Of the two young birds collected, the female had crop and stomach filled to distention. In the partly digested mass there could be distinguished the remains of at least four mice and one toad. The mice could be identified as Microtus mordax. The male bird had its stomach filled with a mass of Microtus bones and hair. The meadow mice that the young hawks had eaten must all have been fed to them by their parents. While Microtus mordax was a fairly common species at that point, still it is noteworthy that a red-tailed hawk should be sufficiently agile to catch so many of them in as short a space of time as must have been the case. The mice in the river bottom, where the hawks were found, were in cover so dense that it was surprising to find a redtail there at all. The hunting of the latter, may of course, have been done on the nearby mountain sides, above the denser timber, but even so it seems rather remarkable that they should find so little difficulty in catching these small rodents.

\section{Buteo swainsoni Bonaparte. Swainson Hawk}

Seen only in the vicinity of Telegraph Creek. A number of dark colored hawks were observed thereabout, some of which were identified as red-tails, while others of lighter build were assumed to be of the present species. Dixon shot one on June 1, but was unable to find the bird until two days later, when it was unfit to preserve as a specimen. One wing, one leg, and the tail were preserved (no. 39760) to make identification certain. The birds seen were undoubtedly nesting near-by.

\section{Aquila chrysaëtos (Linnaeus). Golden Eagle}

One seen at fairly close range near Telegraph Creek on June 22, another at Glenora, July 7.

\section{Haliaeëtus leucocephalus alascanus C. H. Townsend}

\section{Northern Bald Eagle}

In all probability bald eagles extend inland much farther than the points where we were collecting, dependent perhaps upon local conditions, but we ourselves did not see any farther up the river than Doch-da-on Creek. Here, the latter part of July, they were noted on several occasions. On July 23 two were seen circling above the mountain tops, at about 5.000 feet altitude. Descending the Stikine from Doch-da-on Creek, bald eagles were seen at various points. 
On our trip up the river in early May, many nests were noted along the lower parts of the stream, easy to see at that season as the trees were still bare of leaves. On our return trip in August the abundant foliage hid most of the structures, but one at least was noted (on August 16) with a young bird still sitting on the edge of the nest. At Sergief Island bald eagles were seen daily.

Falco peregrinus pealei Ridgway. Peale Falcon

One shot on the marsh at Sergief Island on September 1. This bird, an immature of the year, differs appreciably from the mode of young anatum, as represented by specimens from various parts of North America. The main difference consists in the Sergief Island specimen being more heavily marked beneath, in its almost totally lacking the cinnamon tinge below that is so characteristic of anatum, and in the lack of paler edgings to the feathers of the upperparts. This falcon contained in its stomach the remains of a shoveller (Spatula clypeata).

Falco columbarius columbarius Linnaeus. Pigeon Hawk

Not seen until the latter part of the summer, when the migration had begun. If the species breeds throughout the region we were exploring, it is to be supposed that the birds are few in numbers and in widely scattered pairs. First seen at our Flood Glacier camp, August 1, next, on our way down the river to the Great Glacier, August 8. On Sergief Island, the latter part of August and the first week in September, pigeon hawks were seen almost daily, but they were wary and seldom came within shooting distance.

Two specimens were secured, a female at Great Glacier, August 14 (no. 39762), and a male (no. 39763) at Sergief Island, September 2. Both are immatures. The Sergief Island bird is an average example of columbarius at that stage. The Great Glacier specimen is darker colored. Below, it is indistinguishable from columbarius, but dorsally it is about as dark as examples of immature suckleyi from Vancouver Island. On the whole, it is best referred to columbarius.

Falco sparverius sparverius Linnaeus. American Sparrow Hawk

Seen from time to time in the vicinity of Telegraph Creek, generally not far from the river. There were probably several pairs nesting within a few miles of the town. At Doch-da-on Creek, in July, 
sparrow hawks were seen several times. On July 11 one was observed at about 3000 feet altitude, sitting on a tall dead stub on a burnt-over hillside. On July 23 an adult female was secured at the upper limits of timber, about 4000 feet. At Flood Glacier, August 5, a sparrow hawk was seen several times swooping at a bald eagle that spent that day moping in the rain on the top of a dead tree near our camp. At Sergief Island, sparrow hawks were noted on several occasions. The only previously reported occurrences of this bird in southeastern Alaska seem to have been the capture of one on the lower Taku River, September 16, 1909 (Swarth, 1911, p. 63), and the observation of two at Craig, Prince of Wales Island (Willett, 1921, p. 128), but it is probable that the sparrow hawk is of fairly regular occurrence in the fall at some points on the southern Alaskan coast.

The bird taken at Doch-da-on Creek (no. 39764), an adult female, is essentially like the Taku River specimen referred to, also a female. They are both noticeably dark colored, as compared with California birds, with broader black cross bars on the dorsal surface, and with the rufous areas of a darker shade.

It seems safe to say that the sparrow hawk, as occurring in this general region, is a bird of the interior, and that a few individuals find their way to the coast in the dispersal that takes place in the late summer or early fall. Such migrants would be likely to wander down some large river valley that extends from one region to the other, and it is near the lower ends of such valleys that most of the birds thus far recorded have been seen.

\section{Asio flammeus (Pontoppidan). Short-eared Owl}

One seen on the marshes of Sergief Island on September 2, presumably a migrant from some other place. As these same marshes had been assiduously hunted over for two weeks previously without seeing any of this species, it is fair to assume that the bird noted represented the arrival of its kind at this point on the southward flight.

\section{Cryptoglaux funerea richardsoni (Bonaparte). Richardson Owl}

One specimen, a young bird, molting into first winter plumage, obtained in dense spruce woods at Flood Glacier, July 28. This species, presumably of general distribution throughout northern British Columbia, is a bird of the interior, not known to occur in the humid coast belt, and our specimen may be assumed to have been taken at the extreme western limit of its range in this region. 


\section{Bubo virginianus, subsp.? Horned Owl}

Horned owls occur throughout the country we were visiting, but apparently not in abundance, at least during the summer months. We were told of their presence at Telegraph. Creek, but we saw none, nor did we hear any hooting. At Doch-da-on Creek we were shown the desiccated remains of one that had been killed the previous winter. On Sergief Island, August 31, I found a horned owl's feather in the marsh, far from the timber. At the latter point, the subspecies present is doubtless $B u b o$ v. saturatus; I had no means of ascertaining the subspecific identity of the horned owl of the upper Stikine River.

\section{Glaucidium gnoma, subsp.? Pigmy Owl}

One seen at Doch-da-on Creek on July 14, sitting on a dead tree in a clearing. I had a good enough view of the bird to be certain of its specific identity, but it was too wary to permit a near approach. On July 22 one was heard calling at about the same place.

There is available a specimen of Glaucidium (no. 41193), a mounted bird, taken at Wrangell, Alaska, date of capture and sex unknown. This bird is not an example of the extremely dark colored Glaucidium gnoma swarthi of Vancouver Island, a coastal form that might be supposed to range northward into Alaska. It is closely similar to a specimen of G. g. grinnelli from Humboldt Bay, California (no. 24851), an individual that is not of the rufescent coloration usually seen in this subspecies, but of a decidedly duller brown.

The available information, scanty as it is, indicates the occurrence of Glaucidium in the upper Stikine Valley and on the Alaska coast at the mouth of the same river. There is little doubt that it ranges through the territory intervening between those two points. Whether or not two subspecies are represented in the two regions on either side of the coastal mountains is something that can be determined only by the capture of specimens.

\section{Ceryle alcyon caurina Grinnell. Western Belted Kingfisher}

Kingfishers were unaccountably scarce. The region might be supposed to be a favorable one for the species, but it was encountered on just two occasions: one bird seen at Doch-da-on Creek, July 17, and another at Flood Glacier, July 28. 


\section{Dryobates villosus monticola Anthony. Rocky Mountain Hairy} Woodpecker

The only species of woodpecker that was at all common in the region. About Telegraph Creek there were but few of the birds seen in May and in early June, but by the middle of June, when the young were beginning to fly, hairy woodpeckers were encountered rather frequently. Farther down the river they were decidedly scarce. A few were seen at Doch-da-on Creek. At Flood Glacier, one bird was taken and one other was heard calling.

Two occupied nests were found near Telegraph Creek. One, discovered June 11, contained nearly full-grown young, which could be seen at the entrance calling for food. This nest was in a partly dead poplar, about twenty feet from the ground. The second, found in an exactly similar situation on June 12, contained one young bird, which left at the first disturbance.

By the third week in June the nesting season seemed to be entirely over, and the young were flying about independently of their parents. An adult male shot June 19 was beginning to molt. New remiges have appeared at the junction of primaries and secondaries, and there are new feathers along the center line of the breast and abdomen.

Hairy woodpeckers may be expected to occur continuously along the Stikine River, thus bringing the subspecies monticola and sitkensis together. Unfortunately the birds are so rare along the lower river (as in the southeastern Alaskan coast region in general) that it is difficult to get enough specimens to ascertain the nature of conditions where the two meet. We failed to see any at all at the crucial point.

Sitkensis, in its relatively light ventral coloration, is intermediate between the extremely dark harrisi and the white-breasted monticola. The dark breasted type of coloration reaches its extreme development in picoideus of the Queen Charlotte Islands, interposed between the ranges of harrisi and sittensis. Thus, while specimens of sitkensis as laid out in trays may be arranged to illustrate a step between harrisi and monticola, the geographical distribution of the several forms is not in accordance with this idea. The geographical chains appear to lie as follows: Starting with the white-breasted races of the interior of the northwest, septentrionalis and monticola, there is an extension westward on the coast of a slightly darker breasted race, sitkensis. Starting again with the dark breasted type, harrisi, of the Puget Sound region, and going northward, we reach the extremely dark 
colored picoideus. Thus, sitkensis and harrisi are really far apart genetically, and the appearance of sitkensis as a seeming intergrade between monticola and harrisi must be explained on grounds other than those of such actual intermediate relationship. Sitkensis, as an offshoot of the white-breasted type of the interior, may have arrived at the humid coast at too recent a date to be yet affected by its surroundings to the extent that harrisi and picoideus have been; or it may be more resistant to such an environment. In either case the slight modification of the clear white breast of monticola produced by the humid surroundings would result in an apparent intergrade toward harrisi.

In this connection it may be remarked that the highly distinetive avifauna of the southeastern Alaskan coast is, for the most part, composed of species that occur on the Pacific coast farther south and extend northward along a narrow coastal strip, more or less modified in appearance. Most of these birds extend farther north than does the hairy woodpecker of the same region. Cyanocitta stelleri, Penthestes rufescens, Junco oreganus, and the coastal forms of Melospiza melodia are all birds of this type, and they all occur farther north than does Dryobates villosus sitkensis.

The latter apparently belongs to an aggregation of bird species that has more recently invaded the coast from the eastward along a few favorable avenues of approach. The northern limit reached in such cases would be governed by the chance terminus of the route that happened to open up from the eastward, with, of course, later extension from the new base. Other species in this same category are: Dryobates pubescens, Piranga ludoviciana, Bombycilla cedrorum, Empidonax trailli, and perhaps Geothlypis trichas. These birds are for the most part not nearly so abundant in the coastal region, nor are they so evenly distributed, as species of the first category listed.

Fourteen specimens of Dryobates villosus monticola were collected (nos. 39766-39779), eleven adults and three young. Twelve are from Telegraph Creek, one from Doch-da-on Creek, and one from Flood Glacier.

Sphyrapicus varius varius (Linnaeus). Yellow-bellied Sapsucker

On June 18 an adult male was taken. Immediately after this bird was shot its mate appeared and disclosed the location of the nest. On June 19 another male bird was taken within half a mile of where the first was shot. This was about five miles from Telegraph Creek. The nest referred to was twenty-five feet from the ground, in a dead birch 
in rather open woods. The cavity appeared to be newly finished, and was empty. The two birds at the nest drew attention to their presence by their raucous call notes, screams worthy of a large hawk. The second specimen collected was traced through his noisy drumming upon a dead limb.

These three sapsuckers were the only ones that were seen near Telegraph Creek. The first one obtained (no. 39780) is close to typical varius. It has no red on the nape, and the red chin and throat patch is separated from the white subauricular stripe by a strip of black, these characters being just as in varius. It has less white on the back than most eastern examples of varius, but there is one specimen available from Illinois that resembles it closely. Taken by itself, this specimen would pass unquestioned as an example of varius. The mate of this bird was not obtained, but it was seen for a brief moment close enough to note that it had a great deal of red about the head, almost obliterating the black pectoral patch. The one collected on June 19 (no. 39781) has the red nuchal-stripe, and the red of the chin and throat has obliterated the black malar stripe, invaded the white subauricular stripe beyond, and covers the entire black pectoral patch. In the latter marking the black feathers are tipped with red; the posterior border of this patch is sharply defined against the whitish belly. The dorsal region is but scantily spotted with white. It is just such a specimen as, taken in winter in California, would be defined as an example of nuchalis showing a decided leaning toward ruber.

Ridgway (1914) regards varius and ruber as specifically distinct. In the upper Stikine Valley the two forms do appear to meet as separate species, but intergradation through individual variation occurs elsewhere and by that criterion the two should be regarded as subspecies of one species. A parallel case in the Stikine region is found in the thrushes, Hylocichla ustulata ustulata and H. u. swainsoni. The facts derived from our specimens of Sphyrapicus are as follows: At Telegraph Creek we took one typical example of varius, and one bird that has more the appearance of a hybrid between two species (varius and ruber) than an "intergrade" between two such forms, regarded as subspecies. At Doch-da-on Creek, some fifty miles down the river, we collected specimens of ruber, specimens absolutely typical of that form (see pastea, p. 220). We have here no series of intergrades, difficult of allocation and from an intermediate region. There are instead examples of two extremes, varius and ruber, nesting within a short distance of each other. The one doubtful specimen does not accord with 
typical muchalis, but has all the appearance of what a hybrid should be between two distinct species, varius and ruber. Presumably the form nuchatis does not occur this far north.

\section{Sphyrapicus varius ruber (Gmelin). Red-breasted Sapsucker}

Five specimens taken at Doch-da-on Creek during July, two adult males, one juvenal male and two juvenal females (nos. 39782-39786). Probably several pairs had nested within the area we covered in this region, for the birds were encountered at widely separated points. There were certain favored spots, one clump of willows and one large birch, in particular, where one or more sapsuckers were seen almost every time we passed. These trees showed large areas of scars, the results of assiduous work by the sapsuckers for a considerable period of time.

The five birds taken are typical examples of the dark colored northern race of the red-breasted sapsucker (Sphyrapicus $v$. ruber). This locality, Doch-da-on Creek, may be regarded as the easternmost limit of ruber in this region, yet the race persists in typical form to this extreme boundary. There is no indication of intergradation with varius or muchalis at this margin of its habitat, such as might be expected to occur. The relationships of the three forms, varius, muchalis, and ruber, present an unsolved problem, whether we regard them as species or subspecies. As between ruber and daggetti, however, there is gradual intergradation exhibited by specimens from intermediate points, such as we are accustomed to see in most geographic races, or subspecies.

\section{Colaptes auratus borealis Ridgway. Boreal Flicker}

Fairly common in the vicinity of Telegraph Creek, but so shy and wary as readily to elude observation. The call note was frequently heard, but days might pass during which none of the birds was seen. Usually they kept out of gunshot. The few obtained were taken in dense poplar thickets, where the birds were sometimes observed feeding on the ground.

On June 14 a nest was found containing one egg. On June 15 a female was shot with partly formed eggs in the ovary. None had been laid as yet. On June 17 a nest was found containing newly hatched young. This was in the broken stub of a dead birch, about ten feet from the ground. 
A few flickers were seen in the woods about Glenora, perhaps one or two daily. At Doch-da-on Creek a few were seen, at long intervals. None was observed any farther down the river.

Three specimens were obtained (nos. 39787-39789), all adult females, two from Telegraph Creek and one from Glenora. Specifically, they are all purely of the yellow-shafted auratus type, as regards color and markings. None shows any admixture of cafer characteristics, though the breeding ground of the northwest subspecies of that species (Colaptes cafer cafer ${ }^{2}$ ) approaches this region very closely. No red-shafted flickers were seen by us at any point, though cafer may be expected to ascend the Stikine for some distance. Subspecifically the large size of these birds places them with the form Colaptes auratus borealis Ridgway (1911, p. 31).

\section{TABLE VI}

Measurements in millimeters of Colaptes auratus borealis from the upper Stikine

$\begin{array}{ccccc}\text { No. } & \text { Sex } & \text { Wing } & \text { Tail } & \text { Culmen } \\ 39787 & \circ & 162 & 106 & 37 \\ 39788 & \circ & 163 & 105 & 32 \\ 39789 & \text { o } & 160 & 106 & 33\end{array}$

Chordeiles virginianus virginianus (Gmelin). Eastern Nighthawk

Abundant at Telegraph Creek. The first was heard calling the evening of June 8, the next day one was seen flying overhead, and soon after the birds became common. The species was about as numerous at Glenora; at Doch-da-on Creek it occurred in lesser numbers. None was seen farther down the river.

Three sets of eggs were taken (nos. 1807-1809). On June 20, a single fresh egg, an incomplete set, was found near Telegraph Creek, laid on the bare ground in open woods. The female, shot before the egg was found, contained a second egg, nearly ready to be laid. A set of two eggs, slightly incubated, was taken. June 26 in the same tract of woods. This was an area that had been burned over, leaving a scattering growth of small lodgepole pines, with but little underbrush between. A third set was collected at Doch-da-on Creek, July 18. These were incubated within a few days of hatching. The eggs were placed on the bare ground in an open place in the woods. On all sides, some thirty or forty yards distant, there was dense brush, but the ground was open in the immediate vicinity of the eggs.

2 For the use of this name for the northwestern flicker, see Palmer, 1916, p. 322. 
The parent of the second set was extremely solicitous of their safety. She flew as we approached, coming toward us with a peculiarly halting and uncertain flight, with her tail depressed until it pointed almost straight down, and with her mouth open. Alighting near-by, she wallowed on the ground, thus luring us in pursuit for about twenty or thirty yards, then flew off in a circle through the woods. The parent of the set at Doch-da-on Creek acted quite differently. She left the eggs while the intruder was still some distance away, departing quietly and without any manifestations of solicitude. In just twenty minutes she returned, as secretively as she had left. This course of action was followed without variation on three different occasions.

Four specimens were collected (nos. 39790-39793), two adult males and two adult females. To my eye they are indistinguishable from specimens of Chordeiles v. virginianus from the eastern United States.

\section{Cypseloides niger borealis (Kennerly). Black Swift}

A few seen about six miles from Telegraph Creek on June 12, circling overhead just out of gun shot. From this circumstance the species may be assumed to breed somewhere in that general region. One or two were observed at Glenora early in July. The next place the species was noted was at Great Glacier, where, on the morning of August 9, a flock of fifteen or more was seen. .

At Sergief Island, August 17 to September 7, black swifts were abundant, though 'seen only in cloudy or rainy weather. Then large flocks appeared, as many as seventy-five or a hundred being in sight at once flying over the marshes, the individuals moving about in wide circles, and the flock as a whole moving in a definite path. The birds sometimes flew very low, occasionally skimming along just over the tall grass. A flock would appear, circle about overhead awhile, and then vanish. About fifteen or twenty minutes later, others, or perhaps the same flock, would come in sight again.

Compared with Aeronautes and Chaetura, the flight of Cypseloides (at least as seen thus feeding) is rather slow, a steady sailing with relatively little fluttering of the wings. A high rate of speed can be attained, however, so great that when individuals passed by in pursuit of one another the rush of their wings could be heard to a distance of two hundred yards or more. A weak, chattering note was uttered from time to time, but mostly the birds were silent.

Seventeen specimens were obtained at Sergief Island (nos. 39794 39810), five males and twelve females. It might be supposed that a 
series of specimens taken when these birds were collected (August 19-30), would contain a large percentage of immatures, but if such young birds are included in the lot they possessed no features, either of internal anatomy or external coloration that enabled me definitely to recognize them as such. According to Drew (1882, p. 182) the young of this species is appreciably different from the adult in coloration, the dark feathers being extensively white-tipped, both above and below. Of the five males, two have extremely faint light colored tips to the feathers of the lower abdomen and on the lower tail coverts. One of the five has the tail very slightly forked, in the others it is deeply indented. Of the twelve females, one is uniformly dark colored; it has no trace of any whitish tips to the feathers of the lower parts. In the others such markings are present in varying degrees. The dark colored female has a truncate tail, just as do the others. In every individual, both male and female, the sexual organs were clearly visible. They were shrunken in size, as would be expected in adults at that season, but they were never difficult to see, as is so often the case with young birds. The birds collected had entirely finished the annual molt and were all in the new plumage.

\section{Chaetura vauxi (J. K. Townsend). Vaux Swift}

On June 26 a single bird was noted some five miles from Telegraph Creek. At Doch-da-on Creek, the middle of July; a few were seen on several different days. At Flood Glacier, August 3 and 5, several were observed, flying low in the rain that was falling, and all traveling down stream.

Two specimens were collected (nos. 39811, 39812), an adult male and an adult female, taken at Doch-da-on Creek, on July 16 and 14, respectively.

\section{Selasphorus rufus (Gmelin). Rufous Hummingbird}

Seen at every collecting station, but nowhere in abundance. The species was at Telegraph Creek at the time of our arrival, May 23; at that time it was restricted to the near vicinity of the river, where there were already some flowers in bloom. On the higher slopes the vegetation was not so far advanced, and the hummingbirds were absent.

A nest found at Doch-da-on Creek, July 10, was in a clump of large timber, built near the tip of a spruce limb, about five feet from the ground. The outer surface of the structure was well covered with 
lichens. Attention was drawn to this nest by the sudden flight of the two young birds it contained, when approached too closely.

During the second week in July a female hummingbird was repeatedly seen in the vicinity of our camp. On the 14th a male bird was seen going through his courtship flight, associated with this same female, so nesting may have been going on at that date. In the courting flight the male bird rose slowly to a height of about sixty feet, then swooped down and swung up again for a very short distance. A diagram showing the course of this evolution would be about the shape of a fishhook. When the lowest point was reached, three or four rasping notes were uttered. The evolution finished, he slowly arose once more and repeated the performance. This was done five or six times, when he lit on a nearby limb.

For a hummingbird to appear as a menace to a farm crop was a new rôle for a member of that family, but we heard one such complaint of damage done. Mr. W. E. Parrott, of Sergief Island, had a large strawberry patch, the fruit of which he marketed in the nearby town of Wrangell. Time and again, so he told us, he had seen a hummingbird dash at one of the bright red berries, apparently under the impression that it was a flower, and the bird's bill would be thrust through the fruit, which, of course, was ruined. He had found a number of berries pierced in this way, and was puzzled to account for the damage until he saw a hummingbird in the act.

Two specimens were preserved (nos. 39813, 39814). These are adult males taken at Glenora, June 29 and July 3, respectively.

\section{Sayornis sayus (Bonaparte). Say Phoebe}

Several pairs seen on the upper Stikine River. At Telegraph Creek at least two pairs were domiciled on different houses in the town. On June 6, one pair was seen at work nest building on a beam over the entrance to Hyland's store. At Glenora, June 29, a nest with young was found in one of the deserted houses of the Hudson's Bay Company. A day or two later the birds were gone and search of the adjoining fields failed to disclose their presence; evidently the brood had at once traveled some distance.

On August 21 an immature female was collected on Sergief Island, perched on some drift far out on the marshes. This, I believe, is the first time the species has been reported from the coast of southeastern Alaska. It is, of course, a transient, perhaps no more than a straggler into that region. The bird collected on Sergief Island had probably wandered there from the interior along the Stikine River. 
Sayornis sayus yukomensis was described by Bishop (1900b, p. 115) from Glacier, White Pass, Alaska; as a northern form, differing from S. sayus sayus in darker coloration and in certain structural details. The subspecies was denied recognition by the A. O. U. Committee (1901, p. 312), nor has it been generally recognized since that time. Grinnell (1909a, p. 206) uses the name S. s. yukonensis for a specimen from Forty-Mile, Yukon, which is shown to exhibit the characters claimed for the race by Bishop. The young bird (no. 39815) collected by myself differs appreciably from juvenals from the southwest. It is of darker coloration and has much less rufous on the upperparts, thus agreeing with Bishop's (loc. cit.) deseription of the juvenal plumage of yukonensis. Thus the two northern specimens of Sayornis sayus in this Museum are of a character to justify the recognition of $S . s$. yukanensis, but the material is so scanty that, rather than formally affix that name to these two individuals, I prefer to let the description of their peculiarities rest as evidence for use at some future time when additional material has been acquired.

Nuttallornis borealis (Swainson). Olive-sided Flycatcher

There were a few pairs in the more open wooded country about Telegraph Creek. The birds were extremely shy, not permitting a near approach, and their habit of perching in the tops of tall trees also aided in keeping them out of gun shot. Seen at but the one collecting station.

\section{Myiochanes richardsoni richardsoni (Swainson)}

Western Wood Pewee

Fairly common about Telegraph Creek. First seen on May 27; a few days later present in numbers. A female shot at Glenora on July 7 had laid part of its set. None seen farther down the river than Glenora, though, as the species is known to occur in summer at some points on the coast of southeastern Alaska (Swarth, 1911, p. 75), it might be expected to range through the entire Stikine Valley.

The birds were extremely shy. They were partial to more sparsely wooded areas, especially burnt-over tracts, where they perched upon dead trees affording a wide outlook. In such places they could seldom be approached to within a hundred yards.

Three specimens collected (nos. 39816-39818), one adult male and two adult females. Besides these birds there are in the Museum collection, specimens from the coast of southeastern Alaska and from 
Vancouver Island. A northern race of this species has been designated by Bishop (1900b, p. 116) as Contopus richardsoni saturatus. Certain of the characters ascribed to this race may be discerned in some of the specimens from the several points indicated, but these features seem all to be too inconstant to serve in differentiating a northern subspecies.

Empidonax difficilis difficilis Baird. Western Flycatcher.

Seen nowhere along the upper Stikine, and the call note is sufficiently loud and characteristic to render it unlikely that we should have overlooked the bird, if present. One specimen, an immature male (no. 39819) taken on Sergief Island, August 19.

\section{Empidonax trailli alnorum Brewster. Alder Flycatcher}

Occurs in some numbers in suitable willow and alder thickets as far down the river at least as Doch-da-on Creek. One heard calling near Telegraph Creek, May 23. None seen at the Junction, but at Sawmill Lake there were several pairs in the dense thickets bordering the water. Here, at Glenora and at Doch-da-on Creek, our experience was the same. The birds could be heard calling, and occasionally one could be seen in flight through the bushes, but their habitat was so impenetrable and the birds were so shy and wary that they were almost impossible to approach.

After leaving Doch-da-on Creek the alder flycatcher was seen on but one occasion. On Sergief Island, September 3, an immature female was collected in a tangle of alders. The capture of this bird, of course, is no proof that the species breeds on that island, though it has once been recorded from another point on the coast of southeastern Alaska under circumstances apparently indicative of nesting (Swarth, 1911, p. 76).

Two specimens were collected, an adult male near Telegraph Creek, June 18 (no. 39820), and the young bird above mentioned (no. 39821). The adult somewhat resembles Empidonax $t$. trailli in its large bill and short wing, but in general coloration and in character of wing bars, it is clearly alnorum. The young bird appears to be a typical example of alnorum.

\section{Empidonax hammondi (Xantus). Hammond Flycatcher}

Abundant on the upper Stikine, where it is largely a bird of the poplar woods. Near Telegraph Creek many were seen during the last 
week in May, usually sitting high up in the leafless poplars and conspicuous from their frequently reiterated, sharp che-bec. Like the other small flycatchers of the region, they were extremely shy, but, through peculiarities of habit and habitat, Hammond flycatchers were more easily collected than some of the other species. The olive-sided flycatcher and wood pewee, perched upon isolated lookout points, could not be approached unawares. The alder flycatcher was in tangled thickets not to be penetrated save with much labor and with the accompaniment of threshing branches and broken boughs. The Hammond flycatcher was mostly in woods that could be traversed with fair ease, but which yet afforded some cover to the hunter.

The species was quite abundant at Telegraph Creek and at Glenora, and in lesser numbers at Doch-da-on Creek. Several were seen at Flood Glacier, though whether the species breeds at that point we had no means of telling. One was collected at Great Glacier, August 10.

A female shot near Telegraph Creek, May 27, was incubating a set of eggs. One collected June 1 had laid part of its set. An adult male taken at Glenora, June 30, shows the beginning of the molt. An adult female from Flood Glacier, July 27, had renewed a large part of its plumage. Two specimens in juvenal plumage were taken at Flood Glacier, August 3 and 6. A young bird from Great Glacier, August 10 , shows the beginning of the molt into the first winter plumage.

It is strange that the Hammond flycatcher has not yet been found on the coast of southeastern Alaska south of Skagway. It is abundant in the interior and approaches the coast quite nearly at some points. It is also abundant in the coastal region farther south, as on Vancouver Island. Consequently it is hard to understand the cause of its exclusion from the southern Alaskan coast.

We collected ten specimens (nos. 39822-39831), seven adults and three juvenals.

\section{Fmpidonax wrighti Baird. Wright Flycatcher}

Three specimens taken near Telegraph Creek. This species was not to be distinguished from $E$. hammondi in life; in fact it was not until our return from the field, when the entire collection was brought together, that both species were found to be included in the series of small flycatchers collected. Consequently if there is any difference in local habitat between the two we failed to distinguish it. The three birds taken were obtained at points where examples of hammondi were also collected. 
These specimens are a male (no. 39832), taken at The Junction, May 28; a female (no. 39833), from Sawmill Lake, June 11, not yet laying; a female (no. 39834), taken four miles west of Telegraph Creek, June 18, containing eggs nearly ready to be laid. These facts point to a somewhat later time of nesting than is the case with hammondi.

The species has been reported from Wilson Creek, near Lake Atlin, about 150 miles north of our station, and as far as I know the northernmost point of record (E. M. Anderson, 1915a, p. 13). The specimens we took are typical examples of the species, presenting all the characters of measurements and proportions that distinguish wrighti from hammondi. No equivocal specimens were collected, that is, none that could not be referred without question to one species or the other.

\section{Otocoris alpestris arcticola Oberholser. Pallid Horned Lark}

Seen in small numbers on the mountain tops above Doch-da-on Creek. There, on July 11 and again on July 23, they were found on the open, moss-covered slopes above timber line, associated with rosy finches and pipits. This station is, in a straight line, not more than sixty miles from the coast, farther to the westward than horned larks have been found in this region heretofore. From the mountain we were on, however, we could see many similar peaks and ridges far to the westward, where the species would probably be found could these summits be reached. These mountains are so steep and rough, with such impenetrable forests at the lower levels, and, toward the coast, so frequently encircled by glaciers, that their ascent at most places is extremely difficult. Horned larks may well occur at favorable points but a few miles back from the coast, but the circumstances are such that it is doubtful if this possible habitat will soon be invaded by any collector.

We collected four specimens (nos. 39835-39838), two adult males, one adult female, and one juvenal male. The two adult males, taken July 23, are beginning the annual molt, shown mostly in the wing coverts. The young bird, taken July 23 , is in juvenal plumage throughout. Compared with the young of various of the southwestern subspecies of Otocoris alpestris, it is extremely dark colored. Ground color of the upper parts is blackish, throat and lower belly are white, and there is hardly a trace of rufous or vinaceous anywhere. 


\section{Cyanocitta stelleri stelleri (Gmelin). Steller Jay}

Closely restricted to the coastal region. On our way down stream we saw the first Steller jay at Flood Glacier, some forty miles up the river from the boundary. At that point one was noted on July 26, another on August 1. At Great Glacier, about ten miles above the boundary, two were observed together on August 11, and proved to be both adult males. The species is sufficiently conspicuous and noisy to draw attention to itself when present, and as the above records constitute all of our observations on the upper river, it is obvious that this jay is of relatively uncommon occurrence in that region.

At Sergief Island many were seen, sometimes under circumstances suggesting migration. They were frequently in small gatherings, seven or eight together, and often on the tidal marshes, far from timber, apparently traveling in a definite direction. When thus seen they were flying by easy stages from one drift $\log$ to another, in a southerly direction.

An adult female (no. 39839) taken at Flood Glacier, August 1, is in the midst of the annual molt. Two adult males taken at Great Glacier, August 11 (nos. 39840, 39841), are in the new plumage throughout. Two immatures from Sergief Island (nos. 39842, 39843) obtained on August 23 and 31, respectively, are likewise through the molt, and have fully acquired their first winter plumage. These birds are all typical stelleri. Those taken the farthest inland evidently represent extreme points of dispersal from the coast. There is no evidence that Cyanocitta stelleri stelleri in this region extends inland to the habitat of $C$. s. annectens, with intergradation between the two forms. Annectens probably does not range so far north in British Columbia.

\section{Perisoreus canadensis canadensis (Linnaeus). Canada Jay}

When we arrived at Telegraph Creek, the fourth week in May, this species was through with its nesting. It was not a common bird nor was it ordinarily noisy or conspicuous. Family groups, old and young together, were seen at several points between Telegraph Creek and the Summit, and single individuals were occasionally encountered slipping quietly through the woods.

This jay was one of several species that appeared to be restricted during the breeding season to a higher zone than that immediately bordering the Stikine River. None was seen nearer the river than The Junction, a point four miles north of Telegraph Creek, several 
hundred feet higher in altitude, and about two weeks later in the development of the vegetation. On June 4 at the Summit, a gathering of jays was encountered composed of at least two broods. The old birds were busily engaged in feeding the young, though the latter were also foraging a little for themselves.

We did not see the species either at Glenora or Doch-da-on Creek, but it can hardly be doubted that it occurs at both places. There was at least one brood in the woods about our eamp at Flood Glacier. The forest at that point is not of the type most favored by this species, being almost entirely dense spruce woods such as are seen along the coast, and it is questionable whether the occurrence there of this family of Perisoreus can be assumed to represent a breeding record. None was seen farther down the river.

Individuals taken the last week in May and the first week in June had in several cases already begun the annual molt. Two adults taken at Flood Glacier on July 28 were in the midst of this molt. Two young birds taken at the same place July 28 and August 6 are molting from the juvenal into the first winter plumage.

There have been available for comparison a series of adult Perisoreus canadensis canadensis from Minnesota, and old and young of $P$. c. fumifrons from the Kotzebue Sound and Yukon River regions, Alaska. The Stikine River adults are similar to fumifrons in general body color, but have more white on the crown. They resemble canadensis in head markings but are rather darker colored. The young birds from the Stikine region are distinctly darker colored, more of a slaty black, as compared with the juvenals from Kotzebue Sound and the Yukon River. This tark type of coloration is a character aseribed to the young of $P$. c. canadensis by Ridgway (1904, p. 366). On the whole, the Stikine River series may be assigned to the subspecies Perisoreus canadensis canadensis, though showing a tendency toward P. c. fumifrons.

We collected thirteen specimens of the Canada jay (nos. 3984439856), five adults and four juvenals from points within twelve miles of Telegraph Creek, and two adults and two juvenals from Flood Glacier.

\section{Corvus corax principalis Ridgway. Northern Raven}

Probably occurs throughout this whole region, but, judging from our observations, not abundant at any point. We were at Telegraph Creek three weeks before we saw one. The first was noted on June 17, and afterwards others were seen on several oceasions. At Doch-da-on 
Creek ravens were occasionally observed, and at Great Glacier several were seen. There were a few at Sergief Island, seen from time to time, or heard croaking in the distance.

Corvus brachyrhynchos caurinus Baird. Northwest Crow

Seen only at Sergief Island. Here, during the latter part of August and the first week in September, crows were fairly abundant, usually in small flocks. Young birds were still being cared for by their parents, and the gatherings seen were apparently family groups, though sometimes two broods may have joined forces. This bird is strictly a "beach comber," apparently not venturing inland any distance whatever. We saw none above the mouth of the river. No specimens were taken. This form appears in the A. O. U. Check-List as a distinct species, but it should be regarded as a subspecies of Corvus brachyrhynchos (cf. Rhoads, 1893, pp. 18-21; Ridgway, 1904, p. 272; Oberholser, 1919a, p. 84).

\section{Euphagus carolinus (Müller). Rusty Blackbird}

Breeding in the vicinity of Telegraph Creek. There were several pairs nesting about Sawmill Lake, at different points, not in any one gathering or colony. A female shot June 11 was incubating eggs. At Doch-da-on Creek the species was seen about some swampy meadows and lakes during the latter part of July, when young birds, full grown, though still in the juvenal plumage throughout, were being cared for by their parents. The young sat in the willows, while the adults were foraging through the swamps for the food that was hurried back to the squalling youngsters as rapidly as it was found.

Seen at one other collecting station. On Sergief Island, September 5 , a single bird passed over my head, out of gun shot, while I was out on the marsh.

Ten specimens collected (nos. 39857-39866), an adult male and female from Telegraph Creek, and eight in juvenal plumage from Doch-da-on Creek. There is an appreciable difference in appearance in the two sexes in juvenal plumage. The young male is much more black beneath the prevailing rusty or yellowish hue of the feather tips.

Pinicola enucleator flammula Homeyer. Kadiak Pine Grosbeak

Apparently rather rare in summer in the upper Stikine Valley. We saw single birds or pairs at scattered points and at long intervals of time; they were always shy and it was with difficulty that specimens were taken. 
At The Junction, single red-colored males were seen May 27, 29, and 31. Another was noted some five miles west of Telegraph Creek, June 12. At Doch-da-on Creek, a mated pair was taken July 9, apparently preparing to nest. On July 17, at the same place, a flock of seven or eight was encountered, feeding near the ground in some thick bushes; on July 14 a brilliant red male was seen; on July 22 a dullcolored male was secured. The last mentioned was in full song; it was beyond doubt a breeding bird. On August 2, at Flood Glacier, a red male was seen singing in a tree top near camp.

Five specimens collected (nos. 39867-39871), two adult males from The Junction, May 29 and 31 ; the mated pair from Doch-da-on Creek, July 9 (the male in the female plumage); a dull-colored male from Doch-da-on Creek, July 22. These were identified as Pinicola enucleator flammula by Dr. H. C. Oberholser, of the United States Biological Survey.

Carpodacus purpureus purpureus (Gmelin). Eastern Purple Finch

We had collected during most of the month of June in the vicinity of Telegraph Creek without once encountering this species. Then on July 5 , in a section we had previously worked most thoroughly about a mile from Telegraph Creek, we encountered several small flocks of purple finches. Three were taken (nos. 39872-39874), a male and two females, all birds that apparently were just through breeding. The male is in the streaked female plumage, with just one pink feather on the breast. Both females show some reddish on the rump.

These birds are unequivocally of the subspecies purpureus, and their capture at this point constitutes, I believe, a material extension of range northwestward. The species probably breeds somewhere within a few miles of where the birds were collected.

\section{Loxia curvirostra bendirei Ridgway. Bendire Crossbill}

During the latter part of June a few red crossbills were seen flying overhead in the vicinity of Telegraph Creek. On June 22 a small flock was encountered, apparently a single family, and four birds were collected (nos. 39876-39879), an adult male and three juvenals. It is of interest to note that these birds are of the subspecies bendirei, widely different in appearance from the form inhabiting the nearby coastal region of Alaska. This would indicate that the range of the small sized, red crossbill of the Pacific slope of British Columbia and 
southeastern Alaska is entirely cut off from that of Loxia curvirostra minor of eastern North America through the intervention of the form bendirei. The Alaskan bird has been named Loxia curvirostra sitkensis by Grinnell (1909b, p. 223), based largely on color characters in the adult male. Birds from Vancouver Island do not exhibit the same sort of differentiation from minor, in fact to my eye they are indistinguishable. Nevertheless it seems evident that the Vancouver Island birds also occupy part of the territory that is separated from minor by the habitat of bendirei. The proper nomenclatural treatment of such a form as the Vancouver Island race of Loxia curvirostra is an open question. It seems evident that genetically it is as far from minor as is bendirei; yet, since the birds from the Pacific and Atlantic regions are indistinguishable in appearance, we call them all by the same name.

The characters ascribed to L. c. bendirei by Ridgway (1901, p. 50) are as follows: "Similar to $L$. c. minor, but decidedly larger; adult male averaging rather lighter or brighter in color, the adult female slightly lighter and grayer." These characters are well borne out by the specimens of bendiren in the collection of this museum. In addition, the young birds from Telegraph Creek, all in the streaked juvenal plumage, exhibit well defined features of size and color. They are appreciably larger than comparable examples of sitkensis and minor, and are grayish toned. Juvenals of the small coastal race are much more greenish and olivaceous in general body color.

\section{Loxia curvirostra sitkensis Grinnell. Sitka Crossbill}

On Sergief Island, during August and September, a few red crossbills were seen at various times. On August 28 an adult female was collected (no. 39875). This bird was evidently incubating a set of eggs, judging from the bare breast and the condition of the oviduct. It seems curious that nesting should have been going on at that season, when we had taken full-grown juvenals of bendirei at Telegraph Creek in June.

\section{Loxia leucoptera Gmelin. White-winged Crossbill}

First positively identified at Glenora, July 4, and near Telegraph Creek, July 5, though small flocks had been seen several days before that were suspected to be this species. During the first three weeks in July flocks were seen daily, in rapidly increasing numbers. Then, 
at Doch-da-on Creek, July 21, a male bird was shot that was one of a pair. Several pairs were seen there subsequently, and the flocks appeared to be breaking up. At Flood Glacier, July 26 to August 8, the species was present in great numbers, and breeding. No nests were discovered, but several females were shot that had laid parts of their sets. The birds were fairly numerous at Great Glacier, August 9 to 16 , several were seen about the custom house at the boundary, August 16, and they were frequently observed at Sergief Island up to the time of our departure.

It was a surprise to me to find this crossbill nesting so late in the summer. That this is not the invariable custom of the species is shown by Grinnell's (1900, p. 45) account of their habits in the Kotzebue Sound region, where eggs were found in May. Their actions in the Stikine country may have been influenced by food conditions, for in 1919 throughout the region there was a tremendous crop of spruce cones, which were ripening at the time of the appearance of these birds.

At Glenora the crossbills were feeding on the seed pods of the cottonwoods, as they were also in some degree at Doch-da-on Creek, but farther down the river, and a little later in the season, the spruce cones had their undivided attention.

The song of the white-winged crossbill was one of the most notable features of the bird life of the Stikine Valley. As the flocks broke up, the male birds sang more and more. During our stay at Flood Glacier they were at the height of their efforts, and the music was in our ears at all times. It was a continuous, rollicking, trilling song, lasting for minutes at a time without cessation, and loud enough to be heard several hundred yards. The singer was usually on some high perch, preferably the dead top of a tall spruce; frequently he would fling himself into the air on wide extended, slow beating wings, singing as he went, flying sixty or seventy yards, perhaps, to another perch. The song is somewhat suggestive of that of a caged canary; we also found it reminiscent of that of the California house finch (Carpodacus mexicanus frontalis). The song-flight especially is suggestive of a similar spring performance of the house finch.

Nine specimens collected (nos. 39880-39888), four adult males and five adult females, two from Glenora, two from Doch-da-on Creek, and five from Flood Glacier. 


\section{Leucosticte tephrocotis littoralis Baird. Hepburn Rosy Finch}

Met with at but one locality, on the mountain tops above Doch-da-on Creek. We made two trips to the higher ridges above timber line, and saw rosy finches in some numbers each time. They appeared in view soon after we emerged from the upper edge of the forest (about 3500 feet) and they evidently inhabited all of the open country from there on upward. Upon our first visit to their territory (July 11) not many of the birds were seen, and they were mostly drifting about through the air by twos and threes, as horned larks do at times.

The next time we climbed the mountain, on July 23 , we found them in much greater numbers. Just at the upper edge of the timber a flock of twenty or thirty was encountered, feeding in tall dry grass that had grown up in an area previously swept by fire. Many dead trees stood on this slope, and the rosy finches when startled flew to the tree tops. This entire flock was af adult birds; two males were collected, and my impression was that they were all males, beginning to flock together after the nesting season. A little farther on females and young were found, mostly near extensive snow banks. The young were all in juvenal plumage and were not quite full grown; that is, wing and tail feathers had not reached their full length. The old birds were assiduously feeding the young, and in the pursuit of this duty we several times saw them fly into the air to capture flying insects, which were then carried to the waiting offspring.

Twenty-one specimens collected, all taken July 23 (nos. 3988939909), four adult males, seven adult females, six juvenal males, three juvenal females, and one juvenal with sex not ascertained.

The adults are all in worn breeding plumage, though the feathers are not so ragged as might be expected. Some are just beginning the annual molt. The main plumage variation concerns the gray coloration on chin and throat. In some the brown of the breast extends well up on the chin, in others there are scattered gray feathers extending downward from the throat on to the breast. The juvenals, as compared with the similar stage in Leucosticte tephrocotis dawsoni from the Sierras of California, are noticeably dark colored throughout.

The gullets and stomachs were preserved of sixteen birds, all that contained any food. From these it is evident that insects form a large part of the diet of both old and young during the summer months. Stomach contents (determined at the United States Biological Survey) in detail are as follows : 
No. 39889, adult male. Contents: 1 Elaterid, 1 Ichneumonine, 1 Tipulid, fragments of many plant lice, about 370 seeds of Potentilla, sp., at least 58 seeds of Caryophyllaceae, about 200 small seeds (probably Mollugo), 1 Polygonum viviparum, some vegetable débris.

No. 39891, juvenal male. Contents: 2 Lina interruptum, 1 Scolytid, 1 Lampyrid, 1 Elaterid, 1 Anisotoma, sp., 1 small Jassid, bits of a caterpillar, fragment of a spider, several Tipulids, 6 Empids. 1 Anthomyiid, 1 Syrphid, about 30 Aphids, 1 Camponotus, sp., 1 Leptothorax, sp., about 750 Caryophyllaceae seeds (near Silene), about 152 Polygonum viviparum (small bulblets), and about 54 seeds of Potentilla, sp.

No. 39892, juvenal male. Contents: 1 plant louse, Hymenoptera fragments (including 1 Myrmicinae), Dipterous remains, including Tipulids, 1 Anthomyiid, 1 Mycetophilid, 9 Caryophyllaceae, several bulblets of Polygonum viviparum.

No. 39893, juvenal female. Contents: fragments of a Tipulid, a few Aphids, 216 stamens of Pentstemon, sp., 1 seed of Potentilla, sp., and 17 Caryophyllaceae (near Silene).

No. 39894, juvenal male. Contents: 1 Elaterid, 1 Syneta, sp., 1 Haltica, sp., 2 Scolytids, bits of a weevil, 1 Pytho, sp., 2 Aphids, fragments of Diptera, 33 Potentilla, sp., 22 seeds of Carex, sp., 1 Arenetra, 2 Ichneumonids, 1 Protopanteles, 1 Pteromalid, 3 Belytids, 1 Aphidius, 1 Nematine, 1 Emphytina canadensis, and 1 Amauronematus.

No. 39896, juvenal male. Contents : 1 Megastigmus, sp., 3 Leptothorax, sp., about 150 Aphids, 4 Empids, 1 Plecopteron, 18 stamens of Pentstemon, sp., 21 seeds of Caryophyllaceae (near Silene), and 20 small Dicotyledons.

No. 39897, juvenal, sex not determined. Contents: 1 Neuropterous insect, 214 stamens of Pentstemon, sp., 1 Potentilla, sp., 15 Caryophyllaceae (near Silene).

No. 39898, juvenal male. Contents: fragments of Diptera (including Tipulidae), 25 seeds of Caryophyllaceae (near Silene), about 24 stamens of Pentstemon, sp., 2 seeds of Potentilla, sp., and 1 small sedge seed.

No. 39899, juvenal female. Contents: 1 Emphytina canadensis, 3 Tipulids, several Aphids (including 2 Psylla, sp.), 19 Caryophyllaceae (near Silene), and 81 immature bulblets of Polygonum viviparum.

No. 39900, adult female. Contents : fragments of an Acridid nymph and about 300 seeds of Cyperaceae (probably Carex). 
No. 39901, adult male. Contents : bits of a Carabid, 1 Bythoscopinae, about 40 Aphids, Tipulid remains, 2 Acalyptrate flies, 3 Tenthredinids (Pachynematus), 1 Pteromalid, 1 Camponotus, 1 Diaeretus rapae, 1 Ichneutes reunitor, 1 Braconid, and 1 Diplazon laetatorius, 2 small bulblets of Polygonum viviparum, 18 Caryophyllaceae (near Silene), and 8 small Dicotyledonous seeds.

No. 39903, adult male. Contents: 1 Scarabeid (probably Ataenius), 1 Camponotus, sp., 1 Stenomacrus, 1 Diaeretus rapae, 1 Ephydrid, about 25 Aphids, 1 caterpillar, about 120 seeds of Potentilla, 7 sedge seeds, 10 stamens of Pentstemon, sp., 26 Vaccinium, sp., 2 seeds near Mollugo, sp., 8 Caryophyllaceae seeds (near Silene, sp.), and 3 small Dicotyledonous seeds.

No. 39904, adult female. Contents : 1 Pteromalid, 1 fly (Empidae), about 58 plant lice, 1 insect pupa (probably Lepidopterous), 1 immature bulblet of Polygonum viviparum.

No. 39905, adult female. Contents : 1 nymph of Geocoris, sp., head of a Microlepidoptera, 2 Lycosids, 2 Tipulids, 3 moths, 2 seeds of Cyperaceae.

No. 39906, adult female. Contents: fragments of 2 Lina interruptum, 1 Acalyptrate fly, 1 Psylla, sp., about 75 Aphids, bits of a spider.

No. 39907, adult male. Contents : 3 moths, 1 Tipulid, 225 seeds of Carex, sp.

\section{TABLE VII}

Percentage of animal and vegetable matter in stomachs of Leucosticte tephrocotis

\begin{tabular}{|c|c|c|c|c|c|}
\hline No. & Sex & littoralis & $\begin{array}{c}\text { Percentage } \\
\text { of } \\
\text { animal } \\
\text { matter }\end{array}$ & $\begin{array}{l}\text { Percentage } \\
\text { of } \\
\text { vegetable } \\
\text { matter }\end{array}$ & $\begin{array}{c}\text { Percentage } \\
\text { of } \\
\text { gravel, } \\
\text { etc. }\end{array}$ \\
\hline 39891 & $\sigma^{7}$ & juv. & 46 & 54 & $\ldots$ \\
\hline 39892 & $\sigma^{7}$ & juv. & 80 & 20 & $\ldots$ \\
\hline 39893 & q & juv. & 2 & 98 & $\ldots$ \\
\hline 39894 & $\sigma^{7}$ & juv. & 88 & 12 & 18 \\
\hline 39896 & $\sigma^{\pi}$ & juv. & 84 & 16 & $\ldots$ \\
\hline 39897 & .... & juv. & 1 & 99 & trace \\
\hline 39898 & $0^{7}$ & juv. & 40 & 60 & $\ldots$ \\
\hline 39899 & 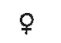 & juv. & 50 & 50 & $\ldots$ \\
\hline 39889 & $0^{7}$ & ad. & 45 & 55 & trace \\
\hline 39900 & $q$ & ad. & $\ldots$ & 100 & $\ldots$ \\
\hline 39901 & $\sigma^{7}$ & ad. & 95 & 5 & $\ldots$. \\
\hline 39903 & $\sigma^{7}$ & ad. & 60 & 40 & $\ldots$. \\
\hline 39904 & q & ad. & 99 & 1 & $\ldots$ \\
\hline 39905 & 우 & ad. & 99 & 1 & $\ldots$ \\
\hline 39906 & 우 & ad. & 100 & $\ldots$ & ... \\
\hline \multirow[t]{2}{*}{39907} & $\sigma^{7}$ & ad. & 55 & 45 & $\ldots$ \\
\hline & & Averag & 59 & 41 & \\
\hline
\end{tabular}




\section{TABLE VIII}

Measurements in millimeters of adults of Leucosticte tephrocotis littoralis All from mountains above Doch-da-on Creek, B. C., July 23, 1919

\begin{tabular}{|c|c|c|c|c|c|c|}
\hline & & Wing & Tail & Culmen & $\begin{array}{c}\text { Depth of } \\
\text { bill }\end{array}$ & Tarsus \\
\hline 39889 & $\sigma^{7}$ & 104. & 69. & 11.5 & 7.5 & 20. \\
\hline 39903 & $\sigma^{7}$ & 103. & 68. & 12. & 8. & 19.5 \\
\hline 39901 & $\sigma^{7}$ & 100 & 65. & 10.5 & 7.5 & 18. \\
\hline 39907 & $\sigma^{3}$ & 103. & 69. & 11. & 8. & 20.5 \\
\hline 39900 & q & 95. & 61. & 11.5 & 7.5 & 19.5 \\
\hline 39902 & o & 98. & 64. & 11. & 8. & 18.5 \\
\hline 39904 & ㅇ & 96.5 & 64.5 & 11. & 7.5 & 19. \\
\hline 39905 & 오 & 96. & 61. & 11.5 & 7.5 & 19. \\
\hline 39906 & 웅 & 101.5 & 65. & 11.5 & 8. & 19. \\
\hline 39908 & q & 97. & 61. & 11.2 & 8. & 19. \\
\hline 39909 & o & 93. & 59. & 11.8 & 7.5 & 19. \\
\hline
\end{tabular}

Spinus pinus pinus (Wilson). Pine Siskin

Fairly common throughout the whole region traversed, and seen in flocks during the entire nesting season. At Telegraph Creek birds were seen carrying building material during the first week of June, and on June 20 a set of three eggs was taken. The extensive open fields at Glenora were thickly grown up with dandelions when we arrived there at the end of June, and the siskins were present in large flocks, feeding upon the dandelion seeds. At the same place they were seen about the log cabins picking at the plaster between the logs.

At Doch-da-on Creek, at Flood Glacier, and at Great Glacier, siskins were encountered daily, usually in small flocks. During our brief stop at the boundary, August 16, the pine siskin was one of the few species of birds noted. It was present at Sergief Island, but not numerous.

The one nest found (no. 1810), taken near Telegraph Creek, was in a small lodgepole pine in very open woods, the same tract where the Bohemian waxwings were nesting. It was about six feet from the ground, resting against the main stem and well-nigh hidden by the clusters of needles upon the small supporting branches. The structure is well built and compact, composed outwardly of small twigs and the white down from the fireweed; the lining, of grasses and some moss from the trees. The outside diameter of the nest is about 90 millimeters, depth, about 60 ; inside diameter, about 60 , inside depth, 25 millimeters.

The eggs, three in number, were slightly incubated. They are a little paler than lichen green; in two cases there is a wreath of reddish 
spots at the large end, in the third egg this wreath is reduced to a few minute spots. Seven specimens of this bird were collected, all adults (nos. 39910-39916). Four are from the vicinity of Telegraph Creek, one from Glenora, one from Doch-da-on Creek, and one from Flood Glacier. These birds are grayer in general coloration than most of the specimens in a comparable series from the Alaskan coast, but there are individuals in the coastal series not to be distinguished from those taken in the interior.

\section{Calcarius lapponicus alascensis Ridgway. Alaska Longspur}

Seen only at Sergief Island, where it occurs merely as a migrant. First noted on September 3, and the two following days, our last in the field, small flocks appeared from time to time. All the birds seen were flying, passing overhead in a southerly direction.

\section{Passerculus sandwichensis savanna (Wilson). Savannah Sparrow}

Seen only at Sergief Island. Upon our arrival there, August 17, Savannah sparrows were present though not abundant. Some days later they increased greatly in numbers, and at the end of August were found everywhere over the marshes. They kept mostly to the flooded grass lands, a much wetter habitat than that favored by the song and Forbush sparrows, also abundant at the same station.

Nine specimens were collected (nos. 39921-39929). The discovery that the subspecies alaudinus breeds but a short distance inland (see p. 240 ) was an incentive toward an accurate determination of the status of the quite distinct coastal subspecies. This coastal subspecies, formerly lumped with Passerculus s. alaudinus, has been latterly referred to savanna, of eastern North America, to which it bears a close resemblance (see Grinnell, 1909b, p. 227; Swarth, .1911, p. 85). 'There is no doubt, however, that the form occurring on the coast of southeastern Alaska is entirely cut off from the habitat of the eastern savanna by the intervention of the range of alaudinus. It is a local race that is probably confined almost entirely to the Alaskan coast, and with but a limited migration, one extending usually not much farther southward than the Puget Sound region. There is apparently no place where it approaches at all closely the habitat of the eastern savanna. A thousand miles or more must intervene. Nevertheless, despite the wide difference in habitat, birds from the two regions are so much alike in appearance that $I$ am unable to detect any character whereby they 
can be distinguished. It is a puzzle just what should be the proper nomenclatural treatment of these forms. In all probability the relationships of the two are not particularly close. It seems likely that there is continuous distribution of Savannah sparrows along the Pacific coast of North America, with probable intergradation between the Alaska forms and the darker colored California subspecies, and this, I believe, is the line of closest affinities.

I am willing to admit geographical distribution as one of the characters of a form, but to make distribution the sole character is farther than I care to go. So, on the ground of external resemblance, the Savannah sparrow of the coast of southeastern Alaska is here recorded as $P$ s. savanna, but with no belief that it is genetically the same as the eastern subspecies bearing that name. The case is closely paralleled by the red crossbills (Loxia curvirostria sitkensis and L. c. minor).

Passerculus sandwichensis alaudinus Bonaparte. Western Savannah Sparrow

Found at but one or two points in the upper Stikine Valley. On May 31, at the Junction, the mangled remains of one were found in a mousetrap, our first intimation of the arrival of the species. Several were seen at the Summit, June 4; a male bird collected at that time appeared to be breeding. At Glenora there were a few scattered through the weed-grown fields, and they were evidently nesting there. The males were uttering their wheezy trills from the tops of low bushes or from fences or stakes, and could be found at about the same spots day after day. Females collected were evidently incubating.

No Savannah sparrows were seen farther down the river than Glenora until we reached the coast, the habitat of another subspecies. There are not many places in the Telegraph Creek region that afford the needed surroundings for this bird, for extensive elearings supplying the open ground they favor are found in but few places. Where we saw them at the Summit is at about the upper limit of timber, and it may be that the species occurs commonly in such a habitat. We saw no Savannah sparrows, however, on the mountain top above Dochda-on Creek.

Four specimens collected (nos. 39917-39920), two adult males and two adult females. These are obviously different from $P$. s. savanna of the coastal region. Compared with the latter the Telegraph Creek birds are of grayer coloration, have a longer wing, and a more slender 
bill. They are apparently the same as the form occurring in the uplands of west central and southern California in winter, to which the name Passerculus s. alandinus has been applied (see Palmer, 1918, p. 123).

\section{Zonotrichia leucophrys gambeli (Nuttall). Gambel Sparrow}

Fairly common in the river valley at Telegraph Creek. This may be taken as near the western limit of the summer habitat of this subspecies in this region, for although the birds were numerous in and about the town of Telegraph Creek, they became notably scarce a very few miles farther down the river. In our two weeks' collecting at Glenora but one bird was seen, and none was observed farther down stream, with the exception of one at Sergief Island after the fall migration had begun.

Several nests were found near Telegraph Creek. On June 6 a bird was seen carrying building material. On June 11 and 14 three nests were discovered on certain slopes near Sawmill Lake where most of the timber had been removed. They were much alike in site and construction, placed on or near the ground under the piles of brush left from the trees that had been cut away. Each contained newly hatched young, three and four in number. The parent bird, when frightened by our near approach, did not fly direct from the nest, but skulked through the brush for ten or twelve yards before flying.

Two specimens collected, an adult male at Telegraph Creek (no. 39930), and an immature female (no. 39931), taken at Sergief Island, September 4 , the only one seen at that point.

\section{Zonotrichia coronata (Pallas). Golden-crowned Sparrow}

The closely related golden-crowned and Gambel sparrows occupied different local habitats, although both occurred commonly in the same general region. Presumably Telegraph Creek is near the eastern limit of the habitat of coronata, just as it is at the western confines of the summer home of gambeli. Their segregation apparently is due to zonal limitations. The golden-crowned sparrow is a bird of a higher zone than the Gambel sparrow, consequently, in the Stikine region, confined to higher altitudes. No coronata was seen near the town of Telegraph Creek (altitude 540 feet), where gambeli was common, but on the trail to the Summit (twelve miles north of town and at about 2700 feet altitude) they appeared in some numbers where the timber 
became dwarfed and scattered. The birds were in full song during the first week in June. A female shot June 5 contained eggs just beginning to form.

As we went down stream the species was seen nowhere in the bottom lands, but it was encountered once more on the mountains above Dochda-on Creek. There we found the birds at timber line, on July 11 and again on July 23. Dixon found them amid similar surroundings on a mountain a few miles north of Doch-da-on Creek ("Kirk's Mountain") on July 16, and saw two bobtailed young. At these several points they were at the extreme upper limit of timber, at about 3000 to 4000 feet altitude, and mostly in dense thickets of prostrate "mountain balsam" (Abies lasiocarpa). From these shelters could be heard a sharp, far-reaching chip, a note that was difficult to locate, but was finally traced to the golden-crowned sparrow. The birds were undoubtedly nesting in the balsam thickets. Probably they had young at the time, but careful search failed to reveal any except the two that Dixon saw while stalking a mountain goat. On July 23 the birds were noticeably fewer in numbers than they had been on our first visit to their habitat on July 11, and it seemed probable that they had already begun to leave.

It seems likely that the timber-line habitat of coronata extends westward nearly or quite to the Alaskan coast. With field glasses we were able to see, at various points down the Stikine, ridges and mountain tops that appeared to be much like the high altitudes we reached from the upper river. Near the coast, however, the mountains are in most places extremely hard to ascend, and the fauna of their summits is as yet unknown. The golden-crowned sparrow is a species of high Hudsonian and Alpine-Arctic. It is a bird of the coastal region rather than of the interior, but, except at the northern end of its habitat, is apparently restricted to high altitudes during the summer months.

During the migrations this sparrow is abundant at sea level. At Sergief Island the first one appeared on September 1. The next day the species was present in considerable numbers. Seven specimens collected (nos. 39932-39938), three at the Summit, June 4 and 5, one on the mountain above Doch-da-on Creek, July 23, and three on Sergief Island, September 1 to 5 .

\section{Spizella monticola ochracea Brewster. Western Tree Sparrow}

Seen at but one place. At the Summit, some twelve miles north of Telegraph Creek and at about 2600 feet elevation, several pairs of western tree sparrows were seen on May 29, June 4 and 5, evidently 
nesting there. The birds were seen feeding on the ground at the edges of marshy meadows, usually near the shelter of thickets of scrubby willow brush. The three specimens collected (nos. 39939-39941) are not to be distinguished from examples at hand from the Yukon and Kotzebue Sound regions, Alaska. I have seen a specimen collected by E. P. Walker at Wrangell, January 16, 1919. This capture may indicate the occasional passage of the species down the Stikine Valley.

Spizella passerina passerina (Bechstein). Eastern Chipping Sparrow

Abundant at low altitudes in the upper Stikine Valley. Many seen near Telegraph Creek, in sparsely wooded sections, the males frequently singing from some low perch. Two nests were found here, on June 19 and 24. Each was in a lodgepole pine sapling, some ten feet from the ground, and in each case the tree was too slender to be climbed. The species was likewise abundant at Glenora and at Dochda-on Creek. It was not seen farther down the river. Seven specimens collected, all adults (nos. 39942-39948). These, and others from northern British Columbia, in color and measurements are much nearer to eastern passerina than to typical arizonae from Arizona.

\section{Junco hyemalis connectens Coues. Cassiar Junco}

We collected forty-four specimens of this junco, as follows: vicinity of Telegraph Creek (between that point and the Summit), twentyeight (fourteen adult males, twelve adult females, and two juvenals); Glenora, seven (one adult male, three adult females, and three juvenals); Doch-da-on Creek, three (one adult male, two juvenals); Flood Glacier, six adult males. (Museum nos. 39949-39988, 39990, 39993, 39998, 39999.)

The systematic status of the junco of the Stikine region is a matter of more than ordinary interest to both the taxonomist and the student of geographic distribution and evolution. Any treatment accorded this form would doubtless arouse criticism from some direction, but it seems to me desirable that the race be accorded formal subspecific status. This junco is, in my opinion, a "good subspecies," a geographic race, in the sense that the birds over a certain area (of undetermined extent but undoubtedly a considerable stretch of country) exhibit a combination of characters distinguishing them from other described forms, and they remain true to these peculiarities within as close limits as do most recognized subspecies. 
The outstanding characteristics of the Cassiar junco are as follows: Most nearly related to Junco hyemalis hyemalis. Males of the two subspecies are very closely similar, differing in minor particulars as detailed beyond. The average female of Junco $h$. connectens is quite unlike female hyemalis. It has ordinarily more or less pink on the sides and brown on the back; the head is of a darker color and is sharply cut off from the brownish back above and from the pink sides and white belly below. The general appearance of the female is like that of the female Junco oreganus shufeldti, from which it differs in having usually less brown on the back and less pink on the sides.

Now, as regards the name to be used for this form. My first impression was that here was an undescribed subspecies, a "new" race that required a new name. It was evident, however, that this was a migratory form, and that individuals must have been collected in their more southern winter home, even though the summer habitat had not heretofore been explored. There was at least a chance that a wintertaken specimen had served as the basis of a description at some time. A search through junco synonymy disclosed one name that seemed to require investigation, Junco hiemalis connectens Coues (1884, p. 378), which has been applied in various ways. Two specimens, the one upon which this name was based, together with another like it, females collected at Colorado Springs, Colorado, April 26 and 27, were described in some detail by Allen and Brewster (1883, p. 189) under the name Junco hiemalis oregonus. They are there considered as "intermediates between hiemalis and oregonus." Ridgway (1901, p. 276) lists Coues" connectens as a probable hybrid under the heading "Junco hyemalis x Junco oreganus shufeldti." In a footnote (loc. cit.) he makes the following comment:

This type specimen, which I have earefully examined and compared, is No. 7046 of Mr. Brewster's collection, and was taken by Mr. Brewster at Colorado Springs April 26, 1882. It is very nearly typical of $J$. hyemalis, with sides only slightly tinged with cinnamomeous and the back slightly brownish. It may be a young female, of the preceding year, of $J$. hyemalis; at any rate it has nothing to do with the form of $J$. oreganus ( $J . o$. shufeldti), to which the name connectens was unadvisedly applied by action of the A. O. U. Committee in 1896.

\section{Dwight (1918, p. 289) remarks as follows :}

This is perhaps an appropriate place to discuss briefly and to dispose of the "Junco hyemalis connectens" of Coues. The original description (1884, Key North Amer. Birds, $2 d$ ed., p. 378) is a curious mixture of fact and fancy but, fortunately, the type is extant in the collection of $\mathrm{Mr} . \mathrm{Wm}$. Brewster (No. 7046, 
9 , April 26, 1882, Colorado Springs, Colo.). I have examined it and, as correctly stated by Mr. Ridgway (1901, Birds North and Middle Amer., Pt. 1, p. 276, footnote), it is clearly a specimen of hyemalis, and shows the characters common to sex and season.

The American Ornithologists' Union Committee (1897, p. 128; 1910, p. 266) follows Coues (1897, p. 94) in applying the name connectens to the form named Junco hyemalis shufeldti by Coale (1887, p. 330) and re-named (as I believe) Junco oregonus couesi by Dwight (1918, p. 291).

It is thus seen that the two men (Ridgway and Dwight) who have most carefully studied the genus Junco in recent years unite in the belief that connectens is not a recognizable form. It is after some hesitation that I offer a contrary opinion, but I believe that the new material at my disposal justifies my view. As to the treatment of the name connectens by the A. O. U. Committee, I am of the same opinion as Ridgway, that it is wrongly applied in the Check-List to the form that should be called Junco oreganus shufeldti Coale. The description by Allen and Brewster (1883, p. 189) of the Colorado bird that served later as the type of connectens, obviously a migrant or winter visitant at the point of capture, fitted so nearly my specimens from the Stikine region as to lead me to suspect them to be the same. This bird, as part of the Brewster collection, is now in the collection of the Museum of Comparative Zoology, at Cambridge. I have not examined it myself, but at the kind suggestion of Mr. Outram Bangs I sent him a selected series of the Stikine birds for comparison with the type of connectens, and, incidentally, with any other pertinent material. He remarks upon them as follows:

I have compared the skins most carefully with our very large series of eastern birds. ... The very black, sharply marked off top of the head in your male birds I cannot match. The type of $J$. connectens Coues is a female taken at Colorado Springs, Colorado, Apr. 26, 1882. It is a counterpart of your no. 10945 (Mus. Vert. Zool., no. 39957). Indeed you would have difficulty in telling the two apart, except that the type of connectens is, although taken at an earlier date, in a little more worn plumage. I can't find spring females from the east just like these, but on the other hand, autumnal females much resembling them (probably young birds of the year?) are common in our series.

For comparison with hyemalis, the form to which I believe connectens is most nearly related, I have had an abundance of non-breeding birds from various places in the eastern United States, and a few from western points. No series of breeding birds of the eastern Junco h. hyemalis is available. 
The adult male of connectens is very similar to hyemalis. At first glance, in the field, there was no doubt in my mind that hyemalis was the form encountered. Comparison with eastern birds, however, shows certain appreciable differences. Connectens is darker colored throughout, and, compared with the more uniformly slaty hued hyemalis, is seen to possess a blackish head, quite sharply defined at a line above the shoulders. Beneath, in connectens, the outline of the black breast is convex against the white belly, forming a sharp angle where it joins the gray sides. In eastern hyemalis the slaty breast and sides usually form a concave outline against the white belly. In most cases, a specimen of connectens viewed laterally is seen to possess a black head pattern above and below, just about as in Junco oreganus, though, of course, more obscurely indicated than in that species. These distinctions, as just detailed, would not amount to very much in a single bird, perhaps, but viewed in mass effect, with specimens of the three forms arranged in parallel rows, the differences are readily noticeable. The black-headed appearance of the male is a feature that is conspicuous in the live bird.

The female of connectens is, as a rule, more nearly like the female of a subspecies of the black-headed Junco oreganus group than like female hyematis. The sides are more or less tinged with pink (often quite strongly so), and the back with brownish. The blackish head is sharply defined against the back and against the pink sides and white belly. Two among the fifteen females from Telegraph Creek and Glenora have no pink on the sides, though with brown on the back. These two birds are most nearly like hyematis. Of the others it is safe to say that not one would be ascribed to hyemalis if taken in its winter home, with nothing but the appearance of the bird as a guide to its specific identity. There are certain winter specimens of Junco oreganus shufeldti at hand from southern Arizona, that, so far as color. and markings are concerned, are indistinguishable from some Stikine River females. Arizona specimens of shufeldti, however, are distinctly longer winged.

Thus there is here a race in which the male bears a strong resemblance to one specific group (Junco hyemalis), and the female to another (Junco oreganus), this race occurring at a point where the boundaries of the two species mentioned come close together. Different authorities take different views regarding the relationship of the two forms, hyemalis and oreganus. In the A. O. U. Check-List of North American Birds (1910, p. 266) they are treated as two subspecies of 
one species. Ridgway (1901, pp. 278, 283) regards them as specifically distinct, each divided into several subspecies. Dwight (1918, pp. 285, 291) also considers them as two species. Dwight, however, regards as of hybrid origin several forms of Junco that are accorded subspecific, or even specific, rank, by Ridgway and others. All "confusing plumages," found in the borderlands where different species of Junco come together, he regards as the result of hybridism.

In view of these different opinions, it is of interest to secure specimens and study conditions at places where two distinctly characterized forms meet. The upper Stikine Valley is such a place, and, with these points in mind, the junco of that region received special attention in our field work. Though anticipating some interesting discoveries in the distribution of the forms involved, it could hardly be foreseen that this borderland should be occupied by a race so curiously combining the characters of the eastern hyemalis and the western oreganus. With the ascertaining of this fact there now remains the proper application of it, and in this I fancy there will be difference of opinion.

First, is the occurrence of birds of this description (in a sense, intermediate between hyemalis and oreganus) to be taken as indicative of intergradation between the two? Are hyemalis and oreganus therefore to be regarded as two subspecies of the same species? I think not. There is no adult specimen in the connectens series that could for a moment be confused with the coastal junco (Junco oreganus oreganus), the subspecies geographically most closely adjacent to the upper Stikine race. There are no doubtful specimens as between these two forms, hence no intergradation. The measurements of connectens do not show intergradation between Junco h. hyemalis and Junco o. oreganus (see table, p. 254). The resemblance of the female connectens is toward Junco o. shufeldti (= Junca h. connectens of the A. O. U. Check-List), a pale colored form of Junco oreganus occurring to the southward. There may be intergradation between connectens and shufeldti farther south in British Columbia, but as yet we do not know that to be the case.

Then, as to the theory of hybridizing, used to a great extent in comparable cases by Dwight in his study of the juncos (1918). Such a decision in the present case (as in certain others so disposed of by Dwight) seems to me to distort the meaning of the word hybrid out of all recognition, and to apply it to facts and conditions it is, not commonly called upon to cover. I am willing to admit that a name such as Junco annectens Baird may have been applied to an individual bird 
actually of hybrid parentage in the usually accepted sense, in that particular case with one parent Junco caniceps, the other, Junco mearnsi; and I am willing to admit (see postea) that individual hybrids may occasionally occur between any species of Junco whose ranges adjoin. To consider as hybrids, however, all the birds (juncos in this instance) of a whole region, despite the facts that they comprise the only representative of the species in that region, that they all exhibit the same combination of characters over a wide stretch of country, and that they breed true, that is, transmit these same characters to their young, is an utterly misleading use of the term. The junco of the Stikine River should not be regarded as a hybrid.

As bearing upon the fact that it is the female of connectens that shows variation from the hyemalis type, attention may be drawn to the following statement by Dwight (loc. cit., p. 289): "The variation in females of the three species [i.e., hyemalis, oreganus, and mearnsi] complicates the question still more, for the average females of the three differ much less from one another than do the males, and the hybrids between them would seem therefore to be much more numerous." I suppose the application of this to the present case (the junco of the Stikine region) would lead to the conclusion that here on a large scale is an example of sex-linked inheritance; that in the hybridization of hyemalis and oreganus the female offspring only show the oreganus characters. That such is not the case is shown by specimens collected at Flood Glacier (described farther on), where the race here designated connectens comes into actual contact with oreganus.

My own conclusions are as follows: The junco of the Stikine region is a recognizable form, apparently the same to which Coues applied the name Junco hiemalis connectens. It is most nearly related to Junco hyemalis hyemalis, and may be conceded to exhibit intergradation of a sort, as between Junco hyemalis and Junco oreganus. That is, the peculiarities of this subspecies undoubtedly have some bearing upon the relationship of those two aggregations of races. The intergradation exhibited, however, is apparently as between the two species Junco hyemalis and Junco oregamus, rather than between two adjacent subspecies, Junco hyemalis connectens and Junco oreganus oreganus. It is not of the sort that is usually found between two subspecies of the same species, and for the present it may well be disregarded as a subspecific criterion. It seems to me that this is a proper place for a somewhat arbitrary division, and that Junco hyemalis and Junco oreganus should still be regarded as separate specific groups. Then, 
as previously shown, the junco of the Stikine region, although in a sense intermediate in appearance between hyemalis and oreganus, can not properly be considered as an aggregation of hybrid individuals. The only alternative left, therefore, is to consider this form as a distinguishable geographical race of the species it most nearly resembles, and apply a separate name, as I have done.

As we descended the Stikine, leaving the habitat of connectens behind and drawing nearer to that of oreganus, every effort was made to secure juncos. At Telegraph Creek and Glenora, juncos (connectens) were abundant. At Doch-da-on Creek, though in lessened numbers they were still fairly numerous, and all still of the same subspecies. Our next stop was at Flood Glacier, some forty miles down stream and about seventy miles from the coast. There we were in a region where either coast or inland species might occur, and the junco was one of several birds that we searched for especially at that point. Juncos were not numerous, however, and our two weeks of collecting there yielded but fifteen specimens. Of these, eight are adults, six males and two females. The two females are Junco o. oreganus, beyond a doubt. Of the male birds, one (no. 39999) is typical connectens. It is in extremely worn plumage but is evidently of exactly the same character as Telegraph Creek specimens. One bird (no. 39993), while not an average connectens (it shows some rusty on the back), can be matched by one variant taken at Telegraph Creek. Another (no. 39998 ) is somewhat more reddish on the back, though the sides are slaty. The remaining three adult males (nos. 39987, 39988, 39990), if taken farther south, in their winter home, would undoubtedly be considered as examples of Junco oreganus shufeldti. They are shorter winged than Arizona winter specimens of shufeldti, but they have the black head (a glossier black above than in connectens), brownish back, and pink sides of that race. However, despite their general appearance, I cannot believe that these birds are shufeldti. I do not believe it possible for the habitat of that subspecies to extend northward as a tongue inserted between the ranges of connectens and oreganus. Juncos can not be distributed uninterruptedly from the southward over the glacier covered mountains that constitute so large a part of this intermediate region. Their distribution must lie in narrow ribbons along the river valleys extending from the interior to the coast, such as the Stikine, and the affinities of birds taken at any one point in these valleys must lie with others immediately adjacent, above and below. Therefore, despite the superficial resemblance of these 
Flood Glacier juncos to shufeldti, I decline to consider them as of that subspecies, or to call them by that name. This despite Dr: Dwight's belief that "we must name a bird by the plumage it is wearing not by the one that it ought to be wearing because it has been captured within the bounds assigned to another geographical race" (1918, p. 294).

Flood Glacier is close to the point where the change in the character of the country takes place, between the humid coast and the arid interior. It is the uppermost point on the river reached by certain coastal species of birds; very few indeed go any farther inland. Not many inland species extend farther down the river. We took here specimens of typical connectens and of oreganus, besides these intermediates. Forty miles up stream nothing but connectens was seen. Thirty miles farther down the river, at Great Glacier, nothing but typical oreganus.

In view of these facts it seems to me that these few specimens of indeterminate character, taken practically on the boundary line between the habitats of the two forms, may be regarded as veritable hybrids between the two. They are certainly not indicative of intergradation as it usually appears between closely related subspecies.

The seven juvenals from Flood Glacier naturally offer difficulties in their allocation such as are not encountered in adults. Young of connectens taken early in the season in the upper Stikine Valley, compared with the corresponding stage of oreganus from the coast, present certain obvious differences. As the juvenal feathers become faded and abraded, however, these distinctions are much less apparent, and the young birds from Flood Glacier had worn the juvenal plumage to the molting time. Those that do show specific peculiarities all lean toward oreganus, and one or two, otherwise indeterminable, were taken in company with an adult female oreganus. There are available but very few breeding specimens of slate-colored junco from Alaskan points. These specimens on the whole look more like eastern hyemalis than like Stikine River comnectens. The only breeding females, one from Cordova Bay and one from Rapids, Yukon River, are quite unlike any females in the Stikine series.

I have had for examination a series of seventeen adult juncos, eight males and nine females, from the collection of the Provincial Museum, Victoria, British Columbia, taken at Atlin, during June and July, 1914. Atlin is at the northern boundary of British Columbia, about one hundred and fifty miles north of Telegraph Creek. For the 
most part these birds are essentially like the Stikine.specimens. One male (Prov. Mus., no. 3683) is much paler colored than the others, more of the slaty gray of eastern hyemalis, a variation that may be indicative of intergradation with hyemalis in Alaska, a little to the northward. One female of the lot (Prov. Mus. no. 3698, Wilson Creek, Atlin, B. C., June 29, 1914) is so very different in appearance from the rest of the series as to suggest its belonging to another species. It is appreciably larger than the others, actually so in length of wing and tail, and to all appearances in bulk also, as well as can be judged from prepared skins. It is faintly brownish on the back, and with a suggestion of pink on the sides. This bird may, perhaps, be an example of montanus, which has been recorded as occurring at Alaskan points not very far distant.

Altogether, the scanty material from Alaska, together with the British Columbian series, points to the restriction of the race connectens to a region mostly south of Alaska, and probably almost entirely in British Columbia. In this connection, attention should be drawn to a record by Bishop ( $1900 a$, p. 86) of the occurrence of "Junco hyemalis connectens, Shufeldt Junco," at White Pass City and Glacier, Alaska, a record that may, perhaps, pertain to connectens as here regarded. Osgood (1909b, p. 41) records Junco hyemalis montanus from points on the upper Yukon: "An adult female having vinaceous sides and pronounced of this form by Mr. Ridgway was collected by Hollister at Circle July 7. . . . A Also a specimen collected by myself near Charlie Creek in 1899 appears to be of this form."

When we arrived at Telegraph Creek, May 23, juncos were abundant and in pairs; evidently nesting was well under way. The male birds at that time were fond of perching on some elevated position, a telegraph pole or a house in town, a dead tree top out in the woods, where, over and over again, they gave utterance to a brief, monotonous trill, hardly long enough or loud enough to merit being termed a song. The first nest was found on June 4, about midway between Telegraph Creek and the Summit, a region in which there was still much snow. This nest was placed in an overhung crevice in the dirt wall bordering the trail, and was discovered through the brooding bird's sudden departure. It contained four eggs with incubation just begun (see fig. Z). From then on, nests were found at intervals up to July 5. On that date two were discovered at Glenora, one with four fresh eggs, one with four young about five days old. 
All nests discovered were on the ground, but in a variety of situations. Some were in the shelter of a bank or stump, others on open, level ground with little or no concealment. Five nests with sets of eggs were preserved (nos. 1811-1815), four sets of four eggs each, one of five. The nests are all much alike in structure, rather flimsily built, mainly of rather fine dry grass or weed stems, with occasionally some shreds of bark or coarser twigs or straws on the outside, and with finer grass or hair for lining.

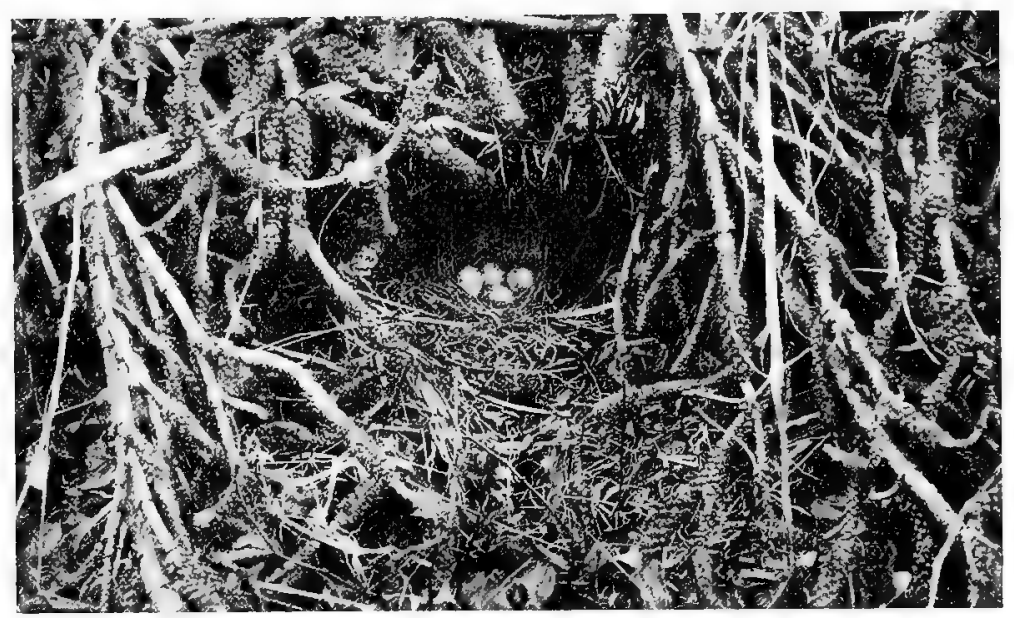

Fig. Z. Nest of the Cassiar junco (Junco hyemalis connectens), placed under a fallen tree at the side of a trail. Photograph taken near the Junction, June 6, 1919.

The first young out of the nest was taken on June 14, hardly able to fly. Shortly after young birds began to appear in considerable numbers. Up to the third week in July they were still in the streaked plumage throughout, the post-juvenal molt had not yet begun; shortly after that time we left the territory of this subspecies, so that no specimens in autumnal plumage were collected.

This junco is mainly a bird of the valleys, mostly in rather open woods. A few were seen well up in the mountains, not in the dense spruce forests of the middle heights, but at the upper edge of the timber, where the trees were more scattered and of smaller size. This was at about 4000 feet elevation.

The male junco was sometimes seen making a display of his plumage. The tail was widely spread, so as to expose the white outer feathers, about the only sharply contrasting feature of the junco's 
plumage. This was done, not on the ground, but up in the shrubbery; the tail was held stiffly spread and pointed straight downward, while the bird hopped from branch to branch about the female.

Young birds, just out of the nest, were several times found infested with parasitic larvae. The first bird in this condition was collected near Telegraph Creek, June 15. On picking it up after shooting it, a maggot dropped to the ground, and I noticed then a bare spot on the bird's head with a small hole where the larva had been attached. Upon skinning it, two more larvae were found, between the skin and skull, surrounded by a mass of yellow serum. Later on other young juncos were taken similarly afflicted, with the larvae always on the top of the head. The larvae were white in color, seven millimeters long and about three in diameter.

\section{Junco oreganus oreganus (J. K. Townsend). Oregon Junco}

Twenty-seven specimens referable to this subspecies were collected at three different points, as follows: Flood Glacier, two adult females, four juvenal males, three juvenal females; Great Glacier, one adult male, one adult female, seven juvenal males, two juvenal females, one juvenal, sex not ascertained; Sergief Island, three males and three females, all immature bịds in freshly acquired first winter plumage. (Mus. Vert. Zool. nos. 39989, 39991, 39992, 39994-39997, 40000-40019).

Specimens of oreganus in juvenal plumage from the coast of Alaska, compared with the same stage of connectens from the upper Stikine Valley, are much more buffy beneath and more reddish dorsally; the red dorsal patch of oreganus is clearly indicated in the young. Young oreganus is a ruddy appearing bird, young connectens, grayish. While these differences are apparent in fresh plumage, they are not so obvious when the feathers become worn. The young birds from Flood Glacier, at about the dividing line between the ranges of oreganus and connectens, are ready to discard the juvenal plumage, and in some specimens it is not possible to tell to which species they belong. However, those which do show specific peculiarities are apparently oreganus. Two young males, beginning the post-juvenal molt, are acquiring pink sides, and in one of them the new feathers on the head are distinctly blacker than in connectens. Young females, undeterminable in appearance, were taken in company with an adult female oreganus. For these several reasons I have assigned the entire series of streaked plumaged young from Flood Glacier to oreganus. 


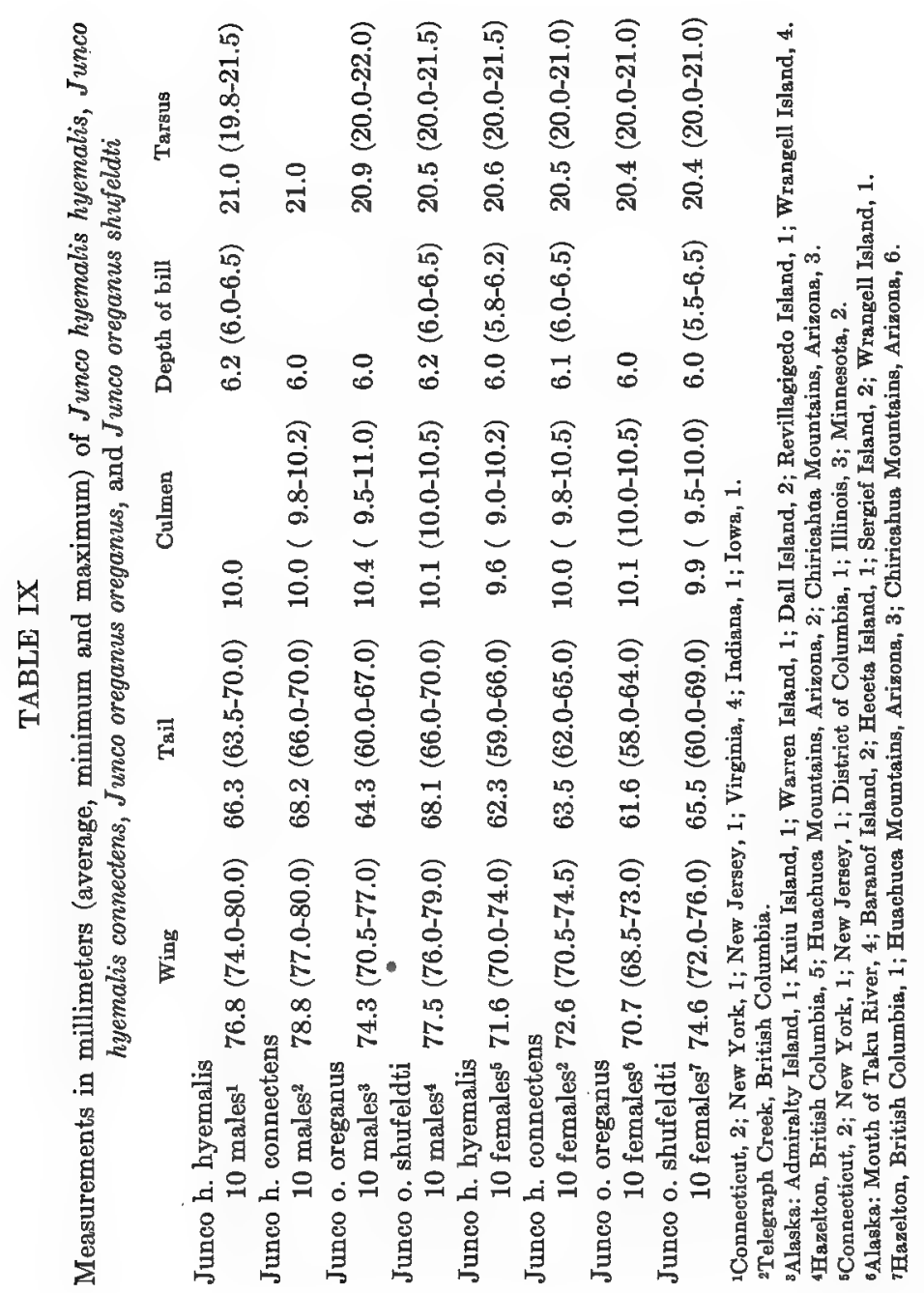


Young birds taken a week or two later at Great Glacier are in most cases well advanced in the post-juvenal molt, and are clearly oreganus. The adult male from this station (no. 40002) may perhaps be of intermediate character, like some of the Flood Glacier birds previously described, but it is in the midst of the annual molt, and the duller red of the back may be an appearance that is largely due to this cause. The six specimens from Sergief Island, in fully acquired first winter plumage, are all typical oreganus.

Neither at Flood Glacier nor Great Glacier were juncos abundant, and it was only by the closest search that specimens were obtained. When we arrived at Sergief Island (August 17) there were no juncos to be seen anywhere. On August 23 two were obtained, the first noted, and a day or two later they became fairly numerous.

\section{Melospiza melodia rufina (Bonaparte). Rusty Song Sparrow}

Song sparrows are rare in the upper Stikine Valley, or, rather, the species occurs in relatively few places. We found some birds around Sawmill Lake and about marshy spots near Telegraph Creek, and a few in similar surroundings between that town and Glenora. A female collected at Sawmill Lake on June 9 contained an egg that would have been laid in a day or two. A young bird just out of the nest was taken on June 18.

Near Doch-da-on Creek and a mile or two back from the Stikine there were certain marshy meadows where song sparrows were really abundant. Bordering the grassy areas were sloughs grown with reeds and surrounded by willows. Here the song sparrows had evidently been nesting, and at the time of our visit (July 8 to 26) were apparently engaged with their second broods. Full-grown young were more abundant than adults, and by the middle of July we found these young birds spreading out farther and farther away from the central swamps and down toward the river. The old birds remained closely within the more restricted meadows where we first found them, and those collected had every appearance of being engaged in nesting. These adults were extremely shy at all times, and specimens were obtained with difficulty.

At Flood Glacier there were a few song sparrows, seen mostly in patches of fireweed near the river. All taken were juvenals, apparently wandering from the nesting ground, as we had found them at Dochda-on Creek. W.e found no place near Flood Glacier offering suitable 
breeding grounds for song sparrows. None of the birds was seen at Great Glacier but one was noted near the custom house just above the boundary, August 16.

At Sergief Island song sparrows were abundant. They were mostly at the upper edge of the marsh land, just below the coniferous forest, where a bordering strip of dense underbrush (alder, willow, devil'sclub, and other shrubbery) afforded shelter to many birds of similar habits. The song sparrows ventured some distance out onto the marshes, but always along narrow tidal channels where tall grass overhanging the sloughs made arched passageways beneath which the birds found concealment when need arose.

A large proportion of those seen at Sergief Island were young birds, and young and old were mostly in various stages of molt. A young male taken August 18 is in first winter plumage throughout. Most of the young birds seen at that time were still in juvenal plumage; one taken as late as September 1 had not yet begun the molt from that stage. Two adults shot August 18 and 22, respectively, had not yet begun to molt; another taken on September 1 had almost completed the change.

Forty-four specimens were collected (nos. 40020-40044, 4004740065), as follows: Telegraph Creek, three adult males, two adult females, one juvenal female; Doch-da-on Creek, three adult males, ten juvenals; Flood Glacier, four juvenals; Sergief Island, two adult males, one adult female, five immature males (first winter plumage), thirteen juvenals.

I had anticipated that the song sparrow of Telegraph Creek would prove to be different from the coast bird, and that it would probably be Melospiza m. inexpectata, as a specimen ascribed to that race was recorded from Telegraph Creek by Riley (1911, p. 234) in his description of the subspecies. I am, however, unable to distinguish any points of difference between birds from the upper Stikine Valley and those from the coast. They seem to me to be all referable to mufina.

Upon first consideration it seems strange that in two regions with such diverse faunas in general, as is the case in the upper Stikine and the coast regions, the song sparrow, usually so variable, should be one of the few birds to remain the same in both places. This is by no means inexplicable, however, upon consideration of some of the factors involved. The species Melospiza melodia extends much farther north along the coast than it does inland; there is no subspecies of the interior that ranges nearly as far north as does rufina of the coast. 
It follows that any song sparrow colony of an interior point closely adjacent to the coast (such as the Telegraph Creek region) must have been derived from the coast region.

Song sparrows in other sections are known to be influenced in their distribution by extent of riparian surroundings suited to their needs. They will follow a favorable water course through otherwise unsuitable surroundings, less regardful of faunal or zonal limitations than of the associations of plants and water. It therefore seems apparent that the occurrence of the song sparrow at the headwaters of the Stikine River represents an outpost of rufina, an overflow of birds that have penetrated to that point by ascending the river from the coast; not part of another race that is of general distribution throughout the interior. Melospiza $m$. inexpectata may be a recognizable race in the region of the type locality (Moose Lake, British Columbia), in southeastern British Columbia, and southwestern Alberta (ef. Oberholser, 1918a, p. 187), but the song sparrow of northwestern British Columbia is unmistakably rufina.

Apparently the song sparrows of the inland regions are not completely enough isolated from the parent stock, or have not been for a sufficient length of time, to produce distinguishable differences. As to the length of time that they have been there we have no means of knowing. As to the completeness of isolation in the upper Stikine Valley, my impression, derived from the season's observations, is that there is practically continuous distribution of song sparrows along the river. Breeding colonies are doubtless scattered, and perhaps at rather wide intervals, but apparently migrating birds occur at any point.

There is an interesting point involved in the migration of the song sparrows at the upper end of the Stikine Valley. Do these birds travel north and south to the eastward of the coast range, as is the case with so many other species of that region, or do they follow the Stikine to and from the coast? Our own observations shed no light upon this question. It can hardly be solved save by some person who is permanently residing in the country.

In this connection it may be noted that Brooks (1912, p. 253) definitely cites the subspecies rufina as the form occurring at Okanagan, British Columbia, where the fauna otherwise is mostly of the interior. Also, Taverner (1919, p. 84) records rufina as the song sparrow at Hazelton, in the interior of British Columbia, some two hundred miles south of Telegraph Creek. I have seen some of Taverner's Hazelton specimens and agree with him in his determination. 
The bird collection of this Museum contains sixty-three specimens of rufina from the islands and mainland of southeastern Alaska, representing many island localities and several points on the mainland. The largest series from any one place is that from Sergief Island. The Alaskan series as a whole displays considerable variation, in color, in general size, and in size and shape of bill. Whether these differences can be correlated with different habitats, island and mainland, or whether they are merely differences between individual specimens, cannot be settled with the material at hand; there are too few breeding birds from any one place. The variation is considerable, and it includes breeding birds that are just like the Telegraph Creek specimens. For the present, at least, the whole aggregation had best be left under the name rufina.

There is one kind of departure from the normal rufina that is comprehensible, and that is a variation illustrated in many individuals tending toward caurina, the subspecies breeding just north of the habitat of rufina. This trend is especially noticeable among the birds collected upon Sergief Island in August and September, birds which I believe were mostly migrants from the north. Typical rufina and caurina are widely different in appearance, in size, color, and shape of bill, but there are specimens at hand forming almost every link in a chain connecting one extreme with the other. The same individual, however, does not necessarily exhibit the same intermediate condition in all characters; there are various combinations in different specimens.

\section{TABLE X}

Measurements in millimeters (average, minimum and maximum) of Melospiza melodia rufina

10 adult males from

Wing Tail Culmen Depth of bill

the coast of southeastern

$\begin{array}{lllll}\text { Alaska }^{1} & 68.4(66.2-71.5) & 64.8(60.0-70.0) & 12.2(11.2-12.8) & 6.7(6.0-7.0)\end{array}$

6 adult males from

the upper

Stikine river $^{2} 67.0(65.0-71.0) \quad 65.9(62.0-70.0) \quad 12.2(11.5-12.8) \quad 6.5(6.0-7.0)$

${ }^{1}$ Glacier Bay, 1; Admiralty Island, 2; Chichagof Island, 1; Kuiu Island, 3; Prince of Wales Island, 1 ; Warren Island, 1 ; Sergief Island, 1 .

${ }^{2}$ Telegraph Creek, 3; Doch-da-on Creek, 3.

During our stay at Sergief Island (August 17 to September 7) it was evident that there was more or less migratory movement of song sparrows. The numbers present fluctuated from day to day in a way that could not otherwise be explained. Typical examples of caurina were taken from time to time, as noted elsewhere in this report, which, 
of course, were migrants, and the assumption is that those individuals of intermediate character that were taken at the same time were also migrating birds, presumably from some intermediate region near the northern limit of the habitat of rufina. Our experience on the upper Stikine leads me to believe that very young birds, even before the juvenal plumage is discarded, may wander many miles from the nesting ground.

Melospiza melodia caurina Ridgway. Yakutat Song Sparrow

A fairly common migrant at Sergief Island, amid the same surroundings as rufina. One was seen the day of our arrival, August 17, and the birds were present in fluctuating numbers up to the date of our departure, September 7. The third week of August was the time of greatest abundance. Usually caurina and rufina could be told apart in life, the greater size and grayer color of the former serving to distinguish it ordinarily. There are, of course, equivocal specimens, as mentioned in this report under mufina, that are practically intermediate between the two subspecies, and difficult of determination even when in hand. There are also in the series of caurina from Sergief Island some specimens closely approaching the larger kenaiensis in appearance. As, however, the latter reach only the minimum measurements of that subspecies it seems best to place them all under caurina. There is thus in the available series of caurina a considerable range of variation exemplified, from small, reddish colored birds not widely different from rufina, to large, gray colored ones that could be inserted in a series of kènaiensis without violence.

There is one bird from Sergief Island (no. 40045, female, August 18) that I refer to caurina despite the fact that it is largely in juvenal plumage and was collected in the breeding range of rufina. Such of the first winter plumage as has been acquired is distinctly of the caurina type, and in the flesh the bulk of this bird was decidedly greater than that of the average rufina. Despite the youth of this individual, I believe it to be a migrant from the distant habitat of caurina. Juvenals of rufina also were found traveling far from the nesting ground.

Fourteen specimens of Melospiza m. caurina were taken at Sergief Island, on dates ranging from August 18 to September 5 (nos. 40045, 40046, 40066-40077). The series comprises one adult male, one adult female, five immature males, six immature females, and the juvenal female above described. 


\section{Melospiza lincolni gracilis (Kittlitz). Forbush Sparrow}

Probably occurs throughout the upper Stikine Valley, but, judging from our experience, in small numbers and at widely scattered points. A female shot June 9 at Sawmill Lake had laid part of its set of eggs; just one other bird was seen at that locality. The species was next encountered at Doch-da-on Creek, where one pair, perhaps more, had nested in the tall grass of a meadow. A young bird caught in a mousetrap at Flood Glacier was the only one seen at that station.

At Sergief Island the species was abundant. Many of the birds were there when we arrived on August 18, and they greatly increased in numbers within the next few days. At the upper margin of the marshes, that section which is but rarely inundated by the tides, there is much willow brush, increasing in density and size of the trees as the salt water is left behind. The lower edge of this strip, where the willow brush was about waist high and rather scattered, and with thick grass beneath, was the preferred habitat of the Forbush sparrow, and here the birds literally swarmed. I was accustomed to think of this species as being rather solitary in its habits, but here, whether or not the birds were in constantly associated flocks, their choice of surroundings brought hundreds of them closely together. In traveling through the willow brush one flushed them from every thicket. On August 22 I stopped to count those that hopped up into the branches of one small bush, preparatory to taking flight at my approach, and there were fifteen in sight at once. The species was still present at the end of our stay, September 7, but much fewer in number.

Fifteen specimens were collected: an adult female and an adult male from Sawmill Lake (nos. 40078, 40079), two adult females and two juvenals, male and female, from Doch-da-on Creek (nos. 4008040083), one juvenal male from Flood Glacier (no. 40084), and eight specimens from Sergief Island, two adult females, five immature males, and one immature female (nos. 40085-40092). The young birds from Sergief Island have all completed, or nearly completed, the postjuvenal molt. An adult female taken August 18 is in the midst of the annual molt. The tail feathers are all gone, and the wings so nearly bereft of flight feathers that the bird could scarcely fly. The second adult female, taken August 22, has finished the molt.

The specimens from the upper Stikine Valley are to my eye indistinguishable from the coast birds, and I therefore consider them all of the subspecies gracilis. There is no question of the distinctness of 
this northern race from the paler colored and more narrowly streaked form breeding in the high mountains of California which is regarded as lincolni, but just what relation either of these races bears toward typical Melospiza lincolni lincolni from eastern North America I do not know. I have no material available from any eastern points.

For the use of the name Melospiza Iincolni gracilis (Kittlitz) rather than M. l. striata Brewster (as in the A. O. U. Check-List), see Oberholser, 1906, p. 42.

Passerella iliaca unalaschcensis (Gmelin). Shumagin Fox Sparrow

Two fox sparrows taken upon Sergief Island, September 5, are referable to this subspecies, an immature female (no. 40107) and an immature male (no. 40108). The two birds were together, in an assemblage of song sparrows, golden-crowned sparrows, and hermit thrushes, feeding in a tangle of red-berry elder, alder, and devil'sclub. The Shumagin fox sparrow is a migrant through this region, and it is probably of rare occurrence.

\section{Passerella iliaca fuliginosa Ridgway. Sooty Fox Sparrow}

Among the most interesting of the season's discoveries were those relating to the manner of occurrence of Passerella in the region explored. Our first experiences were disappointing. I had confidently expected to find some form of this species in the Telegraph Creek region, either $P$. $i$. iliaca or $P$. $i$. altivagans, but failed to do so. It does not follow, of course, that one or the other of these birds does not occur locally somewhere in that general region, but if so I believe it will be found on the higher mountain slopes. I do not believe we could have overlooked the species had it been present in the lower valley.

Fox sparrows were first encountered at Doch-da-on Creek. On July 17 an adult male was obtained, first heard singing from its perch near the top of a small willow. A young bird was taken near-by the same day. Both were in brushy bottom land near a slough, a tangle of willows growing amid nettles, tall grass, and other shrubbery, not at all the kind of place that fox sparrows might be supposed to inhabit.

Later on, at Flood Glacier and again at Great Glacier, fox sparrows of the same subspecies were shot at various times. The birds were far from abundant, and it was only through the most assiduous search that specimens were obtained. They inhabited the densest 
brush, where they remained out of sight for the most part, and there were neither songs nor call notes to draw attention to their presence. At Sergief Island one specimen referable to this subspecies was taken, on August 27.

In all, fourteen specimens were collected (nos. 40093-40106), as follows: Doch-da-on Creek, one adult male, one juvenal male; Flood Glacier, one adult female, one juvenal male, two juvenal females, one juvenal, sex undetermined; Great Glacier, one adult male, two adult females, two juvenal males, one male in first winter plumage; Sergief Island, one male in first winter plumage. The adults are all in worn breeding plumage or just beginning the annual molt. Of the young birds, some are in juvenal plumage throughout, some are partly through the post-juvenal molt, and two, from Great Glacier, August 10, and Sergief Island, August 27, respectively, are in first winter plumage throughout.

I had supposed that the form of fox sparrow that would be found inhabiting the mainland coast of this part of Alaska would necessarily be $P$. i. townsendi, which is known to occur much farther south on certain of the islands. Our Stikine birds, however, unquestionably are not townsendi; for the present, at least, they must be considered as fuliginosa. In my "Revision of the avian genus Passerella" (1920, p. 149), I have described a series of fox sparrows, winter visitants taken mostly in the vicinity of Berkeley, California, that I have referred to fuliginosa, although they are not typical of that form. The statement there made is that these birds are too unlike summer examples of fuliginosa from Washington and Vancouver Island to come from that region, and that they must be migrants from some other section. It was intensely interesting to discover that the Stikine River summer birds exactly matched the winter birds described from California.

As between Alaskan examples of townsendi and the Stikine River fuliginosa, we have in both series, for comparison, adults in similarly worn breeding plumage; also young in juvenal plumage, molting into first winter plumage, and in first winter plumage throughout. The color differences are apparent in every stage. The discovery of fuliginosa in this part of Alaska and British Columbia discloses certain departures from the distribution of that subspecies and of townsendi as given by me in the "Revision" above cited (Swarth, 1920, pp. 144, 149 ; map, fig. N). Fuliginosa evidently occurs from Puget Sound northward to the Stikine River, but, north of Vancouver Island, probably on the mainland only or perhaps on islands close to the British 
Columbia coast. Tounsendi occurs southward on various islands off the coast of southeastern Alaska, and on the Queen Charlotte Islands, British Columbia; its occurrence in summer on the mainland of southeastern Alaska is questionable. I know of no breeding records from that region. On the map above cited there is a cross indicating an occurrence at Helm Bay (south of the Stikine River), but the bird upon which that record is based was an August specimen and may have traveled some distance. I, myself, in 1909, collected many specimens of townsendi at Port Snettisham and the Taku River, Alaska (north of the Stikine River), and under circumstances that make it seem likely that those were breeding stations, but no nests were actually found. In field work of that same year at Boca de Quadra, the Chickamin River, and Bradfield Canal (on the mainland south of the Stikine River), and at Thomas Bay (a short distance north of the Stikine), no fox sparrows were seen (see Swarth, 1911, p. 93). There is a record of the occurrence of townsendi in June on Wrangell Island, near the mouth of the Stikine River (Swarth, 1920; p. 146).

The facts now indicate that the summer distribution of fuliginosa is from extreme northwestern Washington and Vancouver Island northward on the mainland only, at least to the Stikine River. On the latter stream it extends inland about a hundred miles, following the course of the river. Its extension inland elsewhere is unknown to me. In fact, I know of no records of fuliginosa from any mainland station between the two extremes of its range, Puget Sound and the Stikine River.

There is another point to be considered, namely, the possibility of subspecific difference between fuliginosa of the Puget Sound region and the bird I have called futiginosa from the Stikine River, sufficient difference, that is, to be worthy of recognition in nomenclature. This is a contingency that may have to be met in the future. In another connection I have pointed out in some detail differences that appear to exist between the two lots (Swarth, 1920, pp. 149-150). Briefly, the series comprised of the Stikine River specimens and the winter birds from Berkeley differ from certain Vancouver Island specimens and from the type specimen of fuliginosa in being of a duller tone of brown, in having the lower tail coverts less tawny, and in the more stubby bill. The differences are real, as far as the series go, and appear to be fairly constant; the difficulty lies in the few specimens available of typical futiginosa. Under the circumstances further subspecific division does not at present seem desirable. 
Fall specimens of townsendi from Port Snettisham and the Taku River are notably dark colored, as compared with summer specimens of the same subspecies from the adjacent islands. While this may be due in some degree to seasonal differences of plumage, it may also be indicative of intergradation toward fuliginosa at those points.

\section{Piranga Iudoviciana (Wilson). Western Tanager}

A few seen in the vicinity of Telegraph Creek and Glenora, not more than seven or eight individuals in all. The first noted, a male, was encountered near Telegraph Creek on June 18. A nest was found at Four-Mile Creek, between Telegraph Creek and Glenora, in an alder in the rather dense vegetation that bordered the stream, about twentyfive feet from the ground and four feet from the main trunk. The female was seen on the nest July 5 .

Two specimens of the western tanager were preserved, both adult males, and both taken at Glenora, on June 30 and July 4, respectively (nos. 40109-40110).

\section{Petrochelidon Iunifrons lunifrons (Say). Cliff Swallow}

There were a few pairs of cliff swallows breeding at Telegraph Creek, the only place where we saw the species. Nests, old and new, were placed on several houses in the town. One specimen collected, an adult female, on June 23 (no. 40111).

This specimen is of notably large size, as compared with breeding birds from California and from Illinois. Presumably it belongs to the northern subspecies that Oberholser (1919c, p. 95) has named Petrochelidon albifrons hypopolia. As far as it goes, this single bird substantiates the claim of larger size in the northern race. The color differences claimed for that form are not so apparent. The specimen measures as follows: wing, 114; tail, 52.5; exposed culmen, 7 ; tarsus, 13.

Without wishing to decry the probable existence of a recognizable northern race of the cliff swallow, the writer prefers, in this connection, to use the older name, pending a determination by the A. O. U. Committee on Nomenclature of the several questions involved.

\section{Hirundo erythrogaster Boddaert. Barn Swallow}

Breeding in fair abundance in the town of Telegraph Creek. The species was already there at the time of our arrival, May 23, and the birds were occupied with nest building. Nests were seen only on 
buildings, and the birds themselves rarely strayed far outside the town. One nest noted, which was placed upon a telephone insulator on the government agent's office, must have been used for some years, for it was built up to a height of six inches or more.

Flocks of migrating swallows that were seen in August at several points down the river were apparently of this species, but could not be satisfactorily identified. These flocks were invariably traveling up stream. In the harbor at Wrangell, August 16, were large numbers of barn swallows, mostly young, flying about and alighting on the shipping and wharves. On Sergief Island, during the next two weeks, the species was seen frequently, traveling southward in large flocks. The flocks diminished in numbers toward the end of the month; the last bird observed was a single individual on August 30 .

Two specimens of the barn swallow were preserved, an adult male and an adult female, both taken at Telegraph Creek on June 11 (nos. 40112, 40113).

\section{Iridoprocne bicolor (Vieillot). Tree Swallow}

Just one pair seen, at Sawmill Lake, near Telegraph Creek. They were nesting in an old woodpecker hole in a dead birch stub at the margin of the lake. A pair of mountain bluebirds were nesting in the same stub. The swallow's nest held three eggs on June 11; the complete set of seven, with the nest, was taken on June 17 (no. 1816). The nest was built largely of coarse grass and pine needles, mixed with some mammal hair, and was lined with large duck feathers. The two parent birds were taken (nos. 40114, 40115).

\section{Tachycineta thalassina lepida Mearns. Northern Violet-green Swallow}

Abundant about Telegraph Creek. Nesting in erevices in the buildings and in a cliff overlooking the town from the northeast. The birds were settled in their nesting sites when we arrived (May 23), but individuals collected on June 8 had not yet laid their sets. The species was fairly abundant at Glenora. At Doch-da-on Creek, the latter part of July, violet-green swallows were seen frequently.

At Sergief Island, toward the end of August, the species was encountered on so many occasions that it seems probable that it is of regular occurrence as a migrant at some points, at least, on the coast of southeastern Alaska, despite the paucity of records. As far as I know, my own observations on the Chickamin River and at Thomas 
Bay are the only ones from the region that pertain to this species (see Swarth, 1911, p. 96).

At Sergief Island small flocks were seen passing over the marshes in migration, usually in company with barn swallows, upon various dates, ranging from August 20 to September 2. On August 28 a flock of a hundred or more circled about over our camp for several hours. Last noted on September 2, when a single bird was taken, the only one observed. It is a question whether the individuals seen migrating at this point were travelers from points to the northward, or whether they had followed the Stikine River from the interior. I am inclined toward the first alternative, for, in our own leisurely descent of the river we had seen no indication of any such migration of these swallows.

Five specimens preserved, two adult females from Telegraph Creek, one adult male from Glenora, and two juvenal males from Sergief Island (nos. 40116-40120).

\section{Riparia riparia (Linnaeus). Bank Swallow}

A few seen at Glenora, hovering over the fields or flying up and down the river, skimming low over the water. Probably nesting somewhere in the river banks nearby, but we failed to discover where. At Sergief Island a few were seen from time to time (August 18, 19, and 20), passing over the marshes in migration.

Two adults secured, male and female, taken at Glenora, July 2 and 6 , respectively (nos. 40121, 40122).

\section{Bombycilla garrula pallidiceps Reichenow. Bohemian Waxwing}

Found in the lowlands bordering the Stikine River, from Telegraph Creek down stream as far as Doch-da-on Creek. There was no obvious reason why the species should not extend still farther down the river, save that a few miles below this point those changes first begin to be apparent in the general character of the region that culminate in the thickly forested and humid conditions prevalent on the coast. Food conditions appeared ideal, for berries of various species, eaten freely by other birds, occur in abundance throughout this region. If it is solely the question of food that governs the erratic wanderings of the waxwing, as is so frequently contended in connection with its appearance in winter farther south, it would seem that the species should have been noted by us along the entire length of the Stikine. It seems evident, however, that there must be some barrier, more subtle 
than that formed by the abundance or scarcity of food plants, that keeps the waxwing closely restricted to the upper part of the Stikine Valley.

Similarly, restriction to the lower altitudes near the river is probably significant of zonal limitation. We saw no waxwings at high elevations until July 23, when a flock of about twenty birds was encountered at timber line (about 4000 feet) on the mountain above Doch-da-on Creek.

During our first two weeks of field work, at the Junction, the species was not once observed. Presumably the slightly greater elevation at that point was enough of a barrier to keep the waxwing in the warmer section by the river. When we moved from the Junction to Telegraph Creek the birds were encountered at once, and they were found in some numbers thereafter at various nearby points.

A wood road, following the creek from which the town derives its name, turns abruptly aside some half a mile up stream, ascends the steep embankment on the west, and thus reaches a terrace that extends for several miles. Here waxwings were seen upon our first visit to the place, and it was later found to be a favorite resort.

On the morning of June $9 \mathrm{I}$ had my first glimpse of the birds; my attention was attracted by the call note, and a moment later a flock of a dozen or more swung past and disappeared over the tree tops. Later in the day others were seen at almost the same place, two together at two different points. During the next ten days waxwings were seen continually in the same general locality, sometimes two together (mated pairs we supposed at the time), sometimes in small flocks. We shot a few, but mostly we watched them and followed the "pairs" about, hoping, but scarcely expecting, that they would lead us to a nest. The actions of these birds were extremely puzzling, for they seemed quite carefree, and many were in flocks. When we did obtain both birds of a "pair" they proved to be two males. Finally it began to dawn upon us that the waxwings were coming daily to a favorite feeding ground-nothing more; when disturbed they always disappeared in the same direction over some low hills to the westward; and our search was pursued in accordance with this suggestion, with satisfactory results.

The terrace or plateau above mentioned, of which so far we had merely skirted the eastern edge, extends westward a mile-or more, is quite level, and but sparsely covered with forest growth. A year or more before our visit it had been swept by fire and a large part of the 
timber destroyed. As we saw the place there was very little underbrush of any sort, a great many dead trees, mostly pines with some poplars, and a scattering growth of live trees that had escaped destruction. The conifers were the lodgepole pine (Pinus contorta), and were all small trees.

On June 19 we first saw evidence of nesting activities, though, as we afterward learned, the birds must have been busy for some time. On this occasion a pair of birds flew past, each with nest material in its bill, and disappeared in a clump of little pines a short distance away. A short search discovered the nest, just well started, in one of the pines, some six feet from the ground, and quite conspicuous to the view. A second nest was found a short distance away at a point where there had been an Indian wickiup, occupied by a solitary old witchdoctor. Several days before, this habitation had been destroyed by fire, and some of the surrounding trees, including the one with the nest, somewhat scorched. Apparently the fire, smoke, and noise had been too much for the parent waxwings, and they deserted the nest, which contained five newly hatched young. The young were pretty well dried up when found.

On June 22 the third nest was discovered. Two birds were seen in flight toward a pine a hundred yards or so distant. One, the male presumably, lit in the top of the tree, the other disappeared in the foliage below. Almost instantly the male flew high in the air, joined two others that were passing by, and all three went off together toward the slopes where we had previously found so many of the birds feeding. An inspection of the pine disclosed the waxwing's nest. The tree was only about twenty-five feet high, with straggly branches and little foliage. The nest rested upon limbs and against the trunk, about fifteen feet from the ground. It contained six eggs, almost ready to hatch.

During the next few days several other nests were found. A record was kept of each one, though they did not all yield sets of eggs. Following are the particulars of all the nests discovered:

No. 1 (Mus. Vert. Zool., no. 1819). Found June 19, nest just begun; June 21, nest completed; June 22, contained one egg; June 24, 3 eggs ; June 25, 4 eggs ; June 26, five eggs, set taken. Nest in lodgepole pine (tree about twelve feet high), six feet from the ground, resting on two small branches and against trunk. Greatest outside diameter about $230 \mathrm{~mm}$; inside diameter, 77 ; outside depth of main nest structure, 90; depth of nest cavity, 51. Material used: dead twigs 
from pines and poplars, dry black moss from the trees, white, cottony plant fiber, and, for lining, dry grass and a few feathers. See figures AA, DD.

No. 2 (Mus. Vert. Zool., no. 1817). Found June 19; a recently abandoned nest containing five dead young, newly hatched. In situation a duplicate of the last: in a little pine, about six feet from the ground, and resting on two small limbs and against the trunk. Greatest outside diameter about $230 \mathrm{~mm}$. (straggling twigs projecting farther) ; inside diameter, 95 ; outside depth, 77 ; depth of nest cavity,

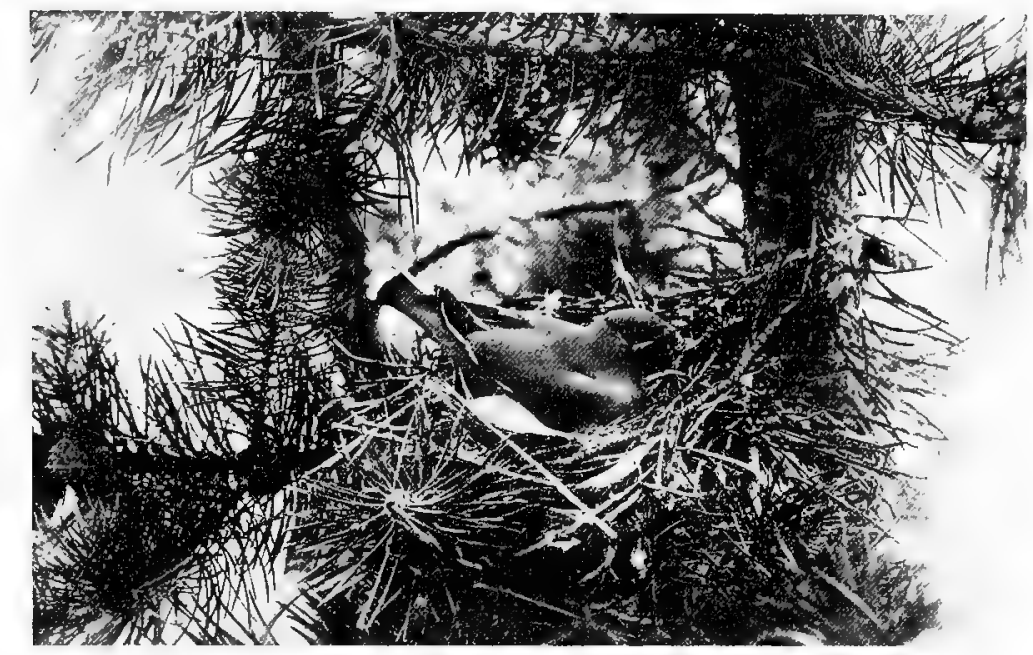

Fig. AA. Waxwing on nest in small lodgepole pine; found near Telegraph Creek. Photograph taken June 25, 1919.

32. This was the only nest found with none of the black tree moss in its composition. There is relatively more of the white plant fiber. It is possible that nest no. 1 was built by the pair that abandoned this nest.

No. 3 (Mus. Vert. Zool. no. 1818). Found June 22, with six eggs, within a few days of hatching. Nest in a small lodgepole pine, about fifteen feet from the ground; on three small limbs and against the trunk. Greatest outside diameter about $230 \mathrm{~mm}$; inside diameter, 90; outside depth, 90; inside depth, 51. Material used: dead pine and poplar twigs, a great deal of black moss, white plant fiber and dry grass. See figure BB.

No. 4. Found June 22. In a little lodgepole pine, about seven feet from the ground. This was the merest beginning of a nest when 
discovered. The birds were seen building rapidly on the morning of June 22 , but on June 23 they were just as busily engaged carrying the same nest material elsewhere. The new nest was not found.

No. 5. Found June 23. In a dense grove of young pines. Nest much like the ones just described, but with a great deal of the moss and not much white fiber. Contained one fresh egg. The nest was deserted when we found it.

No. 6. Found June 24. In top of a slender pine, about 25 feet from the ground. Nest resting on limbs and against the trunk. Contained five young.

No. 7 (Mus. Vert. Zool. no. 1820). Found June 24. The only nest discovered that was not placed against the tree trunk. This nest was in a lodgepole pine of larger size than most in this locality, in the fork of one of the larger branches, about three feet from the trunk. Both birds were building here at 1 P.M. At 4 P.M. both birds were seen hard at work carrying the nest material elsewhere. When we ceased watching there was very little of the nest left. On July 5 we happened to pass this place and were surprised to see the nest intact and a bird upon it. It yielded a set of five eggs. This nest is not so bulky as some of the others. Outside diameter, $153 \mathrm{~mm}$; inside diameter, 77 ; outside depth, 77 ; inside depth, 45 . Construction as usual, of twigs, moss, white plant fiber and dry grass.

No. 8. Found July 5, about half-finished. In the usual location: against the trunk of a small lodgepole pine, about ten feet from the ground. We were not able to return to this nest.

Waxwings were discovered nesting at Doch-da-on Creek, fifty miles down the river, under slightly different conditions from those at Telegraph Creek. On July 9 two occupied nests were found there, and two apparently of the previous year, all in the same patch of woods. This tract was composed mainly of balsam firs of rather large size, with an admixture of cottonwoods and poplars, and with but little underbrush. While these woods were thus fairly open, they were still much denser than those in which. we found the waxwings nesting at Telegraph Creek. The two occupied nests were less than a hundred yards apart, were exactly alike in location and structure, and when found each contained one fresh egg. Each was near the top of a fir, about twenty-five feet from the ground, supported upon a branch and by surrounding twigs, and close to the trunk. On July 15 one of these nests was taken, together with a set of three eggs. The other contained two eggs, and was left undisturbed. No more eggs were laid in this nest, the female being still incubating the two eggs some days later. 
The nest taken (no. 1821) is more compact than most of those found at Telegraph Creek, due to the firmer support given by the short, stiff fir twigs, closely encircling the structure, as compared with the sparse and slender branches of the lodgepole pine. It measures as follows: outside diameter, $178 \mathrm{~mm}$; inside diameter, 76 ; outside depth, 76 ; inside depth, $38 \mathrm{~mm}$. The black moss enters into the construction of this nest to a greater extent than in any of the others. There is but the scantiest framework of twigs on the outside, lending support to the moss, which forms about nine-tenths of the entire strueture. There is but very little of the white fiber that is so conspicuous in some of the others.

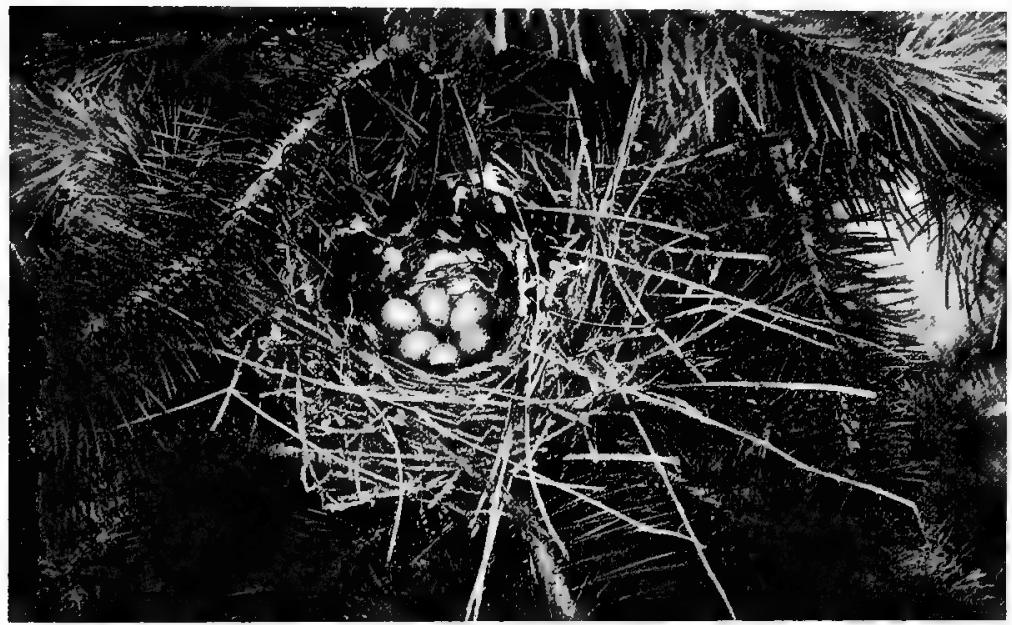

Fig. BB. Nest and eggs of waxwing found near Telegraph Creek; nest near the top of a small lodgepole pine. Photograph taken June 22, 1919.

It will be seen that the waxwings' nests were all very much alike in structure and location. All were in conifers, in rather open woods, and not far above the ground (six to twenty-five feet). The nests with one exception were against the trunk of the tree. The building material was always the same, an outer structure of dead twigs, lending support to a mass of black moss and white plant fiber. Dry grass was used as a lining sometimes but not always. The black moss was the one material that was used in the greatest amount, and it appears in all but one of the nests. This moss grows abundantly on the conifers of the region, depending from the branches in great masses, like coarse hair. The white plant fiber that is also so conspicuous in the nests is from the seed pod of the previous year's dead "fireweed" (Epilobium angustifolium). 
There was one additional feature in which the nests were all alike, something that could not be preserved. Invariably there was a mass of stuff depending six or eight inches below the nest proper, so loosely attached as to seem on the verge of dropping away. This stuff was mostly the moss and the white plant fiber; usually additional tufts of these materials were adhering to nearby branches.

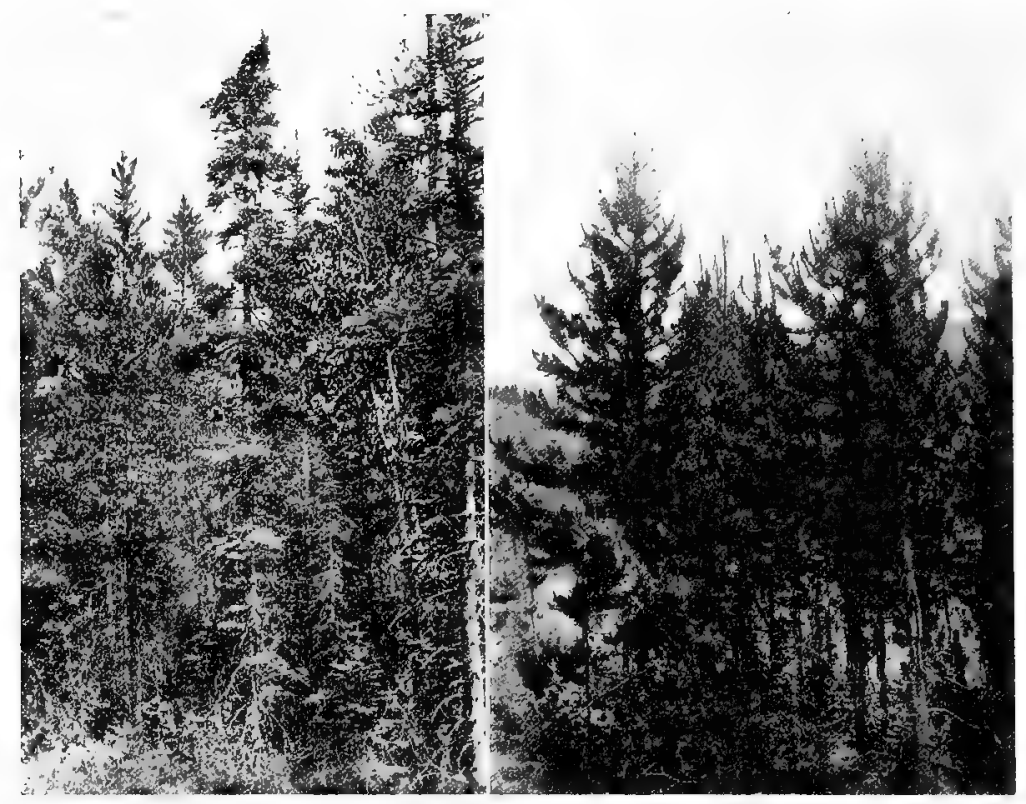

Fig. CC

Fig. DD

Fig. CC. Grove of small fir trees where waxwings were found nesting at Doch-da-on Creek. A nest may be seen in the tree in the center of the pieture, near the top of the tree and close to the trunk. Photograph taken July 15, 1919.

Fig. DD. Grove of small lodgepole pines where waxwings were found nesting near Telegraph Creek. There is a nest in the tree at the left of the picture, about halfway up and against the trunk. Photograph taken June 20, 1919.

The nests seemed large for the size of the bird, and they were not well hidden. Usually they were conspicuous, once we had found them, and no difficulty was experienced in finding a nest we had reason to suppose was in a certain locality. It was surprising, though, how frequently we both walked past nests without seeing them, not having noted the birds, though once found we marveled how we could have overlooked them. 
The Bohemian waxwing, that is, the subspecies Bombycilla garrula pallidiceps, has been discovered nesting at so few points in North America that it seems worth while to give a résumé of the findings of previous observers for comparison with our own.

The first North American breeding record was announced by Baird $(1866,406)$, as follows: "The only instances on record of their discovery in America are of a nest and one egg by Mr. Kennicott, on the Yukon, in 1861, and a nest and single egg on the Anderson River, by Mr. MacFarlane, both of which, with the female parents, are in the possession of the [Smithsonian] Institution."

Kennicott's nest was deseribed by Brewer (in Baird, Brewer, and Ridgway, 1874, 398) : "At Fort Yukon, July 4, Mr. Kennicott met with the nest of this species. The nest, which contained but one egg, was about eighteen feet from the ground, and was built on a side branch of a small spruce that was growing at the outer edge of a clump of thick spruces, on low ground. The nest was large, the base being made of small, dry spruce twigs. Internally it was constructed of fine grass and moose hair, and lined thickly with large feathers."

In 1901, Brooks discovered the waxwing breeding at 158-Mile House, in the southwestern corner of the Cariboo district, British Columbia.

I first noticed them there on 11th June, when I came across a small flock and shot one which proved on dissection to be a female about to lay. On returning to the same spot I found the Waxwings, consisting of a colony of five pairs of birds, still there, and soon diseovered a nest in a Murray pine, near the end of a limb and about twenty-five feet up, this then (12th June) contained two eggs. On the 15th I took this set, which then consisted of four eggs. The nest was loose and bulky, composed of Usnea moss, dry grass and weed stems, and lined with fine material, with a few green aspen leaves in the lining, no doubt to render the eggs less conspicuous. On the 26th June I carefully looked over all the trees in the neighborhood with my binocular, and found three more nests, all in tall Douglas fir trees; two of these I was able to climb to; each contained four eggs within a few days of hatching. The nests were similar to the first but without the green aspen leaves, probably due to the fact that the nests were better concealed from above (Brooks, 1903, p. 283).

On June 10, 1908, R. M. Anderson found the species nesting near Fort Smith, at the boundary between Alberta and Mackenzie. In nearly all respects the circumstances were as we found them on the Stikine.

Soon I saw what appeared to be a nest, a moss-covered buneh near the top of a straight, slender jack-pine (Pinus banksiana), about 45 feet from the ground. The nest, however, was so artfully concealed and draped with mosses that I could not be sure that it really was a nest until I actually peered over the edge of it. 
The nest contained six eggs, which proved to be almost fresh; incubation less than one day.....

The nest measured $61 / 2$ inches in outside diameter, and $21 / 4$ inside; depth (outside) 3 inches, (inside) $1 \frac{1}{2}$ inches; composed externally of small, short, dead pine twigs loosely arranged and partially covered with pale green moss, and small bunches of white cottony vegetable fibres. The nest lining consisted of a few fine grasses, a few bunches of fine wooly black moss, and bunches of the soft white cotton.

The tree containing the nest was at least twenty feet from any other tree and had no limbs for at least twenty feet from the ground. The nest was placed close to the body of the tree and supported by two small nearly horizontal limbs and a few lateral supporting twigs from these (R. M. Anderson, 1909, pp. 11-12).

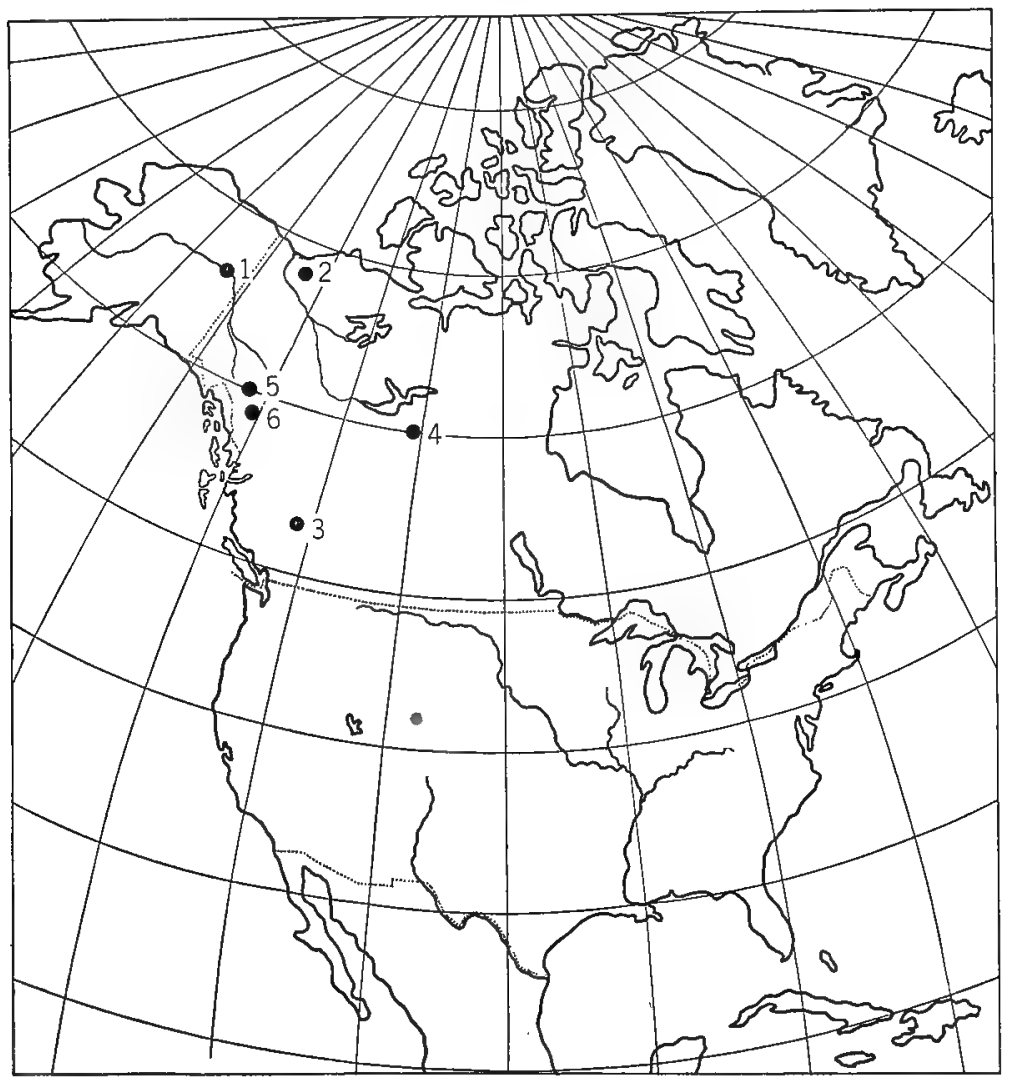

Fig. EE. Map showing the known breeding range of the Bohemian waxwing in North America. Circles indicate points where the species has been found nesting. 1. Fort Yukon, Alaska, July 4, 1861 (Baird, 1866, p. 406). 2. Fort Anderson (Baird, loc. cit.). 3. 158-Mile House, Cariboo District, British Columbia, June, 1901 (Brooks, 1903, p. 283). 4. Fort Smith, Alberta, June 10, 1908 (R. M. Anderson, 1909, pp. 11-12). 5. Atlin Lake, British Columbia, July, 1914 (E. M. Anderson, 1915b, pp. 145-148). 6. Telegraph Creek, British Columbia, June and July, 1919 (Swarth and Dixon, MS). 
In July, 1914, Ernest M. Anderson found the Bohemian waxwing breeding on islands in Atlin Lake, in the extreme northwestern corner of British Columbia. On July 8 he took four sets of eggs (E. M. Anderson, 1915b, pp. 145-148). Without going into details, it may be said that in all essential respects of nest construction and location, his findings accord very closely with our own.

These few records, covering six localities in the Canadian northwest and Alaska, appear to be the only authenticated instances of the actual taking of nests and eggs of the waxwing in North America. In addition may be cited Riley's statement (1912, p. 69) of the probable nesting of the species at Moose, in southeastern British Columbia. Though he found no nests, the conditions under which he found the birds were sufficient proof of their breeding.

The nesting of the European subspecies (Bombycilla garrula garrula) was most carefully described by John Wolley (1857) in his memorable account of the first discovery of the nest and eggs of the Bohemian waxwing in Finland, and by Newton (1861) in a longer paper describing the same material. Wolley's description of the nest reads in part as follows:

“. . . the main substance [of the nest] is of the kind of lichen commonly called tree-hair. . . . This main substance of the nest is strengthened below by a platform of dead twigs, and higher up towards the interior by a greater or less amount of flowering stalks of grass, and occasionally pieces of equisetum." He also found a little reindeer lichen, green moss, willow cotton, and fiber of grass leaves in the structure; sometimes one or two feathers in the lining. The nests were ". . . . built on the branch of a tree, not near the bole, and rather ... . standing up from the branch . . . ., than supported by twigs touching it at the sides. . . . . Of six nests, four were in small spruces, one in a good-sized Scotch fir, and one in a Birch-all placed at a height of from 6 to 12 feet above the ground . . . . the nest seems generally much exposed. ... In parts of the forest considerably open.

"Five seems to be the ordinary number of eggs; in one nest only 'there were as many as six.

"In the backward and cold spring of 1856, Waxwings had their full complement of eggs about the 12th of June" (Wolley, 1857, pp. 55-56). 
The eggs of the four sets of the American subspecies obtained in 1919 on the Stikine River, and now in the Museum of 'Vertebrate Zoology, measure as follows :

Set no. $1818.25 .0 \times 17.8,24.2 \times 17.8,25.5 \times 18.5,25.2 \times 17.5,25.5 \times$ $18.2,26.0 \times 18.0$.

Set no. $1819 . \quad 24.2 \times 17.0,27.0 \times 17.0,27.0 \times 17.2,26.0 \times 17.5,26.2$ $\times 17.2$.

Set no, $1820,26.8 \times 17.8,25.0 \times 18.0,26.5 \times 18.0,25.5 \times 18.0,26.8$ $\times 17.8$.

Set no. 1821 . $24.8 \times 18.0,23.5 \times 17.5,24.0 \times 18.0$.

In color, three of the sets are much alike, a pale glaucous blue, close to Ridgway's "pale dull glaucous-blue," but more washed out. This ground color is marked rather profusely with blackish dots and with a few fine, irregular lines, the dots mostly quite small and occurring over nearly the entire egg, though less numerously at the smaller end than elsewhere. There are also obscure underlying spots of bluish, but faintly seen. The fourth set (no. 1821) is more olivaceous, the ground color close to Ridgway's "mineral gray." The spots are fewer in number than in the other sets, larger, and more sharply defined.

As to plumage, the more conspicuous variable features in the waxwing's markings are the waxlike tips to the secondaries, the white and the yellow markings on primaries, primary coverts, and secondaries, and the yellow tips to the rectrices. The most elaborate study yet made of the plumage of this species is that written by Henry Stevenson (1882), based upon 144 specimens killed in England during the winter of 1866-67. Many of his statements are of interest in connection with the series of waxwings now in the collection of this Museum.

First, as regards the wax secondary tip, he gives the following table, including those birds of which the sex had been ascertained by dissection.

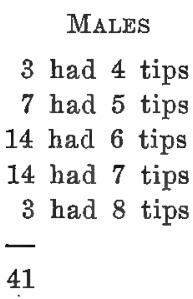

* Sex uncertain.
FemaLes

$* 1$ had 2 tips
4 had 3 tips
7 had 4 tips
6 had 5 tips
7 had 6 tips
2 had 7 tips
1 had 8 tips

28 
A similar table of 38 specimens of the American subspecies in this Museum of which the sex has been ascertained is as follows:

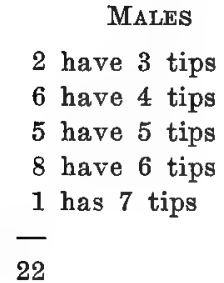

Females

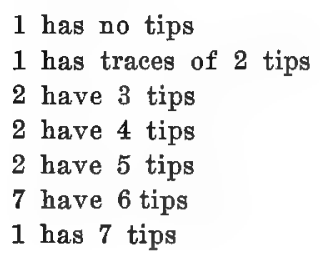

7

Besides those thus tabulated there are certain other variants. One male has a faint trace of a wax tip on a secondary on one side only. One female has two on one side, three on the other. One female has four on one side, two on the other. One female has five on one side, six on the other. Stevenson seemed to believe that such irregularities were due to accidents or wear, but in these birds there is no evidence to show that the unadorned secondaries had received any injury. One female is indicated in the table as having traces of two tips. They are so faint that they can be seen only by the most careful scrutiny, and are devoid of red color. Of all the adult specimens examined, forty-five in number, just one was found (a female) with absolutely no trace of the wax tips. In several cases these tips show a decided tendency to split up like feather barbs. It thus appears that these appendages are formed by the coalescing of barbs, and not by an enlargement of the tip of the central shaft, though the shaft, too, is involved in the general change. The ornamentation, in fact, may well have begun with the coloring of the shaft, spreading later over the adjoining feather barbs. The last stage would have been the coalescing of the barbs, forming the waxlike scale as it is now seen. Various steps of this hypothetical evolutionary development are supplied in the wing and tail feathers of different birds of this series.

The primaries of the waxwing have a white or yellow marking near the tip. This marking is sometimes confined to the outer web, and sometimes continued on to the inner web; the latter, producing a V-shaped marking, has been designated by Stevenson (loc. cit.) as the "return margin." In the brightest colored birds these markings are bright yellow on the inner primaries, becoming more and more white on the outermost ones. In the duller colored birds they are white throughout. The $V$-shaped character is invariably accompanied by 
bright yellow outer margins, but the yellow color is not restricted to the individuals that have this "return margin." Some of the birds with the primary markings absolutely confined to the outer feather margins still have them of brilliant yellow. None of the birds with white primary spots have the "return margin."

There are several birds of both sexes at hand with more or less indication of red at the tips of the tail feathers. This is never at all conspicuous, and is usually confined to the shaft of the feather at the extreme tip. In one or two instances the color spreads out over the adjoining vane, but without any coalescing of the red colored barbs; not one bird in the series has any well defined wax tips to the tail feathers similar to those on the secondaries. There is some variation in the yellow tip to the tail feathers, both in intensity of yellow and in the breadth of the marking. There are also some specimens with one or more tail feathers longer or shorter than the rest and of a different tone of yellow, giving the appearance of having been held over from a previous plumage.

Stevenson (loc. cit.) after careful study of the extensive series of birds at his disposal was unable to discover any external character distinguishing male from female, though he was inclined to believe "that the assumption of the yellow tinge [on the primary markings] is probably more gradual in the female than in the male." The series before the present writer does not shed any additional light upon this question. Although there is considerable variation in the character of wing and tail markings, it appears to be purely individual. It so happens that the brightest colored bird of the lot is a female (Mus. Vert. Zool. no. 17437 , sexed by C. I. Clay). In size (but not in number) of wax wing tips, in "return margins" of primaries, in yellow on primaries, and in size of white spots on secondaries, it is superior to any of the males. In this bird the wax secondary tips are $7 \mathrm{~mm}$. in length, a size attained by only one or two males.

The brood of young birds we collected was naturally of more than ordinary interest. The nest was discovered on June 24, containing five young not more than two or three days old. On July 5 we returned. The nest was in a slender tree that swayed under the least pressure, and at the first disturbance the young birds fluttered to the ground. The brood was about two weeks old at this time. In two or three days more, at most, all would have left the nest voluntarily. The brood consisted of four males and one female. 
These young waxwings presented a most striking appearance in life, for to my surprise they exhibited all the characteristic markings of the adult. Not only that, but the yellow tip to the tail was much brighter, more of an orange yellow, than it is in any of the old birds. The wax tips to the secondaries were present in each of the four males but not in the female. Two of the birds had four such tips, one had five, and one had seven, as many as are seen in any of the adults. These wax tips are as large as in many old birds. As rectrices and remiges were but partly grown out, the brightly colored tips occupied a much greater proportion of the whole than is the case in fully feathered birds. The resulting color effect was most bizarre. The young, with their remarkably vivid markings, looked utterly unlike the soberly colored adults.

The four young males are very much alike in color and markings, the only differences in appearance being those arising from the slight difference in stage of development. The marginal primary markings are present, sharply defined, and in each case bright yellow. In many adults these markings are white. In the young males the terminal tail band is orange-buff, the primary tips, light orange-yellow. In the brightest adult at hand the tail band is light cadmium, the primary tips, lemon chrome. In the young female the tail band is somewhat paler than in the males, though still more orange than in any adult. The primary tips are but slightly tinged with yellow.

A still more remarkable feature in the young males is the fact that in each one the rectrices are distinctly tipped with red. These red tips are not fully developed sealing-waxlike scales such as are on the secondaries, but are produced by red coloration of the terminal portion ( 4 or $5 \mathrm{~mm}$. in length) of the feather shaft of the rectrix.

The female parent of this brood (the only one of the pair collected) is a highly plumaged bird. It has six secondaries of one wing, five of the other, with wax tips, the primary margins are bright yellow, the tail is broadly tipped with yellow, and there is a faint suggestion of red in one or two of the tail feathers.

As regards the young birds, it is seen that they possess all the peculiar markings of the most brightly colored adults except the "return margin" upon the primaries. This is not seen in any of the young. The yellow wing and tail markings are much brighter than in any adult at hand, even than in freshly molted birds with these feathers but partly grown. While the young birds possess all the markings of the adults, they are appreciably different in general body color. They 
have a somewhat streaked appearance, though not as much so as in the young cedar waxwing, the whole body is of a duller, darker gray than in the adult, and the young bird has none of the vinous coloring about the head that is seen in the adult. The crest is present but only slightly developed. The young has a dull black line from the nostril to the eye and posteriorly on the head, in resemblance to that on the adult, but in our specimens of young there is just an indication of the black throat. This may be due to the fact that in these birds the feathers of chin and upper throat are but partly developed, but appearances would indicate that in the fully acquired juvenal plumage the throat is whitish, bordered on each side by a line of dull black. The middle of the belly is whitish, the under tail coverts a paler and duller chestnut than in the adult. One feature in which the young waxwings differ notably from the adults is the color of the inside of the mouth. This was a bright reddish (spinel pink of Ridgway) with a short, sharply defined streak of Mathews purple on each side, at the corner of the mouth. In adults the inside of the mouth is flesh color with but a suggestion of bluish at either side on the roof of the mouth. In the young birds the iris is dark. In adults there is a narrow but distinct red ring surrounding the black pupil.

Although the fact that the young Bohemian waxwing possesses practically all the distinctive markings of the most highly developed adult was a surprise to the writer when the birds were first encountered in the field, it is not new in ornithological literature. There have been a few juvenals collected, but although their appearance has been commented upon at the time of capture, apparently the compilers of the more general handbooks have never cited these scanty specimens as representative of the usual condition. Casual mention of an early streaked stage, "similar to that of the cedar bird," is the information usually given. Wolley's description of a young bird, in his account of the first discovery of the nesting of the European subspecies, is as follows:

A young bird eaught on the 5th of August, as it fluttered from the nest, had a general resemblance to the adult, though all the colours were more dull. The wax-like ends to the wing-feathers, the yellow tip to the tail, the black pateh between the eye and the beak are all there, whilst the rich mahogany of the under tail-coverts is of a quieter brown; the blooming vinous colour of the head and back has not yet emerged from a homely neutral, and the erest is but just indicated by the longish feathers of the crown. The most marked difference between the adult and young is in the throat and under surface generally. There is at present scarcely a trace of the deep black patch of the chin, and the delicate tint of the general under surface of the adult is replaced by mottled 
neutral and white. This upon examination is found to owe its appearance to those longer webs, which arising towards the root of each feather, extend as far outwards as the webs which arise nearer its tip, being very pale or white, and thus relieving, on both sides, the last mentioned darker webs (Wolley, 1857, p. 56).

In Gould's "Birds of Great Britain" there is a colored plate figuring adult birds, a nest, and five young. Of the young, three show the back and wings, all with wax tips to the secondaries. These figures are from young taken by Dresser, July 4, 1858, but although five juveniles are figured, in the text the statement is made that four young were in the nest and just two were caught. (Gould, 1873, vol. 2, pl. 21.)

Bishop (1900a, p. 89) describes three fully fledged young from the Yukon region as having the waxlike appendages to the secondaries, but of a paler red than in the adult. One of these same young birds is described in detail by Ridgway (1904, p. 106). Evidently but few young birds of this species have been collected. Judging from those that have been taken, the waxlike secondary tips occur as frequently in the juvenal plumage as in the later stages. In fact, with respect to all the variable features in this species, wax tips, white or yellow wing markings, and yellow tail band, it is not possible to detect any correlation between the extent of these markings or the intensity of their color, and either age, sex, or season. We have, as described, birds in juvenal plumage as brightly marked as any adult. The fact that in the brood of five collected the four males have the wax tipping and the one female lacks these appendages, gives the appearance of this being a sexual feature. To offset this, the female parent of this brood had the wax tips fully developed. Then, the female parent of a set of five eggs, taken the same day, has the wax tips almost entirely lacking.

In commenting upon the Bohemian waxwing as a winter visitant to Montana, where they were abundant, Cameron (1908, p. 46) says:

Only a small proportion had yellow primary bands; in the great majority these were white. Most birds had no red sealing wax appendages visible and were presumably the young of the year. Others, besides showing white edging to the ends of all the primaries except the two first, had four wax tips on the secondaries. These may have been birds of eighteen months old which had moulted twice, having regard to the fact that the waxwing moults only once a year-in October. A few of the birds had brilliant yellow wing-bars and numerous vermilion appendages, and I concluded that this small minority were old birds. 
Similar lines of reasoning have been followed regarding other birds than the waxwing; that is, different types of plumage have been taken as indicating different ages, rather than descriptions of plumages being based upon specimens whose ages had been definitely ascertained in other ways. There is probably hardly a species where it would seem a more obvious or safer thing to do than to judge the age of a waxwing from the number and size of the waxen wing tips, yet inspection of the juvenal plumage shows how unsafe such assumptions may be.

The most surprising statement in Cameron's account is the assertion that "most birds had no red sealing wax appendages visible." Of the forty-five adults examined in the present connection only one lacks any trace of such an appendage, and except for Cameron's comment I should have believed that it was unusual for a Bohemian waxwing to lack these ornaments. In the smaller cedar waxwing the case is different. An examination of the latter species as represented in this Museum discloses 36 specimens with more or less wax tips to the secondaries, and 41 without a vestige of such marking. Judging from the material at hand, therefore, this character seems to be much more fully developed in Bombycilla garrula than in B. cedrorum.

The flocking instinct is strong in the waxwing at all times. The nests we found, at two different localities, while not sufficiently close together to merit the term "rookeries," were gathered in close proximity, and to the exclusion of surrounding areas apparently just as well adapted to the purpose. The birds obviously prefer to nest in fairly close company. When a sitting bird left the nest for the short time necessary to feed each day, it was to join one or two others and do the foraging in company. While both birds of a mated pair work at nest construction, apparently all the labor of incubation falls upon the female. Her mate, thrown upon his own resources, usually joined some other unoccupied male. Usually two males fed together; occasionally there were more in company. Flocks were noted all through the breeding season, usually of not more than twelve or fifteen individuals; by the end of July gatherings were seen that were several times as large.

In nest building, male and female worked together. Dixon (MS) observed one pair at their labors for some time and made the following notes: After the observer had taken his station the female arrived with some white plant fiber. She put this fiber in place, and then, sitting in the nest, she turned around and around, shaping thus, with her breast, the nest cavity. Then the male arrived with more of the plant 
fiber. He placed it within reach of the female, who proceeded to weave it into the structure. The birds worked so assiduously that the nest was nearly finished by noon of the second day after it was begun.

In approaching and leaving the birds were usually together. Instead of flying directly to the nest they generally lit in some nearby trees, then approached unobtrusively by several short flights through the thicket. In departing similar precautions were used. When perching they almost invariably chose a tree top or some elevated and projecting limb. This was especially noticeable in birds disturbed at their nests, and it was also the manner in which they perched when engaged in flycatching activities.

Different birds varied in the degrees of tameness they showed about the nests. The female of the first set taken remained upon the eggs until the collector's hand was within a few inches of her. Male and female together hovered about for a few minutes, occasionally uttering the usual call note, and raising and lowering the crest. Then they left and did not return at all in the two hours that we remained in the vicinity.

A sitting bird when closely approached invariably pointed the bill almost straight up, and kept the crest closely pressed to the head. The young birds frightened from the nest resorted to the same tactics. On one occasion one of a pair of waxwings, presumably the male, was seen strutting about and exhibiting his beauties to his mate. Considering that the two sexes are alike in every respect, it seemed rather a superfluous performance, but at any rate the one bird was hopping excitedly about from branch to branch, while the other sat still and looked on. The active performer kept the tail partly spread, wings drooping, and crest raised, and the whole body was held stiffy upright. After several minutes the other seemed to tire of the performance and flew away, followed at once by its mate.

Waxwings were seen feeding on insects and also on berries and other vegetable matter. About Telegraph Creek, the first week in June, they were usually seen perched on bare branches and making short sallies after flying insects in true flycatcher style. Early in July a berrybearing shrub (Shepherdia canadensis) of general distribution in the region came into bearing, and the waxwings, as well as other species of birds, fed upon the berries of this plant to a great extent. The young waxwings we took from the nest had also been fed upon these same berries.

Under ordinary circumstances the only sound uttered by the waxwing is a sibilant call note much like that of the more familiar cedar 
bird. While notes of the two species are of the same character, still they are distinguishably different. This difference may, perhaps, be indicated by describing the cedar bird's call as a hiss, the Bohemian waxwing's call as a buzz. The note of the latter is somewhat coarser; the listener has an impression of hearing a series of very slightly separated notes, rather than of a continuous sound such as the cedar bird utters. The call note has been commented upon by Cameron (1908, p. 47), who says: "When flying the birds keep up an incessant twittering, so that high passing flocks are immediately recognized by their call of $z i r-r-r-r$ -a sort of trill."

Griscom and Harper (1915, p. 369) make the following comments upon the waxwing's call: "Though similar in general form to the 'beady notes' of $B$. cedrorum, they are less shrill, are more leisurely uttered, and have a more noticeable rolling sound. They are also more distinct, there being a comparatively greater interval between each syllable in the series. The call has been represented by Seebohm as cir-ir-ir-ir-re (quoted in Sharpe's 'Hand-book to the Birds of Great Britain,' Vol. I, p. 177) and by Cameron as zir-r-r-r...., but neither rendering seems to express exactly the decided sibilant quality of each syllable."

E. M. Anderson (1915b, p. 146) makes a rather surprising statement regarding the voice of the waxwing. "While on the wing the birds uttered a short succession of high-pitched, screaming notes, closely resembling in character, though not in volume, the cries heard on nearing a Pigeon Guillemot rookery on the seacoast." As far as I am aware this is the only published statement that ascribes to the waxwing any note other than the well-known hissing sound.

A bird shot by the present writer, which fell to the ground wounded, uttered a loud, chattering noise, the only time I ever heard anything of the kind. The young birds we removed from the nest called a great deal. One of the five fluttered off into the bushes where he escaped observation, but he soon began calling and was thus discovered. According to Dixon's notes at the time, the call note of the young waxwing was much like that of a young California shrike.

The American waxwing was given the name Bombycilla garrula pallidiceps by Reichenow (1908, p. 191), with the type locality the Shesly River, northern British Columbia. The Shesly River, a tributary of the Inklin, which in turn empties into the Taku, has its source some twenty-five miles northwest of Telegraph Creek, its mouth, some sixty miles beyond. Thus for all practical purposes our Telegraph Creek specimens of the waxwing may be regarded as topotypes. 
I had the opportunity of comparing a selection of these skins with European examples of $B . g$. garrula in the United States National Museum. The color differences distinguishing the two forms were readily apparent in the series thus brought together, and the differences appear to me to be sufficiently pronounced to justify the recognition of the American subspecies, pallidiceps. (Cf. Oberholser, 1917c, p. 333.)

We collected seventeen specimens of the waxwing, nine adult males, three adult females, four juvenal males, and one juvenal female (nos. 40123-40139).

\section{Vireosylva gilva swainsoni (Baird). Western Warbling Vireo}

Common in the poplar woods of the upper Stikine Valley. First taken near Telegraph Creek on May 29; shortly after, the birds arrived in numbers. They were seen daily at Glenora and Doch-da-on Creek, undoubtedly breeding, at both places. When we arrived at Flood Glacier, July 26, the species was present in some abundance; at the time of our departure, August 8, the birds were nearly all gone. Whether or not this vireo breeds at the last mentioned locality was not definitely ascertained, but I am inclined to think that it does, judging from the actions of certain individuals. On July 31 a pair of the birds spent nearly the whole day in an alder thicket near our camp, scolding continually at some disturber of their peace that I could not discover. Posssibly an owl was roosting near-by. Anyway, the vireos acted much as though they were concerned over the safety of their brood.

At Great Glacier, August 10, two were seen. This was the latest date of occurrence, and Great Glacier the westernmost locality at which the species was noted. Our several points of record apparently constitute the farthest known extension of the range of this subspecies toward the northwest. It is not included by Anderson (1915a) in his list of birds from Lake Atlin, some two hundred miles north of Telegraph Creek. The occurrence at Great Glacier carries the range to within ten miles of the Alaskan boundary, and to within about thirty miles of the coast.

Five adult specimens were collected, two from the vicinity of Telegraph Creek, one from Doch-da-on Creek, one from Flood Glacier, and one from Great Glacier (nos. 40140-40144). These birds are in no wise to be distinguished from others from more southern points in the range of the subspecies, as in California. 


\section{Vermivora celata orestera Oberholser. Rocky Mountain Orange- crowned Warbler}

Warblers of this species are rare in the upper Stikine Valley, or else they are so secretive during the nesting season as to avoid observation. Two males (nos. 40145, 40146) were taken near Telegraph Creek on May 27 and 31, respectively, probably migrants, and no more were seen for some time. At Doch-da-on Creek, July 18, when many birds were beginning to move about after the close of the nesting season, a female in juvenal plumage (no. 40147) was obtained. Another young bird, molting into first winter plumage (no. 40148) was taken at Great Glacier, August 11.

The two adults, compared with Vermivora celata lutescens of the coast region, are of greater size and duller coloration. Compared with $V$. c. celata, they are more yellowish, and lack the grayish tinge of that race. Thus they exhibit the characters ascribed to Vermivora celata orestera Oberholser $(1905$, p. $242 ; 1917 b ;$ p. 326$)$. The juvenals may be distinguished from young lutescens by their gray juvenal feathers, yellow in the latter race.

\section{Vermivora celata lutescens (Ridgway). Lutescent Warbler}

An immature male just finishing the molt from the juvenal plumage (no. 40149) was taken at Great Glacier, August 11. At Sergief Island some were seen almost daily, evidently migrating and usually in company with other transient warblers and kinglets. Five specimens were taken, all immature, on dates ranging from August 18 to September 22 (nos. 40150-40154).

\section{Vermivora peregrina (Wilson). Tennessee Warbler}

Met with on but one occasion. On June 12, at a point some five miles southwest of Telegraph Creek, my attention was drawn to an unfamiliar, wheezy song, heard at the edge of a swamp. The singer was discovered flitting from one twig to another in rather slow, vireolike manner, giving his song at frequent intervals. It proved to be an adult male Tennessee warbler, and was undoubtedly nesting near-by. This specimen (no. 40155) was the only one taken or observed, although I kept careful watch for the species from that time on. 


\section{Dendroica aestiva aestiva (Gmelin). Eastern Yellow Warbler}

A few seen near Telegraph Creek on May 26 were the first observed, but the species may have arrived some days earlier. The first week in June the birds were abundant and quite generally distributed through the lower valleys. The males were especially noticeable from their habit of perching at the tops of dead and leafless trees, and there singing. The loud song and brilliant color, with no concealing verdure round about, rendered them as conspicuous as such small birds could well be. On June 14 a set of three slightly incubated eggs was taken (no. 1822). The nest was in a cottonwood sapling, some twelve feet from the ground, at the edge of a dense thicket.

At Doch-da-on Creek, the latter part of July, yellow warblers were fairly numerous, and apparently on the move. At Flood Glacier, early in August, and at Great Glacier, about the middle of the month, they were seen frequently, though not in such numbers as had been present farther up the river.

Eighteen specimens of yellow warbler were collected at points on the Stikine River (nos. 40156-40173). The series comprises six adult males and three adult females from Telegraph Creek, three adult males from Glenora, one juvenal female from Doch-da-on Creek, and one adult female and four immature females from Flood Glacier.

Dendroica aestiva rubiginosa is commonly considered as occupying both the coast and the interior of Alaska and northern British Columbia (see A. O. U. Committee, 1910, p. 311; Ridgway, 1902, p. 514 ; E. M. Anderson, 1915 a, p. 16), but on how extensive a representation of specimens these opinions were based I do not know. My Stikine River series is certainly sufficiently different from the coastal bird to forbid the two lots from being considered of the same subspecies. The series of rubiginosa in the collection of this Museum includes thirteen adult males from Vancouver Island and southeastern Alaska. These birds are distinguished in color from other North American races of Dendroica aestiva primarily by the combination of dark dorsal coloration, paler yellow underparts, and narrow and scanty chestnut streaking below. The Telegraph Creek birds do not fit into this category at all. In this series the underparts are more brilliantly yellow, and the chestnut streaks, are, in most of the specimens, numerous, broad, and conspicuous. As a series the lot fits in absolutely with $D$. aestiva aestiva, in regard to ventral coloration. In dorsal coloration they average somewhat darker than is the case in an equally extensive series of eastern examples of aestiva, though 
selections can be made of closely similar specimens in the two series. The variation in dorsal coloration is, I believe, at least partly due to different degrees of wear and fading of the feathers. Specimens of the two series that were taken at approximately the same dates are practically indistinguishable. Measurements of the three lots are given below. They are of little diagnostic importance.

In my opinion the Stikine River birds should not be classed with rubiginosa. They present certain differences in appearance; and in habitat and migration they are as sharply set off from the coastal birds as is the case with practically all the other bird species of the region where they were taken. On our trip down the river I watched for yellow warblers carefully and purposely, and they are rather more conspicuous in migration than most small birds. The frequently uttered $z i p-z i p$, as they fly from bush to bush, attracts attention, and the yellow color is easily seen. At Doch-da-on Creek, at Flood Glacier, and at Great Glacier, yellow warblers were in evidence, obviously migrating, but below Great Glacier I could not see that there were any traveling down stream. My belief is that they find an outlet through the mountains to the southward, and that they do not reach the coast. When we reached Sergief Island, in the habitat of the coastal race (Dendroica aestiva rubiginosa), yellow warblers abruptly became scarce. We saw very few, whereas this island was directly in the line of travel down the river. During the first two weeks of our stay, the latter part of August, none was seen. On September 1 several were noted in company with other migrating warblers, and on September 2 a single bird was observed.

On both scores, of physical characters and of distribution, I regard the yellow warblers of the upper Stikine River as best referred to Dendroica aestiva aestiva, showing some variation toward mbiginosa. Females and immature birds do not show the subspecific characters as do the adult males, and such of the former as were collected at Flood Glacier and Great Glacier are ascribed to aestiva on the grounds of probability.

\section{TABLE XI}

Measurements in millimeters (average, minimum and maximum) of Dendroica aestiva aestiva and Dendroica aestiva rubiginosa

$$
\text { Wing Tril Culmen }
$$

Dendroica a. aestiva 10 males $^{1} \quad 62.3(60.0-64.0) \quad 43.9(42.0-46.0) \quad 9.6(9.0-10.0)$

Dendroica a. aestiva 9 males $^{2} \quad 62.4(60.5-64.0) \quad 44.5(42.5-46.5) \quad 9.3(8.5-10.0)$

Dendroica a. rubiginosa 10 males $^{3} \quad 61.5(59.5-64.0) \quad 43.6(42.0-46.0) \quad 9.7(9.0-10.0)$

1Ontario, Canada, 4; Wisconsin, 4; Michigan, 2.

${ }^{2}$ Telegraph Creek, 7 ; Glenora, 2 .

3Prince William Sound, Alaska, 2; Sitka, 1; Chickamin River, s.e. Alaska, 3; Vancouver Island, 4. 


\section{Dendroica coronata hooveri MeGregor. Alaska Myrtle Warbler}

Apparently. not common in this region, though some were seen at each collecting station. At the Junction the species was first seen on May 28. Two females taken on May 29 were evidently not breeding; from their actions, these birds and others seen the same day were as yet not even paired. To all appearances they had just arrived. None was seen in the immediate vicinity of Telegraph Creek, but a few pairs were encountered at scattered points some miles away. A few were seen at Glenora. At Doch-da-on Creek, July 8 to 25, small flocks occasionally appeared, sometimes a single family, sometimes evidently composed of two or more broods. The species undoubtedly nests at that point. Whether or not it nests at Flood Glacier, our next station down stream, is questionable, though I should think it likely that a few pairs might extend that far. Several specimens were taken there, and others were seen, some each day. At Great Glacier, August 9 to 16, Hoover warblers were seen frequently, migrating then and evidently traveling down stream. At the time of our arrival at Sergief Island, at the mouth of the river, on August 17, there were none of these warblers present. The first was obtained there on August 30, and in the next day or two the birds were arriving in considerable numbers.

We found no nests. Not many of the birds were seen under such circumstances that it seemed profitable to make search, and when we did attempt to watch individuals that were obviously nesting near-by the results were fruitless. For one thing, the suspects we selected invariably dropped all other interests in order to follow us about, and, each time, the warbler we were watching proved able to sit around doing nothing longer than we ourselves cared to.

The first young bird was collected on June 18, and others in juvenal plumage were taken at later dates, to July 10 . One taken at Dochda-on Creek, July 22, is well advanced in the molt into first winter plumage; another from Great Glacier, August 14, has just begun this change. One from Sergief Island, September 1, still retains much of the juvenal plumage. It is interesting to note that this bird probably traveled some distance from its birthplace while undergoing the molt. Another specimen taken at Sergief Island the same day has practically completed the change into first winter plumage.

Adults in various stages of wear were taken up to the end of July. A female taken July 26 is in extremely shabby and abraded plumage, 
but with no new feathers as yet. A male shot August 2 shows the first indication of the postnuptial molt. This is evident only in the flight feathers, the first primary and the adjoining secondary of each wing being partly grown out. No adults were taken at a later date.

This species is one of the few that migrates coastward at the close of the breeding season. There is probably a movement directly southward east of the coast mountains also, but there is no doubt but that there is a regular late-summer line of travel down the Stikine River to the coast. The birds were noted traveling down stream, and the arrival of the species at Sergief Island was in sufficient numbers to warrant the movement being regarded as of regular annual occurrence. Similar conditions have been noted in the late summer at the mouth of the Taku River, another large stream flowing from the interior to the coast, and emptying about one hundred and fifty miles north of the mouth of the Stikine River (see Swarth, 1911, p. 99). There is no information at hand regarding a return in the spring through the same regions.

Twenty specimens were collected (nos. 40174-40193), the series comprising four adult males, seven adult females, six in juvenal plumage, and three in first winter plumage. These were assembled with other material in this Museum for comparison with the eastern Dendroica c. coronata. Comparable material in the two subspecies comprised, of coronato, 14 adult (summer) males, 10 adult (summer) females, 4 immature (first winter); of hooveri, 13 adult (summer) males, 15 adult (summer) females, 11 immature (first winter). There are also midwinter and juvenal specimens of hooveri, stages at which there are no comparable specimens of coronata available.

Judging from this material, the subspecies Dendroica c. hooveri is but faintly characterized. As claimed by the original describer (McGregor, 1899, p. 32), hooveri averages slightly larger than coronata (see table), but there is much overlapping in measurements. I, myself, am unable to perceive most of the differences of color and markings that have been said to characterize the two subspecies. McGregor (loc. cit.) claimed differences in measurements only. Bishop (1900a, p. 90) advanced certain color characters, found in a series collected by himself in Alaska, notably in the summer plumage of the adult male. He says: "Adult males average paler below than typical $D$. coronata, the black markings being narrower, thus giving an effect of broad longitudinal markings rather than black clouding on the chest." This statement is endorsed by Grinnell (1909b, p. 235). 
- Bishop (loc. cit.) claims further that there are color differences in the juvenal plumage. Oberholser (1918b, p. 465) upholds the validity of hooveri, asserting "that it differs from Dendroica coronata coronata not only in its larger size but in the coloration of male, female, and even young." Ridgway (1902, p. 548, footnote) and Riley (1912, p. 70) each refuse recognition to hooveri.

The series assembled by myself in the present connection demonstrates the average size differences claimed to exist. I fail to appreciate any differences whatsoever of color or pattern between adult males and females of the two lots. The juvenal plumages I have been unable to compare. As regards immatures in first winter plumage, examples of hooveri are slightly (but distinguishably) darker, more brownish, than comparable specimens of coronata (see in this connection Swarth, 1911, p. 99).

\section{TABLE XII}

Measurements in millimeters (average, minimum and maximum) of Dendroica coronata coronata and Dendroica coronata hooveri

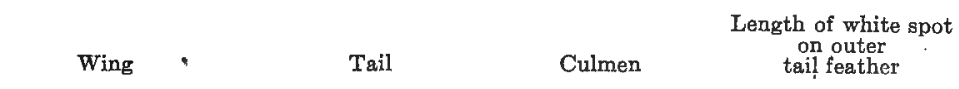

Dendroica coronata coronata, 14 males $^{2}$

$72.4(70.5-76.0) \quad 56.8(55.0-59.2) \quad 8.9(8.5-9.5) \quad 20.8(18.0-22.5)$

Dendroica coronata hooveri, 12 males $^{2}$

$75.7(73.5-79.0) \quad 58.8(57.2-60.0) \quad 8.8(8.0-9.2) \quad 22.0(20.0-25.0)$

1Massachusetts, 3; Connecticut, 1; New York, 1; New Jersey, 2; District of Columbia, 1; Virginia, 1; Indiana, 2; Illinois, 1; Wisconsin, 1; Minnesota, 1.

2Kowak River, Alaska, 4; Yukon River, Yukon and Alaska, 4; Stikine River, British Columbia, 4.

Dendroica townsendi (J. K. Townsend). Townsend Warbler

Very few seen at any point, and none under circumstances that would lead to the belief that the species was breeding east of the coastal mountains. First noted at Flood Glacier, where it may, perhaps, have been breeding, or where the birds seen may have wandered from nearer the coast. The first was taken on July 28 (no. 40194) and another on August 3 (no. 40195), both molting from juvenal to first winter plumage. Several more were seen. A male in first winter plumage throughout (no. 40196) was taken at Great Glacier, August 14, and others were observed at the same point. At Sergief Island but one or two were noted, the last on September 1. 
Seiurus noveboracensis notabilis Ridgway. Grinnell Water-Thrush

At Glenora, July 7, an adult male was obtained that was undoubtedly nesting near-by. At Doch-da-on Creek, July 21, another adult male was taken.

Of these two birds, the Glenora specimen (no. 40197), as compared with the one from Doch-da-on Creek (no. 40198), is appreciably smaller, with smaller bill, is darker colored throughout, and is noticeably more yellowish below. This may represent individual variation toward the eastern subspecies, Seiums n. noveboracensis. The two Stikine specimens, however, resemble each other more nearly than either one resembles any eastern example at hand.

Oporornis tolmiei (J. K. Townsend). MacGillivray Warbler

Abundant throughout the whole of the region we explored. First noted at the Junction, June 1, one bird seen and another heard singing. During the next few days they were evidently arriving in abundance, and thereafter the song was heard nearly everywhere we went. The first young out of the nest was seen July 13, at Dochda-on Creek: A day or two later they were emerging in numbers, and as we went through the woods fussy parents in attendance followed us about. The species was noted in moderate abundance at each of our subsequent stations-Flood Glacier, Great Glacier, and Sergief Island. Last noted, a single bird on Sergief Island, September 3.

Nine specimens were collected (nos. 40199-40207). An adult male taken at Flood Glacier, August 4, is finishing the annual molt; the body plumage is practically renewed, but wing and tail feathers are but half-grown. Two young birds taken August 4 and 12, respectively, are in first winter plumage throughout.

Although the MacGillivray warbler is so abundant in the upper Stikine Valley, that region must be nearly the northern extreme reached by the species. It is not included in E. M. Anderson's (1915a) list of birds of the Atlin District, less than two hundred miles to the northward. I do not know whether this warbler should be considered primarily as a species of the interior or of the coast, or whether it is one of the few birds that occurs in equal abundance in both regions. It has been found in summer at various points on the Alaskan coast (Swarth, 1911, p. 101). 
Wilsonia pusilla pileolata (Pallas). Pileolated Warbler

In our experience a rare species in the upper Stikine Valley. A few were seen from May 29 to June 1, between Telegraph Creek and the Junction, but these appeared to be migrants. None seemed to be nesting. Next encountered at Flood Glacier, where, on August 4, a bird was. caught in a mouse trap. The fall migration was then setting in, and a few days later, at Great Glacier, pileolated warblers were noted from time to time with other migrating warblers. At Sergief Island, the latter part of August they were seen almost daily, the last on September 1.

Six specimens were collected (nos. 40208-40213), two adult males and one adult female from the vicinity of Telegraph Creek, an immature (sex not determined) from Flood Glacier, and an immature male and immature female from Great Glacier. These specimens, in my opinion, are all referable to the subspecies pileolata. The three Telegraph Creek adults are slightly darker and duller colored throughout than coastal birds, and to that extent, presumably, lean toward pusilla, but they are not so dark colored as eastern specimens of that subspecies. In measurements they do not differ from coastal pileolata. With the material at hand it is not possible to tell whether the immatures collected in August at Flood Glacier and Great Glacier are migrants from the interior or from the coast. They are not appreciably different from immature pileolata from Alaskan coastal points.

\section{Setophaga ruticilla (Linnaeus). American Redstart}

First encountered near Telegraph Creek on June 11. From the actions of the birds seen on that date and the number that were observed, it seemed as though they might have arrived some time previously, but the same ground had been traversed two days before without any redstarts being seen or heard. From this time on the song of this species was heard by us practically everywhere we went in the poplar woods of the lowlands. Males in the plumage of the female, supposed to be birds of the previous year, sang just as did those in the brilliant black and orange livery. That the dull feathered males were breeding was shown in one instance in the capture of a mated pair, evidently preparing to nest. This was on June 15. The male was just like the female save for a few black feathers scattered through the body plumage. The female was almost ready to lay. 
At Doch-da-on Creek, the latter part of July, redstarts were present to the same extent as about Telegraph Creek. They were probably still nesting. During the third week in July certain birds could be found daily at the same places in the woods, and they always evinced concern at the presence of an intruder.

That we saw no redstarts at Flood Glacier was probably just chance. The species may not breed that far down the river, but it undoubtedly occurs as a migrant, at least in the fall. At Great Glacier, August 8 to 16 , the birds were frequently seen, and to the last day of our stay. This station is about ten miles from the Alaska-British Columbia boundary, and the redstarts were sufficiently numerous there to make it seem certain that some individuals must occasionally stray the few miles farther that would take them into Alaskan territory. I looked carefully for the species on Sergief Island, at the mouth of the river, but did not see it there.

A set of four eggs was taken near Glenora, July 5 (no. 1823). On July 2 this nest was found containing two eggs. It was placed in an upright crotch in a willow sapling, about eight feet from the ground.

Ten specimens of the American redstart were collected (nos. 4021440223), three adult males, two males, breeding but in female plumage, one adult female, three immature males, one immature, sex not determined. I cannot see that these birds differ in any particular from specimens of Setophaga ruticilla from the eastern United States.

\section{Anthus rubescens (Tunstall). Pipit}

Small flocks that were seen at Telegraph Creek, May 23 and 24, were undoubtedly of migrating birds, for the species does not breed in that region at so low an altitude. On May 29 a number of pipits were seen at the Summit, twelve miles north of Telegraph Creek, and at an altitude of about 2700 feet. They should have been breeding thereabout, for the locality is suitable, and birds taken on this date appeared to be in breeding condition, but on a later visit to the same place, June 4, no pipits were seen.

Next encountered July 11 on the mountains above Doch-da-on Creek at 4500 feet altitude and higher, where they were fairly abundant and evidently feeding young. They were extremely shy, and though a good many were seen they were usually drifting about through the air, and keeping well out of gun shot. They were calling continually, uttering a note that I have never heard in the winter. This was a sharp, oft-repeated wheet, wheet, wheet, the notes given 
singly at intervals of several seconds, and uttered both in flight and from the ground. No nests were found and no young seen. When we reached Sergief Island, August 17, the pipits had not yet arrived. The first was seen on August 25, then they increased in numbers rapidly, and were abundant at the time of our departure, September 7.

Three specimens were collected (nos. 40224-40226), an adult male and female from the Summit, May 29, and an adult female from the mountains above Doch-da-on Creek, July 11.

\section{Nannus hiemalis pacificus (Baird). Western Winter Wren}

Found nowhere in the lowlands of the upper Stikine Valley. On July 23 an adult female (no. 40227) was taken in a spruce forest on the slope of a mountain above Doch-da-on Creek, at about 3000 feet altitude. This was the only one seen at that point. The species was next encountered at Flood Glacier, where a juvenal was collected on August 2 (no. 40228). At Great Glacier, several were seen and two juvenals collected (nos. 40229-40230). Whether or not the two latter places, at the level of the river, are breeding stations I cannot say. The bird collected upon the mountain above Doch-da-on Creek was, I believe, upon its nesting ground.

At Sergief Island the western winter wren was found amid most unusual surroundings in tall grass and reeds, far out on the marshes. The birds were seen thus daily, foraging over the water just as do the marsh wrens. Sometimes they were in small gatherings, five or six at a time being flushed from the grass.

\section{Certhia familiaris occidentalis Ridgway. Tawny Creeper}

A young male just finishing the molt into first winter plumage was taken at Flood Glacier, August 2. On Sergief Island, August 24, two birds in juvenal plumage were collected. These were all that were seen. Once or twice I thought I heard a creeper's call notes at high altitudes in the mountains but was never able to verify my belief. It seems likely that some form of this species breeds throughout the Stikine region, but if so the birds are certainly present in but small numbers or we would have encountered some.

The three specimens collected (nos. 40231-40233) are apparently best referred to Certhia $f$. occidentalis, though they all exhibit a decided leaning toward $C$. f. montana. They may all have been migrants from some inland point, not far distant, inhabited by the subspecies montana. 
Sitta canadensis Linnaeus. Red-breasted Nuthatch

Not breeding at any point visited. One was seen at Doch-da-on Creek on July 22, at a time when birds were generally beginning to move about, and several more on July 26. An immature male (no. 40234) was taken at Flood Glacier, August 2. No more were seen.

\section{Penthestes atricapillus septentrionalis (Harris). Long-tailed Chickadee}

Seen at every collecting station east of the British Columbia-Alaska boundary line. Near Telegraph Creek, the last week in May and the first week in June, those seen were quiet and unobtrusive, and doubtless there were many more pairs nesting in the general vicinity than appeared to be the case from the few we saw. A nest found near Telegraph Creek contained nine young, about ready to leave on June 14. At Glenora, during the first week in July, full-grown young were collected, from flocks formed by the junction of two, sometimes of three, families. Encountered at Doch-da-on Creek and certainly nesting there, but not so abundant as farther up the river. At Flood Glacier there were a few of the birds about, but it seems unlikely that they had nested there. We were not at that station at the proper season to definitely ascertain this, but the woods are not of the character that is most favored by this chickadee; there are no poplars at all, the forest is, for the most part, of conifers with but a few cottonwoods, and is dense and dark. Where the long-tailed chickadee appears to be most at home is in rather open and sunny poplar woods.

Several small flocks were seen at Great Glacier, August 9 to 16, but again it does not seem likely that the species had been nesting there. The Great Glacier is only about ten miles from the British Columbia-Alaska boundary, so that it is probable that the long-tailed chickadee occurs at times quite to the mouth of the river.

The nest discovered near Telegraph Creek was in a tract of rather open woods, mostly of small poplars. It was in a dead poplar stub about three inches in diameter, a mere shell of dead and decayed wood, hardly strong enough to hold the tightly packed and rapidly growing young, who did actually break through the wall at one place. The entrance hole was five inches from the base, the nest itself, flush with the ground. The lining appeared to be entirely of matted moose hair.

Both parents carried food to the nest assiduously after foraging expeditions that lasted from two to five minutes. In approaching the nest, the old birds came through the trees and bushes until within. 
about eight or ter feet of their destination; then they dropped to the ground and hopped to the entrance. To the casual observer they disappeared at a point some distance from the nest, and it was not until they had been observed for some time that this subterfuge was detected. The staple food that was being brought to the young was a small green caterpillar infesting the poplars at that time; also a white grub, a green katydid, and many mosquito-like insects.

Thirty specimens were collected (nos. 40235-40264), six adults, eighteen in juvenal plumage, and six in various stages of the molt from juvenal to first winter plumage. Two of the latter category, from Great Glacier, August 12, have nearly finished the change. The birds of this series, in color and size, exhibit the characters ascribed to the subspecies septentrionalis, that is, as regards differentiation from the eastern atricapillus. Within the rather extensive habitat of septentrionalis there appears to be some variation in color, perhaps enough to separate the Stikine River birds as distinguishably darker colored than typical septentrionalis. A few specimens at hand from the middle .west suggest this possibility, but there is not enough material available to verify the supposition. The buffy coloration on the sides and flanks appears to be an extremely evanescent character, conspicuously present in the fresh fall plumage, but absent in breeding adults (in which this same plumage has been subject to several months of wear). In very young birds (nestlings) it is strongly apparent, but in juvenals that could have been out of the nest no more than a month it has almost entirely vanished.

\section{Penthestes gambeli abbreviatus Grinnell. Short-tailed Mountain} Chickadee

The limited opportunities we had for observation of this bird did not suffice to demonstrate its ecological relationships with $P$. atricapillus septentrionalis. That is, as regards choice of local habitats of the two-an interesting point where two such closely related species of one genus occur in the same general region. Septentrionalis, as previously remarked, strongly favors the poplar woods, and other subspecies of the species atricapillus are known as denizens of deciduous forests elsewhere. The species gambeli, on the other hand, is largely an inhabitant of coniferous woods, and it seems likely that in the Stikine region $P$. gambeli abbreviatus makes its summer home amid the spruce and balsam of the higher mountain slopes, where we never encountered $P$. atricapillus septentrionalis. At Doch-da-on 
Creek, at the end of the nesting season, small flocks of $P$-gambeli abbreviatus were seen on several occasions; it was observed nowhere else. Five specimens were collected (nos. 40265-40269), four on July 14 in woods at the river's edge, and one on July 23, on a mountain slope at about 3000 feet elevation, close to timber line. The series consists of two adults in extremely worn plumage, and three in juvenal plumage. Oberholser $(1919 b$, p. 424) has reported the occurrence of this subspecies at Thudade Lake, British Columbia. The present point of record is about two hundred miles northwest of Thudade Lake, and, in a direct line, about sixty miles from the coast. It must indicate about the extreme northwestern limit reached by this bird. For the use of the name Penthestes gambeli abbreviatis see Grinnell, 1918, p. 510.

Penthestes rufescens rufescens (J. K. Townsend). Chestnut-backed Chickadee

A number of small flocks seen in the dense spruce woods at Flood Glacier. The occurrence of this common coastal species at that point implies its continuous distribution along the river below that station. That we did not meet with it at Great Glacier and Sergief Island was probably fortuitous. Nine specimens were collected at Flood Glacier on dates ranging from July 31 to August 7, all young birds in juvenal plumage (nos. 40270-40278).

Regulus satrapa olivaceus Baird. Western Golden-crowned Kinglet

Very few kinglets were seen anywhere. From May 27 to June 4 several of the present species, apparently migrants, were observed at different times along the trail from Telegraph Creek to the Summit. Our failure to find the species subsequently may, perhaps, have been because the birds were breeding in the spruce timber of the higher mountain slopes, to which we made but few visits. Several times I thought I heard the sibilant call note of the golden-crowned kinglet in some dense timber above Doch-da-on Creek (at about 3000 feet altitude), in July, but I was unable to see the birds. At Flood Glacier, August 7, one was seen in a mixed flock of migrating small birds, and there may have been others passing through at the time. Two specimens were collected during the summer, an adult male at the Junction, May 27 (no. 40279), and an adult female at Flood Glacier (no. 40280). 


\section{Regulus calendula calendula (Linnaeus). Ruby-crowned Kinglet}

Occurred in about the same manner as the golden-crowned kinglet. A few were seen between Telegraph Creek and the Summit during the last week in May and the first week in June. Then on July 18 an adult female was collected on a mountain slope near Doch-da-on Creek, at about 4000 feet altitude, presumably upon its nesting ground. This bird (no. 40281) is in very worn plumage, but, even so, there is no doubt that it does not belong to the coastal subspecies, $R$. calendula grinnelli. It is of a paler colored race of the interior. Whether or not this is the same as the ashy colored subspecies, $R$. c. cineraceus, of the mountains of California, the material at hand does not suffice to determine.

Regulus calendula grinnelli W. Palmer. Sitka Kinglet

A few migrating ruby-crowned kinglets were seen at Great Glacier on August 10, 11, and 13, and four specimens were collected (nos. 40282-40285). At Sergief Island a single bird was seen on September 1. The four obtained are all young birds molting from juvenal into first winter plumage. They are clearly of the subspecies grinnelli.

\section{Myadestes townsendi (Audubon). Townsend Solitaire}

Fairly common at low altitudes in the upper Stikine Valley. There were at least three pairs nesting within half a mile of the town of Telegraph Creek, and others were seen down the river as far as Dochda-on Creek. The solitaires had already reached the region when we arrived, on May 23; in fact, nesting activities must have been well under way by that time. On June 7 a nest was found containing five eggs, just hatching; the next morning it held three young birds. Two of the eggs were apparently not fertile. This nest, close to town and by the side of a road we traversed almost daily, was kept under observation until the family departed. On the morning of June 20 the young were gone, having left since the previous evening.

The nest was placed under the overhanging bank on the upper side of a wood road. The slope was south facing and the nest well exposed to the sun's rays. This exposure, advantageous as far as warmth was concerned, placed the bulky structure conspicuously in view of anyone passing along the road, for there was no concealing vegetation on the bare, dirt bank. 
A second nest, in a somewhat similar situation, was discovered, unfinished, on June 8. Both birds were around at that time, but they deserted this home before any eggs were laid.

The solitaires did not sing much but the call note was uttered continually. From our rooms in town at Telegraph Creek, this was one bird note that could be heard hour after hour, monotonously repeated nearly the whole day through. To our ears it sounded so nearly like the distant barking of a California ground squirrel (Citellus beecheyi) that the sound would surely have been disregarded as a bird call had we been in a region where the squirrels occur.

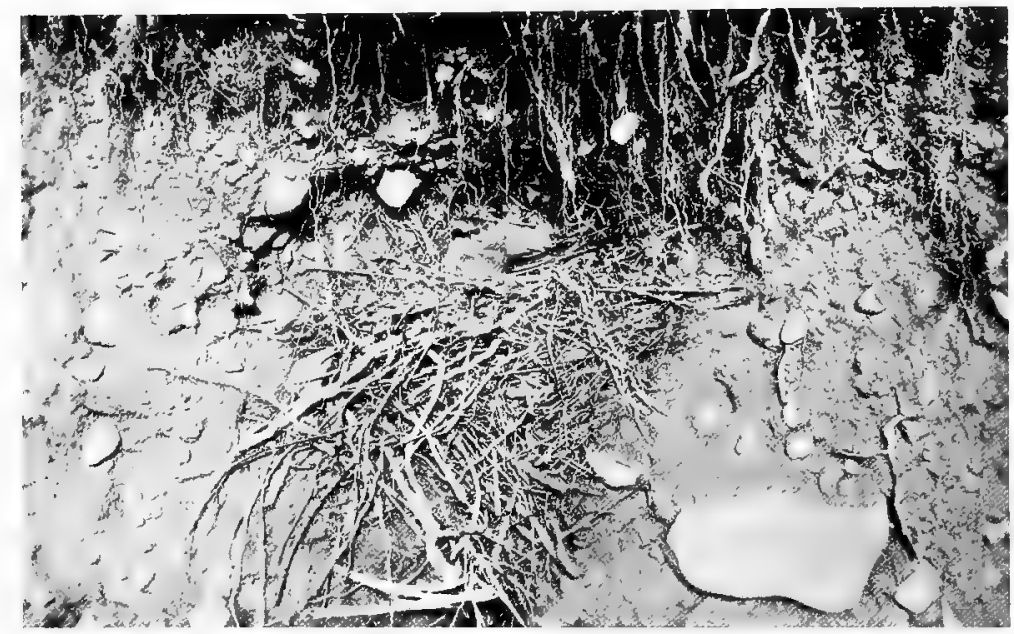

Fig. FF. Townsend solitaire (Myadestes townsendi) on nest. This nest was placed in a cut bank at the side of a road, a southern exposure that received the full benefit of the sun's rays. Photograph taken near Telegraph Creek, June 9, 1919.

At Glenora, early in July, and at Doch-da-on Creek, toward the end of the same month, solitaires were seen at intervals, single birds; and apparently migrating, though nearly all that were seen were still in the juvenal plumage. While none was observed by us any farther down the river, the capture of one at Wrangell on April 30, 1919, by E. P. Walker (no. 41286) indicates the possible occurrence of the species at any point in the Stikine Valley during the migrations.

Two specimens were collected, a male and a female, both in juvenal plumage, taken at Glenora on July 5 and 7, respectively (nos. 40286, 40287). Compared with Californian birds at the same stage, the Stikine River specimens show some difference in coloration. The ground color 
of the upper parts in the northern birds is appreciably more gray, less buffy, and the spots are less yellowish. We obtained no adults, but the Wrangell adult, above mentioned, and others from the Rocky Mountain region farther south are not perceptibly different from the Californian birds. The differences seen in the juvenals may be significant, but our material is not sufficient to demonstrate the fact.

\section{Hylocichla ustulata ustulata (Nuttall). Russet-backed Thrush}

There were a very few individuals of this species still lingering in the region when we arrived at the mouth of the Stikine River, about the middle of August. One was seen on Sergief Island, August 18, and another on September 4, both in the alder thickets that surrounded our camp. As neither one was taken, it is, of course, possible that the birds seen were of the subspecies swainsoni, rather than ustulata. Our experience on the Stikine disclosed the presence of swainsoni so far down the river that it would not be surprising if occasional individuals should wander quite to the coast during migration. However, as Sergief Island is within the known range of ustulata, while swainsoni has never yet been taken on the coast, it is proper to refer the records from that point to the race known to occur there.

\section{Hylocichla ustulata swainsoni (Tschudi). Olive-backed Thrush}

One of the commoner species of the upper Stikine Valley. First noted at the Junction on May 28; the next three days saw an influx of considerable numbers. On May 31 the first song was heard, so similar to the, to us, more familiar notes of the russet-backed thrush as to be indistinguishable. On June 5 a female was shot, with eggs beginning to enlarge in the ovary, on June 9 one was taken which had laid part of its set, and on June 12 the first set of eggs was obtained. A young bird, just out of the nest, was taken at Glenora on July 7, and full-grown juvenals were collected at Flood Glacier early in August.

This is a bird of the poplar woods and willow thickets of the lowlands, primarily, but we found it also in small numbers well up the mountain sides. On July 17 Dixon saw several at the upper edge of the spruce timber (about 4000 feet) on the mountains above Doch-da-on Creek.

Nests found were all at the lower levels. The first discovered was in fairly open woods, mostly of small willows, and in a very exposed 
situation. The nest was about four feet from the ground, between four upright willow branches, and there was no concealing green growth about it. The material used was mostly dried weed stems, grass, and shreds of bark. The lining differs from the outer structure only in that it consists of finer material of the same sort. Dimensions of this nest are as follows: greatest outside diameter, $170 \mathrm{~mm}$; ; inside diameter, 68 ; outside depth, 100 ; inside depth, 40 . It contained four eggs, partly incubated.

A second nest was collected on June 19, essentially like the first except that it is less bulky. This was in an alder, about four feet from the ground, alongside a seldom used road, and again in a most exposed situation. The set was of four eggs. On June 19 still another nest was found, in a crotch in a dead willow, about eight feet up. In this one there are more and coarser bark strips used, and a good deal of the cottony fiber from the fireweed pods. It contained five eggs. The last occupied nest was found at Doch-da-on Creek, July 21, containing three eggs nearly ready to hatch. This was in an alder, about three feet from the ground. In the case of the nest last described, the parent bird, presumably the female, was in great distress and did not go very far away. With each of the others, the sitting bird slipped unobtrusively away and did not return until some time had elapsed, probably never under twenty minutes.

At Great Glacier, August 11, a young bird was collected, not yet able to fly, that is clearly referable to swainsoni. This last record is of considerable interest as it carries the breeding range of swainsoni westward in this region to a point about thirty miles from the coast, the habitat of Hylocichla $u$. ustulata. Although the habitats of the two subspecies thus approach so closely, there is no evidence of intergradation of characters between them. In the Stikine River series of swainsoni there is not one specimen of an equivocal character. On the contrary, these birds, like those from the Yukon region, show an extreme of grayness, compared with typical swainsoni from eastern North America, that carries them farther from ustulata in appearance than are specimens from the Atlantic coast. (In this connection see Oberholser, 1898, p. 305.) It may be pointed out also that although ustulat a and suainsoni breed in different parts of northern California, there is no section of that state that is known to be occupied by birds of intermediate character. As in the Stikine region, both occur in typical form quite to the margins of their respective habitats. Thus, if ustulata and swainsoni are to be regarded as two subspecies of one 
species, it must be on the criterion of individual variation rather than on that of gradual blending through the population of contiguous territories. In the Stikine region the two forms occur, in the interior and on the coast, respectively, and within a few miles of each other, as distinct in appearance as any two species. On the other hand, as regards song, nesting habits and eggs, these features all supply evidence to show close relationships between the two. In none of these respects is there any apparent difference.

Twenty-one specimens of the olive-backed thrush were collected (nos. 40288-40308), fifteen adults and six young.

\section{Hylocichla guttata guttata (Pallas). Alaska Hermit Thrush}

There were a few pairs nesting along Telegraph Creek to within a mile or two of the Stikine, but mostly the birds were at higher elevations. None was seen in the immediate vicinity of Glenora or of Doch-da-on Creek, but the species was encountered in spruce woods on the mountains above the latter point, at about 3000 feet altitude.

Two nests were taken. The first (no. 1827) was found on May 23, with three eggs, and collected on May 26 with a set of five. It was in the ereek bottom, about two miles north of the town of Telegraph Creek, some three feet from the ground, in a spruce sapling. The nest rested against the trunk and upon some small branches. The outer structure is of twigs, weed stems, rootlets and bark strips; the lining is of fine rootlets and grass, with a good many of the long overhairs of a porcupine. It measures as follows: greatest outside diameter 'about $160 \mathrm{~mm}$; outside depth, 90; inside diameter, 60 ; inside depth, $40 \mathrm{~mm}$.

The second nest (no. 1828) was taken June 4, with four slightly incubated eggs. This was found near the Junction, four miles north of Telegraph Creek, amid similar surroundings to the first one. It was placed between two small spruce trees, thirty inches from the ground. In general appearance and in details of structure, it is very similar to the first one found, even to the porcupine hairs in the lining. Both were in situations where there was little concealing vegetation, and were easily seen from some distance.

Five specimens, two males and three females, were collected between Telegraph Creek and the Summit (nos. 40309-40313). The hermit thrush of this general region has been referred to Hylocichla guttata sequoiensis by Ridgwáy (1907, p. 44) ; specimens from Atlin, two hundred miles north of Telegraph Creek, have been recorded as 
sequoiensis (E. M. Anderson, 1915a, p. 17). I cannot agree with this determination, as applied to the Telegraph Creek series. These birds are not the same as the hermit thrush of the Sierra Nevada of California (sequoiensis). They are appreciably smaller than the latter and they are not so gray. They come very close, both in color and size, to a series of guttata, from Prince William Sound, Alaska, being perhaps a trifle paler colored. They are quite different in appearance from the dark colored nanus, of the coast region of southern Alaska.

\section{TABLE XIII}

Measurements in millimeters of Hylocichla guttata guttata and Hylocichla guttata sequoiensis

\begin{tabular}{|c|c|c|c|c|}
\hline Hylocichla guttata guttata & Wing & Tail & Culmen & Tarsus \\
\hline 40312 व Telegraph Creek, B. C., June 4, 1919 & 89 & 69 & 13 & 28.5 \\
\hline 40313 व Telegraph Creek, B. C., June 4, 1919 & 87 & 69.5 & 12 & 28.5 \\
\hline 40310 우 Telegraph Creek, B. C., June 1, 1919 & 84 & 67 & 12 & 29 \\
\hline 40311 † Telegraph Creek, B. C., June 4, 1919 & 83 & 66 & 12 & 28.5 \\
\hline 40309 \& Telegraph Creek, B. C., May 26, 1919 & 85 & 66.5 & 12 & 26.5 \\
\hline \multicolumn{5}{|l|}{ Hylocichla guttata sequoiensis } \\
\hline 22668 or Independence, Inyo Co., Cal., May 9, 1912 & 94 & 72 & 14 & 30 \\
\hline 22669 वै Kearsarge Pass, Inyo Co., Cal., June 12, 1912 & 97 & 72 & 14 & 30 \\
\hline 22670 व Kearsarge Pass, Inyo Co., Cal., June 13, 1912 & 97 & 75 & 13 & 27.5 \\
\hline 22671 \& Kearsarge Pass, Inyo Co., Cal., June 15, 1912 & 91 & 70 & 14 & 30 \\
\hline
\end{tabular}

Hylocichla guttata nanus (Audubon). Dwarf Hermit Thrush

The hermit thrush appears to range the whole length of the Stikine Valley; it is one of the few species of which we found specimens at intermediate points the characters of which indicate a likelihood of intergradation in that region between the two unlike subspecies at the two ends of the stream. A specimen taken at Flood Glacier on July 27 (no. 40314), an adult female not yet beginning to molt, is intermediate in color between the gray Telegraph Creek specimens and the dark colored birds of the coast. Despite the lateness of the season and the consequent greater wear upon the plumage, it is still appreciably browner than the Telegraph Creek birds. On the whole, it seems best regarded as nanus, though not typical of that form. A young bird (no. 40315) from Great Glacier, August 11, in the juvenal plumage throughout, is referred to nanus. 
On Sergief Island, hermit thrushes were fairly numerous up to the first week in September. One was taken on August 23, still in the juvenal plumage (no. 40316), and one on August 27, which had finished the molt into the first winter plumage (no. 40317).

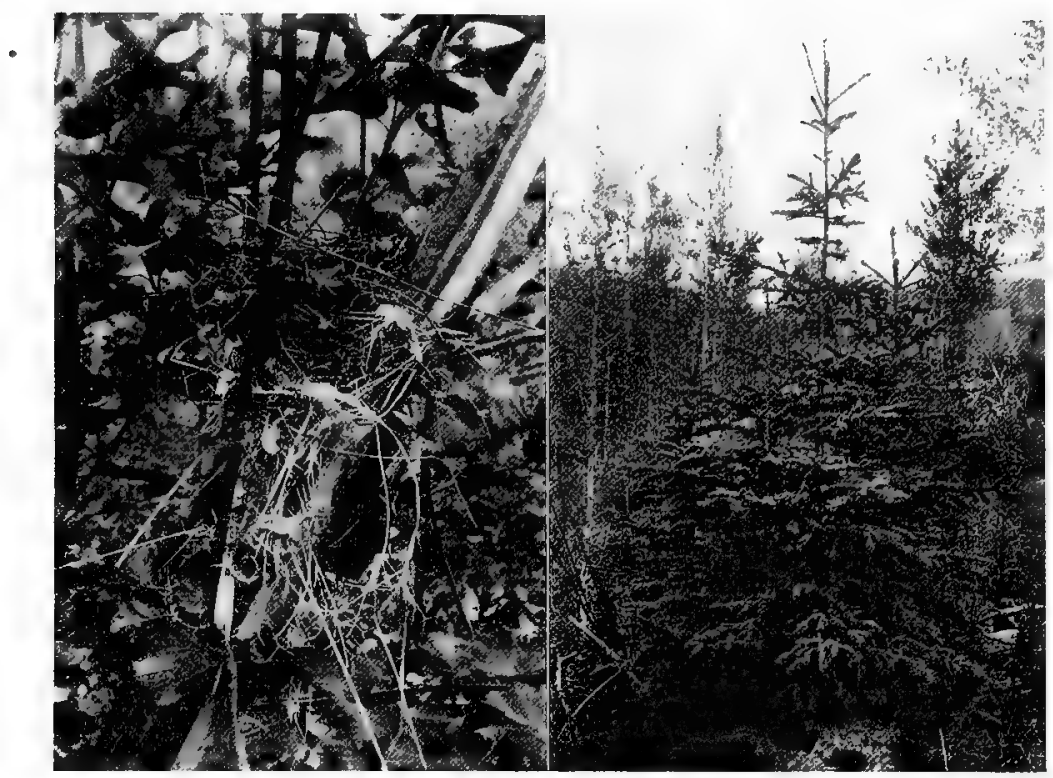

Fig. GG

Fig. $\mathrm{HH}$

Fig. GG. The olive-backed thrush (Hylocichla ustulata swainsoni) is a bird of the dry woods of poplar, alder, and willow, as contrasted with the hermit thrush, a denizen of coniferous woods. The nest of olive-backed thrush here shown was in a thicket of alder and willow mixed, and in all respects is typical of the species as it occurs in this region. At the time this nest was photographed (on June 19, and near Telegraph Creek) it contained four eggs.

Fig. HH. Alaska hermit thrush (Hylocichla guttata guttata) standing over nest. The nest was built upon the interlaced branches of two small spruce trees, about three feet from the ground, and at the bottom of a cool, shady cañon. Photograph taken near Telegraph Creek, June 4, 1919.

\section{Planesticus migratorius migratorius (Linnaeus). Eastern Robin}

At the time of our arrival at Telegraph Creek, robins were present in full force. They were abundant along the river and scarce at higher altitudes, but some were seen clear to the Summit. On May 30 one bird was seen carrying building material, but this must have been rather late, for young were out of the nest on June 9. Robins were fairly numerous at Glenora and at Doch-da-on Creek. By the time we reached the latter place, the middle of July, the spotted young comprised a large proportion of the birds seen. 
At Flood Glacier, our next stopping place down stream, robins abruptly became very scarce. Call notes were heard on July 29, but the birds were not seen. At Great Glacier, too, there were very few around. Two seen, but not obtained, on August 11, were the only ones noted.

Nine specimens (nos. 40318-40326) were collected on the upper. Stikine River, at Telegraph Creek, Glenora, and Doch-da-on Creek. The series comprises two adult males, five adult females, and two juvenals. These birds are referable to the eastern subspecies, Planesticus migratorius migratorius. The outer rectrices are conspicuously tipped with white, which is not the case with the coast form, $P . m$. caurinus, a differentiating character that is readily apparent, even in the live birds. The young from Telegraph Creek are of a different color from the coast birds, being less brownish and more gray, especially on the upper parts.

Just how far down the river $P$. m. migratorius extends we did not definitely ascertain, but, as noted above, robins were abundant as far down the river as Doch-da-on Creek, and abruptly became very scarce just below there. A little below Doch-da-on Creek, and from that point down, forest conditions are such that it seems doubtful that there are many robins breeding anywhere along the lower river. While we saw and heard a few at Flood Glacier and Great Glacier, we obtained no specimens, so cannot be certain which subspecies occurs at those points.

\section{Planesticus migratorius caugrinus Grinnell. Northwestern Robin}

Fairly numerous at Sergief Island, though irregularly so, during the whole of our stay at that place, August 17 to September 7. Most of the birds seen were in the midst of the molt. One specimen was preserved (no. 40327), a young female molting into first winter plumage. Planesticus migratorius caurinus Grinnell (1909b, p. 241) has been refused recognition by the A. O. U. Committee (1909, p. 302), but nevertheless it seems to me a sufficiently distinct subspecies. Additional material acquired since the Committee's action is all corroborative of the describer's diagnosis. (Cf. Swarth, 1912, p. 81; Oberholser, $1917 a$, p. 195.) 


\section{Ixoreus naevius naevius (Gmelin). Varied Thrush}

Seen on Sergief Island at various times during our stay there (August 17 to September 7). The subspecies is, of course, a summer visitant and reasonably abundant throughout the coast region of southeastern Alaska. One specimen was collected (no. 40332), a young male, just beginning to molt into first winter plumage.

Ixoreus naevius meruloides (Swainson). Northern Varied Thrush

There were no varied thrushes in the immediate vicinity of Telegraph Creek, nowhere in the river valley at least. We were constantly - - on the lookout for them, and both the birds and the call notes are sufficiently conspicuous to be readily detected by any one familiar with the species. Subsequent experience farther down the river leads me to believe that they probably breed at higher altitudes throughout the region; we ourselves, found them at but one such station.

At Glenora, early in the morning of July 1, the call note of a varied thrush was heard distinctly, several times repeated. The bird was in thick shrubbery at the river's edge, and could not be seen. It was assumed to be a wandering individual, finished with family cares and straying from the breeding ground on the nearby mountains. On July 11 a male varied thrush was seen on the mountain side above Doch-da-on Creek, at about 3000 feet altitude. The bird was perched high on a dead spruce stub, a hundred feet or more above the ground, uttering at frequent intervals the disconnected notes comprising the song of this species. Later on others were seen or heard at about the same elevation.

On July 18 a young bird was seen at the level of the Stikine River, at Doch-da-on Creek, and from then on a few others were observed from time to time. There were a few in the woods at Flood Glacier and at Great Glacier, exceedingly wary and most difficult to see. Three specimens were collected at Flood Glacier (nos. 40328-40330), an adult male and two juvenal females; and one at Great Glacier, an adult female (no. 40331). These birds are all referable to the interior subspecies, Ixoreus $n$. meruloides. 
Sialia currucoides (Bechstein). Mountain Bluebird

There were two or three pairs in the town of Telegraph Creek, presumably nesting about some of the buildings. A few others were seen within a radius of ten or twelve miles, usually around small clearings, where there had been some attempt at cultivation of the ground, or in burnt-over areas, where fire had swept away most of the large timber.

Two nests were found. On June 14 a set of four eggs (no. 1829), about half incubated, was taken. The nest was in an old woodpecker hole in a dead birch stub, eight feet from the ground. This was near the shore of Sawmill Lake, on a slope that had been lumbered and burnt over, so that it was nearly cleared of large trees. A second nest was found in another birch stub nearby, a trunk that was oceupied by a pair of tree swallows, as well as the bluebirds. This nest on June 17 contained four newly hatched young and one egg about ready to hatch.

Curiously, no bluebirds were seen near Glenora, though the open fields and old houses were features that should have attracted them, and the species undoubtedly does occur thereabout at times. On July 23 a small flock was seen at timber line, about 4000 feet altitude, above Doch-da-on Creek, apparently the beginning of the migratory movement at the close of the nesting season. I have seen specimens of the mountain bluebird taken at the mouth of the Stikine River on April 10, 1919, in migration, by E. P. Walker.

Ten specimens preserved (nos. 40333-40342), three adult males, three adult females, and four rewly hatched young preserved in alcohol. 


\section{AlLen, J. A.}

\section{LITERATURE CITED}

1899. On mammals from the Northwest Territory collected by Mr. A. J. Stone. Bull. Amer. Mus. Nat. Hist., 12, pp. 1-9.

1903. Mammals collected in Alaska and northern British Columbia by the Andrew J. Stone expedition of 1902. Bull. Amer. Mus. Nat. Hist., 19, pp. 521-567.

1904. New forms of the mountain goat (Oreamnos). Bull. Amer. Mus. Nat. Hist., 20, pp. 19-21.

1910. Additional mammals from Nicaragua. Bull. Amer. Mus. Nat. Hist., 28, pp. 87-115.

Allen, J. A., and Brewster, W.

1883. List of birds observed in the vicinity of Colorado Springs, Colorado, during March, April, and May, 1882. Bull. Nuttall Ornith. Club, 8, pp. 151-161, 189-198.

AMERICAN ORNITHOLOGISTS' UNION COMMITTEE.

1897. Eighth supplement to the American Ornithologists' Union check-list of North American birds. Auk, 14, pp. 117-135.

1901. Tenth supplement to the American Ornithologists' Union check-list of North American birds. Auk, 18, pp. 295-320.

1909. Fifteenth supplement to the American Ornithologists' Union checklist of North American birds. Auk, 26, pp. 294-303.

1910. Check-list of North American birds. Ed. 3, revised (New York, American Ornithologists' Union), 430 pp., 2 maps.

1912. Sixteenth supplement to the American Ornithologists' Union checklist of North American birds. Auk, 29, pp. 380-387.

1920. Seventeenth supplement to the American Ornithologists' Union checklist of North American birds. Auk, 37, pp. 439-449.

Anderson, E. M.

1915a. Birds collected and observed in the Atlin district, 1914. Report of the Provincial Museum of Natural History for the year 1914 (Victoria, British Columbia), pp. 8-17.

1915b. Nesting of the Bohemian waxwing in northern British Columbia. Condor, 17, pp. 145-148, 2 figs. in text.

Anderson, R. M.

1909. Nesting of the Bohemian waxwing. Auk, 26, pp. 10-12.

BAILEY, B. H.

1916. Krider's hawk (Buteo boreatis krideri) in Alaska. Auk, 33, p. 321.

BAILEY, V.

1900. Revision of American voles of the genus Microtus. U. S. Dept. Agric., Biol. Surv., N. Amer. Fauna, 17, 88 pp., 5 pls., 17 figs. in text. 
BAIRD, S. F.

1864-1872. Review of American birds in the museum of the Smithsonian Institution. Smithsonian Misc. Coll., 181, pt. 1, vi +478 pp., many figs. in text.

BAIRD, S. F., BREWER, T. M., and RIDGWAT, R.

1874. A history of North American birds. (Boston, Little, Brown \& Co.), 1, xxviii + 596 + vi pp., 26 pls.

Bishop, L. B.

1900a. Birds of the Yukon region, with notes on other species. U. S. Dept. Agric., Biol. Surv., N. Amer. Fauna, 19, pp. 47-96.

1900b. Deseriptions of three new birds from Alaska. Auk, 17, pp. 113-120.

Brooks, A.

1903. Notes on the birds of the Cariboo District, British Columbia. Auk, 20, pp. 277-284, $1 \mathrm{pl}$.

1912. Some British Columbia records. Auk, 29, pp. 252-253.

1920. Notes on some American ducks. Auk, 37, pp. 353-367, 2 pls., 16 figs. in text.

Brooks, A. H., AbBe, C., Jr., and Goode, R. U.

1906. The geography and geology of Alaska, a summary of existing knowledge, with a section on climate and a topographic map and description thereof. U. S. Dept. Interior, Geol. Surv., Professional Paper no. 45 , 327 pp., 34 pls., 6 figs. in text.

Cameron, E. S

1907-1908. The birds of Custer and Dawson counties, Montana. Auk, 24, pp. 241-270, 389-406, pls. V-XII, XIV-XVI, 2 maps; ibid., 25, pp. 39-56.

Chapman, F. M.

1904. A new grouse from California. Bull. Amer. Mus. Nat. Hist., 20, pp. 159-162.

COALE, H. K.

1887. Description of a new subspecies of Junco from New Mexico. Auk, . 4, 1887, pp. 330-331.

Coues, E.

1884. Key to North American birds. Ed. 2. (Boston, Estes and Lauriat), xxx +863 pp., 1 pl., 563 figs. in text.

1897. Rectifications of synonymy in the genus Junco. Auk, 14, pp. 94-95.

DAWson, G. M.

1889. Report on an exploration in the Yukon District, N. W. T., and adjacent northern portion of British Columbia. Geological and Natural History Survey of Canada, Annual Report (new series), 3, pt. 1 , report $B, 1887-88$, pp. 1B-277B, map, plates, and figs. in text.

1891. On the later physiographical geology of the Rocky Mountain region in Canada, with special reference to changes in elevation and to the history of the Glacial Period; being the presidential address for the year. Proc. and Trans. of the Royal Society of Canada for the year 1890,7 , section 4 , pp. 3-74. 
Driw, F. M.

1882. Notes on the plumage of Nephoecetes niger borealis. Bull, Nutt. Orn. Club, 7, pp. 182-183.

DWIGHT, J.

1918. The geographical distribution of color and of other variable characters in the genus Junco: a new aspect of specific and subspecific values. Bull. Amer. Mus. Nat. Hist., 38, pp. 269-309, pls. 11-13, 5 figs. in text (maps).

Eluiot, D. G.

1905. Descriptions of three apparently new species of mammals. Proc. Biol. Soe. Wash., 18, pp. 79-82.

EMMONs, G. T.

1911. The Tahltan Indians. University of Pennsylvania, The Museum, Anthropological Publications, 4, no. 1, 120 pp., map, 19 pls., 28 figs. in text.

GoULD, $\mathbf{J}$.

1862-1873. The birds of Great Britain. (London, published by the author), 5 vols., text unpaged, 367 pls.

GrinneLL', J.

1900. Birds of the Kotzebue Sound region, Alaska. Pacific Coast Avifaưna, 1, 80 pp., map.

1901. Two races of the varied thrush. Auk, 18, pp. 142-145.

1909a. A collection of birds from Forty-mile, Yukon Territory, Canada. Condor, 11, pp. 202-207.

1909b. Birds and mammals of the 1907 Alexander Expedition to southeastern Alaska. The birds. Univ. Calif. Publ. Zool., 5, pp. 181-244.

1910. Birds of the 1908 Alexander Alaska Expedition, with a note on the avifaunal relationships of the Prince William Sound district. Univ. Calif. Publ. Zool., 5, pp. 361-428, pls. 33-34, 9 figs. in text.

1914. An account of the mammals and birds of the lower Colorado Valley, with especial reference to the distributional problems presented. Univ. Calif. Publ. Zool., 12, pp. 51-294, pls. 3-13, 9 figs. in text.

1916. A new ruffed grouse, from the Yukon Valley. Condor, 18, pp. 166167.

1918. The subspecies of the mountain chickadee. Univ. Calif. Publ. Zool., 17, pp. 505-515, 3 figs. in text.

Griscom, L., and HARPER, F.

1915. The Bohemian waxwing (Bombycilla garrula) at Ithaca, N. Y. Auk, 32, p. 369.

HoLlister, N.

1911. A systematic synopsis of the muskrats. U. S. Dept. Agric., Biol. Surv., N. Amer. Fauna, 32, 47 pp., 6 pls.

1912. Mammals of the Alpine Club expedition to the Mount Robson region. Canadian Alpine Journal, special number, pp. 1-44, pls. 1-12. 
HOWELL, A. H.

1915. Revision of the American marmots. U. S. Dept. Agrie., Biol. Surv., N. Amer. Fauna, 37, 80 pp., 15 pls., 3 figs. in text.

KERMODE, F.

1904. Catalogue of British Columbia Birds (Provincial Museum, Victoria, British Columbia), $69 \mathrm{pp}$.

MCGREGOR, R. C.

1899. The myrtle warbler in California and description of a new race. Bull. Cooper Ornithological Club, 1, pp. 31-33. .

Mearns, E. A.

1911. New names for two subspecies of Peromyscus maniculatus (Wagner). Proc. Biol. Soc. Wash., 24, pp. 101-102.

Merriam, C. H.

1896. Synopsis of the weasels of North America. U. S. Dept. Agric., Div. Orn. and Mam., N. Amer. Fauna, 11, 44 pp., 5 pls., 16 figs. in text.

1898. Life zones and crop zones of the United States. U. S. Dept. Agric., Biol. Surv., Bull. no. 10, 79 pp., 1 pl. (map).

1900. Descriptions of twenty-six new mammals from Alaska and British North America. Proc. Washington Acad. Sci., 2, pp. 13-30.

1914. Descriptions of thirty apparently new grizzly and brown bears from North America. Proc. Biol. Soe. Wash., 27, pp. 173-196.

1918. Review of the grizzly and big brown bears of North America (genus Ursus) with description of a new genus, Vetularctos. U. S. Dept. Agric., Biol. Surv., N. Amer. Fauna, 41, 136 pp., 16 pls.

NeWTON, A.

1861. Particulars of Mr. J. Wolley's discovery of the breeding of the waxwing (Ampelis garrulus, Linn.). Ibis, pp. 92-106, pl. IV.

OBERHOLSER, H. C.

1898. Description of a new North American thrush. Auk, 15, pp. 303-306.

1905. The forms of Vermivora celata (Say). Auk, 22, pp. 242-247.

1906. An earlier name for Melospiza lincolnii striata. Proc. Biol. Soe. Wash., 19 , p. 42.

1917a. Notes on North American birds. I. Auk, 34, pp. 191-196.

1917b. Notes on North American birds. II. Auk, 34, pp. 321-329.

1917c. A synopsis of the races of Bombycilla garrula (Linnaeus). Auk, 34, pp. 330-333.

1918a. Notes on North American birds. V. Auk, 35, pp. 185-187.

1918b. Notes on North American birds. VI. Auk, 35, pp. 463-467.

1919a. Notes on North American birds. VII. Auk, 36, pp. 81-85.

1919b. The range of the short-tailed mountain chickadee (Penthestes gambeli abbreviatus Grinnell). Auk, 36, 424.

1919c. A new eliff swallow from Canada. Canadian Field-Naturalist, 33, p. 95. 
OsGood, W. H.

1901. Natural history of the Queen Charlotte Islands, British Columbia. U. S. Dept. Agric., Biol. Surv., N. Amer. Fauna, 21, pp. 1-50, pls. $1-5$.

1905. In Alaska's rain belt. Condor, 7, pp. 68-71.

1909a. Revision of the mice of the American genus Peromyseus. U. S. Dept.

Agric., Biol. Surv., N. Amer. Fauna, 28, 285 pp., 8 pls., 12 figs. in text.

1909b. Biological investigations in Alaska and Yukon Territory. U. S. Dept. Agrie., Biol. Surv., N. Amer. Fauna, 30, 96 pp., 5 pls., 2 figs. in text.

PALMer, T. S.

1916. The type locality of Colaptes cafer. Auk, 33, pp. 322-324.

1918. Another reference to early experiments in keeping hummingbirds in captivity. Condor, 20, pp. 123-124.

Preble, E. A.

1899. Revision of the jumping mice of the genus Zapus. U. S. Dept. Agric., Biol. Surv., N. Amer. Fauna, 15, 42 pp., 1 pl., 4 figs. in text.

1908. A biological investigation of the Athabaska-Mackenzie region. U. S. Dept. Agric., Biol. Surv., N. Amer. Fauna, 27, 574 pp., 25 pls., 16 figs. in text.

Reichenow, A.

1908. Neue Vogelarten. Ornith. Monatsber., 16, p. 191.

RHOADS, S. N.

1893. Notes on certain Washington and British Columbia birds. Auk, 10, pp. 16-24.

RIDGWAX, R.

1901. The birds of North and Middle America. U. S. Nat. Mus. Bull., 50, pt. 1, xxx +715 pp., 20 pls.

1902. Idem, pt. II, $\mathrm{xx}+834$ pp., 22 pls.

1904. Idem, pt. III, $\mathrm{xx}+801$ pp., 19 pls.

1907. Idem, pt. IV, xxii +973 pp., 34 pls.

1911. Diagnosis of some new forms of Picidae. Proc. Biol. Soc. Wash., 24, pp. 31-36.

1914. The birds of North and Middle America. U. S. Nat. Mus. Bull., 50, pt. VI, $x x+882$ pp., 36 pIs.

1916. Idem, pt. VII, xiii +543 pp., 24 pls.

RILEY, J. H.

1911. Descriptions of three new birds from Canada. Proc. Biol. Soc. Wash., 24, pp. 233-236.

1912. Birds collected or observed on the expedition of the Alpine Club of Canada to Jasper Park, Yellowhead Pass, and Mount Robson region. Canadian Alpine Journal, special number, pp. 47-75, pls. 1-2. 
Stetenson, H.

1882. On the plumage of the waxwing, Ampelis garrulus, Linnaeus, from the examination and comparison of a large series of specimens killed, in Norfolk, in the winter of 1866-67. Trans. Norfolk and Norwich Naturalists' Society, 3, pp. 326-344, 2 figs. in text.

SWARTH, H. S.

1911. Birds and mammals of the 1909 Alexander Alaska expedition. Univ. Calif. Publ. Zool., 7, pp. 9-172, pls. 1-6.

1912. Report on a collection of birds and mammals from Vancouver Island. Univ. Calif. Publ. Zool., 10, pp. 1-124, pls. 1-4.

1920. Revision of the avian genus Passerella, with special reference to the distribution and migration of the races in California. Univ. Calif. Publ. Zool., 21, pp. 75-224, pls. 4-7, 30 figs. in text.

1921a. The Sitkan race of the dusky grouse. Condor, 23, pp. 59-60.

1921b. The red squirrel of the Sitkan distriet, Alaska. Jour. Mammalogy, 2, pp. 92-94.

Taverner, P. A.

1914. A new subspecies of Dendragapus (Dendragapus obscurus flemingi) from southern Yukon Territory. Auk, 31, pp. 385-388.

1919. The summer birds of Hazelton, British Columbia. Condor, 21, pp. $80-86,1$ fig. in text.

WILIETT, G.

1914. Birds of Sitka and vicinity, southeastern Alaska. Condor, 16, pp. 71-91, 1 fig. in text.

1917. Another Alaska record for the mourning dove. Condor, 19, p. 22.

1921. Ornithological notes from southeastern Alaska. Auk, 38, pp. 127-129.

Woliex, JoHN, Jun.

1857. On the nest and eggs of the waxwing (Bombycilla garrula, Temm.). Proc. Zool. Soc. London, 25, pp. 55-56, pl. aves CXXII. 


\section{UNIVERSITY OF OALIFORNIA PUBLICATIONS-(Continued)}

15. The Significance of Skeletal Variations In the Genus Peridinium, by A. I. Barrows. Pp. 397-478, plates 17-20, 19 figures in text. June, $1918 \ldots . . . . . . .$.

16. The Subclavian Vein and Its Relations in Elasmobranch Fishes, by J. Frank Daniel. Pp. 479-484, 2 figures in text. August, 1918

17. The Cercaria of the Japanese Blood Fluke, Schistosoma japonicum Katsurada, by William $W$. Cort. $P p .485-507,3$ figures in text.

18. Notes on the Eggs and Miracidia of the Human Bchistosomes, by Wullam W. Cort. Pp. 509-519, 7 figures in text.

Nos. 17 and 18 in one cover. January, 1919 Index, pp. 521-529.

Vol. 19. 1. Reaction of Varlous Plankton Animals with Reference to Their Diurnal Migrations, by Calvin O. Esterly. Pp. 1-83. April, 1919

The Pteropod Desmopterus pacificus (sp. nov.), by Christine Essenberg. $\mathbf{P p}$. 85-88, 2 figures in text. May, 1919

3. Studies on Giardia microti, by William C. Boeck. Pp. 35-136, plate 1, 18 figures in text. April, 1919

4. A Comparison of the Iife Cycle of Crithidia with that of Trypanosoma the Invertebrate Host, by Irene McCulloch. Pp. 135-190, plates 2-6, 3 figures in text. October, 1919

5. A Muscld Larva of the San Francisco Bay Reglon Which Sucks the Blood of Nestiling Birds, by O. F. Plath. Pp. 191-200. February, 1919

6. Binary Fission in Collodictyon triciliatum Carter, by Robert Clinton Rhodes. Pp. 201-274, plates 7-14, 4 figures in text. December, 1919

7. The Excretory System of a Stylet Cercaria, by William W. Cort. Pp. 275 . 281, 1 figure in text. August, 1919

8. A New Distome from Rana aurora, by Wiljam W. Cort. Pp. 283-298, 5 figures in text. November, 1919

9. The Occurrence of a Rock-boring Isopod along the Shore of San Francisco Bay, California, by Albert I. Barrows. Pp. 299-316, plates 15-17. Docember, 1919

10. A New Morphological Interpretation of the Structure of Noctiluca, and Its Bearling on the Status of the Cystoflagellata (Haeckel), by Charles $\mathbf{A}$. Kofoid. Pp. 317-334, plate 18, 2 figures in text. February, $1920 \ldots . . . . . . . . .$.

11. The Life Cycle of Echinostoma revolutum (Froelich), by John C. Johnson. Pp. 338-388, plates 19-25, 1 figure in text. May, 1920

12. On Some New Myriopods Collected in India in 1916 by C. $A$. Kofoid, by Ralph V. Chamberlin. Pp. 389-402, plates 26-28. August, 1920

18. Demonstration of the Function of the Neuromotor Apparatus in Euplotes by the Method of Microdissection, by Charles V. Taylor. P. 403-470, plates 29-33, 2 figures in tert. October, 1920

Index in preparation.

Vol 20. 1. Studies on the Parasites of the Termites. I. On Streblomastix strix, a Polymastigote Flagellate with a Linear Plasinodial Phase, by Charles Atwood Kofold and Olive Swezy. Pp. 1-20, plates 1-2, 1 figure in text. July, 1919

2. Studies on the Parasites of the Termites. II. On Trichomitus ternitidis, a Polymastigote Flagellate with a Highly Developed Neuromotor System, by Charles Atwood Kofoid and Olivo Swezy. Pp, 21-40, plates 3-4, 2 figures in text. July, 1919

3. Studies on the Parasites of the Termites. III. On Trichonympha campanula sp. nov., by Charles Atwood Irofoid and Olive Swez. Pp. 41-98, plates 5-12, 4 figures in text. July, 1919

4. Studies on the Parasites of the Termites. IV. On Leidyopsis sphaerica gen. nov., sp. nov., by Charies Atwood Kofold and Olive Swezy." Pp. 99-116, plates 13-14, I figure in text. July, 1919

5. On the Morphology and Mitosis of Chilomest tx mesnili (Wenyon), a Common Flagellate of the Human Intestine, by Charles A. Kofoid and Olive Swezy. Pp. 117-144, plates 15-17, 2 figures in text. April, 1920

6. A Critical Review of the Nomenclature of Human Intestinal Flagellates, Cercomonas, Chilomastix, Trichomonas, and Giardia, by Charles A. Kofold. Pp. 145-168, 9 figures in text. June, 1920

7. On the Free, Encysted, and Budding Stages of Councilmania lafleuri, a Parasitic Amoeba of the Fruman Intestine, by Charles Atwood Fofoid and Olive Swezy. Pp. 169-198, plates 18-22, 3 figures in tezt. June, 1921 ...

8. Mitosis and Fission in the Active and Encysted Phases of Giardia enterica (Grassi) of Man, with a Discussion of the Method of Origin of Bilateral Symmetry in the Polymastigote Flagellates, by Charles A. Kofoid and Olive Swezy. Pp. 199-234, plates 23-26, 11 figures in toxt. March, 1922

9. The Micro-Injection of Paramaecium, by Chas. Wm. Rees. Pp. 235-242. April, 1922. 


\section{UNIVERSITY OF CALIFORNLA PUBLICATIONS-(ContInuod)}

10. On Balantidium coli (Malmsten) and Balantidium suis (sp. nov.), with an account of their neuromotor apparatus, by J. Daley McDonald. Pp. 243-300, plates 27, 28, 15 figures in text. May, 1922

11. Mitosis in Endamoeba dysenteriae in the Bone Marrow in Arthritis deformans, by Charles Atwood Kofold and Olive Swezy. Pp. 301-307, 7 figures in text.

12. Endamoeba dysenteriae in the Iymph Glands of Man in Hodgkin's Diseage, by Charles A. Kofold, Luther M. Boyers, M.D., and Olive Swezy. Pp. 309. 312,4 figures in text.

Nos. 11 and 12 in one cover. April, 1922

13. Mitosis in the Encysted Stages of Endamoeba coli (Loesch), by Olive Swezy. Pp. 313-332, plates 29-31. May, 1922

Vol. 21. 1. A Revision of the Microtus californicus Group of Meadow Mice, by Remington Kellogg. Pp. 1-42, 1 figure in text. December, 1918

2. Five New Five-Toed Kangaroo Rats from California, by Joseph Grinnell. Pp. 43-47. March, 1919

3. Notes on the Natural History of the Bushy-tailed Wood Rats of California, by Joseph Dixon. Pp. 49-74, plates 1-3, 3 figures in text. December, 1919

4. Revision of the Avian Genus Passerella, with Special Reference to the Distribution and Migration of the Races in California, by H. S. Swarth. Pp. 75-224, plates 4-7, 30 figures in text. September, 1920

5. A. Study of the California Jumping Mice of the Genus $Z$ apus, by A. Brazier Howell. Pp. 225-238, 1 figure in text. May, 1920

6. Two New Rodents (Genera Thomomys and Marmota) from the Eastern Border of California, by Joseph Grinnell. Pp. 239-244, 6 figures in text. November, 1921

7. A Study of the Californian Formas of the Microtus montanus Group of Meadow Mice, by Remington Kellogg. Pp. 245-274, 25 figures in text.

8. A Synopsis of the Microtus mordax Group of Meadow Mice in Callfornia, by Remington Kellogg. Pp. 275-302, plate 8, 29 figures in text.

Nos, 7 and 8 in one cover. April, 1922

Vol. 22. 1. A Quantitative and Statistical Study of the Plankton of the San Joaquin River and Its Tributarles in and near Stockton, California, in 1913, by Winfred Emory Allen. Pp. 1-292, plates 1-12, 1 figure in text. June, 1920. $\$ 9.00$

Vol.23. The Marine Decapod Crustacea of California, by Waldo L. Schmitt. Pp. 1-470, plates 1-50; 165 figures in text. May, 1921

Vol.24. 1. A Geographical Study of the Kangaroo Rats of California, by Joseph Grinnell. Pp. 1-124, plates 1-7, 24 figures in text. June, 1922

2. Birds and Mammals of the Stikine River Region of Northern British Columbia and Southeastern Alaska, by H. S. Swarth. Pp. 125-314, plate 8,34 figures in text. June, 1922 . 


\title{
BIRDS AND MAMMALS OF THE SKEENA RIVER REGION OF NORTHERN BRITISH COLUMBIA
}

\author{
BY \\ HARRY S. SWARTH \\ University of California Publications in Zoologt \\ Vol. 24, No. 3, pp. 315-394, plates 9-11, 1 figure in text
}

UNIVERSITY OF CALIFORNIA PRESS

BERKELEY, CALIFORNIA

1924 


\section{UNIVERSITY OF CALIFORNTA PUBLIOATIONB}

Note.-The University of Calfforna Publications are offered in exchange for the publi. cstions of learned societies and institutions, universities, and 11brarles. Complets lists of all the publications of the University will be sent upon request. For sample coples, list of publications or other information, address the MANAGER OF THE UNIVERSITY PRES8, BERKELEY, CALIFORNIA, U. S. A. All matter sent in exchange ghould be addressed to THE EXCHANGE DEPARTMENT, UNIVERSITY IIBRARY, BERKELEY, OALTFORNIA, U. S.A.

WILLIAM WESLEY \& SON8, LONDON

Agent for the serles in American Archaeology and Ethnology, Botany, Geology, Physlology, and Zoology.

ZOOLOGY.-C. A. Kofold and J. Grinnell, Editors.

This series contains the contributions from the Department of Zoology, from the Marine Laboratory of the Scripps Institution for Blological Besearch, at Ia Jolla, Califormia, and Irom the Callfornia Museum of Vertebrate Zoology in Berkeley.

Cited as Univ. Callf. Publ Zool.

Volume 1, 1902-1906, 317 pages, with 28 plates

Volume 2, 1904-1906, xvil + 382 pages, with 19 plates

$\$ 3.60$

Volume 3, 1906-1907, 383 pages, whth 23 plates $\$ 3.50$

Volame 4, 1907-1908, 400 pages, with 24 plates $\$ 3.50$

Volume 5, 1808-1910, 440 pages, with 34 plates 89.50

Volume 6, 1908-1911, 478 pages, with 48 plates $\$ 3.60$

Volume 7, 1910-1912, 446 pages, with 12 plates $\$ 3.60$

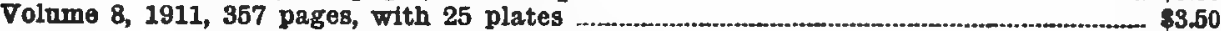

Volume 8, 1911-1912, 365 pages, with 24 plates .................................................. \$3.60

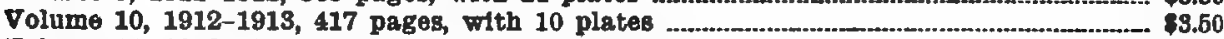

Volume 11, 1912-1914, 598 pages, with 26 plates ........... \$5.00

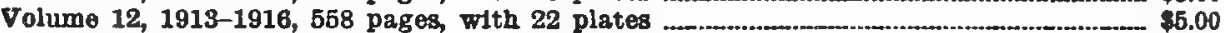

Volume 13, 1914-1916, 529 pages, with 99 plates ......................................................... \$6.00

Volume 14, 19141918,452 pages, with 60 plates ............................................................. \$5.00

Volume 15, 1915-1916, 360 pages, with 38 plates ....................................................... \$4.00

Volume 16, 1915-1917, 522 pages, with 46 plates .............................................................. \$5.00

Volume 17, 1916-1918, 545 pages, with 24 plates .............................................................\$5.00

Volume 18, 1917-1919, 629 pages, w1th 20 plates ......................................................... $\$ 5.00$

Volume 19, 1919-1920, 480 pages, with 33 plates ....

Vol. 19. 1. Reaction of Varlous Plankton Anlmals with Reference to Their Diurnal Migrations, by Calvin O. Esterly. Pp. 1-83. April, 1919 .........................

2. The Pteropod Desnopterus pacificus (sp. nov.), by Chrlstine Essenberg. Pp. 85-88, 2 figures in text. May, 1919.

3. Studes on Giarlia microti. by Wullam C. Boeck. Pp. 85-136, plate 1, 19 figures in text. April, 1919

4. A Comparison of the Life Cycle of Crithidia with that of Trypanosoma in the Invertebrate Host, by Irene McCulloch. Pp. 135-190, plates 2-6, 3 figures in text. October, 1919

5. A Muscid Larva of the Ban Francisco Bay Region Which Buckg the Blood of Nestling Birds, by O. E. Plath. Pp. 191-200. February, 1919

6. Binary Fission in Collodietyon triciliatum Carter, by Robert Clinton Rhodes. Pp. 201-274, plates 7-14, 4 figures in text. December, 1919

7. The Excretory System of a Stylet Cercaria, by Wullam W. Cort. Pp. 275281, 1 figure in text. August, 1919

8. A New Distome from Rana aurora, by Wlllam W. Cort. Pp. 283-298, 5 flgures in text. November, 1919

9. The Occurrence of a Bock-boring Isopod along the shore of Ban Francisco Bay, Calffornia, by Albert I. Barrows. Pp. 299-316, plates 16-17. Docember, 1919

10. A New Morphological Interpretation of the Structure of Noctiluca, and Ito Bearing on the Status of the Oystoflagellata (Haeckel), by Charles A. Kofoid. Pp. 317-334, plate 18, 2 Agures in text. February, 1920

11. The Itfe Cycle of Echinostoma revolutum (Froelich), by John O. Johnson. Pp. 338-388, plates 19-25, 1 figure in text. May, 1920

12. On Some New Myriopods Collected in India in 1916 by 0 . A. Kolold, by Ralph V. Chamberlin. Pp. 389-402, plates 26-28. August, 1920

13. Demonstration of the Function of the Neuromotor Apparatus in Euplotes by the Method of Microdissection, by Charles V. Taylor. Pp. 409-470, plates 29-33, 2 figures in text. October, 1920 Index, pp. $471-480$. 
BIRDS AND MAMMALS OF THE SKEENA RIVER REGION OF NORTHERN

BRITISH COLUMBIA

BY

HARRY S. SWARTH 
University of California Publications in Zoology

Vol. 24, No. 3, pp. 315-394, plates 9-11, 1 figure in text Issued January 24,1924 


\title{
BIRDS AND MAMMALS OF THE SKEENA RIVER REGION OF NORTHERN BRITISH COLUMBIA
}

\author{
BY
}

HARRY S. SWARTH

(Contribution from the Museum of Vertebrate Zoology of the University of California)

\section{CONTENTS}

Introduction

Itinerary and descriptions of localities.

Zonal and faunal position of the upper Skeena Valley................................ 320

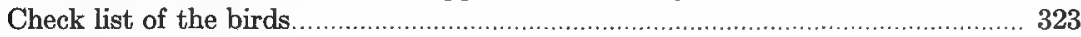

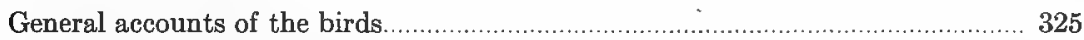

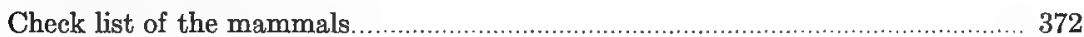

General accounts of the mammals.......................................................... 373

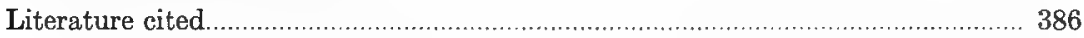

\section{INTRODUCTION}

In pursuance of the plan of zoological exploration which the Museum of Vertebrate Zoology, since its inception, has had under way in northwestern North America, a field trip was made into that region during the summer of 1921. The expenses of this trip, as of the preceding ones, were defrayed by Miss Annie M. Alexander, whose interest in the zoology of the northwest was the determining factor in directing the activities of the Museum toward that part of North America. The locality chosen for the 1921 expedition was the valley of the upper Skeena River, northern British Columbia, centering at the town of Hazelton. Our party consisted of two, the writer and one assistant, Mr. William Duncan Strong, a student at the University of California. The material collected consists of 265 mammals, 687 birds, and 50 reptiles and amphibians.

Acknowledgments are due to several institutions and individuals for aid, both in prosecution of the field work and in the subsequent studies of the material collected. From the Dominion Parks Branch, Department of the Interior, Canada, and from the Game Conservation Board of British Columbia, Vaneonver, permission was received to 
collect birds. I am under obligations to the Bureau of Biological Survey of the United States Department of Agriculture, through its chief, Dr. E. W. Nelson, for the loan of specimens and for the identification of certain mammals. To the Victoria Memorial Museum, Ottawa, through Mr. P. A. Taverner, ornithological curator, and to the Provincial Museum, Victoria, British Columbia, through the director, Mr. F. Kermode, I am indebted for the loan of many specimens.

To Major Allan Brooks, of Okanagan Landing, British Columbia, I am under obligations for the loan of specimens, and for critical comments and advice bearing upon my treatment of various species of birds and mammals. Major Brooks also made the drawing of the tail of the rock ptarmigan that is shown herewith.

Plant names used in this report were kindly supplied by Professor W. L. Jepson, of the University of California, based upon specimens collected.

In treating the birds the nomenclature used is that of the American Ornithologists' Union Check-List (1910) and its supplements (1912, 1920), with such modifications as I employed in my "Birds and Mammals of the Stikine Region"' (1922, p. 127).

\section{ITINERARY AND DESCRIPTIONS OF LOCALITIES}

We reached Hazelton the evening of May 25. On June 20 we removed to Kispiox Valley, twenty-three miles north of Hazelton. On July 15 return was made to Hazelton, and several days devoted to packing specimens and preparing for a mountain trip. On July 21 we ascended Nine-mile Mountain. On August 14 we returned to Hazelton, and on August 16 to Kispiox Valley. Final return to Hazelton was made on September 17; on September 19 Strong took the train for home, and on September 26 the writer took his departure.

\section{HAZELTON}

The town of Hazelton is at the junction of the Skeena and Bulkley rivers. The railroad station (Grand Trunk Pacific R. R.), some two miles to the southeast, is 177 miles from the coast, at Prince Rupert, and 973 feet above the sea. The town is in the low bottom lands through which the rivers flow. On either side of these bottom lands steep bluffs rise, two hundred feet or more, above which the higher 
platean slopes gently upward toward the several nearby mountain ranges. The most conspicuous of these, the towering, rocky peaks of the Rocher Déboulé, ten or twelve miles to the sontheast, rise precipitously to elevations of more than 8000 feet.

In the bottom lands poplar (Populus tremuloides) is the dominant forest growth, covering many square miles in almost pure stands of dense woods. Along the river there are rows of large cottonwoods, and on the ridges thickets of hazel, the abundance of which probably gave the town its name.

The higher slopes and plateaus, above the river bottoms, were once thickly covered with Engelmann spruce (Picea engelmanni), but these areas, at least toward the southeast, have suffered repeatedly from forest fires, so that but remnants of the woods remain standing. The ground beneath is strewn with charred trunks, hidden during the summer months by fire weed and bracken; and partly burned trees remain erect at seattered intervals. The plateau region is drained by numerous small streams, bordered with thickets of willow and alder. At rather frequent intervals there are muskegs, usually unaffected by fire, and affording contrast in several respects to their more monotonous surroundings.

These muskegs, often roughly circular in shape, are of varying size, marshy, with deep, sticky mud, or sometimes a few inches of water, and with mud and water usually concealed by grass. Scattered over them are a few funereal black spruces (Picea mariana), festooned with streamers of black moss. The bordering forest of Engelmann spruce usually forms a ring of denser growth than elsewhere about the margin of the muskeg, where, with the spruce, are mingled a few red cedars (Thuja plicata).

Toward the base of Rocher Déboulé, there are places where red cedar grows in some abundance. Mostly these trees had been cut out years before, but some groves remain, and in these clumps of cedars and in the muskegs species of birds are breeding that are not seen elsewhere at the same altitude.

Our camp in this region was on the opposite side of the Bulkley River from Hazelton, on what is locally known as Mission Point. Mammal trapping was carried on in the bottom lands between the Bulkley River and the railroad. 


\section{KISPIOX VALLEY}

The Kispiox River empties into the Skeena about ten miles north of Hazelton. Our camp in Kispiox Valley was at Beirnes' ranch, twenty-three miles north of Hazelton. The whole valley at that point is of much the same nature as the bottom lands near Hazelton; there is no such extent of spruce forest as is seen in the burned-over areas toward Rocher Déboulé. The forest is mainly of poplar, large sized trees with the dense underbrush that accompanies this growth. Scattered spruces occur everywhere, sometimes little clumps of them, but no extensive stands. Isodgepole pine also occurs in limited amount. In the lower Kispiox Valley there are large areas occupied almost solidly with this pine, small trees in dense groves. The region we covered in Kispiox Valley, though all in the poplar-grown bottom lands, offered a greater variety of conditions locally than is usually the case in this environment. There are many clearings in the woods, mostly pertaining to small ranches that have been abandoned. Along the river are wide expanses of open fields and pastures, some of this cleared land, some of it marshy stretches supporting no growths larger than thickets of willow and spiraea. Many little streams intersect forests and fields, some of these rivulets heading from small lakes buried in the thick woods.

Along the Kispiox River are occasional groves of cottonwood, huge trees, in stands covering large areas, with underbrush beneath that is of a different nature from that in the more open poplar woods. The sun scarcely penetrates into the depths of the cottonwood groves and the gloom of their shade is stiggestive of the dark woods on the coast. Rank grass, tall nettles, thimble-berry thickets, and devil's-club combine to form a tangle that can be penetrated at but few places.

There is an abundance of berry-bearing shrubs throughout the valley. Twin-berry (Lonicera involucratum), dogwood (Cornus pubescens), kinnikinnick (Arctostaphylos wva-ursi), and high bush cranberry (Viburnum pauciflorum) are among the most conspicuous. Thickets of hazel (Corylus rostrata) form a large percentage of the underbrush. 


\section{Nine-Mile Mountain}

This mountain lies a short distance northeast of Hazelton; its southern base is skirted by the Babine trail, leading from the town. Our camp near the summit was about twenty miles, by road and by trail, northeast of Hazelton. In ascending the mountain, the poplar belt is left behind almost at the very base, and a forest of spruce, intermingled with cedar, is entered. At an altitude of about 2000 feet the lower edge of hemlock (Tsuga heterophylla) is reached; at about 2500 feet the forest is practically all hemlock, large trees, with little or no underbrush beneath. Just below timber line (about 4500 feet altitude) the forest is largely composed of white fir (Abies grandis), though some hemlock persists to the upper limit of tree growth.

We camped at timber line in a cabin precariously clinging to a little niche on the steep hillside. The slope was part of a huge amphitheater, the outstanding ridges on either side perhaps a mile apart, and the crest of the mountain about five hundred feet above. Immediately below was the dark hemlock and fir forest, its upper edge as sharply defined as though the open slopes above had been cleared by man. Much of this amphitheater was covered with tall grass, veratrum, and lupine; in places there were extensive thickets of alder. Wide rock slides extended down from the divide in several places, sometimes into the forests below. The trail to the top passed through a notch in the ridge at an altitude of about 5000 feet; rounded summits arose on either side about 500 feet higher. The summit of the mountain is composed of two converging ridges, each five or six miles long at least; we did not cover their entire area. Between these ridges is enclosed a broad, steeply sloping valley.

The country above timber line, covering many miles along the higher ridges, is open and park-like, very attractive to the view. White fir and mountain hemlock (Tsuga.mertensiana) occur, dwarfed and prostrate, forming scattered thickets over ground that otherwise is mostly grass covered. Snow banks persist through the summer, and below the melting snow are occasional little lakes, sometimes an acre or more in extent. On damp slopes grass is replaced by false heather (Cassiope mertensiana), luxuriant growths that cover extensive areas. Below the ridges the grass became much higher and was intermingled with lupine.

An interesting feature of the Nine-mile Mountain avifauna is the unusual number of genera and species of grouse that occur there. At 
the base of the mountain is the ruffed grouse (Bonasa) extending from the poplars below well up into the spruce and cedar woods. In the hemlock belt, upward to the tree limit, the Franklin grouse (Canachites) occurs. Just below timber line, and even in thickets above, is the Fleming grouse (Dendragapus). On the Alpine-Arctic ridges three species of ptarmigan (Lagopus) are found. For six species of grouse to occur so nearly in the same place is, I believe, very unusual.

\section{Zonal and Fatnal Position of the Upper Skeena Valley}

The upper Skeena Valley lies to the eastward of the coast ranges, and its fauna and flora, as a whole, are of the interior, not of the coast. Conditions in many respects are similar to those of the upper Stikine Valley (see Swarth, 1.922, p. 141), two hundred miles to the northward, and observations in the Skeena Valley tend to corroborate conclusions reached in studies of the more northern region (Swarth, loc. cit.). The Skeena Valley is much more humid than the upper Stikine, and neither in animal nor plant life is it so sharply contrasted with the coastal region. The more southern coast ranges are not so high and precipitous as the northern mountains, and the gap through which the Skeena reaches the coast is broad, with sloping walls. Coastal rains often drift inland up the Skeena Valley, and cloudy skies are frequent. Certain coastal species of birds extend inland here much farther than they do along the Stikine.

The upper Skeena Valley, like the Stikine, is in the Canadian life zone, contrasted with the Hudsonian zone of the seacoast (see Swarth, 1922, p. 149). Study of the list of birds breeding in the lowlands of the Hazelton region discloses many that are not found on the coast; mostly these are species that elsewhere occur in zones lower than Hudsonian. Some conspicuous ones are:

Bonasa u. umbelloides

Phloeotomus p. pieinus

Nuttallornis borealis
Empidonax t. alnorum

Fmpidonax hammondi

Piranga ludoviciana

Certain species were seen about Hazelton that are usually found in lower zones even than the Canadian. These are:

Tyrannus tyrannus

Stelgidopteryx serripennis

Vireosylva olivacea
Dumetella carolinensis

Troglodytes a. parkmani 
There are, it is true, a number of birds found at sea level on the coast and in the lowlands of the Hazelton region, represented either by the same species or subspecies in both places, or by closely related subspecies, but these are mostly wide-ranging forms, not closely confined within any particular zone. Some such species are:

\author{
Ceryle a. caurina \\ Spinus p. pinus \\ Melospiza m. morphna
}

Melospiza 1. lincolni

Hirundo erythrogaster

Planesticus m. migratorius

There are eighteen such cases.

Turning now to conditions at high altitudes, we find the following birds in summer at timber line (Hudsonian Zone) on Nine-mile Mountain :

\author{
Dendragapus o. flemingi \\ Canachites franklini \\ Perisoreus c. canadensis \\ Loxia leucoptera \\ Zonotrichia coronata \\ Passerella i. annectens \\ Dendroica townsendi \\ Wilsonia p. pileolata
}

\author{
Nanuus h. pacifieus \\ Certhia f. occidentalis \\ Sitta canadensis \\ Penthestes g. abbreviatus \\ Penthestes h. columbianus \\ Regulus s. olivaceus \\ Regulus c. calendula \\ Hylocichla g. guttata \\ Ixoreus .1. naevius
}

Of these seventeen species, just four (Perisoreus c. canadensis, Zonotrichia coronata, Penthestes $g$. abbreviatus, and Penthestes $h$. columbianus) are not found upon the coast. The others, represented either by the same species or by closely related complementary subspecies, are mostly common and characteristic birds of the forests at sea level in the coastal region. In general, the avifauna at sea level on the coast is thus scen to be closely similar to that found just below timber line ( 4500 feet altitude), two hundred miles inland.

It is of interest to note that muskeg surroundings in the valleys of the upper Skeena region produced certain birds usually found in the Hudsonian Zone. Occasional pairs, at wide intervals, were thus noted of the following species:
Picoides aretieus
Regulus s. olivaceus
Picoides a. fasciatus Regujus e. calendula
Sitta canadensis
Ix́oreus n. naevius

On the treeless summit of Nine-mile Mountain the following birds were found breeding:

Lagopus 1. alexandrae

Lagopus rupestris

Lagopns 1. leucurus

Otocoris a. arcticola
Leucosticte t. littoralis

Passerculus s. alaudinus

Anthus rubescens 
Lack of suitable open country elscwhere may be an element in the occurrence of a horned lark and a Savannah sparrow as Alpine-Arctic species in this region, but the other species listed are all representative inhabitants of the Alpine-Arctic Zone.

Results of this classification of the birds by their zonal predilections may be summarized as follows: that the valleys of the upper Skeena region, east of the coast ranges, are in the Canadian life zone; that on the surrounding mountains there is a well defined belt of Hudsonian Zone; and that the treeless mountain tops pertain to the Alpine-Arctic Zone. At this latitude the Canadian life zone does not reach the coast, where but two life zones can be defined, Hudsonian from sea level upward to the tree limit, and Alpine-Arctic above that.

An analysis of the occurrence of mammals in this general region, as far as our more limited knowledge of them extends, tends to corroborate the above statements based upon the avifauna.

The upper Skeena Valley is the northern limit reached in this region by the following species of birds:

Phloeotomus p. picinus.
Tyrannus tyrannus
Hesperiphona v. brooksi
Zonotrichia albicollis
Junco o. shufeldti
Stelgidopteryx serripennis
Bombycilla cedrorum

Vireosylva olivacea.

Dendroica a. auduboni

Dendroica magnolia

Dumetella carolinensis

Troglodytes a. parkmani

Some of these get no farther north than the town of Hazelton. Of the others, it is doubtful if favorable conditions occur for more than fifty or sixty miles north of that point, at the outside. There are enough of these southern species to give character to the avifauna of this region, they all are stopped at practically the same boundary, and some have closely related congeners in the country immediately to the northward (see Swarth, 1922, p. 152).

Besides the species of mammals collected, certain others came to our attention. Tracks of black bear (Ursus americanus) appeared along the rivers in September when the salmon were dying. Coyotes (Canis), though never seen, were frequently heard howling in Kispiox Valley. Beaver (Castor canadensis) were actively at work in certain small lakes near our Kispiox Valley camp. Fresh tracks of deer (Odocoileus) were noted at the summit of Nine-mile Mountain, and a single deer was seen in Kispiox Valley, September 8. A number of shed horns of caribou (Rangifer) were found on Nine-mile Mountain, but the animals themselves were not there at that time. 


\section{CHECK LIST OF THE BIRDS}

1. Colymbus holboelli (Reinhardt).

2. Gavia immer (Brïnnich).

3. Larus brachyrhynchus Richardson.

4. Mergus americanus Cassin.

5. Anas platyrhynchos Linnaeus.

6. Mareca americana (Gmelin).

7. Nettion earolinense (Gmelin).

8. Dafila acuta (Linnaeus).

9. Anser albifrons (Scopoli), subsp.?

10. Branta canadensis (Linnaeus), subsp.?

11. Botaurus lentiginosus (Montagu).

12. Ardea herodias Linnaeus, subsp. 9

13. Gallinago delicata (Ord).

14. Pisobia bairdi (Coues).

15. Pisobia minutilla (Vieillot).

16. Ereunetes mauri Cabanis.

17. Tringa solitaria cinnamomea (Brewster).

18. Bartramia longicauda (Bechstein).

19. Actitis macularia (Linnaeus).

20. Dendragapus obscurus flemingi Taverner.

21. Canachites franklini (Douglas).

22. Bonasa umbellus umbelloides (Douglas).

23. Lagopus lagopus alexandrae Grinnell.

24. Lagopus rupestris (Gmelin), subsp.

25. Lagopus leucurus leucurus (Swainson).

26. Cireus hudsonius (Linnaeus).

27. Accipiter velox (Wilson).

28. Astur atricapillus atricapillus (Wilson).

29. Astur atricapillus striatulus Ridgway

30. Buteo borealis calurus Cassin.

31. Buteo swainsoni Bonaparte.

32. Aquila chrysaetos (Linnaeus).

33. Haliæetus leucocephalus alascanus $\mathrm{C}$ H. 'Townsend.

34. Falco columbarius columbarius Linnaeus.

35. Faleo columbarius suckleyi Ridgway.

36. Falco sparverius sparverius Linnaeus.

37. Pandion haliaëtus carolinensis (Gmelin).

38. Bubo virginianus lagophonus (Oberholser).

39. Ceryle alcyon caurina Grinnell.

40. Dryobates villosus monticola Anthony.

41. Dryobates pubescens leucurus (Hartlaub).

42. Picoides arcticus (Swainson).

43. Picoides americanus fasciatus Baird.

44. Sphyrapicus varius ruber (Gmelin).

45. Phloeotomus pileatus pieinus Bangs.

46. Colaptes auratus borealis Ridgway.

47. Chordeiles virginianus virginianus (Gmelin).

48. Cypseloides niger borealis (Kennerly).

49. Chaetura vauxi (J. K. Townsend). 
50. Selasphorus rufus (Gmelin).

51. Tyrannus tyrannus (Linnaeus).

52. Sayornis sayus yukonensis Bishop.

53. Nuttallornis borealis (Swainson).

54. Myiochanes richardsoni richardsoni (Swainson).

55. Empidonax trailli alnorurn Brewster.

56. Empidonax hammondi (Xantus).

57. Einpidonax wrighti Baird.

58. Otocoris alpestris areticola Oberholser.

59. Cyanocitta stelleri annectens (Baird).

60. Perisoreus canadensis canadensis (Linnaeus).

61. Corvus brachyrhynehos hesperis Ridgway.

62. Agelaius phoeniceus arctolegus Oberholser.

63. Enphagus carolinus (Müller).

64. Hesperiphona respertina brooksi Grinnell.

65. Carpodacus purpureus purpureus (Gmelin).

66. Loxia leucoptera Gmelin.

67. Leneosticte tephrocotis littoralis Baird.

68. Spinus pinus pinus (Wilson).

69. Calcarins lapponicus alascensis Ridgway.

70. Calcarius pictus (Swainson).

71. Calearius ornatus (J. K. Townsend).

72. Passerculus sandwiehensis alandinus Bonaparte.

73. Zonotrichia leucophrys gambeli (Nuttall).

74. Zonotrichia coronata (Pallas).

75. Zonotrichia albicollis (Gmelin).

76. Spizella monticola ochracea Brewster.

77. Spizella passerina passerina (Bechstein).

78. Junco hyemalis hyemalis (Linnaeus).

79. Juneo hyemalis connectens Coues.

80. Junco oreganus shufeldti Coale.

81. Melospiza melodia mornhna Oberholser.

82. Melospiza lineolni lincolni (Audubon).

83. Passerella iliaca iliaca (Merrem).

84. Passerella iliaca altivagans Riley.

85. Piranga ludoviciana (Wilson).

86. Hirundo erythrognster Boddaert.

87. Iridoprocne bicolor (Vieillot).

88. Tachycineta thalassina lepida Mearns.

89. Stelgidopteryx serripennis (Audubon).

90. Bombycilla garrula pallidiceps Reichenow.

91. Bombyeilla cedrorum Vieillot.

92. Vireosylva olivacea (Linnaeus).

93. Vireosylva gilva swainsoni (Baird).

94. Vermivora celata celata (Say).

95. Vernivora celata lutescens (Ridgway).

96. Vermivora peregrina (Wilson).

97. Dendroica aestiva rubiginosa (Pallas).

98. Dendroica coronata hooveri McGregor.

99. Dendroica auduboni auduboni (J. K. Townsend).

100. Dendroiea magnolia (Wilson).

101. Dendroica striata (J. R. Forster). 
102. Dendroica townsendi (J. K. Townsend).

103. Seiurus noveborrcensis notabilis Ridgway.

104. Oporornis tolmiei (J. K. Townsend).

105. Geothlypis trichas oceidentalis Brewster.

106. Wilsonia pusilla pileolata (Pallas).

107. Setophaga ruticilla (Linnaeus).

108. Anthus rubescens (Tunstall).

109. Dumetella carolinensis (Linnaeus).

110. Troglodytes aëdon parkmani Audubon

111. Nannus hiemalis pacificus (Baird).

112. Certhia familiaris occidentalis Ridgway.

113. Sitta canadensis Linnaeus.

114. Penthestes atricapillus septentrionalis (Harris).

115. Penthestes gambeli abbreviatus Grinnell.

116. Penthestes hudsonicus columbianus (Rhoads).

117. Penthestes rufescens rufescens (J. K. Townsend).

118. Regulus satrapa olivaceus Baird

119. Regulus calendula calendula (Linnaeus).

120. Myadestes townsendi (Audubon).

121. Hylocichla ustulata swainsoni (Tschudi).

122. Hylocichla guttata guttata (Pallas).

123. Hylocichla guttata pallasi (Cabanis).

124. Planesticus migratorius migratorius (Linnaeus).

125. Ixoreus naevius naevius (Gmelin).

126. Ixoreus naevius meruloides (Swainson).

127. Sialia currucoides (Bechstein).

\section{GENERAL ACCOUNTS OF THE BIRDS ·}

\section{Colymbus holboelli (Reinhardt). Holboell Grebe}

An adult male (no. 41986), taken in the Bulkley River at Hazelton, September 18, was the only one seen during the summer.

\section{Gavia immer (Brünnich). Common Loon}

There seemed to be a pair of loons to each of the many little lakes seattered through the woods. The birds were frequently seen circling about overhead, ealling as they flew. Toward the end of summer several might be in sight at once, going through such maneuvers.

\section{Larus brachyrhynchus Richardson. Short-billed Gull}

An immature male (no. 41987) was shot July 31 near the summit of Nine-mile Mountain, at about 5500 feet altitude. There were several small, snow-bordered lakes nearby, but otherwise nothing in the surroundings that might be thought attractive to gulls. 
In late August and September, when the salmon run was drawing to a close, many gulls were seen along the rivers. None was collected, but the birds observed were mostly of some species larger than brachyrhynchus.

\section{Mergus americanus Cassin. American Merganser}

Breeding in Kispiox Valley; adults occasionally flushed from streams and sloughs, and several broods of young encountered. On June 28 a female with eleven ducklings appeared in the swift-flowing creek by our camp, the young still mostly down-covered.

\section{Anas platyrhynchos Linnaeus. Mallard}

Breeding in Kispiox Valley. A nest with eggs was reported by an acquaintance, found about the middle of June in a hayfield. We saw single birds at various times during June and July. Toward the end of August there was an jnflux of migrating ducks, a large proportion of them mallards, and flocks of forty, fifty, or a hundred were seen daily on gravel bars in the Kispiox River. Here the ducks were feeding on salmon roe. Mallard and green-winged teal were the only species present in numbers, and individuals of each of these shot from time to time invariably contained salmon eggs in their gullets. The humpback salmon (Oncorhynchus gorbuscha), the species 'running' at that time, was present in myriads, and the ducks formed but a fraction of the animals that were preying upon fish or eggs.

Two adult males partly in the eclipse plumage were shot on September 10, and one (no. 41988) was preserved. In this bird the chestnut breast and gray underparts of the winter plumage are mostly acquired, while of the eclipse plumage there remain the brownstreaked head and neck, many brown feathers on back and flanks, and the tail feathers. An adult male (no. 12638) taken at Okanagan Landing, British Columbia, on October 1., is not nearly so far advanced in the molt, having but a few scattered new feathers over various parts of the head and body.

\section{Mareca americana (Gmelin). Baldpate}

One was shot on the Bulkley River at Hazelton, September 17. 


\section{Nettion carolinense (Gmelin). Green-winged Teal}

Common in Kispiox Valley in September. First seen August 26, a single bird. On August 30 a pair was noted, and a few days later flocks of from forty to fifty birds were frequently encountered. At the end of our stay, September 17, they were still abundant. Two specimens preserved, a female (no. 41989) and a young.male (no. 41990).

\section{Dafila acuta (Linnaeus). Pintail}

A flock of four seen near the Kispiox River, September 1, and others noted from time to time during the ensuing two weeks. Not abundant.

\section{Anser albifrons (Scopoli), subsp.? White-fronted Goose}

A flock of seven white-fronted geese passed overhead, going south, near Hazelton, September 19.

\section{Branta canadensis (Tinnaeus), subsp.? Canada Goose}

A flock of eight geese was seen in Kispiox Valley, the evening of June 24, flying low and apparently headed for a lake in the woods a few miles from our camp. Their occurrence in a flock at that season seems rather extraordinary. They were geese of the canadensis group, and apparently of large size. The subspecific status, of course, could not be ascertained.

\section{Botaurus lentiginosus (Montagu). Bittern}

A bittern was flushed from a marsh in Kispiox Valley on August 22, at close enough range to make identification certain, though the bird was not shot. On September 3. late in the evening, a heron' of some sort, apparently a bittern, flew over our camp. This, I believe, is as far to the northwest as the species has been seen.

\section{Ardea herodias Linnaeus, subsp.? Great Blue Heron}

One seen near Hazelton, June 10, and two in Kispiox Valley on June 20. We were told that herons sometimes occurred in fair abundance along the Kispiox River. Probably it is Ardea herodias fannini that occurs in this region. 


\section{Gallinago delicata (Ord). Wilson Snipe}

A fairly common fall migrant in Kispiox Valley. First seen August 20, and subsequently on many occasions up to the time of our departure, September 17. Two specimens preserved (nos. 41991, 41992).

\section{Pisobia bairdi (Coues). Baird Sandpiper}

A flock of eight seen on the summit of Nine-mile Mountain, August 5, and again (apparently the same flock) on August 10. One shot but not preserved. A flock of six was about a mud puddle in the town of Hazelton, August 15.

\section{Pisobia minutilla (Vieillot). Least Sandpiper}

Two shot, one (no. 41993) preserved, on the Kispiox River, August 27. An occasional small flock of sandpipers was seen there, but not many.

\section{Ereunetes mauri Cabanis. Western Sandpiper}

One bird (no. 41994) shot from a small flock on the Kispiox River, August 27.

Tringa solitaria cinnamomea (Brewster). Western Solitary Sandpiper

One bird shot, but not preserved, in Kispiox Valley, August 18; the only one seen all summer.

\section{Bartramia longicauda (Bechstein). Tpland Plover}

Appeared in small numbers, migrating, in Kispiox Valley the latter part of August. First scen August 17 (we were told they had appeared some days earlier) and at intervals, two or three birds at a time, until August 26. They frequented open fields where hay was raised, relatively limited areas that had been cleared in recent years. The country in general is densely forested; with settlement, more and more of such clearings have been made, and the species may be extending its range with the opening of favorable areas. This station is, I believe, an extreme western point of record for the upland plover in northern British Columbia. Four specimens were preserved (nos. 41996-41997), apparently all immature birds in first winter plumage. 


\section{Actitis macularia (Linnaeus). Spotted Sandpiper}

A few individuals seen at intervals through the summer, on the shores of the Skeena and Bulkley rivers near Hazelton, and on the Kispiox River. One specimen (no, 41995) preserved, an immature male taken on the Kispiox River, August 18.

\section{Dendragapus obscurus flemingi Taverner. Fleming Grouse}

Found in small numbers on the upper slopes of Nine-mile Mountain, mostly just below the upper limit of upright timber, at from 4500 to 5000 feet altitude. During the three weeks we spent at that place we saw one adult male and eight or ten females. Small young were encountered several times, never more than three or four to a brood, and sometimes only one. Several females seen were alone, and apparently without hroods. Three females collected (nos. 42000-42002). Two, taken August 5 and 8, respectivelv, are just beginning the annual molt. These birds are indistinguishable from specimens taken on the Stikine River, two hundred miles to the northwest (see Swarth, 1922, p. 203).

\section{Canachites franklini (Douglas). Franklin Grouse}

Seen in woods of spruce, fir, and hemlock, near the summit of Ninemile Mountain (4000 to 4500 feet altitude), and along the telegraph line at a point some forty miles north of Hazelton. Eleven specimens collected (nos. 42003-42013) : an adult male, two adult females, and three chicks from Nine-mile Mountain; an adult female, two immature males, and two females probably immature, from the second record station. These specimens bear out Riley's (1912, p. 55) comments upon the earlier molt of the adult male, as compared with female and young. The adult male collected August 2 has nearly completed the annual molt. Adult females taken August 10 and 11 are still in the old plumage. The three chicks, taken with the female parent on August 10, an entire family, are about one-quarter grown, in juvena] plumage save for remnants of natal down on the throats of two. Two young males and two apparently young females taken September 12 have nearly completed the molt into first winter plumage; an adult female taken September 12 is nearly through the annual molt.

The one adult male has a nearly uniformly black tail. There is a slight whitish tip to the central feathers, and a faintly indicated light- 
colored bar across the center of the tail, not to be seen unless the feathers are widely spread. Of the two immature males, one has the tail black except for scattered and faint reddish spots near the tips of some feathers; the other has the central rectrices narrowly tipped with whitish, some of the others very faintly with pale reddish. Of the five females, all have the central rectrices with more or less of a pale margin at the tip, and only one lacks such tipping to the lateral rectrices.

The adult male has large and conspicuous whitish spots on the long upper tail coverts. On the two immature males these spots are poorly indicated. On the two summer females they are inconspicuous; two of the three fall females have them conspicuously present, in one they are slight. In this series of birds there is no evidence of two color phases (as described by Riley, loc. cit.).

\section{Bonasa umbellus umbelloides (Douglas). Gray Ruffed Grouse}

Abundant throughout the poplar woods of the lowlands. On June 18 several broods of small young were seen, and from then on flocks of growing youngsters were frequently encountered. Toward the end of August some flocks were of such size as to make it seem probable that they were composed of two or more broods. The cocks are solitary through the summer; even in September extremely wary single birds were flushed that were assumed to be old males that had not yet joined the flocks.

Fourteen specimens collected (nos. 42014-42027), one old male, June 5, the others all taken in September and in the latter stages of the autumnal molt. The molt is completed about October 1. Two are red tailed, twelve gray tailed, indicating a preponderance of the gray phase in this region.

Two fall specimens at band from St. John trail, upper Peace River, Alberta, may be assumed to be representative of typical umbelloides. The birds from Hazelton and Kispiox Valley, though referable to umbelloides, are appreciably less grayish, more brownish in coloration, than these Peace River specimens, and they are also less gray than ruffed grouse from the upper Stikine River, to the northward. The increased brownness of the Skeena. Valley grouse may be indicative of intergradation toward sabini of the southern coastal region of British Columbia. How far north sabini extends is as yet undetermined. 
Lagopus lagopus alexandrae Grinnell. Alexander Willow Ptarmignn

Ptarmigan are sajd to occur occasionally in the lowlands of the Hazelton region in midwinter, but during most of the year they are restricted to the Alpine-Arctic mountain tops. We found them in limited numbers on the timberless summit of Nine-mile Mountain. There are miles of open country on the two converging ridges that form the top of this mountain, barren of trees save for occasional thickets of dwarfed or prostrate Alpine conifers, and here, at long intervals, we encountered ptarmigan. It is a curious fact, whether or no it was a mere coincidence, that on one of the two ridges only whitetailed ptarmigan were found, on the other, willow and rock ptarmigan were seen, but no white-tailed. To all seeming the two ridges were of exactly the same character. In all, ten broods of willow and rock ptarmigan were encountered (the species were not always to be differentiated) and about five or six single birds in addition. The broods ranged from three to twelve in numher; the aggregate of young birds seen was about fifty. The chicks grew rapidly. Some seen on July 25, and a day or two later, were down-covered and unable to fly. At that time they were accompanied by the female parent only, and the male birds were flushed separately. By August 10 the young ptarmigan were the size of quail and larger, and were strong on the wing. The old males were then associated with the families. In some of the larger broods seen the difference in size among the young was so marked as to suggest the junction of two families. It might happen that upon the death of a hen her offspring would seek the companionship of another family.

Five willow ptarmigan were collected (nos. 42028-42032), four adult males and one adult female. Three males have much white on the lower breast and abdomen, the fourth is almost solidly in the brown summer plumage. Many willow ptarmigan from different localities in the northwest have been available for comparison with these birds. Of Lagopus lagopus lagopus there is in this Museum from northern Alaska and Yukon (Kowak and Yukon-rivers) a series of ninety-four skins, including a number in summer plumage or in process of change. Of $I$. $l$. alexandrae, there are eleven specimens from island localities in southeastern Alaska, including five summer males, and one male and two females in first fall plumage. A pair of breeding adults from Porcher Island. British Columbia, was loaned by Allan Brooks. There have been available, from the collection of the 
Provincial Museum, Victoria, British Columbia, twenty-seven specimens from Lake Atlin, including nine summer males and eight summer females, and a male and female from Anaham Lake.

Island specimens of alexandrae (summer males), compared with lagopus from the Yukon and Kowak regions, are darker colored and with smaller and differently shaped bill. (The bill difference has been figured by Clark, 1910, p. 53.) Color is darkest in specimens from Prince of Wales Island. Atlin birds and Nine-mile Mountain birds are essentially alike, and are intermediate in color between lagopus of the interior and alexandrae from the islands; the average is nearer to alexandrae. The bill in size and shape is just as in alexandrae. Females from Atlin and Nine-mile Mountain differ from Kowak and Yukon birds in bill characters as do the males, and also in color. They are not of darker and richer browns, as might be expected, but present a duller, grayer appearance. In the northern lagopus the feathers above and below are broadly edged with bright hazel; in the southern birds these edgings are narrow and dull. On the basis of these comparisons I feel justified in extending the range of alexandrae eastward from the coast, at the north to Lake Atlin, at the south to Nine-mile Mountain and Anaham Lake. There is no question as to the difference of these southern mainland birds from lagopus of northern Alaska and the interior.

It is of interest to note in alexandrae the frequent presence of black shafts on the primaries, sometimes on secondaries and greater coverts. This character has been considered an important feature of the Newfoundland subspecies (L. l. alleni), as in the "key to the American subspecies of Lagopus lagopus" published by Clark (loc. cit., p. 54), but obviously it cannot be used as a feature characteristic of that race alone. In an immature female from Prince of Wales Island (no. 31343, August 27), which has acquired the winter flight feathers, not only are primaries and secondaries with distinct black shafts, but there are large, tear-shaped spots of black near the tips of all the primaries and most of the secondaries. Furthermore, the primaries have a black 'freckling' over much of their surface, and the greater coverts are also marked with black thongh to a lesser degree. 
Lagopus rupestris (Gmelin), subsp.? Rock Ptarmigan

Three specimens collected on Nine-mile Mountain, two young birds (nos. 42033-42034) partly in natal down, partly in juvenal plumage, taken August 1, and an adult female (no. 42035) collected August 5.

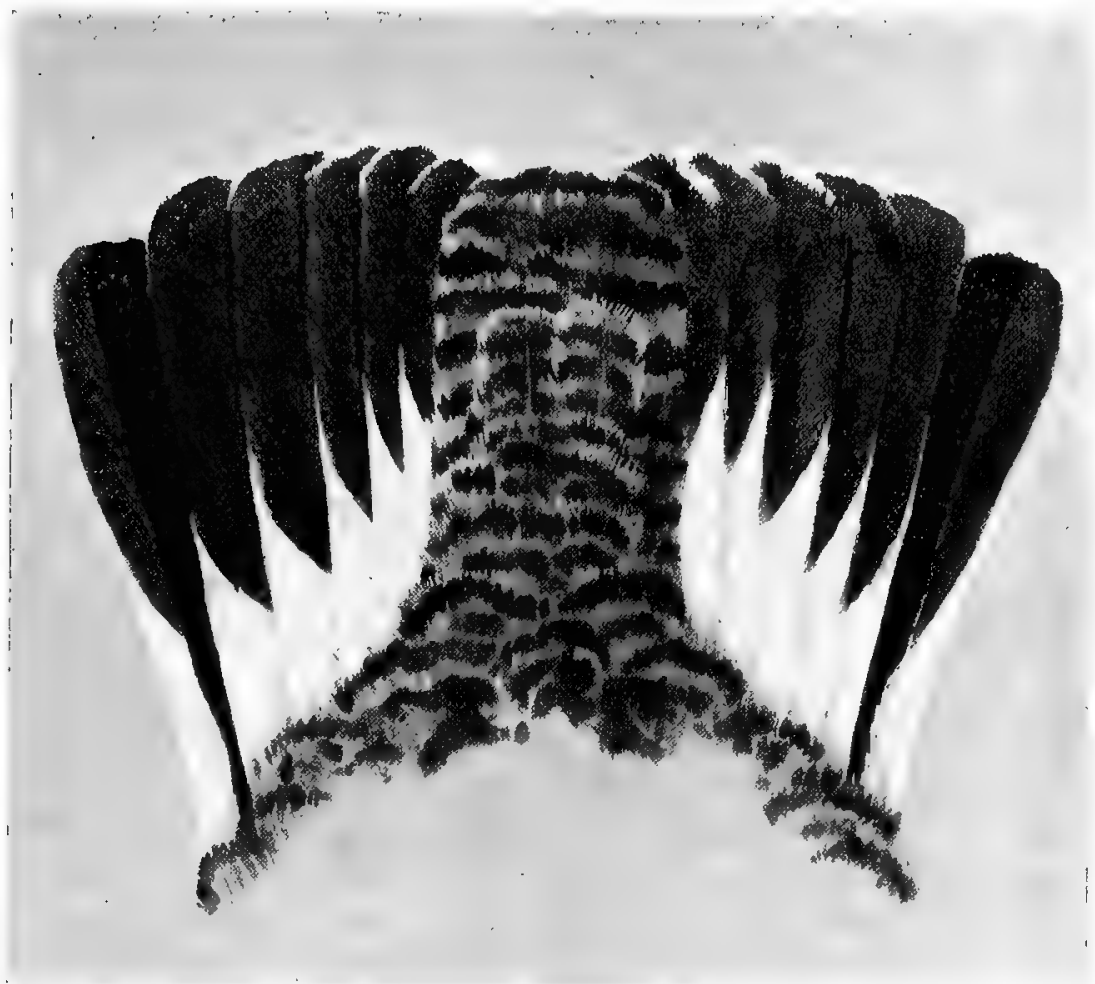

Fig. A. Tail of female rock ptarmigan (no. 42035), natural size. The outermost feather on each side is widely spread from the others to show pattern of coloration on inner web. Drawn by Allan Brooks.

'I'here are not available enough summer specimens from other points to enable me to determine the subspecife status of these birds. There is at hand one summer-plumaged female from the Jade Mountains, north of the Kowak River, collected Mav 28, 1899 (no. 32170), presumably representative of Lagopus rupcstris rupestris. Compared with the Nine-mile Mountain female, the Jade Mountains specimen is much brighter colored. There is a great deal of bright hazel in the plumage. The Nine-mile Mountain bird has a smaller bill (as compared also with many winter females from the Kowak River region), and is darker colored. Areas on individual feathers that in the 
northern bird are rather brilliantly ruddy are of more restricted size and of a dull tone, and there is extension of black and grayish areas. It seems likely that these two birds ropresent two different subspecies.

There are no adult females of Lagopus rupestris dixoni available, and but two summer males (nos. 371, 372, Port Frederick, Chichagof Island, July 30, 1907). Two summer males from Atlin, British Columbia, loaned by the Provincial Museum, Victoria (no. 2566, June 26,1914 ; no. 2589 , July 1, 1914), are quite unlike dixoni, sufficiently so to make it seem improbable that dixoni is a southern race of general occurrence on the mainland as well as on the Alaskan islands.

The Nine-mile Mountain female possesses one feature worthy of comment. The six outer tail feathers on each side are white basally, the total white area covering more than half the tail. On the inner rectrices the white extends over about the basal three-fourths; it decreases on the inner web of the onter feathers, though extending far toward the tip on the outer web (see fig. A). This is exactly the character ascribed to Lagopus hyperboreas Sundevall, of Spitzbergen (see Dresser, 1871, p. 179, col. pl. no. 482, text fig.; Ogilvie-Grant, 1893, p. 51). The white tail was not peculiar to the one specimen collected, for other females were seen on Nine-mile Mountain which had the same marking. It was conspicuous in flight. No male was noted with this charncter; in fact no male rupestris was positively recognized.

The two chicks collected are readily distinguished from young leucurus by their generally browner color. Young leucurus is distinctly gray. The young of lagopus is more ruddy throughout.

\section{Lagopus leucurus leucurus (Swainson). White-tailed Ptarmigan}

Found only on the eastern ridge of Nine-mile Mountain. Four specimens collected, two adult females and two chicks (nos. 4203642039). The young birds, taken on July 26 and August 1, respectively, have some natal down about the head; otherwise they are in juvenal plumage. Three broods of white-tailed ptarmigan were seen, one of two chicks, one of three, and one of trelve.

\section{Circus hudsonius (Linnaeus). Marsh Hawk}

$\Lambda \mathrm{n}$ adult male was seen repeatedly during parts of June and July about the same locality in Kispiox Valley. $\Lambda$ t the end of the summer the first migrant was seen September 10 , and a few others were noted at later dates. 


\section{Accipiter velox (Wilson). Sharp-shinned Hawk}

Several seen near Hazelton, migrating, May 27. As single birds were encountered at intervals during the summer in Kispiox Valley and on Nine-mile Mountain, it seems likely that a few pairs breed in the region. The last week in August, with the beginning of the migration, sharp-shinned hawks became fairly abundant. That is, one or two birds were seen daily, some days four or five might be encountered. Three specimens collected: an adult male, May 31 (no. 42040), an adult female, just beginning the annual molt, July 13 (no. 42042), and an immature male, August 19 (no. 42041).

\section{Astur atricapillus atricapillus (Wilson). Eastern Goshawk}

During the third week in August migrating goshawks appeared, and from then on, during September, they were abundant. Scarcely a day passed without at least one being seen, and frequently seven or eight would be noted within a few hours. The species is usually solitary but it was not uncommon here to find two together. Mostly they were young hirds, and as a rule absurdly unsuspicious. Two of. the three gashawks collected during 1ugust (nos. 42045, 42046), all in immature plumage, are evidently of the subspecies atricapillus, and I believe that nearly all seen at that time were the same. They appeared to constitute a migratory 'wave' from some more northern region.

\section{Astur atricapillus striatulus Ridgway. Western Goshawk}

A female goshawk (no. 42043) of this subspecies collected at Hazelton, on Mar 30 is, save for a few scattered feathers on the tibiae, in immature plumage throughout. A male bird (no. 42044) taken July 16 is in the midst of the molt from the immature to adult plumage. An immature male (no. 42046) was collected in Kispiox Valley, August 29. The last mentioned appeared at the same time as other migrating hawks. The other two, taken in May and July, respectively, may indicate the breeding of this subspecies in the region. They could not be positively recognized as breeding individuals, however. Remains of flicker and ruffed grouse were found in the stomach of no. 42044 ; ruffed grouse in that of no. 42046 . 


\section{Buteo borealis calurus Cassin. Western Red-tailed Hawk .}

Several pairs were breeding near Hazelton and in Kispiox Valley. In the latter locality, not far from our camp, there was an occupied nest at the top of a tall tree that towered above a surrounding jungle, too impenetrable to be traversed.

Toward the end of August there was a noticeable increase in the number of red-tails observed, due probably to an influx of migrants, and many were seen up to the end of my stay, September 26. There was wide variation in color; light-breasted birds were seen and some exceedingly dark ones. One specimen was collected (no. 42048), an immature male, taken in Kispiox Valley August 27. It is in the dark phase of plumage, blackish throughout with extensive white streaks and blotches partly concealed at the bases of the feathers.

\section{Buteo swainsoni Bonaparte. Swainson Hawk}

Hawks supposed to be of this species were seen occasionally late in August and early in September, but only one was shot. This bird (no. 42049) is an immature male, taken in Kispiox Valley, August 24. Its stomach contained a toad.

\section{Aquila chrysaëtos (Linnaeus). Golden Eagle}

Seen at intervals during the summer, at Hazelton, at the base of the nearby mountain range, Rocher Déboulé, and on Nine-mile Mountain. From July 16 to 20 one was seen daily at Hazelton, haunting the river banks and evidently. feeding on dead salmon. On Nine-mile Mountain one followed a regtlar beat almost daily, recognizable as the same individual through a peculiarity of marking. This bird was hunting marmots assiduously and swung about the mountain side low over the ridges, apparently trusting his sudden appearance to enable him to surprise a marmot at a distance from shelter.

\section{Haliaeëtus leucocephalus alascanus C. H. Townsend. Northern Bald Eagle}

Seen in the lowlands at various times during the summer. As the season advanced, the dead and dying salmon on the river banks were a bountiful source of food to the eagles, and increasing numbers of the birds appeared. What seemed to be entire families were seen several times, in July, groups composed of two adults with two or three full-grown young. 


\section{Falco columbarius columbarius T.innaeus. Eastern Pigeon Hawk}

Falco columbarius suckleyi Ridgway. Black Pigeon Hawk

The two subspecies of the pigeon hawk that are found in the region are rarely to be distinguished in life, so that birds seen can be recorded only under the specific name. Two pigeon hawks observed near. Hazelton on May 26 were presumably migrants; none was noted during midsummer. The first fall migrant appeared August 22, and from then on to the end of my stay (September 26) some were seen. nearly every day, sometimes several in one day.

The pigeon hawk is a remarkably swift flier, a fact borne out by the stomach contents of one of my birds, the remains of a black swift (Cypseloides niger. borealis). That this hawk can capture a swift in fair chase in the open is not likely (see Meinertzhagen, 1921, p. 237), but after observation of both species I see no reason to doubt that on occasion the swift could be taken unawares and caught by the hawk after a short burst of great speed. This is in opposition to a possible explanation that in the case in question the hawk had captured a sick or disabled bird.

Six specimens collected: one adult male, three immature males, and two (presumably) immature females. This series is of interest in its bearing upon the relationship of columbarius and suckleyi. Not one of the lot is typical of columbarius, though I have so labeled five of them (nos. 42050-42053, 42055), as most closely resembling that subspecies. One female (no. 42054, Kispiox Valley, August 29) is a typical, even an extreme, example of suckleyi. The second female (no. 42053, Kispiox Valley, September 12) is nearer true columbarius than any others of this series. The three immature males (nos. 42050-42052), taken in Kispiox Valley on August 28, 22, and 23, respectively, are intermediate in appearance between columbarius and suckleyi, an intermediateness that is exhibited in'a rather curious way. Ventrally they are in color and markings practically like columbarius, but dorsally they are quite as dark colored as the average immature suckleyi. This same sort of intermediateness, that is, light ventral and dark dorsal coloration, is also shown in an immature female (no. 39762) from the lower Stikine River, British Columbia, collected August 14, 1919 (see Swarth, 1922, p. 214), and intermediateness both above and below is shown in an immature female (no. 40371) taken near Coulterville, California, on December 20, 1919. 
The adult male collected (no. 42055, Hazelton, September 24) is referred to columbarins, though darker colored than any other adult of that subspecies that $I$ have seen. There are nine adult male pigeon hawks in the several collections housed in the Museum of Vertebrate Zoology, and these exhibit an interesting range of variation. An extreme of darkness is represented by the Hazelton bird above referred to, but slightly removed from that of suckleyn. At the opposite extreme, of light coloration, is an example of richardsoni. Between, there are seven specimens, labeled columbarius, illustrating unbroken gradation from one extreme to the other. Thus, in adult birds as in immatures, there is no one character of color or markings that may be taken as absolutely indicative of any one form. The three names, columbarius, suckleyi, and richardsoni, apply to three subspecies of one species, between which no definite lines may be drawn.

There is this to be said, however, that the above comments are based, not upon breeding birds, but upon specimens collected during the migrations and in winter. The line of nicely graded adults just described was not arranged with regard to geographic continuity. Breeding pigeon hawks are scarce in. collections (not one was available to the present writer) and, for the most part, deductions must be drawn as best they may from non-breeding birds.

The Hazelton series is of interest in that it includes a specimen of suckleyi from what I believe is the northernmost point at 'which this subspecies has been definitely recorded. This place is at an intermediate point between humid coast and arid interior, and most of the pigeon hawks taken there are intermediate in appearance. Of course these birds were not found atually breeding, but the conclusion does not seem forced that they are representative of the form that does breed in that general region.

In this discussion I have ignored the recently described Falco columbarius bendirei of Stwann (1922, p. 66; type locality, Fort Walla Walla, Washington). It may be possible eventually to demonstrate the existence of this additional western subspecies, but the two eastern specimens available to me are not to be distinguished from western birds here regarded.as columbarius.

\section{Falco sparverius sparverius Iinnaeus. American Sparrow Hawk}

A fairly common summer visitant to the lowlands. A few were seen in the open country above timber on Nine-mile Mountain, but that was early in August and the birds noted had probably wandered 
from nesting grounds at lower altitudes. Abundant in Kispiox Valley and about Hazelton during the latter part of August, and in lessening numbers in September. Some were seen up to the time of my departure, September 26.

Fifteen specimens collected (nos. 42056-42070). Full-grown young were taken July 18. An adult female taken August 20 has finished the annual molt; an adult male taken on the same date, and another shot September 7, are still in the midst of the change.

\section{Pandion haliaëtus carolinensis (Gmelin). Osprey}

We found no ospreys breeding in the region covered, but about the middle of August, with the coming of the salmon, the fish hawks began to appear. During the latter part of August and throughout September, some were seen almost daily.

\section{Bubo virginianus lagophonus (Oberholser). Ruddy Horned Owl}

Exceedingly abundant throughout the lowlands. At our timberline camp on Nine-mile Mountain we neither saw nor heard horned owls, but they were present everywhere in the valleys, and in unusual numbers for a large, predatory bird. The abundance of rabbits in the region may have caused a temporary increase in the number of horned owls.

Twenty-one specimens were collected (nos. 42071-42091). Of these, six are young, mostly down-covered (two in one brood, June 5; four in one brood, June 24); the rest are young and old in fresh fall plumage. Food was found in eight stomacks. In one case a young owl had been fed a red squirrel, the others contained rabbit and nothing else. This is noteworthy in view of the general belief that the horned owl is an inveterate enemy of grouse. These owls inhabited the poplar woods, precisely the same environment as the ruffed grouse, and ruffed grouse were abundant.

Considerable color variation is shown in this series of owls, gray colored birds at one extreme, brown colored at the other. The grayest bird (no. 42091) was the last one shot, on September 9, and might be assumed to be a migrant of a race other than the breeding form, but there are earlier taken specimens in the series that are nearly as light colored. I think it safe to say that the differences illustrate the extent of individual variation existent in the subspecies lagophonus in this one region. (For use of the name lagophonus, see Oberholser, 1904, p. 185; Ridgwav, 1914, p. 747.) 


\section{Ceryle alcyon caurina Grinnell. Western Belted Kingfisher}

By streams and lakes everywhere in the lowlands. Present in the region when we arrired, May 25, and up to the time of our departure, September 26. One specimen collected (no. 42092).

\section{Dryobates villosus monticola Anthony.}

\section{Rocky Mountain Hairy Woodpecker}

Fairly common in the lowlands, mostly in deciduous timber. Present during the whole of our stay; probably resident the year through. Young were seen flying about on June 22; birds taken September 1 had finished the molt. Twelve specimens collected (nos. 42093-42104), seven breeding adults, two in juvenal plumage, and three in fresh fall plumage.

Dryobates pubescens leucurus (Hartlaub). Batchelder Woodpecker

In small numbers in deciduous woods in the lowlands. Young out of the nest were taken June 29. Two specimens collected September 5 and 8 , respectively, had finished the molt. Thirteen specimens in all were collected (nos. 42104-42117).

A specimen of downy woodpecker from Fort Babine, in this same general region, has been ascribed by Ridgway (1914, p. 239) to the subspecies Dryobates pubescens glacialis Grinnell (type locality, Prince William Sound, Alaska). This induced comparison of the Skeena Valley series with the four Alaskan specimens of glacialis at hand, and the two lots were found to be indistinguishable. In the original description of glacialis (Grinnell, 1910, p. 390), comparisons are made with nelsoni, of the interior of Alaska, and gairdneri, of the coast of British Columbia. The American Ornithologists' Union Committee (1912, p. 386) refused recognition to the race glacialis on the grounds that it was an "intergrade between $D$. p. nelsoni and gairdneri." Ridgway (1914, p. 239) accords recognition to glacialis, but, in describing the race, compares it again with the Alaskan nelsoni, and also with the eastern medianus.

So far, no comparisons had been made between glacialis and the downy woodpecker of the more southern Rocky Mountains, $D$. $p$. homorus of recent literature. The Skeena Valley series, however, was taken sufficiently near the known range of that subspecies to suggest the desirability of such comparisons. Pertinent material is at hand 
as follows: Prince William Sound, Alaska, 2 specimens (including the type of Dryobates pubescens glacialis) ; lower Taku River, Alaska, 2; Skeena River region (Hazelton and Kispiox Valley), British Columbia, 13; Warner Mountains, California, 4; Sierra Ancha, Arizona, 2. In my opinion, the downy woodpeckers from these several points should all be included under one name. As shown in the accompanying table, the southern birds are slightly larger than the northern ones, which is curious, considering north and south variation in general in the genus Dryobates. The southern birds are also somewhat blacker, that is, with less white spotting upon wings and coverts. Individual variation is such, however, that it is impossible satisfactorily. to diagnose two subspecies in the material examined.

For the application of the name Dryobates pubescens leucurus (Hartlaub) to the downy woodpecker of the Rocky Mountain region, see Grinnell, 1923, p. 30.

TABIJ 1

Measurearfents IN Muldimeters of Dryobates pubescens leucurus

\begin{tabular}{|c|c|c|c|c|c|c|}
\hline $\begin{array}{l}\text { Mus. } \\
\text { No. }\end{array}$ & Sex & Locality & Date & Wing & Tail & Culmen \\
\hline 1287 & $\sigma^{2}$ & Prince William Sound, Alaska, & Sept. 7, 1908 & 93 & 57 & 15.5 \\
\hline 9732 & olim. & Taku River, Alaska, & Sept. 4,1909 & 92.5 & 56.5 & 15.8 \\
\hline 9733 & $0^{7}$ & Taku River, Alaska, & Sept. 13, 1909 & 97.5 & 58 & 15.2 \\
\hline 42117 & $\sigma^{7}$ & Kispiox Valley, B C., & July 13,1921 & 96.5 & 59 & 16.5 \\
\hline 42115 & $\sigma^{7}$ & Kispiox Valley, B. C., & Sept. 5,1921 & 97 & 61 & 15 \\
\hline 14137 & $\sigma^{7}$ & Warner Mts., Calif., & June 29,1910 & 98 & $58 \dagger$ & 18.5 \\
\hline 14138 & $\sigma^{7}$ & Warner Mts., Calif., & June 30,1910 & 101 & 65 & 18 \\
\hline 27710 & $\sigma^{7}$ & Sierra Ancha, Arizona, & June 23,1917 & 99.5 & 65.5 & 18 \\
\hline $1288^{*}$ & 우 & Prince William Sound, Alaska, & Sept. 18, 1908 & 97.5 & 61 & 15 \\
\hline 42105 & q & Hazelton, B. C., & June $16,1921^{\prime}$ & 94 & 60 & 16 \\
\hline 42108 & 우 & Kispiox Valley, B. C., & June 29,1921 & 95.5 & 62.5 & 16 \\
\hline 42111 & oim. & Kispiox Valley, B. C., & July $\quad 9,1921$ & 95.5 & 61.5 & 16.5 \\
\hline 42116 & ๆ & Kispiox Valley, B. C., & Sept. 8,1921 & 97.5 & ......... & 15.5 \\
\hline 14139 & & Warner Mts., Calif., & June 30,1910 & 97.5 & 63.5 & 17.5 \\
\hline 14140 & 우 & Warner Mts., Calif., & July $\quad 6,1910$ & 100 & 62 & 17 \\
\hline 27711 & 우 & Sierra Ancha, Ariz., & June 25,1917 & 100 & 67 & 17 \\
\hline
\end{tabular}

* Type of Dryobates pubercens glacialis Grinnell.

$\dagger$ Rectrices shortened by wear.

\section{Picoides arcticus (Swainson). Arctic Three-toed Woodpecker}

Not common. We had been in the region three weeks before seeing a three-toed woodpecker of either kind. Picoides arcticus and $P$. $a$. fasciatus were then both discovered, each in small numbers, and under precisely the same conditions. They were in the lowlands, but inhabit- 
ing the little muskegs that are scattered through the woods, well defined areas for which certain bird species showed a marked preference. No three-toed woodpeckers were seen on Nine-mile Mountain, though both species occur as a rule in the Hudsonian zone.

A nest of the Arctic tbree-toed woodpecker was found in Kispiox Valley. It was placed in a dead and charred Engelmann spruce, in a strip of spruce woods bordering a muskeg otherwise surrounded by poplar forest. The nest hole was eighty feet from the ground. It was two and one-half inches in diameter and one foot deep, drilled through an outer sheath of sound, hard wood, and downward through soft, rotten 'punk.' On July 3 it held one young bird nearly ready to fly, and a second, not much smaller, which had been dead for some days.

Four specimens collected (nos. 42.118-42121), the young female mentioned above, its female parent, and, at other times, two adult males.

Picoides americanus fasciatus Baird. Alaska Three-toed Woodpecker

Four specimens collected (nos. 42122-42125), one adult male and three adult females. They differ from Alaskan examples of fasciatus in the notable restriction of white dorsal markings. The white bars on the back are limited in extent and in only one specimen is there even a trace of the white coalescing longitudinally. All four, however, show white spots on rump and upper tail coverts, markings that are supposed to distinguish fasciatus from americanus.

\section{Sphyrapicus varius ruber (Gmelin). Red-breasted Sapsucker}

All through the valleys this species was far more abundant than I have ever found sapsuckers elsewhere. It is curious that there should be this abundance here; this must be near the outskirts of the range of the bird. Ruber is regarded primarily as a coastal species, yet nowhere on the coast is it found in sueh numbers. (On the southeastern Alaskan coast, near the Skeena River, it is doubtful if an observer would in a whole summer see twenty birds-the number counted near Hazelton in one forenoon.

During May and June a number of nests were found, mostly through seeing the old birds carrying food to the young. One was drilled in a live poplar, the tree a straight column with no branching limbs save at the very top, the nest some seventy feet from the ground. Another was in a dead birch, sixty feet up. Many others were noted, 
all in birch or poplar, mostly dead trees, and no nest was less than fifty feet above the ground. One male bird collected had the abdomen bare of feathers. It obvionsly had been incubating eggs.

The first young bird was seen flying about on July 7 . Shortly after, the species became notably scarce and few of the birds were observed through July and August. This, perhaps, was from some change in habits rather than a shifting of population. The first week in September numbers appeared once more. Several factors contribute to bring the sapsuckers conspicuously in view. They are assiduous drummers, on dead trees or on telegraph poles; they have querulous and noisy call notes, uttered near the nest; they are active flycatchers, using a telegraph pole or an isolated tree in a clearing as a base from which to fly.

Fourteen specimens collected (nos. 42126-42139). These are exactly like coastal birds in coloration, but differ in average bill structure. Compared with specimens from the nearby coast of southeastern Alaska, the Hazelton birds have the bill noticeably short and heavy. There is some overlapping in the two lots, for some Alaskan specimens have bills as short as some IIazelton birds. None of the latter series, however, has the long, slender bill that is generally characteristic of the Alaskan birds. Adult sapsuckers from the upper Stikine River (see Swarth, 1922, p. 220) have the same type of bill as the Hazelton birds. (For use of the name ruber for the northern subspecies of the red-breasted sapsucker see Swarth, 1912, p. 34.)

Phloeotomus pileatus picinus Bangs. Western Pileated Woodpecker

In June and again in late September, single birds were seen or heard several times near the base of Rocher Déboulé, southeast from Hazelton. This must be ahout the extreme northern limit of the species in this region. None was seen in Kispiox Valley, a few miles to the northward. One specimen collected (no. 42140), a male taken September 22.

Colaptes auratus borealis Ridgway. Boreal Flicker

Breeds abundantly in the lowlands, mostly in deciduous timber. Present when we arrived, May 25, and until our departure, September 26. During the last two weeks in August flickers were extremely searce; then, early in September, they suddenly appeared in numbers and remained abundant throughouit the month. 
Hazelton is near the western limit to which the yellow-shafted flicker might be expected to range; it cannot ioe far to the westward that the red-shafted flicker (Colaptes cafer cafer) occurs. It is of interest that, of the breeding specimens from Hazelton and Kispiox Valley, nearly all show traces of cafer blood. The four adult summer males collected all show more or less red in the normally black 'mustache.' In females the cafer characters are not so conspicuous, showing sometimes in a tinge of reddish in the quills, sometimes in certain details of body markings or color. In one case, wings and tail are nearly as red as in typical cafer. Some young males (nestlings) show red in the 'mustaches,' but not so conspicuously as do the adults.

The flickers that arrived so numerously in September were, I believe, migrants from the north, from a region far removed from any chance of admixture with cafer. Five collected at that time are all typically auratus-like in every detail. In all, twenty-eight yellowshafted flickers were collected (nos. 42141-42168). The series includes twelve nestlings, eight in one lot (the entire brood), and four from another brood that consisted of six in all.

\section{Chordeiles virginianus virginianus (Gmelin). Eastern Nighthawk}

Arrived at Hazelton, June 3. Fairly common in the lowlands thereafter until about the middle of August, when the birds began to disappear. Last seen August 31. Two specimens collected (nos. 42169-42170), adult male and female.

\section{Cypseloides niger borealis (Kennerly). Black Swift}

Abundant throughout the summer. Usually seen flving high overhead, seldom within gunshot of the ground. One specimen collected (no. 42171), an adult female, at Kispiox Valley, August 20.

\section{Chaetura vauxi (J. K. Townsend). Vaux Swift}

A few birds (perhaps three prirs) seen occasionally at a certain spot in the woods near Hazelton. Small flocks or single individuals noted at long intervals in Kispiox Valley. Last seen September 3. One specimen collected (no. 42172), an àdult male, July 20. 


\section{Selasphorus rufus (Gmelin). Rufous Hummingbird}

Abundant about Hazelton when we arrived, May 25. Frequenting gardens in the town and generally distributed through the lowlands. On Nine-mile Mountain a few hummingbirds were seen, perhaps ten or twelve all told during our stay (July 21-August 14); apparently all were young birds, wanderers from the valleys below. By the time we descended from the mountain, there were very few rufous hummingbirds left in the lowlands. No more old males were seen, and the last female or young was noted on August 18. Two specimens were 'collected, an adult male at Hazelton, Mav 30 (no. 42173), and an immature male on Nine-mile Mountain, August 4 (no. 42174).

\section{Tyrannus tyrannus (Linnaeus). Lastern Kingbird}

Two seen during the summer, an adult male taken near our Kispiox Valley camp on June 22 (no. 42175), and an adult female at Hazelton, July 20 (no. 42176). The first mentioned appeared to be in breeding condition. The Hazelton bird was first seen flying, approaching from a distance with all the appearance of a migrant. These captures constitute, I believe, an extreme northwestern point of record for this species.

Sayornis sayus yukonensis Bishop. Northern Say Phoebe

Apparently not breeding in this general region; at least, none was seen until the end of the summer. First noted, a single bird, August 23, obviously a migrant. Another on August 24 and two on August 26 make up the total number recorded. These four specimens (nos. $42177-42180$ ), two males and two females, are all in juvenal plumage. Besides these birds there are two other northern examples of this species in the collection of this Museum, an adult male from Fortymile, Yukon Territory (no. 4594) and a juvenal female from Sergief Island, Alaska (no. 39815). The adult has been described by Grinnell $(1909$, p. 206) as showing the characters ascribed to the subspecies Sayornis sayus yukonensis Bishop (1900, p. 115). The Sergief Island specimen has been recorded (Swarth, 1922, p. 224) as Sayornis sayus, with comment upon its appearance; it is exactly like the Kispiox Valley specimens. Altogether, this series, one adult and five juvenals, bears out Bishop's (loc. cit.) contention of the existence of a recognizable northern form of Sayornis sayus. In the young birds from the north, 
the darker color and the lack of rusty markings dorsally and on the wings, as compared with southern specimens, is constant and conspicuous. The northern adult differs in measurements and proportions from any southern skin.

Nuttallornis borealis (Swainson). Olive-sided Flycatcher

Not common, but occurring as scattered pairs throughout the lowlands. Present when we arrived, the last week in May. Last bird seen September 2. One specimen collected (no. 42181).

\section{Myiochanes richardsoni richardsoni (Swainson). \\ Western Wood Pewee}

Common in the lowlands, usually about clearings. On our first day in the field, May 27, wood pewees were fairly numerous. The last. was seen September 4. Six specimens collected, all breeding adults (nos. 42182-42187).

- Empidonax trailli alnorum Brewster. Alder Flycatcher

An inhabitant of willow thickets in lowland swamps. Not common, and so shy that the species could easily be overlooked were it not for the eall note. First arrival noted June 5; last bird seen August 24. Five specimens collected (nos. 42188-42192), three adult males, and two males in first winter plumage.

\section{Empidonax hammondi (Xantus). Hammond Flycatcher}

Abundant in the poplar woods of the lowlands. Present in numbers when we arrived, the last week in May, and almost up to the time of our departure. Early in September there was a marked diminution in numbers, but a few Hammond flycatchers appeared at intervals up to September 21, when the last one seen was collected. Ten specimens taken (nos. 42193-42202).

A nest (no. 1852) taken near Hazelton, June 16, contained two fresh eggs, probably an incomplete set. It is constructed outwardly of 'cotton' from the fireweed, and some plant fiber, and moss; the lining is of feathers and cattle hair.

A second nest (no. 1853), taken in Kispiox Valley, July 7, contained three slightly incubated eggs, a complete set. It was in a willow thicket at the edge of a small stream, about twenty feet from the 
ground, and welged between several limbs forming an upright crotch. This nest outwardly is composed mostly of finely shredded strips of bark; the lining is of eattle hair, with a few feathers of grouse and other birds. In each set the eggs are white, unmarked.

\section{Empidonax wrighti Baird. Wright Flycatcher}

In the lowlands, in just such surroundings as are frequented by Empidonax hammondi. The two species are so nearly alike in life as to be indistinguishable to the eye, but different call notes serve for identification. On this basis it may be said that $\boldsymbol{E}$. wrighti was rare, compared to the abundant hammondi. Three specimens, all adult, were collected (nos. 42203-42205) ; male, .June 27 ; female, August 17 ; female, August 25. The two August birds are still mostly in worn breeding plumage.

One nest was found in Kispiox Valley. It was in a small, isolated clump of willows, in an upright croteh formed by several dead limbs, and about ten feet from the ground. On July 4 it contained two eggs, just hatching.

\section{Otocoris alpestris arcticola Oberholser. Pallid Horned Lark}

In small numbers on the Alpine-Aretic summit of Nine-mile Mountain. The last week in July young birds were seen flying about. Three adults collected (nos. 42206-42208), a male and a female on July 31, a male on August 1. The males are well advanced in the annual molt, the female has hardly begun.

On September 22 four horned larks were seen flying overhead near Hazelton. This, evidently the beginning of the fall migration, was the only lowland occurrence observed.

\section{Cyanocitta stelleri annectens (Baird). Black-headed Jay}

A few seen the last week in May and early in June, toward the base of Rocher Déboulé, southeast of Hazelton. They did not act like nesting birds, and three specimens collected were evidently not breeding. In Kispiox Valley one appeared August 27, and thereafter, during September, they drifted through from time to time, usually single birds. On September 11 and 12 many were seen along the trail following the telegraph line some forty miles north of Hazelton. The last week in September they were fairly numerous near Hazelton, where we had seen them before in May. No black-headed jays were found on Nine-mile Mountain, where they might have been expected to breed. 
Sixteen specimens collected (nos. 42209-42224), twelve in fresh fall plumage. In this series there is considerable variation in the white spot over the eye, one of the diagnostic features of annectens. In nine specimens it is conspicuously present, in five it appears in slight degree, and in two it is absent. This series was collected at what must be practically the northern and western limits of the subspecies annectens, and variation such as that described is presumably indicative of intergradation toward the coastal subspecies, stelleri. In dorsal coloration this series is decidedly blackish, as compared with the brownish cast seen in comparable examples of stelleri; the blue areas are appreciably paler, more greenish. These differences are sufficiently marked to justify the allocation of the entire series to the subspecies annectens despite the variation shown in one particular. There is no adequate series of typical annectens available to show the extent of divergence from the ordinary body color in that race.

\section{Perisoreus canadensis canadensis (Linnaeus). Canada Jay}

Undoubtedly nests in the Hudsonian Zone on the mountains near Hazelton, descending into the lowlands in fall and winter. There werc a few Canada jays on the middle slopes of Nine-mile Mountain. A young bird shot there on July 23 had nearly finished the post-juvenal molt; an adult taken August 2 was nearly through the annual molt. A number seen forty miles north of Hazelton, September 12 , in Hudsonian Zone surroundings. One noted in Kispiox Valley, August 31, and several toward the base of Rocher Déboulé, southeast of Hazelton, September 22. Four specimens collected (nos. 42225-42228).

\section{Corvus brachyrhynchos hesperis Ridgway. Western Crow}

A few crows were seen in the immediate vicinity of Hazelton during the latter part of May and the first two weeks in June. None was seen later in the summer or at any other point. Four specimens collected, two adult males and two adult females (nos. 42229-42232).

\section{Agelaius phoeniceus arctolegus Oberholser. Northern Red-wing}

An immature male that was collected in Kispiox Valley, Septem- . ber 7 (no. 42233), was the only red-winged blackbird seen; its capture constitutes an extreme northwestern point of record for the species. This bird has a remarkably heavy bill. In depth of bill at base (.14 millimeters) it reaches the maximum of this measurement as given by Oberholser $(1907$, p. 335) in his description of the subspecies arctolegus. 


\section{Euphagus carolinus (Müller). Rusty Blackbird}

Fairly common in the lowlands about Hazelton and in Kispiox Valley, but so quiet and secretive during the nesting season as easily to be overlooked. A female shot June 4 had laid part of its set. On July 5 a flock of old and young together first appeared. An adult female shot August 20 had nearly finished the annual molt; an immature male taken September 9 had finished the post-juvenal molt. The species was present in abundance at the end of my stay, September 26. By the middle of September the birds had gathered into flocks of from twenty to fifty individuals. Thirteen specimens collected (nos. 42234-42246).

\section{Hesperiphona vespertina brooksi Grinnell.}

British Columbia Evening Grosbeak

Small flocks seen near Hazelton during the last week in May and the first week in June. No evidence of breeding was found. Three specimens collected, two adult males and one adult female (nos. 42247-42249). This, I believe, is the northernmost record for the species in British Columbia. (For characterization of the subspecies H. v. brooksi, see Grinnell, 1917, p. 20.)

\section{Carpodacus purpureus purpureus (Gmelin). Eastern Purple Finch}

Not found above the floor of the valley. Single birds and small flocks seen about Hazelton the latter part of May and in June; a female shot June 4 was incubating eggs. In Kispiox Valley, the latter part of August, purple finches were seen occasionally, the last on August 29. Seven specimens collected, four red males, one male in the streaked plumage, and two females. These are all typically of the subspecies purpureus.

\section{Loxia leucoptera Gmelin. White-winged Crossbill}

Small flocks (eight to twelve birds each) seen at Hazelton, June 14, in Kispiox Valley, July 8, and again near Hazelton the latter part of September. On Nine-mile Mountain (July 21 to August 14), whitewinged crossbills were present in small numbers in the hemlock forest immediately below timber line, that is, four or five individuals might be seen during a forenonn. This was evidently the nesting ground, as single males were spaced at intervals through the woods, and were in full song. Four specimens collected, three adult females and one adult male (nos. $42257-42260$ ). 


\section{Leucosticte tephrocotis littoralis Baird. Hepburn Rosy Finch}

Seen only on Nine-mile Mountain. Not abundant, or at any rate not seen frequently. An occasional small flock or a single bird might whirl overhead now and then, or the elusive call note might be heard faintly in a gust of wind, such as often prevailed about the crags and snow banks where the rosy finches dwelt. but the birds were seldom found feeding quietly. On July 26 three adults and three young (nos. 42261-42266) were collected from a flock of several times that number. The jurveniles were as large as their parents, and with wing and tail feathers grown to their full length, but they were still being fed by the old birds.

\section{Spinus pinus pinus (Wilson). Pine Siskin}

The most abundant species of bird in the Hazelton region, both in the lowlands and on the mountains, even above timber line. Present when we arrived, May 25, and at our departure, September 26. On July 19 an old bird was seen feeding a full-grown young one. Siskins were in flocks throughout the summer; there must have been many of the birds that were not breeding. Toward the end of summer the flocks increased in size. On Nine-mile Mountain, at the end of July, twenty-five to thirty was an average sized gathering; the middle of August, forty or fifty would be seen together; and by September 1 flocks numbering a hundred or more were of frequent occurrence. Two adults collected (nos. 42267-42268).

\section{Calcarius lapponicus alasicensis Rirgway. $\Lambda$ laska Longspur}

A fairly common fall migrant. Arrived in Kispiox Valley, September 1, and from then on, during September, small flocks were seen almost daily. Two specimens collected, immature males (nos. 42269$42270)$.

\section{Calcarius pictus (Swainson). Smith Longspur}

An immature male (no. 42271) collected in Kispiox Valley, August 25. This was undoubtedly a migrating straggler to this point. Whether the species breeds east of the Rocky Mountains in northern British Columbia is not known, but it may very well do so. The one previous record for the province is of a single bird taken at the summit of "Boundary Pass" (the extreme southeastern corner of British Columbia), May 15, 1858 (Blakiston, 1862, p. 6; 1863, p. 72). 
Calcarius ornatus (J. K. Townsend). Chestnut-collared Longspur̀

An adult female (no. 12272) in worn summer plumage collected in Kispiox Valley, July 8. I do not believe that this bird was breeding at the point where it was taken; it was most likely a wanderer that had straved far from the breeding grounds. This is an even more extraordinary occurrence than the capture of the Smith longspur six weeks later at the same place. The latter species is known to breed to the northeast of this region, and a slight deflection to the westward by a south-bound migrant would account for the stray we collected. The chestnut-collared longspur, however, is not known to breed nearly so far north as this in the interior: presumably it required a long flight to the northwest to bring this bird to the place where it was found. I believe that this is the first recorded occurrence of the species in British Columbia.

\section{Passerculus sandwichensis alaudinus Bonaparte.}

Western Savannah Sparrow

There were a few Sarannah sparrows migrating through Hazelton during the last week in May. In Kispiox Tralley a little later small numbers were breeding in hay ficlds and pastures. In the open country at the summit of Nine-mile Mountain (5000 to 5500 feet altitude) the species was breeding in fair abundance. In Kispiox Valley again, the third week in August, there was an influx of migrating Savannah sparrows; they came in swarms, reaching the maximum of abundance about the middle of September. Some were seen up to the day I left, September 26 .

Nineteen specimens collected (nos. 42273-42290, 42410) : at Hazelton, May 30, two, adult male and female; Kispiox Valley, adult female, July 9; juvenal male, July 12; two adult females, four immature females, three immature males, August 24 to September 10; Nine-mile Mountain, July 23 to 29 , three adult males, three adult females. The Nine-mile Mountain specimens are alaudinus; they are exactly like Savannah sparrows from more northern points in the interior of British Columbia and Alaska. The status of the Savannah sparrow breeding in the lowlands of the region cannot be settled at this time. The one adult collected that was actually breeding (no. 42275, female, Kispiox Valley, July 9), is of small size and with short, stubby bill. The two shot at Hazelton on May 30 were not breeding; they may or 
may not have been about to nest nearby. They, too, are of rather. small size and with short bill, as compared with typical alaudinus. The juvenal from Kispiox Valley, compared with young of alaudinus from Kotzebue Sound, is slightly darker colored and with noticeably more stubby bill. Savannah sparrows taken in Kispiox Valley during late August and early September are alandinus, presumably migrants from the northward.

To summarize: The Savannah sparrow breeding on the mountain tops of this region is Passerculus sandwichensis alaudinus. The Savannah sparrow breeding in the lowlands appears to be another race. Presumably it would be Passerculus sandwichensis brooksi (Bishop, 1915, p. 187), described from the lowlands of southern British Columbia. There is no series of brooksi available for comparison. For the present the entire series from the Hazelton region may be left under the name alaudinus. None of the lot bears any close resemblance to Passerculus sandwichensis savanna of the coast of southeastern Alaska, a short distance to the westward.

\section{Zonotrichia leucophrys gambeli (Nuttall). Gambel Sparrow}

A fairly common summer visitant, restricted to the lowlands. When we reached Hazelton, May 26, Gambel sparrows were evidently nesting. Singing males were established in many of the gardens in the town; elsewhere scattered pairs were encountered at rather wide intervals in sparse timber. In Kispiox Valley a few were seen early in July; by the middle of the month they had disappeared. This species is remarkably secrefive in its nesting. Specimens in the juvenal plumage were desired and special search made for them, but, although adults were seen in fair abundance, not only were no nests discovered but not a single young bird was seen. Then, the second week in July, came the apparent disappearance of the species for a period of several weeks. On August 24 a bird in first winter plumage was shot, the first of a migratory wave, and the next day the bushes were full of Gambel sparrows. These were all immatures, with brown head stripes; the first adult was seen September 1 . When I left, September 26, the species was still fairly abundant.

Six specimens collected (nos. 42291-42296), three adult males, one adult female, and two immature males. 
Zonotrichia coronata (Pallas). Golden-crowned Sparrow

Breeding in fair abundance above timber line on Nine-mile Mountain. When we arrived there (July 22) the young were out of the nest and flying about; the old birds could be seen singing from perches above the thickets in which they dwelt. Specimens in juvenal plumage were among our special desiderata and every effort was made to shoot them, but so wary were these young birds that we deemed ourselves lucky to get even the three we eventually collected. At the first sign of danger a loud chip from the parent sends every youngster within hearing scuitling for the nearest tangle of prostrate balsam, but not to remain there. A prompt retreat is made to the far side of the bush, followed quickly by flight to another thicket perhaps a hundred yards away. Pursuit is heralded by warning alarm notes from the parent, and the youngster again flees to another refuge. Further pursuit is generally useless. In fact, young birds were seen to go five hundred yards or more in one flight when followed up. Meanwhile, the old bird, perhaps joined by others, remains nearby, giving warning from some conspicuous perch, utterly indifferent to approach within a few yards. The warning chip of the adult golden-crowned sparrow was a familiar note in the balsam thickets along the ridges. It accompanied us nearly everywhere in our travels on the summit.

The extreme wariness of the young golden-crowned sparrow is a trait that receives emphasis from the fact that, when the first winter plumage is attained a few weeks later, these same young birds are peculiarly tame and unsuspicious. Then they will permit of close approach, will in fact come themselves to inspect the stranger in the woods.

The first migrating golden-crowned sparrow appeared in the lowlands, in Kispiox Valley, on September 1. For a short time thereafter they were fairly common.

Six specimens collected (nos. 42297-42302) : two adult males, two juvenal males, and one juvenal female from Nine-mile Mountain; one immature male from Kispiox Valley. The three young (collected July 25; 26) are in juvenal plumage throughout. They are heavily streaked above and below, save on the center of the abdomen, and are generally similar to the same stage in the various races of Zonotrichia leucophrys. Compared with juvenal Z. l. leucophrys, young coronata is darker throughout, the ventral streaking is darker, heavier, and more extensive, and the lateral crown stripes are less plainly indicated. 
Compared with young Z. 1. nuttalli (which is darker-colored than leucophrys), young coronata is again darker, more reddish dorsally, more heavily streaked ventrally, and with less plainly indicated crown stripes. Tip of bill and most of upper mandible is blackish; base of bill and most of lower mandible, yellowish. Feet are whitish; eyes dark.

\section{Zonotrichia albicollis (Gmelin). White-throated Sparrow}

An adult male (no. 42303), one of a mated pair, was collected in Kispiox Valley, June 21. The female was seen repeatedly at the same place, a partly cleared pasture with scattered thickets of second growth, and remained there up to the time of our departure, July 15. When we returned late in August, she had gone. This, I believe, is the farthest northwest that this species has been found.

\section{Spizella monticola ochracea Brewster. Western Tree Sparrow}

One specimen collected (no. 42304), an immature female at Kispiox Valley, September 13. This was evidently a forerunner of the fall migration; the species was not breeding in this general region.

Spizella passerina passerina (Bechstein). Eastern Chipping Sparrow

Fairly common in the lowlands about Hazelton when we arrived, May 26, and evidently settler upon the nesting ground. A female collected June 8 had laid part of its set; by the middle of July young out of the nest were seen. The chipping sparrows apparently leave for the south at an early date. By the middle of August their numbers had decreased markedly; one in juvenal plumage, collected August 22, was the last seen. The species was encountered only in the lowlands.

Eight specimens collected (nos. 42305-42312), two adult males, five adult females, one juvenal male. To my eye the chipping sparrow of northern British Columbia is much nearer to the eastern passerina in appearance and measurements than to typical arizonae.

\section{Junco hyemalis hyemalis (Linnaeus). Slate-colored Junco}

Seen, not abundantly, during the fall migration. The first was collected August 29; no more appeared until September 13. During the next two weeks they were encountered almost every day. Ten specimens collected (nos. 42316-42325), nine males and one female, all immatures in first winter plumage. 


\section{Junco hyemalis connectens Coues. Cassiar Junco}

There were a few of this species breeding in Kispiox Valley, twenty-three miles north of Hazelton, the extreme southern limit of the breeding range. Junco oreganus shufeldti was the common species, present in large numbers, but at least two pairs of connectens were observed, and they were evidently nesting. An adult male (no. 24313) was taken on June 22, and an adult female (no. 42314) with a juvenile (no. 42315) on July 9.

I expected to find connectens appearing in numbers at the beginning of the fall migration, but the slate-colored juncos that were collected at that time are nearly all like typical hyemalis rather than like our Stikine River serjes of connectens" (see Swarth, 1922, p. 243). One specimen (no. 42326), an immature male taken in Kispiox Valley, September 13, does appear to be connectens. The female of that form frequently is so much like female shufeldti in appearance that the two are distinguished in life with difficulty, which may be one reason why specimens were not taken.

\section{Junco oreganus shufeldti Coale. Shufeldt Junco}

Abundant near]y everywhere. On May 26, at Hazelton, a nest was found with eggs just hatching; on June 6 the first young were seen flying about. On July 19 a nest was found, just finished but with no eggs as vet, an unusually late date. On Nine-mile Mountain (July 21 to August 13) a great many juncos were seen, mostly spotted young, frequenting the open slopes and basins immediately above timber line. By the first week in September the molt had been accomplished by most of the juncos and they were then gathered in flocks of from ten to twenty birds. They were present, though in diminished numbers, when I left, the last week in September.

Fifty-four specimens collected (nos. 42327-42380) : eight breeding adults (seven males and one female), seventeen in juvenal plumage or undergoing the post-juvenal molt, three adult males and one adult female in winter plumage, and twelve males and thirteen females in immature (first winter) plumage.

This series from the Hazelton region may be taken as representative of conditions at the northwestern limit of the subspecies shufeldti. Breeding birds show a tendency toward Junco hyemalis connectens, of the country immediately to the northward, exhibited mostly in the grayer dorsum. The flocks of birds in fresh fall plumage yielded no 
specimens showing this sort of variation, but they did contain a percentage of individuals with a decided leaning toward Junco oreganus oreganus. This might be taken to indicate a slight.migratory: movement inland at the end of the summer from the region to the westward. Typical oreganus jnhabits the coastal region less than two hundred miles west of Hazelton. Some of the fall specimens taken, if collected on the coast, might be considered as oreganus; they come within the limits of variation of that subspecies, though not exhibiting oreganus characters in their extreme.

\section{Melospiza melodia morphna Oberholser. Rusty Song Sparrow}

In the immediate vicinity of Hazelton there is not much country suitable for this species and it occurs as scattered pairs in little swales or along small streams. In Kispiox Valley, in the marshes and pastures, it was abundant. None was seen in the mountains. Song sparrows were present, apparently paired and nesting, when we arrived at Hazelton, May 26. A young bird being fed by its parents was seen as late as August 29. By the third week in September the song sparrows were mostly gone; one was seen on September 23.

Twenty-one specimens (nos. 42381-42401) collected, as follows: six breeding adults, one adult in fresh fall plumage, eight immatures in first winter plumage, and six juveniles. (For use of the subspecific name morphna for the song sparrow of this region see Swarth, 1923, p. 214.)

\section{Melospiza lincolni lincolni (Audubon). Lincoln Sparrow}

Exceedingly numerous in the lowlands; next to the siskin probably the most abundant species of bird. There were some even at the summit of Nine-mile Mountain; young in juvenal plumage were seen there during the fourth week in .July.

At Hazelton, male birds singing in the gardens were noted May 30 ; a young bird just out of the nest was collected June 23; young in completely acquired first winter plumage were taken during the third week in August; an adult nearly through the annual molt, August 26. During the latter part of August, in Kispiox Valley, the species was peculiarly abundant. Fifteen or twenty might be routed out of a thicket at once, and some birds might be found at any point where one cared to search for them. By the second week in September their numbers had decreased markedly; the last was noted on September 14. 
Thirteen specimens collected (nos. 4.2402-42409, 42411-42415) : five breeding adults, one adult and four immatures in fresh fall plumage, and three birds in juvenal plumage.

\section{Passerella iliaca iliaca (Merrem). Eastern Fox Sparrow}

On September 14, two fox sparrows were shot from a flock of five or six flushed from a thicket. The two collected proved to be of the subspecies iliaca, and from the glimpses I had of the others they all appeared to be the same. The two specimens collected (nos. 42416, 42417) are females in completely acquired first winter plumage. One is typical of the subspecies itiaca in every respect. The second, though obviously of this same subspecies, is darker colored than the mode, and not so conspicuously streaked on the back. It is more nearly uniform reddish above. Near Hazelton, on. September 22, a single fox sparrow (no. 42418) was collected, an immature male. It is closely similar to the second bird just described, perhaps a trifle darker and more uniformly reddish. These birds were undoubtedly migrants from farther north.

The only previous record of the eastern fox sparrow in British Columbia is of a specimen collected at Sicamous, September 25, 1893 (Swarth, 1920, p. 118).

\section{Passerella iliaca altivagans Riley. Alberta Fox Sparrow}

Breeding, not abundantly, at and a little above timber line on Nine-mile Mountain. In the same general area as the golden-crowned sparrow and in similar surroundings, though not so much in the balsam thickets as in tangles of alder and veratrum. Constantly heard singing but so shy generally as to avoid observation. The young birds (July 22 to August 13) were flying about; mostly they were in process of change from juvenal to first winter plumage. In Kispiox Valley the first migrating fox sparrow of this subspecies appeared on August 29, and a few more were seen at intervals up to September 7 .

Fourteen specimens collected (nos. 42419-42432): on Nine-mile Mountain, two adults (male and female), six in juvenal plumage and in the post-juvenal molt; in Kispiox Valley, three males and three females, all in first winter plumage. These birds, though properly referred to altivagans (see Riley, 1911, p. 234), are not typical of that subspecies. In more uniform coloration above and in darker streaking below they show an unmistakable trend toward the darker coastal 
races whose habitat they approach so nearly. There is hardly a trace in any specimen of the obscure dorsal streaking seen in altivagans from more southern and eastern stations. The Kispiox Valley migrants are even more questionably referred to altivagans than the Nine-mile Mountain specimens. Our collecting station in that valley was northwest of Nine-mile Mountain. Migrating fox sparrows collected there must have traveled from somewhere still farther north, possibly from some region even nearer the coast. These migrating birds in appearance are not unlike some specimens of sinuosa. They differ in shape of bill and in harker, less reddish, coloration, especially dorsally. I believe that they are unquestionably intergrades between altivagans and the nearby coastal subspecies, fuliginosa. When such birds are taken far to the southward, in the winter habitat, it is admittedly difficult to recognize their true relationships (though similar specimens passing through my hands have been hesitatingly labeled altivagans), but in this case the place of capture affords a valuable clew. No undoubted specimens of sinuosa have been found migrating anywhere in the interior of Alaska or Pritish Columbia.

\section{Piranga ludoviciana (Wilson). Western Tanager}

Rather uncommon summer visitant in the lowlands. First noted near Hazelton on June 3, when two were seen ond others heard calling. Not more than ten or twelve, all told, seen during the summer, the latest on August 30. Four specimens collected (nos. 42433-42436), an adult male, and three immature males.

\section{Hirundo erythrogaster Boddaert. Barn Swallow}

A few pairs were nesting in buildings in Hazelton. Elsewhere, an occasional bird passing overhead was all that was seen. First noted on June 1. On July 20 small flocks were observed flying southward, apparently migrating.

\section{Iridoprocne bicolor (Vieillot). Tree Swallow}

Abundant in the lowlands, and already nesting when we reached Hazelton, May 26. Seen entering erevices in buildings in the town, and old woodpecker holes in trees elsewhere. Apparently migrates south at an early date for none was seen after our descent from the mountains, August 14. One specimen collected, an adult male (no. 42437). 
Tachycineta thalassina lepida Mearus. Northern Violet-green Swallow

The most abundant species of swallow. Like the tree swallow it was nesting when we arrived, the end of May, and, similarly, occupying sites in buildings in town and on the farms. Seen only in the lowlands. The latter part of August the species disappeared, and I supposed had already gone south, but on September 24 and 26 large flocks appeared circling about over Hazelton.

Stelgidopteryx serripennis (Audubon). Rough-winged Swallow

Breeds in small numbers about Hazelton and in Kispiox Valley, twenty-three miles to the northward. Present when we arrived, the end of May. Seen only in the lowlands, and not met with after our return from the mountains, the middle of August.

\section{Bombycilla garrula pallidiceps Reichenow. Bohemian Waxwing}

First seen in Kispiox Valley, July 5. Five birds appeared, and three were collected. They seemed to be birds that had finished nesting. Next encountered August 22, a fock of twenty or more at the same place. During the remainder of our stay flocks numbering from ten to twenty were seen occasionally, generally flying overhead, in. Kispiox Valley and about Hazelton. Five specimens (nos. 4243842442) were collected, all adults. One bird shot August 22 is just beginning the annual molt; another, taken August 27, is in the midst of it. Both these molting birds have new tail feathers (some of them less than half-grown) and in one specimen the yellow-marked wing feathers also are new. It is a curious fact that these yellow markings, especially those on the tail, are not so brilliant in these adult birds as they are in certain nestlings at hand. (For description of these young birds see Swarth, 1922, p. 279.) In the juveniles the tail band is decidedly orange, a color not seen in any other specimen examined, summer or winter. Winter flocks must be composed largely of young of the previous season, and the absence of any birds with orange colored tail band probably means that this color fades appreciably soon after the feathers get their growth. It seems strange, though, that similar changes cannot be traced in the rectrices of the adult.

There is a slight difference in the sexes of the Bohemian waxwing described by Tischler (1918, p. 85) that had apparently escaped the notice of earlier observers. In his opinion the only passably sure mark 
of difference lies in the coloration of the throat. In the males the black is darker, more extended and sharply separated from the rest of the underparts. In the females the throat patch is smaller, duller, and not so sharply delimited, fading more gradually into the gray of. the underparts. The present writer has tested this character on two occasions, series of Bohemian waxwings being laid out with the labels hidden from view, and the sexes then separated by the above criterion. In each case the division was made without a mistake.

(For use of the name pallidiceps see Reichenow, 1908, p. 191.)

\section{Bombycilla cedrorum Vieillot. Cedar Waxwing}

On June 17 a small flock was seen near Hazelton. Others were noted in Kispiox Valley a few days later; by the last week in June these flocks were breaking up into pairs. When we returned, the middle of August, nesting was finished and young and old were gathered in flocks once more. During the last two weeks in September cedar waxwings were seen daily about Hazelton.

Seven specimens collected, five adults and two juveniles (nos. 42443-42449). An old bird shòt August 22 is just beginning the annual molt; another collected September 5 has finished it. One young bird still in juvenal plumage throughout was collected September 5. One of the two juveniles has small but distinct red tips to four secondaries on each wing, whereas in four of the five adults these markings are utterly lacking.

\section{Vireosylva olivacea. (Iinnaeus). Red-eyed Vireo}

Fairly common in poplar woods near Hazelton. On the evening of June 7 the first arrival was heard singing; the next day a number were encountered. Hazelton is apparently the northern extreme reached by the red-eyed vireo, none being seen in Kispiox Valley, a few miles farther north. Five specimens collected, four adult males and one adult female (nos. 42450-42454).

\section{Vireosylva gilva swainsoni (Baird). Western Warbling Vireo}

Fairly common in the lowlands. Present when we reached Hazelton (May 26), and beginning breeding activities. On June 3 a warbling vireo was seen at work at a nest. The species remained in fair abundance through Angust, leaving rather abruptly at the end of that 
month. Last seen September 3. Eight specimens collected, five adult males, and twro males and one female in first winter plumage (nos. 42455-42462).

Vermivora celata celata (Say). Orange-crowned Warbler

An orange-crowned warbler in juvenal plumage (no. 42463), collected on the summit of Nine-mile Mountain, July 31, is either of the subspecies celata or orestera. The young of these subspecies are difficult to distinguish, but as no undoubted examples of orestera were taken I am ascribing this individual to the race celata, of which other specimens were collected. Celata may well have been breeding on Nine-mile Mountain, but the presence of this young bird cannot be taken as proof, for a juvenile lutescens also was collected during the same week. It is most unlikely that both subspecies were breeding there, but which (if either) was nesting, and which the migrant, was not ascertained.

Migrating celata first appeared in Kispiox Valley on August 26, and until September 14 was of daily occurrence. Eight specimens collected (nos. 42464-42471), three males and five females, all immatures in first winter plumage.

Vermivora celata Iutescens (Ridgwav). Lutescent. Warbler

A young lutescent warbler (commented upon above), in juvenal plumage throughout (no. 42472), was collected at the summit of Ninemile Mountain, July 24, an immature female in first winter plumage (no. 42473), in Kispiox Valley, August 28. These are all that were seen of this subspecies, and presumably they were migrants from the coast. It is possible, however, that lutescens occasionally breeds this far inland, at high altitudes. A bright colored warbler of this species (subspecies uncertain) was seen near Hazelton on May 27, among the .last of. the spring migrants to pass through.

\section{Vermivora peregrina (Wilson). Tennessee Warbler}

A rare summer visitant. A male bird was seen singing near .Hazelton on June 2, and another observed in a garden in the town on July 19. On June 22, in Kispiox Valley, a male (no. 42474) was collected, and his mate seen. On July 10, at the same place, a pair of Tennessee warblers was discovered making a great fuss over some young hidden in a thicket nearby. These were the total of records for the summer. 


\section{Dendroica aestiva rubiginosa (Pallas). Alaska Yellow Warbler}

Yellow warblers were extremely scarce, in notable contrast to the abundance in which I found them on the upper Stikine River, two hundred miles to the northward (see Swarth, 1922, p. 287). Furthermore, the yellow warbler of the upper Stikine is the eastern subspecies, $D$. aestiva aestiva, that of the upper Skeena is the coastal subspecies, $D$. aestiva rubiginosa. The scarcity of this bird in the migrations as well as in midsummer shows that the travels of aestiva to and from its more northern breeding ground follow a northwest-southeast line that lies to the eastward of Hazelton.

The first yellow warbler was seen near Hazelton on June 6 ; from then on a few were encountered from time to time through the summer. On June 23, in Kispiox Valley, a nest was found containing five eggs. On Nine-mile Mountain, the first week in August, several yellow warblers were seen, presumably migrants; during the latter part of the month a very few were observed migrating in Kispiox Valley, the last on August 22.

Five specimens (nos. 42475-42479) collected. 'Three breeding birds (one male and two females) are unequivocally rubiginosa. Two adult females just finishing the annual molt, taken August 19 and 22, respectively, are not so certainly of that subspecies. They may be migrating individuals of aestiva from farther north, but their molting condition and the lack of comparable specimens in the several subspecies precludes a decision.

\section{Dendroica coronata hooveri MeGregor. Alaska Myrtle Warbler}

Myrtle warblers had already passed through on their northward journey when we reached Hazelton, May 26. In the fall they appeared in numbers, abruptly; on September 10 the first one arrived, on the 11th they were abundant. They were still present when I left, September 26. Two specimens collected, immatures in first winter plumage (nos. 42480-42481).

Dendroica auduboni auduboni (J. K. Townsend). Aububon Warbler

Fairly common in the lowlands through the summer, both at Ilazelton and in Kispiox Valley to the northward; not seen at high altitudes. Present when we arrived, May 26, and apparently then in pairs. During the first week in September the Audubon warblers 
began to disappear. The last to be positively identified as such was seen on September 9, but Alaska myrtle warblers arrived from the north in numbers a day or two later and the two species are sufficiently alike so that a few Audubon warblers might have lingered somewhat later and been overlooked.

Thirteen specimens collected (nos. 42482-42494): nine summer adults (six males, three females). three males in first winter plumage, and one male in juvenal plumage. These birds were taken at the northernmost points at which the Audubon warbler has been found. Two hundred miles farther north, in the T'elegraph Creek region, it is replaced by the Alaska myrtle warbler, there near its southern limit (see Swarth, 1922, p. 289). Comparing the two series, auduboni from the upper Skeena Valley and hooveri from the upper Stikine Valley, there cannot be seen the least approach of one to the other. Specimens of anduboni from its northern limit are exactly like others from California; specimens of hooveri from its southern limit show no departure from the characters of specimens from northern Alaska. The two species, though closely related, evidently preserve their distinctness where their ranges most closely adjoin. It would be interesting to ascertain if there is any place between Hazelton and Telegraph Creek where both species breed. A hybrid between the two has been described (Taylor, 1911).

Dendroica magnolia (Wilson). Magnolia Warbler

Fairly common summer visitant to the lowlands about Hazelton, where it arrived June 3. In Kispiox Valley, June 21 to July 15, it was decidedly rare, not more than five or six birds being seen in that period of time. At the same place when the migration began, the third week in August, magnolia warblers became more numerous and they were seen daily up to the first week in September. Last noted on September 5. Six specimens collected (nos. 42495-42500), two adult males, one adult female, two immature males, one immature female.

\section{Dendroica striata (J. R. Forster). Plack-poll Warbler}

Two immature males (nos. 42501-42502), migrants, were collected in Kispiox Valley on August 18 and September 1, respectively. No others' were seen. 


\section{Dendroica townsendi (J. K. Townsend). Townsend Warbler}

This species may have been breeding in the Hudsonian Zone on Nine-mile Mountain. Two were seen there, one observed in hemlock woods just below timber line on July 30, and one collected on August 5. The latter is still largely in juvenal plumage. Townsend warblers appeared in Kispiox Valley the latter part of August, migrating. First seen August 27, and thereafter, in swall numbers, until September 15. Four specimens collected (nos. 42503-42506), one young bird from Nine-mile Mountain and three immature females from Kispiox Valley.

Seiurus noveboracensis notabilis Ridgway. Grinnell Water-thrush

Breeding in fair abundance along marshy streams in Kispiox Valley. A young female mostly in juvenal plumage was collected July 14 ; a young male but slightly more advanced in the post-juvena! molt was taken August 27. Seven specimens in all collected (nos. 42507-42513), the two juveniles mentioned, two adults (male and female), and three in first winter plumage (two males, one female).

Oporornis tolmiei (J. K. Townsend). MacGillivray Warbler

Abundant summer visitant to the lowlands; one of the commonest birds of the region. First seen on June 6 though possibly present at an earlier date. A nest with four eggs (no. 1856) was found in Kispiox Valley on June 22. Remained in considerable numbers until September; last seen September 14. Three specimens collected (nos. 42514-42516), adult male, adult female, and one bird in first winter plumage.

\section{Geothlypis trichas occidentalis Brewster. Western Yellowthroat}

Breeding in fair abundance in Kispiox Valley, but secretive in habit and easily overlooked. Last seen September 12. Eleven specimens collected (nos. 42517-42527), two adults (male and female), four males and four females in first winter plumage, and one male in juvenal plumage. 


\section{Wilsonia pusilla pileolata (Pallas). Pilealated Warbler}

On May 26 and 27 (our first days at Hazelton), pileolated warblers were migrating abundantly through that region. They then abruptly disappeared, one shot on May 30 being the only other one seen in the spring, and were not found breeding anywhere in the lowlands. An adult male shot near the summit of Nine-mile Mountain, July 30, was just beginning the annual molt. It was one of two birds seen together, perhaps a mated pair nesting there. An immature male taken at the same place August 11 was in first winter plumage throughout, and may have been a migrant. The three were the only birds of this species seen upon the mountain.

The first migrant appeared in Kispiox Valley on August 19. Pileolated warblers were then fairly common until the first week in September; the last was seen September 11. Six specimens in all collected (nos. 42528-42533) : two adult (summer) males, one adult male in fresh fall plumage, and three immature males.

\section{Setophaga ruticilla (Linnaeus). American Redstart}

Abundant in the lowlands. Present when we reached Hazelton, May 26, and in increasing numbers during the next few days. Several nests were found in Kispiox Valley late in June and early in July, all very similar in structure and location. The usual site was an upright fork of willow or alder, from eight to fifteen feet from the ground. The supporting branches were generally so large as nearly to conceal the tiny nest, or else to make it appear as part of the fork. Nests were in exposed situations more often than in thick shrubbery, sometimes in dead branches, but nevertheless, because of this peculiarity of construction, they were not easy to see. One nest collected (no. 1857, Kispiox Valley, June 27) contained four eggs ; others examined held either two eggs or two young birds.

Redstarts remained in fair abundance until the end of August; the last was seen September 8. Unlike some species, of which the adults leave ahead of the young, sometimes before the molt, the adult redstarts seemed to linger quite as late as the juveniles. The adult males, of course, are readily distinguishable, contrary to the rule covering most small birds in the fall, and the number that were seen justifies the statement. An adult female was collected August 29, an adult male September 7. Thirteen specimens in all taken (nos. 42534 42546). 


\section{Anthus rubescens (Tunstall). Pipit}

A large flock that was seen near Hazelton on May 26 was the last migrating band to pass through. The species was next encountered on the summit of Nine-mile Mountain, where it was breeding in small numbers. A special effort was made there to get birds in the juvenal plumage, but the young were extremely wary, in striking contrast to the tameness of their parents, and only one was collected. Pipits reappeared in the lowlands, in Kispiox Valley, on September 2, and were seen in fair abundance there and at Hazelton until September 20.

In Kispiox Valley, September 4, two pipits were collected, the two together and not otherwise accompanied. One was still mostly in juvenal plumage. The other, in fully acquired winter plumage, I assumed to be an attending parent, but on dissection it proved to be an immature bird. The occurrence is of interest, first, as indicating that a young bird still in juvenal plumage can start to migrate and travel a considerable distance, for the juvenal mentioned must have come a long way from where it was hatched, if only from the nearest mountain top; and secondly, as demonstrating the early age at which a young bird can care for itself, independent of its parents.

Pipits in late March and early April undergo an extensive molt whereby the breeding plumage is acquired. In this plumage the upper parts are grayish, compared with the brown winter plumage, and the lower parts cinnamon buff. The female, as compared with the male, is less gray (more brownish), above, and more heavily spotted below. The cinnamon is evanescent, and by the end of July has almost all faded away. Then, by the fall molt, in late August and early September, the winter plumage is acquired, differing from the breeding garb in being brown above and more heavily streaked below, but, in both old and young, distinctly cinnamon tinged ventrally. Again the cinnamon fades out and by the end of November the birds are dull brown above, and whitish, streaked with dusky below, as we usually see them in their winter home.

Thirteen specimens collected (nos. 42547-42559).

\section{Dumetella carolinensis (Linnaeus). Catbird}

On June 10 a catbird was shot within a stone's throw of the railroad station at Hazelton. This bird (no. 42560) was an adult male and in breeding condition, but his mate was not seen,.nor was any other of the species encountered during the summer. This, I believe, is a material extension northwestward of the range of this species. 


\section{Troglodytes aedon parkmani Audubon. Western House Wren}

An adult male (no. 42561) was collected in Kispiox Valley on July 2, the only one seen during the summer. It had the appearance of a breeding bird. This is considerably farther north than the species has heretofore been found in British Columbia.

\section{Nannus hiemalis pacificus (Baird). Western Winter Wren}

Breeding in dense spruce woods on the higher slopes of Nine-mile Mountain. Young out of the nest were seen July 30, and the same day an adult was encountered that was carrying feathers as though engaged in nest building. Winter wrens appeared in the lowlands at the end of the summer. First noted in Kispiox Valley on September 10; others were seen at intervals during the rest of the month. Three specimens collected (nos. 42562-42564), an adult and two juveniles from Nine-mile Mountain.

\section{Certhia familiaris occidentalis Ridgway. Tawny Creeper}

One in juvenal plumage taken on Nine-mile Mountain, July 29; on August 28 a creeper was seen in Kispiox Valley. These are all that were noted during the summer. The specimen collected (no. 42565) is nearest C. f. occidentalis in appearance, though not so reddish above as extremes of that subspecies.

\section{Sitta canadensis Ijinnaeus. Red-breasted Nuthatch}

Breeds in small numbers in the lowlands and more abundantly at high altitudes. On Nine-mile Mountain some were seen daily in the hemlock forest just below timber line. A nest was found in Kispiox Valley, placed in a dead stub at the edge of rather dense poplar woods. The stub was perhaps four or five inches in diameter at the base, and was broken off about twenty feet from the ground. The nest hole was near the top and was about one and one-half inches in diameter. On July 12 it contained at least two young birds, nearly ready to fly, whose heads could be seen protruding from the opening. They called incessantly, uttering the characteristic nasal yang of the species until either parent appeared, when this was changed to a hissing and squalling, like most other young birds appealing for food.

In August and September red-breasted nuthatches became fairly common in the lowlands, frequently seen in company with chickadees, kinglets, or migrating warblers. One specimen collected (no. 42566), an adult male taken in Kispiox Vallev, July 2. 


\title{
Penthestes atricapillus septentrionalis (Harris).
}

\author{
Long-tailed Chickadee
}

Of general distribution in the lowlands though nowhere abundant. Not encountered in the mountains. One specimen still in the juvenal plumage was collected on September 5, but by the last week in August both adults and young had for the most part finished the molt. At that time the species seemed much more abundant than earlier in the year; a flock of chickadees usually served as a nucleus around which were gathered a few individuals of various other species, such as kinglets, warblers, and nuthatches. Seven specimens collected (nos. 4.2567-42573).

\section{Penthestes gambeli abbreviatus Grinnell.}

\section{Short-tailed Mountain Chickadee}

Seen only on Nine-mile Mountain, in spruce and hemlock woods just below timber line, at about 4500 feet altitude. Small flocks seen, on July 30 and again on August 10. Two specimens collected, an adult male (no. 42574) in extremely worn plumage, shot on July 30, and a juvenile female (no. 42575), collected on August 10. (For use of the name abbreviatus see Grinnell, 1918, p. 510.)

Penthestes hudsonicus columbianus (Rhoads). Columbian Chickadee

Found only near the summit of Nine-mile Mountain. On July 30 and on August 10 Hudsonian chickadees were seen, each time in company with mountain chickadees. Four specimens collected (nos. 42576-42579), a male and three females, all in juvenal plumage. Eight adults at hand from more southern points in British Columbia (Okanagan, Edgewood, Gold Range, Pearson Mountain, and Mabel Lake) bear out the color characters ascribed to the subspecies columbianus (Rhoads, 1893, p. 23 ; Ridgway, 1904, p. 414) and thus justify the use of that name for the British Columbia Hudsonian chickadee. There are no young birds at hand from the known habitat of columbianus, nor any of typical hudsonicus, for comparison with the young birds taken on Nine-mile Mountain. The last mentioned, however, are appreciably darker colored than adult hudsonicus and of about the same shade as columbianus, so it seems safe to regard them as columbianus. 


\section{Penthestes rufescens rufescens (J. K. Townsend) \\ Chestnut-backed. Chickadee}

Apparently occurs this far inland as a rare migrant in late summer. On August 24 two were seen in Kispiox Valley and one (no. 42580) was collected, a male in juvenal plumage. On September 23 a small flock was encountered near Hazelton and one bird (no. 42581) was shot, a male in first winter plumage.

Regulus satrapa olivaceus Baird. Western Golden-crowned Kinglet

Breeds in small numbers in the lowlands near Hazelton and more abundantly in the nearby mountains. In the valley an occasional pair found shelter in spruces growing about little muskegs, and some were seen in a dense stand of cedar toward the base of Rocher Déboulé. On Nine-mile Mountain the species was rather more abundant; by the end of July flocks of old and young together appeared near our camp. In Kispiox Valley, the second week in September, flocks of goldencrowned kinglets were frequently encountered. Two specimens collected, an adult male near Hazelton, June 3 (no. 42582), and a juvenile male on Nine-mile Mountain, July 31 (no. 42583).

\section{Regulus calendula calendula (Linnaeus). Ruby-crowned Kinglet}

In manner of occurrence about the same as the golden-crowned kinglet. In the lowlands, an occasional ruby-crown was heard singing in spruces about the muskegs; on Nine-mile Mountain the species was a little more abundant, in spruce and hemlock forests immediately below timber line. In Kispiox Valley an influx of ruby-crowned kinglets began about September 1. They were not numerous, but one or two could usually be found in the mixed flocks of chickadees and warblers that were then traveling through the woods. Some were seen up to the day of my departure, September 26.

Ten specimens collected (nos. 42584-42593), two adult males and one adult female from Kispiox Valley in June and July, two (male and female) in juvenal plumage from Nine-mile Mountain, and one adult female and one male and three females in first winter plumage from Kispiox Valley in September. These are indistinguishable from specimens of the eastern ruby-crowned kinglet from Illinois and Connecticut. They are not the puler-colored $R$. c. cineraceus of the sierras of California. 


\section{Myadestes townsendi (Audubon). Townsend Solitaire}

Extremely rare, though as one was seen in Kispiox Valley on June 24, the species probably breeds in the region. Others seen on September 2, September 13 (two birds), and September 17, make up the total of observations. One specimen collected (no. 42594), an immature male taken in Kispiox Valley on September 2.

\section{Hylocichla ustulata swainsoni (Tschudi). Olive-backed Thrush}

Common in the lowlands; not seen at high altitudes. The first arrival was heard singing on June 1 ; on June 3 olive-backed thrushes were everywhere in the woods. In August they became very scarce, so much so that none was seen for some weeks and I supposed they had already gone south. Then, the last week in August a few reappeared, and, while not abundant, one or two were seen almost daily. until late in September. The last was noted on September 21. Eleven specimens collected (nos. 42595-42605), six adult males, two adult females, and three immature males in first winter plumage.

\section{Hylocichla guttata guttata (Pallas). Alaska Hermit Thrush}

There were a few hermit thrushes on Nine-mile Mountain, breeding in the spruce and hemlock forest immediately below timber line. The song was heard occasionally and at longer intervals a glimpse was caught of one of the birds flitting through the dense shrubbery. Two specimens collected (nos. 42606-42607), both adult males, taken on July 29 and August 10, respectively. They are essentially like breeding birds from the upper Stikine River, and, as with the latter series, are not to be referred to Hylocichla guttata sequoiensis, a name that has been applied to the hermit thrush of this general region (see Swarth, 1922, p. 303).

\section{Hylocichla guttata pallasi (Cabanis). Eastern Hermit Thrush}

During the second week in September a very few migrating hermit thrushes appeared in the woods of Kispiox Valley. Two were shot September 10, and others seen up to September 14. The two collected (nos. 42606, 42607), both immature males in first winter plumage, are obviously not the same as the breeding bird of this region, and appear to be best referred to the eastern subspecies, Hylocichla guttata pallasi. They are not so bright reddish dorsally as are most eastern specimens, but they are distinctly more reddish than guttata, they are larger than guttata, and they have the buffy flanks of pallasi. The subspecies 
pallasi has been reported as breeding at Lac La Hache, British Columbia (Rhoads, 1893, p. 58), and as migrating at Quesnelle (Brooks, 1903, p. 284).

\section{Planesticus migratorius migratorius (Linnaeus). Eastern Robin}

Found everywhere in the lowlands; absent from the dense woods of the middle altitudes on the mountains, but reappearing in the open country above timber. When we reached Hazelton, May 26, robins were already sitting on eggs. The first young out of the nest appeared on June 16 ; by July 1 spotted young were about in numbers. During the second and third weeks in August there was a notable scarcity of robins; by September 1 an influx of migrants had set in, and soon they were as numerous as ever. During the third week in September the southward exodus was in full swing. Day after day migrating flocks of robins trailed overhead, in loosely assembled companies and flying at a great height. There were a good many still around though, up to the time of my departure, September 26.

Eighteen specimens collected (nos. 42610-42627): six breeding adults (four males and two females), seven birds in the spotted juvenal plumage or in the post-juvenal molt, two adult males in fresh winter plumage, and one male and two females in first winter plumage.

I have ascribed this series to the subspecies migratorius, the form to which on the whole it bears closest resemblance, but there is considerable individual variation, with obvious intergradation toward the coastal subspecies caurinus. It might be that further collecting would show such intergradation to be mostly in breeding birds from this region, while September migrants, presumably from more northern points, are closer to typical migratorius. However, spotted young: from the Hazelton region are more nearly like young migratorius than like caurinus at the same stage.

\section{Ixoreus naevius naevius (Gmelin). Varied Thrush}

Ixoreus naevius meruloides (Swainson). Northern Varied Thrush

One family of varied thrushes was found in a lowland locality, in Kispiox Valley. They were in a grove of huge cottonwood trees bordering the Kispiox River, a dark, gloomy place, grown up underneath the trees with an impenetrable tangle of devil's-club, thimble-berry, and alder, in appearance just such a jungle as this thrush frequents on the coast. Here, on June 22, a brood of young, out of the nest, were being attended by their parents. The old male was collected (no. 42628). 
There were a few varied thrushes breeding on Nine-mile Mountain, in the dense woods just below timber line. An adult female (no. 42629 ) collected there on July 23 had laid part of its set.

The two specimens unentioned above, the only breeding birds collected, belong to the coastal subspecies, naevius. At the end of the summer, migrating varied thrushes of another sort appeared. The first was seen September 1, a week later they were abundant, and there were numbers in the woods about Hazelton (mostly feeding in the sumac bushes) when I left, September 26. These migrating varied thrushes, judging from three males collected (nos. 42630-42632), were of the subspecies $I$. n. meruloides.

\section{Sialia currucoides (Bechstein). Mountain Bluebird}

A summer visitant to the lowlands, not abundant but of general distribution in the more open country. Present and in pairs when we arrived at Hazelton, the last week in May. The first young bird out of the nest was seen July 4. In August the species disappeared from sight, but early in September a few migrating bluebirds appeared from time to time, and they continued to be seen until September 22, when the last was observed.

Three specimens collected, all adult males (nos. 42633-42635).

\section{CHECK IIST OF' THE MAMMALS}

1. Sorex personatus personatus I. Geoffroy.

2. Sorex obscurus obscurus Merriam.

3. Microsorex eximius (Osgood).

4. Myotis longicrus fongicrus (True).

5. Mustela cicognani richardsoni Bonaparte.

6. Mustela vison energumenos (Bangs). .

7. Peromyscus maniculatus borealis Mearns.

8. Neotoma cinerea saxamans Osgood.

9. Synaptomys borealis dalli Merriam.

10. Phenacomys intermedius Merriam.

11. Evotomys gapperi saturatus Rhoads.

12. Microtus drummondi (Audubon and Bachman).

13. Microtus mordax mordax (Merriam).

14. Ondatra zibethica spatulata (Osgood).

15. Zapus saltator Allen.

16. Zapus hudsonius hudsonius (Zimmermann).

17. Erethizon epixanthum nigrescens Allen.

18. Marmota caligata oxytona Hollister.

19. Marmota monax petrensis Howell.

20. Eutamias amoenus ludibundus Hollister.

21. Lepus americanus columbiensis Rhoads. 


\section{GENERAL ACCOUNTS OF THE MAMMALS}

Sorex personatus personatus T. Geoffroy. Masked Shrew

Six specimens collected (nos. 32526, 32528-32530, 32543, 32552), three from Hazelton and three from Kispiox Valley. A female taker at Hazelton on June 7 contained nine embryos.

For identification of the three species of shrews collected, I am indebted to Dr. Hartley H. T. Jackson of the United States Biologieal Survey.

\section{Sorex obscurus obscurus Merriam. Dusky Shrew}

Twenty-two specimens from Hazelton (nos. 32527, 32531-32542, $32544-32551,32788$ ), six from Kispiox Valley (nos. 32553-32558), and eleven from Nine-mile Mountain (nos. 32559-32569). According to Jackson there are some specimens from each locality that show an approach to Sorex setosus Elliot in cranial characters.

On Nine-mile Mountain shrews were trapped on a steep slope just above timber line ( 4500 to 5000 feet altitude), in dense growths of veratrum, lupine, and grass.

\section{Microsorex eximius (Osgood). Osgood Shrew}

A specinien of Microsorex (no. 32570) that was collected near Hazelton on June 8 has been provisionally identified by Jackson as M. eximins. It measures in millimeters as follows: total length, 88 ; tail vertebrae, 28 ; hind foot, 10.

Myotis longicrus longicrus (True). Northwestern Long-legged Bat

Two specimens collected, one at Hazelton, June 18 (no. 32571), and one in Kispiox Valley, July 9 (no. 32572). The Hazelton specimen was found, freshly killed, on the ground under a telephone line. At that point the wire was strung through timber and not easily seen amid the trees, but even so it is noteworthy that this bat should have collided with it. The wire had struck the upper part of the breast: and had cut through to the spine; the animal was all but cut in two.

The Kispiox Valley specimen was dislodged from a crack in the trunk of a dead poplar, felled for firewood. The first few blows of 
the axe sent it fluttering out, quickly to take refuge in a similar crevice in a nearby tree. Small bats were seen occasionally up to August 21, but not many and always late at night.

Mustela cicognani richardsoni Bonaparte. Richardson Weasel

Five specimens taken (nos. 32573-32577), four males and one female, all from Kispiox Valley. These exhibit the cranial characters of richardsoni, as contrasted with the subspecies alascensis of the coast. (see Merriam, 1896, p. 13). Besides skull variation, there are color differences distingujshing the forms in the summer pelage. The five Kispiox Valley specimens are of a dark, dull brown, close to raw umber, the underparts almost pure white. The alascensis series at hand (thirteen summer skins from the coast of southeastern Alaska), are more reddish, the brightest colored specimens close to auburn, and the underparts are often strongly tinged with yellow.

Weasels are probably fairly abundant in the region, for, besides those collected, others were seen at various times. On July 5 one was encountered in the daytime, carrying a freshly killed Drummond meadow mouse. The weasel dropped his prey and escaped in the tall grass; the meadow mouse on examination was found to have the marks of four tiny canine teeth, two in the base of the skull, above, and two in the neck just below the skull. Weasels sometimes took mice from our traps, and, acting on this hint, we were able to catch several in steel traps baited with mice or birds.

\section{Mustela vison energumenos (Bangs). British Columbia Mink}

One specimen (no. 32578, adult male) collected in Kispiox Valler, September 4. It is a dark-colored animal, similar to others at hand from the lower Taku River and Wrangell, Alaska, the upper Stikine River, and Seattle. (In this connection see Swarth, 1922, p. 163.)

\section{Peromyscus maniculatus borealis Mearns.}

\section{Northern White-footed Mouse}

Thirty-seven specimens collected near Hazelton (nos. 3257932615), twelve in Kispiox Valley (nos. 32616-32627), and ten on Ninemile Mountain (nos. 32628--32637).

The series as a whole is so nearly intermediate between Peromyscus maniculatus borealis and $P$. $m$. macrorhinus that neither name is 
satisfactory to use. There are some differences apparent between the series from the three different localities. Among the mice taken at Hazelton there is a preponderance of small, short-tailed, brightcolored specimens (borealis-like) and there are no large, long-tailed individuals. From Kispiox Valley and Nine-mile Mountain there are certain large, long-tailed, dark-colored specimens (macrorhinus-like), and there is none that is as near typical borealis as are some specimen. in the Hazelton series. The darker colored mice differ from typical macrorhinus in their duller shares; they lack the rich brown apparent in coastal specimens of macrortinus.

Skulls, also, in size and character are variously intermediate between borealis and macrorhinus. There is individual variation, notably in the series from Nine-mile Mountain, some skulls being generally long and slender, especially as regards the rostrum, others more short and broad.

The differences between the series from Hazelton and those from Kispiox Valley and Nine-mile Monntain are not obviously correlated with geographic position; for Hazelton, with the more borealis-like mice, is nearest the habitat of macrorhimus, and in a broad valley that Jeads direct to the coast.

Individual variation obtains in each series to a notable extent. Relative length of tail is a conspicuously variable feature, apparent as soon as the animals were handled. Other variations appeared upon closer study. It may be suggested that two distinct forms are represented in the series under discussion, but in contravention to this idea is the fact that the several distinguishing characters of either subspecies are not always uniformly developed in the same specimen. Size, color, length of tail, and character of skull, are the characters used in differentiating these races, and some individuals possess certain features more nearly like one subspecies, some that are more nearly like the other.

It will take many specimens representing numerous localities in northern and central British Columbia, to demonstrate the distribution and relationships of the forms of Peromyscus maniculatus occurring in that general region. In the nortbern interior of the province is borealis, on the northern coast is macrorhinus, at the southwest is oreas, and at the southeast, artemisice. These subspecies are distinct enough at the centers of their respective ranges, but at the edges of their habitats there are many difficulties in the way of satisfactory allocation of specimens. It will require an immense amount of detailed work to 
arrive at an understanding of conditions. Osgood (1909, pp. 50, 52, 59) has commented upon the situation and pointed out some of the difficulties. If, as he asserts, there are places where two subspecies occur together, each in typical form, the problem is even more involved than appears from my own material. I did not find this to be the ease in the critical regions worked on the Skeena River or on the Stikine River (see Swarth, 1922, p. 164).

TABLE 2

Measurements in Milismeters (Average, Minimum, and Maximum) of AdULT Peromyscus

\begin{tabular}{|c|c|c|c|c|}
\hline & & $\begin{array}{l}\text { Total } \\
\text { length }\end{array}$ & $\begin{array}{c}\text { Tail } \\
\text { vertebrae }\end{array}$ & $\begin{array}{l}\text { Hind } \\
\text { foot }\end{array}$ \\
\hline $\begin{array}{l}\text { Peromyscus } \mathrm{m} \text {. borealis } \\
\qquad(10 \text { spec. })\end{array}$ & Telegraph Creek, B.C. & $\begin{array}{c}170.2 \\
(158-192)\end{array}$ & $\begin{array}{r}75.3 \\
(65-105)\end{array}$ & $\begin{array}{c}20.2 \\
(19-22)\end{array}$ \\
\hline $\begin{array}{l}\text { Peromyscus } \mathrm{m} \text {. borealis } \\
\quad \text { (10 spec.) }\end{array}$ & Hazelton, B.C. & $\begin{array}{c}176.5 \\
(170-186)\end{array}$ & $\begin{array}{r}87.3 \\
(75-95)\end{array}$ & $\begin{array}{c}20.6 \\
(19.5-22)\end{array}$ \\
\hline $\begin{array}{l}\text { Peromyscus } \mathrm{m} \text {. borealis } \\
\quad(8 \text { spec.) }\end{array}$ & Kispiox Valley, B.C. & $\begin{array}{c}192.8 \\
(186-210)\end{array}$ & $\begin{array}{r}97.0 \\
(88-106)\end{array}$ & $\begin{array}{c}22.0 \\
(21-24)\end{array}$ \\
\hline $\begin{array}{l}\text { Peromyscus } \mathrm{m} \text {. borealis } \\
\quad \text { (10 spec.) }\end{array}$ & Nine-mile Mt., B.C. & $\begin{array}{c}190.0 \\
(168-214)\end{array}$ & $\begin{array}{r}99.0 \\
(79-121)\end{array}$ & $\begin{array}{c}22.1 \\
(21-23)\end{array}$ \\
\hline $\begin{array}{l}\text { Peromyscus m. macror- } \\
\text { hinus (10 spec.) }\end{array}$ & SE. Alaska. & $\begin{array}{c}203.3 \\
(197-218)\end{array}$ & $\begin{array}{c}108.2 \\
(104-116)\end{array}$ & $\begin{array}{c}24.3 \\
(23-26)\end{array}$ \\
\hline
\end{tabular}

Neotoma cinerea saxamans Osgood. Northern Bushy-tailed Wood Rat

Seven specimens collected (nos. 32699-32705) : three adults and two juveniles on Nine-mile Mountain; one adult and one juvenile in Kispiox Valley. They are indistinguishable from specimens from the Stikine River and all are apparently typical of the subspecies saxamans.

The local distribution of the bushy-tailed wood rat in this region presents some puzzling features. The animals are abundant in the mountains, where they are preëminently rock dwellers, and it is an easy matter to find sign of their presence in such surroundings. The valleys generally are covered with forest, with dense underbrush beneath the trees, and there are vast areas where no rock formation of any sort is to be seen. In such woods I was never able to find wood rat sign. In many places in these poplar-covered lowlands, however, ranching has been attempted, ground has been cleared and cabins 
erected, and wherever a cahin is built the wood rats take prompt possession. Where they come from is not evident, their natural habitations in the poplax woods not being visible, but they are abundant enough to be a decided nuisance.

\section{Synaptomys borealis dalli Merriam. Dall Lernming Mouse}

One specimen (no. 32641) was trapped in a Phenacomys runway at the summit of Nine-mile Mountain (5500 feet altitude), on August 10. Synaptomys andersoni was described from the interior of British Columbia to the northward of this regon (Allen, 1903, p. 554), and S. chapmani from the Selkirk Range of sonthern British Columbia (Allen, 1903, p. 555), but there probably is not sufficient material extant anywhere to determine the validity of these species. The one lemming mouse at hand from Nine-mile Mountain did not seem to me sufficiently different from the specimens of dalli in the collection of the Museum of Vertebrate Zoology to justify the use of another name. Mr. A. Brazier Howell, to whom I forwarded the specimen, making comparison with more extensive series in the United States National Museum, came to the same conclusion.

\section{Phenacomys intermedius Merriam. Kamloops Phenacomys}

On the summit of Nine-mile Mountain the extensive masses of false heather (Cassiope mertensiana) were in places criss-crossed with well defined runways much like meadow-mouse paths in appearance. Thesc runways occurred at scattered intervals, usually in patches of cassiope that were greener than elsewhere, as about the edges of snow banks or little lakes, and they favored also places where there were breaks in the ground, such as a little earth bank or some protruding rocks. They connected tiny holes that ran back into the ground or under rocks; here and there round nests were found, eight or ten inches in diameter, made of soft grass and moss, and not unlike birds' nests in appearance. At intervals there were piles of faeces, in extraordinary amount. Fresh faeces and green cuttings of grass and cassiope were evidence that the runways were in use, but trapping brought meager results. One Phenacomys, one Synaptomys, and one Evotomys was the sum total of two weeks' trapping. The runways I took to be the work of Phenacomys, for I had never found similar trails elsewhere where I had trapped the other two species that were taken here. 
The specimen of Phenocomys above mentioned (no. 32639) was an adult male, taken August 28 at an altitude of about 5500 feet. Two young males (nos. 32638, 32640) were trapped on July 26 and August 11., respectively, in growths of lupine and veratrum just at timber line (about 4500 feet), near our camp.

I am indebted to Mr. A. Brazier Howell for the identification of these three specimens of Phenacomys.

\section{Evotomys gapperi saturatus Rhoads.}

\section{British Columbia Red-backed. Mouse}

Found in small numbers in poplar woods at Mission Point, near Hazelton, where eight specimens (nos. 32642-32649) were trapped from June 2 to June 18. Trapping in similar surroundings in Kispiox Valley produced no red-backed mice. One specimen (no. 32650) was taken at the summit of Nine-mile Mountain, about 5500 feet elevation, in a Phenacomys runway.

I am indebted to Mr. A. Brazier Howell for the identification of this series of Evotomys.

\section{Microtus drummondi (Audubon and Bachman).}

Drummond Meadow Mouse

Seventeen specimens collected at Hazelton, twelve in Kispiox Valley, and one on Nine-mile Mountain (nos. 32651-32681). Apparrntly of general distribution in the lowlands, though not abundant at any point where we trapped. The single sperimen from Nine-mile Mountain was caught in a tangle of grass and veratrum just at timber line, about 4500 feet altitude. It was the only one of the species that was seen at that point.

Microtus mordax mordax (Merriam). Cantankerous Meadow Mouse

Six specimens, four adult and two juvenile (nos. 32682-32687) trapped at timber line on Nine-mile Mountain. The species was not found in the lowlands. The four adults are distinctly dark colored as compared with mordax from the upper Stikine River, and while the series is too small for satisfactory comparison, it apparently illustrates intergradation between mordax of the interior and macrurus of the coast, such as we found in the meadow mice of the lower Stikine (see Swarth, 1922, p. 175). 


\section{Ondatra zibethica spatulata (Osgood). Northwestern Muskrat}

Fairly common in Kispiox Valley, where three adults and eight young (nos. 32688-32698) were collected in August and September. These specimens are decidedly dark colored, compared with Alaskan skins, and are probably intermediate toward osoyoosensis. In external measurements also they are similarly intermediate according to the figures given by Hollister (1911, pp. 22, 25).

\section{Zapus saltator Allen. Stikine Jumping Mouse}

Twenty specimens collected near Hazelton, three in Kispiox Valley, and one on Nine-mile Mountain (nos. 32706-32728, 32731). All are adult. Our latest lowland capture of Zapus was on July 13, and up to that time apparently no young were yet born. No nursing females were caught, and only two that were pregnant, one taken on June 14 containing five small embryos, one on .June 16, containing six. The one specimen from Nine-mile Mountain (adult female, July 27) was eaught in a thick growth of veratrum just above timber line, at about 4500 feet altitude. It is small, compared with lowland specimens, but dies not otherwise depart from the characters of saltator, and this small size may indicate nothing more than an extreme of variation in the species.

This series of Zapus saltator from the Skeena Valley, compared with a somewhat larger series from the upper Stikine Valley, presents no obvious points of difference. In each lot there is considerable variation in color, a number of specimens being noticeably grayish, as compared with a larger proportion of reddish-colored ones.

\section{Zapus hudsonius hudsonius (Zimmermann).}

\section{Hudson Bay Jumping Mouse}

Two specimens taken near Hazelton, an adult male on June 15, an adult female on June 18 (nos. 32729, 32730). These were caught in the same trap line with the more numerous Zapus saltator. They were submitted for identification to Mr. Edward A. Preble, of the United States Biological Survey, who remarks that he "cannot separate them from typical hudsonius." In this connection it is of interest to recall the capture by the present writer of a jumping mouse of the Zapus hudsonius group (tentatively identified as $Z$. $h$. alascensis), on Revillagigedo Island, Alaska (see Swarth, 1911, p. 135), which island is 
about eighty miles north of the mouth of the Skeena River. Much collecting must be done, and in localities as yet unworked, before an understanding can be reached regarding the distribution and relationships of the species of Zapus occurring in the northwest, but certain ideas of Mr. Preble, expressed to me in a letter, seem to point so surely toward a solution of the problem, in its general features, that $\mathrm{I}$ append his comments here.

I believe $Z$. saltator to be related to $Z$. princeps, a supposition which is borne out in a measure by its distribution in northern British Columbia. There it supplements in some degree the Rocky Mountain distribution of $Z$. princeps, reaching the coast from the mouth of the Skeena northward. The $Z$. hudsonius group has evidently intruded into British Columbia from the east, being represerited by the colony named $Z$. tenellus, and by your Hazelton specimens. Doubtless it covers a wide area. Your Revillagigedo Island (Portage Bay) specimen may represent an intrusion from the north, where $Z$. hudsonius (or alascensis) is common. Zapus h. alascensis, though recognizable in its typical form, is a rather faintly characterized subspecies, and the Portage Bay specimen, like the Hazelton ones, is very elose to typical hudsonius.

\section{Erethizon epixanthum nigrescens Allen. Dusky Porcupine}

Porcupines were abundant at timber line on Nine-mile Mountain. The lowlands are doubtless visited frequently during the winter months, but in summer the species seems to be rather closely restrieted to the Hudsonian Zone of the higher mountains. Rock slides, just above the limit of upright timber, evidently form the preferred habitat. The animals were numerous enough to be a decided nuisance. They are nocturnal for the most part, and but few were seen abroad in daylight; activities began at dusk, and during the three weeks we spent upon the mountain there was not one night when we were not disturbed by visiting porcupines.

Three specimens were preserved: no. 32755 , skin and skull; no. 32757, skin and skull; no. 32756, complete skeleton. All are adrut males. There was great variation in color among the animals we saw; the two skins preserved were taken as representing extremes of light and dark coloration. Number 32757 is very dark, black in general effect, and is doubtless the same sort of animal as served as the type of Erethizon epixunthum nigrescens Allen. Number 32755. yellowish in general appearance, is not to be distinguished in color from four California specimens at hand.

Porcupine skulls are said to exhibit great individual rariation (see Hollister, 1912b, p. 27), but as far as our series goes, there are cranial characters which can be used to differentiate the animals of British 
Columbia and California. In the skulls from British Columbia the nasals are short and the zygomata are rather evenly bowed for their whole length. The skulls from California have longer nasals, and straight, angular zygomata. In the four skulls from California, a straight edge (such as a rule) laid alongside the zygomatic arch will touch the bone for distances of from 20 to 33 millimeters. In the skulls from British Columbia the contact is from 10 to 15 millimeters. There is not much individual variation among the specimens in each series, the four skulls from California, on the one hand, and the three from Nine-mile Mountain on the other. Porcupines from the coast of southeastern Alaska have skulls that most nearly approach the British Columbia type of structure. One from Telegraph Creek, upper Stikine River, is closely similar to the specimens from Nine-mile Mountain.

\section{Marmota caligata oxytona Hollister. Robson Hoary Marmot}

Abundant on Nine-mile Mountain, at timber line and higher. Occupied burrows were mostly in the rock slides, but not invariably so. Some were found on sunny slopes that were not especially rocky, one or two in dense spruce woods (not far from openings), and a number that were hidden in thickets of prostrate balsam above the limit of upright timber. Young marmots, a quarter-grown or less, were seen during the last week in July. Two such youngsters with their parent were in view daily at the mouth of a burrow a stone's throw from our camp.

Five marmots (nos. 32760-32764) were collected, three adult males and two young females. Besides these I exarnined eight or ten Indian robes made of about thirty marmot skins each, all from animals killed in the general vicinity of Hazelton. Skins from this region are dark colored ventrally, compared with average caligata from the coast of Alaska, and, in the five specimens from Nine-mile Mountain, there is almost complete elimination of the white mark found between the eyes in caligata. Otherwise, marmots from the Hazelton region are not markedly different from caligata in coloration. The skulls of the specimens from Nine-mile Mountain show the elongation attributed to oxytona (Hollister, 1912a, p. 1; Howell, 1915, p. 63), as compared with the broader skull of caligata. Thus marmots from the Hazelton region appear to be intermediate between caligata and oxytona, much like the former in general coloration, like the latter in skull characters. 


\section{Marmota monax petrensis Howell. British Columbia Woodchuck}

A resident of the lowlands of the Hazelton region; possibly common but, from its shyness and the nature of its surroundings, difficult to see. We collected two specimens in Kispiox Valley, all that we encountered, and were told of several others seen nearby. The two collected were an adult female (no. 32758), taken August 21, and a male of the previous year (no. 32759), on September 8. The year following our visit to the region four additional specimens (nos. 32965-32968, three males and one female), were sent me by an acquaintance, Mr. Charles Lindahl, who shot them at the same locality, in May, 1922.

TABLE 3

Mgasurfments IN MiLLimeters of SKells of Marmnta monax petrensis from Kispiox VALLEY, B. C.

\begin{tabular}{l|c|c|c|c|c|c|c|c|c|c}
\hline \hline & $\begin{array}{c}\text { Condylo- } \\
\text { basal } \\
\text { length }\end{array}$ & $\begin{array}{c}\text { Palatal } \\
\text { length }\end{array}$ & $\begin{array}{c}\text { Pcst } \\
\text { palatal } \\
\text { ength }\end{array}$ & $\begin{array}{c}\text { Length } \\
\text { of } \\
\text { nasals }\end{array}$ & $\begin{array}{c}\text { Zygo- } \\
\text { matic } \\
\text { breadth }\end{array}$ & $\begin{array}{c}\text { Breadth } \\
\text { across } \\
\text { mas- } \\
\text { toids }\end{array}$ & $\begin{array}{c}\text { Least } \\
\text { inter- } \\
\text { orbital } \\
\text { breadth }\end{array}$ & $\begin{array}{c}\text { Breadth } \\
\text { of } \\
\text { rostrum }\end{array}$ & $\begin{array}{c}\text { Maxil- } \\
\text { lary } \\
\text { tooth } \\
\text { row }\end{array}$ \\
\hline 32758 & $\circ$ & 81.8 & 48.5 & 30.0 & 31.5 & 56.0 & 39.8 & 21.0 & 16.0 & 19.2 \\
32968 & $\circ$ & 80.3 & 47.8 & 29.8 & 32.5 & 55.0 & 39.5 & 20.0 & 14.8 & 20.0 \\
32759 & $\sigma^{7}$ & 75.8 & 45.2 & 27.0 & 31.2 & 53.8 & 38.2 & 19.0 & 14.2 & 18.5 \\
32965 & $\sigma^{7}$ & 85.0 & 50.0 & 30.5 & 34.0 & 56.8 & 40.5 & 21.2 & 15.2 & 19.0 \\
32966 & $\sigma^{7}$ & 82.5 & 49.0 & 29.0 & 32.0 & 57.0 & 40.0 & 20.2 & 14.0 & 19.2 \\
32967 & $\sigma^{7}$ & 78.5 & 46.0 & 29.0 & 30.5 & 55.0 & 40.0 & 20.0 & 15.0 & 21.0 \\
\hline
\end{tabular}

*Estimated.

Howell (1915), upon the basis of skulls without skins, ascribes to Marmota monax ochracea a range extending south to the Babine Mountains and Stuart Isake, a little southeast of the place where we were collecting. Our specimens, however, are not ochracea; in color at least they are widely different from that subspecies. Five of the six are almost uniformly black. The one in 'normal' pelage is in markings closely similar to a Wisconsin specimen of rufescens at hand, though darker colored throughout; it has not the cinnamon-colored tail of ochracea.

The five black skins came all from the same small clearing on the Kispiox River, but nevertheless the melanism exhibited by them is not to be regarded as peculiar to a limited strain, a single family group. We were told by several people that most of the lowland woodchucks of this general region were black, and that it was only an occasional one that showed the yellow-brown type of coloration. Of 
the five black skins, the four taken in May are black throughout save for a more brownish appearance upon the head. The September skin has an infusion of chestnut on neck and shoulders, and scattered white hairs elsewhere.

We had slight opportunity of observing the habits of this woodchuck, but we were told that the preferred habitat was in clearings, such as were afforded by abandoned ranches. All our specimens came from such places.

\section{Eutamias amoenus ludibundus Hollister.}

\section{Canadian Mountain Chipmunk}

Occurs in small numbers in the vicinity of Hazelton. Chipmunks came to the barns and corrals at Mission Point, where we were camped, in fair abundance, attracted by the scattered grain, and they were seen also in the burned over areas toward Rocher Déboulé, but they were absent from the dense woods that cover most of this region. None was seen in Kispiox Valley nor on Nine-mile Mountain.

Five specimens were collected (nos. 32732-32736). These were identified by Mr. A. H. Howell, of the United States Biological Survey.

\section{Sciurus hudsonicus picatus Swarth. Northwest Coast Red Squirrel}

Twelve red squirrels were collected near Hazelton, five in Kispiox Valley, and one on Nine-mile Mountain (nos. 32737-32754). The squirrel of this region, as exemplified in the series collected, is referable to the coastal subspecies picatus; in just one specimen (no. 32742, Hazelton, June 6) is there shown any intergradation toward hudsonicus, of the interior.

Squirrels collected about Hazelton during the last week in May, one even as late as June 2, were in winter pelage throughout; one taken on June 16 was in complete summer pelage. Squirrels in the lowlands had entirely finished the molt by the end of June. One that was shot at timber line ( 4000 feet) on Nine-mile Mountain on August 2 was about midway through the change. (For the use of the name Sciurus hudsonicus picatus see Swarth, 1921, p. 92.) 
Lepus americanus columbiensis Rhoads.

\section{British Columbia Varying Hare}

Twenty-two specimens collected (nos. 32765-32786) : sixteen summer adults (skins with skulls), four juveniles, one skeleton (without skin), and one flat winter skin without skull (the gift of an acquaintance). This series seems with fair certainty to belong to the subspecies columbiensis (though collected far north of the known range of that form), judging from the characterization of the northwestern hares given by Nelson (1909), and from the appearance of a single specimen (no. 33412), an adult female, taken at Vernon (the type locality of columbiensis), November 6, 1922. Specimens from the Hazelton region are essentially like this topotype of columbiensis, due allowance being made for seasonal difference. The Skeena Valley hares are small for macfarlani, occurring immediately to the northward (see table of measurements), and, also, in summer pelage the feet are brown. According to Nelson (op. cit., pp. 49, 50, 86), in macfarlani the feet in summer pelage are white, in columbiensis they are brown.

Considerable field. work and study is still required to arrive at art understanding of the distribution of the species of Lepus in British Columbia. Thus, the type locality of Lepus americanus columbiensis is Vernon, British Columbia. Nelson records $L$. a. columbiensis from Vernon (1909, p. 104), and L. bairdi cascadensis from 'Okanagan' (op. cit., p. 114). Vernon and Okanagan are practically the same locality, Vernon being the principal town in the Okanagan Valley. There is no town of Okanagan, though there is a locality called Okanagan Landing some four miles south of Vernon. Thus Nelson in his text has $I$. bairdi cascadensis and $L$. americanus columbiensis occurring at the same place; in the map of the ranges of these animals (op. cit., p. 85, fig. 8) they are not shown to overlap. If the two forms actually do occur together in any one locality it is a matter of some importance, as bearing upon their specific distinction (see Nelson, op. cit., pp. 84, 85).

There is at hand a specimen of Lepus (no. 32789), an adult female, collected by the writer near Okanagan Landing, October 1, 1921, that differs in color and skull from the Hazelton hares and from the specimen from Vernon referred to above, and it is apparently Lepus bairdi cascadensis. There mav be local differences of environment 
separating the two species in this region, or their ranges may really overlap for some distance. More data are required to establish the actual conditions.

We happened to visit the Skeena Valley in a "good rabbit year" and the animals were abundant everywhere in the lowlands. None was seen at high altitudes. In the poplar woods the ground was conspicuously crisscrossed with rabbit trails, and these trails were in constant use. The rabbits themselves were most often encountered about dusk; at that time, too, in a walk through the woods there could be heard again and again the resounding thumps of rabbits' feet, as the startled creatures fled unseen. This alarm note, usually

TABLE 4

MEASUREMENTS IN MLLLIMETHRS OF Lepus americanus columbiensis FROM THE UPPER SkeENa VALleY, B. C.

\begin{tabular}{|c|c|c|c|c|c|}
\hline & & $\begin{array}{l}\text { Total } \\
\text { length }\end{array}$ & $\begin{array}{c}\text { Tail } \\
\text { vertebrae }\end{array}$ & $\underset{\text { foot }}{\text { Hind }}$ & $\begin{array}{c}\text { Ear from } \\
\text { notch }\end{array}$ \\
\hline 32776 & $\sigma^{7}$ & 438 & 46 & 130 & 76 \\
\hline 32778 & $\sigma^{7}$ & 450 & 58 & 133 & 70 \\
\hline 32779 & $\sigma^{7}$ & 420 & 42 & 130 & 77 \\
\hline 32782 & $\sigma^{7}$ & 451 & 45 & 132 & 65 \\
\hline 32777 & 우 & 466 & 55 & 138 & 75 \\
\hline 32780 & q & 439 & 41 & 130 & 70 \\
\hline 32785 & 웅 & 445 & 40 & 133 & 70 \\
\hline
\end{tabular}

repeated many times, presumably serves some good purpose, but it seemed as though in this region it could act only as a guide for some pursuing horned owl that otherwise would have had difficulty in following its prey through the bushes.

By the middle of June young rabbits were seen in some numbers, but we found it impossible to shoot them. They were much more active than the adults, and in the tangles of windfall and brush where we saw them, usually close underfoot, they could dart under cover with amazing speed. The juveniles collected were all trapped.

Adults taken early in June still retained some of the white winter pelage. One collected on June 6 is pure white below, the feet are white (with pale cinnamon under-fur), and there are scattered white hairs on the rump and sides. The white lingers longest upon the feet, traces being seen even upon one or two rabbits that were shot in July.

Pregnant females taken on June 1, June 12, and July 11, contained, respectively, eight, one, and five embryos. 
By the middle of August rabbits were noticeably less abundant than they had been a month earlier. Then, too, we began to find them dead in the trails, evidently from some disease. It seemed apparent that they were beginning to suffer from the ravages of the epidemic that periodically reduces the northern rabbits, though from all accounts their numbers locally had not yet reached the maximum that was to be expected. This was but the second year of increase since the last period of scarcity, we were told."

\section{IITERATURF CITED}

ALLEN, J. A.

1903. Mammals collected in Alaska and northern British Columbia by the Andrew J. Stone expedition of 1902. Bull. Am. Mus. Nat. Hist., $19,521-567$.

AMERICAN ORNithologists' UNion Committee.

1910. Check-list of North American birds. Ed. 3, revised (New York, American Ornithologists' Union), 430 pp., 2 maps.

1912. Sixteenth supplement to the American Ornithologists' Union checklist of North American birds. Auk, 29, 380-387.

1920. Seventeenth supplement to the American Ornithologists' Union checklist of North Ameriean birds. Auk, 37, 439-449.

BISHOP, L. B.

1900. Descriptions of three new birds from Alaska. Auk, 17, 113-120.

1915. Description of a new race of Savannah sparrow and suggestions on some California birds. Condor, 17, 185-189.

Ri:AKISTON, T. W.

1861-1862. On birds collected and observed in the interior of British North America. Ibis, October, 1861, pp. 314-320; January, 1862, pp. 3-10.

1863. On the birds of the interior of British North America. Ibis, January, pp. 39-87; April, pp. 121-155.

Prooks, A.

1903. Notes on the birds of the Cariboo District, British Columbia. Auk, 20, 277-284, pl. X.

Clark, A. H.

1910. The birds collected and observed during the cruise of the United States Fisheries Steamer "Albatross" in the North Pacific Ocean, and in the Bering, Okhotsk, Japar, and Eastern seas, from April to December, 1906. Proc. U. S. Nat. Mus., 38, 25-74.

Dresser, H. E.

1871-1896. A history of the birds of Europe, including all the species inhabiting the western Palaearctic region (9 vols.), 7 , viii +660 , col. pls. 456-544, text figs.

GRINNELL, J.

1910. Birds of the 1908 Alexander Alaska expedition, with a note on the avifaunal relationships of the Prince William Sound district. Univ. Calif. Publ. Zool., 5, 361-428, pls. 33-34, 9 figs. in text. 
1917. The subspecies of Hesperiphona vespertina. Condor, 19, 17-22, text figs.

1918. The subspecies of the mountain chickadee. Univ. Calif. Publ. Zool., 17, 505-515, 3 figs. in text.

1923. The status of the Rocky Mountain downy woodpecker in California. Condor, 25, 30-31.

FIoLLISTER, N.

1911. A systematic synopsis of the muskrats. U.S. Dept. Agr., Biol. Surv., N. Am. Fauna, 32, 47 pp., 6 pls.

1912a. New mammals from Canada, Alaska, and Kamchatka. Smithson. Misc. Coll., 56, no. 35, 8 pp., 3 pls.

1912b. Mammals of the Alpine Club expedition to the Mount Robson region. Canadian Alpine Journal, special number,.pp. 1-44, pls. 1-12.

HowELL, A. H.

1915. Revision of the American marmots. U.S. Dept. Agr., Biol. Surv., N. Am. Fauna, 37, 89 pp., 15 pls., 3 figs. in text.

Meinertzhagen, $R$.

1921. Some preliminary remarks on the velocity of migratory flight among birds, with special reference to the Palaearctic Region. Ibis, April, pp. 228-238.

MERRIAM, C. H.

1896. Synopsis of the weasels of North America. U. S. Dept. Agr., Div. Ornith. and Mam., N. Am. Fauna,. 11, 44 pp., 5 pls., 16 figs. in text.

NGLson, E. W.

1909. The rabbits of North America. U. S. Dept. Agr., Biol. Surv., N. Am. Fauna, 29, 314 pp., 13 pls., 19 figs. in text.

OBERHOLSTR, H. C.

1904. A revision of the American great horned owls. Proc. U. S. Nat. Mus., 27, 1.77-192.

1907. A New Agelaius from Canada. Auk, 24, 332-336.

OGILVLF-GRANT, W. R.

1893. Catalogue of the game birds (Pterocletes, Gallinae, Opisthocomi, Hemipodii) in the collection of the British Museum. Catalogue of Birds, 23, xvi + 585 pp., 8 pls., text figs.

Osgoon, W. H.

1909. Revision of the mice of the American genus Peromyscus. U. S. Dept. Agr., Biol. Surv., N. Am. Fauna, 28, 285 pp., 8 pls., 12 figs. in text.

Reichenow, A.

1908. Neue Vogelarten. Ornith. Monatsber., 16, 191.

RríADS, S. N.

1893. Notes on certain Washington and British Columbia birds. Auk, 10, $16-24$.

RJDGWAY, R.

1904. The birds of North and Middle America. U.S. Nat. Mus. Bull., 50, pt. III, $\mathbf{x x}+801$ pp., 19 pls.

1914. Idem, pt. VI, xx +882 pp., 36 pls.

RILEY, J. H.

1911. Descriptions of three new birds from Canada. Proc. Biol. Soc. Wash., 24, $233-236$. 
1912. Birds collected or observed on the expedition of the Alpine Club of Canada to Jasper Park, Yellowhead Pass, and Mount Robson region. Canadian Alpine Journal, special number, pp. 47-75, pls. $1-2$.

SWANN, H. K.

1922. [Remarks upon a visit to American museums.] Bull. Brit. Ornith. Club, $42,65-68$.

SWARTH, H. S.

1911. Birds and mammals of the 1909 Alexander Alaska expedition. Univ. Calif. Publ. Zool., 7, 9-172, pls. 1-6.

1912. Report on a collection of birds and mammals from Vancouver Island. Univ. Calif. Publ. Zool., 10, 1-124, pls. 1-4.

1920. Revision of the avian genus Passerella, with special reference to the distribution and migration of the races in California. Univ. Calif. Publ. Zool., 21, 75-224, pls. 4-7, 30 figs. in text.

1921. The red squirrel of the Sitkan district, Alaska. Jour. Mammalogy, 2, 92-94.

1922. Birds and mammals of the Stikine River region of northern British Columbia and southeastern Alaska. Univ. Calif. Publ. Zool., 24, 125-314, pl. 8, 34 figs. in text.

1923. The systematie status of some northwestern song sparrows. Condor, 25, 214-223, 1 fig. (map).

TAYLOR, W. P.

1911. An apparent hybrid in the genus Dendroica. Univ. Calif. Publ. Zool., 7, 173-177.

TISCHLER, F.

1918. Die Geschlechtsunterschiede beim Seidenschwanz (Bombycilla garrula).

Ornith. Monatsber., 26, 85-89. 



\section{EXPLANATION OF PLATES}

\section{PLATE 9}

Rocher Déboulé Mountain from Hazelton; the Bulkley River in the foreground. Photograph taken September 26, 1921. 


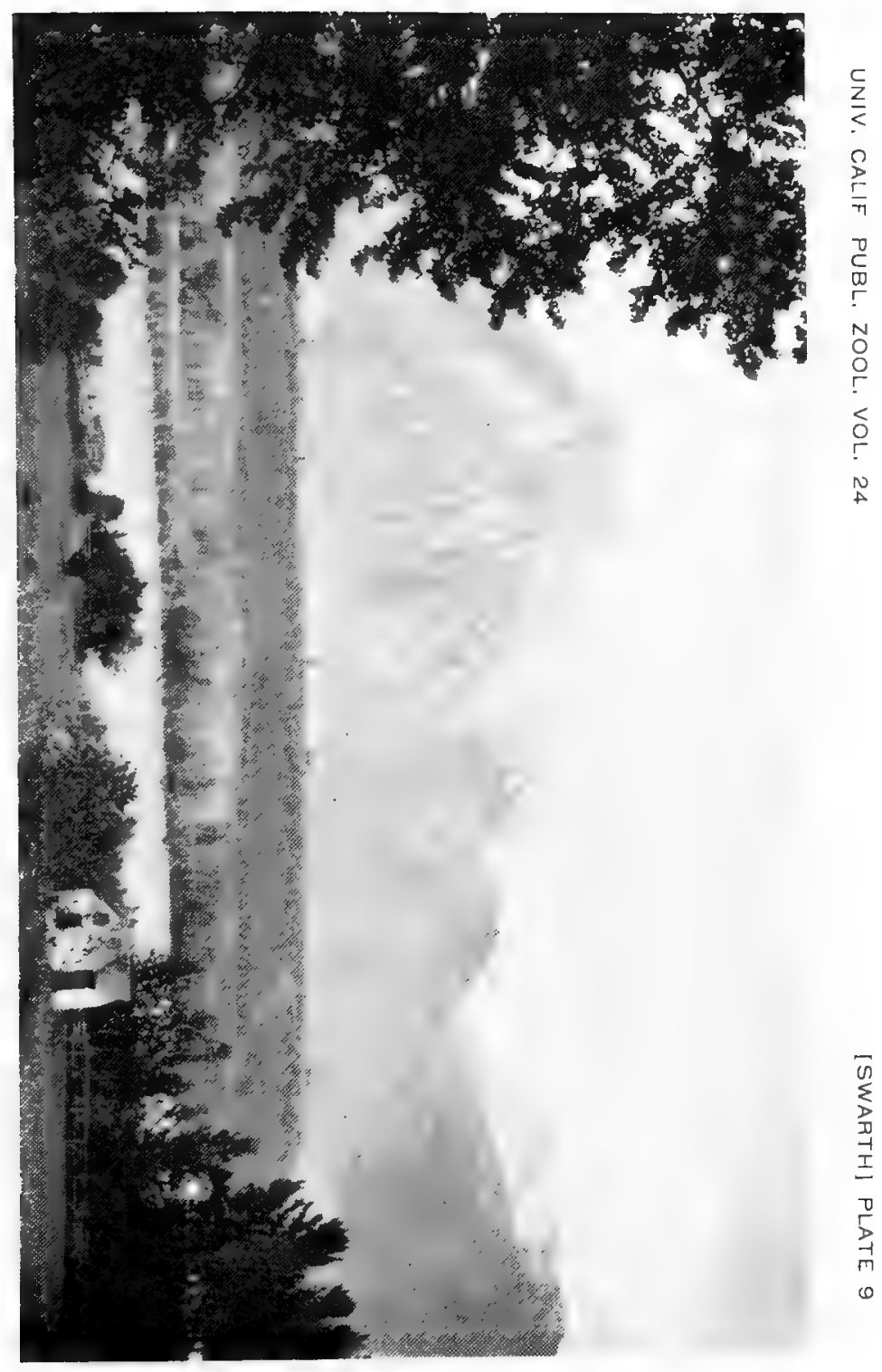






\section{PLATE 10}

Fig. 1. Woods and elearing in Kispiox Valley. Marmota monax petrensis was found in the meadow here shown. Photograph taken September 10, 1921.

Fig. 2. Ridge at the summit of Nine-mile Mountain, about 5000 feet altitude. The thickets are of dwarfed white fir and mountain hemlock. Habitat of caribou and marmot, of ptarmigan, pipit, and golden-crowned sparrow. P'hotograph taken July 29, 1921. 


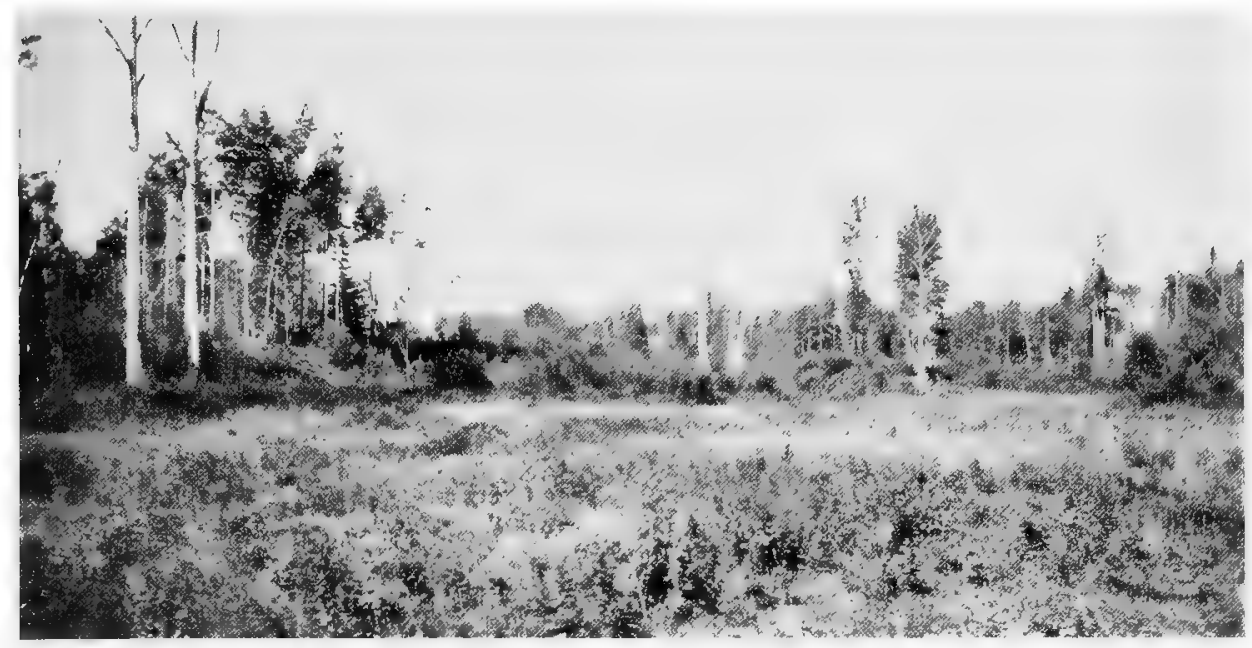

Fig. ]

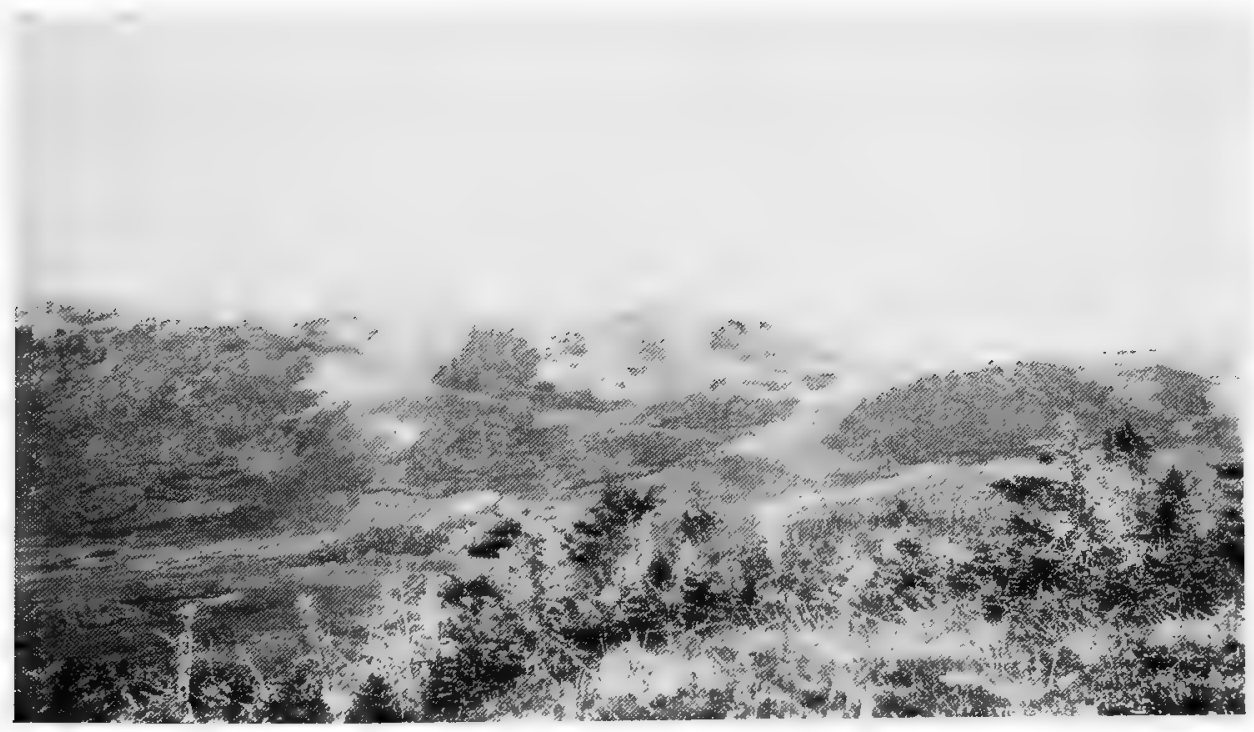

Fig. 2 




\section{PLATE 11}

Fig. 1. Rock slides at timber line (about 4500 feet altitude), on Nine-mile Mountain. The expedition's camp was located in the tongue of timber extending up the slope in the middle distance. These rocky mountain slides are the preferred habitat of marmot and porcupine, fox sparrows inhabit the thickets, and the Fleming grouse is found at the edge of the big timber. Photograph taken July 25, 1921.

Fig. 2. Upper edge of spruce and hemlock forest at about 4500 feet altitude on Nine-mile Mountain. In these woods (Hudsonian zone) were found Franklin grouse, white-winged crossbill, Hudsonian chickadee, mountain chickadee, and hermit thrush. Photograph taken July 30, 1921. 


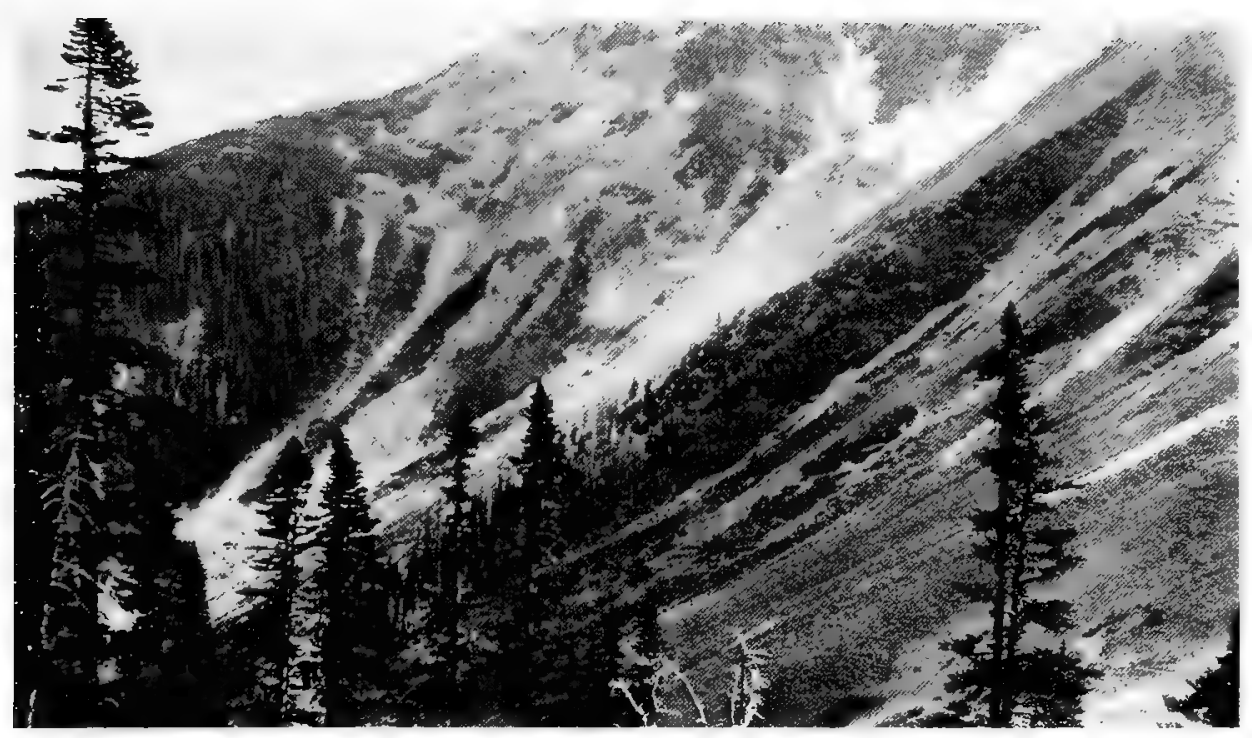

Fig. 1

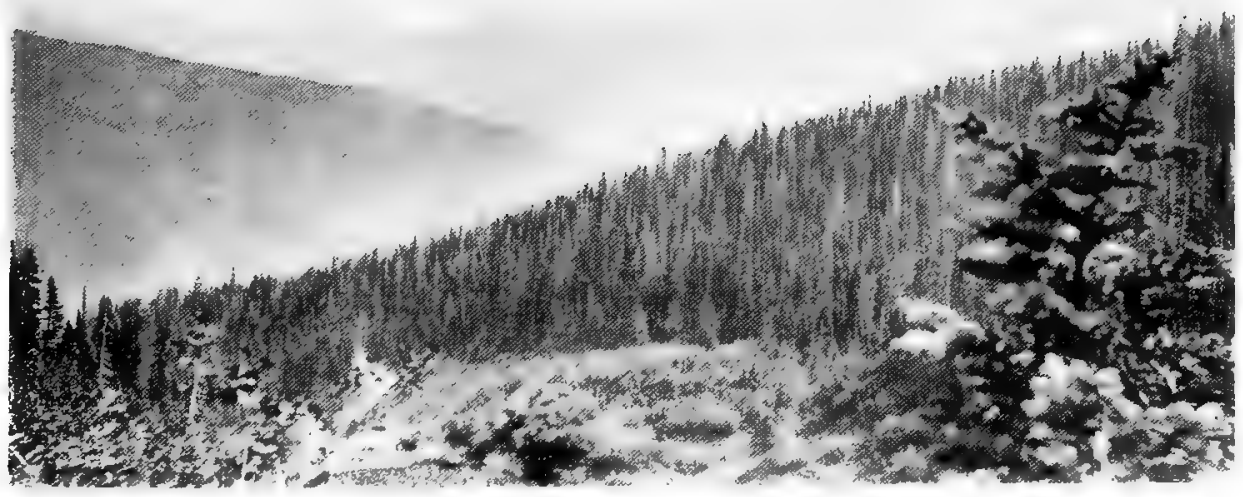

Fig. 2 



Vol 20. 1. Studies on the Parasites of the Termites. I. On Streblomastix strix, a Polymastigote Flagellate with a Linear Plasmodial Phase, by Charles Atwood Kofoid and Olive Swezy. Pp. 1-20, plates 1-2, 1 figure in text. July, 1919

2. Studies on the Parasites of the Termites. II. On Trichomitus termitidis, a Polymastigote Flagellate with a Highly Developed Neuromotor System, by Charles Atwood Kofotd and Ollve Swezy. Pp. 21-40, plates 3-4, 2 figures in text. July, 1919

3. Studies on the Parasites of the Termites III. OR Trichonympha campanula sp. nov., by Charles Atwood Kofold and Olive Swezy. Pp. 41.98, plates 5-12, 4 figures in text. July, 1919

4. Studies on the Parasites of the Termites. IV. On Leidyopsis aphaerica gen nov., sp. nov., by Charles Atwood Kofold and Ollve Swezy. Pp. 99-116, plates 13-14, 1 figure in text. July, 1919

5. On the Morphology and Mitosis of Chilomastix mesnili (Wengon), a Common Flagellate of the Human Intestine, by Charles $A$. Kofold and Olive Swezy. Pp. 117-144, plates 15-17, 2 figures in text. April, 1920

6. A Critical Review of the Nomenclature of Human Intestinal Flagellater Cercommas. Chilomastix, Trichomonas, and Giardia, by Charles A. Fofold. Pp. 145-168, 9 figures in text. June, 1920

7. On the Free, Encysted, and Budding Stages of Councilmania lafleuri, a Parasitic Amoeba of the Human Intestine, by Charles Atwood Kofold and Olive Swezy. Pp. 169-198, plates 18-22, 3 flgures in text. June, 1921 .....

8. Mitosis and Flssion in the Active and Encysted Phases of Giardia enterioa (Grassi) of Man, with a Discussion of the Method of Origin of Bilateral Symmetry in the Polymastigote Flagellates, by Charles A. Kofold and Olive Swezy. Pp. 199-234, plates 23-26, 11 flgures in text. March, 1922

9. The Micro-Injection of Paramaecium, by Chas. Wm. Rees. Pp. 235-242. April, 1922

10. On Balantidium coli (Malmsten) and Balantidium suis (sp. nov.), with an account of their neuromotor apparatus by $\mathbf{J}$. Daley McDonald. Pp. 243-300, plates 27, 28, 15 figures in text. May, 1922

11. Mitosis in Endamoeba dysenteriae in the Bono Marrow in Athritis de. formans, by Charles Atwood Kofold and Olive Swezy. Pp. 301-307, 7 figures in tert.

12. Endamoeba dysenteriae in the Iymph Glands of Man In Hodghin's Diseage, by Charles A. Kolold, Inther M. Boyers, M.D., and Olive 8wezy. Pp. $\mathbf{8 0 9}$. 312, 4 flgures in text.

Nos. 11 and 12 in one cover. April, 1922

13. Mutosis in the Encysted Stages of Endamoeba coli (Toesch), by Olive Swezy. Pp. 313-332, plates 29-31. May, 1922

14. The Neuromotor Apparatus of Paramaecium, by Charles William Rees. Pp. 333-364; plates 32-36, 5 figures in text. November, 1922

15. A Comparison of the Cysts of Endamoeba coli and Councilmania lafleuri in Congo Red, by Nathaniel Bercovitz, M.D. Pp. 365-371. February, 1923.

16. On the Morphology and Behavior of Pentatrichomonas ardin delteili (Derrieu and Raynaud), by Charles Atwood Kofoid and Olive \$\$wez马. Pp. 373-390, plate 37, 1 figure in text. Angust, 1923.

17. The Pseudopodial Mothod of Feeding by Trichonymphid Flagellates Para. sitic in Wood-eating Termites, by Olive Swezy. Pp. 391-400, 14 figs. In text. August, 1923

18. Methods of Obtaining Amoeba-free Rats for Experimental Infection with Intestinal Amoebae, by John F. Kessel Pp. 401-408.

19. Experimental Infection of Rats and Mice with the Common Intestinal Amoebae of Man, by John F. Kessel. Pp. 409-430, plates 38-39.

Nos. 18 and 19 in one cover. October, 1923

20. On the Genus Councilmania, Budding Intestinal Amoebae Parasitic in Man and Rodents, by Charles A. Kofoid, Olive Swezy, and John F. Kessel. Pp. 431-445, 19 figures in text. October, 1923

21. Morphology and Binary Fission of Menoidium incurvum (Fres.) $\mathbf{K l o b s ,}$ by Richard P. Hall. Pp. 447-476, plates 40-41, 2 flgures in text. November, 1923

22. A Skin Reaction to Extracts of Leishmania tropica and Leishmania infantum, by Edna Hannibal Wagener. Pp. 477-488, plate 42 . December, 1923

Vol. 21. 1. A Revision of the Microtus californicus Group of Meadow Mice, by Remington Kellogg. Pp. 1-42, 1 figure in text. December, 1918

2. Five New Five-toed Kangaroo Rats from California, by Joseph Grinnell. Pp. 43-47. March, 1919

3. Notes on the Natural Flstory of the Bushy-talled Wood Bats of Callfornia by Joseph Dixon. Pp. 49-74, plates 1-3, 3 figures in text. December, 1910 


\section{UNIVERSTTY OF CALIFORNIA PUBLICATIONS-(Continued)}

4. Revision of the Avian Genus Passerella, with Special Reference to the Distribution and Migration of the Races in California, by $\mathbf{H} . \mathbf{S}$. Swarth. Pp. $75-224$, plates 4-7, 30 figures in text. September, 1920

5. A Study of the California Jumping Mice of the Genus Zapus, by A. Brazer Howell. Pp. 225-238, 1 figure in text. May, 1920

6. Two New Rodents (Genera Thomomys and Marmota) from the Eastern Border of California, by Joseph Grinnell. Pp. 239-244, 6 figures in text. November, 1921

7. A Study of the Callformian Forms of the Microtus montanus Group of Meadow Mice, by Remington Kellogg. Pp. 245-274, 25 figures In text.

8. A Symopsis of the Microtus mordax Group of Meadow Mice in Callfornia, by Remington Eellogg. Pp. 275-302, plate 8, 29 figures in text. Nos. 7 and 8 in one cover. April, 1922

9. Behavior of the Leaf-nosed Snake, Phyllorhynchus decurtatus, by Sarah Rogers Atsatt. Pp. 303-312. February, 1923

10. A Systematic Iist of the Mammals of California, by Joseph Grinnell. Pp. 313-324. January, 1923.

11. The Systematic Status of the Mountain Lion of California, by Joseph Grinnell and Joseph Dixon. Pp. 325-332, plates 9-10. April, 1923.

12. New Subspecies of Birds from Patagonia, by Alexander Wetmore. Pp. 333-337. June, 1923

13. Revision of the Genus Lynx in California, by Joseph Grinnell and Joseph Dixon. Pp. 339-354, plate 11, 1 figure in text. January, 1924

Vol. 22. 1. A Quantitative and Statistical Study of the Plankton of the San Joaquin Rjver and Its Tributartes in and near Stockton, California, in 1913, by Winfred Fmory Allen. Pp. 1-292, plates 1-12, 1 figure in text. June, 1920.

2. Variations in the Shell of Teredo navalis in San Francisco Bay, by Robert Cunningham Miller. Pp. 293-328, plates 13-17, 6 figures in text. November. 10 :

5. Quantitative Studies on Marine Phytoplankton at Ia Jolla in 1919 , by Winfred Emory Allen. Pp. 329-347, 2 flgures in text. November, 1922

4. On the Effect of Low Salinity on Teredo navalis, by Harold Francis Blum. Pp. 349-368, 4 figures in text. December, 1922

5. Quantitative Studies on Inshore Marine Diatoms and Dinoflagellates of Sotthern California in 1920, by Winfred Emory Allen. Pp. 369-378, 1 figure in text.

6. Stylarioides papillosa, sp. nov., a New Annelid from the San Diego Region, by Christine E. Essenberg. Pp. 379-381, 8 figures in text.

Nos. 5 and 6 in one cover. December, 1922

7. The Digestion of Wood by Teredo navalis, by Walter H. Dore and Bobert C. Miller. Pp. 383-400, plate 18. February, 1923

8. Variations in the Pallets of Teredo navalis in San Francisco Bay, by Robert Cunningham Miller. Pp. 401-414, plates 19-20. February, 1923

9. Some Tide-Water Collections of Marine Diatoms taken at Half-Hour Intervals near San Diego, California, by Winfred F. Allen. Pp. 413-416, 1 figure in text. June, 1923

10. Preliminary Statistical Report on the Occurrence of Marine Copepoda in the Plankton at La Jolla, Califorma, by Calvin O. Fsterly. Pp. 417-438. June, 1923

11. Studies on Marine Diatoms and Dinoflagellates Caught by Aid of the Kofoid Bucket in 1922, by Winfred Emory Allen. Pp. 435-445, 5 figures in text. October, 1923

12. Statistical Studies of Marine Diatoms of the San Diego Region Collected by U.S.S. Pioneer in Midwinter of 1923, by Winfred Emory Allen. Pp. 445-448. November, 1923

13. Iife Cycle of Githona nana Reared Experimentally, by Helen E. Murphy. Pp. 449-454, 5 figures in text. November, 1923

14. Morphology of the Digestive Tract of Teredo navalis, by Edgar Locke Lazier. Pp. 455-470, plates 21-24. December, 1923

Vol. 23. The Marine Decapod Crustacea of California, by Waldo I. Schmitt. Py. 1-470, plates 1-50, 165 figures in text. May, 1921

Vol 24. 1. A Geographical Study of the Fangaroo Rats of California, by Joseph Grinnell. Pp. 1-124, plates 1-7, 24 figures in test. June, 1922

2. Birds and Mammals of the Stikine River Beglon of Northern British Columbia and Southeastern Alaska, by H. S. Swarth. Pp. 125-314, plate 8, 34 figures in text. June, 1922

3. Birds and Mammals of the Skeena River Region of Northern British Columbia, by Harry S. Swarth. Pp. 315-394, plates 9-11. 1 figure in text. January, 1924

Vol 25. A Bibliography of Eugenics, by Samuel J. Holmes. Pp. 1-514. January, 1924

Vol. 26. 1. On the Family of Achiridae or Broad-Soles, with description of a new species, Achirus barnharti, from California, by David Starr Jordan. Pp. 1-11, plate 1. December, 1923

2. A Precipitin Test in Experimental Amoebic Dysentery in Cats, by Edna

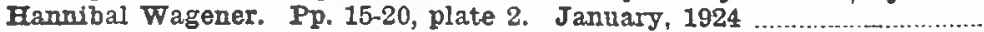

81.75

.26 


\title{
REPORT ON A COLLECTION OF BIRDS AND MAMMALS FROM THE ATLIN REGION, NORTHERN BRITISH COLUMBIA
}

\author{
BY
}

HARRY S. SWARTH

University of CaLifornia PUblications in Zoology

Kolume 30 , No. 4, pp. 51-162, plates 4-8, 11 figures in text

UNIVERSITY OF CALIFORNIA PRESS

BERKELEY, CALIFORNIA

1926 


\section{UNIVERSITY OF CALIFORILA PUBLICATIONS}

Tote.-The University of Callfornia Publications are offered in exchange for the publcations of lesrned societies and Institutions, universitles and libraries. Completo lists of all the publications of the University will be sent upon request. For sample coples, list of prblications or other information address the MANAGER OF THE UNIVERBITY PREBS, BERKEIEY, CALIFORNIA, U.S.A. All matter sent in exchange should bo addressed to EXCHANGE DEPARTMENT, UNIVERSITY ITBRABY, BERKELEY, CAI.IFORNIA, U. S. A.

Publications of the Unfversity of California Pross may be obtained from ItEe OAMBRIDGE UNIVEBSITY PRESE, FETTER IANE, LONDON, E. O. 4, ENGTAND, to which orders orfiginating in Great Britain and Ireland should bo sent.

zooLOGY.-C. A. Kofola and J. Grinnell, Editors.

This series contains the contributions from the Department of Zoology, from the Marine Laboratory of the Scripps Institution of Oceanography, at Ia Jolla, Callformta, and from the Callfornia Musenm of Vertebrate Zoology in Berkeley.

Cited as Univ, Calte. Publ. Zool.

Volume 1, 1902-1905, 317 pages, with 28 plates

Volume 2, 1904-1906, Ivil + 382 page日, with 19 plates

$\$ 3.60$

Volume 8, 1906-1907, 388 pages, with 23 plates

$\$ 8.60$

Volume 4, 1907-1908, 400 pages, with 24 plates $\$ 3.60$

Volume 5, 1008-1910, 440 pages, with 34 plates $\$ 3.60$

Volume 6, 1908-1911, 478 pages, with 48 plates $\$ 3.60$

Volume 7, 1910-1912, 446 pages, with 12 plates. $\$ 8.50$

Volume 8, 1911,357 pages, with 25 plates $\$ 3.60$

Volume 8, 1911-1912, 366 pages, with 24 plates $\$ 3.50$

Volume 10, 1912-1913, 417 pages, with 10 plates $\$ 3.50$

Volume 11, 1912-1914, 538 pages, with 26 plates $\$ 3.60$

Volume 12, 1913-1916, 558 pages, with 22 plates. $\$ 5.00$

Volnme 13, 1914-1916, 529 pages, with 39 plates. $\$ 5.00$

Volume 14, 1914-1918, 462 pages, whth 60 plates $\$ 5.00$

Volnme 15, 1915-1916, 360 pages, with 38 plates $\$ 5.00$

Volume 16, 1815-1917, 622 pages; with 46 plates

Volnme 17, 1916-1918, 545 pages, with 24 plates

$\$ 5.00$

Volume 18, 1817-1919, 529 pagen, wh 20 plates.

Volume 19, 1919-1920, 480 pages, with 93 plates

Volume 20, 1819-1924, 571 pages, with 48 plates $\$ 5.00$

Vol. 21. 1 A Revision of the Microtus californicus Gronp of Meadow Mice, by Remington Kellogg. Pp. 1-42, 1 figure in text. December, 1918. $\$ 6.00$

2. Five New Five-toed Kangaroo Rats from Callfornta, by Joseph Grinnell Pp. 43-47. March, 1919

3. Fotes an the Matural History of the Bushy-tailed Wood Bats of Oallermis by Joseph Dixon. Pp. 49-74, plates 1-3, 8 flgures in text. December, 1919

4. Revision of the Avian Genus Passerolla, with Epecial Reference to the Distribution and Migration of the Races in Callfornia, by H. B. Bwarth. Pp. 76-224, plates 47, 80 figures in text. September, 1920

5. A Study of the Califormla Jumping Mice of the Genus Zapus, by A. Brader Howell. Pp. 225-238, 1 flgare in text. Mag, 1920

6. Two New Bodents (Cenera Thomomys and Marmota) from the Eastern Border of Callfornis, by Joseph Grinnell. Pp. 239-244, 6 figures in text November, 1921

7. A Study of the Californian Forms of the Miorotus montanus Group of Meadow Mice, by Remington Kellogg. Pp. 245-274, 25 figures in text

8. A Synopsis of the Miorotus mordax Croup of Meadow Mice in Cajiformia, by Remington Kellogg. Pp. 275-302, plate 8, 29 figures in text.

Nos. 7 and 8 in one cover. Aprll, 1922

9. Behsvilor of the Ieaf-nosed Snake, Phyllorhynohu decurtatus, by Sarah Bogars Atsatt. Pp. 308-312. February, 1923

10. A Bytematic Ifst of the Mammals of Callfornis, by Joseph Getnnall. Pp. 813-324. January, 1923

11. The Bystematic Btatus of the Mountain Ilon of Califormis, by Joseph Grinnell and Joseph DKron. Pp. 325-332, plates 9-10. Apiti, 1925

12. New Bubspecies of Birds from Patagonte, by Alexander Wetmore. Pp. 393-837. June, 1923 
REPORT ON A COLLECTION OF BIRDS AND MAMMALS FROM THE ATLIN REGION, NORTHERN BRITISH COLUMBIA

HARRY S, SWARTH 
University of California Publications in Zoology

Volume 30, No. 4, pp. 51-162, plates 4-8, 11 figures in text Issued September 24, 1926

\section{University of California Press}

Berkeley, California

\section{Cambridge University Press \\ LONDON, ENGLAND}





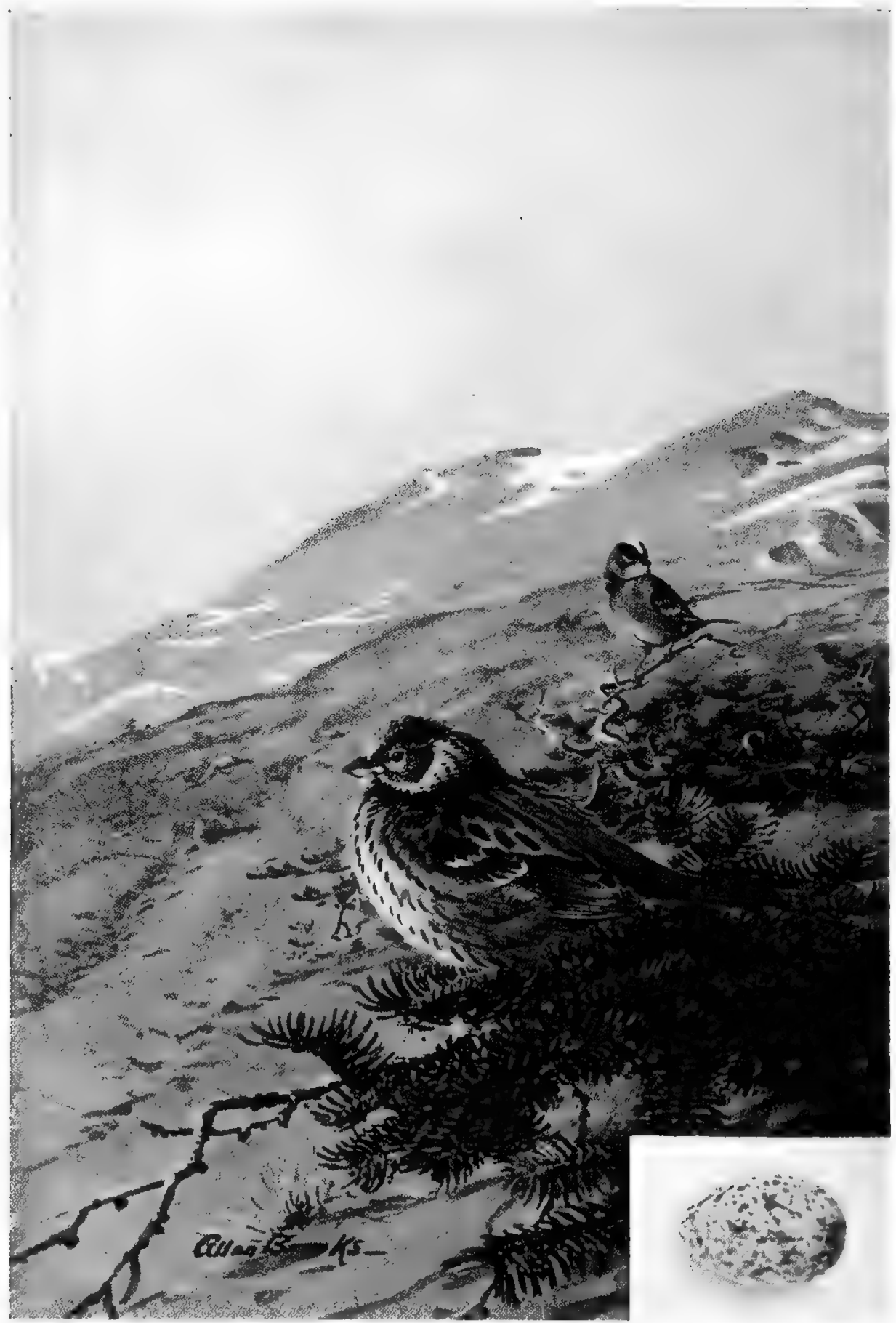

Young (in the foreground) and allust (in the distance) of the golden-crowned sparrow (Zonotrichia coromata), shown in the surroundings frequented by the species in northern British Columbia. Inset, egg of the golden-crowned sparrow, natulal size. 


\section{REPORT ON A COLLECTION OF BIRDS AND MAMMALS FROM THE ATLIN REGION, NORTHERN BRITISH COLUMBIA}

BY

HARRY S. SWARTH

(Contribution from the Museum of Vertebrate Zoology of the University of California)

\section{CONTENTS}

PAGE

Introduction 51

Itinerary and descriptions of localities. 53

Zonal and faunal position of the Atlin region.

Check list of the birds.

General accounts of the birds.

Check list of the mammals.

\section{INTRODUCTION}

During the summer of 1924 the Museum of Vertebrate Zoology sent an expedition into the Atlin region, in extreme northwestern British Columbia. The expenses of this expedition, as of all previous zoological work carried on in the northwest by this Museum, were defrayed by Miss Annie M. Alexander, whose interest in the Museum's work, and particularly in developing a knowledge of the vertebrate natural history of the northwest, has been unflagging. Atlin was chosen as a base largely on account of its geographical position with relation to the valleys of the Stikine and Skeena rivers, to the southward, which had been visited by Museum parties in previous years.

The writer went alone from the Museum, that is, unaccompanied by any Museum assistant, but he was fortunate in being joined at the outset by Major Allan Brooks, of Okanagan Landing, British Columbia. Major Brooks painted and collected specimens independently, but the companionship proved mutually helpful in many ways. Specimens collected by the writer consist of 387 birds, 76 mammals, 12 amphibians, 11 birds' nests, and 16 sets of birds' eggs. Major Brooks' collection of birds was also at my disposal in writing the report that follows. 
Acknowledgments are due to the Dominion Parks Branch, Department of the Interior, Canada, for permission to collect migratory birds, and to the Game Conservation Board, Vancouver, for permission to collect non-migratory birds and for other courtesies.

In working up the collection it proved necessary to borrow specimens from many institutions. The study of the ptarmigans in particular called for the assemblage of as large series of certain forms as could be brought together, and appeal was made to all museums and private collections that seemed likely to have pertinent material. Generous response to the many requests for the loan of specimens came from all who were asked, comprising the following: American Museum of Natural History, New York (including many specimens from the Sanford collection); Carnegie Museum, Pittsburgh; Colorado Museum of Natural History, Denver; Museum of Comparative Zoology, Cambridge; Museum of History, Seience and Art, Los Angeles; Provincial Museum, Victoria; United States Biological Survey; United States National Museum; Victoria Memorial Museum, Ottawa; Louis B. Bishop; Donald R. Dickey; George Willett.

To Major Brooks I am indebted for help extended daily during the season's field work, for specimens turned over to me from day to day, field observations proffered, and for advice and critical comments pertaining to the systematic treatment of various species. The cordial assistance extended to us both by individuals resident in Atlin, whose acquaintance we made there, was a most important factor in making our work pleasant and profitable. In particular, mention should be made of Mr. C. L. Monroe, Government agent, for aid in his official capacity, and, together with Mrs. Monroe, for many unofficial courtesies; of Mr. A. B. Taỹlor, Government telegraph operator, a sportsman and a keen observer, in whose company I made many pleasant trips, who aided in securing numerous specimens and who, with Mrs. Taylor, did all he could to make our summer a pleasant one; and of Mr. H. Maluin, whose cordial welcome to his mining camp on Otter Creek enabled us to work in that region. On the train, en route from Skagway, we first made the acquaintance of Inspector Moorhead, of the Royal Canadian Mounted Police, who, then and later in the summer, lost no opportunity of extending such courtesies as lay in his power. To Corporal Robert MeCleery and Mrs. McCleery, in their isolated post on Lake Teslin, the writer is indebted for cordial hospitality and for aid in securing needed specimens. From Mr. and Mrs. John Garrett, of Atlin, we received innumerable courtesies. 
The drawings of birds' bills and tails illustrating parts of this report were made by Miss Anna Hamilton. The outline maps illustrating birds' ranges are the work of Miss Margaret W. Wythe, of the Museum staff.

In September, 1913, and from June 5 to August 19, 1914, the Provincial Museum, Victoria, British Columbia, carried on field work in the Atlin region. The first trip was conducted by Mr. F. Kermode, Director, with Mr. E. M. Anderson as assistant, the second by Mr. Anderson and Mr. C. B. Garrett, and both were reported upon in annual reports of the Provincial Museum for the years 1913 and 1914, respectively. We found these published accounts of the birds and mammals that were collected extremely useful, and had occasion to refer to them constantly during our season's work.

\section{ITINERARY AND DESCRIPTIONS OF LOCALITIES}

I was joined by Major Brooks at Vancouver the morning of May 17. We left Vancouver that evening, arrived at Skagway, Alaska, early in the morning of May 21, and at Carcross, Yukon Territory, the afternoon of the same day. We had planned to go on at once to Atlin, but navigation had not yet opened on the lakes, and we therefore remained at Carcross for one week. On May 27 we took advantage of an opportunity to reach Atlin on a motor boat that was taking the mail, the first to be forwarded to that place for many weeks. We left Carcross at 1 P.M., reached the portage at Taku about midnight, and Atlin, across the lake, two hours later.

The town of Atlin remained our base throughout the summer, the only long departure therefrom being to a camp in lower Otter Creek, where we stayed from July 26 to August 9. Major Brooks left on August 30, for a brief stay at Log Cabin, White Pass, en route homeward. I left Atlin on September 24, reaching Berkeley on October 3.

On September 7, at the invitation of Captain Moorhead, Mr. Monroe, and Mr. Taylor, I accompanied them on a trip to the police post at Nisuttlin Bay, Teslin Lake, some eighty miles (by the trail) northwest of Atlin. The first day we traversed the length of Surprise Lake and then the trail to Gladys Lake, twelve miles beyond. The second day was spent at that point (fortunately in comfortable quarters) in a downpour of rain that lasted the whole day long. The third evening we reached Grouse Creek, and the fourth afternoon 
Teslin Lake. We left Teslin on the return trip the morning of September 13, reaching Atlin September 15. The trail lies in the lowlands the whole distance, passing through stretches of spruce, pine, and poplar woods at intervals, with occasional tracts of open meadow and marsh land. Rugged mountains enclose Surprise Lake, but beyond that point, to the northeast, the mountains are left behind and rolling, forested country stretches in all directions, save for isolated groups of peaks such as the conspicuous Dawson Peaks (locally known as the Four Aces) on the British Columbia-Yukon boundary at Lake Teslin.

\section{CARCROSS}

This is the Caribou Crossing of former days, now a station on the White Pass and Yukon Railroad. It is situated at the junction of Bennett and Tagish lakes, near the north base of White Pass, sixtyeight miles inland from Skagway. Our limited work here was within a radius of six or eight miles of the town, and entirely in the lowlands, as the nearby mountains were inaccessible from the depth of soft, melting snow with which they were then covered. The valley is clothed with open woods, poplars and small jack pine mostly, interspersed with stands of white spruce, and with willow copses in the more swampy ground. A large slough (with wide margins of exposed mud in May, filled with water in September) lies but a short distance from the town, an attraction for water birds of many sorts. A striking feature of this region is the vast expanse of shifting sand dune country. The lower end of Lake Bennett is broadly margined with sand dunes, and as far as we went in the woods to the northward we found similar sandy mounds covered with forest trees. It is a windy region; during our stay there were strong winds daily rushing inland through the White Pass. (For a detailed discussion of the faunistic features of the region, see Osgood, 1900, pp. 8-12.)

\section{ATLIN}

The town of Atlin is on the east shore of Lake Atlin, at an altitude of 2200 feet. The valley bordering the east side of the lake is forest covered mostly, but the woods are open and easily traversed. Quaking aspen, or "poplar," is the dominant deciduous tree, and almost unbroken stands of poplar cover miles of territory. White spruce grows in many places in the lowlands, and in denser stands and over greater areas on the adjoining mountain sides. The lowland woods are broken 
in many places by tracts of swamp, grass-covered or grown up with willow thickets, and the woods are interspersed with many small lakes. Three or four miles east of Atlin, Lake Como, the largest of these small lakes near the town, supports a considerable population of water birds.

Some four miles south of Atlin, Monarch Mountain rises (see pl. 6, fig. 5), the nearest peak of a series of rounded and, for the most part, not particularly rugged mountains, that border Pine Creek Valley to the eastward of Atlin and the lake shore to the southward. Conditions on this mountain may be briefly described, as generally applicable to that type of country in this region. Poplar woods border the lowest slopes of the mountain, but ascend its sides only a few hundred feet before giving way to the belt of darker and denser spruce. Between 3500 and 4000 feet altitude spruce is largely replaced by balsam fir, growing to large size at its lowest level and persisting over the summit of the peak in more or less dwarfed and prostrate form. At the upper edge of the spruce belt the woods become more thin, and are cleft by wider and wider areas of open grass or lupine covered slopes. On the summit ( 3800 to 5000 feet altitude) upright timber of any size disappears, save in a few sheltered spots, and the scattered thickets of scrubby balsam sprawling close to earth are surrounded by wide areas of open ground, grass covered or here and there grown up with false heather over limited damp areas. Creeping birch grows here, too, and in extensive tracts; on this particular mountain. I saw little that was more than knee-high.

Directly opposite the town of Atlin lies a group of three islands, the nearest within a quarter of a mile from the shore, and none of them more than a few acres in extent (see pl. 5, fig. 2). A striking feature of these islands is the fact that of the forest trees with which they are covered nearly all are balsam fir. There are relatively few spruce or jack pine. On the adjacent mainland I saw no balsam at the lake level. The islands are the nesting grounds of small colonies of water birds (short-billed gull, Bonaparte gull, and Arctic tern) and they harbor an extraordinary number of small land birds. We listed fifteen species of land birds as nesting there, some of them (such as the black-poll warbler) extremely scarce on the neighboring mainland. These small birds, too, were rearing their young successfully, in. contrast to conditions on the mainland, where subsequent destruction of nest, eggs, or young was the usual fate of most of the nests we found. On the islands there were no red squirrels, no chipmunks, and no 
Canada jays; the absence of these factors may have been the favorable feature of the place. The nesting species of gulls and tern were not so fortunate, for they suffered severely from the raids of herring gulls, to the ultimate destruction of nearly all the young that were hatched.

\section{OTTER CREEK}

The upper portion of Otter Creek (3500 to 4000 feet altitude), where we worked for two weeks, may be described as characteristic of vast areas throughout this region that lie in an intermediate position between the wooded lowlands such as border Lake Atlin and the timberless mountain tops. Willow is the dominant forest growth along the bottom of this valley, never as large trees but as densely growing, rounded bushes, rarely more than twenty feet high and usually much lower. On Otter Creek, as on some other streams, the necessities of hydraulic mining have caused the damming of the stream far up the valley. For miles above the lake thus formed the valley floor is transformed into a willow swamp, a haven for ducks.

The mountain slopes on either side, and much of the valley floor in the upper reaches of the stream, are dry and more sparsely covered with vegetation. There are extensive grassy areas, and at about 3800 feet altitude the creeping birch begins to be conspicuous. Mostly this is a rather innocuous shrub, low-growing and easily walked over or avoided, but I found some sections (at about 4000 feet altitude) where it formed a chaparral on hill sides and ridges ten feet high or more and well-nigh impenetrable.

On the surrounding mountain sides, especially on north and east facing slopes, spruce, and above that, balsam, grow in small groves in some places, in solid stands for miles on favored exposures. On Spruce Mountain, forming the western boundary of Otter Creek Valley, this forest ceased abruptly between 4500 and 5000 feet altitude. Above that boundary grassy slopes and ridges prevail, with a very little false heather in places and a few scattered thickets of balsam.

\section{ZONAL AND FAUNAL POSITION OF THE ATLIN REGION}

Atlin occupies a position relative to the coast about the same as Telegraph Creek, in the Stikine Valley, and Hazelton, in the Skeena Valley, 150 miles and 375 miles to the southward, respectively. Both of these places I had visited in previous years (see Swarth, 1922, 1924), and comparisons between the regions naturally follow. Atlin Lake is at 
an altitude of 2200 feet, compared with Telegraph Creek at 540 feet, and Hazelton at 973 feet, and this increase in elevation, together with the more northern location, has almost eliminated at Atlin certain Canadian Zone elements that are conspicuous at the more southern stations. The lowlands of the Atlin region, it seems to me, are Hudsonian Zone, with but a slight infiltration of Canadian Zone species. There is no definable zone between the lowlands (2200 feet altitude) and the Alpine-Aretic mountain tops, with timber line between 3500 and $\mathbf{4 0 0 0}$ feet. The same species of plants, mammals, and birds, with few exceptions, range from timber line downward in suitable places throughout the valleys. The converse of this, however, is not true, of birds at least, for all species of birds that occur in the lowlands do not range upward to timber line. Then, a further exception must be made of three species of birds, Dendragapus abscurus flemingi, Spizella monticola ochracea, and Lanius borealis, the former two oceupying in abundance, the latter in small numbers, types of country that are found in some places immediately below timber line (see pl. 6, fig. 4). However, making due allowance for the more decidedly Hudsonian character of higher altitudes, the general tone of the valleys, too, is of the Hudsonian Zone. This is exemplified in the extensive stands of white spruce with such accompanying bird species as the Alaska hermit thrush, Hudsonian chickadee, Canada jay, goshawk, and spruce grouse, all occurring in abundance.

In the upper Skeena Valley the Canadian Zone is dominant, as demonstrated by the presence of many elements over a vast expanse of country. In the upper Stikine Valley, while the Canadian Zone characterizes the region, there are fewer bird species represented and they occur over a relatively restricted area. In the lowlands of the Atlin region there is but the merest infiltration of Canadian Zone elements into prevailing Hudsonian Zone surroundings.

Lakes and streams in the Atlin region all find their way into the Arctic drainage, and here, too, in coming from the south, one first finds a few real Arctic birds. Among such may be mentioned the pair of black-throated loons we saw, apparently in two minds as to nesting in the region, the northern phalarope, apparently breeding at Carcross, the gyrfalcon, and the northern shrike.

Some comparisons can be made of the status of certain species of birds at Hazelton, Telegraph Creek, and Atlin. Bubo virginiamus Lagophonus is abundant at Hazelton. We secured no horned owls at Telegraph Creek, but at Atlin the breeding subspecies is the more northern form, B. v. subarcticus. Dryobates villosus monticola is abundant at 
Hazelton and Telegraph Creek. At Atlin, hairy woodpeckers were all but absent, but the specimens secured were the northern $D$. $v$. lencomelas. Dryobates pubescens leucurus is common at Hazelton, we found no downy woodpecker at Telegraph Creek, and at Atlin the one specimen of this species that was taken proved to be the northern D. p. nelsoni. Selasphorus rufus is abundant at Hazelton, less common at Telegraph Creek, and decidedly rare at Atlin. Carpodacus purpureus purpureus, abundant at Hazelton, was rare at Telegraph Creek, and seen once at Atlin. Vireosylva gilva swainsoni, abundant at Hazelton and Telegraph Creek, was represented by one pair seen at Atlin. Oporonis tolmiei, abundant at Hazelton and Telegraph Creek, was doubtfully identified once at Atlin (June 24, 1924; not included in the following list). Setophaga ruticilla, abundant at Hazelton and but little less numerous at Telegraph Creek, was decidedly rare at Atlin. Penthestes gambeli abbreviatus, found in small numbers near Hazelton and Telegraph Creek, was seen once at Atlin. Cypseloides niger borealis, Chaetura vanxi, Melospiza melodia morphna, and Piranga ludoviciana, are species that apparently all find their northern limit near Telegraph Creek, none being seen at Atlin.

The non-occurrence of any form of Passerella in the Atlin region is of interest. $P$. iliaca altivagans was found breeding in the vicinity of Hazelton but nowhere near Telegraph Creek. Its absence in the Atlin region, too, suggests that there is a wide gap between the breeding ranges of $P$. i. iliaca and $P$. $i$. altivalgans, and thus that these forms may not really be so closely related as I had supposed (Swarth, 1920, p. 93), a belief founded largely upon the appearance of certain winter birds of intermediate character. Altivagans apparently occurs throughout a wide range of territory between the habitat of $P$. $i$. schistacea, of the Rocky Mountain and Great Basin regions, and of $P$. $i$. fuliginosa, of the coast, but it does not seem to range northward as far as the summer home of $P$. i. iliaca.

Faunally, Atlin may be considered as the extreme southern limit of the Yukon region. As regards birds there are many southern species that find their northern limit a short distance to the southward, and certain characteristic northern species that extend barely this far south. The Atlin avifauna is of the interior, purely. There is not a single distinctively coastal species that penetrates this distance inland, less than one hundred miles away from salt water. 


\section{CHECK LIST OF THE BIRDS}

1. Colymbus holboellii (Reinhardt)

2. Colymbus auritus Linnaeus

3. Gavia immer Brünnich

4. Gavia pacifica (Lawrence)

5. Gavia stellata (Pontoppidan)

6. Stercorarius parasiticus (Linnaeus)

7. Larus argentatus Pontoppidan

8. Larus brachyrhynchus Richardson

9. Larus philadelphia (Ord)

10. Sterna paradisaea Brünnich

11. Mergus americanus Cassin

12. Mergus serrator Linnaeus

13. Lophodytes eucullatus (Linnaeus)

14. Anas platyrhynchos Linnaeus .

15. Nettion carolinense (Gmelin)

16. Spatula clypeata (Linnaeus)

17. Dafila acuta tzitzihoa (Vieillot)

18. Marila affinis (Eyton)

19. Glaucionetta islandica (Gmelin)

20. Charitonetta albeola (Linnaeus)

21. Histrionicus histrionicus pacificus W. S. Brooks

22. Oidemia deglandi dixoni W. S. Brooks

23. Oidemia perspicillata (Linnaeus)

24. Branta canadensis (Linnaeus), subsp.

25. Lobipes lobatus (Linnaeus)

26. Gallinago delicata (Ord)

27. Pisobia maculata (Vieillot)

28. Pisobia bairdii (Coues)

29. Pisobia minutilla (Vieillot)

30. Ereunetes pusillus (Linnaeus)

31. Totanus flavipes (Gmelin)

32. Tringa solitaria Wilson

33. Heteroscelus incanus (Gmelin)

34. Actitis macularia (Linnaeus)

35. Numenius hudsonicus Latham

36. Oxyechus vociferus (Linnaeus)

37. Charadrius semipalmatus Bonaparte

38. Aphriza virgata (Gmelin)

39. Dendragapus obscurus flemingi Taverner

40. Canachites canadensis osgoodi Bishop

41. Bonasa umbellus umbelloides (Douglas)

42. Lagopus lagopus albus (Gmelin)

43. Lagopus rupestris rupestris (Gmelin)

44. Lagopus leueurus leucurus (Swainson)

45. Cireus hudsonius (Linnaeus)

46. Accipiter velox (Wilson)

47. Astur atricapillus atricapillus (Wilson)

48. Buteo borealis harlani (Audubon) 
49. Aquila chrysaëtos (Linnaeus)

50. Haliaeetus leucocephalus alascanus C. H. Townsend

51. Falco rusticolus rusticolus Linnaeus

52. Falco peregrinus anatum Bonaparte

53. Falco columbarius suckleyi Ridgway

54. Cerchneis sparveria sparveria (Linnaeus)

55. Pandion haliaetus carolinensis (Gmelin)

56. Bubo virginianus subareticus Hoy

57. Bubo virginianus lagophonus Oberholser

58. Surnia ulula caparoch (Müller)

59. Ceryle alcyon caurina Grinnell

60. Dryobates villosus leucomelas (Boddaert)

61. Dryobates pubescens nelsoni Oberholser

62. Picoides americanus fasciatus Baird

63. Colaptes auratus borealis Ridgway

64. Chordeiles virginianus virginianus (Gmelin)

65. Selasphorus rufus (Gmelin)

66. Sayornis sayus yukonensis Bishop

67. Nuttallornis borealis (Swainson)

68. Myiochanes richardsonii richardsonii (Swainson)

69. Empidonax traillii alnorum Brewster

70. Empidonax hammondii (Xantus)

71. Empidonax wrightii Baird

72. Otocoris alpestris arcticola Oberholser

73. Pica piea hudsonia (Sabine)

74. Perisoreus canadensis eanadensis (Linnaeus)

75. Corvus corax prineipalis Ridgway

76. Euphagus carolinus (Müller)

77. Carpodacus purpureus purpureus (Gmelin)

78. Loxia leucoptera Gmelin

79. Spinus pinus (Wilson)

80. Calcarius lapponicus alascensis Ridgway

81. Passerculus sandwichensis alaudinus Bonaparte

82. Zonotrichia gambelii (Nuttall)

83. Zonotrichia coronata (Pallas)

84. Spizella monticola ochracea Brewster

85. Spizella passerina passerina (Bechstein)

86. Spizella taverneri Swarth and Brooks

87. Junco hyemalis connectens Coues

88. Melospiza lincolnii lincolnii (Audubon)

89. Petrochelidon lunifrons lunifrons (Say)

90. Hirundo erythrogaster Boddaert

91. Iridoprocne bicolor (Vieillot)

92. Tachyeineta thalassina lepida Mearns

93. Riparia riparia (Linnaeus)

94. Bombycilla garrula pallidiceps Reichenow

95. Lanius borealis Vieillot

96. Vireosylva gilva swainsonii (Baird)

97. Vermivora celata celata (Say)

98. Vermivora celata orestera Oberholser

99. Vermivora peregrina (Wilson)

100. Dendroica aestiva aestiva (Gmelin) 
101. Dendroica coronata hooveri MeGregor

102. Dendroica striata (J. R. Forster)

103. Dendroica townsendi (J. K. Townsend)

104. Seiurus noveboracensis notabilis Ridgway

105. Geothlypis trichas occidentalis Brewster

106. Wilsonia pusilla pileolata (Pallas)

107. Setophaga ruticilla (Linnaeus)

108. Anthus rubescens (Tunstall)

109. Sitta canadensis Linnaeus

110. Penthestes atricapillus septentrionalis (Harris)

111. Penthestes gambeli abbreviatus Grinnell

112. Penthestes hudsonicus columbianus (Rhoads)

113. Regulus satrapa olivaceus Baird

114. Regulus calendula calendula (Linnaeus)

115. Myadestes townsendi (Audubon)

116. Hylocichla ustulata swainsoni (Tsehudi)

117. Hylocichla guttata guttata (Pallas)

118. Hylocichla guttata pallasii (Cabanis)

119. Planesticus migratorius migratorius (Linnaeus)

120. Ixoreus naevius meruloides (Swainson)

121. Sialia eurrucoides (Bechstein)

\section{GENERAL ACCOUNTS OF THE BIRDS}

Colymbus holboellii (Reinhardt). Holboell Grebe

Present during our entire stay in the region. Pairs were seen in various lakes, large and small; and early in June the curious courting antics were commonly observed. No nests were found, nor were any young birds seen.

\section{Colymbus auritus Linnaeus. Horned Grebe}

A pair or more could be found on every lake, large or small. Seen at Carcross, May 22, and a single bird was noted near Atlin on September 21, my last day afield. Migrating in numbers during the second and third weeks in September.

On July 18 a nest was found in a small lake at the head of Cañon Creek, about 3500 feet altitude. The young birds had apparently but just hatched. They, with one parent, were occupying the nest when it was found, and the family, as observed from a distance, returned to it when I left. The nest was a circular mass of sodden grass floating amid a sparse growth of short, green grass, about three feet from the shore. It was somewhat hidden by a small willow overhanging from the adjacent bank. 


\section{Gavia immer Brünnich. Common Loon}

Seen on most of the lakes, and presumably nests in the region. No evidence of breeding was found, however, other than the presence of loons, some in pairs, throughout the summer.

\section{Gavia pacifica (Lawrence). Pacific Loon}

Seen at Carcross, presumably migrating, on May 22. The presence of a pair of Pacific loons on a small lake a few miles north of Atlin, on June 23 and 24, led to the hope that they would nest there. A few days later, however, they were gone, and no others were seen.

\section{Gavia stellata (Pontoppidan). Red-throated Loon}

Seen on but one occasion, a single bird on Lake Atlin on June 20.

\section{Stercorarius parasiticus (Linnaeus). Parasitic Jaeger}

One seen in pursuit of a gull at Lake Teslin, September 11. The jaeger was at close enough range to permit observation of details of color and markings.

\section{Larus argentatus Pontoppidan. Herring Gull}

A nesting colony of this species on an island in Atlin Lake has been described by Anderson (1915, p. 9). Herring gulls were seen commonly along the shore of Atlin Lake all through the summer, at Surprise Lake in August, and at Teslin Lake during the second week in September. Herring gulls raided certain breeding colonies of shortbilled gulls, Bonaparte gulls, and Arctic terns near the town of Atlin, to such effect that only an extremely small proportion of the young of those species survived.

There is a published record of the occurrence of Larus californicus at Lake Atlin (Anderson, 1915, p. 9), based upon a specimen in the collection of the Provincial Museum, Victoria. I have examined this specimen, which proves to be, though a rather small individual, unquestionably Larus argentatus.

\section{Larus brachyrhynchus Richardson. Short-billed Gull}

Seen at Carcross, May 22. A small nesting "colony," consisting of at least four pairs and perhaps seven or eight, was distributed over the three islands nearest the town of Atlin. Short-billed gulls were 
seen continually in some numbers along the lake shore, and the species was probably nesting at various points. We did not discover the colony alluded to above until all young birds had left the nests. Due to the ravages of the herring gull, as seemed evident, eggs and young in this colony were destroyed until just one young bird remained. This lone survivor, with wing quills partly grown but not yet able to fly, was several times seen, swimming on the lake, dodging attacks from a herring gull, which persisted until the entire adult population of short-billed and Bonaparte gulls came to the reseue.

A short-billed gull's nest was discovered July 15 on the "middle island" opposite the town of Atlin. It was placed in the top of a small balsam fir (with which trees these islands are thickly covered), about fifteen feet from the ground, and not at all easy to see in the flattened tree-top where it was placed. The young had been gone for some days at least, and buried in the bottom of the nest, entirely covered and hidden, was an addled egg (no. 1978). One or two other nests were seen in similar situations.

Two specimens of short-billed gull were preserved, an adult male (no. 44628) taken June 15, and a young female (no. 44629) molting from down to first winter plumage, taken July 14.

\section{Larus philadelphia (Ord). Bonaparte Gull}

Seen at Carcross, May 22. Two days later a pair of these birds had apparently preëmpted one end of a slough at the edge of the town, and they dived at our heads with loud outcries whenever we approached.

At Atlin, this species, like the short-billed gull, was nesting on the islands opposite the town, and, as with the larger species, the young had left the nests before we discovered this breeding ground. There were apparently ten or twelve pairs of Bonaparte gulls domiciled upon the islands, and, due again to the raiding herring gulls, from all these broods but three young birds reached an age when they could fly.

Several nests were found on the islands, which, without question, must have belonged to this species. They were frail affairs, not much larger than waxwings' nests, placed on widespreading side branches of balsam firs, near the tops of the trees, some fifteen or twenty feet from the ground. Just as is seen in the descriptions of Bonaparte gulls' nests given by the several authors that are quoted in Bent's (1921, p. 176) "Life Histories," they were suggestive of pigeons" nests more than anything else. 
Bonaparte gulls were seen on all the small lakes of the region, and may have been nesting in such places, too, though we had no positive evidence to this effect. The species apparently left early in August; none was seen after the first week of this month.

One specimen was collected (no. 44630), a young bird, taken July 14, molting from the down to first winter plumage, and not yet able to fly.

Sterna paradisaea Brünnich. Arctic Tern

Seen at Carcross, May 22, on Tagish Lake May 27, and at Atlin upon our arrival the next day. Nesting in some numbers (ten or twelve pairs at least) on the islands opposite Atlin, and certainly at other nearby points also, for the birds were seen constantly along the shore of Atlin Lake and about some of the smaller lakes. On the islands mentioned, none of the young survived the onslaughts of the herring gulls.

The species was last seen August 8. One specimen was collected (no. 44631), a young bird taken July 14, molting from the down to first winter plumage.

\section{Mergus americanus Cassin. American Merganser}

A single male bird was seen at Carcross on May 24. The species was not otherwise observed during the summer.

Mergus serrator Linnaeus. Red-breasted Merganser

Apparently rare. An adult male was seen on Atlin Lake, June 6. Several were seen on Surprise Lake, September 15, and one collected (no. 44632), a young bird, fully feathered as regards body plumage but not yet able to fly.

\section{Lophodytes cucullatus (Linnaeus). Hooded Merganser}

An adult male, a single bird, seen on a pond near Atlin on June 17, and watched through binoculars for some time. This is perhaps the most northwestern point of record for the species. Great Slave Lake, its northernmost limit in the interior, is but a little farther north than Atlin.

Anas platyrhynchos Linnaeus. Mallard

Seen at Carcross, May 22. There were probably a few scattered pairs breeding in the marshes about Atlin, but not many. Only an 
occasional bird was encountered, and at long intervals, during the summer. Flocks were seen at Lake Teslin, September 11, and at Fat Creek (between Teslin and Gladys lakes) on September 13. On September 21, my last day afield, I saw two mallards near Atlin.

\section{Nettion carolinense (Gmelin). Green-winged Teal}

Seen at Carcross, May 23. About Atlin, though not common, there were scattered pairs nesting in most of the marshes. More were seen in flooded bottom lands of the upper portion of Otter Creek than anywhere else. Flocks of nearly full-grown young were noted July 28, on Otter Creek, but on August 6, at the same point, a brood of downy young was seen that could have been hatched but a few days. The species apparently leaves early for the south, though such late-hatched young as were just mentioned must linger to a relatively late date. No green-winged teal were seen about Atlin after the middle of August.

\section{Spatula clypeata (Linnaeus). Shoveller}

A single bird, a cripple, was seen by Brooks on a pond near Atlin on June 27. At Carcross we were shown a mounted shoveller that had been shot near that town. The rarity there of this species may be attested by the fact that this bird had been preserved as a curiosity. No one in the community knew what it was.

\section{Dafila acuta tzitzihoa (Vieillot). American Pintail}

Seen at Carcross, May 22. A fairly common species about Atlin during the summer, and especially abundant in the swampy upper reaches of Otter Creek. The first young were noted on June 23, when two newly hatched broods appeared on Lake Como.

I saw no pintails, definitely recognized as such, after the end of August.

\section{Marila affinis (Eyton). Lesser Scaup Duck}

Scaups seen at Carcross, May 22, were presumably $M$. affinis. This was the most numerous breeding duck in the Atlin region, where hardly a pond could be found that did not harbor at least one scaup family. Nests were built in grassy swales or marshes adjoining open sheets of water. Early in June these ducks were in pairs, but by the third week of that month most of the drakes were congregated in flocks by themselves, sometimes three or four birds together, sometimes ten or twelve. 
On June 23 three nests were found in one marsh. Two of these were about twenty feet apart, the other some two hundred yards away. The two closely adjoining nests when found held, respectively, two and four eggs, the other, eight. The nests with two and four eggs, on July 2 held, respectively, nine and ten.

The three nests were similarly placed, each in a tussock of long marsh grass, barely above the level of the water, and they were similarly built. Construction was of the slightest, the nest walls being formed largely of growing grass, and the bottom of the same sort of grass, some placed there but mostly consisting of the crushed vegetation that had been growing on the hummock. The upper rim of the nest wall was dry, but the lower two-thirds was sodden and the eggs were wet. There was no down in any of the nests. In each case the parent bird could slip off of her eggs directly into water deep enough to swim in, six or eight inches in depth, and, by narrow channels through the hummocks, she could reach an open pond nearby.

On July 7 many male scaups were seen that were assuming the eclipse plumage. Two drakes noted July 18 were mostly in eclipse, but were strong on the wing. On July 20 the first downy young appeared. On September 19, the last date on which I visited a suitable spot for this species, several small flocks were seen, perhaps twenty-five or thirty birds, all told.

Four specimens were collected (nos. 44633-44636), one adult male, one adult female, and two downy young.

\section{Glaucionetta islandica (Gmelin). Barrow Golden-eye}

Present at Carcross when we arrived, May 22. One of the most abundant ducks about Atlin; nearly as numerous as the lesser scaup and of even more general distribution. The difference in habitats of the two species lay in the greater abundance of the golden-eye in the little mountain lakes at high altitudes. We found no nests, but the situation of some of the broods seen precluded the possibility of their having been hatched within cavities in trees. Many families were found on lakes above timber line, long distances from trees of sufficient size to afford sheltering holes.

The first young appeared July 3. This particular brood was kept under observation until August 13. Originally nine in number, it was reduced (cause unknown) to seven by July 7. On August 13, the flock consisted of six, plus the mother, and the young then were about three- 
fourths the size of their parent. Small patches of pale-colored down on the sides of the head were all that remained of the young plumage. The young were as yet unable to fly.

On June 14 six adult males were seen together, first evidence of the impending departure of the drakes, and during the next few days southward flying flocks were noted over Lake Atlin and elsewhere. No old drakes were seen during the latter part of the summer. One shot on June 30 was beginning to molt into the eclipse plumage.

Golden-eyes were seen on Lake Teslin, September 11, and there were a few still on Lake Como on September 19.

Six specimens collected, the adult male mentioned above, and five downy young, from two broods of different ages (nos. 44637-44642).

Charitonetta albeola (Linnaeus). Buffle-head

Seen at Carcross, May 22 and 24. Not otherwise observed.

\section{Histrionicus histrionicus pacificus W. S. Brooks}

\section{Western Harlequin Duck}

Breeds in small numbers and at widely scattered intervals throughout the region, where the species generally passes by the name of "wood duck." Two were seen on Lake Atlin, June 20. On September 1 a brood was encountered at "Blue Cañon," and two were collected, an adult female and a young male (nos. 44643-44644). The female had finished the annual molt and the young were full grown. On September 7 a brood was seen in the rushing water of Consolation Creek, near Gladys Lake.

Oidemia deglandi dixoni W. S. Brooks. Dixon White-winged Scoter

At Carcross, May 24 to 26, white-winged scoters were arriving in numbers from the coast. The flights occurred in the evenings, when flock after flock appeared from over the snowy mountain barrier to the westward. They circled about overhead, a few individuals uttering harsh quacks at infrequent intervals; some flocks dropped down to rest in the nearby lakes, while others, after many aerial evolutions, eventually speeded on farther into the interior.

In the Atlin region there was a colony of this species established at Lake Como, but we saw none during the summer on any of the smaller lakes. Just how many pairs nested could not be accurately determined, 
but there were at least twenty or twenty-five adults of each sex settled there at the beginning of the nesting season, and eight or ten broods of ducklings appeared upon the lake later on.

On June 1, at Lake Como, the scoters were all in pairs, and they continued so until near the end of the month. On June 29 the first small flocks of males were seen leaving for the coast; some remained inland until near the end of the summer.

On July 20 the first brood of young was seen, others following within a few days. Broods counted consisted of eight or nine ducklings, but counts had to be made soon after hatching, for the broods quickly merged into loosely assembled flocks so that it was not long possible to keep track of separate families. Sometimes two or three adults were seen in attendance upon sixteen or twenty young, and once a single duck appeared leading thirty-two small ducklings across the lake. The young were very self-reliant, and sometimes six or eight would be found foraging independently, unattended by any old bird. Thus this colony of white-winged scoters led a markedly communistic existence, individuals, young and old, gathering together into larger or smaller groups as suited their convenience at the time. The scaups, too, had as little seeming regard for family ties, their habits in these matters being much the same as with the scoters.

Young scoters but a day or two old were seen diving expertly, making long stays below the surface. Old birds, carefully watched through binoculars, were frequently seen to make use of their wings as they dived, but this was not invariably the case. White-winged scoters to the number of twenty or more were still on Lake Como on September 19, the last day I visited the lake.

Four specimens were preserved, ducklings not more than two or three days old (nos. 44645-44648).

\section{Oidemia perspicillata (Linnaeus). Surf Scoter}

An adult male that was seen on Lake Atlin, opposite the town, on July 21 and on several days following, was the only surf scoter encountered during the summer.

\section{Branta canadensis (Linnaeus), subsp.? Canada Goose}

Canada geese were migrating in some numbers at Gladys Lake, September 8, and they were abundant at certain points on Lake Teslin, September 10 to 13. A flock of about fifty passed over Atlin on 
September 21. As these were the only migrating geese I saw there, though they were so abundant on the more eastern lakes mentioned above, it would seem that Atlin Lake is not on the most generally used migration route of this species.

\section{Lobipes lobatus (Linnaeus). Northern Phalarope}

A pair of northern phalaropes that were seen in a swamp several miles north of Carcross on May 23 were observed going through courting antics and then copulating, and were thus judged to be preparing to nest there.

The first south-bound migrant, a single bird still in summer plumage, was seen near Atlin on July 21; a flock of about thirty-five birds appeared on August 27. On September 1 single birds and groups of two and three were found scattered over various small lakes above timber line.

\section{Gallinago delicata (Ord). Wilson Snipe}

Seen at Carcross, May 22. Breeds in fair abundance in the Atlin region; there was probably a pair or two in every swamp of any size. From the town of Atlin the "bleating" of the snipe could be heard almost continuously during June and early in July. Frequently when awakening at night during the brief period of partial darkness at that season, I heard snipe circling about overhead. The "bleat" under such conditions was very suggestive of the call of the California screech owl.

The birds were often observed performing these aerial evolutions, and in practically all respects our observations bear out the descriptive comments of Kitchin, Dawson, and Hoffmann, as detailed by the last mentioned writer (Hoffmann, 1924, p. 175). This performance ceased abruptly the middle of July, the last "bleating"' being heard on July 17. The birds are otherwise unobtrusive, and I saw none after that date.

Pisobia maculata (Vieillot). Pectoral Sandpiper

Seen on but one occasion, a single bird in a flock of lesser yellowlegs on June 4.

Pisobia bairdii (Coues). Baird Sandpiper

Seen at Carcross, May 22. Not otherwise observed. 
Pisobia minutilla (Vieillot). Least Sandpiper

Seen at Carcross May 22. At Atlin the first south-bound migrants appeared June 29, when two single adults were seen at different points. One of the birds was performing the usual mating flight. A few days later small flocks began to drop in at intervals, continuing until August 27, when the last was seen.

\section{Ereunetes pusillus (Linnaeus). Semipalmated Sandpiper}

A single bird, a south-bound migrant, was collected at Atlin, July 17. This specimen (no. 44649) is an adult female, in which the annual molt has just begun. Two were seen at close range on the shore of Morley Bay, Lake Teslin, September 12.

\section{Totanus flavipes (Gmelin). Yellow-legs}

Present in some numbers at Carcross, May 22, and evidently then preparing to nest. The birds were in pairs and noisy and solicitous at any invasion of their territory. Some were going through the nuptial flight and "song," some perched on tree-tops scolded the intruder. About Atlin there were yellow-legs in nearly every lowland swamp. While the breeding birds were thus distributed in pairs over the country, there were also wandering flocks that appeared at intervals during June and July. These were evidently composed of non-breeding individuals.

We found no nest, but Brooks collected a newly hatched chick on June 17. The downy young had the faculty of remaining invisible, or nearly so, but when almost full grown they became conspicuous about the edges of the ponds, and were then indifferent to approach. By July 20 the yellow-legs had nearly all left for the south; the last birds were seen August 13 and 14.

Three specimens were collected by me, young nearly or quite full grown (nos. 44650-44652).

\section{Tringa solitaria Wilson. Solitary Sandpiper}

First seen at Carcross, May 25. Early in June the species was encountered not uncommonly about Atlin, and the birds seen had all the appearance of being upon their nesting grounds. Individuals were going through their courting flight and song overhead, and some were 
settled at certain spots where they resented intrusion. Whatever the reason, these birds all disappeared before the end of June, and we had no evidence that any broods were hatched in that vicinity. The first fall migrant appeared on upper Otter Creek, July 27, and during the next ten days they were of daily occurrence. Last seen August 6.

Two specimens were collected (nos. 44653-44654), an adult male at Carcross, May 25, and an immature male on Otter Creek, July 27. From outward appearances these birds might be referred to two different subspecies, the first to the eastern form, Tringa solitaria solitaria, the other to the western, T. s. cinnamomea, but I am not satisfied that this division is justified. These two subspecies, at best, are but poorly defined. The latest monographer of the group (Ridgway, 1919, pp. 353, 358, 363) gives the distinguishing characters of the two as follows: Tringa s. solitaria. Size smaller. "Summer adults with upper parts much more distinctly spotted with white; young with spotting on upper parts white or grayish white; white bars on tail averaging wider; the middle pair of rectrices never wholly grayish brown."

T. s. cinnamomea. Size larger. "Summer adults with upper parts much less distinctly spotted with white; young with spotting of upper parts brownish buffy or cinnamomeus; white bars on tail averaging narrower, the middle pair of rectrices often (usually?) wholly deep grayish brown."

An additional character cited by Brewster (1890, p. 377) in his description of Totanus solitarius cinnamomeus, but not used by Ridgway, is the presence in cinnamomeus of more or less "freckling", at the inner base of the outermost primary.

Examination in the present connection of some forty-odd specimens of eastern and western birds revealed no more satisfactory mode of dividing them than by regard to the points of capture. Some eastern specimens (from Indiana and Pennsylvania) are smaller than any western birds, but others are well within the size limits of cinnamomea. Also, some western birds, taken in the fall and presumably immature, are more cinnamomeous in color of upper parts. As regards distinctness of spotting above, and character of tail markings, I found it impossible to make division by these features. Most (but not all) western birds show more or less of the "freckling" at the base of the primary, and it is not present in any eastern specimens at hand.

The several characters indicated are independently variable, so that a given specimen may, on the basis of one certain feature, seem 
referable to the eastern subspecies, and to the western on just as strong resemblances in other respects. The fact that so little is known of the breeding ranges of the two forms is an added reason for conservative systematic treatment of non-breeding birds.

Heteroscelus incanus (Gmelin). Wandering Tattler

An adult male, a single bird (no. 44655), was shot by Brooks at Carcross, the evening of May 25. It was presumably en route to its breeding grounds farther inland.

\section{Actitis macularia (Linnaeus). Spotted Sandpiper}

Seen at Careross, May 22. Abundant in the Atlin region. Breeding along the lake shore and along stream beds; inevitably encountered wherever conditions are favorable. During the second week in June unfinished nests and incomplete sets were found; by the third week in July young birds had appeared; by the middle of August the young were full grown and in the first fall plumage. The last spotted sandpiper was seen at Surprise Lake, September 15.

\section{Numenius hudsonicus Latham. Hudsonian Curlew}

One was shot near Atlin by one of the residents of the town, about the middle of May, shortly before our arrival. I saw the mounted bird. This is of interest as an inland occurrence of an usually maritime species; I know of no other occurrence in British Columbia away from salt water.

\section{Oxyechus vociferus (Linnaeus). Killdeer}

At Atlin, May 28, a pair of killdeers were found established in a marsh immediately behind the town. They were seen there several times, but apparently left without successfully nesting. On July 7 a single bird was seen on the shore of Lake Como, and on July 10 one was flushed from a marshy spot in dense woods near that lake. These occurrences constitute probably the northernmost records of this species so near the coast, though inland it has been found somewhat farther north, to Great Slave Lake.

Charadrius semipalmatus Bonaparte. Semipalmated Plover

Present at Carcross, May 22, and at that time in pairs and evidently ready to nest. Fairly common in the Atlin region; that is, a pair or 
two could be found wherever conditions were favorable, a gravelly or sandy shore being the main requisite. The birds were noisy and solicitous on the breeding grounds. The sitting bird left the nest at the first appearance of an intruder in the distance, and male and female together hovered about, calling overhead or fluttering painfully over the ground with wings and tail outspread and dragging.

A nest was found June 10, containing four eggs, heavily incubated. This was in a gravelly area of wide expanse where Pine Creek empties into Atlin Lake, a locality that held at least three pairs of the plovers. The nest was in hard gravel, a depression about one inch deep and with vertical, sharply defined walls, the hole partly filled with small chips of wood and a few coarse straws. The eggs were placed perpendicularly, points down.

On June 20 the first young were seen, just hatched. The last semipalmated plover, a single bird, was seen at Como Lake, August 21. Two specimens were collected (nos. 44656-44657), both newly hatched young, one taken June 20, the other, July 21.

\section{Aphriza virgata (Gmelin). Surf-bird}

A single bird was shot by Brooks at Careross, on the morning of May 27. It was taken at the same spot as the wandering tattler of two days before.

\section{Dendragapus obscurus flemingi Taverner. Fleming Grouse}

Nine specimens were collected by me (nos. 44658-44665, and one, unnumbered, presented to Allan Brooks). The series includes one small chick changing from natal down to juvenal plumage; one young male nearly through the post-juvenal molt; two old cocks, two years old or more; two males of the previous summer; two females in fully acquired first winter plumage; one adult female just through the annual molt. Brooks collected additional specimens, old and young, all of which I examined, and there are at hand, from previous expeditions in northern British Columbia, five adult females and three birds in juvenal plumage throughout. During the late fall following my departure from Atlin, Mr. A. B. Taylor, of that place, secured for me twelve additional specimens (nos. 46091-46102), six males and six females, some fully adult and some birds of the year. These constitute an invaluable series, as all are in freshly acquired fall plumage. 
All this material affords an opportunity both for determining the characters of the subspecies flemingi and for following some of the complicated plumage changes that are undergone by grouse of this genus.

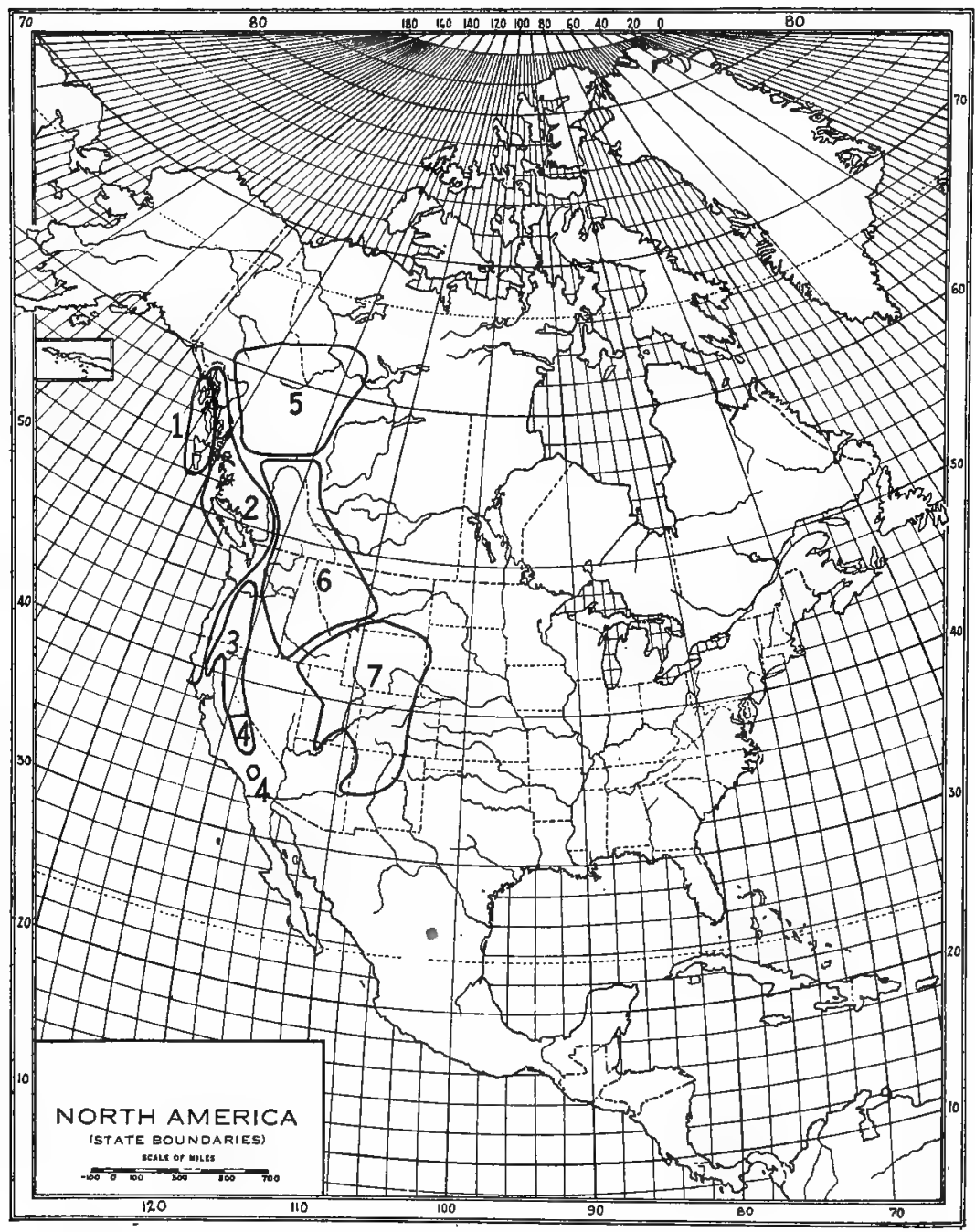

Fig. A. Map showing distribution of grouse of the genus Dendragapus: $1, D$. fuliginosus sitkensis; $2, D$. $f$. fuliginosus; $3, D$. $f$. sierrae; $4, D$. f. howardi; 5. D. obscurus flemingi; $6, D$. o. richardsonii; $7, D$. o. obscurus.

The type locality of flemingi is given by Taverner (1914, p. 386) as "near Teslin Lake." The country about Teslin Lake is mostly lowland, with not much mountainous territory suitable to this species. 
I learned that the man who collected the type series of flemingi (a trapper, who sold specimens to the Canadian Geological Survey) had had his headquarters at Nisuttlin Bay, on the east side of the lake, and, from what I was told, in all probability his birds were shot on a low mountain that rises some four or five miles north of that point.

Fleming $i$ is unquestionably closely related to richardsonii and much farther removed, genetically, from the coastal forms of Dendragapus whose ranges it approaches so nearly on the westward. In the descrip-
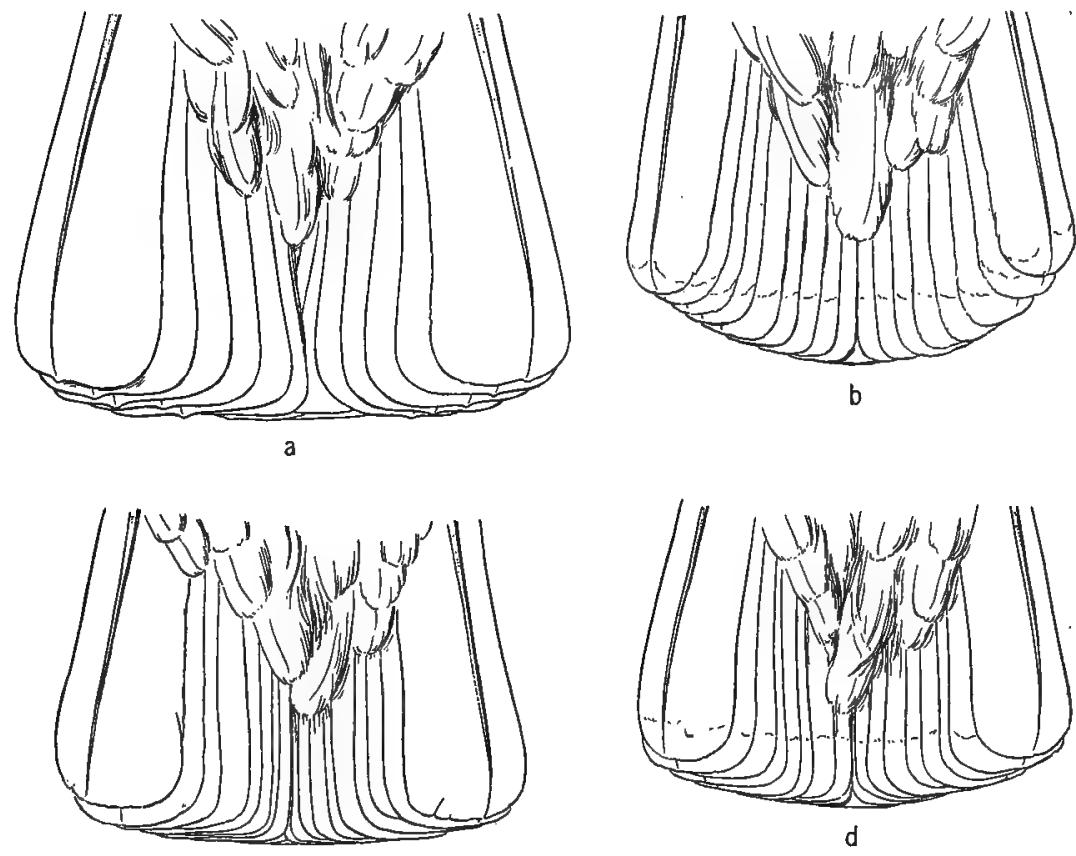

Fig. B. Tails of Dendragapus obscurus flemingi, showing variation due to sex and age; about $1 / 2$ natural size. a, adult male, in second year or older (M. V. Z. no. 46091) ; b , immature male, during first year (M. V. Z. no. 46092); $c$, adult female (M. V. Z. no. 42001); d, immature female (M. V. Z. no. 46093).

tion of flemingi, Taverner (loc. cit.) properly makes most of his comparisons with richardsonii, as its closest relative, but he lays undue stress upon certain features that are of no systematic import. In the description of the tail he says: "Tail feathers not having the same chopped off appearance. Middle and several lateral feathers slightly to markedly double-rounded at end." This is a matter of age (see figs. $B$ and $C$ ); the shape of the tail is the same in both subspecies. 
The distinguishing feature between the two is color. The adult male of richardsonii is grayish in general appearance with some light brown mottling on back and sides. In flemingi the brown markings are much reduced and of a darker shade; in general appearance the fully adult male bird is almost black. In the adult female and in immatures (natal down and juvenal plumage of richardsonii not seen), corresponding differences exist. In most cases the distinctions between the two subspecies are evident upon the most cursory examination, and with the exception of one specimen they are uniformly maintained throughout the series at hand. The exception is an immature female of flemingi (no. 44665, head of Surprise Lake, Atlin region, September 14, 1924), which is much paler than others from the same general region, and hardly to be distinguished from a selected specimen of richardsonii from southern British Columbia. This bird may be taken to exemplify intergradation by individual variation between the two subspecies.

The sequence of plumage-changes with age in the grouse of the genus Dendragapus is sufficiently complicated to be difficult to follow, and extensive series of specimens are needed to trace the different stages. An understanding of the development of the individual bird is, however, absolutely necessary in order to avoid mistakes in making comparisons between the several forms included in this group.

Taking the subspecies flemingi as a basis, the following stages may be described as indicating the course of development followed in these grouse. Dates given apply to conditions in northern British Columbia.

Natal down: Sexes alike. There is no specimen of fleningi at hand entirely in the down, but comparing small young, still down-clothed on head and breast, with specimens of sitkensis and fuliginosus at the same stage, young flemingi is seen to be much less yellow, more gray, than are the young of those forms.

Juvenal: Again much more gray than in sitkensis and fuliginosus. Rectrices and remiges begin to appear a few days after hatching, and the young birds are able to fly long before the natal down is all lost. The head and neck are the last parts to be clothed in feathers, as shown in a specimen collected July 8. There is continuous replacement of plumage on the wings from the time the bird is hatched until it has finally completed the post-juvenal molt and is practically full grown. As shown by specimens of young flemingi and of other subspecies also, there are two complete sets of primaries, secondaries, tertials, and greater coverts, at least, acquired during the juvenal stage. The 
newly hatched bird grows a set of small-sized wing feathers to accord with the tiny wing, and these are molted and replaced with others of the same juvenal type but of larger size. This can be demonstrated by measurement of corresponding feathers upon the wings of young birds of different ages.
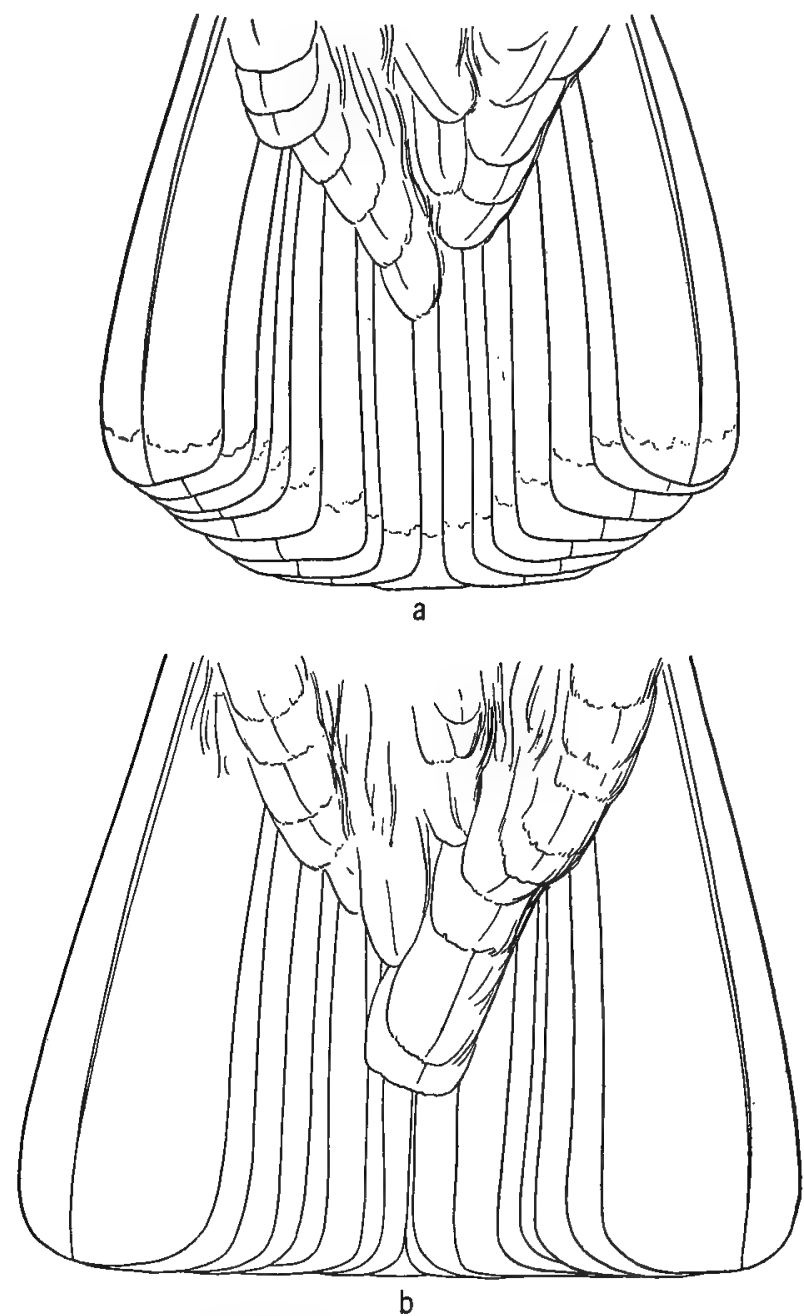

Fig. C. Tails of Dendragapus obscurus richardsonii, showing variation due to age; $1 / 2$ natural size. a, immature male, during first year (M.V.Z. no. 42642); $\boldsymbol{b}$, adult male, in second year or older (M.V.Z. no. 533).

First winter plumage (male): The sexes are unlike at this stage, nearly as much so as in the fully mature birds. The post-juvenal molt begins late in July or early in August, inaugurated by the shedding 
of the juvenal rectrices (as pointed out by van Rossem, 1925, p. 417), and continues until nearly the middle of September. It may not continue over this entire period in the case of any one bird, but the time indicated is when the young, as a group, are undergoing this molt. The molt of the tail begins with the outermost feathers and progresses toward the middle. As in the post-natal molt, the head and neck are almost the last parts affected. The very last feathers to be changed appear to be the tertials. Juvenal tertials may be found on birds otherwise entirely in first winter plumage, as in two females at hand, collected September 14 and 15, respectively. The male in first winter plumage is in general like the fully adult except in tail character. The young male (until the end of the second summer) has the tail rounded, with the individual feathers relatively narrow and rounded. As a rule it has the tail more distinctly gray-tipped than is the case in adults. Minor color characters that appear in the first winter plumage, as compared with the fully adult, are: much more white spotting on upper breast, sides, and flanks; on the wings, the primaries, secondaries, tertials, and coverts are all more extensively mottled with rusty.

Adult plumage (male): The first post-nuptial molt begins about the middle of July of the second year and lasts until about the middle of September. The change in character of rectrices is the one conspicuous feature of the mature plumage. I cannot find that there is any renewal of rectrices (except sporadically, presumably as the result of accidental feather loss) until this molt regularly begins. This, I believe, is the only point in which I disagree with van Rossem (1926, pp. 417-422) in the conclusions drawn by him regarding molt in this gemus. The fully adult tail, now acquired, is square ended, the feathers broad and truncate. Minor color differences are a clearer gray coloration below and less white spotting on breast and sides, while the mottling on dorsal surface of wings and on interscapulars is less in extent, and gray instead of brown.

In the female the differences between first winter and later plumages are not so apparent, but here, too, the greater breadth of the tail feathers is a feature of the mature bird.

The several recognized forms of Dendragapus are currently regarded as being all subspecies of one species, Dendragapus abscurus, but it seems to me that there are, rather, two species involved in this assemblage. Under the species Dendragapus obscurus I would place (from north to south) the subspecies $D$. o. flemingi, $D$. o. richardsonii, and $D$. o. obscurus. Under the species Dendragapus fultiginosus I 
would place as subspecies, $D$. $f$. fuliginosus, $D$. $f$. sitkensis, $D$. f. sierrae, and $D$. f. howardi. The differences between the obscurus and fuliginosus aggregations are trenchant ones and I have seen no doubtful specimens, no "intergrades," from regions where the two come closest together. There are various statements in literature affirming the existence of intergradation between obscurus and fuliginosus, but these are all assertions of the most casual nature, with no detailed information accompanying them.

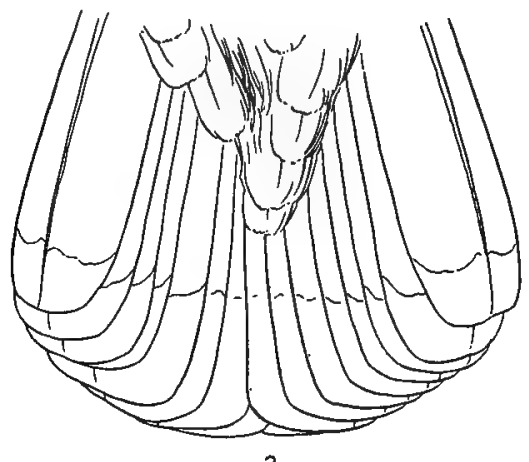

a

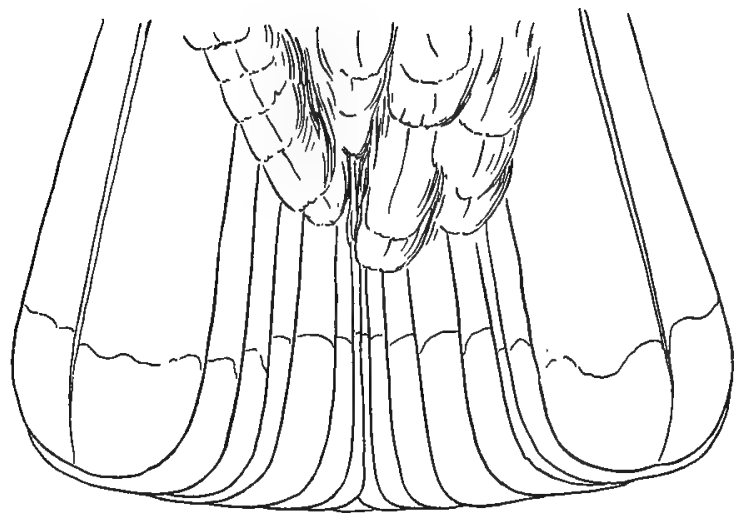

b

Fig. D. Tails of Dendragapus obscurus obscurus; $1 / 2$ natural size. a, immature female, during first year (M.V.Z. no. 32051); $b$, adult male, in second year or older (M.V.Z. no. 45556).

In this connection it is pertinent to note conditions at Log Cabin, on the east slope of White Pass, about on the boundary between the ranges of fulliginosus and flemingi, where Brooks hoped to collect specimens of grouse that would have bearing on this problem. $\mathrm{He}$, himself, found no Dendragapus there, and he was told by residents that none occurred in that stretch of country. 
As between the two aggregations, obscurus and fuliginosus, besides color differences and besides the shape of the tail, so markedly contrasted in the closely adjacent northern subspecies, account must be taken of the call-notes of the male birds, which are so radically different as to indicate a wide divergence and one of long standing, a specific difference. The reverberant, wooden call of an old "hooter" (Demdragapus fulviginosus) is the same from Alaska to southern California, a sound that carries a half-mile or more, and a very different call from the subdued tooting of the Richardson grouse and its allies. Complementary to this, the relative development of a part of the hooting apparatus, the naked skin on the sides of the neck, is another difference between the two forms (see Brooks, 1912, p. 252; 1926, p. 283).

It looks as though in all the earlier studies of these grouse the presence of a terminal gray band on the tail alike of obscurus and of fuliginosus was allowed to outweigh all other features of resemblance or dissimilarity between the several forms. Aside from this, an adult male of obscurus is very closely similar to an adult male richardsonii. The tail of an adult male obscurus at hand, from Colorado, is nearly as square as in richardsoniu, not rounded as in fuligimosus. The rectrices of obscumus, however, are not markedly truncate.

In years past richardsonii has sometimes been regarded as a species, distinct from the several other forms of "blue grouse," all regarded as subspecies of $D$. obscurus, but study of a map outlining the distribution of the races will show how illogical such division would be (see fig. A).

It is curious to what an extent certain of the characters of richardsonii parallel the distinguishing features of Canachites franklinii. This grouse (which is currently regarded as a species, distinct from other forms of Canachites) has developed the same square-tipped tail with broad, truncate feathers, and, besides this striking resemblance, the distribution of the Franklin grouse is almost the same as in the Richardson grouse; almost, but not exactly, for northward the range of Canachites franklinii extends well within the territory of Dendragapus o. flemingi. In the northern portion of its range, D. o. flemingi is accompanied by Canachites canadensis osgoodi.

In differentiating the several subspecies of "blue grouse" (both species), shape and markings of the tail are useful characters, but to ascribe proper weight to these variations an understanding is necessary of the development of the individual bird, of the stages gone through to reach maturity, as previously indicated in this paper. In both sexes 
of all the forms of Dendragapus there is more or less variation with age in the shape of the tail feathers, in the length of the tail, and in the shape of the tail as a whole.

In the plumage as a whole there is marked seasonal variation, too, that must be taken into account. Birds in fresh fall plumage (both sexes and both the yearlings and fully mature) are of a clearer bluegray, compared with late spring and summer specimens, in which this color has changed to a dingy brown.

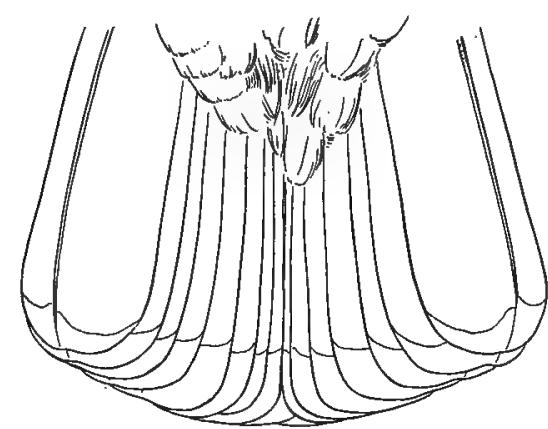

a

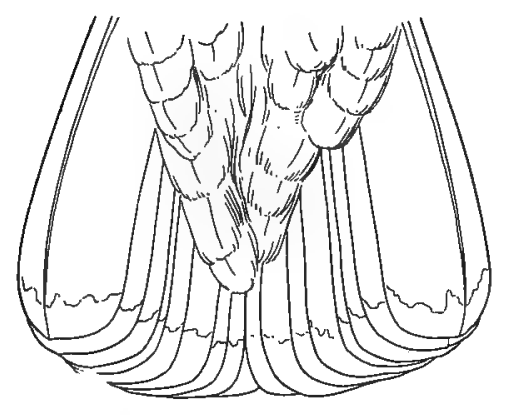

$c$
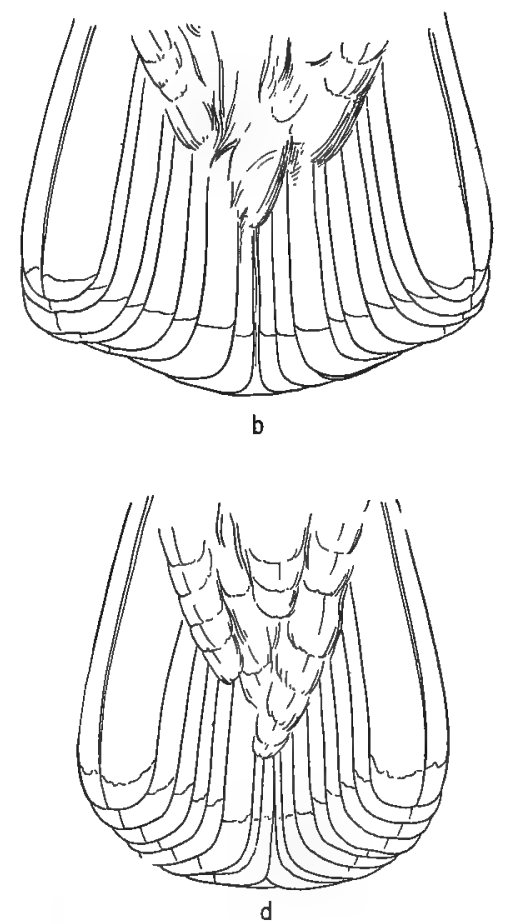

Fig. E. Tails of Dendragapus fuliginosus sitkensis, showing variation due to sex and age, about $1 / 2$ natural size. $a$, adult male, in second year or older (M.V. Z. no. 133); $b$, immature male, during first year (M.V.Z. no. 136); $c$, adult female (M.V.Z. no. 134); $d$, immature female (M.V.Z. no. 135).

Relative roundness of tail, besides being a marked age character in certain forms, is also a feature in geographical variation. The subspecies howardi was described as having the tail longer and more graduated than sierrae (Dickey and van Rossem, 1923, p. 168), and the comment is made that "throughout the range of Dendragapus obscurus in California there is a gradual geographic variation which particularly affects the length and graduation of the tail." This same variation can be traced beyond California. From the northern limit 
of the species Dendragapus fuliginosus in southeastern Alaska to its southern limit at Mt. Pinos, California, there is a steadily increasing degree of graduation in the tail. The same sort of geographical variation (that is, shape of tail) is seen to some extent in the richardsonii group. Flemingi and richardsonii are alike in possessing squaretipped tails, but the more southern form, obscurus, has the tail slightly rounded.
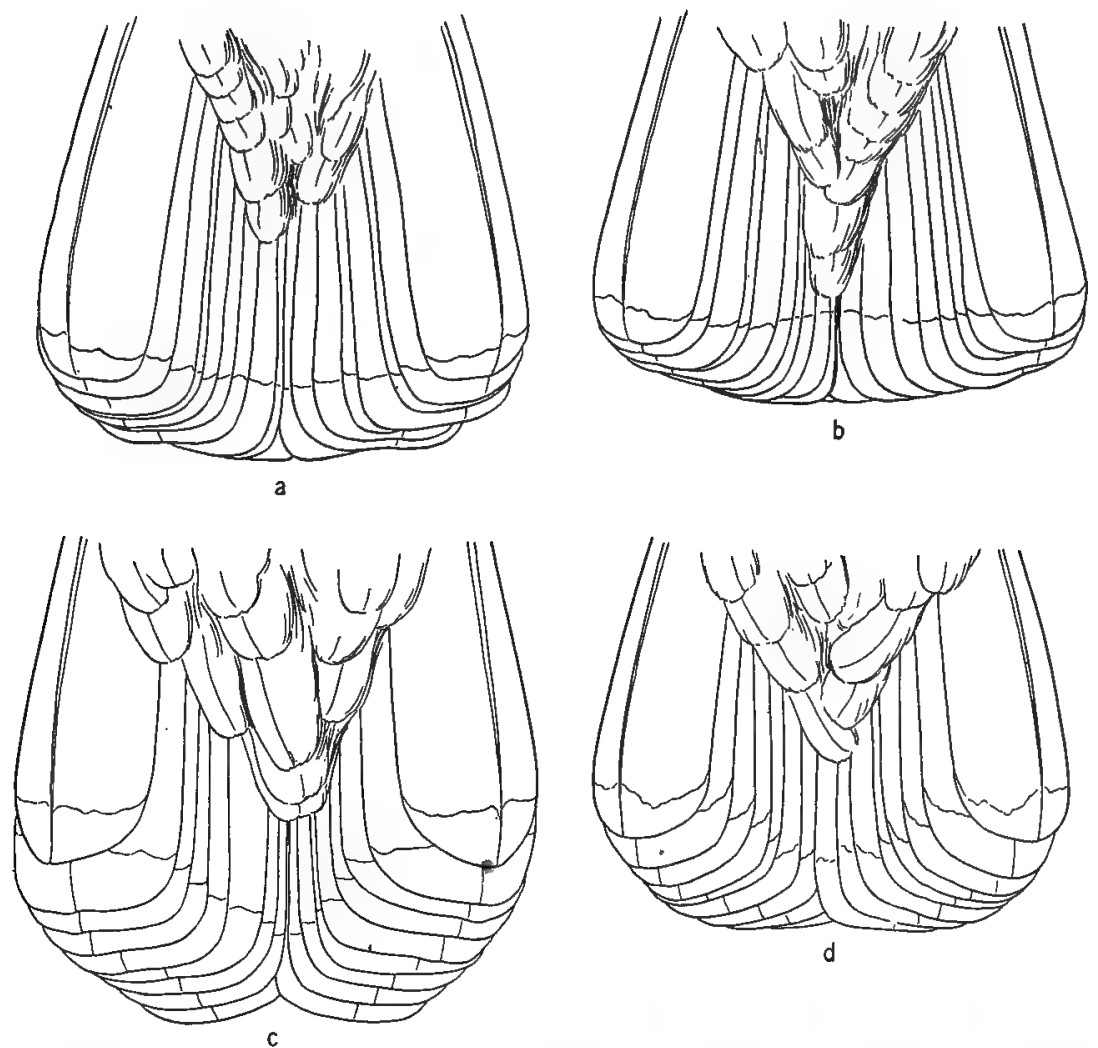

Fig. F. Tails of Dendragapus fuliginosus sierrae and $D . f$. howardi; about $1 / 3$ natural size. $a, D$. f. sierrae, adult male (M.V.Z. no. 5082); $b, D$. f. sierrae, adult female (M.V.Z. no. 14069); $c, D$. f. howardi, adult male (coll. D. R. Dickey, no. K-240); $d, D$. f. howardi, adult female (coll. D. R. Dickey, no. J-881).

In the more southern subspecies of the fuliginosus group the gray terminal tail band is notably broader than in the northern races. In the southern obscurus, again, this feature is prominently developed, in contrast to conditions in the more northern richardsonin and flemingi, where it is all but absent. 
In the course of this study I had occasion to examine five adult Dendragapus (in the D. R. Dickey collection) from the coastal side of White Pass, above Skagway, Alaska, and, most unexpectedly, these birds proved not to be of the subspecies sitkensis. They are exactly similar to specimens of fultiginosus from Vancouver Island. Prior. to this I had seen but two specimens of Dendragapus from a mainland point in Alaska, a male and a female from Glacier Bay. The female was recognized as darker colored and less reddish than any island specimens of sitkensis, but it is in badly worn plumage, and this worn condition, it was assumed, might account in part for the difference.

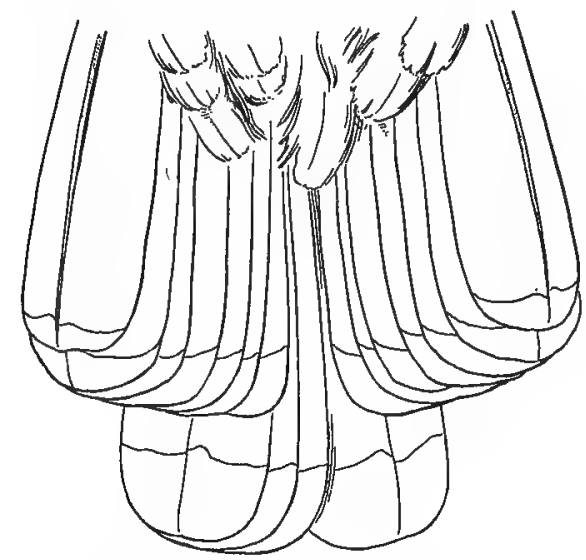

Fig. G. Tail of Dendragapus fuliginosus fuliginosus, showing variation due to age; immature male (M.V.Z. no. 15579); $1 / 2$ natural size. Four centrai immature rectrices were lost by this bird in some way other than by the regular molt. The four longer rectrices that replaced them are of the adult type. The shorter lateral rectrices are of the immature type and have their full length. This bird, shot June 22, would not have molted for two months.

In the light of the additional specimens from Skagway, however, a revision of this view is necessary. It looks as though the subspecies Dendragapus fuliginosus fuliginosus must occur northward continuously along the mainland coast of British Columbia and southeastern Alaska, leaving sitkensis restricted to an island habitat.

In the Atlin region the "blue grouse" is resident and fairly common at high altitudes. It is a favorite game bird of the region, both from its large size and from the excellent quality of its flesh. Its habitat is about timber line, where there is open country interspersed with clumps of balsam firs. The dense thickets of these stunted trees, with their gnarled and spreading branches, afford shelter from enemies and from inclement weather, and in the foliage food also is furnished when other sources fail. 
Small chicks were seen on July 8. By the first of September young birds were nearly finished with the post-juvenal molt, and about twothirds the size of adults by measurement, though of only one-half the weight. The broods are cared for solely by the hen. The old cock is usually solitary during the summer, though males of the previous year sometimes form small coveys, together with non-breeding females. Such gatherings were encountered on several occasions. The hen with a brood is sometimes tame to the verge of stupidity; I found several that were, literally, as indifferent to approach as any barn-yard fowl. I have, however, seen an occasional covey of young birds that was extremely hard to approach. The broods often feed over open meadows, where they are exposed to attack by hawks and other enemies, and there must be a heary mortality from such causes. That this is so is borne out by the small size of most of the broods encountered, and by the number of hens seen with no broods at all.

Following is a list of subspecies of the grouse of the genus Dendragapus, arranged according to their geographical position, from north to south.

1. Dendragapus obscurus flemingi Taverner. Fleming Dusky Grouse.

2. Dendragapus obscurus richardsonii (Douglas). Richardson Dusky Grouse.

3. Dendragapus obscurus obscurus (Say). Colorado Dusky Grouse.

4. Dendragapus fuliginosus fuliginosus (Ridgway). Oregon Sooty Grouse.

5. Dendragapus fuliginosus sitkensis Swarth. Sitka Sooty Grouse.

6. Dendragapus fuliginosus sierrae Chapman. Sierra Sooty Grouse.

7. Dendragapus fuliginosus howardi Diekey and ran Rossem. Mount Pinos Sooty Grouse.

\section{Canachites canadensis osgoodi Bishop. Alaska Spruce Grouse}

Ordinarily this is a common species in the region, but in 1924, for some reason that was not obvious, spruce grouse had declined in numbers to a point of actual scarcity. Single birds were flushed at long intervals, as were occasionally hens with their broods, consisting of one, two, or three chicks. No larger broods were seen. Early in September, traveling from Atlin to Lake Teslin and back, a week's trip, I saw all told only ten or twelve spruce grouse. This was in country that was throughout suitable to the species, and where during other years it had been found in abundance.

The spruce grouse is primarily a lowland species in the Atlin region. In the valleys it occupies the spruce woods almost entirely, being 
rarely seen in the groves of poplar (the principal deciduous forest tree), and it follows the spruce up the mountain sides as far as that tree goes. We saw none in the balsam woods of slightly higher altitude, where the blue grouse (Dendragapus) is found.

Twelve specimens of spruce grouse were collected (nos. 4466644677) : two adult males, one adult female, one downy chick, near Atlin, June and July; one adult male, Spruce Mountain, August 8, nearly through the molt; one adult female and one immature male, Atlin, August 27, both finishing the molt; one male, Gladys Lake, September 9 ; one male and three females, Fat Creek, five miles west of Lake Teslin, September 13.

These birds were all taken within fifty or sixty miles of Lake Marsh, the type locality of osgoodi, and may fairly be assumed to be typical of that subspecies. Through the courtesy of Dr. L. B. Bishop I have been able to examine three near-topotypes of osgoodi, females from Lakes Marsh and Lebarge, but these birds, taken in July, are in such worn plumage as to be of little value for color comparisons. Most of the specimens from southern Yukon and northern British Columbia are appreciably different from birds from the northern limits of the habitat of osgoodd, as currently defined. Northern Alaskan birds exhibit the extreme of grayness seen in the species Canachites canadensis. One female taken in June at Atlin is as gray as any of the more northern birds, but the rest of the series are less overcast with grayish dorsally, less heavily marked with white on the breast, and are generally more richly colored. For the present it seems best to continue to use the name osgoodi for the race of spruce grouse occurring from northern Alaska south into northern British Columbia, but future collecting, especially of series from Alberta and Mackenzie, may show the desirability of a different arrangement.

\section{Bonasa umbellus umbelloides (Douglas). Gray Ruffed Grouse}

An uncommon species in the Atlin region, in our experience. An occasional cock bird was flushed in poplar thickets, and two broods of young were seen during the summer. Aside from the chicks, not more than eight or ten birds, all told, were seen. Two specimens were collected (nos. 44678-44679), adult males, taken September 19 and 21, respectively. 


\section{Lagopus lagopus albus (Gmelin). Southern Willow Ptarmigan}

Specimens of willow ptarmigan collected by myself in the Atlin region include three adult males and one adult female in summer plumage, two in natal down, two in juvenal plumage, twelve adult males and five adult females in "winter plumage, preliminary" or partly in that plumage, five immature males and two immature females, mostly in first "winter plumage, preliminary," a total of thirty-two skins (nos. 44680-44711). Additional specimens collected by Brooks near Atlin and near Log Cabin were also at my disposal.

In previous papers I have used the name alexandrae for the willow ptarmigan of British Columbia, but this additional mainland material, together with a large series of alexandrae from the Alexander Archipelago, southeastern Alaska (in the collection of George Willett), now available, demonstrates differences that exist between the two.

Riley (1911, p. 233) divided the willow ptarmigan of the North American mainland into two subspecies, Lagopus lagopus ungavus from the region east of Hudson Bay, and $L$. $l$. albus from the region to the westward. Ungavus he describes as having a heavier bill than albus. The range of albus is given as "from the west side of Hudson Bay, west through northern Alaska to eastern Siberia."

Clark (1910, p. 52), on the other hand, had previously said of the mainland birds (to which he gives the name Lagopus lagopus albus) that "all those from Labrador and central arctic America, with others from Point Barrow, Kotzebue Sound, Cape Lisbourne, Kowak River, Yukon River, and near St. Michaels, belong to a well-differentiated race, with the beak very large, high, and stout, the culmen strongly arched, and usually with a prominent ridge from the inferior corner of the maxilla to in front of the nostril. They are identical among themselves, it being impossible to tell from the examination of any one specimen whether it was taken in Alaska or in Labrador."

Thayer and Bangs (1914, p. 4) described Lagopus lagopus koreni from eastern Siberia, as differing from the willow ptarmigan of northern Alaska in its still heavier bill.

Differences which I had previously noted between British Columbia ptarmigan and those from northern Alaska were not to be reconciled by either Clark's or Riley's treatments of the races, and compelled further comparisons. Through the courtesy of Dr. Alexander Wetmore, Assistant Secretary of the Smithsonian Institution, I was enabled to borrow from the United States National Museum three specimens of 
willow ptarmigan (Lagopus lagopus albus) from the west coast of Hudson Bay, and ten (L. l. ungavus) from Fort Chimo, Ungava. Comparison of these birds with the series in this museum convinced me of the existence of the following recognizable subspecies of the willow ptarmigan on the North American mainland: (1) Lagopus lagopus ungavus from the region east of Hudson Bay, as defined by Riley (loc. cit.); (2) Lagopus lagopus albus from the west shore of Hudson Bay westward to the coast ranges of northern British Columbia, and for an undetermined distance northward; (3) an undescribed subspecies from the Alaskan mainland and extending for an undetermined distance eastward in the extreme north.

To clear the ground for further discussion the Alaskan bird may now be described, as follows:

\section{Lagopus lagopus alascensis, new subspecies}

Alaska Willow Ptarmigan

Type.-Male; no. 32125, Mus. Vert. Zool.; Kowak River Delta, Alaska; June 20, 1899; collected by J. Grinnell; original no. 4031.

Distinguishing characters.-Slightly larger than albus. A large-billed race; bill slightly smaller than in ungavus, much larger than in albus (see fig. $\mathrm{H}$ ). In summer plumage, generally more reddish-colored than either ungavus or albus, a difference that is most conspicuous in females in the barred breeding plumage.

Range.-The Alaskan mainland except on the southeastern coast, northern Yukon Territory (specimens from vicinity of Forty-mile), and eastward for an undetermined distance.

Two males and one female ptarmigan at hand from the west side of Hudson Bay, one from Fort Churchill, July 24, and two from a point 75 miles north of York Factory, July 19, may be assumed to represent Lagopus l. albus (Tetrao albus Gmelin, 1788, p. 750, described from Hudson Bay). In bill structure they are like the British Columbia birds. In color the two males are like the British Columbia birds, but the Hudson Bay female is more reddish as compared with the gray-colored females of the latter series. Despite this difference in the females it seems best for the present to regard all as of the same subspecies, a small-billed southern race of the willow ptarmigan extending from Hudson Bay westward to the coast ranges of southeastern Alaska and northern British Columbia. 
Alexandraie and albus are alike in possessing a small, slender bill, as contrasted with the heavy, more stubby bill of alascensis, and in color and markings they are closely similar in some plumages. Adult males in breeding plumage are essentially alike. The adult female of albus in breeding plumage (this and further allusions to albus refer to the British Columbia series) differs from the female alascensis in that stage, being much darker and less ruddy. The breeding female of alexandrate (one specimen from Porcher Island, British Columbia) is also a dark-colored bird but with a maximum of brown coloration in the plumage. The dark-colored female of albus has extensive blackish areas on the feathers, which are edged with dull brown or with grayish. In the dark-colored female of alexandrae there is an extension of rich brown markings on all parts of the bird.

Differences between albus and alexandrae are readily apparent in the "winter plumage, preliminary," that is, in the brown, late summer garb (the plumage stage inserted between breeding plumage or juvenal plumage, and the white winter plumage) in which both sexes and old and young become essentially alike-or would do so if this plumage were ever acquired in its entirety.

Alexandrae in this plumage is well represented in a series of specimens at hand collected by George Willett, mostly from Prince of Wales and Dall islands. In an adult male (Willett coll., Dall Id., September 3, 1919), head, neck, and body (except for a limited white area on the abdomen) are almost solidly dark brown, ranging from "brick red" to "Hessian brown" (Ridgway, 1912), with hardly a trace of vermiculation or mottling on the breast, and relatively little on the upper parts. In color tone and in markings on individual feathers there is extraordinarily close resemblance to winter specimens of the Scotch red grouse (Lagopus scoticus).

In albus in the same plumage, the browns are paler, there is much black or dusky barring and vermiculation, and dorsally the feathers are extensively black centered, and are gray tipped to such a degree as to affect the color tone of the whole upper surface. In alascensis the browns are still paler, and the black centers and gray tips of the dorsal feathers are almost or entirely lacking.

Conditions in these western races of willow ptarmigan parallel to some extent those found in the rock ptarmigan. In each species the northern Alaskan subspecies is an extremely ruddy-colored bird compared with the others, and in each the British Columbia subspecies seems to reach an extreme of grayness. In each species, too, the 
Labrador birds are much more grayish than are those from Alaska. Thus the Labrador willow ptarmigan (ungavus') and the British Columbia bird (albus) are much alike as regards color but differ in size of bill. The Labrador bird and the northern Alaskan bird (aloscensis) are both large-billed forms, but differ in coloration.

As regards the ranges of the several North American subspecies of Lagopus lagopus, it is not feasible at this time to indicate them with exactness. Series of birds from the Kowak River, Alaska, and from points on the Yukon as far upstream as Forty-mile, Yukon Territory,
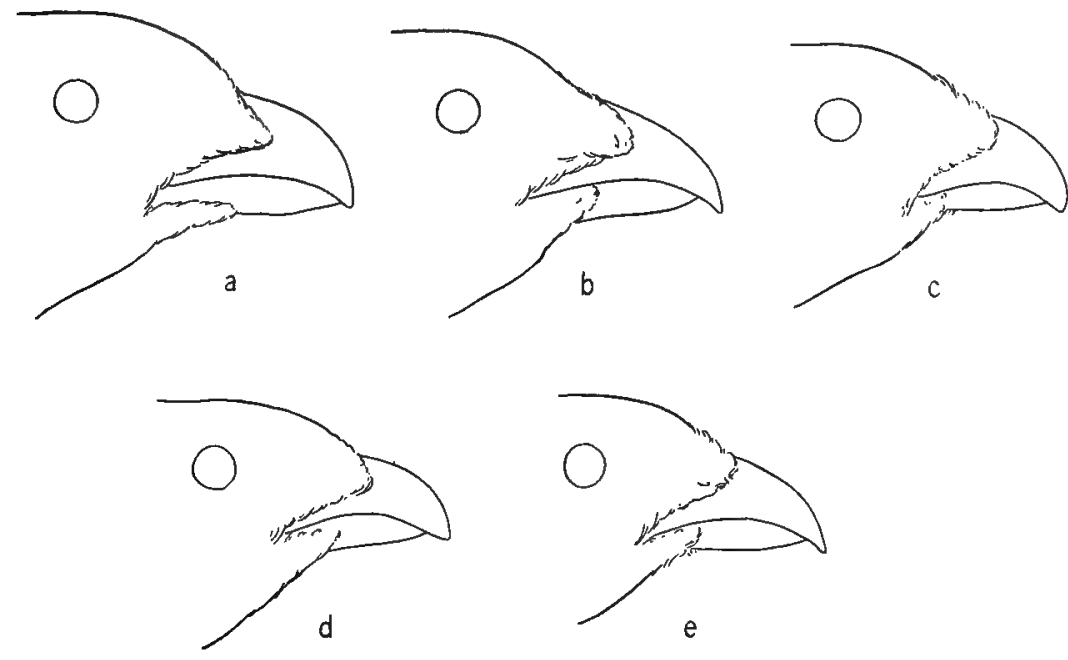

Fig. H. Bills of willow ptarmigan; adult males, w, Lagopus lagopus ungavus, coll. United States National Museum, no. 101037, Fort Chimo, Ungava; $b, l . l$. alascensis, M.V.Z. no. 32125, Kowak River delta, Alaska; $c$, L. l. albus, M.V.Z. no. 44681, Atlin, British Columbia; $d$, L. l. albus, United States Biological Survey, no. 167057, 75 miles north of York Factory, Hudson Bay; $e, L$. $l$. alexandrae, M.V.Z. no. 319, Baranof Island, Alaska.

belong to alascensis. A winter bird from a point 250 miles north of Edmonton, Alberta, is of the small-billed form, albus. Specimens collected by Brooks near Log Cabin, on the east side of White Pass, are albus.

Lagopus $l$. alexandraie is probably confined mostly to an 'island habitat, with perhaps a narrow strip of the adjacent mainland included, from Glacier Bay south to central British Columbia, at least as far as Campania Island. The series of alexandrase at hand shows some variation that may be correlated with distribution. Willett's specimens are all from Dall, Prince of Wales, and San Juan islands, in the southern portion of the habitat of the subspecies, and some of these, together 
with a pair of breeding birds from Porcher Island (coll. Allan Brooks), still farther south, are distinctly darker colored than skins from the more northern Chichagof and Baranof islands and Glacier Bay. There are, however, some southern skins that are indistinguishable from northern ones.

On May 21 we traveled from Skagway to Carcross on the White Pass Railroad. Soon after passing the summit we began to see ptarmigan, and for an hour or more they were frequently in sight from the train, sometimes but a few yards from the track. The ground was still largely snow covered, though the snow was melting, and small ponds were partly free of ice. The male ptarmigan seen were with brown head and neck, the body plumage all white, and they were conspicuous objects. Courting was in progress and the cock birds, standing erect on projecting boulders or strutting with spread tail and lowered wings over some limited stretch of open ground, caught the eye from a long distance. A soaring Buteo flying alongside the train started birds in flight from several points.

On June 30 we found willow ptarmigan in fair abundance at the head of Cañon Creek (about 3000 feet altitude), near Atlin. They were in pairs, spaced at intervals through the low willow brush, and, from the broods seen, eggs must have hatched during several days immediately preceding. One nest was found, containing six eggs nearly ready to hatch. It was on a bare dry hillside, placed between two fallen saplings, just at the edge of some burnt spruce woods. Fire had passed through here years before, killing the timber, though most of the dead trees remained standing, and the ground beneath was barren of any vegetation. The nest itself was a shallow depression, scantily lined with a few bits of dry grass and weedstalks. The hen was sitting on the eggs and the cock bird was on guard nearby.

In this case, as in others, the devotion of the male willow ptarmigan was most apparent, and in striking contrast to the irresponsibility of the males of the other species of grouse of the region. Broods of young willow ptarmigan were invariably attended by both parent birds. It seemed evident that the large winter flocks of ptarmigan were formed by the junction of many families which had remained together, male, female, and young, since the eggs were hatched. It was very rarely that a solitary willow ptarmigan was flushed.

At the head of Otter Creek, July 26 to August 9, willow ptarmigan, though not abundant, were frequently encountered. Young birds were then about half grown, and in juvenal plumage throughout. The 
willow ptarmigan frequented the floor of this valley and the lower slopes of the surrounding mountains. Their preferred habitat was a tangle of low willow and birch brush, with grassy open patches at intervals. None was seen on the higher ridges or the slopes higher than about 4000 feet; there this species was replaced by the rock and the white-tailed ptarmigans.

On September 1, a trip was made to "Blue Cañon," a local name for a section of upper Spruce Creek some twelve to fifteen miles southeast of Atlin. Willow ptarmigan were then beginning to gather in large flocks. In the valley bottom relatively few birds were seen, though some were scattered all through this section, too; the center of abundance was on the lower slopes of the mountains, at from 3500 to 4000 feet. This was above the more extensive tangles of willow and trailing birch, and was a much more open sort of country. Thickets of dwarfed balsam, and some of willow and birch, were interspersed with open stretches, grass-covered or carpeted with Empetrum and other low-growing shrubs.

Willow ptarmigan, in flocks of from ten or twelve (single families, presumably) up to sixty or seventy, were within sight or hearing practically all of the time that we remained at that level. The larger flocks were, I was told, the first indication of much greater gatherings that were assembled during the winter months. On this date (September 1) specimens were taken of adults and young of both sexes.

Adult males taken in midsummer (June 30) in the breeding plumage retained a great deal of white on the belly, and these old white feathers apparently remain until replaced by white feathers at the end of August. Adult males taken September 1 are mostly white on the lower breast and abdomen. Adult females are mostly in the reddish "winter plumage, preliminary," to use the descriptive phrase originating with Dwight (1900), though always with many barred feathers of the breeding plumage persisting on breast and flanks, and some blackish feathers of the same plumage on the back. Over the whole belly the molt in every specimen examined was direct from the barred breeding plumage to white winter garb. There is an adult female of alexandrae at hand (Willett coll., Prince of Wales Island, Alaska, September 23, 1919) in the reddish post-breeding plumage, with but a few seattered barred feathers left. I have seen none from the interior that has assumed this plumage so nearly in its entirety. In the Atlin. region it is evident that the white winter plumage begins to come in before the reddish "winter plumage, preliminary" is more than half acquired. 
In young birds, too, the first "winter plumage, preliminary" is only partly acquired. Over the whole of the lower parts below the upper breast the molt is direct from the juvenal to the white winter plumage. On the head, neck, and dorsum, the "first winter, preliminary" is partly acquired, but white feathers appear on the chin and throat long before the juvenal plumage is lost on back and flanks. Young birds of alexandrae at hand (Willett coll.), taken in October, are in "first winter, preliminary," almost complete. There are but a few juvenal feathers left to distinguish young from old. In every case, though, young birds and adults may be distinguished by the differently shaped tertials, which linger longer than almost any other feathers of the brown-colored plumages.

On September 1, adults from the Atlin region had almost all acquired new flight feathers and rectrices. In the young, the juvenal rectrices are lost at a very early age, before the bird is half grown, being almost the first of that plumage to go. On September 1 nearly all young birds seen had completely acquired the black rectrices of the first winter plumage, slightly narrower than in adults but not otherwise different.

To summarize these details of plumage, they all go to show the incomplete nature of the "winter plumage, preliminary," inserted between the breeding plumage and the white winter plumage in adults, between the juvenal plumage and white winter plumage in young birds. Judging from material at hand it is less perfectly acquired at the northern limit of the range of the willow ptarmigan, and more perfectly acquired toward the southern limit, where longer summers give more time before the white winter plumage is essential. On the islands of southeastern Alaska, the habitat of Lagopus l. alexandrae, a region of relatively mild winters, the "winter plumage, preliminary" is acquired more nearly to perfection than perhaps anywhere else in the general range of the species. As a result of the perfect acquisition of this plumage in this particular dark-colored race, we see fall birds that closely resemble the Scotch red grouse (as described above), which bird, of course, is a southern species of Lagopus which does not acquire a white winter plumage at all.

In this account of the plumage variations of the several subspecies of the willow ptarmigan here under consideration I have used throughout the terminology employed by Dwight (1900, p. 147) in his exposition of the seasonal and other changes undergone by these birds. My own observations (made much easier through a previous reading of 


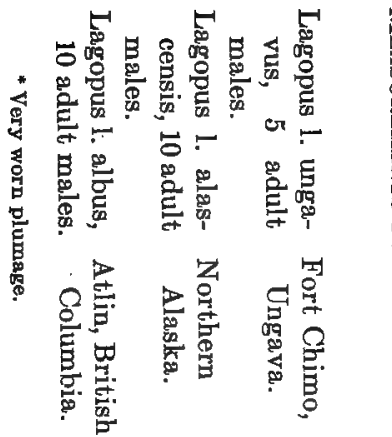

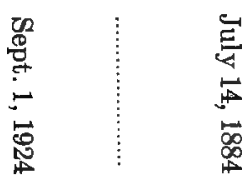

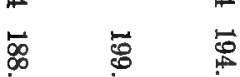

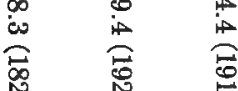

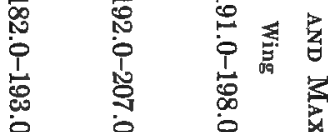

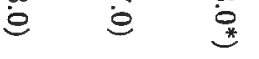

牙 $\overline{0}$

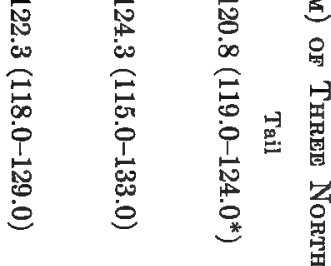

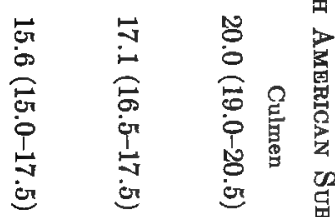

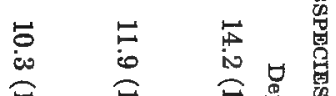

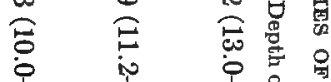

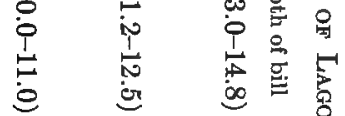

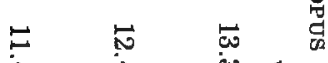

i

E

赛

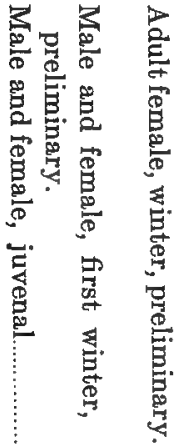

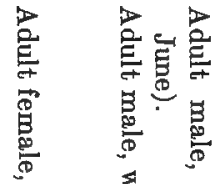

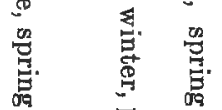

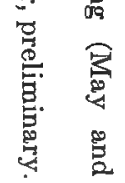

宊

政

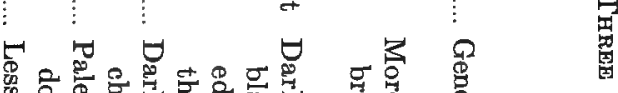

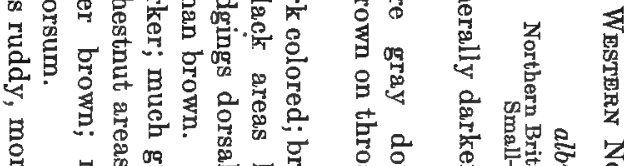

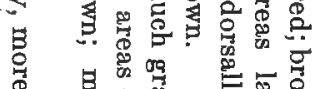

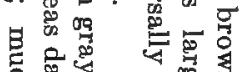

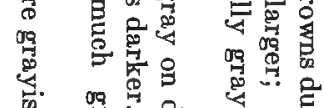

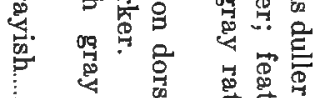

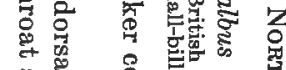

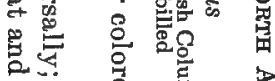

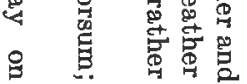

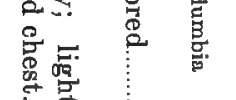

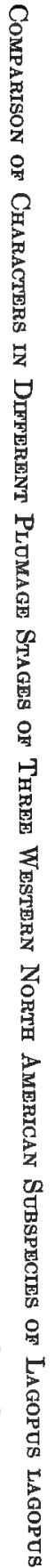

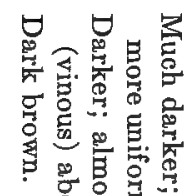

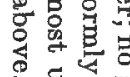
空学骂 然音 全号 总总总

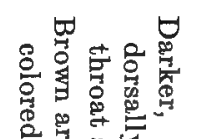

댄

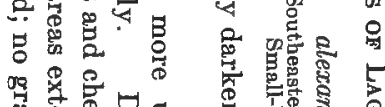

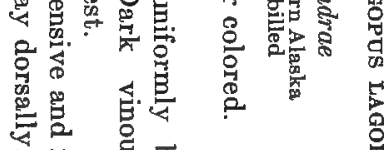

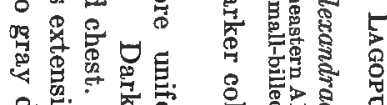

e ن 
Dwight's paper) accord with his statements, I believe, in every particular. Details here given are amplified in the belief that such studies from all parts of the range of the willow ptarmigan are necessary to a thorough understanding of geographical variation in this species.

\section{LIST OF THE NORTH AMERICAN SUBSPECIES OF THE WILLOW PTARMIGAN (LAGOPUS LAGOPUS)}

1. Lagopus lagopus alleni Stejneger. Allen Willow Ptarmigan.

2. Lagopus lagopus ungavus Riley. Ungava Willow Ptarmigan.

3. Lagopus lagopus albus (Gmelin). Southern Willow Ptarmigan.

4. Lagopus lagopus alascensis Swarth. Alaska Willow Ptarmigan.

5. Lagopus lagopus alexandrae Grinnell. Alexander Willow Ptarmigan.

\section{Lagopus rupestris rupestris (Gmelin). Gray Rock Ptarmigan}

Thirteen specimens of rock ptarmigan (nos. 44712-44724) were collected by myself in the Atlin region, including seven adult males, two adult females, and four young birds. Brooks' Atlin series comprised about as many, similarly apportioned, and he later (September 11) collected at White Pass summit four additional specimens, two adult females and male and female immature.

The ptarmigans form a group of birds that offers many difficulties to the systematist. The rapid and continuous changes of plumage undergone by any one bird during the summer months, together with a rather wide range of individual variation among specimens from any given locality, are puzzling features in themselves, still further complicated by other differences du to sex and age. Then, ptarmigan, and the rock ptarmigan in particular, are not well represented in collections, inhabiting, as they do, relatively remote and inaccessible regions. So, more often than not, when specimens are brought together from different sections they prove to be not comparable, and deductions then can only be made by inference.

In a previous publication (Swarth, 1924, p. 333) I have commented upon the appearance of a female rock ptarmigan from Nine-mile Mountain, near Hazelton, British Columbia, a bird that differed appreciably from the few Alaskan specimens available to me at that time. The series we collected near Atlin, evidently in the same category as the Nine-mile Mountain bird, seemed again so different from Alaskan specimens as to justify more extensive comparisons. 
Through the courtesy of several museums and private collectors (to whom acknowledgment is made elsewhere in this paper) a series of 168 rock ptarmigan in summer plumage was brought together, representing many parts of the mainland of North America and some Aretic islands also. A few of these localities are represented by extensive series of summer birds, and some such points fortunately prove to be rightly placed to illustrate certain important features of geographical variation in the northwest. This study has not included the ptarmigans of the Aleutian Islands, Greenland, Newfoundland, and Anticosti.

In the portion of North America indicated, excluding the islands mentioned, the rock ptarmigan has differentiated into three easily recognizable branches. First, there is a gray-colored bird that extends from Labrador westward to the coast ranges of northern British Columbia. In the east it apparently extends northward into the Arctic regions; it also occurs on islands north of Mackenzie, but elsewhere in the west it is restricted to the southern part of the region covered by the species Lagopus rupestris. Second, there is a ruddycolored form that occupies almost the entire mainland of Alaska and extends eastward along the Arctic coast about to the one hundredth meridian. Third, there is a dark colored form with a rather limited range in the coastal region of southeastern Alaska (see fig. I).

The first-mentioned race, the gray-colored bird, may probably be assumed to represent Lagopus rupestris rupestris (Gmelin), described from "Hudson Bay." It was the gray coloration of British Columbian birds, as compared with the ruddy Alaskan specimens, that first attracted my attention, and it seems evident that this gray race extends practically across the continent. There are two males and one female at hand from McLellan Strait, Labrador, and one female from the mouth of the Nastapoka River (east coast of Hudson Bay), Ungava. The two male birds can be matched exactly in the series of Atlin specimens. The female from McLellan Strait is even more gray than any of the British Columbia birds; the one from the Nastapoka River is indistinguishable from Atlin skins.

A half-grown juvenal from Ponds Inlet, Baffin Land, is a trifle more gray than comparable Atlin specimens, but very slightly so. The variation is no more than occurs within series from any one place. The locality of capture of this specimen might be considered as within the range of Lagopus $r$. reinhardi (see A. O. U. Committee, 1910, p. 141), but in appearance it certainly agrees with rupestris, as repre- 
sented from other regions. There are few specimens available from intermediate points between the extremes of Labrador and British Columbia, but two females from Clinton-Golden Lake and Cap Mountain, Mackenzie, respectively, are unmistakably of the gray rupestris mode of coloration. Specimens from the Arctic islands north of Mackenzie are also to be referred to rupestris.

In my published comments upon the female rock ptarmigan from Nine-mile Mountain, British Columbia (Swarth, 1924, p. 333, fig. A), I described in detail the striking white tail markings seen in some birds from that region. This proves not to be a character of any systematic value. At the time we were shooting rock ptarmigan in the Atlin region they were molting their tail feathers, and many birds were flushed which, if they possessed this character, would not have shown it in their then condition. Several were shot with tail fully grown and with rectrices black throughout (save for the usual restricted white markings at base and tip), and several that exhibited white markings of irregular extent on some of the tail feathers. I found some molted rectrices where they had been dropped on the hillsides that were marked as in the Nine-mile Mountain bird. Among all the specimens assembled in the present study, just one bird, an adult female of dixond from the White Pass, Alaska (D. R. Dickey coll., no. 13462), has this feature developed as in the specimen I figured. Judging from the material at hand, it would seem that this character occurs irregularly in the female bird in the extreme southwestern part of the range of the rock ptarmigan; irregularly in that it may or may not exist in individuals from any one place, in that it may occur on some tail feathers and not on others, and in that it may cover a greater or lesser area on corresponding feathers on different birds. Curiously, there is an adult female at hand, taken near Bennett, on the east side of the White Pass, September 11, 1924 (coll. of Allan Brooks), mostly in the white, winter plumage, in which the central (usually white) tail feathers are basally black, a condition I do not find in any other specimen.

The small size of bill in the Nine-mile Mountain bird was another feature that was commented upon in my previous paper. The larger series now available shows that while in the more southern birds the bill is frequently smaller than in any of the northern specimens, it is not a character to be relied upon. It can be described as a tendency of the southern birds. 


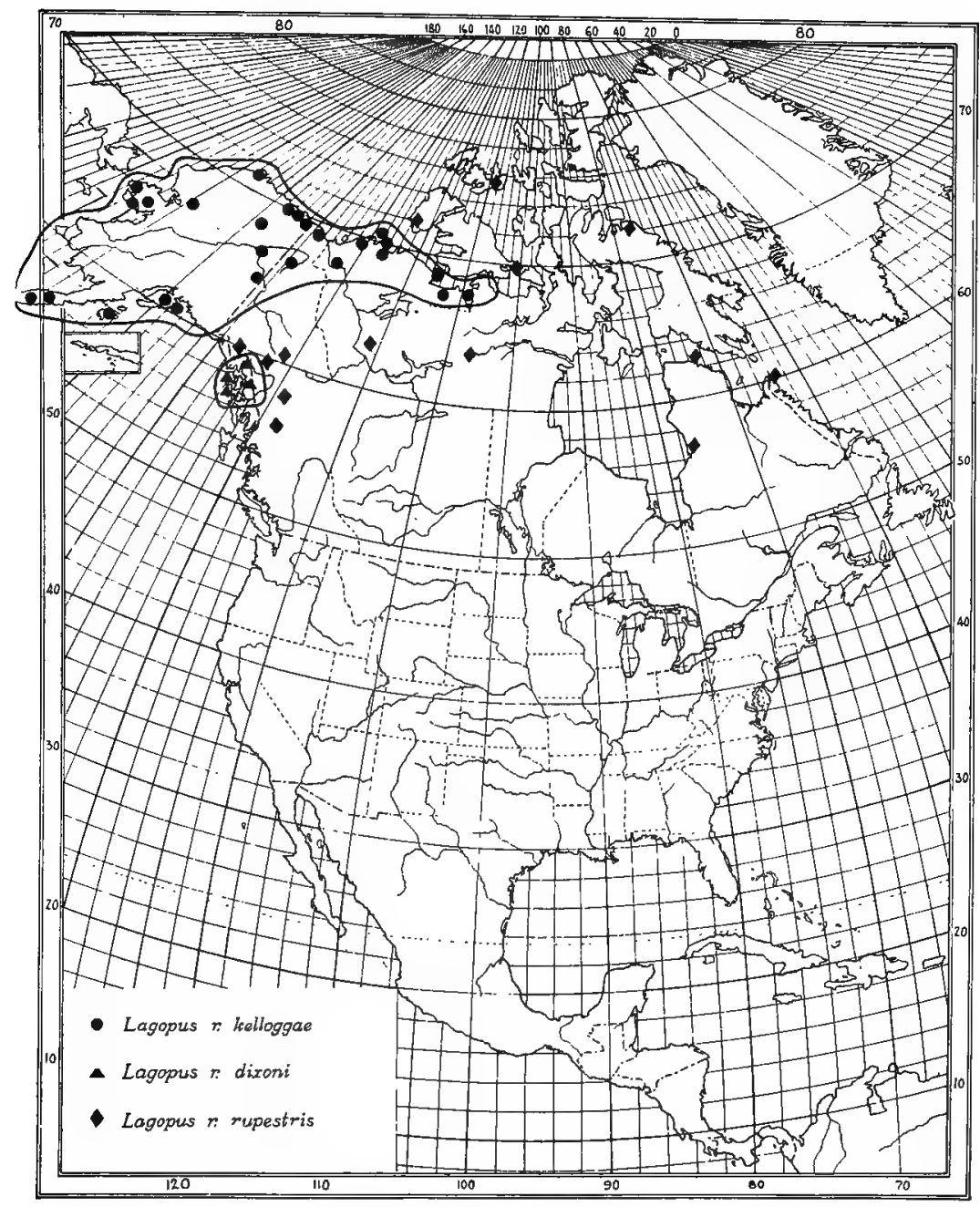

Fig. I. Map showing distribution of certain subspecies of rock ptarmigan (Lagopus rupestris). The approximate habitats of $L . r$ kelloggae and $L$. $r$. dixoni are outlined. Symbols indicate localities from which specimens were examined. 
Next to be considered is the Alaska race. The notable feature of this bird is its bright ruddy tone of coloration, a character that is evident in both sexes and in all stages of the summer plumages. As compared with rupestris, the general tone of color throughout is brighter and more reddish, and there is notable restriction of the dark areas on individual feathers.

The extreme manifestation of this race is reached on the northwestern and northern coast of Alaska, it occupies practically the whole of the Alaskan mainland, and it extends eastward of Alaska along the Arctic coast for some distance. In the latter region the duller color of specimens from Baillie Island, Coronation Gulf, and Bathurst Inlet, is to be interpreted, to my mind, as indicative of intergradation with rupestris.

Southeastward there is intergradation again with rupestris as occurring in British Columbia, about at the Alaska-Yukon boundary line. A series of seventeen skins from the vicinity of Eagle (U. S. Biol. Surv. coll.), in the upper Yukon region, demonstrates such intergradation satisfactorily. Certain selected skins from this series and from the British Columbia aggregation are hardly to be distinguished, and none of the Eagle specimens shows the extreme of ruddiness that is seen in Alaskan birds from more northern points. The Eagle series as a whole, however, certainly belongs with the northern Alaska subspecies rather than with rupestris. On the southern coast there is apparent intergradation with dixomi, as shown by skins from Kodiak Island, Seward, and Prince William Sound.

The matter of a name for the Alaskan bird requires careful consideration. The race assuredly is distinct from rupestris of the Hudson Bay region, and as such is deserving of nomenclatural recognition. To have been able to fix a type locality somewhere in northern Alaska would have been desirable, for it is there that this form is developed in its extreme manifestation, but as it happens, the boundaries of the subspecies, as indicated by the specimens at hand, include a region from which a form of rock ptarmigan has already been named. I refer to Lagopus rupestris kelloggae Grinnell (1910, p. 383), type locality, Montague Island, Prince William Sound. It is true that in describing that subspecies Grinnell made detailed comparison with the same series of birds from Eagle to which I have already referred, and which I consider as belonging to the same race; and he based his belief in the distinctness of kelloggae partly upon the differences he could discern between birds from Prince William Sound and those from Eagle. 
My own conviction of the desirability of including both series under the same name, rests upon the facts that birds from neither place are representative of the extreme manifestation of the Alaskan race; and that the differences between them are due to one series (from Eagle) illustrating intergradation toward rupestris, the other (from Prince William Sound) illustrating to some slight degree intergradation toward dixani.

The type specimen of kelloggae (Mus. Vert. Zool., no. 1169, adult male, Montague Island, Prince William Sound, July 7, 1908) can be matched almost exactly by a selected specimen from Demarcation Point, Arctic coast of Alaska (Mus. Comp. Zool., no. 68933, adult male, July 10, 1914). Of the several Prince William Sound specimens, as with one adult male from the nearby mainland point of Seward, it seems to me that in whatsoever features they differ slightly from the mode of birds from northern Alaska, they show some approach toward dixoni.

For all these reasons I am regarding the name kelloggae as having been applied to a variant of the Alaskan mainland subspecies, and, with regard to the true features of this same subspecies, properly applicable to the whole aggregation.

There are fewer specimens of dixoni available than of either of the other subspecies here under consideration, but nevertheless this relatively scanty material suffices to show that it is a well marked form, and to indicate the range of the subspecies with fair accuracy.

Dixoni is a dark, slaty-colored race, with, in the male, the rufescent markings greatly reduced or altogether wanting. There are specimens at hand from Baranof and Chichagof islands, and from Port Snettisham and White Pass on the adjacent mainland. There is as yet no proof of the extension of the range of this form south of Christian Sound or north of White Pass. However, I have seen no rock ptarmigan from Yakutat Bay or from any other point on the long stretch of coast line between Lynn Canal and Prince William Sound, and dixoni may be found to extend for some distance in that direction.

The one specimen from Port Snettisham is a young female (Mus. Vert. Zool., no. 9796, August 29, 1909). Exactly comparable plumages are at hand from Atlin, from near Bennett, and from northern Alaska. From the Atlin birds it is widely different. The Atlin specimens are predominantly gray, the Port Snettisham specimen dark and rufescent. Two young birds from Bennett (coll. of Allan Brooks), though intermediate toward dixani, are still much nearer to rupestris of the Atlin 
region. The Port Snettisham bird differs but slightly from skins from Seward Peninsula and rather more so from young birds from the Arctic coast of Alaska. It is somewhat darker colored. It can be matched very closely by a young bird from Kodiak Island.

A pair of adults from Mount Dewey, on the Alaska side of the White Pass, are of especial interest. These are from the D. R. Dickey collection: no. 13462, female, July 26, 1923; 13463, male, August 7, 1923. The male bird is exactly like others from Baranof and Chichagof islands. The female is distinguished from other rock ptarmigan by dark tone and extremely rufescent coloration. It differs far more from Atlin females, and indeed from a female from Bennett, on the opposite side of White Pass, than from those from northern Alaska. Whether or not this specimen represents the mode of female dixcomi, in its typical form, on Baranof and Chichagof islands remains to be seen. So far as I know there are no such specimens extant in any collection at this time.

The present study takes into account certain phases of geographical variation in the North American rock ptarmigan, and suffices to make clear some certain points, but there still remains far more work to be done before any satisfactory understanding can be reached of the manner of variation over the whole of the range of this species, or several species, as the case may be.

It may be pointed out that I have not touched upon the relations of the New World Lagopus rupestris and the Old World Lagopus mutus, which are admittedly close; the two forms may well be conspecific, as has been claimed (see Hartert, 1921, p. 1871): It is conceivable that the ptarmigan of northeastern Siberia is the same as the Alaskan subspecies here designated Lagopus mupestris kelloggae. The latter certainly attains its extreme of differentiation from rupestris on the Alaskan coast most nearly approaching Siberia.

I have not attempted to take into consideration such variation as occurs among the several forms described from the Aleutian Islands. There, too, a comprehensive study should help toward an understanding of the relationships of Old World and New World forms. The few specimens that I have examined from the Alaska peninsula exhibit, it seems to me, intergradation from kelloggae toward nelsoni, of the easternmost Aleutian Islands, but there is not at hand material to demonstrate this satisfactorily. 


\section{SUMMER SPECIMENS EXAMINED}

1. Lagopus rupestris rupestris (Gmelin), Gray Rock Ptarmigan.

Labrador: East end of MeLellan Strait, 3.

Ungava: Mouth of Nastapoka River, 1.

Franklin: Hudson Strait, 2; Ponds Inlet, Baffin Land, 1; Griffith Point, Melville Id., 2; Cape Kellett, Banks Id., 2; Taylor Id., Victoria Land, 2. Mackenzie: Clinton-Golden Lake, 1; Cap Mountain, 1.

British Columbia: Mountains near head of Chapatan River (headwaters of Stikine River), 3; near Atlin, 16; White Pass, 4; Nine-mile Mountain (near Hazelton), 3.

Total, 41.

2. Lagopus rupestris kelloggae Grinnell. Alaska Rock Ptarmigan.

Alaska: Collinson Point, 9; Demareation Point, 4; Griffin Point, 5; Camden Bay, 1; Point Barrow, 1; Jade Mountains, 1; Gens de Large Mountains, 1; Hula-hula River, 1; Okpela River, 1; Humphrey Point, 1; Nome, 1; Wales, 5; Teller, 2; Kruzgamepa River, Seward Peninsula, 24; Pilgrim River, Seward Peninsula, 4; Kings Cove, Alaska Peninsula, 2; Thin Point, Alaska Peninsula, 5; Kodiak Island, 1; Seward, 1; Montague Island, 1; Hinchinbrook Island, 2; Hawkins Island, 2; Fort Yukon, 1; mountains near Eagle, 17.

Mackenzie: Arctic coast east of Fort Anderson, 1; Fort Anderson, 1; Baillie Island, 3; Coronation Gulf, 8; Cape Bathuret, 1; Franklin Bay, 2; Kanyah Island, Bathurst Inlet, 2; Cockburn Point, 2; Bernard Harbor, Dolphin and Union Strait, 1.

Yukon Territory: Kay Point, Aretic Coast, 3.

'Total, 117.

3. Lagopus rupestris dixoni Grinnell. Dixon Rock Ptarmigan.

Alaska: Port Frederick, Chichagof Island, 2; mountains near Sitka, 4; Port Snettisham, 1; White Pass, 2. Total, 9.

Our field experiences wih the rock ptarmigan were productive of some facts of interest. One feature of the species (one that has been commented upon by others) was its irregular and local distribution. A male, a single bird, was shot by Brooks near the summit of Monarch Mountain, June 9. This was the only one that was seen by us on that mountain during the summer, though we ascended it many times.

On one of the ridges of Spruce Mountain, during the last week in July and the first two weeks in August, rock ptarmigan were found regularly and in fair abundance, every time we climbed that particular ridge. On an adjoining ridge, of similar aspect, none was seen, and certain other nearby mountains were also explored to no avail. 
We visited rock ptarmigan territory too late to find nests, but from the actions of the birds as we saw them it would seem that the male of this species is not a devoted and constantly attendant mate to the hen, as is notably the case in the willow ptarmigan. The male rock ptarmigans were gathered, two, three, or four together, while the females bore the care of the young alone. Occasionally a female (presumably a non-breeding bird) was seen with several males. On August $8 \mathrm{I}$ did flush a flock consisting of at least one brood of large young ones, and several adult males. This $I$ took to be the beginning of a general flocking together, as might be looked for at the end of the summer.

The adult male taken on June 9 is still largely in winter plumage, especially below. There are barred feathers on the throat and upper breast, and the back is mostly clothed in summer plumage. Adult males taken during the last week of July and early in August are in summer plumage in as nearly perfect condition as it can probably ever be found, though in all the rectrices are being renewed. In the perfection of this plumage even the abdomen is partly or even entirely clothed in dark-colored feathers, but usually a large white area persists on the lower parts of summer birds. In some specimens old white body feathers are being replaced by new white ones, showing that there is not always an intervening dark summer plumage on parts of the body that are dark on some birds.

The adult male rock ptarmigan does not seem to go through the stage termed by Dwight (1900, p. 162) "second, or adult, winter plumage (preliminary)," that is so well defined in the willow ptarmigan. I am aware that the contrary has been argued (see, for instance, the account of Lagopus ridgwayi by Stejneger [1885, p. 195]), but whatever may be the facts as regards other forms of the rock ptarmigan, in British Columbia the male bird of this species does not exhibit two distinct plumages during the summer months. The female does, and the fact that we collected male birds during the period when the females (as well as both sexes of the willow ptarmigan) were molting from one plumage stage to the other, enabled me to make satisfactory comparisons of the different plumages. The first appearance of the brown and black barred feathers upon the head, neck, and upper breast in the male rock ptarmigan (early in June in northern British Columbia) is followed so uninterruptedly by the spread of more finely mottled feathers over the rest of the body, that these can hardly be considered as two distinct plumages. Furthermore, the first 
acquired barred feathers of the neck and upper breast persist until replaced by white ones in the fall. Late in July and early in August the rectrices and remiges are renewed, accompanied usually by the appearance of the first white winter feathers upon the abdomen and flanks. The two white central tail feathers persist, in some cases at least, until the end of the summer, though they are hidden by long upper tail coverts. Whether or not these late retained feathers are at once replaced with other white ones I do not know.

The above remarks all pertain to the adult male. The adult female undergoes a more or less extensive molt, beginning late in July, following the barred breeding plumage and marking a well-defined plumage stage. She then acquires, above and below, finely mottled feathers like those of the male, but this plumage is never (or at any rate very rarely) acquired in its entirety before the white winter feathers appear. Young birds of both sexes begin a replacement of juvenal plumage with finely mottled feathers as in the adult, but here, too, the white winter feathers appear before the first change is accomplished. So quickly do the several molts follow one another during the summer months, that it is not uncommon to find female birds in August with remaining patches of white feathers from the previous winter, the greater part of the body clothed in the barred breeding plumage, some extensive areas of mottled feathers of the "winter plumage, preliminary," and some areas of new white feathers.

\section{Lagopus leucurus leucurus (Swainson). White-tailed Ptarmigan}

Occurs, apparently not abundantly, at high altitudes. The predilection of this species for exposed, rocky ridges is reflected in the local name "rock ptarmigan." The few people we met who recognized the existence locally of three species of ptarmigan called the true rock ptarmigan by the name of "croaker."

I encountered the white-tailed ptarmigan on but one occasion, on September 1, when a flock of from fifteen to twenty birds was flushed on a rocky slope between the head waters of Spruce and McKee creeks, at about 5000 feet altitude. Three specimens were collected (nos. 44725-44727), an adult female and a young male and female. In all three the lower breast and belly are clothed in new white winter plumage, the molt on those parts being direct from the barred breeding plumage in the case of the old bird, from the juvenal plumage in the young. Elsewhere these birds are entirely in the soft gray colors of the "winter plumage, preliminary." 


\section{Circus hudsonius (Linnaeus). Marsh Hawk}

Found nowhere about Atlin during the breeding season. The first south-bound migrant appeared August 26; then, September 9 to 15, between Atlin and Lake Teslin, marsh hawks were seen in numbers flying southward. Last seen, near Atlin, September 21.

\section{Accipiter velox (Wilson). Sharp-shinned Hawk}

Seen at Skagway, May 21. Undoubtedly nests in the Atlin region, for occasional individuals were seen throughout the summer. Not common at any time, not even after the southward migration had begun. Last seen on August 29. One specimen collected, an immature male, August 18 (no. 44728).

\section{Astur atricapillus atricapillus (Wilson). Eastern Goshawk}

Undoubtedly nests in the Atlin region, probably in the lowlands, for individuals were seen at fairly frequent intervals throughout the summer. In August there was a noticeable increase in numbers, mostly of young birds, flying southward. Several immatures were shot but not preserved, and all were of the pale coloration that appears to be characteristic of the subspecies atricapillus. One specimen was skinned (no. 44729), a male in adult plumage, almost fully acquired, taken September 5. This bird is of interest in view of the argument advanced by Taverner (1916, p. $360 ; 1918$, p. 216) that the goshawk molts from the streaked juvenal plumage into a coarsely barred stage (the subspecies striatulus) and later into the more finely barred plumage that is considered to be typical of the subspecies atricapillus.

The bird in question had just molted from the juvenal plumage. Very few juvenal feathers remain, but careful investigation before the bird was skinned showed enough old streaked feathers on various parts to demonstrate that this was the first assumption of adult plumage. This bird is pale colored and finely barred, as in atricapillus. Some of the breast feathers have rather broad mesial streaks but it is otherwise just like other specimens of atricapillus at hand, and very different from coastal examples of striatulus.

The status of the two forms atricapillus and striatulus cannot be regarded as settled, but the evidence at hand points to the existence of two such subspecies. Characteristic color differences occur in both 
adults and young, and these differences are fairly well correlated with certain regions. The specimen just described (as well as another similar bird collected by Brooks) shows that differences of coarse or fine markings cannot be explained as different stages reached by the same individual.

The last goshawk was seen by me near Atlin, September 19, but it seems likely that the species remains to a later date.

Buteo borealis harlani (Audubon). Harlan Hawk

I collected in the Atlin region six specimens (nos. 44730-44735) of a dark-colored Buteo that was of fairly common occurrence there. The series consists of one adult female, three young males, and two young females. Two of the young birds are just out of the nest, partly feathered and not able to fly any distance, the other three are full grown. In addition, Brooks collected an adult female and one young bird. There are at hand also two specimens loaned by the Provincial Museum, Victoria. Both are from the Atlin region, an adult female (Prov. Mus. no. 2664) taken at Wilson Creek, June 19, 1914, an immature bird (Prov. Mus. no. 2666) from Blue Cañon, August 18, 1914. The first mentioned has been recorded as Buteo swainsani (Anderson, 1915 , p. 12), the second as Buteo borealis alascensis (Anderson, loc. cit., p. 11).

The two adult females collected by Brooks and myself, both in worn plumage and just beginning the annual molt, are essentially alike. They are uniformly dark-colored, almost sooty, and in each there are white markings at the base of the feathers that show through more, probably, than they would in fresh plumage. New feathers coming in are darker, more sooty, than the old, worn plumage.

In Brooks' specimen the tail is mostly dark, with scarcely a trace of red, it is mottled longitudinally with whitish, and there is a subterminal band of blackish. There are two aberrant rectrices. One has the inner web mostly white; the other is broadly barred with dusky, there is a sharply defined triangular white spot at the tip of the outer web, and the subterminal dusky band is broader than on the other feathers.

In the adult female taken by myself the exposed portions of the rectrices are dusky, mottled longitudinally with whitish and with dark markings, and there is a good deal of reddish on the terminal fourth 
of the tail. There is a broad subterminal band of black, and the tip is white, suffused with reddish. The inner.webs, and part of the outer webs, are white or gray, irregularly flecked with dusky. The outer rectrix (present only on the left side) has the outer web barred with blackish its entire length. Below, the tail is mostly white, with small, irregular dusky markings. On certain of the upper tail coverts is the only part of the body plumage of the bird where distinctly chestnut markings appear.

Brooks" specimen is peculiar in that but the three outer primaries are emarginate, a condition that is not supposed to exist in the Buteo borealis group of hawks, where the presence of four emarginate primaries has been accepted as one of the diagnostic features of the species. We examined the freshly killed bird carefully, and there is no question but that the full number of primaries was present.

The adult female in the Provincial Museum, Victoria, differs somewhat from the two just described. It is a darker colored bird even, with the concealed white markings greatly reduced in size and number. The feathers on chin, throat, and upper breast are dusky to the base. The plumage generally is not so worn as in our two birds, and there is hardly a trace of white showing through on the breast.

The tail is quite different from those of the other two adults. There is but a mere trace of rufous upon it. There is a terminal band of black, $35 \mathrm{~mm}$. to $45 \mathrm{~mm}$. in width (widest on the outer feathers), and above this the tail is crossed by a series of narrower bands, seven black and eight light colored, the dark colored strips becoming broader toward the base of the tail. The light colored areas are white on the inner web, grayish on the outer. The tail differs from that of the immature in the broad, black terminal band, in the lesser number of narrower bands, in. the more distinctly whitish color of the paler areas, and in that it is more squarely truncate at the end. Individual rectrices are broader and more square ended than those of the young bird. The two central tail feathers of this adult are being renewed, and are about one-third emerged from their sheaths. They are of exactly the same character as the others, in interesting confirmation of the fact that this type of plumage is retained year after year. The older birds do not eventually acquire a red tail.

This specimen has lost one primary of the left wing, giving it an appearance of having but three emarginate primaries on that side, a condition which is probably responsible for the misidentification of the bird as Buteo swainsoni at one time. 
The immature birds are like the adults with the exception of the tail. The tail feathers are dark sooty brown (the same color as the body plumage) on the outer web, lighter colored on the inner web, and crossed by eight or nine blackish bands. The tail pattern, essentially similar to that of immature calurus, differs from conditions in that form in being darker (even than in the darkest calurns), and in that the cross-bars are broader and fewer in number. Often, too, in young harlani the cross-bars tend to be U-shaped or V-shaped on individual feathers, rather than extending horizontally across. In two specimens there is a faint tinge of rufous at the tip of the tail. These hawks are generally dark colored birds but differ from even the darkest phase assumed by calurus (of which there are both adult and young at hand) in their sooty hue. In calurus there is a great deal of rich brown or chestnut in the coloration, which is, altogether lacking in the Atlin birds.

In this series of specimens there is some variation, shown principally in extent of the partly concealed white markings. In the darkest colored birds the white markings in the body plumage are mostly reduced to small paired spots on feathers that are blackish over most of their area. The white markings are almost entirely concealed; the birds are almost uniformily dark. On the thighs and tibial plumes there are the merest flecks of whitish. The lightest extreme is represented by a bird with broadly white-barred thighs and tibial plumes, conspicuous bars and blotches on breast and belly, and with chin and throat mostly white.

The "soft parts" of two of the birds collected were colored as follows. No. 44730 ; $\delta$ juv. (just out of the nest) : Eye stone gray; feet pale greenish yellow; bill black; cere and gape greenish. No. 44731; $q$ ad: Eye dark sepia; feet greenish yellow; bill mostly black, tinged with bluish along cutting edges; cere and gape greenish.

One fact stands out clearly; these birds are identical with the Falco harlami of Audubon (1830, pl. 86), which is the Buteo borealis harlani of the A. O. U. Check-list (1910, p. 158). Our two adults are closely similar to Audubon's plate, and they answer exactly the description of Audubon's type specimen given by Sharpe (1874, p. 191). The fact that the supposed young of harlami as described by Sharpe (loc. cit) is not at all like the young birds I collected is of no moment, for Sharpe's bird (from "Western Mexico") was not harlani at all. It appears to be the young of calurus. The same sort of mistake was made by Cassin (in Baird, 1858, p. 24) where one phase of 
coloration seen in calurus is described as young harlani, a mistake that is pointed out in Baird, Brewer and Ridgway (1874, vol. 3, p. 294).

At first glance it seems startling to aseribe to the Harlan hawk a far northern breeding habitat. In the A. O. U. Check-list (1910, p. 158) the range given is as follows: "Lower Mississippi Valley and Gulf States, from Louisiana to Georgia and Florida; casual in Colorado, Texas, Kansas, Nebraska, Iowa, Illinois, and Pennsylvania." I cannot find, though, that there are definite published accounts of the breeding of harlani in any region whatever. Audubon's belief that the birds he shot near St. Francisville, Louisiana, had bred in that vicinity was based on hearsay. He shot his birds in November (see Coues, 1880, pp. 202-203) and had no first-hand knowledge of their nesting. Beyer, Allison and Kopman (1908, p. 442) in their "List of the Birds of Louisiana" state: "None of the writers has evidence of its breeding in Louisiana." It seems to me, in the absence of any positive published statements, that the assumption that the breeding ground of the Harlan hawk is in the Gulf states is an utter mistake.

Besides the Atlin series there are at hand three specimens of hawks from the northwest that I think are referable to harlani. These are two young birds (nestlings), from a point sixty miles below Fortymile, Yukon Territory, July 28, 1894, collected by C. L. Hall ( Mus. Vert. Zool. nos. 4966, 4967); and an immature male (Mus. Vert. Zool. no. 42048), a migrant, shot by the present writer in Kispiox Valley, near Hazelton, British Columbia, August 27, 1921 (see Swarth, 1924, p. 336).

These birds in life were extremely puzzling. While there was much to suggest Buteo borealts in the actions of the living bird, the uniformly dark coloration brought B. swainsoni to mind, and an oceasional glimpse of white marked rectrices in a bird wheeling in distant flight was distinctly suggestive of Archibuteo. With specimens in hand, Buteo swainsoni and Archibuteo were quickly eliminated, of course, but other questions remained.

The status of the Harlan hawk as a distinct subspecies has been questioned. Our own findings in the Atlin region, while not assumed to be a final disposal of all the difficulties involved, do seem to place this form in a more secure position as a geographic race than it has yet enjoyed. The birds were abundant and nesting over a wide expanse of territory, and within that region they were the only form of Buteo borealis that was seen. Parents and young were seen together 
on many occasions, and an old bird and one of its offspring were secured, probably the first time that old and young of this form have actually been collected. The young are distinctive and quite unlike the young of calurus, the other dark colored form of Buteo borealis. All this is corroborative of the theory that harlani is a "good" subspecies, in the sense of being a geographic race.

There is interesting evidence, of a negative sort, bearing upon the migration route of the Harlan hawk, in the fact that in our series of red-tails from the southwest, comprising about one hundred skins from California, Nevada and Arizona, there is not one specimen unequivocally of harlami. The only possible exception is an immature female (Mus. Vert. Zool. no. 4094) taken at Julian, San Diego County, July 27, 1908. This is a dark, blackish colored bird, like harlani in shade of color, but it is peculiar in lacking any of the partly concealed white spots and blotches that occur in that form. The uniformly black color of this bird may well be explained on some ground other than subspecific identity with harlani.

The non-occurrence of harlani in so large a series of specimens from the southwest is strongly suggestive of the migration route of this bird extending southeast from the breeding ground, crossing the Rocky Mountains in the far northern portion of that range. This is the route that is known to be traversed by many species that spend the summer in the extreme northwest, and what is known of the winter habitat of the Harlan hawk is corroborative of such a theory.

It is of interest to note that the red-tail (Buteo borealis alalscensis Grinnell) of the Sitkan district, Alaska, some one hundred miles to the westward of the Atlin region, across the coast ranges, is of the same general type of coloration as calurus, to the southward, and shows no approach toward the characters of harlani.

In the light of all the foregoing facts, a revised statement of the range of Buteo borealis harlani might be worded as follows: Breeds in extreme northern British Columbia, east of the coast ranges, north into the valley of the Yukon, and eastward for an undetermined distance. Migrates southward east of the Rocky Mountains, through the Mississippi Valley to a winter home in the Gulf states.

While the bulk of evidence, as just given, is all corroborative of this view, there are some opposing facts that should still be borne in mind. The palest extreme of the red-tailed hawk, Buteo borealis krideri, has been taken in the same general region, at Eagle, Alaska, in winter (Bailey, 1916, p. 321), and on the Stikine River, breeding 
(Swarth, 1922, p. 212). Bishop (1900a, p. 73) speaks of the red-tails of the Yukon region (referred to $B . b$. calurus) as being in both the light and the dark phase, about half of each, and of light colored and dark colored birds breeding together. Nothing of the sort was seen in the Atlin region, which may indicate that while harlami alone occurs in that section, it has a relatively limited range. I did see one palecolored bird, apparently kridemi, near Gladys Lake, but this was on September 7, when the southward migration was going on, and many hawks were seen passing southward overhead.

Both as regards different color phases and geographic variation, the coloration of the Buteo borealis group (as well as of some other species of hawks) is admittedly a difficult subject, and one that is still far from being understood by any one. The most I can claim for the facts here adduced is that they are corroborative of the idea of Buteo borecolis harlami being a geographic race rather than a "color phase," such as is the darkest type of coloration seen in B. b. calurus.

These dark-colored Buteos were seen by us almost daily through the summer and in all parts of the region that we visited. On May 21 several were observed soaring low over the snow-covered slopes on the east side of White Pass. During the next week, at Carcross, they were seen daily ; apparently several pairs were settled on their nesting grounds near the town.

About Atlin these hawks were distributed throughout the lowlands; there were nesting pairs at intervals of a few miles in whatever direction one traveled. Although the species was thus relatively numerous, specimens were hard to obtain; the birds were remarkably wary.

The Harlan hawk is in the Atlin region mostly a bird of the timber. The sort of perch most often chosen is the top of one of the taller spruce trees, often in fairly dense woods but always with such a commanding view as to make approach unseen out of the question. With the exception of the dark colored hawks seen in White Pass early in the season and supposed to be of this species, none was observed in the open country above timber line. The abundance of ground squirrels might have been supposed to be an attraction to that region, too. They were extremely wary always, so much so that although both birds of a pair might circle about, screaming, as long as an intruder remained in their territory, it was generally impossible to approach within gun shot.

One nest was found. It was in the valley a few miles from Atlin, in rather open spruce woods, just above a stretch of marsh land. The 
nest was near the top of an isolated spruce, on a branching limb, about sixty feet from the ground. It was a huge mass of sticks, a platform that had been flattened to such an extent that the young birds were in plain sight from the ground nearby. On July 6 it held two young, with feather rows showing through the down on the breast. Returning on July 20 we found the young birds gone, but discovered them in nearby trees. They had evidently just left the nest; wing and tail feathers were not yet full grown, and they could make but short flights. On August 11 a second brood, again of two birds, was found, obviously just out of the nest. These birds could fly but feebly; when found they were on the ground in dense spruce woods. One young bird and one parent were shot.

Of the six specimens I collected four had crop or stomach or both well filled. Two contained rabbit (Lepus americanus macfarlani), one held ground squirrel (Citellus plesins plesins) and chipmunk (Eutamias borealis caniceps), and one held rabbit and chipmunk.

During September, Harlan hawks were migrating in numbers. They were seen near Atlin daily, and between Atlin and Teslin (September 7 to 15) a number were observed drifting southward. On September 21, I saw two, the last observed.

\section{Aquila chrysaëtos (Linnaeus). Golden Eagle}

Seen at Carcross, May 22, and near Atlin on September 21, my last day in the field. Occasional birds were encountered throughout the summer, so the species may be assumed to breed in this general region. Restricted mostly to the mountains, where presumably the open country is more favorable to the eagle's mode of hunting than are the heavily forested lowlands.

\section{Haliaeëtus leucocephalus alascanus C. H. Townsend}

\section{Northern Bald Eagle}

One was seen near Atlin, May 29; not otherwise observed. The species has been found nesting in this region (see Anderson, 1914, p. 12).

Falco rusticolus rusticolus Linnaeus. Gray Gyrfalcon

An important discovery was the finding of this species, to all appearances upon its nesting ground. On July 28, on the summit of Spruce Mountain, Brooks first encountered a gyrfalcon, feeding upon 
a Citellus. Investigation showed that rock piles upon each of several commanding eminences had been used as look-out points by one or more of these falcons, evidently for a long time. The rocks were plentifully splashed with droppings, and ptarmigan feathers and other fragments scattered about told their own story. Brooks set steel traps at three places, and on July 31 he caught a gyrfalcon in one of them. It was an adult female, well started in the annual molt. Molting tail feathers produced a gap that would have been conspicuous in flight and which did not appear in the bird first seen, so there were evidently two, at least, of the species, ranging over this mountain.

On August 28 another gyrfalcon was seen on the slope of Monarch Mountain, near Atlin.

This, I believe, is the first reported summer occurrence of the species in British Columbia. Atlin is far south of any previously known breeding station in western North America. In all likelihood, though, the gyrfalcon will be found nesting some distance still farther south, on the high Alpine-Arctic plateau that covers so much of northwestern British Columbia.

Falco peregrinus anatum Bonaparte. Duck Hawk

Of rare occurrence. Single birds were seen on Tagish Lake, May 27, near Atlin, June 29, on Spruce Mountain, August 8, and at Lake Teslin, September 12.

\section{Falco columbarius suckleyi Ridgway. Black Pigeon Hawk}

No pigeon hawks were seen until the southward migration had begun. First noted August 11, when two were observed at different times. From then on until September 21 (the last date of record) an occasional bird was seen at long intervals, probably not more than ten or twelve, all told.

It was distinctly surprising that the two specimens collected should prove to be typical examples of the subspecies suckleyi. Besides these two, another, not collected, was observed through binoculars at close enough range to establish its identity also as suckleyi without a doubt. The other pigeon hawks seen were at too long range to permit of subspecific determination. The two birds collected were an immature male, shot in the town of Atlin on August 15 (no. 44736), and an adult female, in the midst of the annual molt, shot on August 28 (no. 44737). 
The breeding range of suckleyi is, I believe, unknown, but it has been assumed to be along the coast and farther south than is indicated by the occurrence of these migrants in the Atlin region. The northernmost record of the subspecies prior to this was, I believe, from the upper Skeena Valley, British Columbia (Swarth, 1924, p. 337).

That Falco columbarius columbarius also occurs at Atlin is proved by a specimen in the Provincial Museum, Victoria, collected there August 13, 1914 (Anderson, 1915, p. 12). I have seen this bird and it is unquestionably of the subspecies columbarius.

\section{Cerchneis sparveria sparveria (Linnaeus). Sparrow Hawk}

Fairly common and of rather general distribution. The sparrow hawk occurs in the more open country in the lowlands, and also above timber line; it usually avoids the denser woods. Present at Carcross when we arrived the latter part of May. The last bird I saw was at Gladys Lake, September 8, but the species has been recorded from Atlin as late as September 18 (Kermode and Anderson, 1914, p. 19).

\section{Pandion haliaëtus carolinensis (Gmelin). Osprey}

Seen about Lake Atlin at rare intervals during the summer, and at Gladys Lake, September 7. Has been found nesting near Atlin (Anderson, 1915, p. 12).

\section{Bubo virginianus subarcticus Hoy. Arctic Horned Owl}

Bubo virginianus lagophonus Oberholser. Ruddy Horned Owl

- Six horned owls were collected as follows: an adult male, June 5 (no. 44738) ; an adult male, and male and female in post-juvenal molt, July 3 (nos. 44739-44741); adult male in annual molt, August 4 (no. 44742) ; adult male, August 25 (no. 44743). These birds are puzzling in appearance, but, although I cannot assume to have interpreted their peculiarities beyond possibility of mistake, they seem to me to demonstrate with fair certainty that the breeding horned owl of this section is the subspecies subarcticus. I had expected to find lagophonus in the Atlin region, as the ascribed range of that subspecies includes this section, but four of the six specimens cannot possibly be considered as of that race. Nos. 44739, 44740, 44741, 44743, are extremely gray-colored birds, with perhaps the minimum of rufous in their coloration that is seen in horned owls from any section. No. 44743 has legs and toes gray-barred; in the other three, those parts 
are mostly white. Altogether, the black-and-white appearance of these owls is in striking contrast to the tawny-colored lagophomus, as represented by a series from the upper Skeena Valley, British Columbia. Nos. 44739 and 44740 are two juvenals, taken with the male parent (no. 44741). The two young are quite unlike, one being much darker than the other; the pale colored bird is the more rufescent of the two.

Two specimens were collected that are like lagophonus from the Skeena Valley. One of these (no. 44738, adult male, June 5) with hardly a doubt was not a breeding bird. Of the second (no. 44742, adult male, August 4 ) it cannot be said with any certainty whether or not it had bred in the region. These two individuals may be, as their appearance indicates, examples of lagophonus that had wandered beyond the usual confines of that race. The breeding birds in the series are most nearly like specimens of subarcticus from the Yukon region, a short distance to the northward. The Atlin region forms the southern boundary of the Yukon drainage, and it is to be expected that the distribution of some Yukon species should be co-extensive with this drainage system.

Horned Owls were fairly common in the Atlin region; hooting could be heard almost every night. One bird was seen at Lake Teslin, September 12. Of the six horned owls collected, four had their stomachs filled with remains of rabbits. Those of the other two were empty.

\section{Surnia ulula caparoch (Müller). Hawk OwI}

On May 29 a hawk owl was found in a tract of spruce timber at the northern base of Monarch Mquntain, and as the bird was seen subsequently at the same place on several occasions, it may have been nesting there. This was the only one seen until the end of the summer. On August $19^{\circ}$ Brooks shot a young bird, in first winter plumage throughout save for remnants of down about the head, and from then on others were seen at frequent intervals.

The three birds collected, two by Brooks, the other by myself (no. 44744, male, September 19), are alike and are extremely dark colored. Compared with a large series from northern Alaska, the Atlin specimens are more slaty above and less reddish below. These color differences cannot be explained as illustrating seasonal change or sexual or age variation, but neither can they with any certainty be correlated with any geographic area.

One hawk owl had in its stomach the remains of a Peromyscus. 
Ceryle alcyon caurina, Grinnell. Western Belted Kingfisher

There appeared to be a few pairs of kingfishers nesting in the region about Atlin. The species was far from common but an occasional bird was seen throughout the summer.

\section{Dryobates villosus leucomelas (Boddaert)}

Northern Hairy Woodpecker

Only three hairy woodpeckers were encountered during the summer, one seen July 6, a male collected on July 7 (no. 44745), and a male collected on August 22 (44746). The two specimens, collected near the town of Atlin, are unquestionably of the subspecies leucomelas, here near the southern limit of that race. In the upper Stikine Valley, 150 miles south of Atlin, the subspecies monticola occurs, in fair abundance (Swarth, 1922, p. 217). In the monticola series at hand from that region there are specimens that show intergradation toward leucomelas.

Dryobates pubescens nelsoni Oberholser. Nelson Downy Woodpecker

An adult male downy woodpecker (no. 44747), shot near Atlin, June 8, was the only one of the species that was seen. This bird is referable to the subspecies nelsoni. It has slightly more black marking on the outer rectrices than is seen in specimens of nelsomi from the Yukon, but in all other respects it appears to be typieal of that race.

Picoides americanus fasciatus Baird. Alaska Three-toed Woodpecker

Unexpectedly rare. The first was seen July 11; afterward perhaps five or six, all told, were encountered. One seen at Lake Teslin, September 11. One specimen collected, an adult female, July 11 (no. 44748).

Colaptes auratus borealis Ridgway. Boreal Flicker

Present at Carcross when we arrived, May 22, and at Atlin when we reached there a few days later. Breeds in fair abundance throughout the lowlands. A nest hole, partly finished, was found May 31, in a stump in a clearing, one foot from the ground. On June 24 a flicker was seen feeding young in a hole in a dead poplar about three feet 
from the ground. Other nests were found, similarly placed, low down in dead timber. The last flicker was seen September 5.

Two specimens were collected (nos. 44749-44750), a female on August 17, a male on August 22.

Chordeiles virginianus virginianus (Gmelin). Eastern Nighthawk

The first nighthawk arrived at Atlin on the evening of June 12; the species was fairly common thereafter in the lowlands. During the last two weeks in August the southward migration was under way, and every evening the birds could be seen passing by, all going in the same direction. Last seen on the evening of September 6. Two specimens collected (nos. 44751-44752), both females, taken on August 12 and 20, respectively.

\section{Selasphorus rufus (Gmelin). Rufous Hummingbird}

Seen on only three occasions, on June 11, June 13, and July 12, all within a few miles of the town of Atlin. One of the three was an adult male, hence easily recognizable, the others were inferentially of the same species.

Sayornis sayus yukonensis Bishop. Northern Say Phoebe

Present at Carcross upon our arrival, May 22. Breeds in the town of Atlin, and scattered pairs occur elsewhere, usually about abandoned buildings. The southward migration of this species was under way after the middle of August. On August 24, near the summit of a high mountain, a Say phoebe, first observed perched upon a rocky pinnacle, was seen starting southward, ascending higher as the mountain was left behind, the beginning of what was to be, apparently, a long flight. The last Say phoebe was seen at Lake Teslin, September 10.

I collected three adults (nos. 44753-44755) and Brooks collected others, and these, together with additional northern specimens in this museum, bear out the validity of the subspecies yukonensis (Bishop, 1900, p. 115). The northern bird has a slightly smaller bill than the southern race; otherwise, differences of measurements between the two are of slight moment. The color differences, however, are readily apparent, both in the juvenal and adult plumages, yukonensis being clearer gray where sayus is brownish or rusty, as deseribed by Bishop (loc. cit.). 


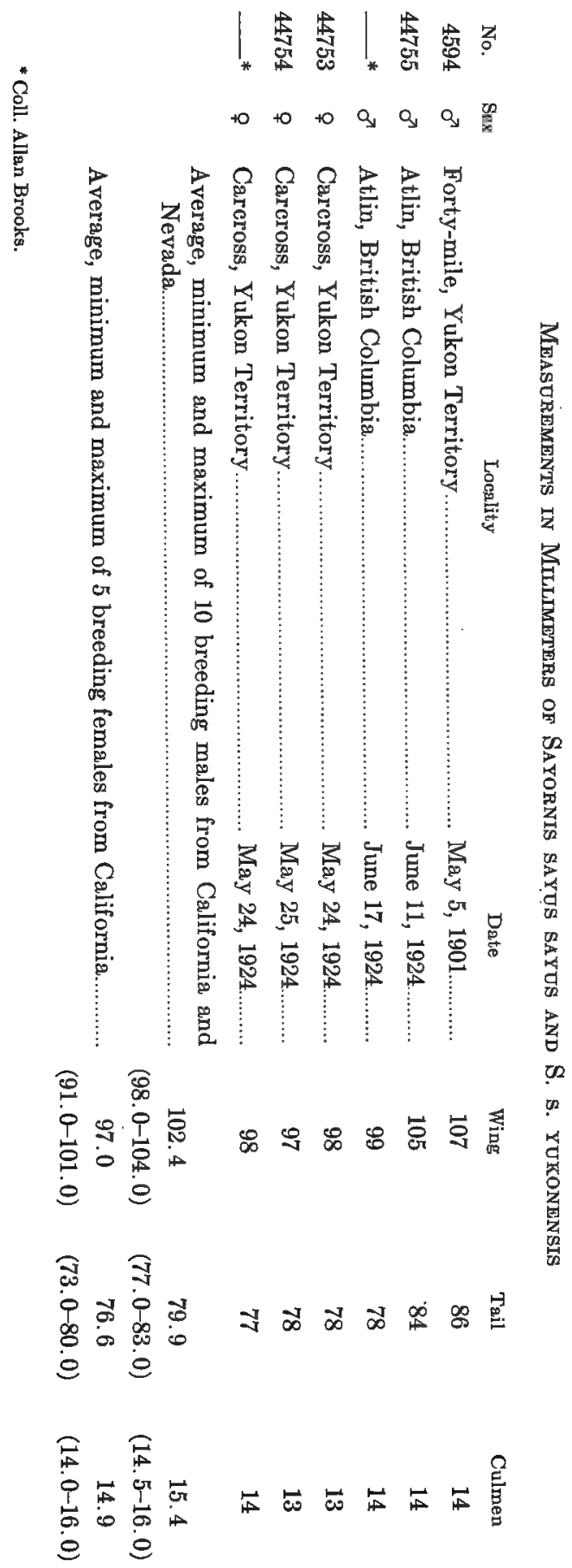


Nuttallornis borealis (Swainson). Olive-sided Flycatcher

First seen at Carcross, May 26. Summer visitant to the Atlin region in small numbers. An occasional pair was nesting at wide intervals throughout the surrounding lowlands. In August, when the southward migration had begun, the birds were more frequently seen. Last noted August 28. One specimen was collected, an adult male taken June 2 (no. 44756).

\section{Myiochanes richardsonii richardsonii (Swainson) \\ Western Wood Pewee}

Present at Carcross, May 22. About Atlin the species was fairly common throughout the lowlands. Last seen August 28. Three specimens were collected, two adults and one juvenile (nos. 4475744759). There are at hand twelve additional specimens from northern localities, from the Skeena River and the Stikine River, British Columbia, and from the coast of southeastern Alaska, and judging from this series I can see no justification for recognition of the subspecies saturatus (of Bishop, 1900, p. 116). These birds are to my eye indistinguishable from more southern specimens.

Empidonax traillii alnorum Brewster. Alder Flycatcher

Arrived at Atlin on June 12. Not common, but found in willowgrown swamps throughout the lowlands. Last seen August 29. Three specimens were collected, two adults and one immature in first winter plumage (nos. 44760-44762).

\section{Empidonax hammondii (Xantus). Hammond Flycatcher}

Fairly abundant in the lowlands of the Atlin region throughout the summer. Arrived on June 1, and was last noted August 31. Three specimens were collected (nos. 44763-44765), an adult male on June 3 , a female in winter plumage throughout on August 21, and a male still in juvenal plumage on August 24.

\section{Empidonax wrightii Baird. Wright Flycateher}

Three specimens were collected (nos. 44766-44768) : an adult male at 3000 feet altitude on Monarch Mountain, June 22, an adult female 
at 3500 feet on Otter Creek, July 30, and a male in juvenal plumage at the base of Monarch Mountain, August 17, the last date of record.

The Wright flycatcher was of decidedly rare occurrence, not more than six or eight individuals, all told, being seen during the summer. Breeding birds were taken at a higher altitude than that at which hammondii occurs.

\section{Otocoris alpestris arcticola Oberholser. Pallid Horned Lark}

Breeds in fair abundance throughout the open country on the ridges above timber line. On June 19, young out of the nest were seen. During the last week in July and the first week in August, old and young were in the midst of the molt; two adult males collected on August 7 and 8, respectively, have nearly completed the change. During this season of molt, the horned larks were generally found either as single birds or two or three together, but before the end of August they were gathered in flocks of from fifty to one hundred individuals.

Fourteen specimens were collected (nos. 44769-44782), three in juvenal plumage, three adults in worn breeding plumage, and one immature and seven adults in more or less completely acquired winter plumage. The species was last seen on August 24, though later trips were made to the high altitudes where it occurs.

\section{Pica pica hudsonia (Sabine). American Magpie}

Several pairs were seen near Carcross during the last week in May, and two nests found, occupied but without eggs. None was seen about Atlin during the early part of our stay, and we were told that magpies did not nest in that section but that the birds did appear there at the very end of the summer. I saw several at Gladys Lake, September 8. On September 19 one appeared at Atlin, and I saw the species each day until the 23rd, when I left.

The late summer invasion of the Atlin region by the magpie is probably related to the migration of this species to the coast of southeastern Alaska, as observed by me on the lower Taku River in September, 1909 (Swarth, 1911, p. 77). The valley of the Taku, lying southwest of Lake Atlin, is a natural outlet from this region to the coast, and the magpies I saw there were, together with other species, migrating down this valley from the interior. 


\section{Perisoreus canadensis canadensis (Linnaeus). Canada Jay}

Fairly common, both at Carcross and about Atlin. At the time of our arrival, during the last week in May, old and young together were roving through the woods in small bands, apparently family groups. During July both old and young were going , through the molt; specimens of adults and young collected on August 14 had completed the change. Seventeen specimens were collected (nos. 4478344799), including three summer adults (two from Carcross), seven in juvenal plumage, and seven adult and immature in fresh winter plumage.

Corvus corax principalis Ridgway. Northern Raven

This is another species that appears in the Atlin region in the fall. Kermode (1914, p. 21) found it common there during September, 1913 (recorded as Corvus caurinus). Seen by me on just one occasion, at Lake Teslin, September 12, when two birds appeared, attracted by refuse from the carcass of a moose that was being cut up.

\section{Euphagus carolinus (Müller). Rusty Blackbird}

One bird seen at Carcross, May 24, but the species had probably arrived some time before. Upon our arrival at Atlin a few days later we found scattered pairs established in most of the little swamps that are distributed throughout the lowlands. Small flocks of young appeared in July, but the species was not abundant at any time, and most of the birds had gone by the middle of August. I saw a few at Gladys Lake, September 8 and 9 , the last I encountered, thongh Kermode (1914, p. 21) has recorded it from this region as late as September 19.

Carpodacus purpureus purpureus (Gmelin). Eastern Purple Finch

On June 25, near the town of Atlin, I heard a purple finch utter a few notes of its song, and on June 28, at the same place, I collected an adult male (no. 44800). This constitutes, I believe, the extreme northwestern point of record for this species.

Loxia leucoptera Gmelin. White-winged Crossbill

First seen on June 3, a single bird. Increasing numbers arrived daily, until by the middle of June flocks of fifty or sixty birds 
appeared. By the last week of June the crossbills were in pairs, apparently preparing to nest, but soon after their numbers lessened until relatively few remained. Two specimens were collected, both adult males (nos. 44801-44802).

\section{Spinus pinus (Wilson). Pine Siskin}

Arrived at Atlin toward the end of June. Finst noted June 25, and became fairly numerous by the middle of July. At the time of my departure, September 23, siskins were still present in numbers.

\section{Calcarius lapponicus alascensis Ridgway. Alaska Longspur}

At Carcross, May 23, the cat at the hotel where we stayed brought in a longspur, which we were able to identify from the feathers scattered about. This, presumably, was a belated north-bound migrant. The species was next encountered on September 1, when I flushed several high upon the mountain above "Blue Cañon." On September 7 several large flocks were observed between Surprise and Gladys lakes.

\section{Passerculus sandwichensis alaudinus Bonaparte.}

Western Savannah Sparrow

When we reached Atlin, May 28, Savannah sparrows had already arrived, and the male birds could be seen singing from low perches in the more open swamp-land. The species was not common, but a few pairs were scattered through the wet meadows that partly encircle the town of Atlin, and small numbers were seen elsewhere, where suitable conditions obtained. On June 25 a nest was found, containing six eggs on the point of hatching. The nest was sunk in the ground, in marsh grass, with no trees or bushes in the near vicinity.

On September 1, Savannah sparrows were seen in numbers, migrating, on some of the higher, more open, mountain slopes. The last bird was seen September 21. Three specimens were collected, an adult male, and male and female in first winter plumage (nos. 44803-44805).

Zonotrichia gambelii (Nuttall). Gambel White-crowned Sparrow

An abundant summer visitant to the lowlands of this region. At Carcross when we arrived, May 22, the Gambel sparrows were already paired and preparing to nest. The first nest was found at Atlin on 
May 31, containing two eggs; on June 4 it held a set of four. Other nests were found on June 11, with four eggs (no. 1983), and on June 12, with five eggs (no. 1984). These were all essentially alike in structure and location. They were on the ground in rather damp meadow land, in fairly open areas interspersed with thickets of willow and dotted with tiny wild rose plants. The nests were well hidden under tufts of grass, willow shoots, or roses.

One (no. 1983) measures $120 \mathrm{~mm}$. outside diameter, $65 \mathrm{~mm}$. inside diameter, $40 \mathrm{~mm}$. inside depth. The outer walls are mostly shreds of bark and coarse (dry) grass stems, the lining is of fine grass and a little horse hair.

Another nest (no. 1984) measures $110 \mathrm{~mm}$. outside diameter, $65 \mathrm{~mm}$. inside diameter, $35 \mathrm{~mm}$. inside depth. The outer walls are mostly shreds of bark, the lining is of fine grass and a little manmal hair, mostly dog and mountain sheep (taken from a nearby carcass of the first, and scraps of hide of the second).

On June 25 the first young birds appeared, but although the species was common, relatively few spotted young were seen at any time. The birds nested in fair abundance in gardens in the town of Atlin, and in waste land between the houses, and more young birds were seen there than elsewhere. On July 11 the first juvenile was collected showing beginnings of the post-juvenal molt, which, roughly, continues through the month of July. On August 6 a young male was taken, still with many pinfeathers but with none of the juvenal plumage left. By August 14 the young birds were practically through the post-juvenal molt. Adults at that date were nearly all stubbytailed. A young female collested August 24 is in perfect first winter plumage.

During the breeding season the Gambel sparrow was confined to the lowlands, but soon after the beginning of the post-juvenal molt there was a scattering of old and young that took many individuals high up into the mountains. There they formed loosely connected flocks in company with the golden-crowns, the beginning of an association that in California we see carried on throughout the winter.

On August 29 the species was still abundant. It was last noted on September 5, but as a number of the birds were seen on that date, some probably lingered several days longer. Careful search on September 19, however, failed to disclose a single one.

Sixteen specimens were collected (nos. 44806-44821), fourteen in juvenal plumage or in various stages of the post-juvenal molt, and two in first winter plumage. 
I am using the binomial name for this bird in the convietion that the three white-crowned sparrows, leucophrys, gambelii, and nuttalli are three distinct species. There are various trenchant external characters of plumage and other parts distinguishing them, there are just

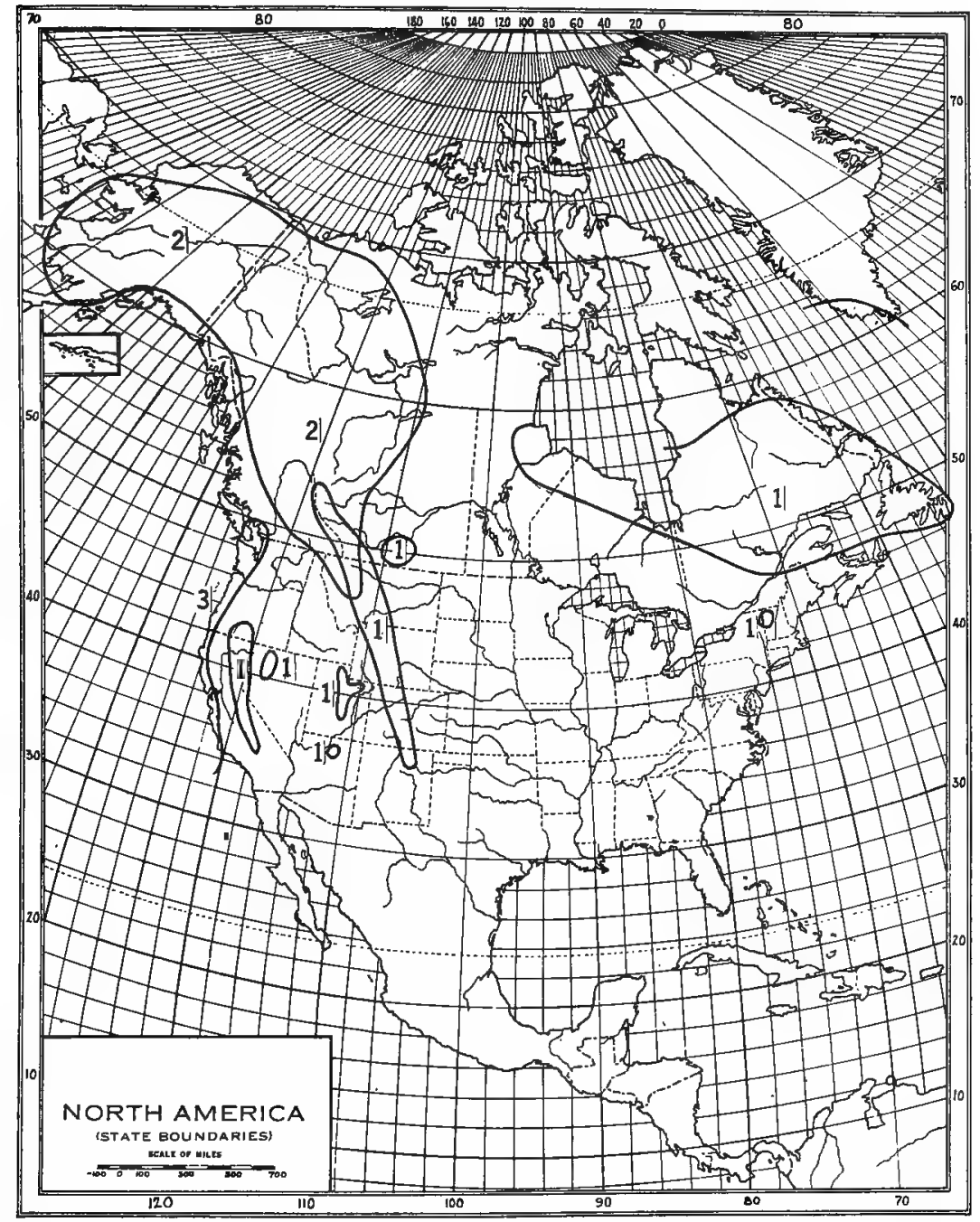

Fig. J. Map showing breeding ranges, approximately outlined, of (1) Zonotrichia leucophrys, (2) Zonotrichia gambelii, and (3) Zonotrichia nuttalli.

as notable differences of song, and the breeding ranges and migration routes also ure indicative of specific differences (see fig. $J$ ). As regards external characters, while I am aware that there are various published statements of the existence of intergradation between these forms, these 
assertions are all rather vague. In this museum there are approximately 200 specimens of leucophrys, 270 of gambelii, and 200 of nuttalli. There is not one equivocal specimen in this series, not one that can be said to illustrate in even the slightest degree intergradation between any of the forms. Nor have I seen intermediates in other collections. If any such do sporadically occur it seems to me that they should be regarded as hybrids rather than geographic intergrades. Riley (1912, pp. 66-67) has given conclusive evidence as to conditions at the one place where the ranges of leucophrys and gambelii are known to abut. Each retains its specific identity. As far as I know, the breeding range of nuttalli is widely separated both from that of lencophrys and of gambelii.

The different songs of these three birds also is something that cannot fail to impress one. When in addition to the consistently uniform external characters found in each form, there are also such differences of song and breeding ranges as are seen, it seems to me that every condition is met whereby they should be accorded specific rank.

\section{LIST OF FORMS OF THE WHITE-CROWNED SPARROWS OF THE GENUS} ZONOTRICHIA

1. Zonotrichia leucophrys (J. R. Forster). Eastern White-crowned Sparrow.

2. Zonotrichia gambelii (Nuttall). Gambel White-crowned Sparrow.

3. Zonotrichia nuttalli Ridgway. Nuttall White-crowned Sparrow.

\section{Zonotrichia coronata (Pallas). Golden-crowned Sparrow}

There is a small and yearly diminishing list of North American birds, the breeding habits of which are almost or quite unknown, and the golden-crowned sparrow has been one of the few passerine species included in that category. It is true that many years ago detailed accounts were published professing to give particulars of the nesting of this bird, but those were cases of mistaken identification and so far as I know there has not yet been printed any unquestioned account of the breeding of the golden-crowned sparrow. I was, indeed, under the impression for a time that nests and eggs taken by Major Brooks and myself in the Atlin region were the first authentic sets to be collected, but, as I learned, there are sets in the collection of Colonel John E. Thayer, Lancaster, Massachusetts, that were taken some years ago. Through the courtesy of Colonel Thayer details regarding these sets are given below. 
The old records by Heermann (1859, p. 48) and by Brewer (1878, p. 48), the former describing the nesting of the golden-crowned sparrow near Sacramento, California, the latter, in Shasta County, California, were mistakes that are obvious enough to us at the present

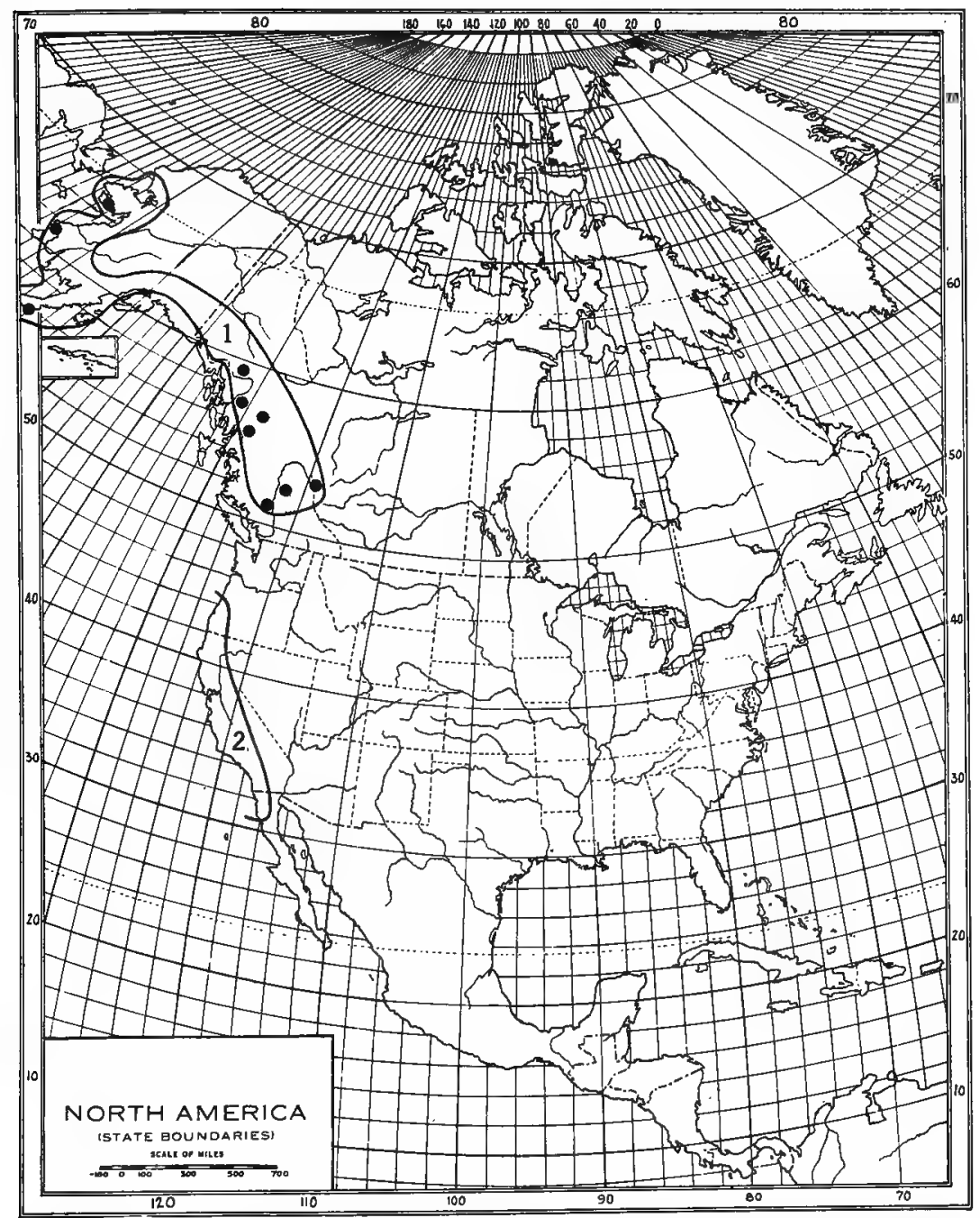

Fig. K. Map showing distribution of the golden-crowned sparrow (Zonotrichia coronata), with (1) breeding range and (2) main winter habitat approximately outlined. Symbols within the outlined breeding range indicate localities where the species has been found actually breeding.

time, but they were accepted at face value for many years. Their widespread repetition created an impression that the nest and eggs of this bird were well known, an impression that persisted long after 
those records were specifically discredited. The only other published accounts bearing upon this subject that I have seen are by Bishop (1900, p. 85), who describes an unfinished nest found in White Pass; and by Osgood (1904, p. 75), who casually mentions "several" nests found at Bay, Alaska Peninsula, the latter part of June, containing from four to six eggs each.

I, myself, had been twice before on the nesting grounds of the golden-crowned sparrow, and the fact that $I$ had failed to find nests then spurred me on to renewed efforts on this third opportunity. In British Columbia this bird is a summer visitant at high altitudes, nesting above the limit of upright timber. In the Atlin region it is so closely restricted to the heights that $I$ did not see even a migrant in the lowlands.

On May 29 we made our first climb above timber line, to the top of Monarch Mountain, some 4500 feet altitude, about three miles south of Atlin. The golden-crowned sparrows had arrived and were singing from the tops of the balsam thickets, but no nest building was detected. This mountain top, as it proved, was peculiarly adapted to the needs of this species. At least there were more of the birds here within a relatively limited area than we saw anywhere else. Long stretches of rolling hilltops, grass-covered for the most part, were interspersed with scattered thickets of prostrate or stunted balsam, and with larger areas of trailing birch. This birch was in most places not over knee high and easily walked over. Little lakelets occupied some of the hollows, and from them small streams flowed part way down the mountain. Lakes and streams both were almost or entirely dry before the summer was over.

On June 19 we returned to this same summit, to make a thorough search for nests. A general notion that these would be in the balsams, as the most effective cover in sight, led us first to direct our attention to these thickets, the more so as they formed the singing perches of the male birds. Half an hour's search brought no results other than the discovery of old robin nests, so the balsams were abandoned for the time. A little later, as I was traversing a dry, open ridge, ploughing through a mat of birch, a sparrow darted out some eight or ten feet away, not to fly, but to scuttle, mouse-like, along the ground under the sparse, sprawling branches. A brief search disclosed the nest (see pl. 7, fig. 6). A ledge of rock protruded a few inches from the ground in the center of the thicket, and the nest was sunk against this shelter, fairly well concealed by the vegetation above. There were five eggs, 
incubated about one-half. Within a few hundred yards a second nest was found in a similar situation, on the ground under some trailing birch, with four eggs incubated as the first lot were. Again the bird was seen running from the nest under the bushes.

The first nest was built externally of gray plant fiber, a few balsam twigs, bits of dried flakes of bark, and a very little green moss; the lining was of dry grass, with several white ptarmigan feathers interwoven. External diameter, $120 \mathrm{~mm}$; internal diameter, $65 \mathrm{~mm}$; outside depth, $55 \mathrm{~mm}$; inside depth, $35 \mathrm{~mm}$.

The second nest differs in minor details, having far more green moss worked into the outer wall, and lacking any feathers in the lining. External diameter, $135 \mathrm{~mm}$; internal diameter, $65 \mathrm{~mm}$; outside depth, $55 \mathrm{~mm}$; inside depth, $35 \mathrm{~mm}$.

The two sets of eggs measure, in millimeters, as follows :

First set (no. 1986) ; $22.0 \times 15.8,22.2 \times 16.2,22.2 \times 15.5,23.0 \times 16.0$, $22.0 \times 16.0$.

Second set (no. 1985), 23.5 × 16.2, $24.0 \times 16.0,23.0 \times 16.5$, $22.8 \times 16.5$.

The eggs are speckled and mottled with brown on a pale greenish ground. Of the two sets here described, one (no. 1986) is much more heavily marked than the other, the ground color being almost obliterated. The eggs of the golden-crowned sparrow are closely similar to those of the Gambel and Nuttall sparrows. Both of the above described sets can be duplicated almost exactly in series of eggs of those species.

Several hours after our first two discoveries, Brooks found a third nest, this one in a low thicket of balsam, a thicket about twenty feet square but with the sprawling branches rising not more than knee high above the ground. The nest was in the branches, about ten inches up, and was much bulkier than those on the ground. It was a graycolored structure, the outer walls of coarse weed stalks and shredded stuff that appeared to be the bark of some of the annuals growing thereabout. The lining was mostly fine grass, with one conspicuous white ptarmigan feather. The whole nest was about $180 \mathrm{~mm}$. in diameter, and $90 \mathrm{~mm}$. deep. The nest cavity was $76 \mathrm{~mm}$. across. It contained four fresh eggs.

On June 22 a fourth nest was found on the same mountain, in much the same situation as the first two (see pl. 7, fig. 7). It was on a dry ridge under a scant growth of dwarf birch, the nest buried between tufts of long, dry grass, and itself constructed mostly of dry grass and 
plant fiber, the lining of fine grass. It contained four slightly incubated eggs. This nest, like the others, was found by flushing the bird. The last two nests discovered, both taken by Brooks, are now in the collection of Colonel John E. Thayer, Lancaster, Massachusetts.

The dates on which these nests were taken is probably indicative of the usual time of egg-laying, but some sets are evidently laid at a much later date. On August 3, on Spruce Mountain, a pair of birds was seen, which, from their actions, obviously had a nest nearby, and on August 5, on the same mountain, a nest was found containing naked young, probably about a week old.

The Thayer collection contains four sets of eggs of the goldencrowned sparrow, collected by John Koren, with data as follows:

(1) Anvil Mountains, near Nome, Alaska; June 21, 1910; 5 eggs.

(2) Anvil Mountains, near Nome, Alaska; June 21, 1910; 7 eggs

( 3 broken).

(3) Nelson Island, Bering Sea, Alaska; July 3, 1910; 3 eggs.

(4) Shumagin Island, Alaska; July 8, 1911; 5 eggs.

The parent birds of each set are also in the Thayer collection.

On July 8 young out of the nest were first seen on Monarch Mountain, and here, as in previous experiences, I had impressed upon me the extreme wariness of the young birds. They were in thickets of dwarf birch and balsam. When a brood was flushed they scattered to distant points, and each bird, alighting in a bush, at once scuttled through and was away to another hiding place. The adults are not hard to approach; they apparently watch and direct the retreat of their offspring.

On July 18 young were taken in juvenal plumage throughout and with full-grown rectrices. Others molting into first winter plumage were collected July 27 and August 5. One young bird still mostly in juvenal plumage was taken August 24.

The young of the golden-crowned sparrow is generally similar to the same stage in the three species of white-crowned sparrows. Coronata lacks the decided head markings that are seen in the juvenal white-crowns and it has a suggestion of yellowish upon the forehead. Compared with the grayish leucophrys, young coronata is generally darker colored and the ventral streaks are darker, heavier, and more extensive. Compared with gambelii, young coronata is generally browner. Young coronata and young nuttalli are closely similar in 
body coloration, but the former is slightly darker colored as a rule. Coronata has a heavier bill than the white-crowned sparrows, and this character is apparent in the young birds.

The accompanying illustration (pl. 4) was made from studies of the freshly killed bird. The yellowish tinge to the lower parts, as there shown, is an evanescent color that soon disappears from the study skin. Color of bill and feet in the picture is, of course, as those parts were in the living bird.

On September 5 I made my last climb to the summit of Monarch Mountain, and on that day but a single golden-crowned sparrow was noted, the last for the season.

In all, I collected six specimens of the golden-crowned sparrow (nos. 44822-44827), as follows: one adult female (with the first set of eggs), two males in juvenal plumage, and three birds in various stages of the post-juvenal molt.

Spizella monticola ochracea Brewster. Western Tree Sparrow

An abundant summer visitant in the region at an altitude higher than the town of Atlin. Tree sparrows may appear in the lowlands upon their advent in the spring, but when we arrived, at the end of May, they were already established on their nesting ground and we saw none in the valley. We found them in abundance at the head of Cañon Creek (from 3500 to 4500 feet altitude) and in somewhat similar surroundings at the same elevation on upper Otter Creek. In each place they occurred where willow is the prevailing tree growth, ranging in size from scrubby, mat-like thickets that can be walked over, to tangled bushes ten feet high or more. The tree sparrows were practically always found in or about the willows.

On June 30 tree sparrows appeared to be carrying food to young in the nest; by the last week in July the young were going through the post-juvenal molt. During September a few migrating tree sparrows appeared in the lowlands. Single birds were seen at Lake Teslin, September 12, and near Atlin on September 19 and 21. Eleven specimens were collected (nos. 44828-44838), two adult females in worn breeding plumage, eight young (July 30 to August 6) in various stages of the post-juvenal molt, and one immature female in first winter plumage. 


\section{Spizella passerina passerina (Bechstein). Eastern Chipping Sparrow}

Seen at Carcross, May 22. In the Atlin region this is a fairly common species in the lowlands. It probably does not nest on the higher mountain slopes, but at the end of the summer there was a slight movement toward higher altitudes. In the upper part of Otter Creek, up to about 4500 feet altitude, chipping sparrows were fairly common at the end of July and during the first week in August. The last chipping sparrow was seen August 24, near Atlin. Three specimens were collected (nos. 44839-44841), two adult males and one male in juvenal plumage.

Spizella taverneri Swarth and Brooks. Timber-line Sparrow

The discovery of this species (see Swarth and Brooks, 1925, p. 67) was one of the most interesting of the season's results. In general appearance Spizella taverneri resembles Spizella breweri closely enough that we could not be sure in the field that it was not breweri that we had found, but the known range of breweri was so distant, and the conditions surrounding this bird were so widely different from those in the habitat of breweri, as to arouse our strong interest.

We first encountered the timber-line sparrow on July 8, near the summit of Monarch Mountain, about 4500 feet altitude. The surroundings there are such as obtain generally above timber line in this region, the country being open, grass covered for the most part, the damper portions with small areas of false heather and the whole interspersed with clumps of scrubby balsam, mostly prostrate, but sometimes ten or fifteen feet high. It was a raw day, with showers at frequent intervals, the rain driving before a sharp wind, conditions such as to render a search for small birds difficult and unproductive. We were following a flock of horned larks when two sparrows appeared, perched upon a balsam thicket some distance away and jerking their tails nervously. Their appearance did not accord with anything we knew in the region, and Brooks started at once in pursuit. With some difficulty, for the birds were wary, he secured one of them. This proved to be an adult female with a denuded abdomen, indication that she was, or had been, incubating eggs.

The species was next encountered in the upper part of Otter Creek, at about 3500 feet altitude, and on the surrounding mountains up to their summits, nearly 5500 feet altitude. In Otter Creek Valley 
these birds were not seen along the wet bottom lands, but they frequented the dry hillsides, where the trailing birch afforded the cover they favored the most. They were at all times wary and hard to approach, far more so than most small birds, and in contrast to the actions of the several species of Spizella and Zonotrichia with which they were associated.

During the last week in July and the first week in August, spotted young were seen being fed by their parents, but mostly the young were larger, undergoing the post-juvenal molt. The species might easily be overlooked, for besides their habitual wariness the birds are with difficulty dislodged from the sheltering cover they frequent. If flushed at a distance from the tops of the balsam thickets on which they often perched when suspicious of danger (and they rarely permitted a near approach), the timber-line sparrow might easily be overlooked amid the tree sparrows, chipping sparrows, and even the Zonotrichicas, which were in the same surroundings and arising from the bushes near at hand. When flushed they flew long distances, to dive into birch thickets, tangled masses of shrubbery about waist high, and it was rarely that a bird could be dislodged from such a refuge. They ran beneath the shrubbery, to take flight at some distant point, and such tactics, repeated over and over again, inevitably left the person in pursuit floundering clumsily through entangling branches far behind.

So, although the species was really abundant in some places, such as on certain of the higher slopes of Spruce Mountain, we secured relatively few specimens.

Together, we collected twenty-three skins, as follows: adult male, 3 ; adult female, 4 ; immature, first winter plumage, 4 ; juvenal, 6 ; molting from juvenal to first winter, 6. Fifteen of these (nos. 4484244856) came to the Museum of Vertebrate Zoology. Two of this series have since been deposited in the United States National Museum.

\section{Junco hyemalis connectens Coues. Cassiar Junco}

Thirty-five specimens of junco were collected (nos. 44857-44891), sixteen breeding adults (thirteen of these from Carcross), the remainder comprising some streaked juveniles and adults and immature in fall plumage. I am listing these all as of the subspecies connectens; but there are equivocal specimens in the series (among migrants collected toward the end of the summer) that would fit as readily into a series of hyemalis. 
Breeding juncos from Carcross show a distinct approach to the subspecies hyemalis, as compared with connectens from the Stikine region, so much so that Carcross may be regarded as near the northern limit of the range of connectens.

At Carcross, May 22, male juncos were singing from the tops of bushes and small trees. Females collected during the next few days had their sets partly laid. Two nests, each with four fresh eggs, were found near Atlin, May 31. These and other nests subsequently found were all very much alike. They were all in fairly open bottom land, on the ground, and well concealed in sheltering grass and other vegetation. Juncos bred most abundantly in the lowlands, but on June 30 I found a nest with five fresh eggs on a mountain side at about 3500 feet altitude. The situation was a warm, south-facing slope; the nest was buried in a dense clump of bear-berry and grass.

On June 26 the first young out of the nest was seen, and from then on through August spotted young were fairly common in small flocks throughout the lowlands. During September juncos were migrating through the region. The last were noted September 19, but from the number seen that day I am sure that some must linger to a much later date.

\section{Melospiza lincolnii lincolnii (Audubon). Lincoln Sparrow}

Breeding in fair abundance in the disconnected marshy areas that occur throughout the lowlands. On June 14 a nest was found with five eggs at the point of hatching. The first young was seen flying on July 2. The species was last noted on August 29. Two specimens (nos. 44892-44893) collected by myself, and others taken by Brooks, are all typical of the subspecies lincolnii.

\section{Petrochelidon lunifrons lunifrons (Say). Cliff Swallow}

Nests were seen on buildings at Carcross. The first cliff swallow was noted there on the evening of May 26, some days after our own arrival, and when we reached Atlin, May 28, the species was present in force. It nests in some numbers in the town, but we found it breeding nowhere else. The last eliff swallow was noted August 16.

\section{Hirundo erythrogaster Boddaert. Barn Swallow}

This species arrived at Careross on the morning of May 26. Old nests were seen on several houses there. It was abundant in the town of Atlin, but was not found nesting elsewhere. Last noted September 1 . 
E. M. Anderson (1915, p. 15) has described the nesting of a pair of barn swallows on a passenger coach that traverses the two-mile portage at Taku. The birds still rear their broods in the same place. For their convenience a box is affixed near the roof of the coach within (the sides of the car are open), and year after year the box is occupied. The coach travels back and forth across the portage several times a week, filled with people, throughout the nesting period.

\section{Iridoprocne bicolor (Vieillot). Tree Swallow}

Arrived at Atlin on June 3. Found by us nesting only about human habitations, but during the third week in July there were so many young tree swallows gathered upon the largest of the three islands nearest to Atlin that it seemed as though they must have been reared elsewhere than in the town.

\section{Tachycineta thalassina lepida Mearns \\ - Northern Violet-green Swallow}

Abundant at Skagway, May 21, at Carcross, May 22, and at Atlin, when we reached there on May 28. Last seen near Atlin on September 1. There are no rocky ledges near Atlin, such as the violet-green swallow occupies elsewhere in the north, and as with all the other swallows found breeding in the region, they were nesting about human habitations, occupied or deserted, and nowhere else.

Riparia riparia (Linnaeus). Bank Swallow

A flock of migrating bank swallows appeared near Atlin on June 10, and a single bird was seen on July 12. The species was not otherwise observed.

Bombycilla garrula pallidiceps Reichenow. Bohemian Waxwing

A single bird seen at Carcross, May 24. At Atlin, the third week in May, waxwings were fairly common and in pairs. On June 3 the beginning of a nest was found, on June 4 one that was ready for lining, and on June 11 the first set of eggs. These and several other nests were on the mainland, not far from the lake shore, and in rather open groves of jack pine. Nests were mostly near the ground, the highest being some thirty feet up. They were all in the terminal forks of downward drooping branches, six to ten feet from the trunk. 
Waxwings build their nests in scattered communities, so that where one pair is found there are pretty sure to be others not far distant. Within a few miles of Atlin there were several such groups, comprising at least eight or ten pairs at each place. We collected but three sets of eggs at these places, but evidently there was some more formidable enemy of the birds at work, for the waxwings gradually disappeared, and not one young bird was reared in these colonies.

On July 15 we made the first of several visits to three small islands opposite Atlin, and there we found waxwings in numbers, and nesting. Apparently every pair that had started the breeding season on the nearby mainland had moved out to the islands, where they seemed free of whatever scourge it was that had destroyed their first nests. We saw no Canada jays, no squirrels, and no chipmunks on the islands; any or all of these may have been responsible for the shifting of the birds.

On the mainland nests were all in jack pines, but on the islands they were nearly all in small balsam firs. Mostly they were built low, ten feet from the ground or less, and several were within reach from the ground. During the third week in July" nests held fresh eggs or incomplete sets. Complete sets, on the islands and on the mainland, ranged from four to six eggs.

On Otter Creek, July 26 to August 9, waxwings were occasionally encountered, in small flocks, old and young together. During August the species almost entirely disappeared, days and weeks passing without one being seen. On September 7 a small flock was seen near Gladys Lake, and 'on the 10th another flock between Gladys Lake and Lake Teslin. Not seen subsequently, though the species might be expected to remain until a mưch later date.

Three waxwings were collected (nos. 44894-44896), male and female taken July 27, full grown but in juvenal plumage throughout, and an adult male, August 5, not yet beginning the annual molt. The young male has four large wax tips on each wing, the young female, two small ones. Neither has the vivid orange tail tipping noted on certain young birds from the Stikine River (Swarth, 1922, p. 279), though the female shows an approach to that color.

\section{Lanius borealis Vieillot. Northern Shrike}

Our discovery of the northern shrike in the Atlin region establishes this bird as a breeding species in extreme northern British Columbia, though the previous capture of one by W. H. Osgood, for the U. S. 
Biological Survey, at Bennett, June 9, 1903, made it a fair presumption that this was the case. We found no nest, but on June 30 we collected a brood of six young, just able to fly; the nest must have been close by. The young birds, huddled together in a spruce thicket, were being fed by one parent, which escaped. This was at the head of Cañon Creek, altitude 4000 feet, in a sparsely wooded mountain valley, close to the upper limit of upright timber. The young birds were extremely noisy ; it was the incessant squalling for food that drew our attention, from a distance. Their stomachs were well filled, mostly with insect remains, including some small Coleoptera; in one stomach there were parts of a very young ptarmigan chick, including the bill. Three of the young were preserved by Brooks, three by Swarth (nos. 44897-44899).

On July 28 an adult male (no. 44900) was collected at the head of Otter Creek (about 3500 feet altitude). This bird is in the midst of the annual molt. Above and below the old feathers are extremely pale colored. The underparts are almost pure white, the old feathers having lost every vestige of the dusky vermiculations. Such markings show plainly enough on the new breast feathers, just coming in. The stomach held insect remains. The species was observed only on these two occasions.

A notable feature of the shrikes in juvenal plumage is their gray coloration. In the freshly acquired first winter plumage there is a decidedly brown tone both above and below, but, save for the wing markings, none of this appears in the juvenal stage. This plumage is mostly clear gray, slightly darker on the dorsum, and finely vermiculated below.

Through the courtesy of Dr. Louis B. Bishop there are available from his collection 57 specimens of Lanius borealis, about equally divided between eastern and western localities. In this museum there are twenty-six skins, fourteen western and twelve eastern. From the Carnegie Museum, Pittsburgh, I was able to borrow two adult males from the east side of Hudson Bay. These two, with one from Magdalen Island, in the Bishop collection, are the only breeding birds I have seen from eastern localities.

The subspecies invictus (Grinnell, 1900, p. 54), described from the Kowak River, Alaska, was characterized as of larger size, paler coloration dorsally, and with the white markings greater in extent, as compared with eastern birds. I can distinguish a slight average difference in size (see table), and, in some specimens, in the color characters also. 
Certain Alaskan skins are paler colored than any eastern birds, and some have decidedly more extensive white markings (as on the lateral rectrices) than most eastern skins. An exceptional British Columbian specimen has the outer rectrices entirely white. There are Alaskan birds, though, that lie well within the range of variation of eastern birds, and there are one or two eastern birds with white markings on the tail feathers nearly as extensive as in any western ones.

There are a number of winter birds in this series from points lying between the Great Lakes and the Rocky Mountains, and nearly all of these I am unable to allocate to an eastern or a western race with any degree of assurance. Thus, while recognizing in the northern shrike a tendency toward development of the characters ascribed to invictus in the western part of its habitat, it seems to me so impossible to define the boundary between an eastern and a western race, or to identify most winter birds taken south of the breeding range, that I am disinclined to use different names for the variations exhibited.

\section{Vireosylva gilva swainsonii (Baird). Western Warbling Vireo}

A rare species, here probably at the extreme northern limit of its range. First seen June 8 , and from then on, at this one place, a vireo could be seen or heard singing at almost any time during the next few weeks. The indications were that a pair was nesting thereabout. The only other occasion on which the species was seen was on August 17, when one bird was collected by Brooks.

\section{Vermivora celata celata.(Say). Orange-crowned Warbler}

Migrating, not uncommonly, about Atlin, during August. Three specimens were collected (nos. 44901-44903), two females taken August 13, and one male on August 17, all immatures in first winter plumage. Others of this subspecies, easily recognized as a rule by the gray head, were seen until August 31.

\section{Vermivora celata orestera Oberholser}

\section{Rocky Mountain Orange-crowned Warbler}

An "orange-crowned warbler," apparently of this subspecies, was seen at Carcross, May 24. Small numbers were migrating through the Atlin region during the last week in May and first week in June, and a few pairs bred in the lowlands thereabout, where they were seen 


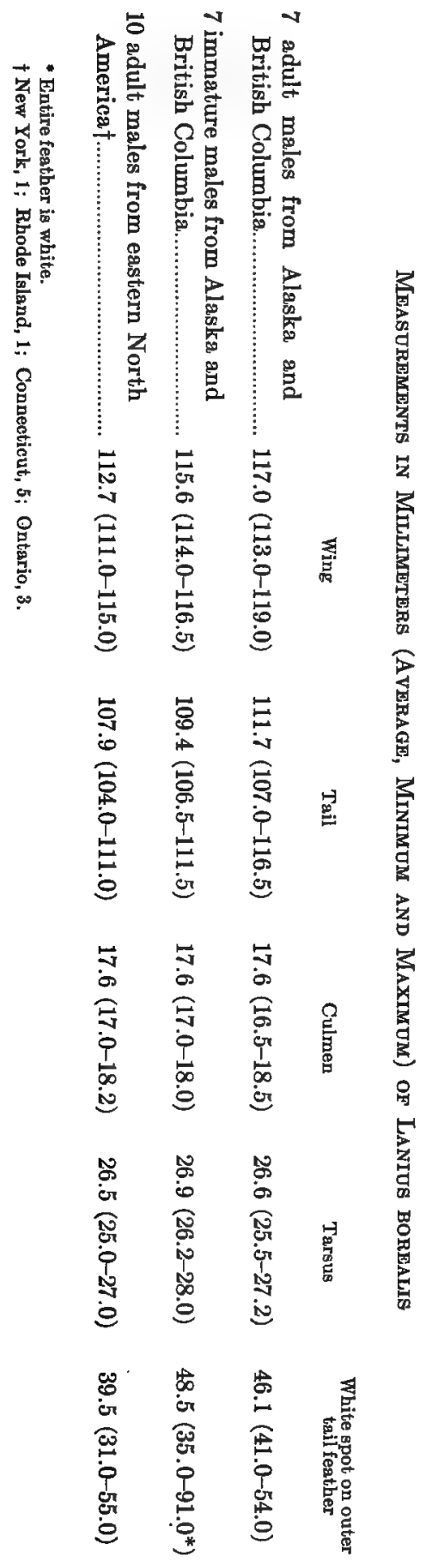


at intervals during the summer. After the middle of August they were more frequently encountered, migrating through the poplar woods in company with other warblers. Last definitely recognized on August 28, though others may have been included with "orangecrowned warblers" seen on August 31.

Nine specimens were collected (nos. 44904-44912), five' breeding adults, three in juvenal plumage, wholly or partly, and one immature female in first winter plumage, taken August 28. A young bird collected August 21 is still mostly in juvenal plumage.

In my opinion orestera is a valid subspecies, and on the basis of the characters ascribed to it by Oberholser (1905, p. 243). It is slightly duller colored than lutescens, much brighter yellow than celata, and of greater size than either. The juvenal plumage of orestera, as shown by young birds from the Atlin region, is gray; juvenal lutescens is yellow.

It will be of interest to ascertain the dividing line between the breeding ranges of celata and orestera in the north. This is something that is as yet but imperfectly understood, and it will be a difficult line to draw. Atlin specimens of orestera are not typical of that subspecies in that they are smaller (or at least shorter winged) than those from more southern points. This may, perhaps, be evidence of intergradation toward celata.

\section{Vermivora peregrina (Wilson). Tennessee Warbler}

Breeds in small numbers in the lowlands of the Atlin region. Three specimens were collected (nos. 44913-44915), an adult male on June 29 and two females on fuly 14, all in poplar woods. The species was not otherwise positively identified.

\section{Dendroica aestiva aestiva (Gmelin). Eastern Yellow Warbler}

Common in the lowlands of the Atlin region, and here, as in most places, showing a predilection for willow copses. First arrival noted May 31, last seen August 26.

Eleven specimens were collected (nos. 44916-44926), three adult males, two adult females, three males and one female in juvenal plumage, male and female in first winter plumage. I refer these birds to the eastern subspecies, Demdronica aestiva aiestiva, as the form they most nearly resemble. Such variation as is exhibited from the average of aestiva is shown in a slight darkening of the dorsum, in which 
respect they approach rubiginosa, of the Alaskan coast. The juvenal plumage is extremely dark, sooty almost, different from that of any other young yellow warblers that I have seen.

\section{Dendroica coronata hooveri MeGregor. Alaska Myrtle Warbler}

Present at Carcross when we arrived, May 22; one was seen there carrying nest material on May 23. About Atlin it is a common species, breeding mostly in the lowlands.

A nest with five fresh eggs (Mus. Vert. Zool. no. 1992) was taken by Brooks on June 15. It was in a slender spruce, one of a small thicket in a locality that is largely poplar grown, about forty feet from the ground and near the top of the tree. It rested on the twigs forming the terminal forks of a branch, about three feet from the trunk. The outer walls of the nest were built mostly of the shredded bark of fire-weed stalks, with a little fire-weed "cotton," some coarse grass and small twigs, and several wing and tail feathers of a small bird. In the lining there was some horse hair, mountain sheep hair and a few soft feathers.

Another nest, containing newly hatched young on June 28, was in a small jack pine in open woods on the shore of Lake Atlin.

During the last week in August and the first week in September the southward exodus was at its height. Flocks of warblers, mostly this species, flitted rapidly through the poplar woods, and there was a constant stream of myrtle warblers making long flights overhead. The last one, a single bird, was seen September 19.

Eight specimens were collected (nos. 44927-44934), one adult female, five in juvenal plumage, and a male and female in first winter plumage.

Dendroica striata (J. R. Forster). Black-poll Warbler

Fairly common but easily overlooked. Only one or two pairs were seen on the mainland, and it was not until the young were hatched that we discovered that the species was nesting in fair abundance on certain islands in Lake Atlin. The birds are inconspicuous, and the call-note is sufficiently like that of the abundant Dendroica coronata to be readily mistaken. The first young, just out of the nest, was seen July 13, and thereafter the species was encountered commonly. Young were molting from juvenal to first winter plumage during the last week in July and first week in August. The young birds lingered until 
this molt was finished, but the adults apparently left as soon as the young could care for themselves. No old bird was seen after August 1, and the last few that were noted were still in breeding plumage. The black-poll warbler was numerous up to August 22; the last was seen on August 27.

The Atlin region may be assumed to be about the southwestern limit of the breeding range of this species, and in view of the abundance of the birds at that point it is of interest to note their scarcity farther south in British Columbia. There are only a few seattered records, all but one during fall migration, the southernmost at Quesnelle. Apparently the black-poll warbler has an east and west route over the Rocky Mountains of northern British Columbia, seldom or never traversing the southern two-thirds of the province.

Eleven specimens were collected (nos. 44935-44945), one adult female, four in juvenal plumage, four in various stages of the postjuvenal molt, and two in first winter plumage.

\section{Dendroica townsendi (J. K. Townsend). Townsend Warbler}

A few pairs were nesting at isolated points in the lowlands, in clumps of tall spruce trees. They remained in the tree tops and would have been overlooked entirely during the breeding season were it not for the singing males. During the second week in August, young birds in completely acquired first winter plumage appeared in the poplar woods, and, while they were never numerous, some were seen daily thereafter during that month. Last noted August 31.

Two specimens were collected, an adult male, June 5 (no. 44946), an immature male, August $14^{\circ}$ (no. 44947).

Seiurus noveboracensis notabilis Ridgway. Grinnell Water-thrush

One was collected by Brooks in the bottom lands of Pine Creek near Atlin, August 21. This was the only one seen.

Geothlypis trichas occidentalis Brewster. Western Yellowthroat

On September $10 \mathrm{I}$ saw several and heard others in the marsh at Fat Creek, six or seven miles southwest from Lake Teslin and just north of the British Columbia-Yukon boundary. On September 13, returning over the same trail, no yellowthroats were seen. Not otherwise observed in the Atlin region, to my surprise, for in September, 
1909, I had found the species on the lower Taku River, Alaska, which drains from the country immediately south of Lake Atlin (see Swarth, 1911, p. 101). Occurrence in migration on the lower reaches of the stream would imply occurrence also toward the head of the river.

\section{Wilsonia pusilla pileolata (Pallas). Pileolated Warbler}

Seen at Carcross on May 22 and subsequently, and, in small numbers, migrating in the Atlin lowlands during the first week in June. Occasional birds were seen near Atlin throughout the summer, and these may have been nesting there, but the breeding ground for the most part, if not entirely, lies above timber line. On the higher ridges, pileolated warblers could always be found in the balsam thickets, where, presumably, the nests were placed.

On August 8, migrating pileolated warblers, with some other smal! birds, were flitting through the bushes on the summit of Spruce Mountain. Throughout August they could be found daily in small numbers in the poplar woods around Atlin. The last one seen was at Lake Teslin, September 12.

Three specimens were collected (nos. 44948-44950), an adult male and two immature males.

\section{Setophaga ruticilla (Linnaeus). American Redstart}

One bird was collected near Atlin by Brooks on June 14, another (no. 44951) by myself on June 17, and several others were seen during June and July. Atlin must be at practically the northwestern limit of distribution of this species.

\section{Anthus rubescens (Tunstall). Pipit}

This species must breed in some parts of the mountains near Atlin, but we saw none until late in the summer. First encountered August 1, on the summit of Spruce Mountain, and seen several times during the next few days. These were mostly birds in juvenal plumage, but strong on the wing. First seen in the lowlands near Atlin on August 26, and frequently observed during the next few weeks. A small flock of pipits was seen from the steamer on Tagish Lake, as I was leaving, September 23.

Two specimens were collected (nos. 44952-44953), both in juvenal plumage, taken on the summit of Spruce Mountain, August 3. 
Sitta canadensis Linnaeus. Red-breasted Nuthatch

A red-breasted nuthatch heard calling in woods near Atlin on June 5 was the only one of the species noted during the nesting season. Next seen (a single bird) on Spruce Mountain, August 1. During the latter part of August the species was migrating through the woods near Atlin in fair abundance. Last seen by me on August 31 , though it may be expected to occur in this region until a much later date.

\section{Penthestes atricapillus septentrionalis (Harris)}

Long-tailed Chickadee

Presumably resident in the region throughout the year, though not abundant. Seen at Carcross during the last week of May, and about Atlin during the whole of my stay, usually in poplar woods. Six specimens were collected (August 16 to 28), all in fresh fall plumage (nos. 44954-44959).

\section{Penthestes gambeli abbreviatus Grinnell}

Short-tailed Mountain Chickadee

A male bird (no. 44960) in breeding condition was shot in spruce woods near Atlin, June 12. Presumably the species nests in this general region, but it was not otherwise observed. This is the northernmost station at which it has been found, Grand Rapids, on the Stikine River, 160 miles to the southward, being the nearest point of record (Swarth, 1922, p. 297).

Penthestes hudsonicus columbianus (Rhoads). Columbian Chickadee

A fairly common species in the Atlin region, more so than the longtailed chickadee. Showed decided preference for spruce woods. Twenty-three specimens were collected (nos. 44961-44983), comprising six breeding adults, six juvenals, and three adults and eight immatures in fresh fall plumage.

The subspecies columbianus, described by Rhoads (1893, p. 23), was included in the 1895 edition of the A. O. U. Check-list, but it was eliminated later (A. O. U. Committee, 1908, p. 355) for reasons that are not known to me. The series of birds above listed, together with others from more southern points in British Columbia (see Swarth, 
1924, p. 368) strongly support the validity of the race. Compared with series of specimens from more northern points in Alaska, assumed to be typical hudsonicus, they exhibit, conclusively as it seems to me, the color characters ascribed to columbianus by Rhoads (loc. cit.) and by Ridgway (1904, p. 414).

Regulus satrapa olivaceus Baird. Western Golden-crowned Kinglet Seen but once, a single bird near Atlin on May 29.

Regulus calendula calendula (Linnaeus). Ruby-crowned Kinglet

Seen at Carcross on May 24. Found in small numbers throughout the lowlands of the Atlin region during the summer and in rather greater abundance after the southward migration began. The first broods of young appeared on July 16. Seen daily during the early part of September, and one bird was seen at Carcross on September 24. Four specimens were collected (nos. 44984-44987).

Myadestes townsendi (Audubon). Townsend Solitaire

Breeds in small numbers about Atlin, mostly on the partly open mountain sides just below timber line. First seen on May 29, the last September 1. One specimen collected, a juvenal male, June 30 (no. 44988).

\section{Hylocichla ustulata swainsoni (Tschudi). Olive-backed Thrush}

Breeds in fair abundance in the poplar and willow woods of the lowlands. Arrived June 4; last seen August 29. Nine specimens were collected (nos. 44989-44997). These, together with others from previous expeditions to the Stikine and Skeena valleys, comprise a series of forty-one specimens of olive-backed thrush from northern British Columbia now in this museum. This series throughout exhibits the grayish dorsal coloration described by Oberholser (1898, p. 304) as the principal character of Hylocichla ustulata almae. I would be inclined to recognize that subspecies were it not for the fact that the same coloration occurs in series from eastern localities, among the more numerous olivaceous-backed birds that are supposed to represent typical swainsoni. The name almae may well rest in abeyance for the time being until a better understanding is reached of the meaning 
of these color variations. However, while these gray-backed birds do occur throughout the east, the extreme olivaceous type of coloration seen commonly in eastern birds is not found in series of breeding birds from the northwest, in British Columbia and Alaska (see Bishop, 1900, p. 119).

\section{Hylocichla guttata guttata (Pallas). Alaska Hermit Thrush}

A fairly common species in the lowlands. Seen at Carcross, May 22, and at Atlin upon our arrival there, May 28. The last bird was seen September 19.

Three nests were found: One, June 13, with three fresh eggs; one June 23, with four fresh eggs; and one July 12, with four fresh eggs. All were on the ground, the first in a clump of small willows at the edge of a muskeg, the second in an opening in mixed poplar and spruce woods, and the third in rather dense poplar woods. It seems noteworthy that this species should be nesting upon the ground here, in view of the fact that on the upper Stikine River, a short distance to the southward, hermit thrush nests were found placed in small spruce trees several feet from the ground (Swarth, 1922, p. 303).

Ten specimens were collected, two breeding adults, one juvenal, three in the post-juvenal molt, and four immatures in fresh fall plumage (nos. 44998-45001, 45003-45008). One or two of the fall birds show slight intergradation toward. pallasii, in the buffier, less grayish flanks, and in dorsal coloration.

\section{Hylocichla guttata pallasii (Cabanis). Eastern Hermit Thrush}

One specimen collected, an immature female on migration, August 23 (no. 45002). This bird is essentially like two others collected by myself in the Skeena Valley (Swarth, 1924, p. 370), and, like those birds, while not as bright reddish as typical pallasiin, it is distinctly nearer to that form than to the darker, gray-flanked guttata, the breeding bird of northern British Columbia.

\section{Planesticus migratorius migratorius (Linnaeus). Eastern Robin}

Present at Carcross, May 22, and at Atlin upon our arrival there a few days later. Last seen August 31. Robins breed in fair abundance in the more open woods in the valleys. They shun the dense spruce woods of the middle altitudes, but are present again in some numbers at timber line, where the scattered balsam thickets supply needed shelter. Many old nests were found in these trees. 
The first young out of the nest was seen June 11. During August robins were gathered in noisy flocks, twenty or thirty together, preparatory to departure for the south.

Four specimens were collected (nos. 45009-45012), one adult male, two in juvenal plumage, and one adult female taken August 16, which had then finished the annual molt.

Ixoreus naevius meruloides (Swainson). Northern Varied Thrush

The varied thrush apparently does not breed in the Atlin region, for it was encountered nowhere during the summer months. First appeared on September 5, when several were seen, evidently migrating southward. A few others were noted, near Atlin and at points between Atlin and Teslin, the last on September 21. One specimen was collected, a female taken September 5 (no. 45013); it is typical of the subspecies meruloides.

Sialia currucoides (Bechstein). Mountain Bluebird

A fairly common species and with a predileotion for human habitations, whether occupied or abandoned. Seen at Carcross, May 22, and at Atlin when we arrived. Young birds were flying about during the second week in July. The bluebirds linger to a later date than most of the summer visitants. I saw a flock of fifteen at Carcross on September 24.

\section{CHECK LIST OF THE MAMMALS}

1. Sorex personatus personatus I. Geoffroy

2. Sorex obscurus obscurus Merriam

3. Neosorex navigator navigator Baird

4. Mustela eicognanii richardsonii Bonaparte

5. Gulo luscus (Linnaeus)

6. Vulpes alascensis abietorum Merriam

7. Canis lestes Merriam

8. Marmota caligata caligata (Eschscholtz)

9. Citellus plesius plesius (Osgood)

10. Eutamias minimus caniceps Osgood

11. Seiurus hudsonicus hudsonicus (Erxleben)

12. Castor canadensis canadensis $\mathrm{Kuhl}$

13. Peromyscus maniculatus borealis Mearns

14. Neotoma cinerea saxamans Osgood

15. Synaptomys borealis dalli Merriam

16. Microtus drummondii (Audubon and Bachman)

17. Microtus mordax mordax (Merriam)

18. Ondatra zibethica spatulata (Osgood)

19. Erethizon epixanthum nigrescens Allen

20. Lepus americanus macfarlani Merriam

21. Alces gigas Miller 


\section{GENERAL ACCOUNTS OF THE MAMMALS}

The collection of mammals was inadequate and disappointing. I had not as much time to give to this work as would have been desirable, but, nevertheless, assiduous trapping in a variety of surroundings was so uniformly unsuccessful that failure could hardly have been due to any cause other than the actual scarcity of most of the smaller mammals. As an instance in point, trapping was carried on for a week at a place where lemmings were known to have been abundant at the same season in previous years, but not one was caught. At several places extensive systems of runways were trapped over for days and weeks with but an occasional mouse as a result. Another year might find small rodents swarming over the same region.

It was a question just what might be included in the following list ; as it stands it comprises the species that were personally encountered and specifically identified. Bats were seen on several occasions but not collected. Atlin is in the center of a region that supports a large amount of big game (sheep, caribou, mountain goat, and bear) of species that I either did not encounter at all or so casually as not to be worth reporting. Similarly, there are fur bearers throughout the region regarding which I learned nothing. I saw skins of flying squirrels killed near Atlin, and there are doubtless yet other species still to be included in any comprehensive account of the mammals of this section.

\section{Sorex personatus personatus I. Geoffroy. Masked Shrew}

Five specimens collected (nos. 34389-34393), one from Surprise Lake (3200 feet altitude), three from the head of Otter Creek ( 4000 feet altitude), and one from Atlin.

\section{Sorex obscurus obscurus Merriam. Dusky Shrew}

Two specimens collected (nos. 34394-34395), from near the summit of Spruce Mountain (4500 feet altitude), on August 1.

\section{Neosorex navigator navigator Baird. Water Shrew}

A water shrew, presumably of this form, was seen at the head of Otter Creek (4000 feet altitude), July 30. It was at mid-day, and the little animal was ascending a small stream, sometimes swimming in the pools, then running through the shallows. It dived when it saw me and did not appear again. 
Mustela cicognanii richardsonii Bonaparte. Richardson Weasel

Encountered but once during the summer, on July 14, when one was seen. It was enduring the attack of a number of Gambel sparrows that were protesting at the weasel's being abroad during the day.

\section{Gulo luscus (Linnaeus). Wolverene}

I obtained from a trapper at Carcross the skull of a female wolverene (no. 34396) trapped by him some sixty miles west of Carcross, during the winter of 1923-24.

\section{Vulpes alascensis abietorum Merriam. British Columbia Red Fox}

The collection includes a red fox skull, picked up on the summit of Spruce Mountain. The species was not otherwise encountered in a wild state. "Silver fox" farming is an established industry in this section, and both at Carcross and at Atlin there are successful fox farms.

\section{Canis lestes Merriam. Northern Coyote}

The northern extension of the range of the coyote into this region seems to have taken place in relatively recent years, according to local report, but however that may be the species now occurs in some numbers at least as far north as southern Yukon Territory.

On August 3, five coyotes, apparently a family, were encountered on the summit of Spruce Mountain, above timber line (at about 5000 feet altitude), and two half-grown young ones (nos. 34397-34398) were shot. After my return to Berkeley I received skin and skull of an adult male coyote (no. 34992) trapped at Grouse Creek, Yukon Territory (just north of the British Columbia boundary, on the trail to Teslin), January 10, 1925, and of an adult female (no. 36469) trapped at Teslin, January 15, 1926.

In a letter received from Mr. A. B. Taylor, government telegraph operator at Atlin, and an accurate observer of animal life, under date of November 5, 1925, he states: "The country is overrun with coyotes, and they have pretty well cleaned out the rabbits and grouse. They come quite close to town and set up a howling that starts all the dogs, especially in the early morning, just before dawn. After the lake freezes there will be some sport chasing them in automobiles. One man got eight last winter in that way." 
Marmota caligata caligata (Eschscholtz). Hoary Marmot

A few were seen on various mountains not far from Atlin. The species is apparently of general distribution, though not numerous, above timber line (about 3500 feet) throughout the region. One specimen (no. 34276), an adult male, was collected by Brooks near Log Cabin (White Pass), on September 1.

\section{Citellus plesius plesius (Osgood). Bennett Ground Squirrel}

Extremely abundant about Carcross. The grounds of the "Gopher Golf Club," on the outskirts of the town, supported a large population of the squirrels, as is suggested by the club's name, and we saw them elsewhere wherever we walked. The light sandy soil and open woods seem to form a favorable set of conditions for the species.

In the immediate vicinity of Atlin I saw no ground squirrels, but there were small colonies at certain points in the lowlands within a few miles of town. Above timber line on the nearby mountains they were present everywhere, in some places in great numbers. Along Otter Creek, ground squirrels fairly swarmed, the whole length of the valley and on the surrounding mountains. Between Surprise Lake and Teslin I saw none. Just what the important factors are that determine the local distribution of the species in this region could not be ascertained with certainty, but in general the ground squirrels favored open country.

The small colonies near Atlin were in open woods, and there were miles of similar woods where none was seen. Along Otter Creek they were numerous over ground that was densely grown with willow thickets. None was seen at any time, however, in even fairly dense woods of large conifers.

On August 24 ground squirrels were abundant and active on the summit of Monarch Mountain. On September 5, at the same place, none was seen. As this was a cold, stormy day, however, their disappearance may have been but temporary and due to the weather at that time.

Five specimens were preserved (nos. 34399-34403), one from Carcross, May 22, two from Spruce Mountain, July 31 and August 3, respectively, and two from Monarch Mountain, August 24. 


\section{Eutamias minimus caniceps Osgood. Gray-headed Chipmunk}

Nine specimens collected (nos. 34410-34418), all adult. Chipmunks were seen about Carcross, and they were fairly common in the lowlands of the Atlin region. In the town they came familiarly about barns and in the gardens.

\section{Sciurus hudsonicus hudsonicus (Erxleben) Northern Red Squirrel}

Six specimens collected (nos. 34404-34409), all adults that are entirely or mostly in summer pelage. In this small series there is rather notable variation from grayish to reddish extremes; the reddish specimens may be taken to illustrate intergradation by individual variation toward S. h. petulans of the nearby Alaskan coast.

Red squirrels are fairly common and of general distribution throughout the wooded parts of the region.

\section{Castor canadensis canadensis Kuhl. Beaver}

Beaver have little chance of survival anywhere near human habitations unless accorded rigid protection, and throughout such parts of the Atlin region as we visited trapping had reduced their numbers to the vanishing point. On the evening of September $9 \mathrm{I}$ spent an hour or more watching a pair of beavers in a pond a few miles north of the British Columbia-Yukon boundary, on the trail to Lake Teslin. They were then actively engaged in laying away winter stores, in the shape of willow cuttings, and trip after trip, with monotonous regularity, was made by the laboring animals, across the pond to the growing willows, and back to the house again, where entrance was effected by diving.

\section{Peromyscus maniculatus borealis Mearns}

Northern White-footed Mouse

Thirteen specimens were collected (nos. 34419-34431), twelve from the vicinity of Atlin, and one from lower Otter Creek. White-footed mice were about as scarce as the other small rodents of the region, and even this small series was acquired, usually one specimen at a time, at long intervals through the summer. 
Neotoma cinerea saxamans Osgood. Northern Bushy-tailed Wood Rat

Three specimens collected (nos. 34432-34434), one at Atlin and two at our camp on lower Otter Creek. In this region, as elsewhere in the northwest, the wood rat is more or less of a pest, invading cabins and destroying or carrying away almost anything that can be moved. We saw slight trace of the presence of this species, however, and it seems likely that the wood rats had suffered temporary reduction of numbers together with other small rodents.

\section{Synaptomys borealis dalli Merriam. Dall Lemming Mouse}

One specimen (no. 34435), a young male, was trapped on upper Otter Creek (3800 feet altitude), on July 30. The species was not otherwise encountered.

\section{Microtus drummondii (Audubon and Bachman)}

Drummond Meadow Mouse

Fourteen specimens were preserved (nos. 34436-34449), thirteen from the vicinity of Atlin and one from the summit of Spruce Mountain (5000 feet altitude). They were rare, one specimen in two or three nights being the most to be hoped for in a line of twenty-five or thirty traps.

Microtus mordax mordax (Merriam). Cantankerous Meadow Mouse

Nine specimens were collected (nos. 34450-34458), four from Atlin, four from Otter Creek ( 3000 to 4000 feet altitude), and one from near the summit of Spruce Mountain (5000 feet altitude). These nine specimens represent approximately the result of eighty traps set out for two weeks. Not that just that number of traps was set for exactly that number of days at any one period, but that would be about the sum total from traps placed where Microtus should have been trapped. Two pregnant females contained three and four embryos, respectively. In an extensive series from the upper Stikine River, trapped when the animals were abundant, the number of embryos was usually five. or six.

\section{Ondatra zibethica spatulata (Osgood). Northwestern Muskrat}

Muskrats were seen at various times in ponds at the edge of the town of Atlin, and elsewhere in suitable places east to Lake Teslin. The species is abundant throughout this whole region. 
Erethizon epixanthum nígrescens Allen. Dusky Porcupine

A porcupine killed while it was invading the garden at the mounted police post at Nisuttlin Bay, Teslin Lake, on September 11, was the only one seen all summer.

Lepus americanus macfarlani Merriam. Mackenzie Varying Hare

Abundant everywhere in the lowlands. In crossing White Pass, May 21, we saw rabbits from the train when we had descended on the east slope as far as the upper edge of timber. At Carcross they were seen daily during our short stay, as they were also in the woods near Atlin throughout the summer. Stands of young poplars and sometimes of young jack-pine were attacked and girdled by the rabbits on such a scale that over areas acres in extent well nigh every tree would be killed. Larger trees, too, were sufferers to some extent (see pl. 8). Where trees had been chopped down and the smaller branches left piled to one side, these brush piles were invariably browsed upon by rabbits until nearly every vestige of bark was removed.

Five specimens were collected (nos. 34459-34463). An adult male shot July 10 still has white feet and white margined ears. In an adult female taken August 22 the feet are buffy and there is no white on the ears. An adult male shot September 21 has both front and hind legs white and the ears are mostly white.

These animals, all in summer pelage, are notably more grayish colored, less reddish, than varying hares from the upper Skeena Valley, which I have elsewhere (Swarth, 1924, p. 384) referred to the subspecies L. a. columbiensis.

\section{Alces gigas Miller. Alaska Moose}

Abundant throughout the region. Fresh tracks were seen constantly within a few miles of the town of Atlin, both in the lowlands and well up on the mountain slopes. On the shores of Lake Teslin I saw certain favorad spots where the muddy banks were trodden like cattle yards. That but few of the animals were seen by us through the summer was largely due, of course, to the fact that, not hunting for them, we made no effort to avoid noises and actions that would alarm them; nevertheless, they showed wariness and ability in keeping out of sight. In a country similarly populated with deer many more of those animals would have been encountered. 


\section{LITERATURE CITED}

\section{American Ornithologists' Union Committee}

1908. Fourteenth supplement to the American Ornithologists' Union checklist of North American birds. Auk, 25, 343-399.

1910. Check-list of North American birds (ed. 3, revised; New York, American Ornithologists' Union), 430 pp., 2 maps.

ANDERson, E. M.

1915. Birds collected and observed in the Atlin district, 1914. Report of the Provineial Museum of Natural History for the year 1914 (Victoria, British Columbia), pp. 8-17.

AUdubon, J. J.

1830. The birds of America (London, published by the author), 1, pls. $1-100$.

Bailey, B. H.

1916. Krider's hawk (Buteo borealis krideri) in Alaska. Auk, 33, 321.

BAIRD, S. F. ("with the coöperation of"' CASSIN, J., AND LAWRENCE, G. N.)

1858. Birds. Pacific Railroad Reports, 9, lvi + 1005 pp.

Baird, S. F., Brewer, T. M., AND Rideway, R.

1874. A history of North American birds. Land birds (Little, Brown and Bent, A. C. Co., Boston), 3, 560 + xxviii pp., pls. 57-64, many figs in text.

1921. Life histories of North American gulls and terns, order Longipennes. U. S. Nat. Mus. Bull,, 113, $x+345$ pp., 93 pls.

Beyer, G. E., Allison, A., ANd Korman, H. H.

1908. List of the birds of Lotisiana. Part v. Auk, 25, 439-448.

BISHOP, L. B.

1900a. Birds of the Yukon region, with notes on other species. U. S. Dept. Agr., Biol. Surv., N. Am. Fauna, 19, 47-96.

1900b. Descriptions of three new birds from Alaska. Auk, 17, 113-120.

BREWER, T. M.

1878. Nest and eggs of Zonotrichia coronata. Bull. Nuttall Ornith. Club, 3, $42-43$.

BREW STER, W.

1890. A new subspecies of the solitary sandpiper. Auk, 7, 377-379.

Brooks, A.

1912. Some British Columbia records. Auk, 29, 252-253.

1926. The display of Richardson's grouse, with some notes on the species and subspecies of the genus Dendragapus. Auk, 43, 281-287, pls. 10-11. 
Clark, A. H.

1910. The birds collected and observed during the eruise of the United States Fisheries Steamer "Albatross" in the North Pacific Ocean, and in Bering, Okhotsk, Japan, and eastern seas, from April to

Cours, E. December, 1906. Proc. U. S. Nat. Mus., 38, 25-74.

1880. "Behind the veil." Bull. Nuttall Ornith. Club, 5, 193-204.

Dickey, D. R., AND van Rossem, A. J.

1923. Deseription of a new grouse from southern California. Condor, 25, 168-169.

DWIGHT, J., JR.

1900. The moult of the North American Tetraonidae (quails, partridges and grouse). Auk, 17, 34-51, 143-166, pls. 4-5.

GMeLiN, J. F., ED.

1788-1789. Linné. Systema naturae per regna tria naturae, secundum elasses, ordines, genera, species, cum characteribus, differentiis, synonymis, locis (cura Jo. Frid. Gmelin, Lipsiae, Beer), 1, $[\mathrm{x}]+$

GrinNelt, J. $1032 \mathrm{pp}$.

1900. Birds of the Kotzebue Sound region, Alaska. Pacifie Coast Avifauna, 1, $80 \mathrm{pp}$., $1 \mathrm{pl}$. (map).

1910. Birds of the 1908 Alexander Alaska expedition, with a note on the avifaunal relationships of the Prince William Sound district.

HARTERT, E. Univ. Calif. Publ. Zool., 5, 361-428, pls. 33-34, 9 figs. in text.

1921. Die vögel der paläarktischen fauna (Berlin), 3, 1765-1892.

HEERMANN, A. L.

1859. Report upon the birds collected on the survey. Pacifie Railroad Reports, 10, part 4, pp. 29-80, 7 pls.

HOFFMANN, $\mathbf{R}$.

1924. Notes on the flight performance of the Wilson snipe. Condor, 26, $175-176$.

Kermode, F., AND ANDERSON, E. M.

1914. Report on birds collected and observed during September, 1913, on Atlin Lake, from Atlin to south end of the lake. Report of the Provincial Museum of Natural History for the year 1913 (Victoria, British Columbia), pp. 19-21.

OBERHOLSER, H. C.

1898. Description of a new North American thrush. Auk, 15, 303-306.

1905. The forms of Vermivora celata (Say). Auk, 22, 242-247.

OsGood, W. H.

1900. Results of a biological reconnoissance of the Yukon River region. General account of the region. U. S. Dept. Agr., Biol. Surv., N. Am. Fauna, 19, 7-20, pls. 2-3.

1904. A biological reconnaissance of the base of the Alaska Peninsula. U. S. Dept. Agr., Biol. Surv., N. Am. Fauna, 28, 285 pp., 8 pls. 
RHOADS, S. N.

1893. Notes on certain Washington and British Columbia birds. Auk, 10, 16-24.

RIDGWAX, $\mathbf{R}$.

1904. The birds of North and Middle America. U. S. Nat. Mus. Bull., 50, Part III, xx +801 pp., 19 pls.

1912. Color standards and color nomenelature (Washington, D. C.; published by the author), $3+44$ pp., 53 pls.

1919. The birds of North and Middle America. U. S. Nat. Mus. Bull., 50, Part VIII, xvi +852 pp., 33 pls.

RILEy, J. H.

1911. Deseriptions of three new birds from Canada. Proc. Biol. Soc. Wash., 24, 233-236.

1912. Birds collected or observed on the expedition of the Alpine Club of Canada to Jasper Park, Yellowhead Pass, and Mount Robson region. Canadian Alpine Journal, special number, pp. 47-75, pls. 1-2.

Sharpe, R. B.

1874. Catalogue of the Accipitres, or diurnal birds of prey, in the collection of the British Museum. Catalogue of Birds, 1, xiii +480 pp., 14 pls., many text figs.

STEJNGGER, L.

1885. Results of ornithological explorations in the Commander Islands and in Kamtschatka. U. S. Nat. Mus. Bull., 29, 382 pp., 8 pls., several text figs.

SWARTH, H. S.

1911. Birds and mammals of the 1909 Alexander Alaska expedition. Univ. Calif. Publ. Zool., 7, 9-172, pls. 1-6.

1920. Revision of the avian genus Passerella, with special reference to the distribution and migration of the races in California. Univ. Calif. Publ. Zool., 21, 75-224, pls. 4-7, 30 text figs.

1922. Birds and mammals of the Stikine River region of northern British Columbia and southeastern Alaska. Univ. Calif. Publ. Zool., 24, 125-314, pl. 8, 34 text figs.

1924. Birds and mammals of the Skeena River region of northern British Columbia. Univ. Calif. Publ. Zool., 24, 315-394, pls. 9-11, 1 text fig.

Swarti, H. S., AND Brooks, A.

1925. The timberline sparrow, a new species from northwestern Canada. Condor, 27, 67-69.

TAVERNER, P. A.

1914. A new subspecies of Dendragapus (Dendragapus obscurus flemingi) from southern Yukon Territory. Auk, 31, 385-388. 
1916. Preliminary list of specimens taken by C. H. Young and William Spreadborough, at Brackendale, Lillooet, and MeGillivray Creek, British Columbia, between June 11 and September 12, 1916. Summary Report, Geol. Surv., Dept. of Mines, Ottawa, pp. 359-368.

1918. Trinomials and current practice. Condor, 20, 213-216.

ThaYer, J. E., AND Bangs, 0 .

1914. Notes on the birds and mammals of the Arctic coast of east Siberia. Birds. Proc. New England Zool. Club, 5, 3-48.

\section{VAN ROSSEM, A. J.}

1925. Flight feathers as age indicators in Dendragapus. Ibis, ser. 12, no. 2, pp. 417-422, text figs. 10-12. 


\section{PLATE 5}

Fig. 2. Islands in Lake Atlin opposite the town. These islands are clothed with balsam fir, which does not grow on the adjacent mainland at this level. They are much more densely populated with small land birds than is the mainland, and several species of water birds nest there also. Photo taken September 6, 1924.

Fig. 3. "Blue Cañon," at about 4000 feet elevation on upper Spruce Creek; a scene of former mining activities. The valley and lower mountain slopes here shown are typical of the habitat of the willow ptarmigan in this region. The rock and white-tailed ptarmigans inhabit the higher ridges. Photo taken September 1, 1924. 


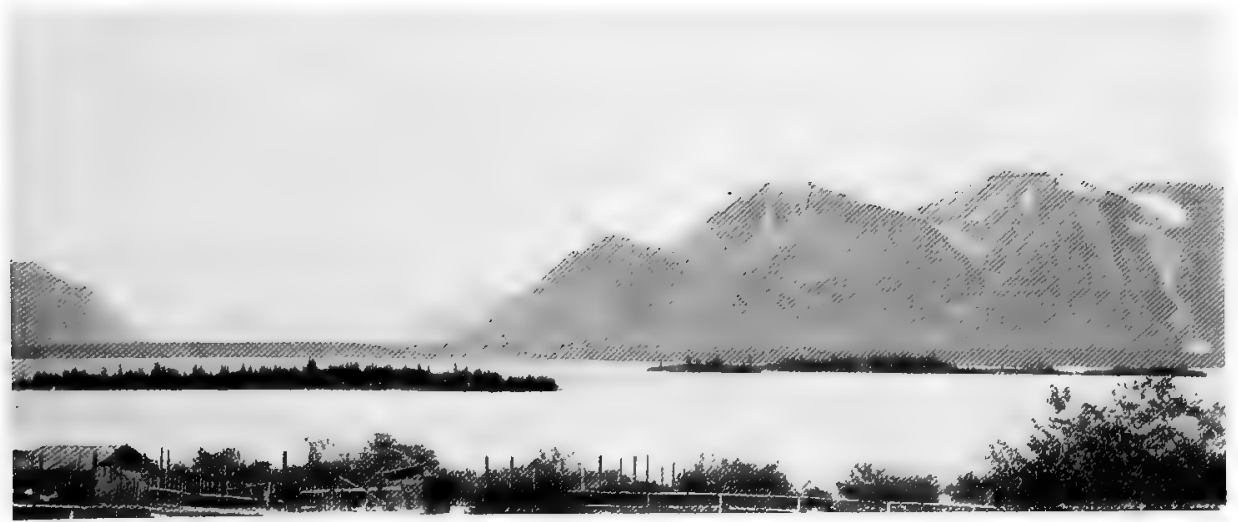

Fig. 2

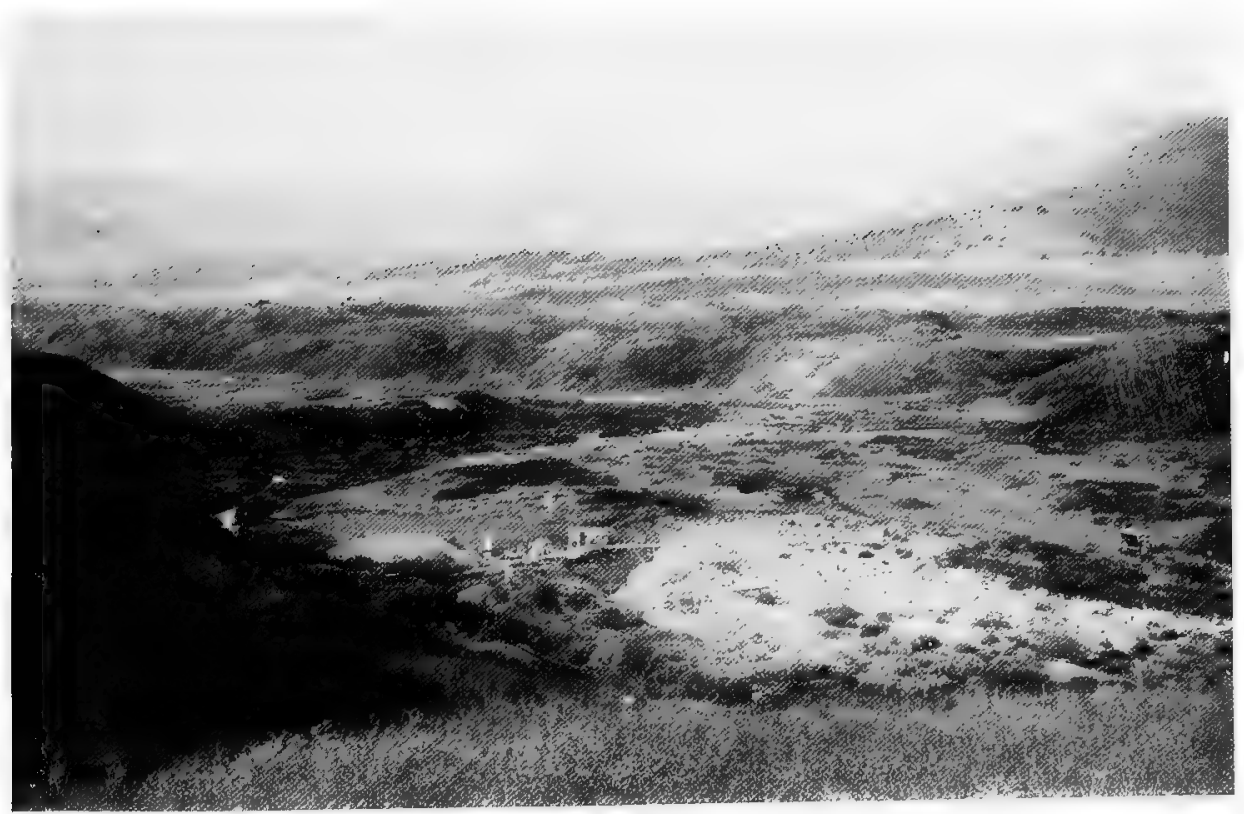

Fig. 3. 




\section{PLATE 6}

Fig. 4. Lake at the head of Cañon Creek, about 4000 feet altitude, near Atlin. Willow ptarmigan nested abundantly here, Fleming grouse were in the timber on the adjacent slopes, western tree sparrows were present in great numbers in the bushes about the lake, a brood of northern shrikes was found in the fir trees on the left, and families of eared grebes and Barrow golden-eyes were swimming about the lake. Photo taken July 18, 1924.

Fig. 5. North-facing slope of Monareh Mountain, near Atlin. The summit is at about 5000 feet altitude, the base, about 2500 feet. The recent snowfall, conspicuous on the timberless summit, indicates the upper limit of forest trees on the mountain. Photo taken September 22, 1924. 


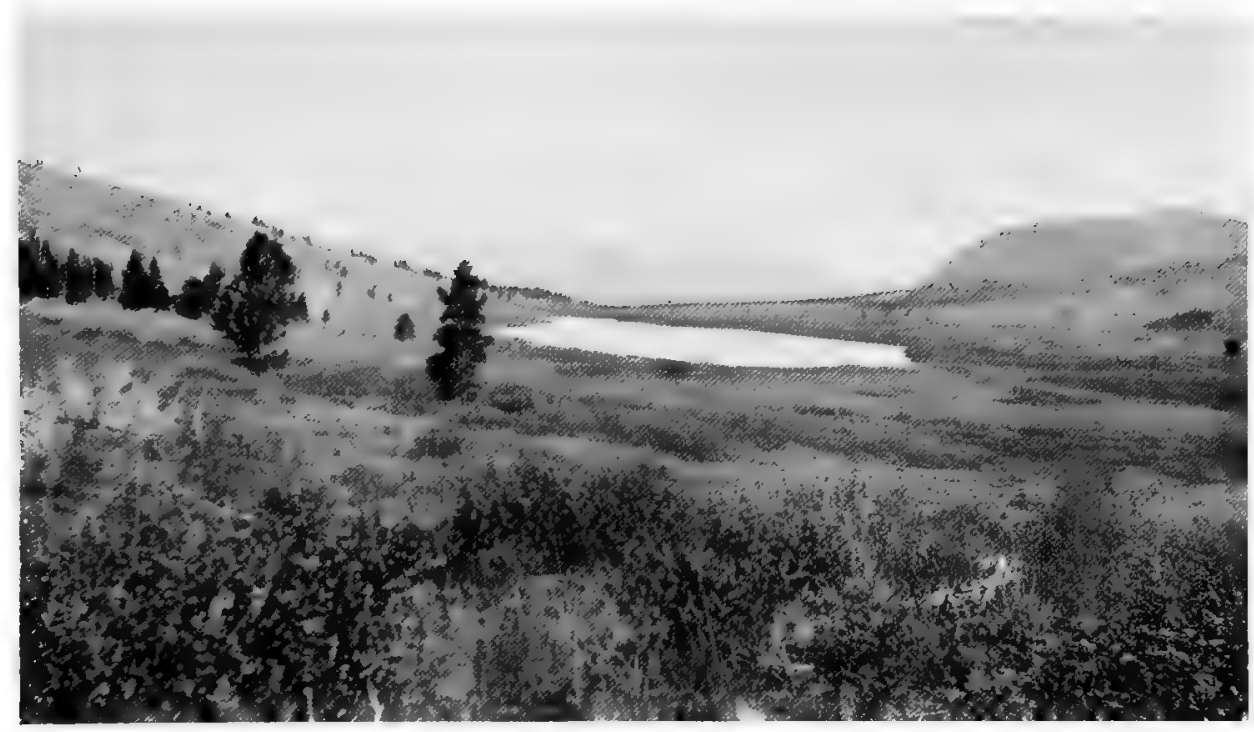

Fig. 4

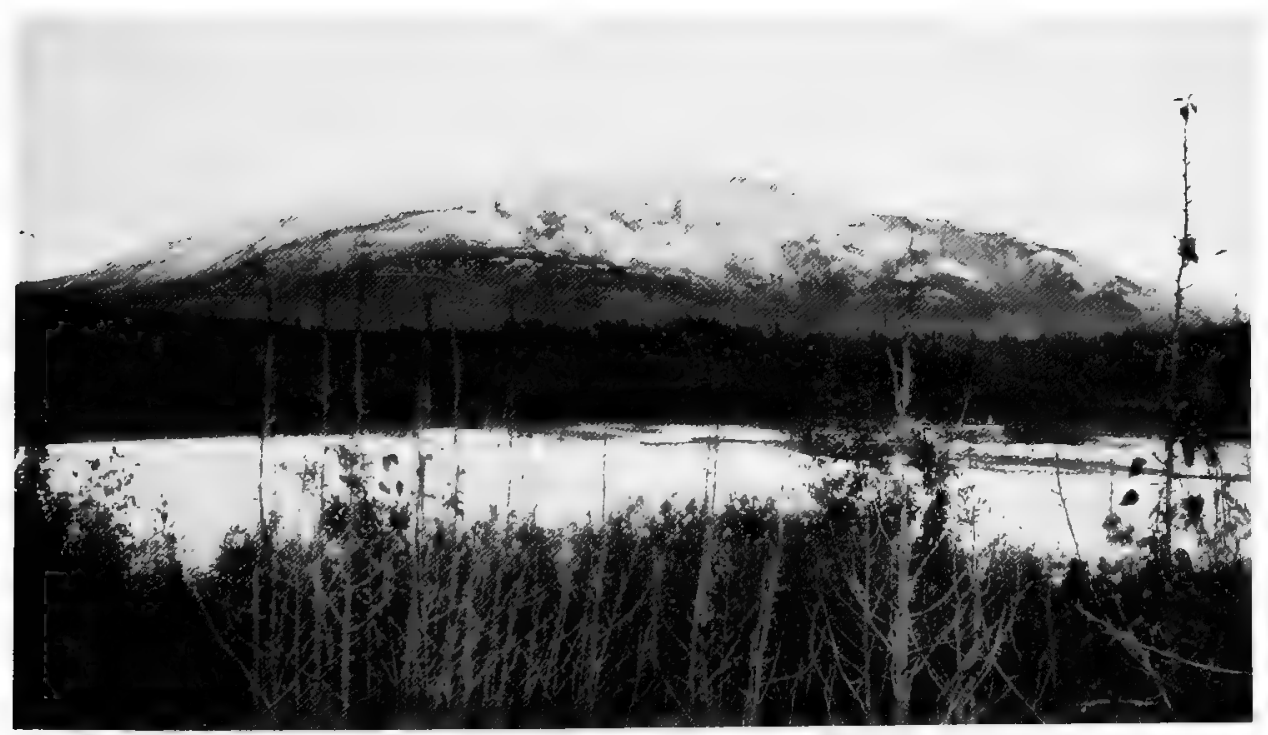

Fig. 5 . 




\section{PLATE 7}

Fig. 6. Nest site of golden-crowned sparrow, on the summit of Monarch Mountain. The nest was on the ground in the brush (trailing birch) at the left of the thicket of balsam. The balsam trees shown are about ten feet high. Photo taken June 22, 1924.

Fig. 7. Nest of golden-erowned sparrow, on the ground, in grass, under a tangle of trailing birch. Photo taken June 22, 1924. 


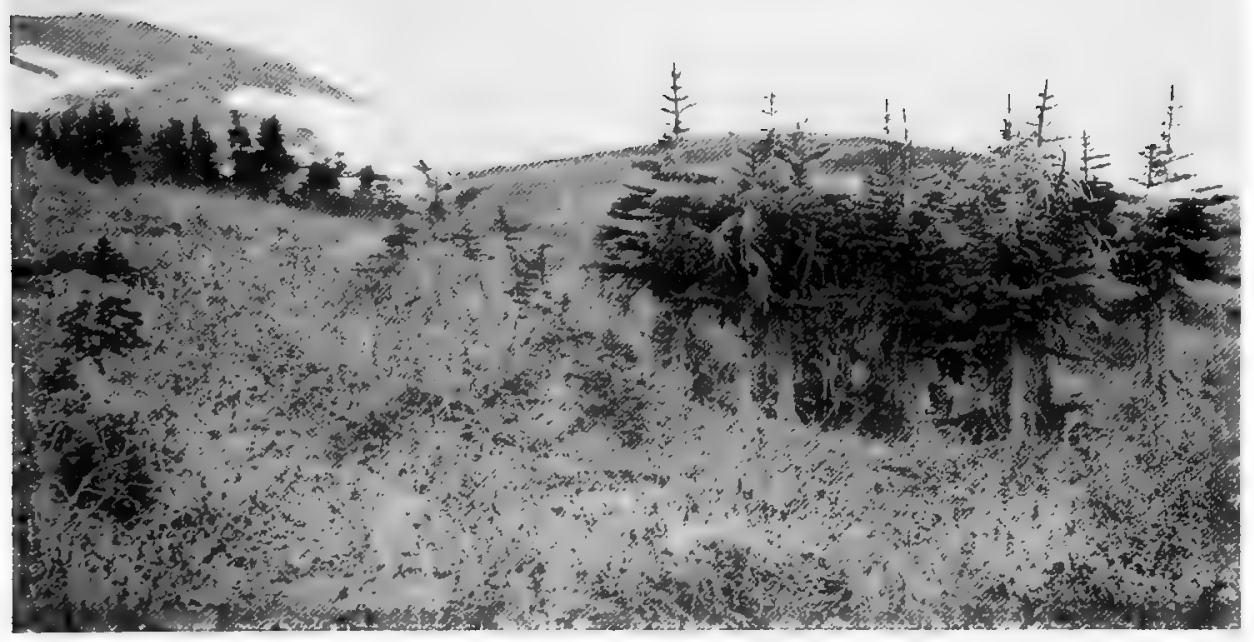

Fig. 6

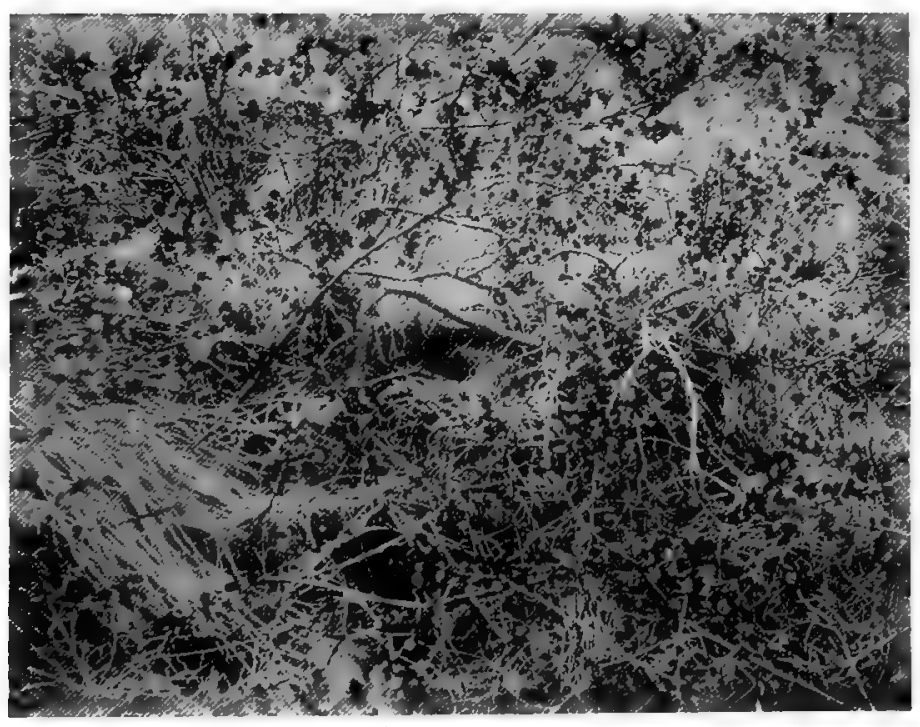

Fig. 7 




\section{PLATE 8}

"Poplars"' (quaking aspen) girdled by rabbits, a common sight in the woods when these animals are abundant. The largest trees shown are four or five inches in diameter. The highest points gnawed by the animals, some three or four feet. above the ground, were reached in winter when snow lay deep about the trees. Photo taken June 6, 1924. 


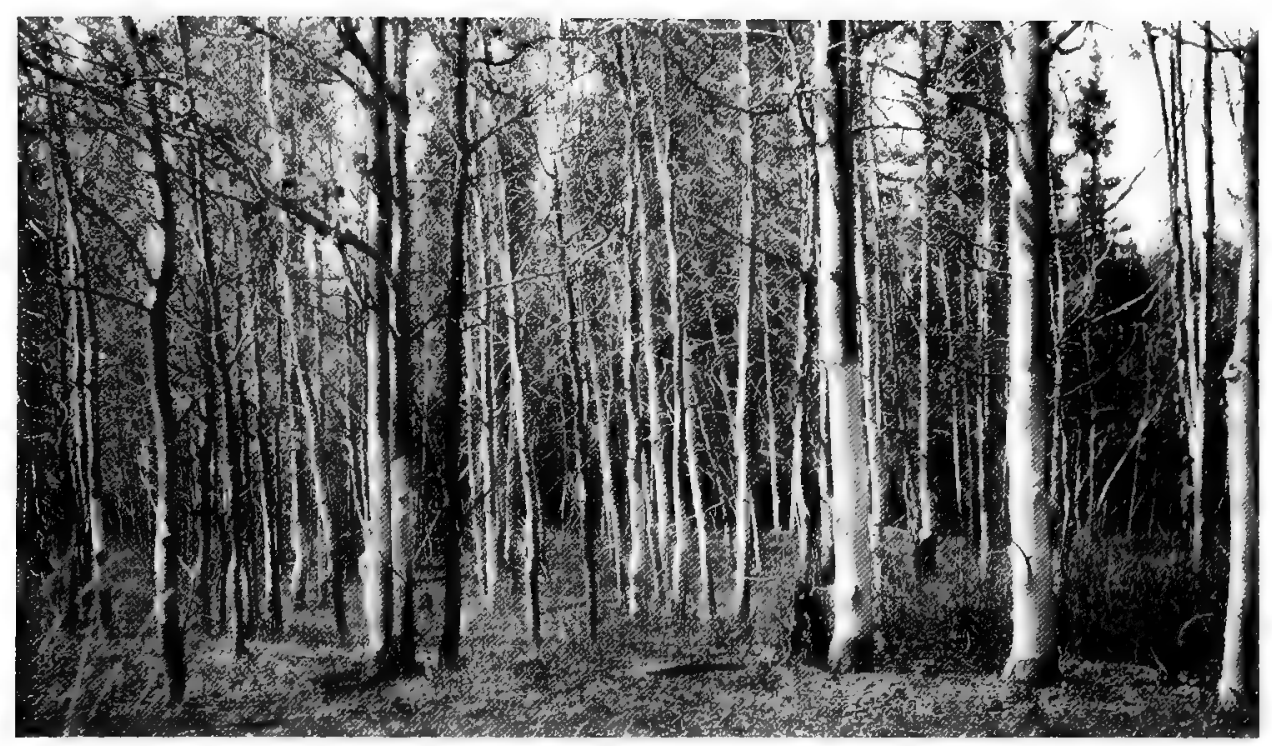







\section{UNIVERSTIY OF OALIFORNLA PUBLIOATIONS-(Continned)}

13. Bevigion of the Genus Lynx in Callfornia, by Joseph Grinnell and Joseph Dixon. Pp. 339-354, plate 11, 1 figure in text. January, 1924

14. Changes during Growth in the \$kull of the Eodent Otospermophilus gram murus beecheyi, by E. Raymond Hall, Pp. 355-404, 43 figures in text. March, 1926

15. A New Bace of the White-breasted Nuthatch from Irower Califormia, by Joseph Grinnell. Pp. 405-410. March, 1926

16. Two New Races of the Pine Marten from the Pacifle Coast of North America, by Joseph Grinnell and Joseph Diron, Pp. 411-417, 9 figures In text. March, 1926

17. The Trout of the Biexra San Pedro Martir, Lower Callforna, by John Otterbein Snyder. Pp. 419-426. March, 1926

18. Systematic Review of the Paclfic Coast Brown Towhees, by Joseph Grinnell and Harry S. Swarth. P.p. 427-433,2 figures in text. April, 1926 ...........

Volume 22. 1920-1923, 485 pages, with 24, plates

Vol. 93. The Marino Decapod Orustacea of Callfornia, by Waldo I. פchmitt. Pp. $1-470$, plates 1-60, 165 figures in text. May, 1921

Vol 24 1. A Geographical Stzdy of the Kangaroo Rats of Callfornitu, by Joseph Grinnell. Pp. 1-124, plated 1-7, 24 figures in text. June, 1922

2. Btrds and Mammals of the Stikine River Region of Northern Britioh Columbia and Bouthewstern Alaska, by H. S. Swarth. Pp. 125-314, plate 8, 34 flgures in text. June, 1922

3. Birds and Mammals of the Skeena Blver Reglon of Northern Britlsh Columbia, by Harry 8. Swarth. Pp. 315-394, plates 19-11, 1 figure in text. January, 1924

4. Report on a Collection of Birds Made by J. R. Pemberton in Patagonia, by Alexander Wetmore. Pp. 395-474, plates 12-14, 11 figures in text. April, 1926

Vol 25. A Btbllography of Eugentcs, by Samael J. Holmes. Pp. 1-514. January, 1924 Volume 26, 1925-1925, 453 pages, 34 plater

Vol 27. A 8ypopsts of the Amphibia of California, by Tracy I Itorer. Pp. 1-342, plates 1-18, 42 figures in text. June, 1925

Vol 283. 1. Mitochondrta and Golg1 Bodies in Bndampeba gingivalio (Cros) Brumpt, by Darid Oausey. Pp. 1-18, plated 1-3.

2. Mitochondria in Loichmania brantionsis, by Darld Oaneeg. Pp. 12-28, plate 4.

Nos. 1 and 2 in one cover. Notember, 1925

8. Mitosis in Ceratiuminiridinella O. F. Me, with Notes on Nucloar Phenomena in Encysted Forms and the Question of sexrual Reproduction, by Richard Pa Hall. Pp. 29-64, plates 5-9, 5 figures in tert. TNovember, 1825.

1. The Cuitivation of Indamoeba gingivalis (Gros), by Bestrice Fay Howith Pp. 65-126, plates 10-12, 4 figures in text. November, 1925

5. The Behavior of Eindamocba dysenterias in Malred Oultures with Bactectis, by Oharles A. Kofodd and Edns Hannibal Wagener. Pp. 127-154, plates 13-15.

6. Btudies of the Effects of Certain Drugs upon Endamabba dysenteriae in vitro, by Charles A. Kofold and Edna Hannibal Wagener. Pp. 155-166. Nos. 5 and 6 in one cover. NTovember, 1925

7. Bome New and some Previously Unreported Hydroids, Mainly from the Oallfornian Coast, by O. McLean Fraver. Pp. 167-172, 7 flgures in teaxt. December, 1925

8. The Effoct or Certain Drugs and Dyes upon the Growth of Endamoeba gingivalie (Gros) in vitro, by Beatrice Fay Howltt. Pp. 173-182.

9. Expertments with Fndamoeba gingivalis (Gros) in Mixed. Bactertal Cultures; in Futered Saliva; on a Solld Baso; and with Peritoneal Cells; and whth Digestive Secretions, by Beatrice Fay Howitt. Pp. 189-202, plates 16 and 17

Nos, 8 and 8 in one cover. February, 1828

10. On Oxyphysis oxytoxoides gen nov., sp. nov., A Dinophysodd Dinollagellate Convergent toward the Perldiniold Type, by Charles A. Kofold Pp. 208-216, plate 19. " February, 1926

11. Mitochondria in Eriglena graoilis Klobs, by Davld Causey. Pp. 217-224, plater 19-20.

12. Mitochondria in Noctileca sointillans (Macartney, 18i0), by Davld Carseg. Pp. 225-230, plato 21 . 
18. Mitochondria in Cillates with Especlal Reference to Paramecium Zhr. by David Causey. Pp. 231-250, plates 22-24.

Nos. 11, 12, and 18 in one cover. February, 1926

14. Etudies on the Ingestion of Ireucocytes, and on Mitosts, in Endamoeba gingivalis, by Horace J. Child. Pp. 251-284, plates 25-29, 9 figs in text. Fobruary, 1926

15. On Oxymonas, a Flagellate whth an Extensile and Retractile Proboscla, from Kalotermes from British Cuiana, by Charles A. Kofold and Olive Swezy. Pp. 285-S00, plate 30, 5 flgures in text

16. On Proboscidiella multimucleata gen. nov., sp. nov., from Planocryptotermes nocens From the Phillppine Islands, by Charles A. Kofold and OLve Bweay. Pp. 301-316, plates $\$ 1,32,4$ figures in text

Nos. 15 and 16 in one cover. February, 1926

17. On the Cestode Genus Dipylidium from Cats and Dogs, by Theresa Marte Mallzner. Pp. 317-356, plates 33-39. Pebruary, 1926

18. A Useful Modifcation of a Clearing Fludd Formulated by Bpaltehols, by Franklin P. Reagan. Pp. 357-350.

19. The Earlieat Blood Vessels of the Mammalian Embryo, Studied by Means of the Injection Method, by Franklin P. Reagan. Pp. 361-364.

Nos. 18 and 19 in one cover. February, 1926

20. The Blological Relationships of Leishmania and Certain Herpetomonads, by Edna Hannibal Wagener and Dorothy Ann Koch. Pp. 365-388, plates 40-43. March, 1926

21. Notes on Termites from Arizona with Descriptions of Two New Specles, by Thomas E. Snyder. Pp. 389-397, 6 figures in text. Aprll, 1926 .......

22. Copelata from the San Diego Begion, by Christine E. Essenberg. Pp. 899-521, 170 figures in text.

23. Observations on Gradual Disintegration and Death of Copelaten by Chris. tine E. Essenberg. Pp. 583-525.

Nos. 22 and 28 in one cover. May, 1926

Vol.29. 1. The Lateral Blood Supply of Primitive Flasmobranch Fishes, by J. Frank Daniel. Pp. 1-7, 1 figure in text. April, 1926

2. Experimental Amoebiasis in the Rabbit, by Margaret Dora Thomson. Pp. 9-23, 5 figuros in text. June, 1926

3. On Staurojoenina assimilis, sp. nov., an Intestinal Flagellate from the Termite, Kalotermes minor Hagen, by Harold Kirby, Jr. Pp. 25-102.

4. The Intestinal Flagellates of the Termite, Cryptotermes hermsi Kirby, by Harold Kirby, Jr: Pp. 103-120.

Nos. 3 and 4 in one cover, September, 1926

5. On Hoplonympha natator gen. nov., sp, nov., A Non-xylophagous Hypermastigote from the Termite, Kalotermes simplicicornis Banks, Gharacterized by Biradial Symmetry and a Highly Developed Pellicle, by S. F. Iight. Pp. 123-139, 28 figures in text.

6. On Metadevescovina debilis gen. nov, sp. nov., A Xylophagous Polymastigote from the Termite, Kalotermes hubbardi Banks, by S. F. Light. Pp. 141-157, plate 10, 3 figures in text.

Nos. 5 and 6 in one cover. September, 1926

7. On the Morphology and Mitosis of Trichomonas buccalis (Goodey) Kofoid, by F. Corwin Hinshaw. Pp. 159-174, plate 11, 2 figures in text. September, 1926

Vol 30. 1. The Pocket Gopher of Honey Iake Valley, by Joseph Grinnell. Pp. 1-6, pl. 1. August, 1926

2. The Muscular Anatomy of Three Mustelid Mammals, Mephitis, Spilogale, and Martes, by E. Raymond Hall. Pp. 7-38, 5 figures in text. September 1926 .

3. Systematic Notes on the Subspecies of Bassariscus Astutus, with Description of One New Form from Callfornia, by E. Raymond Hall. Pp. 39 50 , plates 2 and 3. September, 1926

4. Report on a Collection of Birds and Mammals from the Atlin Region, Northern British Columbia, by Harry S. Swarth. Pp. 51-162, plates 4-8, 11 figures in text. September, 1926

5. New Subspecies of Birds (Penthestes, Baeolophus, Psaltriparus, Chamaea) from the Pacific Coast of North America, by Joseph Grinnell and Harry S. Swarth. Pp. 163-175, 2 figures in text. September, 1926 
Reprinted from 'ThE CONDOR, Vol. XXY. pp. 214 223, Vremler, 1923

THE SYNTEMATI STATLA OF SOME NORTHWESTERN SONG SPARROWS

(WITH NAP)

By HARRY S. SWARTH

C'nt.ibution from the Museum of Vertebrate Zoology of the liviventy of Califorma 




\section{THE SYSTEMATIC STATUS OF SOME NORTHWESTERN}

\section{SONG SPARROWS}

(WITH MAP)

\section{By HARRY S. SWARTH}

(Contribution from the Museum of Vertebrate Zoology of the University of California.)

$\mathrm{T}$

$\mathrm{HE}$ present paper is the result of an attempt to outline the ranges in British Columbia of the races of Melospiza melodia that inhabit the province, this for a distributional list of the birds of British Columbia now in course of preparation by Major Allan Brooks and myself.

The greater part of the material upon which the study is based is contained in the Museum of Vertebrate Zoology, but the following specimens were borrowed from other institutions: from the Victoria Memorial Museum, Ottawa, an extensive series of song sparrows representing many localities in British Columbia; from the United States National Museum, a series of birds representing Melospiza melodia inexspectata, including the type of that subspecies; from the United States Biological Survey, a series of birds from the Queen Charlotte Islands; from the Museum of Comparativie Zoology, Cambridge, MIassachusetts, the type specimen of Melospiza fasciata merrilli Brewster. For the use of all this material, indispensable to such a study as this, my thanks are extended to each of the institutions concerned and to the individual curators through whom the loans were made.

I am also under a debt of gratitude to Major Allan Brooks for criticism and aid of various sorts. His assistance was sufficient to justify the appearance of his name as co-author of this paper had he not wished otherwise.

Although it is the song sparrow of British Columbia that is of first concern here, the status of the bird of southeastern Alaska (the Alexander Archipelago and the adjacent mainland) is so much a part of the same problem that that region is necessarily included. For convenience the term 'rufina group' will be used to designate the birds here treated, the reddish brown song sparrows of the coast of northwest America from central Oregon north to Glacier Bay, and, in British Columbia, west from the Rocky Mountains. To the birds of that general area the subspecific names rufina, guttata, morphna, merrilli, montana, inexspectata, and phaea, have been variously applied.

My own first impression was that the song sparrows of the entire region might well all be listed under one name. I had several times studied series of specimiens from southeastern Alaska and from different parts of British Columbia without being able to correlate definite subspecific characters with particular regions, and at first it did not seem to me that such correlations 'ould be established. Inasmuch, however, as certain extremes of variation are represented by birds from localities as near together as the Queen Charlotte Islands and Vancouver Island, and as these extremes are different enough to be recognizable in the living bird, it is apparent that at least two subspecies of Melospiza melodia will have to be conceded. It then remains to bring the rest 


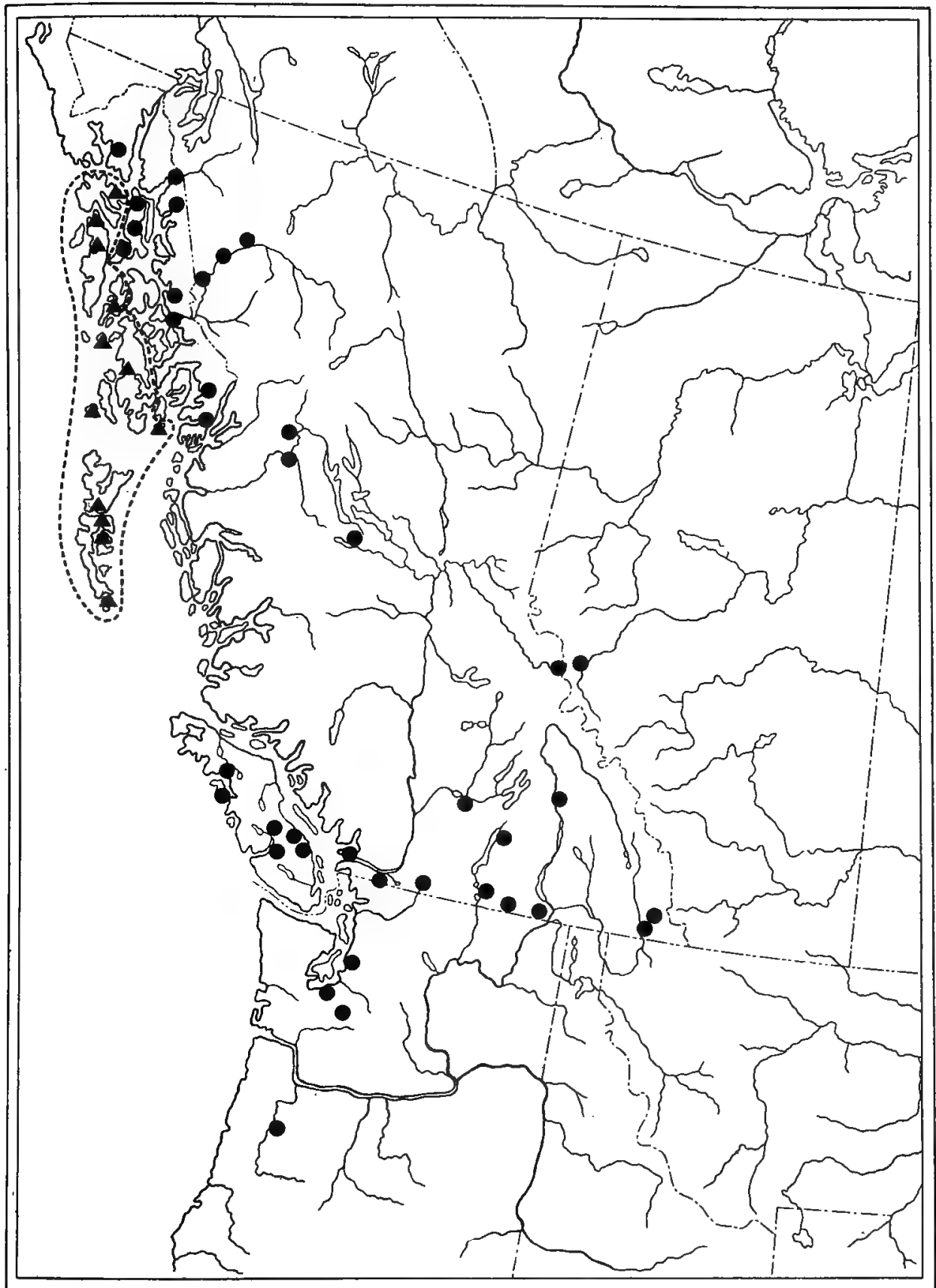

- Melosprza melodia rufina

- Melospiza melodia morphna

Fig. 61. Map of a PORTION OF NORTHWESTERN NORTH AMERICA, SHOWING BREEDING RANGE of Melospiza melodia rufina and $M$. $m$. morphna. Symbols indCate Localities EROM WHICH SPECIMENS WERE EXAMINED, 
of the series into harmony with the division indicated between the birds from these two island localities, a task of some difficulty, for it means attempting to indicate by definite names and definite geographic boundaries average differences that do not lend themselves to hard and fast diagnoses. It is hoped, however, that the division here indicated, in accord with the facts illustrated in an extensive series of specimens, will be satisfactory as a rather gross separation of races. For any minute and detailed study of geographic variation in Melospiza melodia in this general region, I do not believe that our system of nomenclature can be used to advantage. That is; $\mathrm{T}$. do not think that it is practicable to give names to any divisions smaller than are here indicated.

Comparing the extremes mentioned, from the Queen Charlotte Islands and from Vancouver Island, the outstanding characters of the birds from the Queen Charlotte Islands are large size, long bill, and dark coloration; from Vancouver Island, smaller size, rather stubby bill, and bright reddish color. Other birds with characters the same as those of the specimens from the Queen Charlotte Islands were found from the westernmost islands of the Alexander Archipelago, Alaska, including two adults from Sitka, the type locality of Emberiza rufina Brandt. Also, specimens closely similar to Van. couver Island skins were found from the eastern islands of the Alexander Archipelago and from the adjoining mainland. So. making due allowance for variation in each series, a fairly satisfactory division of races could be made, as is indicated in the accompanying map (fig. 61.)

Birds from Chichagof, Baranof, and the Queen Charlotte Islands are alike and are here taken to represent rufina in the extreme manifestation of that race. Specimens from Kuiu, Prince of Wales, Warren, and Forrester jslands are intermediate in character, between rufina and morphna. Two specimiens from. Duke Island are distinctly like rufina. The apparent anomaly in distribution in this last-mentioned case (see map) assumes added interest in view of the fact that a white-footed mouse (Peromyscus) is similarly isolated on Drike Island, the species found there ( $P$. sitkensis) being the same as the one that occurs on the distant Baranof and Chichagof islands,

As regards names for the two subspecies of song sparrow here recognized, the following appear to be applicable. To the song sparrow of the western islands of the Alexander Archipelago, Alaska (Chichagof, Baranof, Kuiu, Prince of Wales, Dall, Duke, and adjacent small islands), and the Queen Charlotte Tslands, British Columbia, the name Melospiza melodia rufina (Bonaparte) will apply. This name dates from: [Passerella $\rceil$ rufina Bonaparte, Consp. Av., J, July 15, 1850, 477 (Sitka, Alaska; ex "Emberiza rufina Brandt, Desic. Av. Rossic, 1836, tab. ii, 5"). (Citation copied from Ridgway, UT. S. Nat. Mus., Bu11. 50, part 1, 1901, p. 374.)

Melospiza melodia morphna Oberholser (Auk, xvI, April, 1899, p. 183), substitute subspecific name for guttata, preoccupied, type locality near mouth of Columbia River, will apply to the song sparrow of the eastern islands of the Alexander Archipelago (Admiralty, Wrangell, Revillagigedo, etc.) and the adjacent mainland coast from Glacjer Bay southward, over most of the mainland of British Columbia (except the extreme northern and northeastern sections), and Vancouver Island, and south at least to central Oregon.

This arrangement of the song sparrows of the section of the northwest coast under consideration is in a sense a recession from my attitude in previous 
papers, for I have always regarded birds from all sections studied as Melospiza m.,rufina. (See Univ. Calif. Publ. Zool., x, 1912, p. 60; ibid., xxIv, 1922, p. 255.) I did recognize certain differences between specimens in the Alaskan series, differences which are here correlated with the names rufina and morphna, but heretofore I have not been able to associate these characters with definite regions. It is the series from the Queen Charlotte Islands that proves the decisive factor. On those islands, apparently, the characters of rufina reach their extreme development, and with less variation between individuals than is seen elsewhere, where the range of morphna is approached.

In the rufina group, a feature that is at once apparent on examination of the large series now available is the surprising amount of individual variation in series from almost any section that is fairly well represented; and also the unexpected sort of variation that may crop up anywhere, as exemplified by certain skins from scattered localities.

As will be seen from the list of specimens appended, the material assembled includes extensive series from many places. It is the sort of variation that is cxhibited in certain of these series that made me formerly unwiling to recognize two races, rufina and morphna, from; the coastal region, north and south. Following are brief comments upon certain of the larger and more important series here considered.

Breeding birds from Vancouver Island are rather more uniform in appearance than Alaskan specimens, and generally they are brighter colored, more ruddy, than are the latter. Even in the Vancouver Island series, though, there are specimens, taken at the same place and the same time, that are markedly different in appearance. Together with the usual type of bird, with ruddy coloration and rather soft, blended markings, there is a considerable mixture of others, some darker, others more grayish, and some more heavily streaked above and below. A breeding bird from Alberni (Mus. Vert. Zool., no. 16199, adult female) can be closely matched in a series of the distant cleonensis, from the coast of northern California. A series from Nootka Sound is notable in the matter of bill development. In these birds the bill is long and slender, closely similar in shape to the bill of rufina.

In a series of seven birds, immatures in first winter plumage, taken near the mouth of the Taku River, Alaska, September 7 to 16, 1909, there is as much color variation as between Alaskan and Vancouver Island specimens. Some of the Taku River skins may be matched very closely by comparable specimens from Vancouver Island. Seven immatures and adults in fresh winter plumage taken on Sergief Island, Alaska, August 18 to September 4, 1919, are about like the Taku River birds, and show the same sort of variation.

Eight breeding adults from the upper Stikine River, British Columbia, taken June 9 to July 17, 1919, show a surprising amount of variation, in relative redness or grayness of general coloration and in the amount of red or of black in the streaking on the breast and on the back. Among six breeding adults from Hazelton, British Columbia, taken in May and June, 1921, there are extremes of redness and grayness as far apart as those distinguishing the average red-colored morphna of Puget Sound from the gray-colored merrilli of the interior. Fall plumaged birds from the same place show similar, though not as great, variation.

A series of eleven breeding birds (coll. Victoria Memorial Museum) 
from Osoyoos Lake, Okanagan Valley, taken May 6, 10, 11, 15, 16 (1922), is of exceptional interest from the standpoint of the variation exhibited. Here, from the same spot, are breeding birds exhibiting dark coloration exactly like Alaskan specimens of morphna, others with the ruddy color of morphna as seen on Vancouver Island, and still others, gray of color and with sparsely streaked breast, that closely approach merrilli.

There is a single bird at hand (no. 9693, Mus. Vert. Zool., adult female), collected at the head of Marten Arm, Boca de Quadra, Alaska, June 10, 1909. This specimen, taken in a region where extremely dark-colored song sparrows are the rule, exhibits the extreme of gray coloration that can be seen in morphna from any part of its range. It matches exactly three specimens (nos. 3168, 2791, 2773, Victoria Memorial Mus.) from Midway and Trail, in extreme southeastern British Columbia. These three have been labeled merrilli, and, indeed, in appearance they and the Boca de Quadra skin approach very closely to that subspecies.

I have examined the type specimen of Melospiza melodia inexspectata Riley (Proc. Biol. Soc. Wash., xxI, 1911, p. 234), together with several other specimens from the general region of the type locality and I cannot regard that subspecies as worthy of recognition. It is indistinguishable from morphna. Oberholser (Auk, xxxv, 1918, p. 187), urging the validity of the race, says: "It is most nearly allied to Melospiza melodia rufina, but is decidedly smaller, particularly in so far as the bill and wing are concerned; and is, in fact, a smaller, darker, somewhat heavily streaked edition of that bird."

As regards color and markings, specimens of "inexspiectata" can be duplicated from the Alaskan coast. Furthermore, individual variation in the rufina group is so extensive, as I have shown, that it is not practicable to make the division indicated. As regards measurements, the appended table shows the similarity of "inexspectata" of the interior and morphna of the coast.

In British Columbia there remains to be considered the status of Melospiza melodia merrilli Brewster. I cannot find that this name has been published as pertaining to a British Columbia bird, but $I$ have examined specimens in the Victoria Memorial Museum that were so labeled by different authorities. These are apparently some of the same birds listed by Macoun and Macoun (Catalogue of Canadian Birds, 1909, p. 540) as Melospiza cinerea montana, taken at various points in southeastern British Columbia. Specimens from that section, from Midway, Trail, and Fernie, for example, do certainly approach merrilli pretty closely, though I have seen none that are as gray as the type of that subspecies. I have no grounds for discrediting the validity of merrilli as occurring elsewhere, but it is not practicable on the basis of these variable specimens to give the race formal standing in a list of the birds of British Columbia, with any definitely outlined range in that province.

There are at hand seven specimens (including the type) of the type series of Melospiza cinerea phaea Fisher (Condor, Iv, 1902, p. 36) from the coast of southern Oregon. These birds average of small size, but all things considered, I do not regard them as representing a recognizable subspecies. Such variation from the mode of morphna as is seen, both in color and measurements, appears to me to be in the nature of intergradation toward rleonensis, the adjoining subspecies to the southward. 
The one outstanding fact brought out by an adequate series of specimens of the rufina group is the relative uniformity of characters presented over a tremendous area; and this despite the fact that there is a wide range of variation among birds from any one locality, for the same sort of variation crops up almost everywhere. This uniformity in the British Columbian andi southeastern Alaskan song sparrow is in marked contrast to the manner in which the species breaks up into local races to the northward and to the southward. To the north are the several more grayish-colored Alaskan races, exhibiting well-defined characters of color and structure, and each occupying a definite and relatively circumscribed habitat. To the southward, Melospiza melodia again breaks up into rather sharply defined races, mostly of limited distribution.

To some it may seem that the proper procedure in handling the rufina group would be to recognize four subspecies where I have defined two. These, centering about extremes that are admittedly appreciable, would be (1) the ruddy bird (morphna) of Vancouver Island and the adjacent mainland; (2) the grayish-toned merrilli extending into southeastern British Columbia; (3) a darker-colored race (inexspectata) from the northern mainland and part of the Sitkan district, Alaska; (4) a larger, dark-colored race (rufina), with range as previously outlined in this paper.

These, however, certainly are not definable races in the same sense as caurina, kenaiensis, or sanaka, to the northward, or cleonensis, samuelis, pusillula, and others to the southward. Their characters are hard to define, and, as previously shown, individual variation in nearly all sections is so great that there would be a large proportion of specimens in any series that could not be subspecifically allocated on any ground but the geographic situation of the place of capture.

It may be said that caurina and the related gray-colored subspecies to the northward, the blackish California subspecies to the southward, and what might be termed the melodia group to the southeastward, each represents a section of the species comparable to what I have here called the rufina group. Within each of the three first mentioned divisions, local differentiation has proceeded to a point where several races, more or less sharply defined and of restricted range, can readily be recognized. In the rufina group we can see a strong tendency toward such subdivision, but, save between the very extremes, it has not advanced far enough to permit of ready definition of characters in the birds from different parts of the general range.

It seems to me that in any study of a variable bird like Melospiza melodia, stress should first be laid upon the major divisions of the species. In the present case this would be on the reddish-colored rufina group in its entirety, as compared with the group formed by the gray-colored Alaskan races occurring abruptly to the northward, the brownish-colored melodia group (connected through merrilli) to the southeastward, and the blackish-colored California subspecies (connected through phaea) to the southward. It seems to me that it would be well to regard observed differences within each of these larger divisions in a somewhat different light from those by which these same divisions are separated from each other.

In the mechanical handling of names, in our efforts to convey observed facts, it seems to me that we are making a mistake when, for example, we publish lists of names as the song sparrow names appear in our Check-List 
of North American Birds. To scatter closely connected, sometimes scarcely distinguishable forms, among others most remotely related, is to obscure the facts. All recognizable subspecies are not equidistant from one another, and they should not be treated as if they were. As more and more material accumulates, permitting careful study of variation in one species after another, facts come to light that modify our conceptions of racial differences and our standard books should reflect such advances in knowledge. The application of this in the present instance is to urge, in any new edition of the A. $O$. U. Check-List, or any other general work on North American birds, a modification of the present mode of listing the local races of such birds as Melospiza melodia. In place of a string of heterogeneous subspecies, listed according to a chronological system true enough, but absolutely at haphazard as regards relationship, degree of difference, or geographical position, I would urge that, where possible, stress be placed upon the main divisions of the species with some subordination of the differences within each such section.

It is perhaps permissible to speculate somewhat as to the relationship borne by rufina and morphna toward caurina, immediately to the northward. Rufina in certain characters occupies an intermediate position between morphna and caurina, but geographically morphna (as here defined) impinges more directly upon the habitat of caurina than rufina does. It may seem startling to affirm the close resemblance of the Queen Charlotte Islands song sparrow to that of Yakutat Bay (see Brooks, Auk, xL, 1923, p. 223), but there is no gainsaying the similarity in size and, to some extent, in color and in shape of bill. Study of the map will demonstrate that the close relationship implied by such a claim is not so unreasonable as it first appears to be. Directly south of Glacier Bay extend the western islands of the Alexander Archipelago, and south of them the Queen Charlotte Islands. In many respects the animal life of the western islands differs markedly from that of the inner islands and the mainland, and it is easy to conceive of the dispersal of song sparrows in such a way as to produce different lines of variation in the two regions, west and east. Thus there might be produod in dispersal southward from the mainland, on the western islands and on the Queen Charlottes, a modification of the caurina type in which size remained the same, bill remained as long and nearly as slender, and color became darker and more brown. Morphna, in similarly hypothetical dispersal northward along the mainland coast, became slightly darker colored but otherwise almost unchanged. Something of the sort is what I believe really happened, with the resulting implication that caurina and rufina may be more nearly related, than are morphna and rufina.

There are two specimens at hand that have a decided bearing upon this theory, two breeding birds from Glacier Bay. One of these (Mus. Vert. Zool., no. 514, female, July 16, 1907), is an example of caurina. It may be taken as indicative of the southern extremity of the breeding range of that subspecies. The other (Mus. Vert. Zool., no. 512, male, July 2, 1907), is typical, not of 'uf ina, but of morphna. In small size, ruddy color, and stubby bill, it is like breeding birds from Vancouver Island, rather than like those from the western islands of the Alexander Archipelago. These, the only adults at hand from Glacier Bay, are too few specimens to permit of any finality in the deductions made therefrom (especially in view of the variation exhibited in series from 
other points), but the appearance of these birds fits well enough into the theory just outlined: that is, that the habitat of morphna extends northward on the mainland clear to the habitat of caurina; abrupt transition from one type to the other would be indicative of relatively remote relationship. Rufina, extending southward in its interrupted island range, would exhibit more or less intergradation with the closely related caurina, as is exhibited by many specimens. Intergradation between rufina and morphna, as certainly exists to a marked degree, might result from long ages of contact along a wide frontier.

The southernmost point from which I have seen a breeding specimen of morphna is Salem, Oregon. The type series of "phaea" from southern Oregon consists of winter birds. Rusty Song Sparrows are not uncommon in some parts of California during the winter months, and a number of specimens therefrom are included in the series studied. Birds from the coastal region are mostly of the reddish coloration seen in morphna; some are similar to the type series of "phaea." From the interior of California there are many that in their grayish color tend distinctly toward merrilli. They are like birds from southeastern British Columbia, before described. I have seen no winter birds from southern localities that are like the song sparrows of the Queen Charlotte Islands and the western islands of the Alexander Archipelago. In this connection the possibility suggests itself' of some birds from southern points that have been recorded as caurina being really examples. of rufina from Chichagof, Baranof, or the Queen Charlotte Islands. Supposed examples of caurina from southern localities should be carefully examined with this point in mind; as I have pointed out, some specimens of rufina approach caurina very closely in appearance.

\section{SPECIMENS EXAMINED}

\section{Melospiza melodia rufina}

Alaska: Chichagof Island, 4 ad.; Baranof Island, 3 ad., 1 im., 2 juv.; Kuiu Island, 3 ad.; Warren Island, 2 ad.; Prince of Wales Island, 1 ad.; Forrester Island, 6 ad., 2 juv.; Duke Island, 2 ad.

British Columbia: Queen Charlotte Islands, 17 ad., 4 juv. (all from collection of the U. S. Biological Survey). Total 47.

Melospiza melodia morphna

Alaska: Glacier Bay, 1 ad., 1 juv.; Taku River, 7 im., 1 juv.; Port Snettisham, 1 im.; Thomas Bay, 1 ad., 2 juv; Chickamin River, 3 ad.; Boca de Quadra, 1 ad.; Admiralty Island, 4 ad.; Sergief Island, 3 ad., 7 im., 11 juv.

British Columbia: Upper Stikine River, 8 ad., 15 juv.; Hazelton, 9 ad., 3 juv.; Kispiox Valley, 3 ad., 7 im., 6 juv.; Vanderhoof, 3 ad., 4 juv.; Moose Lake, Yellowhead Pass, 1 ad., 1 juv. ("inexspectata"); Revelstoke, 2 ad.; Kamloops, 1 ad.; Elko, 1 ad.; Fernie, 1 ad. ("merrilli"); Trail, 3 ad. (2 "merrilli"), 1 juv.; Midway, 3 ad. (1 "mer. rilli"); Okanagan Landing, 1 ad., 1 im.; Osoyoos Lake, 11 ad.; Skagit River, 2 ad.; Chilliwack, 1 ad.; Vancouver, 1 ad.; Vancouver Island: Parksville, 10 ad.; Little Qualicum River, 30 ad., 4 juv.; French Creek, 7 ad., 1 juv.; Errington, 23 ad., 7 im., 7 juv.; Alberni, 17 ad., 17 juv.; Golden Eagle Basin, 1 juv.; Nootka Sound, 11 ad., 8 juv. Alberta: Henry House, 1 ad.; Jasper Park, 4 juv. ("inexspectata").

Washington: Seattle, 3 ad., 3 juv.; Tacoma, 3 ad. ( 1 “merrilli"); Nisqually Flats, 1 ad.

(Oregon: Gardiner, 4 ("phaea"); Goldbeach, 3 ("phaea"); Tillamook, 1; Corvallis, 1; Salem, 1.

California: Siskiyou Mts., 3 (Oct. 30, Nov. 6, Dec. 5); Helena, Trinity Co., 3 (Feb. 15, 23, 24); Tower House Shasta Co., 2 (March 1, 7); Laytonville, Mendocino Co., 1 (Oct. 9); Fyffe, Eldorado Co., 2 (Nov. 25', 27); Coulterville, Mariposa Co., 2 


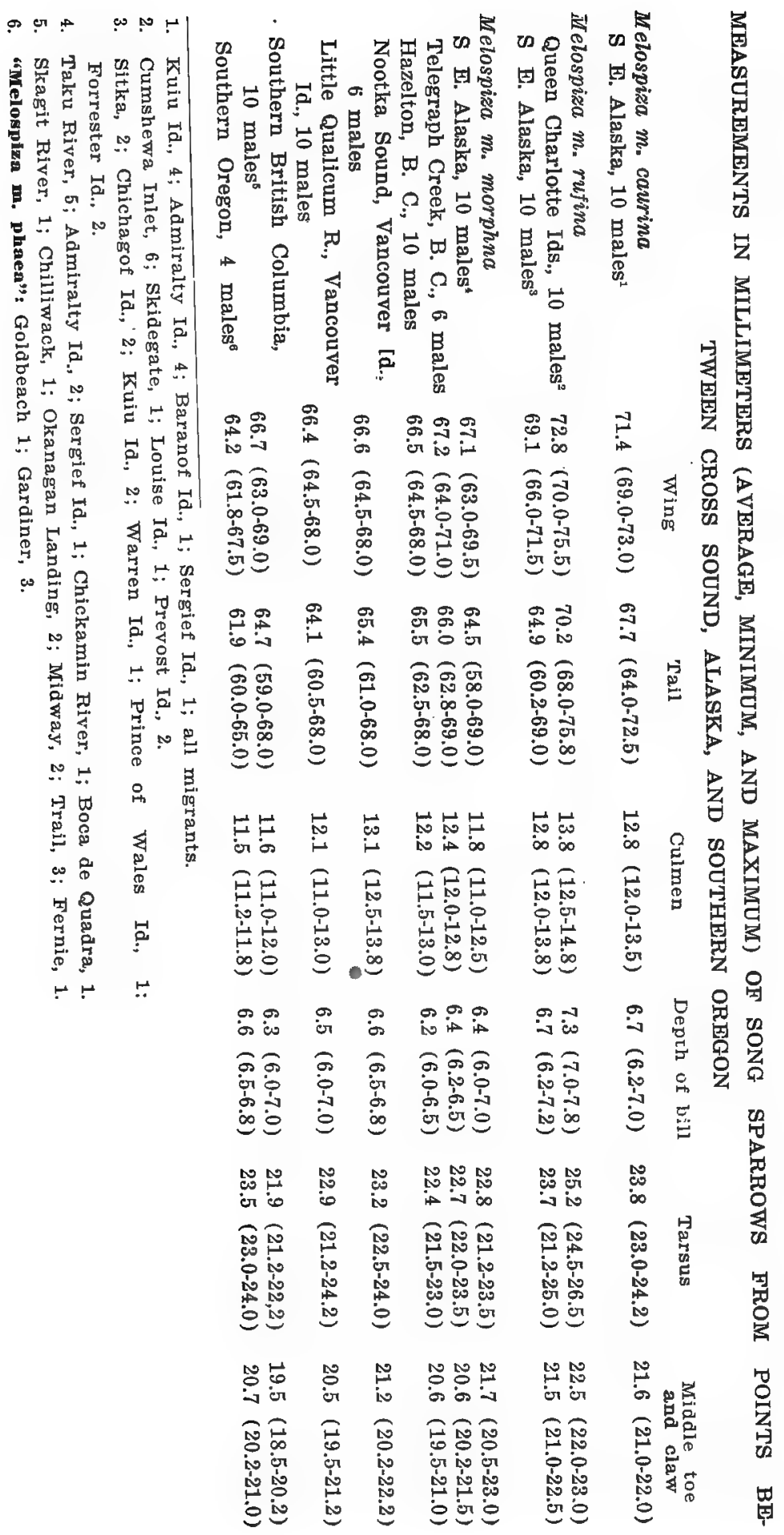


(Nov. 26, March 3); Snelling, Merced Co., 1 (Jan. 6); Grizzly Id., Solano Co., 1 (March 14); Nicasio, Marin Co., 2 (April 9, 14); Oakland, 2 (Dec. 4, Jan. 7); Santa Cruz Mts., 1 (Nov. 25); Riverside, 1 (Nov. 3). Total, 322.

Berkeley, California, September 15, 1923. 



White Wing-markings in the Heermann Gull: A Record from the Past.-I have recently received from Mr. Ruthven Deane a postal card written by Dr. J. G. Cooper, the subject matter of which seems of sufficient interest to place on record, even at this late date. It was written at a time when Mr. Deane was gathering data on albino birds, and is evidently a reply to queries along that line. It was addressed to "Ruthven Deane, Esq., Cambridge, Mass.", and is worded as follows: "Hayward, Cal. Nov. 12 78. Dear Sir, I never got but one albinescent spec. in Cal. a Larus Heerm'ni with a white patch $1 / 2$ size of this card on middle of each wing, that is across 2 ndy quills. It looked very pretty in the air, like a new sp. but when I shot it I found no other difference. I have seen pale brown \& mottled Dendrocygna fulva \& blotched Bernicla Gambeli, imperfect albinos of T. migratorius \& Scolecoph. but they are rare here yet. Yours ete. J. G. Cooper."

Inscribed across this writing is a postscript, "Dr. Brewer may have this Larus in hand now."

It will be recalled that Willett (CoNDoR, vol. 20, May, 1918, p. 122) has recorded the capture of Heermann Gulls (Larus heermanni), both by himself and by L. E. Wyman, that were marked as Dr. Cooper described so many years before. Willett's record stimulated P. A. Taverner (CoNDOR, vol. 20, September, 1918, p. 187) to describe a similar specimen from British Columbia; and yet others have been recorded (C. L. Hubbs, CoNDor, vol. 21, May, 1919, p. 121). Evidently this peculiarity of the Heermann Gull, noted as a novelty by present-day collectors, is one of long standing.-H. S. SwarTh, Museum of Vertebrate Zoology, Berkeley, California, May 1, 1924. 

Reprinted from The Conpor, Vol. XXVI, pp. 183-190, September, 1924

FALL MIGRATION NOTES FROM THE

SAN FRANCISCO MOUNTAIN REGION, ARIZONA

(WITH TWO PHOTOS)

By HARRY S. SWARTH

(Contribution No. 424 from the Museum of Vertebrate Zoology of the University of California) 



\section{FALL MIGRATION NOTES FROM THE SAN FRANCISCO MOUNTAIN REGION, ARIZONA (WITH TWO PHOTOS)}

\section{By HARRY S. SWARTH}

(Contribution No. 424 from the Museum of Vertebrate Zoology of the University of California)

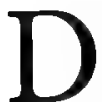

URING the fall of 1922 the present writer spent two months in field work in the vicinity of San Francisco Mountain, Arizona. This work was conducted in conjunction with Dr. Francis B. Sumner, of the Scripps Institution for Biological Research, and his assistant, Mr. Ralph R. Huestis. The expenses of the trip were defrayed in part by Mr. E. W. Scripps, through the Scripps Institution, in part by Miss Annie M. Alexander, through the Museum of Vertebrate Zoology. Dr. Sumner was in charge of the expedition, the main object of which was a study of certain small rodents of the region explored. (See "The supposed effect of the color tone of the background upon the coat color of mammals," by F. B. Sumner and

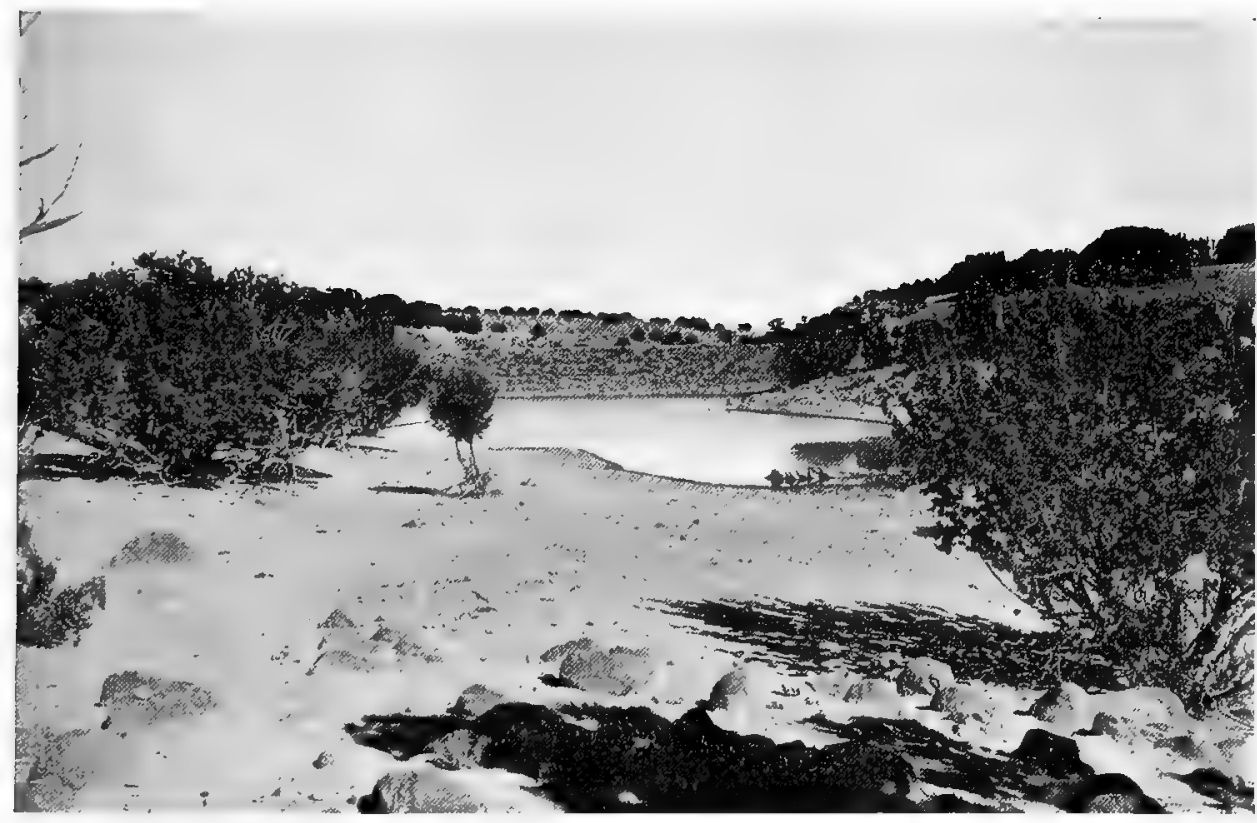

Fig. 47. Dove Tank, Near Deadman Flat; ARTtFicial storage of surface water IN A Region With FeW Permanent springs and streams. Photographed October 11, 1922.

H. S. Swarth, Journal of Mammalogy, vol. 5, May, 1924.) Mammal collecting took up all of the time of Dr. Sumner and Mr. Huestis, and a large portion of my own. I did give some time to birds, however, keeping notes on all species observed, and, especially in the latter part of our stay, collecting specimens of many of the species. Most of the mammals and all of the birds I collected, together with field notes and photographs, are in the Museum of Vertebrate Zoology.

The following notes are presented mainly for their value as statements of occurrence. Our time in the field covered most of the period in the fall when birds were actively migrating, and in many cases I was able to ascertain exact dates of arrival and departure. I believe there have been few observations of the sort from this section. 
We arrived at Flagstaff on September 3, and on September 5 we established a permanent camp 21 miles northeast of that city. This was on Deadman Flat, northeast of the main San Francisco Peak and a little northwest of O'Leary Peak. This section has recently been opened to settlement, and several ranchers are attempting, more or less experimentally, to raise crops of various sorts by dry farming. We were able to establish ourselves comfortably in a cabin belonging to Mr. Carr H. Schwarz, for living quarters and work shop. Our meals we obtained at the nearby ranch house of Mr. W. J. Osborn. To Mr. and Mrs. Osborn and their family, and to Mr. Schwarz, we are indebted for many kindnesses. The interest they took in our work and the aid they gave us were important factors in making a success of our trip, and it is a pleasure here to make acknowledgment of our indebtedness.

The region about San Francisco Mountain is historic ground to the zoologist. In 1851 the Sitgreaves expedition traversed this section en route from Santa Fé, New

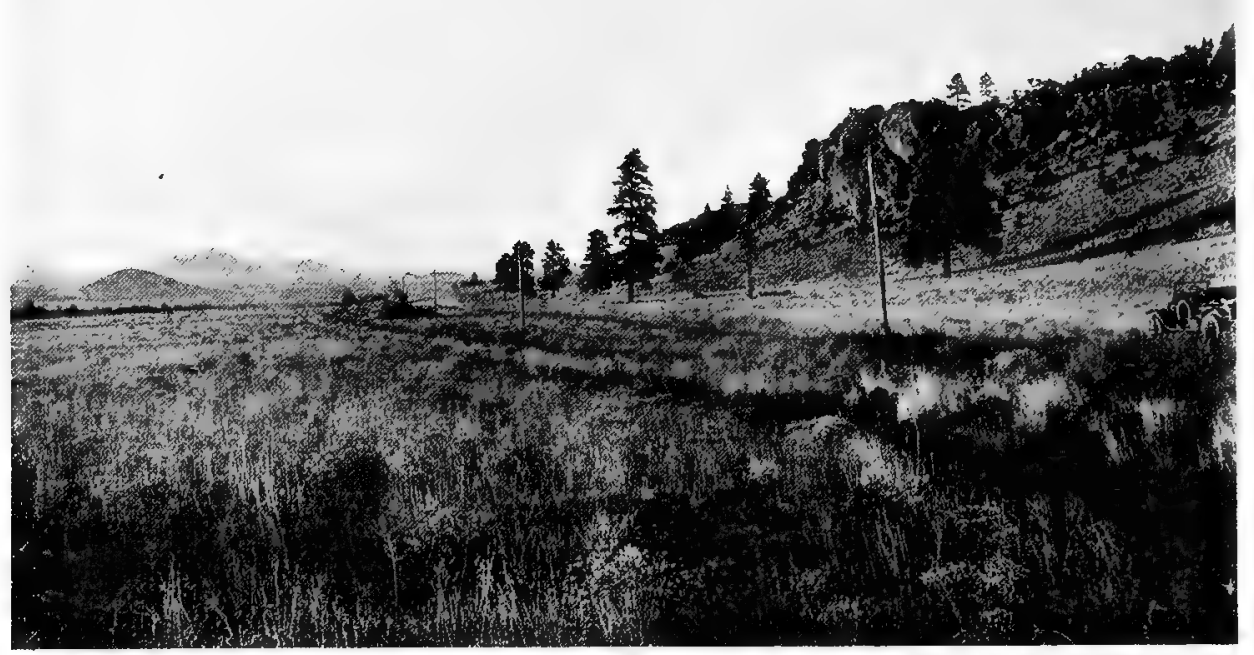

Fig. 48. Looking toward Deadman Flat from the south, at the Lower edge of THE Yellow PINe Belt. Photographed OCtOber 12, 1922.

Mexico, to San Diego, California. Dr. S. W. Woodhouse, naturalist attached to the party, made collections and reported upon the natural history of the expedition. ${ }^{1}$ From the printed account it is evident that Sitgreaves' route led directly across the section where our own work was pursued. We were there at the same time of the year and it proved of decided interest to compare our own day-to-day observations with the diaries printed in Sitgreaves' report.

During August and September, 1889, San Francisco Mountain again served as a field for zoological observations, this time by a party under the direction of Dr. C. Hart Merriam. Observations of the birds are included in the report subsequently published. ${ }^{2}$

1 In "Report of an Expedition down the Zuni and Colorado Rivers," by Captain L. Sitgreaves, Washington, $1858 ; 198$ pp., 77 pls., map.

${ }^{2}$ Results of a Biological Survey of the San Francisco Mountain Region and Desert of the Little Colorado, Arizona. U. S. Dept. Agric., N. Amer. Fauna no. 3, 1890, pp. 1-136, pls., figs. 
In view of Merriam's detailed description of the region there is no need of going into particulars here, but there are some points that it seems well to emphasize. Our headquarters was in the piñon belt, and most of our work was done there. Many short trips were made into the yellow pine belt, at a slightly higher altitude, and several to points above the limits of the yellow pine. This whole region is extremely arid. There are no running streams and very few springs, and there is in consequence a marked scarcity of certain types of small birds, of the sorts that frequent such shrubbery as appears in the vicinity of streams. In the piñon belt and in the yellow pine belt there is very little underbrush.

At a few places in the pines, and more numerously at lower levels, gullies have been dammed to check the flow of surface water, with resulting reservoirs, primarily for the use of cattle, that are locally known as tanks. These become filled with water as a result of winter snow and of the heavy thunder storms of midsummer, and they diminish in size at other seasons. Some of the larger tanks attract a few passing water-fowl.

The plains at the base of San Francisco Mountain are at an altitude of about $6000 \mathrm{feet}$, and in consequence of this high elevation the winters are rather severe. When we arrived, the first of September, the summer heat was still intense, and warm weather continued until early in October. On the morning of September 24 the green belt of quaking aspen, conspicuous on the higher slopes of San Francisco Mountain, was seen to have suddenly developed spots of brilliant yellow and orange, an indication of the first frost at that height. A few days later the green had all changed to yellow, and early in October there was a light frost at the level of our camp. On October 27 a light rain that began to fall late in the afternoon changed to snow during the night, the beginning of a storm that lasted three days. When I left for home, November 2, the weather had not been warm enough to melt the fallen snow to an appreciable extent.

Erismatura jamaicensis. Ruddy Duck. One seen October 15 on a tank some thirty miles north of San Francisco Mountain. There were flocks of larger ducks on the same tank, too far distant to be identified.

Fulica americana. American Coot. Several seen at the same time and place as the last mentioned species.

Totanus melanoleucus. Greater Yellow-legs. Two seen October 15, at a tank some thirty miles north of San Francisco Mountain.

Oxyechus vociferus vociferus. Killdeer. Seen throughout September and October, usually a single bird or two together at the edge of a tank.

Columba fasciata fasciata. Band-tailed Pigeon. One seen September 14, at about 10,000 feet on San Francisco Mountain. Reported from the same mountain by Woodhouse, but not found by Merriam. According to local report it occurs sometimes in fair abundance.

Zenaidura macroura marginella. Western Mourning Dove. In fair abundance during the first two weeks in September. A single bird appeared October 29; none had been seen for the previous six weeks.

Circus hudsonius. Marsh Hawk. Seen frequently during September; became rare by the middle of October. An adult male was seen on October 29, drifting over the prairie in a driving snow storm.

Accipiter velox. Sharp-shinned Hawk. Seen at frequent intervals; last noted October 27.

Accipiter cooperi. Cooper Hawk. Seen, rather infrequently, until October 12. Two killed, not preserved, while attacking poultry.

Astur atricapillus. Goshawk. Two seen circling overhead at Deadman Flat September 11. 
Buteo borealis calurus. Western Red-tailed Hawk. Seen frequently during the whole of our stay.

Archibuteo ferrugineus. Ferruginous Rough-legged Hawk. First seen October 9. Fairly common thereafter, and seen to the end of my stay, November 1 . On one occasion a Ferruginous Rough-leg and a Western Red-tail were seen perched on the ground about twenty feet apart, each with a freshly killed prairie dog.

Aquila chrysaëtos. Golden Eagle. Of frequent occurrence. Sometimes five or six seen in one day.

Falco mexicanus. Prairie Falcon. Encountered at frequent intervals during the whole of our stay. Once observed in pursuit of domestic pigeons in Flagstaff, and several times after poultry about ranch houses. The one specimen preserved was shot while making off with a chicken.

Falco columbarius, subsp.? Pigeon Hawk. Two seen on the outskirts of Flagstaff, October 31 and November 1, respectively.

Falco sparverius sparverius. Sparrow Hawk. Common during September, and early in October. A single bird seen October 31 was the only one noted after October 15.

Otus asio, subsp.? Screech Owl. The call of a screech owl was heard several times during the night of October 15 in piñon and juniper woods thirty miles north of San Francisco Mountain.

Bubo virginianus, subsp.? Horned Owl. Heard hooting occasionally; apparently not numerous.

Dryobates villosus leucothorectis. White-breasted Woodpecker. A few seen, mostly in the pine woods. Late in October individuals occasionally strayed down to lower levels.

Sphyrapicus varius nuchalis. Red-naped Sapsucker. Two seen October 13 in junipers near a tank.

Sphyrapicus thyroideus nataliae. Williamson Sapsucker. First noted September 14, in the pines, and on several occasions thereafter. On October 10, 11, and 17, others were seen in junipers, far from the mountain.

Asyndesmus lewisi. Lewis Woodpecker. A few seen near Flagstaff early in September.

Colaptes cafer collaris. Red-shafted Flicker. Fairly common, mostly in the pines during September; descending into the piñon and juniper woods in October.

Phalaenoptilus nuttalli nuttalli. Poor-will. Last seen September 29.

Aëronautes melanoleucus. White-throated Swift. A few seen at irregular intervals.

Sayornis sayus. Say Phoebe. A few seen early in September.

Empidonax griseus. Gray Flycatcher. An immature male, still undergoing the post-juvenal molt, was collected in juniper woods September 6. An unidentified Empidonax seen October 5 was the only other individual of this genus that was seen.

Otocoris alpestris leucolaema. Desert Horned Lark. The horned larks collected all appeared to be migrants. During the first two weeks in September they were rare. Then flocks appeared more and more frequently, and by the middle of October they were abundant, though restricted to certain favored localities. The twenty-eight specimens collected, from September 11 to October 26, appear to belong all to the same subspecies.

Cyanocitta stelleri diademata. Long-crested Jay. Abundant in the pines along the road between Deadman Flat and Flagstaff. Decidedly rare in the pine woods on the northern slope of San Francisco Mountain. Merriam speaks of its occurrence "everywhere from timber line to the lower part of the cedar belt," but I saw none in the piñons and junipers. Two immature birds collected September 14 are in the midst of the post-juvenal molt. In the northern subspecies, stelleri and annectens, this molt is usually accomplished by the end of August.

Aphelocoma woodhousei. Woodhouse Jay. Rather uncommon, and, as noted by Merriam, usually "shy and difficult to procure." Restricted to the piñon-juniper belt. In the lower portion of this belt there are far more junipers than piñons; in the upper portion the piñons preponderate markedly. The Woodhouse Jay was always among piñons, although this year there were no cones on any of the trees. The juniper woods, 
bearing a fairly plentiful crop of berries, were seldom entered; in fact I did not see a single Woodhouse Jay in certain sections where there were nearly pure stands of juniper.

Corvus corax sinuatus. Southern Raven. Beginning October 10 a few ravens appeared, apparently migrating. At any rate, these scattered companies, containing from three to ten individuals, were always drifting in a southerly direction.

Nucifraga columbiana. Clark Nutcracker. A few seen at high altitudes, above the yellow pine belt.

Cyanocephalus cyanocephalus. Piñon Jay. Abundant and in flocks numbering hundreds of individuals throughout the piñon-juniper region. Failure of the crop of piñon nuts had left these jays without their usual food, and they were doing considerable damage to some ranch crops. Certain fields of corn and beans were raided constantly. Curiously enough there were other fields, around which the jays were seen daily, which they never touched. I was told that ordinarily, with a normal supply of piñon nuts, the jays did not damage cultivated crops. There was no indication of an exodus of the birds as a result of the absence of their usual food.

Xanthocephalus xanthocephalus. Yellow-headed Blackbird. Occasional individuals appeared in the corn fields or else about the Osborn ranch house. Seen from September 16 to October 7.

Agelaius phoeniceus fortis. Thick-billed Red-winged Blackbird. Migrating southward in small numbers, never more than eight or ten in a fiock. First seen October 7, and from then on until my departure.

Sturnella magna hoopesi. Rio Grande Meadowlark.

Sturnella neglecta. Western Meadowlark. Meadowlarks were present in the region when we arrived, September 1, but whether or not both species breed there, could not be ascertained. Eleven specimens of hoopesi and three of neglecta were collected, but this is no indication of their relative abundance. A special effort was made toward securing hoopesi, and the call-notes and songs of the two species are so different that there seldom was any doubt as to which kind I was pursuing. Meadowlarks were plainly migrating southward. They would be present in a field one day and absent the next, and flocks were seen again and again that were rapidly drifting in a southerly direction, walking and feeding on the ground and always flying in the same general direction when disturbed. For hoopesi to be migrating southward through this part of Arizona is an indication that the breeding range extends some distance farther north, probably into southern Utah and perhaps into southwestern Colorado. By the third week in October Meadowlarks had become very scarce, but some were seen on October 31 .

Specimens of hoopesi collected September 9 and 11 were molting from juvenal to first winter plumage. On October 9 several Meadowlarks were seen that were molting, so as to be able to fly but with difficulty. Wing and tail feathers had apparently been lost almost all at once, and were but partly replaced.

It is of interest to compare the occurrence of these two species in this region with Wetmore's reports of conditions in the vicinity of Bill Williams Mountain (Kansas University Science Bulletin, Iv, Sept., 1908, p. 381; Condor, xxII, March, 1921, p. 62).

Euphagus cyanocephalus. Brewer Blackbird. Seen during September and the first half of October. Usually about barns and corrals.

Carpodacus cassini. Cassin Purple Finch. First seen October 17 at about 8000 feet altitude on San Francisco Mountain. After the heavy snow storm of October 28-30, Cassin Purple Finches appeared in numbers in the lowlands. Between Deadman Flat and Flagstaff flock after flock was seen feeding in weed patches alongside the road.

Carpodacus mexicanus frontalis. House Finch. First appeared September 19, a single bird. A few others were seen, never more than three or four together, at long intervals.

Passer domesticus. English Sparrow. First seen at Deadman Flat on October 7. That morning I was standing in the yard of the Osborn ranch when, with a whirr of wings, a flock of about twenty English Sparrows, all females, swooped from the sky and settled down in the chicken yard. I shot three and the survivors, rising high in the air, flew to the northward until out of sight. Later on, other flocks were seen, both here and in the town of Flagstaff. 
Their manner of occurrence at Deadman Flat is plainly indicative of a tendency to wander at the close of the breeding season, even though there is no established migration route to be followed. It shows one way in which the species spreads, and the manner in which the birds will pick out an isolated ranch for occupancy. I have never seen an English Sparrow drop down into "wild" country in the manner in which they constantly came to this and other nearby ranches.

Astragalinus psaltria hesperophilus. Green-backed Goldfinch. A few seen from time to time on the road between Deadman Flat and Flagstaff. Last noted October 17.

Calcarius ornatus. Chestnut-collared Longspur. An abundant migrant. A single bird seen September 18, three together September 20, and then flocks every day. Last observed October 26.

Rhynchophanes mccowni. McCown Longspur. One specimen collected October 16. A few others were seen in company with the abundant Chestnut-collared Longspur.

Pooecetes gramineus confinis. Western Vesper Sparrow. Present when we arrived, September 1, and in increasing numbers for about two weeks. By September 15 swarms of Vesper Sparrows arose everywhere one went in the grass land and rabbitbrush. On September 19 their numbers had decreased markedly, and by October 1 they were rather scarce. Last seen October 11.

Passerculus sandwichensis nevadensis. Nevada Savannah Sparrow. None present early in September. First seen September 20 and abundant for'some days thereafter. On September 29 they were swarming in the grass land and in cultivated fields but nearly all were gone on the 30th and none was seen later. Two birds were collected, both distinctly referable to nevadensis.

Chondestes grammacus strigatus. Western Lark Sparrow. Seen in fair abundance early in September, mostly along the road between Deadman Flat and Flagstaff. They disappeared early in October.

Zonotrichia leucophrys leucophrys. White-crowned Sparrow.

Zonotrichia leucophrys gambeli. Gambel Sparrow.

Two specimens of the subspecies leucophrys were shot on September 21, the first arrivals. White-crowned sparrows of one kind or the other were seen occasionally from then on, never in abundance. On October 18 the last were noted; several seen that day were definitely recognized as gambeli.

Spizella passerina arizonae. Western Chipping Sparrow. Seen from the lower part of the yellow pine belt downward. Abundant during September and in lessening numbers early in October. Last seen October 17.

Spizella breweri. Brewer Sparrow. In fair abundance on Deadman Flat during September. Exact time of departure was not noted, but no observation of this species was recorded in October.

Junco hyemalis hyemalis. Slate-colored Junco. A male bird seen near the lower edge of the yellow pine belt (about 7500 feet altitude) on October 27, in a small flock of shufeldti and caniceps.

Junco oreganus shufeldti. Shufeldt Junco. Arrived October 8. Seen thereafter in fair abundance, mostly in the piñon-juniper belt, but also upward to the lower edge of the yellow pines.

Junco mearnsi. Pink-sided Junco. First seen October 17 at about 7500 feet altitude. A few noted at irregular intervals during the rest of my stay, usually single birds in flocks of shufeldti and caniceps.

Junco caniceps. Gray-headed Junco. An adult female collected October 1 on Deadman Flat was the first migrating junco of any kind to appear. By the middle of October caniceps was present in fair abundance, in the piñon-juniper belt to some extent, but in greater numbers in the yellow pine belt. Flocks of juncos were frequently encountered composed of as many as fifty or sixty individuals. Nine-tenths of such a flock would consist of caniceps and shufeldti in about equal numbers, with a few mearnsi and perhaps an occasional hyemalis.

Junco dorsalis. Red-backed Junco. The breeding species of Junco. Found by me in the same sections as are designated by Merriam, "throughout the upper levels of the pine plateau region and in the balsam and spruce belts." One specimen was collected in juniper woods September 28, accompanied by another that was supposed to be of the same kind. This was the only occasion on which dorsalis was seen below the yellow pine belt. When the migrating northern juncos arrived, the mixed flocks of 
caniceps, shufeldti and others were abundant at the lower edge of the pines and in the piñons and junipers, but no specimen of dorsalis was found in any of these aggregations. I found dorsalis at a higher altitude, in small flocks, and never accompanied by any other species.

On September 14, specimens were collected that were still in molt, some young birds with remnants of the juvenal plumage. The species was still abundant at the end of October, and is probably permanently resident.

Amphispiza nevadensis nevadensis. Sage Sparrow. First seen at Deadman Flat September 25. Ten days later a few more appeared and by October 17 they were present in fair abundance. At the end of the month the Sage Sparrows had disappeared again, but it might be that they had merely been driven to lower lovels toward the Painted Desert by the storm that, during the last week in October, covered the higher country with snow.

Pipilo maculatus montanus. Mountain Towhee. Of rare occurrence. Three specimens collected, on September 8, October 10 and October 13, respectively, and two or three others seen at long intervals, were all that were noted. Those collected were found in juniper woods, where they must be merely of transient occurrence.

Oberholseria chlorura. Green-tailed Towhee. Fairly common throughout September. Last noted October 2, though probably present for another week at least.

Piranga hepatica. Hepatic Tan'ager. Seen once, an adult male, September 14, in the yellow pine belt, at about 7500 feet altitude.

Petrochelidon lunifrons. Cliff Swallow. A few seen migrating overhead on September 12.

Hirundo erythrogaster. Barn Swallow. Seen migrating during September. Last noted September 30.

Iridoprocne bicolor. Tree Swallow. A few seen migrating September 12.

Tachycineta thalassina lepida. Northern Violet-green Swallow. Migrating in fair abundance during September. Last seen September 28.

Stelgidopteryx serripennis. Rough-winged Swallow. A few seen migrating September 9.

Bombycilla cedrorum. Cedar Waxwing. Two seen October 16 feeding on juniper berries.

Lanius ludovicianus excubitorides. White-rumped Shrike. Seen at intervals during September and early in October, always in the piñon-juniper belt. Last noted October 17.

Dendroica aestiva, subsp.? Yellow Warbler. A few migrating Yellow Warblers were seen near Flagstaff September 4 and 5.

Dendroica auduboni auduboni. Audubon Warbler. Seen in small numbers early in September. On September 23 the species was fairly abundant at the lower edge of the yellow pine forest, and a little later many appeared in the piñon-juniper belt. Last seen October 19.

Dendroica nigrescens. Black-throated Gray Warbler. A rare migrant. Several were seen on September 7, one on September 13, and one (the last noted) on September 22, all in the piñon-juniper belt.

Wilsonia pusilla pileolata. Pileolated Warbler. One seen September 24.

Anthus rubescens. Pipit. First seen October 17 and occasionally thereafter.

Oreoscoptes montanus. Sage Thrasher. First seen September 11; a few days later this became the most abundant bird species in the piñon-juniper belt. The Sage Thrashers were obviously migrating, and some days all the birds seen would be rapidly moving southward, an advaneing army really impressive in numbers. Scores were in sight at once on the ground, running from bush to bush, others were taking short flights through the trees, and still others were in scattered companies overhead, almost like flocks of bluebirds in flight. The usual call-note is a harsh chuck, suggestive of that of a blackbird, but some thrashers were heard giving fragments of their striking song from perches in the junipers.

By the middle of October the number of Sage Thrashers had markedly diminished. On the 20 th none were seen, but on the $23 \mathrm{rd}$ two appeared, the last observed. flows.

Salpinctes obsoletus obsoletus. Rock Wren. Very few seen. Usually on lava

Catherpes mexicanus conspersus. Cañon Wren. A few seen or heard on lava and in rocky gulches on the lower slopes of San Francisco Mountain. 
Thryomanes bewicki eremophilus. Desert Wren. One seen September 19, and one collected September 29 (both in junipers) were all observed.

Troglodytes aëdon parkmani. Western House Wren. One seen at the lower edge of the yellow pines September 8. Not otherwise observed.

Certhia familiaris montana. Rocky Mountain Creeper. One collected October 27 on the northeast slope of San Francisco Mountain at about 8000 feet altitude; the only one seen.

Sitta carolinensis nelsoni. Rocky Mountain Nuthatch. In small numbers at the lower edge of the yellow pines, and occasionally in the piñons and junipers.

Sitta canadensis. Red-breasted Nuthatch. One bird seen October 17 at about 8000 feet altitude on the northeast slope of San Francisco Mountain. Not otherwise observed.

Sitta pygmaea pygmaea. Pygmy Nuthatch. Fairly abundant in the yellow pine belt, but not once encountered in the piñons and junipers just below.

Baeolophus inornatus griseus. Gray Titmouse. Closely restricted to the piñonjuniper belt. Not abundant anywhere; at the most perhaps six or eight might be seen in a forenoon.

Penthestes gambeli gambeli. Mountain Chickadee. Fairly common in the lower part of the yellow pine forest and throughout the piñon-juniper belt. On October 16 my eye happened to be caught by a single Mountain Chickadee coming straight down from high overhead, to alight in an isolated juniper. This seems clear evidence of migration.

Psaltriparus plumbeus. Lead-colored Bush-tit. Not at all common. Small flocks were encountered at long intervals, near the upper limit of piñon and juniper and in the lower portion of the yellow pines.

Regulus satrapa olivaceus. Western Golden-crowned Kinglet. In Woodhouse's report on the natural history of Sitgreaves' Expedition down the Zuni and Colorado Rivers (1853), there is casual reference to the occurrence of this species on San Francisco Mountain (p. 68, under Parus montanus). The date of observation would have been somewhere from October 9 to 22. There was no more definite record for Arizona until Cooke (Auk, 1914, p. 404) reported a specimen taken by C. Birdseye, September 14, 1908, in the White Mountains. On October 24, in a clump of Douglas fir near the upper edge of the yellow pines, at 7500 feet altitude on the northeast slope of San Francisco Mountain, I heard the lisping note of the Golden-crowned Kinglet. I collected one bird and heard one or two others. It was interesting thus to be able to corroborate Woodhouse's observation of many years before, and at a point that must have been within a few miles of where he crossed the northern shoulder of the mountain.

Regulus calendula calendula. Rulwy-crowned Kinglet. Several seen at high altitudes on San Francisco Mountain September 14, two at Deadman Flat September 29, and one at 8000 feet altitude on San Francisco Mountain October 27.

Polioptila caerulea obscura. Western Gnatcatcher. Two seen at Deadman Flat September 6. Not otherwise observed.

Myadestes townsendi. Townsend Solitaire. Appeared in the piñon-juniper belt September 28, when two were seen. By the middle of October they were abundant, and remained so through the month. On October 11 about sixty Townsend Solitaires were in sight at once about a small "tank".

Planesticus migratorius propinquus. Western Robin. Abundant in the juniper thickets, where they were feeding on the berries, the latter part of September and throughout October.

Sialia mexicana bairdi. Chestnut-backed Bluebird. Seen in some numbers in the yellow pine region near Flagstaff upon our arrival there, September 3. A few days later they appeared at Deadman Flat, and in increasing numbers during September and throughout October.

Sialia currucoides. Mountain Bluebird. As with $S$. $m$. bairdi this species was seen early in September in the yellow pine belt, and a little later at Deadman Flat. During the latter part of October both species of bluebirds were extremely abundant in the juniper thickets. On October 25, at Dove Tank, there was a solid mass of bluebirds congregated at the water's edge that I estimated to contain two hundred or more individuals, a brilliant blue margin bordering one entire side of the tank. About two-thirds of the flock were currucoides.

Berkeley, California, December 20, 1923. 


Reprinted from THE CoNDOR, Vol. XXVII, pp. 67-69, March, 1925 THE TIMBERLINE SPARROW A NEW SPECIES FROM NORTHWESTERN CANADA

By HARRY S. SWARTH and ALLAN BROOKS

(Contribution no. 442 from the Museum of Vertebrate Zoology of the University of California) 



\title{
THE TIMBERLINE SPARROW A NEW SPECIES FROM NORTHWESTERN CANADA
}

\author{
By HARRY S. SWARTH and ALLAN BROOKS
}

(Contribution no. 442 from the Museum of Vertebrate Zoology of the University of California)

$\mathrm{D}$

URING the summer of 1924 the two authors of the present paper were collecting birds together in the Atlin region, in the extreme northwestern corner of British Columbia. One of the most interesting of our finds was the discovery, in the higher parts of the mountains of that region, of a Spizella apparently distinct from any other known species. This bird is closely similar to Spizella breweri in general appearance, but it differs appreciably from breweri in details of structure and coloration. This northern Spizella we propose to name

\section{Spizella taverneri*, new species}

Timberline Sparrow

TYPE.-Male adult; Museum of Vertebrate Zoology, no. 44856; Spruce Mountain, at 5000 feet altitude, 10 miles east of A.tlin, British Columbia; August 8, 1924; collected by H. S. Swarth; original no. 13048.

DiAGNosis.-Most nearly like Spizella breweri. Slightly larger, with (usually) rather longer tail, and with weaker, more slender bill. Coloration darker than in breweri, with heavier streaking on top of head and back, darker flanks, and a tendency toward the development of narrow streaks on breast and flanks. Bill and feet darker than in breweri: "bill black at tip; upper mandible brownish, lower mandible flesh; feet pale drab, tarsus brownish flesh" (Brooks' field notes).

SPECIMENS EXAMINED.-Adult male, 3; adult female, 4; immature, first winter plumage, 4; juvenal, 6; molting from juvenal to first winter, 6. Total, 23.

It seems best to accord this form specific standing, rather than to regard it as a subspecies of breweri. The characters of taverneri seem constant. At any rate, in the series at hand there is none that could be confused with breweri, and in extensive series of breweri (numbering some hundreds of skins, from many localities) we have found no specimen of equivocal character. The difference in bill alone seems diagnostic. This member is slender and dark colored in taverneri, relatively stubby and pale colored in breweri. In the dried skin this feature is retained to its full extent, so that the darker bill of a specimen of taverneri appears in strong contrast to that of any breweri with which it is compared.

- Named for P. A. Taverner, Ornithologist, Canadian Geological Survey, Ottawa, Canada. 
In dorsal coloration breweri, in all plumages, presents a ground color of sandy buff, with narrow streakings. In taverneri there is none of this pale sandy appearance. The general ground color is grayish, with the limited brownish areas of individual feathers of a darker shade than in breweri. In coarser dorsal streakings, in the fairly well defined grayish area between streakings of head and back, in the suggestion of a median line upon the crown, and in the fairly distinct superciliary stripe, taverneri shows an approach toward the characters of Spizella pallida.

In juvenal plumage, taverneri and breweri present differences comparable to what is seen in adults, young taverneri being darker colored generally, and more heavily streaked. In later plumages there is in taverneri a tendency toward the development of narrow streaks on breast and sides to a far greater extent than is ever seen in breweri. This is most noticeable in certain immatures in first-winter plumage (but these streaked feathers are not left-overs of the juvenal plumage), and it appears also to some extent in freshly molted adults.

In a study of the relationship of taverneri and breweri, account must be taken of the geographical ranges of the two forms. Breweri finds its center of abundance in the Great Basin region. It is an inhabitant of arid portions of the Upper Sonoran and Transition zones, a desert bird, that, as a rule, follows the sage-brush in its distribution. It extends northward along the lower valleys of the interior of southern British Columbia, as far as the sage-brush goes. Taverneri is an inhabitant of the Alpine-Arctic zone on mountain tops far to the northward of the known range of breweri. We found it only above the limit of upright timber. It occupies a higher zone in the Atlin region than do the Western Tree Sparrow and the Willow Ptarmigan; it is associated rather with the Golden-crowned Sparrow and the Rock Ptarmigan. While it would not be safe to say that taverneri occurs nowhere in the 800 miles to be traversed to the southward before the nearest record station of breweri is reached, still parts of that region have been visited by various collectors who have failed to find either species there.

There seem to be some notable differences in actions. Breweri is essentially a retiring and unobtrusive species, though not particularly wild. Taverneri, on the other hand, is extremely wary, and is frequently seen, apparently on the lookout, on the tops of the stunted trees of its timberline home. On two occasions, pairs of birds, presumably near their nests, were seen perched on the tallest bushes, jerking their tails in a manner seen in no other Spizella except monticola. On the whole, considering the differences in geographical distribution and the differences in zonal distribution, coupled with the physical characteristics of the two forms, it seems logical to regard breweri and taverneri as distinct species.

The Timberline Sparrow is, of course, a summer visitant only, in the Atlin region. It must spend the winter far to the southward, and it seems likely that the line of migration lies to the eastward of the Rocky Mountains, as is the case with so many non-resident birds of the region. Its winter home, however, is as yet unknown. We are indebted to Dr. Joseph Grinnell for making comparisons of specimens of taverneri with series of brequeri in the collections of the United States National Museum, including that of the Biological Survey. He failed to find a single example of taverneri in those collections. It seems likely, though, that winter specimens must have been collected somewhere, and it would be advisable to subject series of breweri, wherever available, to close scrutiny on the chance of finding examples of taverneri from southern record stations. 
MEASUREMENTS IN MILLIMETERS (AVERAGE, MINIMUM AND MAXIMUM) OF SPIZELLA BREWERI AND SPIZELLA TAVERNERI

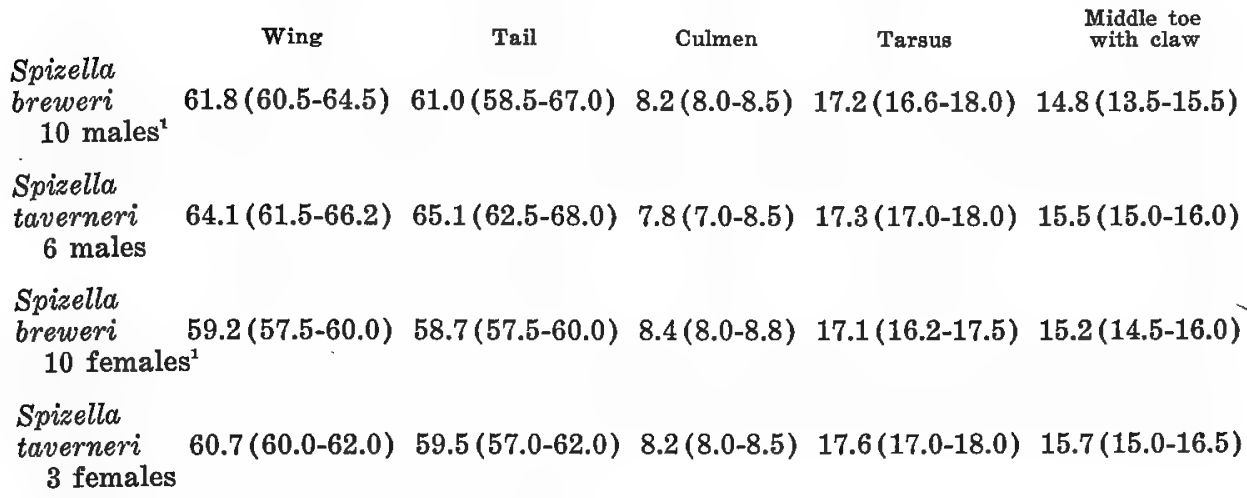

Spizella

breweri 10 males $^{1}$

$61.8(60.5-64.5) \quad 61.0(58.5-67.0) \quad 8.2(8.0-8.5) \quad 17.2(16.6-18.0) \quad 14.8(13.5-15.5)$

Spizella

taverneri 6 males

$64.1(61.5-66.2) \quad 65.1(62.5-68.0) \quad 7.8(7.0-8.5) \quad 17.3(17.0-18.0) \quad 15.5(15.0-16.0)$

Spizella

breweri $\quad 59.2(57.5-60.0) \quad 58.7(57.5-60.0) \quad 8.4(8.0-8.8) \quad 17.1(16.2-17.5) \quad 15.2(14.5-16.0)$ 10 females $^{1}$

Spizella

taverneri $\quad 60.7(60.0-62.0) \quad 59.5(57.0-62.0) \quad 8.2(8.0-8.5) \quad 17.6(17.0-18.0) \quad 15.7(15.0-16.5)$ 3 females

${ }_{1}^{1}$ Breeding birds, from Humboldt County, Nevada.

WEIGHTS IN GRAMS (AVERAGE, MINIMUM AND MAXIMUM) OF SPIZELLA BREWERI AND SPIZELLA TAVERNERI

Spizella breweri

10 males $\quad 10.6(9.8-11.5)$

5 females $10.6(9.3-11.8)$
Spizella taverneri

6 males $12.3(10.0-14.0)$

2 females $12.3(11.5-13.0)$

Berkeley, California, January 26, 1925. 



Reprinted from THe CoNDOR, Vol. XXVIII, pp. 249-253, Nov., 1926

JAMES HEPBURN, A LITTLE KNOWN

CALIFORNIAN ORNITHOLOGIST

By HARRY S. SWARTH 



\title{
JAMES HEPBURN, A LITTLE KNOWN CALIFORNIAN ORNITHOLOGIST
}

\author{
By HARRY S. SWARTH
}

$I^{N}$

$\mathbf{N}$ the course of some recent house cleaning in a storeroom in the Department of Agriculture of the University of California, there were unearthed two old manuscript note books pertaining to birds, which have since come into my hands. Their rescue was effected by. Prof. T. F. Tavernetti, of the Department of Agriculture, who turned the books over to the Museum of Vertebrate Zoology, where they now are. The history of these note books is unknown; there is no information as to when or how they came into the possession of the University.

One of the two books ( $8 \mathrm{r} / 2$ inches by $5 \frac{1}{2}$ inches in size) is a catalogue of birds collected, many of them in California, the specimens numbered serially from 1 to 1436, and covering the period from May 6, 1852, to January 17, 1868. The other book ( 8 by $63 / 4$ inches) contains a series of written accounts of various species of birds and is evidently based upon the collection listed in the catalogue. In neither volume is there any signature of the author, nor any other direct suggestion as to who the writer could be. The names of many individuals are mentioned, mostly in acknowledgment of aid in securing specimens, but it apparently never occurred to the owner of the books to put his own name on record. Both volumes are in an excellent state of preservation. They are strongly bound, the paper is white and unstained, and for the most part the ink is clear and unfaded.

It is, of course, a matter of considerable interest to us, working in present day ornithology in California, to know who it was who was making extensive collections of birds, with carefully written observations upon the species, in this state so long ago. The most promising clue to the problem, next to the period at which the work had been done, was to be found in the list of localities visited. These were all on the Pacific Coast, ranging from Los Angeles to Sitka, and with the bulk of the collecting centering about San Francisco and Victoria. The names of various old-time Californian ornithologists suggested themselves, such as Cooper, Gambel, Heermann, and others, but of all these men enough was known of their travels to be an assurance that none of them had followed the itinerary covered in this notebook.

In the original description of Leucosticte littoralis Baird ('Trans. Chicago Acad. Sci., I, i, 1869, p. 318), the bird then and since known as the Hepburn Rosy Finch, a statement occurs that came into my mind as soon as I had glanced over the notebooks, as perhaps supplying the solution of the question. This is a reference to the collector of the specimen which was afterwards selected as the type of this form, taken at Fort Simpson "by Mr. Hepburn, an eminent English naturalist, long time resident at San Francisco and Victoria." 
The next step was to consult certain old government publications which contained lists of specimens of birds, and a pertinent entry was found in a "Catalogue of the aquatic and fish-eating birds exhibited by the United States National Museum" [at the Great International Fisheries Exhibition, London, 1883], by Robert Ridgway. Under Aphriza virgata (p. 146) a specimen is listed as follows: " $q$ juv. San Francisco, California, September 11, 1856; J. Hepburn." In the notebook, a specimen of Surf-bird is listed under exactly corresponding data, and it is, furthermore, annotated as "Sent S. I." This, in itself, seems conclusive evidence as to the author of the notebooks.

Through the assistance of Dr. Alexander Wetmore, Assistant Secretary of the Smithsonian Institution, Dr. T. S. Palmer, of the Biological Survey, and Mr. J. H. Riley, of the United States National Museum, I have been able to gather a little information as to the relations of Hepburn to the Smithsonian Institution and to collect further corroborative evidence regarding his ownership of the notebooks in question. Hepburn was in correspondence with Baird, who was then Assistant Secretary of the Smithsonian Institution, and he sent to Washington many specimens of birds. Mr. Riley has supplied me with a list of birds received from Hepburn, compiled from the records of the National Museum (the birds themselves in many cases are not to be found ; of some there is record of their disposal elsewhere), and for the most part the data pertaining to these specimens agree so closely with corresponding entries in the notebooks as to remove any possible doubt as to Hepburn being author of these records.

Dr. Wetmore kindly sent me a letter written to Baird by Hepburn, from San Francisco, September 19, 1859. This was a disappointing exhibit, in a way, for the sprawling, careless writing of this epistle bears at first glance no resemblance to the usually neat and closely written pages of the notebooks. However, careful inspection of the latter discloses different types of writing in different places. The same letters, or combinations of letters, are formed in widely different ways on different pages. Altogether, I receive the impression that the writer is holding himself in and forcing himself to write carefully. In places, especially in the book containing general accounts of the species, there are lapses into an extremely hasty scrawl. I am no handwriting expert and can not give a positive statement that letter and notebooks were written by the same hand. They are very unlike at first glance, but I believe may have been the product of the same writer. At any rate, however the notebooks were written, there can be no doubt that they pertain to the Hepburn collection.

His system of numbering specimens is complicated by the fact that when a skin left his hands the corresponding number in the notebook was then regarded as vacant, to be filled by a later taken specimen. I was at first startled by an entry, doubtless due to this system, of a Hammond Flycatcher on a page headed 1854, four years before the species was discovered.

The following scanty biographical notes concerning Hepburn were supplied me by Dr. T. S. Palmer: "James Hepburn was born in Scotland in 1811 and died in Victoria, B. C., April 16, 1869. He was educated as a barrister but emigrated to the Pacific coast where he resided at San Francisco and Victoria. He collected seeds of conifers for some English horticultural society and also, I believe, made collections of shells and some other natural history specimens, including the type of the bird named in his honor."

I have been able to find but one published contribution from Hepburn's pen. In the Ibis for 1869 (pp. 126-127), the same volume that contains a notice of his death, there is a brief "communication" regarding the identity of a "booming swallow", ascribed to North America by another writer. Editorial comment that instead of a swallow the bird was probably a snipe, called forth Hepburn's statement (undoubtedly 
correct) that the travellers' "booming swallow" was really the Nighthawk (Chordeiles virginianus). Although he published nothing himself, his ability to write is demonstrated in one of his notebooks, which, in fact, has the appearance of being prepared as preliminary to a book on western American birds. As regards his ability as a collector and observer, we have the following statement from an excellent judge, Robert Brown, as given in the preface to his "Synopsis of the Birds of Vancouver Island" (Ibis, 1868, p. 416) : "I received much assistance from my friend Mr. James Hepburn, a gentleman who has spent many years in collecting the birds of the North Pacific, and whose knowledge is only equalled by his liberality in imparting it to his less fortunate brother naturalist. His princely (for no other term will designate it) collection is now in San Francisco, and I trust that he will by-and-by favour us with an extended account of North-Pacific ornithology; but in the meantime this synopsis, which owes all that is most original in it to his notes, may stand as a contribution to zoogeography, which can alone proceed on a sure basis by the collection of local faunas."

Some time after proving to my own satisfaction, in the round-about way outlined above, that Hepburn was the author of the notebooks here described, it was drawn to my attention that he is quoted over and over again, and at some length, in Baird, Brewer, and Ridgway's "A History of North American Birds" (1874). Comparison of the published quotations with notebook entries discloses such agreement of facts stated, and even of wording, as to make it seem likely that this very notebook was in the hands of one of the authors of the work cited. For example, in the account of the White-bellied Swallow (loc. cit., vol. 1, p. 347) there is an account, seven or eight lines in length, describing a nest placed on the yard-arm of a ship, and this description, with hardly the change of a word, appears also in the notebook account of that species.

What became of Hepburn's collection I do not know. His notebook catalogue contains 1436 entries, and, due to his peculiar system, some numbers represent several specimens each. A few skins went to the Smithsonian Institution, and there are entries of some that went elsewhere, notably a good many to "Sir W. Jardine", but it would seem that the bulk of his collection was intact at the time of his death.

Perhaps the main interest attaching to the notebooks is the opportunity of tracing Hepburn's travels in the west. The first entry in his catalogue is dated at Martinez, California, May 6, 1852. During each of the following eight years, until July 21, 1860 , there are numerous entries from Californian localities, implying continuous residence at or near San Francisco, though there are gaps of time long enough to have permitted of short trips as far as Victoria. Localities mentioned include Benicia, Oakland, Pulgas Ranch (San Mateo County), Twelve-mile House (San Jose Road), San Mateo, Pacific Beach, Sausalito, Half Moon Bay, Santa Clara, and San Bruno, in the San Francisco Bay region. There were also trips to the Sierras, such as to Grass Valley, to Bear River, Placer County, and to the "Pine Tree Mines", Mariposa County.

On November 5, 1860, is the first entry from British Columbia, at Nanaimo. He remained in the colony until July 20,1861, collecting at points near Victoria (Esquimalt, San Juan Island, and Saanich), and on the west coast, at Somass, Alberni Canal, and at Barclay Sound. June 5 to 16 was devoted to a trip to Smith's Island, Bird Rock, and Williamson's Rock, Washington Territory. From August 12 to October 15 he was at, or near, Fort Colville, Washington Territory. "November 28 found him back in California, where he remained until March, 1862.

In April he returned to Victoria, and we find entries from various points thereabout: from Bird Rock and Smith's Island, Washington Territory, early in June; Barrier Island, Haro Straits, June 25; and about Victoria until July 20. From 
August 28 to September 8, five specimens are listed from the "Russian Possessions", at Sitka. Then, September 26 to 27 he was at Fort Simpson, and October 8 to 26 in the vicinity of Fort Rupert, at the north end of Vancouver Island. December 17 he was back in Victoria.

During 1863 he seems to have been at or near Victoria, with one trip to Fort Rupert, most of the time until at least the middle of December. There is a single California record interpolated, of a Virginia Rail collected at Tẁelve-mile House, San Jose Road, April 22, which may indicate a hurried trip to San Francisco. At least such a trip would not conflict with the notebook entries. December 31 , he was at San Francisco once more.

Early in 1864 there are numerous entries from the San Francisco Bay region up to April 2. The scene of activities then shifts again to British Columbia. Collecting was carried on about Victoria during May, June, and July. Then, abruptly, we find him in the interior of the mainland, at Lac La Hache, September 6-9, at Soda Creek, September 13, at Richfield, September 20-23, and at Alexandria, October 1. The next entry is from near Victoria, November 1, and there are others from there until December 31.

In 1865, entries begin in the San Francisco Bay region March 27 and continue there until the end of June. He was in Victoria again October 1-3, and back to San Francisco by November 13. In 1866, we find two pages of entrieś from Los Angeles, comprising a series of "marsh blackbirds" shot March 21-23. He was again in San Francisco in April, and continuously until the latter part of August. On December 10 he was in Victoria. In 1867, he was in Victoria throughout the year save for trips to islands off the coast of Washington in June and again in the fall (October 22 to November 3). The last entry in the notebook is for January 17, 1868, but this fills the book, and entries may have been continued in another volume.

There are, naturally, many items of decided interest in these notebooks, far too many for repetition here. One or two such may, however, be cited as examples.

Hepburn made two trips to the Farallon Islands, June 10 to 16,1854 , and again June 19 to July 5, 1859. On the first trip not many entries were made, but on the second trip fifty-seven specimens were catalogued, not at all a bad showing, considering that they were all water birds. They are, with one exception, species that are known to be abundant on the islands at the present time. The exception is the Rhinoceros Auklet (Cerorhinca monocerata), called by Hepburn the Horned Guillemot. This is of especial interest in view of the facts regarding the previous occurrence of this species on the Farallones recently brought to light by Grinnell (Condor, vol. 28, 1926, pp. 37-40). Seven specimens are listed in his catalogue, six young birds and one adult. They are all entered as "taken from the nest", and from the manner of entry (two young each from nests nos. 1 and 2, and the adult and two young from nest no. 3) the inference is drawn that he found two young constituting a brood in this species. On June 29, 1865, there are entries of two Brandt Cormorants from the Farallones, but they are annotated as killed by "one of the men". It seems likely that they were brought from the Farallones to Hepburn in San Francisco, and that he himself was not on the islands at that time.

One of the notebooks contains an important comment upon an occurrence of the Burrowing Owl on Vancouver Island, as follows: "On arriving at Fort Rupert in 1863, I found a few birds which had been shot there and left for me by my friend Mr. Moffatt, among which was an owl unquestionably the $A$. hypugaea .... I was not previously aware that any burrowing owls had ever been seen in Vancouver Island." This specimen, if it was preserved, is not entered in his catalogue. It is mentioned in Cooper's Ornithology of California (1870, p. 438, note). 
It was disappointing to me to find no reference in Hepburn's notes to the specimen of Rosy Finch supposed to have been taken by him at Fort Simpson, and serving as the type of Leucosticte tephrocotis littoralis. Incidentally, it may be said that Fort Simpson, at sea level, is a curious place for this bird to have been found, save perhaps in midwinter. I doubt if it is anything but rare there even at that season, and Hepburn was at Fort Simpson in September.

Judging from some of his written accounts of different species of birds, it may be said that Hepburn possessed more than ordinary ability in describing what he had observed, so that in his failure finally to publish any of the results of his studies of western birds we have been deprived of what would have been a valuable and eminently readable contribution to our knowledge of the ornithology of the Pacific coast in early days.

There may be people in England or Scotland who have knowledge of Hepburn's personal career, and also of what became of his collection, but in this country, heretofore, the attachment of his name to a species of bird and a few scattered references in literature were all that saved it from oblivion.

Dickens' story of the Haunted Man centers largely about the sentiment inscribed below the painting of the founder of the institution in which the story is laid, "Lord, keep my memory green." It is a sentiment that appeals to everyone; it is what we all wish. That a man like Hepburn should die, leaving so little trace of the excellent work he evidently was carrying on, was a most lamentable ending. For years past I had wondered about this man, this "eminent English naturalist, long time resident at San Francisco and Victoria", who vanished so completely, so far as American ornithology is concerned, and it seemed a peculiar piece of luck, to me, that his notebooks should have fallen into my hands. I feel grateful to have been the means, in some measure, to aid in keeping green the memory of a man who assuredly deserves such remembrance but who has been well-nigh forgotten by the bird lovers who came after him.

Museum of Vertebrate Zoology, Berkeley, California, March 22, 1926. 





Northern Say Phoebe in California.--The Northern Say Phoebe (Sayornis sayus yukonensis) was described by Bishop (Auk, vol. 17, April, 1900, p. 115), with type locality at Glacier, White Pass, Alaska. It was refused recognition by the A. O. U. Committee (Auk, vol. 18, July, 1901, p. 312), and has since been generally ignored. The only published use of the name, I believe, has been once by Grinnell (Condor, vol. 11, 1909, p. 206), by myself (Univ. Calif. Publ. Zool., vol. 24, 1924, p. 345), and by Brooks and Swarth (Pacific Coast Avifauna, no. 17, 1925, p. 73). As may be inferred, I regard yukonensis as a recognizable subspecies. There are now available to me six adults and five in juvenal plumage from localities in northern British Columbia, southern Yukon, and southeastern Alaska, and all these birds, both old and young;, exhibit the peculiarities of color and markings pointed out by Bishop (loc. cit.) as distinguishing the northern race. The differences in measurements of bill and tail claimed by Bishop are not apparent in these specimens.

A bird of this sort can remain in its northern breeding range only during the summer months, and, once the color differences between the races were recognized, a search was instituted through the Museum series for winter-taken specimens at southern points. The rather surprising result was that in a series of about 130 skins (mostly from California, a few from Nevada and Arizona), at least half of which were non-breeding birds, only two examples of yukonensis were discovered. Particulars of these specimens are as follows: Mus. Vert. Zool. no. 29717, adult male; Morro, San Luis Obispo County, California; September 21, 1918; collected by J. Grinnell. Mus. Vert. Zool. no. 45945, female; one mile west of Stanford University, Santa Clara County, California; December 2, 1923; collected by Richard Hunt.

Bishop (loc. cit., p. 116) mentions a winter specimen from Hayward, California, as "intermediate", and I find two or three in our series to which the same term might be applied; but the two above described specimens are the only ones that are unequivocally of the subspecies yukonensis.

The apparent scarcity of this bird in California implies a southeastward migration from its northern breeding ground. In this it would be following the route traversed by most of the summer visitants of the northwestern interior. There are many species of birds in northern British Columbia and Yukon which in their southward fiight cross to the eastward of the Rocky Mountains before even the southern half of British Columbia is reached.-H. S. SWARTH, Museum of Vertebrate Zoology, Berkeley, California, September 30, 1925. 

Notes upon Certain Summer Occurrences of the Gray Flycatcher.-In the recently published "Birds of California," Mr. Dawson's description of the nesting habits of the Gray Flycatcher (Empidonax griseus) attracted my attention at once, it was so strongly in accord with certain unpublished data in this Museum, which, as it happened, I had just had occasion to bring together. While this information has no longer any claim to originality, as pointing to the nesting ground of this hitherto elusive species, it seems worth while to place it on record. It is all corroborative of Mr. Dawson's contentions.

We have what appear to be breeding birds from the Pine Forest Mountain region, northern Nevada; from the Warner Mountain region, northeastern California; and from the White Mountain region, east central California. There are also series of Empidonax wrighti from the same mountain ranges, and it was the presence of obviously mislabeled specimens in one series or the other that happened to attract my attention. I then carefully went over all the specimens of wrighti and griseus in the Museum collection, with interesting results.

From the Pine Forest Mountains, Nevada, we have a fairly large series of $E$. wrighti, mostly breeding birds from high altitudes. Included in this series I found four specimens of griseus. Three of these (Mus. Vert. Zool. nos. 8561, 8562, 8563) were breeding birds (from annotations on labels or in the collectors' notebooks) taken in sagebrush at Quinn River Crossing, on May 22, May 29, and June 2, 1909, respectively. One young bird, full grown but in juvenal plumage (no. 8580), was taken in the Pine Forest Mountains at 9000 feet altitude, July 31, but this capture cannot be regarded as constituting a breeding record.

From the Warner Mountains, Modoc County, California, we have nine sperimens of wrighti, all breeding birds and all collected from 5500 feet altitude upward. Four specimens of griseus were taken (June 9 and 10, 1910, and May 20 and 25, 1920, respectively) in the valley below, in the general vicinity of Alturas. There is also a breeding griseus from a nearby locality (mouth of Little High Rock Cañon, Washoe County, June 1, 1920) in the lowlands of Nevada. From the White Mountains, California, we have thirteen specimens (breeding birds and young from the nest) of wrighti taken at altitudes ranging from 8300 to 10,300 feet. These were oxiginally catalogued as griseus, but, although the color differences between this species and wrighti are somewhat obscured in badly worn specimens, there is no doubt that all of these birds are wrighti. From this same mountain range there are at hand five specimens of griseus. Two of these, from the dates of capture, were certainly breeding birds. These were taken July 5 and 7,1917 , respectively, " $2 \frac{1}{2}$ mi. s. e. of Head of Black Canyon," at an altitude of 8000 feet. Despite the high elevation, this locality, I am informed, is in the Transition Zone, with an abundant growth of sagebrush, so the species is not necessarily out of place there. Two other adult griseus were taken, respectively, at the head of Silver Canyon (altitude 10,000 feet), July 29, 1917, and again at the head of Silver Canyon (altitude 8000 feet), August 21, 1917. It is not certain that they were breeding at the exact places where they were collected.

In an article in THE Condor (vol. 24, July, 1922, p. 137) Dickey and van Rossem record the capture of certain specimens of griseus in the White Mountains at high elevations ( 8000 to 10,000 feet) and draw the inference that these birds (wholly or partly in juvenal plumage), taken August 27, September 3 and 4, were probably hatched somewhere in the near vicinity. This may or may not have been the case. As before indicated, the Transition Zone ascends to 8000 feet in the White Mountains, and griseus doubtless follows the sagebrush upwards. Any of these young birds, however, might have traveled many miles. I myself have collected juvenal plumaged birds of various species (including Empidonax grisens) that must have gone a surprisingly long distance from where they were hatched. It may suffice to cite here, as an example near at hand, a young Desert Sparrow (Amphispiza bilineata deserticola) in juvenal plumage throughout, that I collected above timber line in the Sierra Nevada, at Charlotte Lake (10,406 feet), near Kearsarge Pass, September 3, 1916.

Some of the confusion that exists regarding the relationship of griseus and wrighti is probably due to faulty observations in the field. This does not imply criticism of those who have made observations in the past; for the two species, of course, require the most painstaking discrimination; but future studies and records should be prefaced 
by careful consideration of existing facts. It seems safe to prophesy that certain apparently anomalous occurrences now on record will find their explanation in conditions that were overlooked at the time those observations were made. It is evident from Mr. Dawson's evidence, from the record by Alexander Walker in THE CoNDOR (vol. 16, 1914, p. 94) which first gave Dawson his clue, from the statements in Grinnell and Storer's "Animal Life in the Yosemite" (pp. 373-374), and from additional corroborative facts that I have found in the collection of the Museum of Vertebrate Zoology, that Empidonax griseus is an upper Sonoran and Transition Zone species, confined in the breeding season mainly to sagebrush surroundings in the Great Basin. Empidonax wrighti nests mainly in the Canadian Zone, occasionally in the Hudsonian Zone, from southern California north at least to extreme northern British Columbia. Any apparent overlapping of breeding ranges (as is claimed to occur in the White Mountains) is doubtless to be explained either by the upward extension locally of lower zones, thus carrying griseus to an altitude where wrighti usually breeds, or else as an unwarranted assumption of nesting from the mere occurrence of birds (juvenal or adult) outside their normal nesting ground.-H. S. SWARTH, Museum of Vertebrate Zoology, University of California, Berkeley, April 21, 1924. 
Reprlnted from T вг A סx. Vol. XLI; A pril, 1924.

Editor of 'The Auk:'

In 'The Auk' for January, 1924 (Vol. XLI, pp. 68-71) there is "A Review of the West Indian Black Swifts" by Ludlow Griscom. In his comments upon sexual variation in this species Mr. Griscom makes certain statements with which I take issue. I have no personal knowledge of the West Indian subspecies of Nephoecetes niger, but the statements to which I object are made as generalizations covering the species as a whole, and they assuredly do not apply to the race with which I am familiar, the North American subspecies, Nephoecetes niger borealis.

Mr. Griscom describes certain variations of color and markings as distinguishing males and females, and remarks of such supposed sexual variation that "this has already been correctly described by Mr. Ridgway" (Birds of North and Middle America, part V, 1911, pp. 703-710). He says further that "Hartert (Catalogue of Birds, Brit. Mus., XVI, 1892, p. 94 [ sic; correctly, 494]) errs in regarding the adults as similar, and the birds with light tips to the feathers below as immature." This last assertion of error is altogether too positive and sweeping a statement of what is really no more than Mr. Griscom's opinion. My own conviction is that Hartert is correct.

There is an article on this subject by Frank M. Drew (Bull. Nutt. Orn 
Club, VII, 1882, pp. 182-183), cited at some length by Ridgway (loc. cit., p. 707, footnote) and so, of course, familiar to Mr. Griscom, though ignored by him. This need not be dwelt upon further here, but I do wish to point out that there have also been published papers of my own ('Auk,' Vol. XXIX, 1912, pp. 241-242; Univ. Calif. Publ. Zool., Vol. XXIV, 1922, pp. 222-223), giving facts that are in contradietion to Mr. Griscom's opinions on sexual variation in this species.

Of the series of Black Swifts in this Museum I have myself shot and digsected twenty-eight specimens. Briefly, my assertion is that I have collected females of the Black Swift (Nephoecetes niger borealis) which in color and in lack of white markings ventrally are indistinguishable from adult males. I have talked on this subject with Major Allan Brooks, who has collected many more specimens of this Swift than I have, and he had long been familiar with the fact that some females lack any whitetipped feathers on the lower parts.

It seems then that three men who have themselves shot and dissected a number of these Swifts (and there are not many who are familiar with the species) are agreed that the (presumably fully mature) female is indistinguishable from the adult male. Surely this is evidence sufficient to establish this statement as a fact.

University of California,

HARRY S. SW ARTH.

Museum of Vertebrate Zoology.

February 13, 1924. 
Valley Quail Imported from Chile.-Perhaps no other American game bird has been so successfully acclimatized in other countries as has the California Valley Quail (Lophortyx californica). For many years it has been known that this bird had been successfully introduced in such remote regions as British Columbia, Chile, and New Zealand, and now there has come to hand some interesting information as to the magnitude of the success attained in one of these places. Mr. F. E. Booth, of San Francisco, while on a visit to Santiago, Chile, noted Valley Quail for sale in the market there. On inquiry he learned that they were abundant enough to be obtained in quantity, and as a consequence he has begun the importation of stock from Chile for introduction into coverts on a game preserve in Sonoma County. The first shipment arrived during the early part of January, 1927, consisting of 134 birds, which reached their destination in good condition. Thus, depleted game coverts in California are being re-stocked with Chilean-raised California Quail.

Mr. Booth's importation of birds received newspaper publicity, and as an outcome of this there resulted some information regarding the early exportation of quail from California to Chile that seems worth placing upon record. The newspaper item was seen by Mr. E. F. Greenwood, of San Francisco, who wrote to me, giving information substantially as follows:

"My wife, a Chilean, is a grand-daughter of one William Govers, formerly of California and before that of Holland, who had a ranch near San Jose. He decided to migrate to Chile about 1864 . Being a thrifty Hollander he took many things with him, including a brace of quail which he had captured on his ranch. When he arrived in Chile there were no quail in that country, and his birds, exhibited in a store window, were quite a novelty. He bought a ranch at Limache, near Valparaiso, and had his birds there for some time. Then, while feeding them one day, their cage tipped over and they escaped. This is the reason for the abundance of quail in Chile."

A second letter, from Mr. Henry J. Besant, Sonora, California, received by one of the daily papers and forwarded to me, reads thus: "I was in Chile with Mr. C. J. Lambert, who had a copper mine and smelter at La Compania, near Serena, Province of Coquimbo. In the park in which he had his residence at La Compania he released a lot of quail which he had had sent down from San Francisco. The climate and other conditions evidently being favorable, they increased in numbers rapidly and spread out over the country. I cannot now remember the exact date when this was done, but I think it must have been in 1881 or $1882 . "$

It is possible, of course, that these were not the only importations of quail into Chile, but here, at any rate, is definite information as to the exact subspecies first introduced there, information to be taken into account in any study of the characters now exhibited by Chilean Valley Quail.-H. S. SWARTH, Museum of Vertebrate Zoology, Berkeley, California, February 9, 1927. 



\title{
PROCEEDINGS
}

\author{
or THX
}

\section{BIOLOGICAL SOCIETY OF WASHINGTON}

\section{THE LEMMING OF NUNIVAK ISLAND, ALASKA.}

\author{
BY HARRY S. SWARTH.
}

During the summer and fall of $1927 \mathrm{Mr}$. C. G. Harrold was occupied collecting birds and mammals in Alaska for the California Academy of Sciences, mostly upon Nunivak Island. A series of Lemmus that he obtained upon that island appears to represent an unnamed form. This may be designated

Lemmus harroldi, ${ }^{1}$ new species.

Type.-Male adult, skin and skuil, no. 6294, Mus. Calif. Acad. Sci.; collected by C. G. Harrold (orig. no. 244); Nunivak Island, Alaska; July 14, 1927. Measurements of type: Total length, 156.0; tail vertebræ, 15.0; hind foot, 21.0.

Diagnosis. - A lemming of the group that is otherwise represented in Alaska by the described forms alascensis (Point Barrow), yukonensis (Charlie Creek, Yukon River), minusculus (Kakhtul River, Alaska Peninsula), and nigripes (St. George Island, Pribilof Group). Coloration dull blackish brown, with slight suggestion of the bright ruddy hue of alascensis and yukonensis; similar to the color of nigripes. Skull smaller than in alascensis, but more massive than in yukonensis and nigripes. Audital bullæ larger than in nigripes, as is the case in the mainland forms; not quite as large as in yukonensis.

Remarks. - The several Alaskan forms of Lemmus will probably turn out to be only subspecifically separable, but until sufficient material and data are gathered to prove this supposition the Nunivak Island Lemming may be accorded specific standing with the rest. It is in general terms similar to the Pribilof Island nigripes in coloration, like the mainland animals in skull characters. The following specimens have been available for comparisons:

Lemmus harroldi. California Academy of Sciences collection, 11 skins with skulls, 1 dessicated carcass, entire.

Lemmus nigripes. California Academy of Sciences collection, 8 skins with skulls; 3, skins only; 2 , skulls only.

Lemmus alascensis. California Academy of Sciences collection, 2 skins only. Biological Survey collection, 5 skins with skulls.

\footnotetext{
1 Named in memory of the collector of the type series, the late Cyril Guy Harrold, u gifted naturalist and a remarkably able collector.
} 
Lemmus yukonensis. Biological Survey collection, 5 skins with skulls.

In the lack of a revisionary study of the genus, the original descriptions of the various species remain our main source of published information, and the several small series before me show certain disagreements with those descriptions. The principal discrepancy lies in the characterization of alascensis as of small size, whereas it appears to be the largest of the Alaskan forms. This seems evident, both from externals and from the skulls, but unfortunately collectors' measurements can not be tabulated to show the differences. Measurements by different individuals, by different methods, and with a proportion of evident mistakes, are factors that debar comparisons. The four Alaskan forms of Lemmus before me present the following characteristics:

Lemmus alascensis. Size large; skull large and massive; coloration bright ruddy.

Lemmus yukonensis. Size small; skull small but audital bullæ large in proportion, as compared with alascensis; coloration bright ruddy.

Lemmus nigripes. Size small; skull small with small audital bullæ; coloration dark brown.

Lemmus harroldi. Size larger, nearly as in alascensis, and skull most nearly as in that form. Coloration dark brown.

The above color comparisons are between specimens taken at the same season and presumably in comparable condition. In the Nunivak Island series there is a mummified specimen, a "pick-up," that is more ruddy than the rest and may represent winter conditions. In the Pribilof Island series two skins collected in February are more ruddy than the others, taken from June to August. I have not seen Lemmus minusculus Osgood. In the description thereof comparisons are all made with alascensis, and it is not apparent how minusculus and yukonensis are to be distinguished.

$$
\text { Measurements of Skulla. }
$$

\begin{tabular}{|c|c|c|c|c|c|c|}
\hline Museum & No. & Sex & & Length & $\begin{array}{l}\text { Width } \\
\text { acroses } \\
\text { bullyos }\end{array}$ & $\begin{array}{l}\text { Spread of } \\
\text { maxillary } \\
\text { arohes }\end{array}$ \\
\hline Biol. Surv, & 107677 & $0^{\pi}$ & Lemmus alascensis & 31.0 & 15.5 & 21.5 \\
\hline Biol. Surv. & 107689 & $0^{7}$ & Lemmus alascensis & 32.5 & 16.2 & 22.8 \\
\hline Biol. Surv. & 107720 & $0^{7}$ & Lemmus alascensis & 33.5 & 16.5 & 23.2 \\
\hline Biol. Surv. & 107688 & 우 & Lemmus alascensis & 36.0 & 16.2 & 23.5 \\
\hline Biol. Surv. & 107710 & $\stackrel{+}{q}$ & Lemmus alascensis & 32.0 & 15.8 & 21.2 \\
\hline Biol. Surv. & 159085 & $0^{7}$ & Lemmus yukonensis & 30.0 & 15.0 & \\
\hline Biol. Surv. & 159086 & $0^{\pi}$ & Lemmus yukonensis & 29.0 & 14.2 & 19.0 \\
\hline Biol. Surv. & 159101 & $0^{7}$ & Lemmus yukonensis & 31.0 & 15.0 & 20.0 \\
\hline Biol. Surv. & 159089 & $\%$ & Lemmus yukonensis & 28.0 & 14.8 & 18.2 \\
\hline Biol. Surv. & 159096 & $\stackrel{+}{+}_{+}^{+}$ & Lemmus yukonensis & 28.5 & 15.0 & 18.5 \\
\hline C. A. S. & 6294 & $0^{7}$ & Lemmus harroldi & 33.5 & 16.2 & 22.0 \\
\hline $\begin{array}{l}\text { C. A. S. } \\
\text { C. A. S. }\end{array}$ & $\begin{array}{l}6296 \\
6295\end{array}$ & 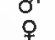 & $\begin{array}{l}\text { Lemmus harroldi } \\
\text { Lemmus harroldi }\end{array}$ & 320 & 15.2 & 20.5 \\
\hline C. A. S. & 6297 & $\begin{array}{l}q \\
9\end{array}$ & Lemmus harroldi & 31.8 & 15.0 & 21.0 \\
\hline C. A. S. & 2843 & क & Lemmus nigripes & 31.5 & 16.0 & 20.5 \\
\hline C. A. S. & 2846 & \pm & Lemmus nigripes & 29.0 & 15.0 & 19.0 \\
\hline C. A. S. & 2847 & $\sigma^{x}$ & Lemmus nigripes & 30.0 & 15.2 & 19.0 \\
\hline C. A. S. & 2851 & $\sigma^{\pi}$ & Lemmus nigripes & 28.5 & 14.0 & 18.5 \\
\hline
\end{tabular}


Swarth-The Lemming of Nunivak Island, Alaska. 103

I am indebted to the authorities of the Bureau of Biological Survey, United States Department of Agriculture, for the loan of series of Lemmus alascensis and Lemmus yukonensis.

\section{REFERENCES.}

True, F. W. Diagnoses of new North American mammals, April 26, 1894. (Advance reprint from Proc. U. S. Nat. Mus., vol. 17, pp. 241-243, Nov. 15, 1894.)

Description of Myodes nigripes, p. 242.

Merriam, C. Hart. Papers from the Harriman Alaska expedition. 1. Descriptions of twenty-six new mammals from Alaska and British North America. Proc. Wash. Acad. Sei., vol. II, March 14, 1900, pp. 13-30.

Descriptions of Lemmus alascensis, p. 26, and Lemmus yukonensis, p. 27.

OsGood, Wilfres H. A biological reconnaissance of the base of the Alaska peninsula. North American Fauna, no. 24, 1904, pp. 1-86, pls. I-VII.

Description of Lemmus minusculus, p. 36.

STONE, WitMER. Report on the birds and mammals collected by the Mallhenny expedition to Pt. Barrow, Alaska. Proc. Acad. Nat. Sci. Phila., 1900, pp. 4-49.

A discussion of the lemmings of the northwest occupies pages 35-42. 






